\title{
WEST INDIES
}

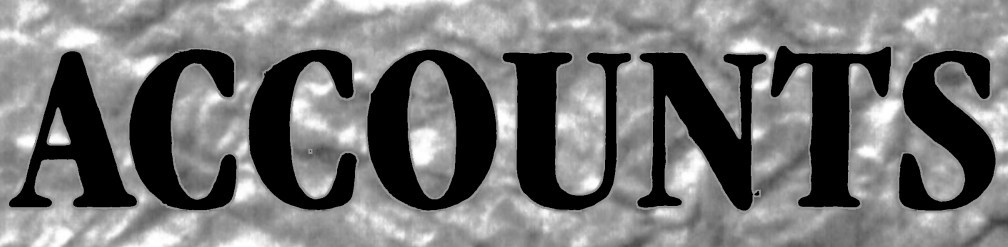

BS SAYS ON THE HISTORY

OF THE BRITISH CARIBBEAN AND THE ATLANTIC ECONOMY IN HONOUR OF RICHARD SHERIDAN

\section{edfeaby \\ RODERICK A. MEDONAID}
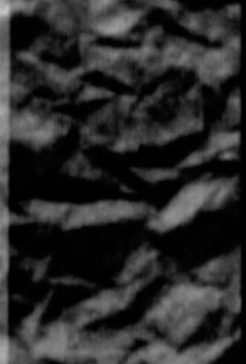


\section{WEST INDIES ACCOUNTS}




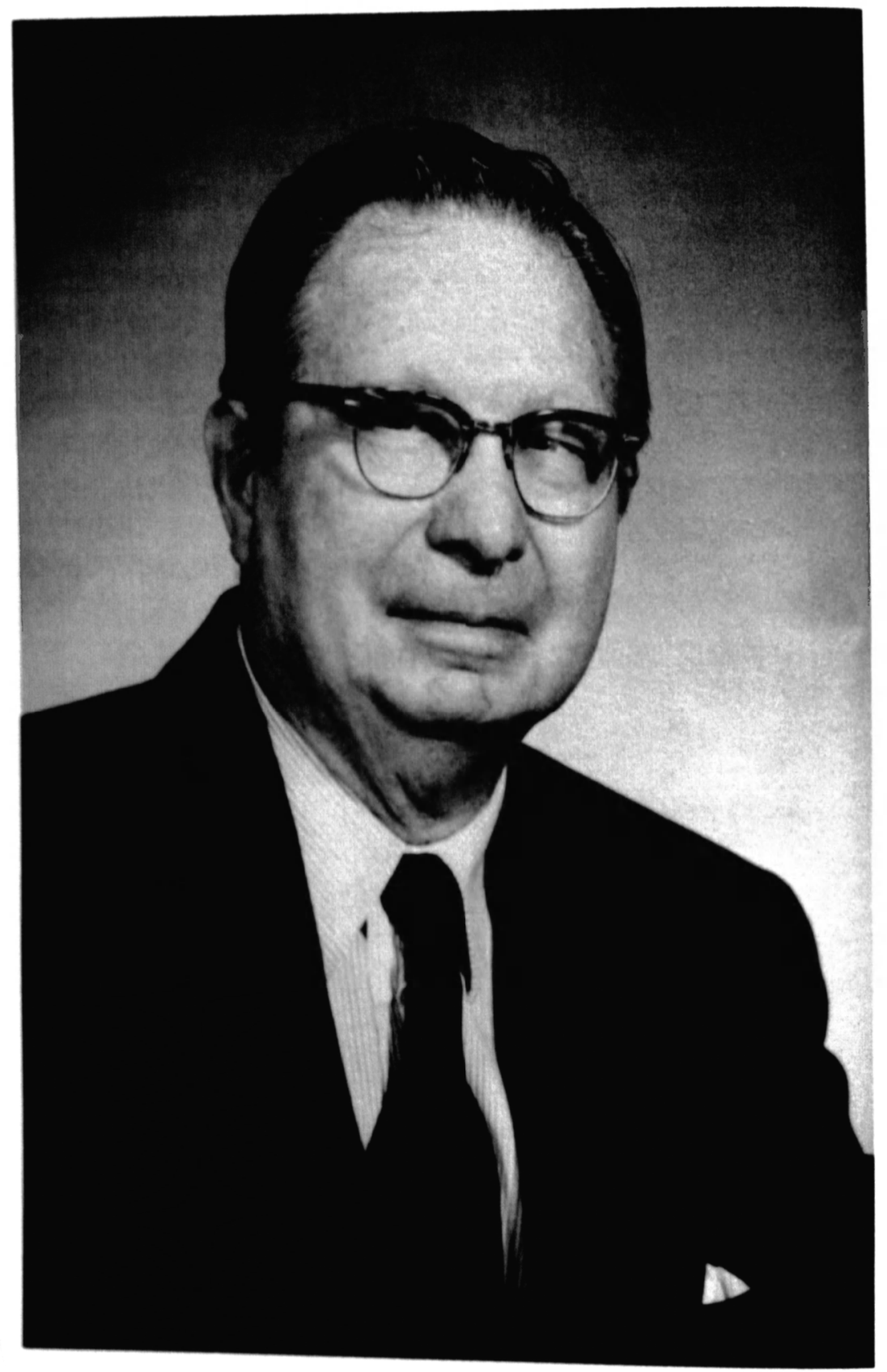

PROFESSOR RICHARD B. SHERIDAN 

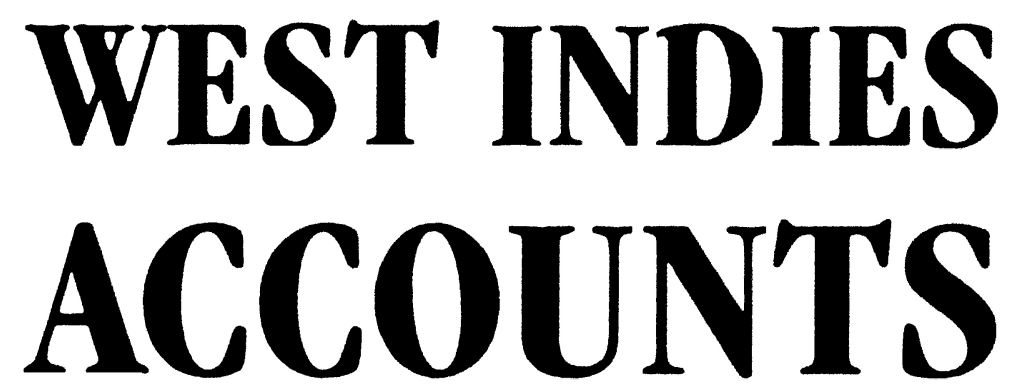

ES SAYS ON THE H IS TORY

OF THE BRITISH CARIBBEAN

AND THE ATLANTIC ECONOMY

IN HONOUR OF RICHARD SHERIDAN

\author{
e d i t e d b y \\ RODERICK A. MCDONALD
}

THE PRESS University of the West Indies

Barbados - Jamaica - Trinidad and Tobago 
The Press University of the West Indies la Aqueduct Flats Kingston 7

Jamaica WI

- 1996 by Roderick A. McDonald

All rights reserved. Published 1996

Printed in Canada

$\begin{array}{llllllllllll}01 & 00 & 99 & 98 & 97 & 96 & 6 & 5 & 4 & 3 & 2 & 1\end{array}$

CATALOGUING IN PUBLICATION DATA

West Indies accounts : essays on the history of the British Caribbean and the Atlantic economy in honour of Richard Sheridan / edited by Roderick A. McDonald.

p. $\mathrm{cm}$.

Includes bibliographical references and index.

ISBN 976-640-02-9

1. West Indies, British-History. 2. West Indies,

British-Economic conditions. 3. Sheridan, Richard B.

I. McDonald, Roderick A. II. Sheridan, Richard B.

F2131. W475 1996

972.9

Book and cover design by Robert Harris

Text set in $10.5 \mathrm{pt} / 15$ Atlantix $\times 27$ 


\section{Contents}

Pretace

Richard sheridan Published Works

1 Richard B Sheridan the Making of a Caribbean teonomic Historian

Howard Johnson

2 The (apture of the Hlue Dove, Inot Policy, Profits and

Protection in Farly Fnglish lamaica

Nuala Zahedich

3 The Taylor Manuscript and Seventeenth I entury lamaica

48 David Buisseret

4 English Quaker Merchants and War at Sed, 1689-1783

Jacob M. Price

5 Edward Trelawny's "Girand Flixir": Metropolitan

Weakness and Constitutional Reform in the

Mid Eighteenth Century British Empire

Jack P. Greene

6 Botanical and Horticultural Enterprise in Fighteenth.

Century lamaica

Douglas Hall

7 The West India Interest and the Crisis of American

Independence

126

Andrew J. O'Shaughnessy

8 The United States and the British West Indian Tiade.

1783-1807

Selwyn H. H. Carrington

9 Property Rights in Pleasure: The Marketing of Slave Women's Sexuality in the West Indies 
10 The Story of Two Jamaican Slaves: Sarah Affir and Robert McAlpine of Mesopotamia Estate

Richard S. Dunn

11 Patterns of Exchange within a Plantation Economy: Jamaica at the Time of Emancipation

B. W. Higman

12 Planter Profits and Slave Rewards: Amelioration

Reconsidered

Mary Turner

13 Abolition and Emancipation: Williams, Drescher and the Continuing Debate

Walter Minchinton

14 The Ambivalencies of Independency: The Transition out of Slavery in the Bahamas, c. 1800-1850

Michael Craton

15 The Land and Labour Problem at the Time of the Legal

Emancipation of the British West Indian Slaves

Stanley L. Engerman

16 Urban Crime and Social Control in St. Vincent during the Apprenticeship

Roderick A. McDonald

17 "Repression is not a policy": Sydney Olivier on the West Indies and Africa

Richard A. Lobdell

Bibliography

Index

Contributors' biographical data 


\section{Freface}

At the twenty fifth annual conference of the Association of Caribbean Histori ans (ACHI) held at the Mona campus of the University of the West Indies (UW'I) in March 1993, a group of Richard Sheridan's colleagues, former students, and fellow-Caribbeanists, including Richard Lobdell, Arnold Sio, Barry Higman, Howard Johnson and myself, decided that the best way to recognize his distin guished contribution to Caribbean historiography, and to mark his recent retirement as Professor of Economic History at the University of Kansas, would be to compile a volume of essays in his honour. It is most fitting that presentation to Professor Sheridan of West Indies Accounts: Essays_on the History of the British Caribbean and the Atlantic Economy in Honour of Richard Sheridan will take place during the twenty-eighth meeting of the ACH at the UWI Cave Hill campus in April 1996, since his connections with both the university and the organization have been extensive and enduring. It is also appropriate that The Press University of the West Indies publish the volume. The historiographical tradition associated with Dick Sheridan's work is central to the first-rate catalogue of scholarship established by the press which, in 1994, reprinted Dick's pioneering study, Sugar and Slavery: An Economic History of the British West Indies, 1623-1775.

These layers of connection with the British Caribbean echo Dick's involvement with the region throughout his academic career. He developed an interest in British West Indian history as a postgraduate student at the London School of Economics (LSE), and thereafter the topic has been the principal focus of his research. Although he spent most of his academic career teaching in his native state of Kansas, landlocked in the midwestern United States, he has travelled extensively throughout the West Indies, beginning with active service in the United States Navy during World War "Two, and subsequently at the rather more measured pace of the scholar, conducting research and attending conferences. Dick has also taught in the Caribbean, as a Visiting Professor at the UWI St. Augustine campus and at the University of the Virgin Islands, has served as an External Examiner for the UWI Department of History, and in 1987, 
delivered the Elsa V. Goveia Memorial Lecture, "Why the Condition of the Slaves was 'Less Intolerable in Barbadoes, than in the other Sugar Colonies," at the UWI Cave Hill campus.

In the perceptive and comprehensive discussion of "The Making of a Caribbean Economic Historian" that opens West Indies Accounts, Howard Johnson chronicles the more than four decades of scholarly activity that have established Dick Sheridan as a pre-eminent historian of the British West Indies. The subsequent sixteen essays range broadly, both topically and chronologically, in the history of the British Caribbean and the Atlantic economy, and yet all embrace central themes of Dick's scholarship, whose remarkable reach and richness can be gauged in the accompanying bibliography of his published work. A number of the essays emphasize the prosopographical orientation that Dick has long favoured, including one from Douglas Hall, a fellow-postgraduate student at LSE, and the "long-time friend and counsellor" whose "encouragement and advice" Dick acknowledges in the preface to Sugar and Slavery (p. xviii). The analysis of British West Indian trade within the context of the Atlantic economy, which established Dick's scholarly reputation, is a recurrent theme in the volume (and the inspiration for its title). Essays on this topic examine various aspects of the sugar plantation economy as it developed in British Caribbean from the seventeenth to the nineteenth centuries, and lend additional support both to Dick's argument for the importance of the West Indies to the accumulation of wealth in Europe, and to his defence of the related thesis that Eric Williams advanced in Capitalism and Slavery (Chapel Hill: University of North Carolina Press, 1944). After the publication of Sugar and Slavery $m$ 1974, the focus of Dick's research shifted perceptibly from an analysis of the creation and distribution of capital to an assessment of the social consequences of the sugar plantation system under slavery, and a number of contributions to West Indies Accounts draw on this theme. Similarly, his more recent interest in the domestic economy of British Caribbean is represented, as is his current work, which examines the transition from slavery to freedom in the British West Indies that was initiated by challenges to the transatlantic slave trade and the institution of slavery, culminating in the 1833 Emancipation Act and full freedom in 1838. The broad sweep of Dick's distinguished scholarship thus gives thematic shape to this testimonial.

My editorial responsibilities have been eased considerably by the conscientrousness of participants in the project. Discussions at the Mona conference 
resulted in the formulation of a list of potential contributors to the volume, all of whom, when first contacted, responded most enthusiastically, and subsequently managed to adhere to the tight schedules and editorial strictures imposed on them. Although the prolect would, of course, have run to many volumes if essays had been submitted by everyone who has profited from Dick's scholarship, the profile of those invited to participate perhaps convers the extent to which he has influenced W'est Indian historiography. Fonomic historians, historical geographers, historians and economists, from the Caribbean, North America and Britain, are represented in West Indies Aicounts, as scholars of Dick's generation (including two more of his postgraduate cohort at LSE, Walter Minchinton and Jacob Price) join those whom they have taught to produce this token of our respect and appreciation.

My own intellectual debts to Dick Sheridan are enormous. As a postgraduate student at the University of Kansas, 1 benefitted immeasurably from Dick's tutelage. With unfailing grace, patience and generosity, he shared his encyclopedic knowledge of West Indian history with me at our regular Friday afternoon meetings, he inspired and guided my research, and set the high standards of scholarship to which I aspire. I also harbour fond memories of the hospitality of Dick and his wife Audrey, and their many kindnesses towards me during my years in Kansas. Now I value their friendship, as I do the intellectual guidance and counsel with which Dick continues to be so generous.

Publication of West Indies Accounts was greatly facilitated by the thorough professionalism of the staff of The Press University of the West Indies whose director, Linda Cameron, encouraged the project from its inception. I should also like to acknowledge the financial and technical support provided by Rider University, including the 1994 Summer Research Fellowship that assisted me in fulfilling my duties as editor, and the Grant-in-Aid that financed the index and the preparation of maps and charts. Marge Raynor performed numerous secretarial functions with her characteristic efficiency and good humour, and I am most grateful for typing done by Sue Ferry at Rider's Educational Support Center. 


\section{Richard B. Sheridan: Published Works}

\section{BOOKS}

An Economic History 1500-1900: Economic Development in South Central Kansas. Part 12. Lawrence, Kansas: Bureau of Business Research, University of Kansas, 1956.

Chapters in Caribbean History. London: Caribbean Universities Press, 1970.

The Development of the Plantations to 1750 [and] An Era of West Indian prosperity, 1750-1775. Barbados: Caribbean Universities Press, 1970.

Sugar and Slavery: An Economic History of the British West Indies, 1623-1775. London and Baltimore: Caribbean Universities Press and Johns Hopkins University Press, 1974. Reprint, Kingston, Jamaica: Canoe Press University of the West Indies, 1994.

Doctors and Slaves: A Medical and Demographic History of Slavery in the British West Indies, 1680-1834. Cambridge: Cambridge University Press, 1985.

\section{ARTICLES}

"The Molasses Act and the Market Strategy of the British Sugar Planters." Journal of Economic History 17 (1957): 62-83. Reprinted in Essays in American Colonial History, edited by Paul Goodman, pp. 363-81. New York: Holt, Rinehart and Winston, 1967.

"Letters from a Sugar Plantation in Antigua, 1739-1758." Agricultural History 31 (1957): 3.23.

"The Commercial and Financial Organization of the British Slave Trade, 1750-1807." Economic History Review, 2nd series, 11 (1958): 249-63.

"Samuel Martin, Innovating Sugar Planter of Antigua, 1750-1776." Agricultural History 34 (1960): 126-39.

"The British Credit Crisis of 1772 and the American Colonies." Journal of Economic History 20 (1960): 161-86. Reprinted in Views of American Growth. Vol. 1, The Agricultural Era, edited by Thomas C. Cochran and Thomas B. Brewer, pp. 47-66. New York: McGraw-Hill Book Company, 1966.

"The West India Sugar Crisis and British Slave Emancipation, 1830-1833." Journal of Economic History 21 (1961): 539-51.

"The Rise of a Colonial Gentry: A Case Study of Antigua, 1730-1775." Economic History Review, 2nd series, 13 (1961): 342-57. 
"Temperate and Tropical: Aspects of European Penetration into Tropical Regions." Caribbean Studies 3 (1963): 3-20.

"Slavery and Antislavery Literature." Books and Libraries at the Linversity of Kansas, Lawrence, Kansas 2 (1963): $11-15$.

"Planter and Historian: The Career of William Beckford of lamaica and England, 1744-1799." Jamatcan Historical Review 4 (1964): 36-58.

"The Wealth of lamaica in the Eighteenth Century." Economic History Review, 2nd series, 18 (1965): 292-311

"William Beckford (1744-1799), Patron of Painters of lamaica." The Register of the Museum of Art, University of Kansas 3 (1967): 14-23.

"The Wealth of Jamaica in the Eighteenth Century: A Rejoinder." Economic History Review, 2nd series, 21 (1968): 46-61.

"The Plantation Revolution and the Industrial Revolution, 1625-1775." Caribbean Studies 9 (1969): 5-25. Reprinted in Readings in Caribbean History and Economics: An Introduction to the Region, edited by Roberta Marx Delson, pp. 44-51. New York: Gordon and Breach Science Publishers, 1981.

"Simon Taylor, Sugar Tycoon of Jamaica, 1740-1813." Agricultural History 45 (1971): 285-96.

"Planters and Merchants: The Oliver Family of Antigua and London, 1716-1784." Business History 13 (1971): 103-13.

"Africa and the Caribbean in the Atlantic Slave Trade." American Historical Review 77 (1972): 15-35.

"Comments on papers by Jones, Shepherd, Walton, and McCusker, at the Annual Meeting of the Economic History Association, Atlantic City, New Jersey, September 8-10. 1971." Journal of Economic History 32 (1972): 159-62.

Introduction to A History of the Virgin Islands of the United States, by Isaac Dookhan, pp. v-xiv. London: Caribbean Universities Press, 1974.

"Mortality and the Medical Treatment of Slaves in the British West Indies." In Race and Slavery in the Western Hemisphere: Quantitative Studies, edited by Stanley L. Engerman and Eugene D. Genovese, pp. 285-310. Princeton: Princeton University Press, 1975.

"'Sweet Malefactor': The Social Costs of Slavery and Sugar in Jamaica and Cuba, 1807-54." Economic History Review, 2nd series, 29 (1976): 236-57.

"The British Sugar Planters and the Atlantic World, 1763-1775." In Eighteenth-Century Florida and the Caribbean, edited by Samuel Proctor, pp. 1-14. Gainesville: The University Presses of Florida, 1976.

"The Jamaican Slave Insurrection Scare of 1776 and the American Revolution." Journal of Negro History 61 (1976): 290-308. 
"The Crisis of Slave Subsistence in the British West Indies during and after the American Revolution." William and Mary Quarterly, 3rd series, 33 (1976): 615-41.

"The Role of the Scots in the Economy and Society of the West Indies." In Comparative Perspectives on Slavery in New World Plantation Societies, edited by Vera Rubin and Arthur Tuden, pp. 94-106. New York: The New York Academy of Sciences, 1977.

"The West Indian Antecedents of Josiah Martin, Last Royal Governor of North Carolina." North Carolina Historical Review 54 (1977): 252-70.

"Materials Relating to the West Indies from the Senhouse Papers, 1762-1831." In British Records Relating to America in Microform, edited by W. E. Minchinton, pp. 1-10. East Ardsley, Wakefield, Yorkshire: EP Microform Ltd., 1977.

"The Gale-Morant Papers, 1731-1925, in the Library, University of Exeter." In British Records Relating to America in Microform, edited by W. E. Minchinton, pp. 1-11. East Ardsley, Wakefield, Yorkshire: EP Microform Ltd., 1977.

"The Land Use Value Tax in California: Alternatives and Lessons for Kansas." Kansas Business Review 9 (1978): 1-4.

"Slave Demography in the British West Indies and the Abolition of the Slave Trade." In The Abolition of the Atlantic Slave Trade: Origins and Effects in Europe, Africa and the Americas, edited by David Eltis and James Walvin, pp. 259-85. Madison: University of Wisconsin Press, 1981.

"The Guinea Surgeons on the Middle Passage: The Provision of Medical Services in the British Slave Trade." The International Journal of African Historical Studies 14 (1981): 601-25.

"John Ise, 1885-1969, Economist, Conservationist, Prophet of the Energy Crisis." Kansas History 5 (1982): 83-106.

"From Jamaican Slavery to Haitian Freedom: The Case of the Black Crew of the Pilot Boat Deep Nine." Journal of Negro History 67 (1982): 328-39.

"The Slave Trade to Jamaica, 1702-1808." In Trade, Government and Society in Caribbean History, 1700-1920: Essays Presented to Douglas Hall, edited by B. W. Higman, pp. 1-16. Kingston, Jamaica: Heinemann Educational Books, 1983.

"The Domestic Economy." In Colonial British America: Essays in the New History of the Early Modern Era, edited by Jack P. Greene and J. H. Pole, pp. 43-85. Baltimore: Johns Hopkins University Press, 1984.

"Exploitative Systems: Slavery, Commerce, and Industry." In Research Guide to Central America and the Carbbean, edited by Kenneth J. Grieb, pp. 207-16. Madison: University of Wisconsin Press, 1985.

"The College Student Employment Project at the University of Kansas, 1934-1943." Kansas History 8 (1985-86): 206-16. 
"The Maroons of Jamaica, 1730-1830: Livelihood, Demography and Health." In Out of the Howse of Bondage: Runaways, Resistance and Marronage in Africa and the New World, edited by Gad Heuman, pp. 152-72. London: Frank Cass, 1986.

"The Doctor and the Buccancer: Sir Hans Sloane's Case History of Sir Henry Morgan, Jamaica, 1688." Journal of History of Medicine and Allicd Sciences 41 (1986): 76-87.

"Eric Williams and Capitalism and Slavery: A Biographical and Historiographical Essay." In British Capitalism and Caribbcan Slavery: The Legacy of Eric Williams, edited by Barbara Solow and Stanley L. Engerman, pp. 317-45. New York: Cambridge University Press, 1987.

"Changing Sugar Technology and the Labour Nexus in the British Caribbean, 1750 1900, with Special Reference to Barbados and Jamaica." New West Indian Guide/Nicuwe West-Indische Gids 63 (1989): 59-93.

"From Slavery in Missouri to Freedom in Kansas: The Influx of Black Fugitives and Contrabands into Kansas, 1854-1865." Kansas History 12 (1989): 28-47. Reprinted in Kansas Revisited: Historical Images and Perspectives, edited by Paul E. Steuwe, pp. 79-99. Lawrence, Kansas: University of Kansas, Division of Continuing Education, 1990.

"Captain Bligh, the Breadfruit, and the Botanic Gardens of Jamaica." Journal of Caribbean History 2.3 (1989): 18-50.

"The Condition of the Slaves in the Settlement and Economic Development of the British Windward Islands, 1763-1776." Journal of Caribbean History 24 (1990): 121 - 45.

"Slave Medicine in Jamaica: Thomas Thistlewood's 'Receipts for a Physick', 1750)- 1786." Jamaican Historical Review 17 (1991), 1-18.

"From Chattel to Wage Slavery in Jamaica, 1740-1860." In Proceedings of the Conference on From Chattel to Wage Slavery, edited by Michael Twaddle. Slavery \& Abolition 14 (1993): 13-40.

"Strategies of Slave Subsistence: The Jamaican Case Reconsidered." In Chattel Slaves to Wage Slaves: Labour Bargaining in the Americas, edited by Mary Turner, pp. 48-67. London, Indianapolis and Bloomington: James Currey and University of Indiana Press, 1995.

\section{PUBLISHED LECTURES}

"Why the Condition of Slaves was 'Less Intolerable in Barbadoes, than in the other Sugar Colonies"' (The 1987 Elsa Goveia Memorial Lecture). In Inside Slavery: Process and Legacy in the Caribbean Experience, edited by Hilary McD. Beckles, pp. 31-42. Kingston, Jamaica: Canoe Press University of the West Indies, 1996. 


\section{BOOK REVIEWS}

Richard Pares, "Yankees and Creoles: The Trade between North America and the West Indies before the American Revolution," William and Mary Quarterly 13 (1956): 414-17. lohn H. Davis, and Ray A. Goldberg, "A Concept of Agribusiness," American Economic Review 48 (1958): 211-13.

Aaron M. Sakolski, "Land Tenure and Land Taxation in America," American Economic Review 48 (1958): 739-40.

I. Keith Horsefield, "British Monetary Experiments, 1650-1710," American Economic Review 51 (1961): 200-02.

Curtis P. Nettels, "The Emergence of a National Economy, 1775-1815," The University of Kansas Alumni Magazine (1962): 33.

Richard Eburne, "A Plain Pathway to Plantations (1624)," Caribbean Studies 3 (1964): 49. 51 .

David H. Makison, "Barbados: A Study of North-American West-Indian Relations, 1739-1789," Business History 8 (1966): 158-59.

Henry Hamilton, "An Economic History of Scotland in the Eighteenth Century," lournal of Economic History 24 (1967): 270-72.

Carl Ortwin Sauer, "The Early Spanish Main," Joumal of Economic History 27 (1967): 265.66.

Elsa V. Goveia, "Slave Society in the British Leeward Islands at the End of the Eighteenth Century," Agricultural History 42 (1968): 160-61.

Sir Harold Mitchell, "Contemporary Politics and Economics in the Caribbean," Journal of Economic History 29 (1969): 374-75.

Carleen O'Loughlin, "Economic and Political Change in the Leeward and Windward Islands," Journal of Economic History 29 (1969): 379-80.

Arthur R. Corwin, "Slavery and the Abolition of Slavery in Cuba, 1817-1886," Agricultural History 43 (1969): 416-17.

Michael Craton, and James Walvin, "A Jamaican Plantation: The History of Worthy Park, 1670-1970," Business History Review 45 (1971): 548-49.

Carl Bridenbaugh, and Roberta Bridenbaugh, "No Peace beyond the Line: The English in the Caribbean, 1524-1690," Journal of American History 59 (1972): 676-78.

Franklin M. Knight, "Slave Society in Cuba During the Nineteenth Century," American Historical Review 77 (1972): 848.

Richard S. Dunn. "Sugar and Slaves: The Rise of the Planter Class in the English West Indies, 1624-1713," Journal of Southern History 39 (1973): 98-99.

Alan H. Adamson, "Sugar Without Slaves: The Political Economy of British Guiana, 1838-1904," American Historical Review 78 (1973): 1153. 
Cyril Hamshere, "The British in the Caribbean," Journal of American History 60 (1973): $781-82$.

Gwendolyn Midlo Hall, "Social Control in Slave Plantation Societies: A Comparison of St. Domingue and Cuba," William and Mary Quarterly' 30 (1973): 3.39-41.

James F. Shepherd, and Gary M. Walton, "Shipping, Maritime Trade and the Economic Development of Colonial North America," Florida Historical Quarterly 52 (1974): 324-26.

Joseph Albert Ernst, "Money and Politics in America, 1755-1775: A Study in the Currency Act of 1764 and the Political Economy of Revolution," Florida Historical Quarterly 53 (1975): 347-49.

Ralph Davis, "The Rise of the Atlantic Economies," Journal of European Economic Histon 4 (1975): 796-98.

Peter H. Wood, "Black Majority: Negroes in Colonial South Carolina, From 1670 through the Stono Rebellion," Florida Historical Quarterly 53 (1975): 470-71.

B. L. Anderson, ed., "Capital Accumulation in the Industrial Revolution," Philological Quarterly 54 (1975): 717.

Jacob R. Marcus, and Stanley F. Chyet, eds., "Historical Essay on the Colony of Surinam, 1788," Philological Quarterly 54 (1975): 758-59.

John Foster, "Class Struggle and the Industrial Revolution: Early Industrial Capitalism in Three English Towns," Philological Quarterly 54 (1975): 740-41.

K. G. Davies, "The North Atlantic World in the Seventeenth Century," William and Mary Quarterly 33 (1976): 690-92.

David Brion Davis, "The Problem of Slavery in the Age of Revolution, 1770-1823," New York Historical Society Quarterly 60 (1976): 85-87.

Edgar T. Thompson, "Plantation Societies, Race Relations, and the South: The Regimentation of Populations: Selected Papers," Florida Historical Quarterly 55 (1976): 203-05.

William A. Green, "British Slave Emancipation: The Sugar Colonies and the Great Experiment, 1830-1865," Agricultural History 51 (1977) 783-85.

Peter C. Hogg, "The African Slave Trade and its Suppression: A Classified and Annotated Bibliography of Books, Pamphlets and Periodical Articles," in The Eighteenth Century: A Current Bibliography, edited by Robert R. Allen, n.s. 1-for 1975 (Philadelphia and Los Angeles: American Society for Eighteenth-Century Studies, 1978), p. 56.

Roger Anstey, "The Atlantic Slave Trade and British Abolition, 1760-1810", in The Eighteenth Century: A Current Bibliography, edited by Robert R. Allen, n.s. 1-for 1975 (Philadelphia and Los Angeles: American Society for Eighteenth-Century Studies, 1978), pp. 20-21. 
Sevmour Drescher, "Econocide: British Slavery in the Era of Abolition," Journal of Economic History 38 (1978): 764-66.

B. W. Higman, "Slave Population and Economy in Jamaica, 1807-1834," Agricultural History 52 (1978): 321-22.

Michael Craton, "Searching for the Invisible Man: Slaves and Plantation Life in Jamaica," William and Mary Quarterly 37 (1980): 337-39.

lacob M. Price, "Capital and Credit in British Overseas Trade: The View from the Chesapeake, 1700-1776," American Historical Review 86 (1981): 837.

Kenneth F. Kiple, and Virginia Himmelsteib King, "Another Dimension to the Black Diaspora: Diet, Disease, and Racism," Slavery o Abolition 5 (1984): 177-79.

Kenneth F. Kiple, "The Caribbean Slave: A Biological History," Hispanic American Historical Review 66 (1986): 584-85.

C. Robert Haywood, "Trails South: The Wagon-Road Economy in the Dodge City-Panhandle Region," Kansas History 10 (1987): 241.

David W. Galenson, "Traders, Planters, and Slaves: Market Behavior in Early English America," Economic Development and Cultural Change 37 (1988): 203-08.

I. R. Ward, "British West Indian Slavery, 1750-1834: The Process of Amelioration," Slavery o Abolition 11 (1990): 115-17.

Michael Duffy, "Soldiers, Sugar and Seapower: The British Expeditions to the West Indies and the War Against Revolutionary France," American Historical Review 95 (1990): 487-88.

Thomas Goodrich, "Bloody Dawn: The Story of the Lawrence Massacre," Kansas History 15 (1992): 147-48. 


\section{1 \\ Richard B. Sheridan:

\author{
The Making of a Caribbean Economic Historian
}

HOWARD IOHNSON

In the opening decades of the twentieth century, three United States historians-Ulrich B. Phillips, Frank W. Pitman and Lowell J. Ragatz-were instrumental in establishing economic history as a separate category in British Caribbean historiography. Up to that point, the economic history of the British West Indies had usually been treated as part of the panoramic general studies produced by individuals who were historians by "avocation rather than vocation." In a series of influential books and articles, these U.S. historians established the parameters of present-day discussion on the slave plantation in British Caribbean historical writing. ${ }^{2}$ As B. W. Higman has asserted, the work of these academic historians provided "those central, unifying themes of Caribbean history, the nature of slave society and the economics of slavery." Richard B. Sheridan's scholarly output, with its emphasis on sugar and slavery in the British Caribbean, falls within that distinguished U.S. historiographical tradition. This essay assesses Sheridan's contribution to the literature on Caribbean economic history with particular reference to the intellectual influences on his scholarship, his thematic concerns and the methodologies and source materials which he has employed.

Richard Sheridan was born on 10 February 1918, the eldest son of Bert and Olive Sheridan in Emporia, Kansas, then a small town with a population of approximately 13,000. The Sheridans were Quakers and for Richard, whose early social life centred on the church, religion was a formative influence on his 
outlook and temperament: "I imbibed the Quaker beliefs in pacifism, a modest but not austere lifestyle, and the Protestant virtues of honesty, thrift, industry and good works. ${ }^{\text {. }}$ As Sheridan has admitted, the teachings of the Quaker faith were also to shape his political views.

Sheridan completed both his high school and undergraduate education in Emporia. He graduated from the local high school in May 1936 and entered the Kansas State Teachers College later that year where he initially took pre-engineering courses. Without the necessary background in science and mathematics which would have made engineering a viable option, Sheridan turned reluctantly to courses in history and government, business, economics and education in his sophomore year. Although he demonstrated an aptitude for and excelled in history and government courses, the difficulty involved in securing a teaching appointment in those areas at the height of the Depression, ultimately dictated Sheridan's academic concentration. As a result, he decided on a Bachelor of Science in Commerce degree, taking courses in typewriting, shorthand, business arithmetic, bookkeeping, economics and marketing. In addition, he completed courses in history and government as his minor field of study.

After graduating in 1940, Sheridan taught business skills in two small-town high schools in his native state: in Edna in the southeast in 1940-41 and Bancroft in the fall of 1941. In December 1941, he left for Washington, D.C. where he had secured an appointment as a clerk typist in the Quartermaster Corps of the Army, after taking a civil service examination. That month was also marked by the Japanese attack on Pearl Harbor and U.S. entry into World War II. Sheridan received notices from his draft board in Emporia with increased regularity and urgency, and finally decided to enlist in the Navy. He was initially made a Yeoman Third Class in the United States Naval Reserve but (as a college graduate) successfully applied for a commission as an Ensign. He saw active service during the war on the U.S.S. Kretchmer which, among its several functions, escorted convoys within the Caribbean and tankers transporting high octane aviation fuel between Curaçao and Naples, Italy. Sheridan ended the war as a lieutenant, having served as the ship's communications officer and a deck officer.

On his return to Kansas, Sheridan resumed his education by enrolling for an M.S. in Education at the University of Kansas in the spring semester of 1946 - a career decision made possible by the provisions of the G.I. Bill. His 
primary objective in undertaking graduate work was to improve his chances of obtaining a better teaching position at the high-school level. However, his graduate school experience decided him on a different career path. During this period he completed several advanced courses in economics and in economic history "because they linked economics together with history and government." On the completion of his degree, he was invited to join the University of Kansas Department of Economics where he taught Introductory Economics and American Economic Development in the 1947-48 academic year. By the time of his departure for the London School of Economics (LSE) in 1948 to pursue a Ph.D. in economic history, Sheridan had opted for a teaching career at the university level.

Working under the supervision of F. J. Fisher, then Reader in Economic History at LSE, Sheridan selected "The Sugar Trade of the British West Indies from 1660 to 1756, with Special Reference to the Island of Antigua," as the topic for his $\mathrm{Ph}$.D. thesis. This subject reflected his interest in researching "something that had to do with the Old World and the New World." ${ }^{\text {"H }}$ His wartime naval service in the Caribbean had aroused his interest in the region, and his journeys across the Atlantic, escorting convoys with vital supplies, must also have heightened his awareness of its historical importance as a trading area. The choice of his area of study was clearly influenced by the existing body of work in US colonial history and by current trends in North American economic history. Charles McLean Andrews, the leading figure in the "imperial school" of historians, wrote US colonial history within a transatlantic framework in which he also examined British settlement in the West Indies. ${ }^{7}$ At the outset of his doctoral studies, Sheridan had been directed by Fisher to read the four massive volumes of Andrews' The Colonial Period of American History. ${ }^{8}$ F. W. Pitman, Andrews' student, had, moreover, published a pioneering study on the growth of the West Indian plantation economies and their external trade, which had focussed on the economic links between the Caribbean colonies, the mainland colonies and Britain. Pitman's conclusions about the importance of sugar colonies to the economic development of both Britain and the mainland colonies would be further confirmed by Sheridan's findings on the nature of the Atlantic economy. ${ }^{9}$

Sheridan's research area was also suggested by two relatively new fields of inquiry which engaged the attention of US economic historians: the business cycle and business history. In the United States, these themes attracted the bulk 
of graduate students in the interwar years and beyond. ${ }^{10} \mathrm{~A}$ more direct intellectual influence was the work of the Canadian economic historian, H. A. Innis. In historical studies of the fur trade and the cod fisheries, Innis advanced the staple approach as the unifying theme of Canadian development. He argued that export staples formed the leading sector of the Canadian economy and demonstrated how each of these products had different effects on the process of colonial development. " Sheridan, like Eric Williams before him, would find Innis' analysis of the impact of the dominant export sector on the Canadian economy applicable to the British Caribbean context.

The academic environment at LSE provided the major early intellectual influences which shaped Sheridan's development as an economic historian. By the time he completed his Ph.D. in 1951, he had already worked out the main approaches to his discipline which would inform his research and writing. In the late 1940s, the Department of Economic History at LSE was one of the key centres of this relatively new subject specialism and was staffed by eminent scholars such as R. H. Tawney and T. S. Ashton. Foremost among Sheridan's influences was F. J. Fisher whose research area was the social and economic history of London and England between 1500 and $1700 .^{12}$ Fisher's area of specialisation might not appear directly relevant to Sheridan's research concerns, but his focus on trade and the role of London as an economic capital, were to prove invaluable in the supervision of a thesis on the British West Indian sugar trade. His work on London's overseas trade in the early eighteenth century based, in part, on the Customs Accounts and metropolitan Port Books, must have inspired Sheridan's pioneering exploration of the Customs House Accounts and the Revenue Accounts of the Treasury in connection with the colonial economies. ${ }^{13}$ Fisher was also interested in colonial economic development, especially that of the tropical colonies, on which he taught a course in the postwar years. He expressed the view that "an understanding of the economy of Tudor and Stuart England is not the worst equipment for a study of the economically less developed parts of the modern world. ${ }^{.14}$ One aspect of Fisher's influence on Sheridan's approach to economic history was his perspective on the role of economics. According to P. J. Corfield, Fisher "viewed economics as an analytical tool rather than as a satisfactory interpretation of human behaviour." ${ }^{\text {15 }}$

Professors R. H. Tawney and T. S. Ashton were also important formative influences on Sheridan during his years of graduate training. Tawney had 
retired from his personal chair before Sheridan's arrival but continued to offer a seminar. Sheridan was a member of that seminar and Tawney was later to serve on his Ph. D. examining committee. Tawney's views as a Christian Socialist reinforced Sheridan's left-of-centre political outlook, while his research findings on Tudor and Stuart economic history would both inspire and inform Sheridan's discussion of the economic history of the British Caribbean. ${ }^{16}$ Ashton's work and influence reflected the most recent developments in economic history and the quantitative nature of the subject. One of Ashton's main contributions to British economic history was his reliance on statistics to "illuminate the cycles of economic growth" in eighteenth-century England. ${ }^{17}$ Ashton's influence would have strengthened the business history orientation of Sheridan's research for, as $\mathrm{R}$. S. Sayers has pointed out, "the histories of individual firms formed an integral part of his industrial histories." ${ }^{18}$

On completing his Ph.D., Sheridan returned to the United States where he was appointed Assistant Professor in the Department of Economics at the University of Kansas in 1952. Initially, his time was divided between teaching responsibilities and research on Kansas economic history at the Bureau of Business Research. These research activities resulted in the publication of $A n$ Economic History 1500-1900: Economic Development in South Central Kansas in 1956. With the completion of that project, Sheridan turned his attention to collecting additional material for the revision of his thesis and the publication of his research findings in a series of articles dealing primarily, but not exclusively, with the Caribbean.

The articles which Sheridan published between 1957 and 1961 were based mainly on the historical records which he had consulted in Great Britain. These essays reflect some of his enduring thematic concerns and the intellectual influences on his work. They also demonstrate some of the methods which he has consistently employed in his writing. In his first article, "The Molasses Act and the Market Strategy of the British Sugar Planters," Sheridan examined the controversy over this legislation "in terms of the international sugar economy" which linked the North American colonies, the European colonies in the Caribbean, the British Isles and continental Europe in an Atlantic trading network. ${ }^{19}$ This approach suggests the influence of H. A. Innis who had earlier discussed the Canadian cod fisheries as "the history of an international economy." ${ }^{20}$ Sheridan's interest in the transatlantic context was also evident in his article on "The British Credit Crisis of 1772 and the American Colonies." 
Although the discussion centred on the effects of the crisis on the tobacco-growing Chesapeake colonies, there was a transatlantic dimension. He showed how staple production in the mainland and Caribbean colonies was financed. This involved an examination of the metropolitan financial institutions, capital investment in the expanding British Empire, and the nature of debtor-creditor relations. In this interlocking credit network, Sheridan argued, "the crisis of 1772 which originated in London . . spread to Scotland, the Continent of Europe and the outlying parts of the British empire." ${ }^{11}$

In the remaining essays from this period, Sheridan focussed on the economic history of the Caribbean colonies. The first of these was "Letters from a Sugar Plantation in Antigua, 1739-1758," which reproduced letters written by Dr. Walter Tullideph, sugar planter and attorney of Antigua, to Sir George Thomas, an absentee planter. These letters, excerpted from an unpublished letter book, were selected to provide "insight into the problems of plantation management and the functions performed by attorneys and overseers." ${ }^{22}$ This article is significant as the earliest example of Sheridan's detailed use of family plantation papers. Richard Pares had pioneered this practice (in the case of the British Caribbean) in A West India Fortune but it would become increasingly identified with Sheridan's historical scholarship. ${ }^{23}$ In "Samuel Martin, Innovating Sugar Planter of Antigua, 1760-1776," Sheridan also relied on private papers to revise the traditional view of the planter class as generally uninterested in the introduction of improved agricultural techniques. In this micro-study of Martin's planting career, he discussed plantation layout, the methods of tillage and processing, capital and labour requirements, technology and the role of management. Martin, Sheridan demonstrated, "sought to introduce ... innovations into an environment that was generally hostile. ${ }^{\text {24 }}$

The two most important contributions to Caribbean historiography from this phase of Sheridan's writings are those articles which discuss "The Commercial and Financial Organization of the British Slave Trade, 1750-1807," and "The Rise of a Colonial Gentry in Antigua, 1730-1775." In the 1958 article on the slave trade, Sheridan refuted the commonly-held view that the triangular trade remained essentially unchanged over its 150 -year existence. He argued that the West India branch of the trade was initially controlled by slave merchants but became increasingly dominated by sugar planters who appointed Londonbased commission agents to market their crops and perform a wide range of financial services. The slave merchants, Sheridan contended, also lost much of 
the slave factorage business in the West Indies to the commission agents. As a result, London became as involved in the slave trade as Liverpool. This article is notable for the appearance, in embryonic form, of a central argument in Sheridan's writing on sugar and slavery: that a measure of vertical integration existed within a network of family enterprises (spanning the colonies and the metropolis) which performed most economic functions associated with the sugar industry. ${ }^{25}$

In his 1961 study of the rise of a colonial gentry in Antigua, Sheridan investigated the social origins of the island's economic elite and the diverse sources of wealth and income which allowed members of that group to retire to England. In this examination, he used prosopography as his principal method, carrying out both career and social reconstitution of members of sixty-five families over several generations. The source material for the multiple-career biographies included the genealogical studies of Vere Langford Oliver, and the letter books of planters and merchants. In this analysis, Sheridan demonstrated the changing composition of the Antiguan ruling elite and developed an argument, earlier advanced by Richard Pares, that colonial planters and London-West India merchants were often linked by ties of marriage and kinship. ${ }^{26}$

This article, which was as much an exercise in social as in economic history, reflected the influence of two British historians. The subject was clearly inspired by R. H. Tawney's celebrated article, "The Rise of the Gentry, 1558-1640," in which he had described the emergence, in England, of a new social class composed of landowners, office-holders, lawyers, merchants and other men of substance. ${ }^{27}$ The other historian was Sir Lewis Namier whose "calculated use of structural analysis" in The Structure of Politics at the Accession of George III. became widely influential in historical writing, especially in the post-Second World War years. ${ }^{28}$ Prosopographical analysis subsequently became a regular feature of Sheridan's work, whether he wrote on the plantation economy or on the slaves' medical history.

The period 1962-71 saw a shift in the focus of Sheridan's work from the external aspects of the sugar industry (trade, finance, and markets) to the internal organisation of the plantation economy. This changed emphasis reflected, in part, the nature of the source materials which he consulted in Jamaican archives during 1962-63 on a Fulbright Research Scholarship. Sheridan's historical analysis also demonstrated his responsiveness to "changing 
patterns of events and currents of opinion." ${ }^{29} \mathrm{~A}$ major influence on his writing, during this period, was the process of decolonization in the major British Caribbean colonies. In his 1963 article, which examined "Temperate and Tropical: Aspects of European Penetration into Tropical Regions," Sheridan noted that it was "no longer possible to view the tropics solely from the standpoint of Western Civilization." ${ }^{30}$ The period of decolonization, as he recognized, provided an opportunity to assess the role of the British Caribbean in the growth of the metropolitan economy: "From the vantage point of the colonial revolt it will be instructive to re-examine the role of tropical colonies, and particularly the West Indian plantation colonies, in the century or more leading up to the democratic and industrial revolutions. ${ }^{31}$ Sheridan's perspective on the Caribbean past was also shaped by the emergence of development economics, which focussed on problems of Third World economic development in the post-war years. ${ }^{32}$ He thus wrote with a consciousness of the widening gap between the rich and poor nations and an interest in exploring the historical origins of contemporary underdevelopment. ${ }^{33}$

A constant theme of Sheridan's historical writing during this period was the accumulation of wealth in the British Caribbean (at the family and colonial levels) and its eventual transference to the metropolis. His 1964 article, "Planter and Historian: The Career of William Beckford of Jamaica and England, 1744-1799," was the first of a series of case studies which traced the rise of three colonial planting families to great wealth and power. ${ }^{34} \mathrm{His}$ central argument in these studies was that colonial planters extracted wealth from the Caribbean colonies not only by sugar production but also by active involvement in trade and finance in Great Britain. Sheridan contended that, in the eighteenth century, planting families frequently established financial ties with London sugar factors who were often family members. In a discussion of the career of "Simon Taylor, Sugar Tycoon of Jamaica, 1740-1813," he also demonstrated how this planter-attorney, a lifelong resident of the colony, transferred wealth and income to England by direct investment in government securities and a financial interest in a London trading house. ${ }^{35}$

In the case studies relating to Jamaica, Sheridan pioneered the use of a wide range of local records (housed in the newly-reorganised Island Record Office in Spanish Town) to illuminate the operation of the plantation system, especially at the level of the individual unit. Manuscript sources like wills, land patents, inventories, deeds, and crop accounts, had hitherto been so infre- 
quently used by academics that his case study of William Beckford was "intended, in part, at least to show how the Spanish Town papers may contribute to our understanding of plantation history. ${ }^{36}$ The two principal series which he consulted were the Inventories of personal property drafted for the execution of wills and the Accounts Produce, which were annual returns of produce sold by plantations owned by absentee proprietors. It was Sheridan's achievement to recognise the importance of probate records as a source of quantitative data on colonial economic growth and of detailed information useful in constructing career profiles for the colony's social and economic elite. ${ }^{37}$ These records also provided other kinds of data, including demographic information on the slave population. As Sheridan observed: "the Beckford estate inventories yield a wealth of information concerning the labour force and livestock population. In fact, each Negro slave is listed separately by name, occupation, and appraised value, and there are broad classifications by age group and sex." ${ }^{38}$

In "The Wealth of Jamaica in the Eighteenth Century," Sheridan measured wealth levels in "the richest colony in the British Empire" between 1741 and 1775. This article addressed a question which had been initially posed in the eighteenth century and had continued to divide modern historians - whether the colonies represented a profit or loss to Great Britain. Although he recognised the contribution of historians like Pitman and Williams to this debate, Sheridan believed that their conclusions had been based on limited data. He admitted that he was not asking new questions but rather re-evaluating the old generalisations on the basis of a wider range of sources. ${ }^{39}$

Sheridan's re-examination of questions raised by Williams in Capitalism and Slavery was based primarily on the probate records and the Accounts Produce in the Jamaica Archives. As he noted: "these series yield statistical data of a neutral and fairly objective nature. The data is sufficiently abundant so that, in conjunction with other materials, it will be possible to estimate the wealth of Jamaica in selected years with some degree of reliability. ${ }^{40}$ Using the "inventory aggregation method," Sheridan estimated that the total wealth of Jamaica in the years before the American War of Independence was no less than $\mathfrak{E} 18,000,000$ sterling. His research corroborated Williams' thesis that sugar production in the British Caribbean resulted in substantial profits which were generally repatriated to Great Britain. Sheridan argued that in the closing years of the eighteenth century, Britain derived between eight and ten percent of its income from the West Indies. Although he advanced his arguments about the colonial 
contribution to the metropolitan economy mainly on the basis of global estimates of wealth and income, the prosopographical method was an important aspect of his discussion.

In "The Plantation Revolution and the Industrial Revolution, 1625-1775," Sheridan lent support to yet another of Williams' major arguments in Capitalis $m$ and Slavery: that the slave plantations provided the capital which financed the Industrial Revolution. In this article, however, he developed and extended Williams' familiar argument to include "a whole trading area of economic interactions" based on the Atlantic." In Sheridan's formulation, the slave plantations remained the most important element in the growth of the Atlantic trading area whose constituents included the West African slave trade, the trade in foodstuffs, building materials and livestock with North America, Ireland, Bermuda and the wine islands and the informal empire trade with the Spanish Main and Brazil. These interlocking trading relationships, he argued, yielded both direct and indirect economic benefits to the metropolis. Sheridan explained the economic implications of the Atlantic trading area for the metropolitan economy in terms of $\mathrm{M}$. H. Watkins' staple theory of economic growth which emphasised the "linkage effects" of increased activity in the export sector on domestic investment. ${ }^{42}$ Thus he concluded: "Britain's industrial development was in no small way a process of diversification around her export base in the Caribbean slave-plantations. ${ }^{\mathrm{n} 3}$

Sheridan's findings on the wealth of Jamaica and the West Indian contribution to British economic growth did not long go unchallenged. In a rejoinder, Robert Paul Thomas, using a cost-benefit analysis largely based on data provided by Sheridan's article, argued that the West Indian colonies were not profitable to Britain but rather retarded its growth. He noted that Sheridan had not taken into account either the costs involved in the administration and defence of the colonies, or the operation of a monopolistic sugar market which taxed British consumers to the advantage of merchants and planters. Thomas arrived at his conclusions by formulating "a counterfactual proposition" about what Britain's income would have been without the West Indies. He estimated that "the income of Englishmen would have been at least $£ 500,000$ higher in the absence of the West Indies from the empire. ${ }^{\text {"4t }}$ This clash of opinion between Sheridan and Thomas was primarily about the historical methods employed by traditional economic historians and those who adopted the "cliometric" meth- 
ods of the "new" economic history. This debate illuminates Sheridan's views on questions of methodology.

Sheridan's methodological approach was shaped by his graduate studies in England at a time when economic history was becoming more quantitative in nature. F. J. Fisher, in his inaugural lecture on his appointment to the Chair of Economic History at LSE in 1956, commented on the current state of British economic historiography: "A generation ago, the main requirement of an economic historian was that he should be able to read since most of his sources were literary. ... Today, the first requirement of an economic historian is that he should be able to count, for his materials are highly statistical." 45 Sheridan's training thus demanded an ability to manipulate quantitative (especially statistical) data. By the mid-1960s, however, economic historians were increasingly economists who applied "highly developed economic theory to the quantitative record of history. ${ }^{46}$ The practitioners of cliometrics relied on sophisticated statistical techniques and the use of models which involved counterfactual hypotheses. Most studies in the new economic history, as Elias H. Tuma has observed, "set up models of competitive economic behavior in which rationality and mobility of factors of production are assumed, realistically or not, to prevail. ${ }^{\text {"47 }}$ This new trend in the methods of economic history would gradually alienate Sheridan from members of his own department: "The kind of economic history I learned and taught was kind of put on the back burner, downgraded to make room for an emphasis on statistics and 'pure' theory. ${ }^{\text {"48 }}$

Sheridan's initial scepticism about the "new" economic history was based primarily on a belief that its methods did not adequately explain the economic past. His published work provides several clues to the sources of his misgivings. In his response to Thomas's critique, for example, he recognised the usefulness of cost-benefit analysis as a heuristic device, but questioned its applicability to "a pre-statistical and nascent capitalist era," given its rudimentary state of development. ${ }^{49}$ Sheridan was, moreover, disturbed by the tendency among cliometricians to view economic history as "past economics." He took the view that a valid social income account of the British West Indies could not exclude "non-economic factors and imponderables." ${ }^{50}$ For Sheridan, Thomas's use of the counter-factual approach was "an essay into conjectural history." ${ }^{51}$ In 1971, he observed of the "new" economic history:

One of the shortcomings of the "new" economic history, as I view it, is that disproportionate emphasis is put on measurement of long-term growth. 
Colonial economic growth was obviously irregular, being influenced by such phenomena as wars, natural disasters, poor communication, and government trade policies. ${ }^{52}$

By 1984 , Sheridan was reconciled to the methods of the cliometricians, but continued to regard economic history as a subject which should integrate the disciplines of history and economics:

We should keep in mind that economic history is the product of the marriage of two separate disciplines, that its survival depends on maintaining a balance between the historian's interest in the process of change and the study of personal and cultural elements on the one hand and the economist's interest in theory and quantitative evidence to verify hypotheses on the other. We should keep in mind that many, if not most, of the important questions in economic history do not lend themselves to quantitative treatment, that quantitative methods are only a tool, and that explanation requires both quantitative and qualitative evidence. ${ }^{53}$

In his work, Sheridan persisted in the traditional empiricism, emphasising "economic forces in a broad social setting. ${ }^{54}$ This approach was evident in his most significant publication of the 1962-71 phase-the two chapters in Caribbean history which he wrote for A History of the West Indies proposed by the Department of History of the University of the West Indies (UWI) ${ }^{55}$ In those chapters-The Development of the Plantations to 1750 [and] An Era of West Indian Prosperity, 1750-1775-he examined the organisation and operation of the plantations and their contribution to the metropolitan economies in a comparative framework that included selected French and Spanish colonies. Sheridan was careful "to illustrate the similarities and differences that existed between the French and British colonies and to compare and contrast the developments in the smaller and larger islands. ${ }^{n 6}$ His discussion reflected his earlier thematic concerns: the social origins of the planter class, wealth-holding in the plantation colonies and their role in the emergent Atlantic economy.

Sheridan's analysis showed a sensitivity to questions of racial and national identity and the search for a usable past in the Caribbean. His comments on the African contribution to Caribbean plantation society and on slave resistance were thus consciously revisionist:

The African contribution to Caribbean plantation society has not always been sufficiently appreciated. Rather than being primitive food gatherers and hunters, the Africans in the old slaving area had a culture which contained such elements as settled community life, political organisation, 
handicrafts, art and religion . . Neither should it be thought that the African was resigned to a system which appropriated his labour power without monetary compensation or the promise of freedom. ${ }^{57}$

Writing against the background of decolonization and persistent poverty in the Caribbean (a problem highlighted by the work of academic economists at (JWI), Sheridan also emphasised the social costs of plantation production and the role of the plantation in Caribbean underdevelopment:

The plantation was at the vortex of dynamic forces-some creative and others destructive - which culminated in slave revolts, anti-slavery movements, and political and industrial revolutions in North America and Northern Europe. More than any other factor, the extension of plantations depended on slave or indentured labour which was tied to the land. So destructive to life and well-being was this labour system in most parts of the tropical world that insuperable political obstacles have been erected to bringing men and land together on plantation units. Plantation history thus goes far to explain the revolutionary impact of Western civilisation and the revolt of non-Western peoples against Western ascendancy. ${ }^{58}$

The two chapters on Caribbean history were essentially synopses of Sheridan's findings in his monumental Sugar and Slavery: An Economic History of the British West Indies 1623-1775, which was published in $1974 .^{59}$ This volume, based on more than twenty years of multiarchival research, was, as Jack P. Greene noted at the time of its publication, "the most comprehensive and authoritative study yet published on the socioeconomic development of the early British Caribbean. ${ }^{60}$ Twenty years after its publication, Greene's assessment of Sugar and Slavery remains valid. ${ }^{61}$ Several historians had written on aspects of British Caribbean plantation society and economy in the seventeenth and eighteenth centuries, but Sheridan was the first to produce a comprehensive economic history for that period. The principal argument of his study was that "however inhumane, the sugar industry made a notable contribution to the wealth and maritime supremacy of Great Britain. ${ }^{\text {} 62}$ Sheridan supported this contention by extensive and detailed research into the printed and manuscript sources in British and Caribbean archives and by an examination of the external and internal relations of the slave plantation.

In his discussion of the external relations of the slave plantation, Sheridan concentrated on trade and its political regulation, shipping, finance, the markets for sugar products and absentee proprietorship. His analysis of those topics 
benefited from the fact that he covered an extended time period in his study, while in a pioneering discussion, he traced the changing patterns of sugar consumption in English, Scottish, Irish, North American and foreign markets. $\mathrm{He}$ also analysed the fluctuating fortunes of the sugar industry over the long term, identifying the factors that affected the movements in output, costs, and prices. Moreover, he charted the changes in the financial services available to West Indian planters. An important aspect of his discussion on the external relations of the slave plantation was his Namieresque analysis of the West Indian planter interest in the House of Commons and their influence on imperial economic policy. The combined effect of Sheridan's careful research on Members of Parliament with West Indian connections and the London-West India merchants was to direct attention to the existence of a metropolitan-based group (bound to colonial planters by ties of marriage, kinship, and friendship) which was crucial to the successful functioning of the plantation economy.

Sheridan's examination of the internal relations of the slave plantation focused on the settlement of the Caribbean colonies, the sequence of their development as sugar economies, the organisation of sugar production and the slave system. In the case of each colony, he illustrated the stages of economic growth and the concomitant rise of a planter class by individual career profiles. In Jamaica, for example, he recreated the emergence of the Dawkins family as members of the planter elite by research on land patents, quit rent books and inventories. This detailed examination of colonial social structure and the careers of individual planters allowed Sheridan to revise two commonly-held views on the social origins of the planter class and the quality of plantership. Lowell Ragatz had argued, for example, that the plantation colonies became "the dumping-ground for the riff raff of the parent country" and that the quality of plantership had subsequently deteriorated. ${ }^{\text {63 }}$ Sheridan dismissed Ragatz's characterization as "a static rather than a dynamic view of Creole society and its principal actors. ${ }^{164} \mathrm{He}$ contended that the origins of the planter class were more diverse than previously thought and demonstrated that Caribbean planters were willing to experiment in an effort to improve plantation management especially after 1750 - "the near monoculture era."

Sheridan's treatment of slaves and slavery was, by contrast with his analysis of other aspects of plantation society and economy, almost perfunctory. In a chapter on "Slavery and Sugar," he briefly discussed the shift from Indian slavery and white indentured servitude to African slavery, the stages in Caribbean 
plantation slavery, the dimensions of the slave trade and British participation in that enterprise. He dealt with the subject of runaways and rebels but did not assess bow slave rebellions might have affected sugar production. His case study of Roaring River Estate in Westmoreland, Jamaica, examined the organisation of labour on a sugar plantation, drawing attention to the wide range of slave occupations and skills. Sheridan acknowledged the importance of the slaves' provision economy which emerged in Jamaica alongside the sugar economy but neglected to provide an extended discussion of these developments in that colony and elsewhere in the British Caribbean. This omission is best explained by the study's emphasis on the major export staple-sugar-and on external trade. Writing in 1984, Sheridan provided a critique of this aspect of his work: "It is perhaps correct to say that the staple theory has done more to disguise domestic economic developments in the Caribbean region prior to 1763 than to illuminate them." ${ }^{.65}$

Using the analytical framework of the staple theory, Sheridan argued that the plantation colonies served as a base for the expansion and diversification of an Atlantic trading empire. He asserted, for example, that the development of the sugar plantations was accompanied by "the rise of multivarious channels of trade and shipping which came to constitute an important part of Britain's 'grand marine' empire in the Atlantic basin." ${ }^{66}$ In his supporting analysis, Sheridan developed and extended arguments which had been advanced by Williams and Pares. He discussed, for example, the North American-West Indian trade before the American Revolution, familiar from Pares' Yankees and Creoles, but located his discussion in the broader context of the international sugar trade. ${ }^{.67} \mathrm{He}$ also developed, in detail, Pares' contention that the sugar industry quickly became self-financing and yielded surplus capital for investment in Great Britain. Sheridan similarly provided authoritative support for Williams' argument that the wealth generated by the plantation colonies helped to stimulate the Industrial Revolution. He demonstrated, however, that the metropolis benefited not only from the formal empire in the Caribbean, but also from colonial trade with neigbbouring Spanish colonies and the economic activities of British subjects in Dutch and Danish Caribbean colonies.

Sheridan's use of the staple approach to the study of economic history illuminated the process of economic growth, particularly in the metropolis. However, the emphasis on sugar as the staple which shaped colonial development served to obscure other aspects of colonial economies, like Jamaica, which 
were diversified. B. W. Higman has since argued that Sheridan understated the contribution of the non-sugar sector in his estimate of Jamaica's wealth. ${ }^{68}$

With the publication of Sugar and SlaverySheridan turned his attention from the production and unequal distribution of wealth derived from the Caribbean slave plantations to the social costs of slavery. This change in focus was foreshadowed in comments in his rejoinder to Thomas's critique of "The Wealth of Jamaica" essay: "when the social costs of Negro slavery are given their due weight it may be argued that the social income account of the sugar colonies had a negative balance. ${ }^{169}$ The form which Sheridan's examination of the social costs of sugar and slavery eventually took was shaped, in part, by developments in the historiography of slavery in the Americas. Among the influences on his scholarship was Philip D. Curtin's The Atlantic Slave Trade: a Census which examined the demography of the slave trade in a hemispheric context. ${ }^{70}$ As David Brion Davis has observed of Curtin's study: "His careful assessments underscored the importance of the natural increase of the black population in the United States, of the net natural decrease of the slave populations in the sugar colonies and in Brazil, and of the long dependence of the latter regions on a continuing labor supply from Africa." Curtin's work prompted further research on "regional mortality and morbidity rates, on the sex and age structure of slave populations, on African origins and changing patterns of slavetrading. ${ }^{71}$

Another major influence on Sheridan was Robert W. Fogel and Stanley L. Engerman's Time on the Cross: The Economics of American Slavery which concluded, inter alia, that the slave population in the US South achieved a standard of living comparable to that of free industrial labour. In a discussion of the nature of the treatment which slaves received, Fogel and Engerman examined slave rations and slave diet, medical care, life expectancy and infant mortality, and provisions for clothing and housing the slaves. This pioneering work on the health and demography of the slave population inspired several studies in demography, nutrition and biomedicine. ${ }^{72}$

The studies by Curtin and Fogel and Engerman raised questions about the material welfare of slave populations in the Americas for which Sheridan provided answers in the case of the British Caribbean. In a series of articles published between 1972 and 1983, he investigated aspects of slave health and demography in the Atlantic slave trade and the Caribbean. The first of these, "Africa and the Caribbean in the Atlantic Slave Trade," argued that the major 
influences on the Atlantic slave trade, in Africa and the Caribbean, were changing agricultural systems, land-labour ratios, demography, epidemiology and the varied slave systems. Subsequent papers dealt with aspects of the Atlantic slave trade. "The Guinea Surgeons on the Middle Passage," for example, discussed the provision of medical services in the British slave trade. Sheridan examined the disease environment on the slave ships and the attempts of medical officers to treat the diseases which affected the slaves. He also assessed the importance of advances in medical science and practice and increased government regulation in reducing mortality on the Middle Passage. Sheridan did not abandon his established methodological approach in his new research venture. Prosopography remained, for example, an essential component of his historical method. Thus he carefully reconstructed the careers of the Guinea surgeons, examining their training, recruitment, compensation and medical practice. $^{73}$

In his investigation of slave health and demography, Sheridan concentrated primarily on the Caribbean slave plantations where the slave population experienced high mortality rates especially during the period of "seasoning." "Mortality and the Medical Treatment of Slaves in the British West Indies" examined the death rates of slaves in Barbados, Jamaica, and Antigua, and argued that the improvement in demographic performance in the last century of slavery could partly be explained by the effectiveness of medical treatment. ${ }^{74}$ Sheridan also analysed other variables which affected Caribbean slave demography. His discussion of "The Crisis of Slave Subsistence in the British West Indies During and After the American Revolution," thus emphasised the consequences for the slaves rather than the plantation economy: "Together with war and natural disasters, American secession from the British Empire and British mercantile policies resulted in a subsistence crisis that bore heavily upon the slaves in the West Indies. ${ }^{\text {.75 }}$

Sheridan's research on slave demography allowed him to offer an explanation for the failure of British Caribbean sugar colonies (with the exception of Barbados) to produce a self-sustaining slave population. He argued that the planters' continued reliance on the slave trade for a viable plantation labour force was a consciously economic decision, because rearing a child to working age was more expensive than purchasing an imported slave. In the article, "Sweet Malefactor: The Social Costs of Slavery and Sugar in Jamaica and Cuba, $1807-54$, " Sheridan pointed out that in 1830 , rearing a slave to working age in 
Jamaica was estimated to cost almost twice as much as buying a newly-imported slave in Cuba. It was this article which indicated most clearly the shift in the nature of his research interests: "any analysis of the cost of slave-produced wealth must consider the social costs that were borne by the slaves as well as the non-slaves. This fact has been lost in the modern debate on the profitability of the sugar colonies to the British Empire." 76

Sheridan's new interest in the base rather than the superstructure of Caribbean plantation society and economy was reflected in two articles which examined aspects of slave resistance in Jamaica-"The Jamaican Slave Insurrection Scare of 1776 and the American Revolution," and "From Jamaican Slavery to Haitian Freedom: The Case of the Black Crew of the Pilot Boat Deep Nine." 77 These publications must be seen, in part as a response to trends in the historiography of Caribbean slavery. The late 1960s and the early 1970s had witnessed the publication of several books and articles by such Caribbean scholars as Orlando Patterson, Edward Brathwaite and Monica Schuler, examining slavery from the bottom up. ${ }^{78}$ Patterson, in his seminal study, The Sociology of Slavery, had noted, for example, that the emphasis in his analysis would be placed on "the mass of the Negro people." 79 An important aspect of Patterson's book was a discussion of patterns of slave resistance in Jamaica, and Sheridan's subsequent examination of the Jamaican slave insurrection scare of 1776 was located within the framework of Patterson's analysis, as well as Schuler's pioneering discussion of ethnic slave rebellions in the Caribbean.

Sheridan's research interest in slave health and demography culminated in the publication of Doctors and Slaves: A Medical and Demographic History of Slavery in the British West Indies, $1680-1834$ in $1985 .{ }^{80}$ In the preface, he noted that his study was intended to examine "the opposite face of materialist success and riches-namely the catastrophic health and welfare costs of slavery and dependency, in short, the "curse of slavery and monoculture." ${ }^{181}$ His principal objective was to investigate and explain why British Caribbean sugar colonies failed to achieve a natural slave population growth. This involved an assessment of the quality of medical care which slaves received on the Middle Passage and the Caribbean slave plantations. Sheridan identified the common theme of his study as "the significant impact of environmental and economic factors on the health and well-being of the slaves." This perspective on slave health-care and demography reflected, as be admitted, the influence of "the environmental and ecology movements of recent decades. ${ }^{182}$ His interpretation was, moreover, 
informed by the work of William H. McNeill, who argued in Plagues and Peoples that micro- and macro-parasitism shaped world history. ${ }^{8.3}$

In Doctors and Slaves, Sheridan displayed his characteristic mastery of the extant manuscript and printed sources. This study, which focussed on the demographic experience of the Jamaican slave population, was based on extensive research at archives and libraries in the United States, the United Kingdom and Jamaica. Among the sources consulted were the accounts of physicians who had served on slave ships and sugar plantations, and contemporary treatises and manuals on medical care and plantation management. Sheridan evaluated the contemporary diagnoses and treatment of diseases in the light of modem findings in tropical medicine, medical ecology, medical history, demographic theory and epidemiology. In this book (as in the articles which preceded it) collective biography remained a central part of his historical method. His analysis was amply supported by tables and other statistical data.

In a wide-ranging discussion, Sheridan argued that monocrop dependence in the British Caribbean sugar colonies upset the ecological balance, creating an environment which increased the incidence of disease, malnutrition and death among the slave population. In the Caribbean setting, the Atlantic slave trade acted both as a source of labour and a disease vector. The effects of the plantation disease environment on the slave labour force were compounded by a brutal work regime, poor nutrition and an inadequate health-care system which resulted in low fertility and high mortality. Sheridan contended that the provision-ground system did not effectively supplement the slaves' diet because there was little time to tend and market the crops especially during crop time. In a context where women were treated as "work units" rather than "breeding units," and purchasing new slaves was cheaper than rearing them to working age, planters depended on the Atlantic slave trade for the recruitment of a plantation labour force. He attributed the demographic failure of the Caribbean slave population, regardless of sex or age group, in large measure to poor working and living conditions. ${ }^{84}$

By focussing narrowly on the sugar plantation and associating slavery too closely with sugar, Sheridan overlooked the varied demographic experiences of the slave population throughout the British Caribbean. There was little sustained attempt to examine slavery on other plantations or in the urban context. As Higman has demonstrated, most work regimes did not have the devastating 
impact of work on the sugar estates. Slaves employed in the towns had the longest life expectancy because their work was generally less arduous. ${ }^{85}$

Doctors and Slaves has provided the most comprehensive discussion of the medical and demographic aspects of slavery in the British Caribbean to date. The book's importance for Caribbean historiography, however, goes beyond the depth and scope of its treatment of slave demography, since it introduced much that was new. Sheridan examined, in detail, the provisions for medical care in the Atlantic slave trade and on the plantations, extending his discussion to include the architecture, equipment, and personnel, of the slave hospitals. Even more significant was his pioneering study of black folk medicine and its practitioners. He investigated the transformation of West African medical culture in the British Caribbean slave societies and argued that there were European doctors who attempted to incorporate African herbal remedies into their professional practice. Sheridan's major achievement in Doctors and Slaves has been to establish authoritatively British Caribbean slave medicine as a field for research.

Since 1985, Sheridan has continued his work on medical history and the black demographic experience during slavery. ${ }^{86}$ This work has been largely comparative in nature. In the article, "The Maroons of Jamaica, 1760-1830: Livelihood, Demography and Health," for example, he compared favourably the demographic and health experience of that group (who lived outside the work and disease environment of the sugar plantation) with that of the slave population. In "The Condition of Slaves in the Settlement and Economic development of the British Windward Islands, 1763-1776," he compared the working and health conditions of the Windward Islands' slave population with that of Barbados and the Leeward Islands, arguing that on the new sugar frontier of the Windward Islands, planters tended to purchase adult slaves who were immediately assigned heavy-labour tasks without the benefit of a seasoning process. Moreover, family life and reproduction were discouraged in these colonies, where planters displayed a marked preference for purchasing new slaves. The effects of these practices, as Sheridan concluded, were "high mortality and low fertility and a net annual decrease of the slave population of from five to ten percent per annum, which was two to five times greater than the rates prevailing in the other British sugar colonies during the third quarter of the eighteenth century." 87 
In recent years, Sheridan has extended his research interests to examine aspects of the welfare of wage labourers in the post-emancipation years. A 1989 article, "Changing Sugar Technology and the Labour Nexus in the British (aribbean, 1750-1900, with Special Reference to Barbados and Jamaica," discussed the pattern and direction of the sugar industry's technological development, and examined its impact on the employment, productivity, and welfare, of the slaves and free labourers engaged in sugar production. ${ }^{88}$ A 1993 article. "From Chattel to Wage Slavery in Jamaica, 1740-1860," re-examined the working and health conditions of Jamaican slaves on sugar plantations and analysed the operation of the provision-ground system. Those developments during slavery were briefly compared with conditions affecting the health, demography, and general welfare, of freed persons in the period up to $1860 .^{89}$

Scholarly assessments of the contribution of individual historians to historical scholarship have generally gauged their effectiveness as teachers at the graduate level, as inspirers of research, and as producers of published work which has significantly enriched their chosen area of investigation. ${ }^{90}$ Sheridan has trained historians in Caribbean economic history, but his main contribution is his substantial corpus of work which, in its meticulous scholarship, is indispensable for an understanding of the British Caribbean economic past. Since his earliest publication in 1957, he has dominated British West Indian economic history for the period up to the outbreak of the American Revolution. He has written within a continuum established by historians like Pitman, Pares, and Williams, whose work he extended and developed. His major contribution to the historical literature on that period, Sugar and Slavery, provided a comprehensive economic history, notable for its long-term analysis of socio-economic developments. Sheridan's scholarly interests have not remained fixed. Initially, he emphasised the role of planting and mercantile elites in the establishment and operation of slave plantation economies, but later shifted his focus to the social costs of sugar production. The main product of this interest, Doctors and Slaves, opened up new areas of historical research on British Caribbean slave medicine. His perspective on this and other aspects of Caribbean economic history was shaped by an awareness of the "unequal exchange" which was a feature of the British Caribbean colonial record. Writing in 1963, Sheridan quoted approvingly Pares' views on the historian's role in the period of decolonization. Pares had suggested that Western historians needed "to try to come to an agreement with the African and Asian peoples on the rights and 
wrongs of our relations with them in the past." ${ }^{\text {"91 }}$ Sheridan's historical writing may not have been consciously an act of expiation, but his knowledge of the colonial record and the slave past gradually prompted a detailed examination of the impact of slavery and the plantation economy on the slave population.

Sheridan's contribution to British Caribbean economic historiography has been based on traditional empirical research rather than on the econometric approach of the "new" economic history. He did not fail to quantify or apply economic theory to the study of economic history, but preferred to examine the operation of economic forces in a wider social context. Sheridan's approach to the study of economic history can be summed up in the words of T. S. Ashton who, in his 1946 inaugural lecture as Professor of Economic History at LSE, observed: "it is the wills and choices and acts of men and women that are the ultimate data for economists and historians alike." ${ }^{\text {"2 }}$ Sheridan's belief in the importance of the "discourse between the two disciplines"-history and economics-in the writing of economic history has served to broaden and deepen our knowledge of the Caribbean economic past. ${ }^{93}$

\section{NOTES}

1. The phrase is H. C. Allen's. H. C. Allen, "Samuel Flagg Bemis," in Pastmasters: Some Essays on American Historians, ed. Marcus Cunliffe and Robin W. Winks (New York: Harper and Row, 1969), p. 192.

2. U. B. Phillips, "A Jamaica Slave Plantation," American Historical Review 19 (1914): 543-58; Frank Wesley Pitman, The Development of the British West Indies 1700-1763 (New Haven: Yale University Press, 1917); Slavery on the British West India Plantations in the Eighteenth Century (Washington, D.C.: Association for the Study of Negro Life and History, 1926); Lowell Joseph Ragatz, The Fall of the Planter Class in the British Caribbean 1763-1833: A Study in Social and Economic History (New York: The Century Company, 1928).

3. B. W. Higman, "American Influences on the Development of British West Indian Historiography." Paper presented at Department of History seminar, University of the West Indies, Mona, February 1976, p. 1.

4. "Some Memoirs of Richard B. 'Dick' Sheridan, Unedited and Incomplete," July 1990, p. 2. See also "An Interview with Richard Sheridan" by Jewell Willhite, August 6, 1991 - Oral History Project. K. U. Retirees' Club, University of Kansas.

5. "An Interview with Richard Sheridan," p. 16.

6. Ibid., p. 22. 
7. Richard R. Johnson, "Charles McLean Andrews and the Invention of American Colonial History," William and Mary Quarterly, 3rd series, 43 (1986): 536.

8. Telephone interview with Richard B. Sheridan, October 1994.

9. Pitman had observed: "it was from the West Indies that England derived, perhaps, the greatest increment of wealth in modem times ... To the British Northern Colonies, moreover, the West Indies were no less significant. For in the great slave communities to the southward Americans found the only great and permnanent market for all their staples. It was the wealth accumulated from West India trade which more than anything else underlay the prosperity and civilization of New England and the Middle Colonies." The Development of the British West Indies, p. vii.

10. Arthur H. Cole, "Economic History in the United States: Formative Years of a Discipline," Journal of Economic History 28 (1968): 574-76.

11. For an informed discussion of the staples approach and the impact of H. A. Innis' ideas on the economic historiography of British America, see John J. McCusker and Russell R. Menard, The Economy of British America 1607-1789 (Chapel Hill: University of North Carolina Press, 1985), chapter 1.

12. For an assessment of F. J. Fisher's scholarship see P. J. Corfield, "F. J. Fisher and the Dialectic of Economic History," in F. J. Fisher, London and the English Economy, 1500-1700, ed. P. J. Corfield and N. B. Harte (London: The Hambledon Press, 1990), pp. 3-22.

13. Ibid., p. 11. For a comment on Sheridan's use of those sources see Jacob M. Price, "The Transatlantic Economy," in Colonial British America: Essays in the New History of the Early Modern Era, ed. Jack P. Greene and J. R. Pole (Baltimore: Johns Hopkins University Press, 1984), pp. 19-20.

14. F. J. Fisher, "The Sixteenth and Seventeenth Centuries: The Dark Ages in English Economic History?" in The Study of Economic History: Collected Inaugural Lectures 1893-1970, ed. N. B. Harte (London: Frank Cass, 1971), p. 200.

15. Corfield, "F. J. Fisher and the Dialectic of Economic History," p. 6.

16. For Sheridan's comments on his association with R. H. Tawney, see "An Interview with Richard Sheridan," p. 21.

Tawney's influence was evident in Sheridan's assertion that "religion was by no means a negligible influence on economic behaviour." Richard B. Sheridan, Sugar and Slavery: An Economic History of the British West Indies 1623-1775 (Barbados: Caribbean Universities Press, 1974 and Baltimore: Johns Hopkins University Press, 1974), p. 364.

17. In the preface to Sugar and Slavery, Sheridan noted: "As a postgraduate student at L.S.E., I also profited by the kindness, learning, and wisdom of Professor Richard H. Tawney and T. H. Ashton." Sugar and Slavery, p. xii. For an assessment of Ashton's contribution to British economic historiography see D. C. Coleman, History and the Economic Past: An Account of the Rise and Decline of Economic History in Britain (Oxford: The Clarendon Press, 1987), p. 82. 
WEST INDIES ACCOUNTS

18. R. S. Sayers, "Thomas Southcliffe Ashton, 1889-1968," Proceedings of the British Academy 55 (1970): 277.

19. "The Molasses Act and the Market Strategy of the British Sugar Planters," Journal of Economic History 17 (1957): 62.

20. Harold Adams Innis, The Cod Fisheries: The History of an International Economy (New Haven: Yale University Press, 1940). Innis studied the fishing industry "in the hope that it will throw light on the significance of that industry for the economic, political and social organization of North America and Europe." See "Author's Preface," p. ix.

21. "The British Credit Crisis of 1772 and the American Colonies," Journal of Economic History 20 (1960): 162.

22. "Letters from a Sugar Plantation in Antigua, 1739-1758," Agricultural History 31 (1957): 3.

23. Richard Pares, $A$ West-India Fortune (London: Longmans, 1950).

24. "Samuel Martin, Innovating Sugar Planter of Antigua, 1750-1776," Agricultural History 34 (1960): 126.

25. "The Commercial and Financial Organization of the British Slave Trade, 17501807," Economic History Review 11 (1958): 249-263.

26. "The Rise of a Colonial Gentry: A Case Study of Antigua, 1730-1775," Economic History Review 13 (1961): 342-57.

27. See T. S. Ashton, "Richard Henry Tawney, 1880-1962," Proceedings of the British Academy 48 (1962): 474.

28. Linda Colley, Lewis Namier (London: Weidenfeld and Nicolson, 1989), p. 50; Christopher Parker, The English Historical Tradition since 1850 (Edinburgh: John Donald Publishers, 1990), p. 40. See also Lawrence Stone, The Past and Present Revisited (London and New York: Routledge and Kegan Paul, 1987), p. 57.

29. The phrase is H. C. Allen's, "Samuel Flagg Bemis," Pastmasters, p. 199.

30. "Temperate and Tropical: Aspects of European Penetration into Tropical Regions," Caribbean Studies 3 (1963): 21.

31. The Development of the Plantations to 1750 [and] An Era of West Indian Prosperity, 1750-1775 (Barbados: Caribbean Universities Press, 1970), p. 9.

32. For evidence of this influence see "Temperate and Tropical," 21. For a discussion of the evolution of development economics see Pioneers in Development, eds. Gerald M. Meier and Dudley Seers (New York and Oxford: Oxford University Press, 1984).

33. In 1969 Sheridan wrote: "it is ironical that after contributing so markedly to the progress of Northerners in the age of slavery, the peoples of the tropics are today in an economically inferior condition." "The Plantation Revolution and the Industrial Revolution, 1625-1775," Caribbean Studies 9 (1969): 25.

34. "Planter and Historian: The Career of William Beckford of Jamaica and England, 1774-1799," Jamaican Historical Review 4 (1964): 36-58; "Simon Taylor, Sugar Tycoon of Jamaica, 1740-1813," Agricultural History 45 (1971): 285-96; "Planters 
and Merchants: The Oliver Family of Antigua and London, 1716-1784," Business History 13 (1971): 103-13.

35. "Simon Taylor, Sugar Tycoon of Jamaica," 294-95.

36. "Planter and Historian," 37.

37. For a discussion of probate records as a source see Gloria L. Main, "Probate Records as a Source for Early American History," William and Mary Quarterly, 3rd series, 32 (1975): 89-99.

38. "Planter and Historian," 50.

39. Frank W. Pitman had arrived at estimates of the wealth of lamaica and the British West Indies as early as 1931. See Frank Wesley Pitman, "The Settlement and Financing of British West India Plantations in the Eighteenth Century," in Essays in Colonial History Presented to Charles McLean Andrews by His Students (New Haven: Yale University Press, 1931), pp. 252-83. For an appraisal of Eric Williams' contribution to Caribbean historiography see Richard B. Sheridan, "Eric Williams and Capitalism and Slavery, A Biographical and Historiographical Essay," in British Capitalism and Caribbean Slavery: The Legacy of Eric Williams, eds. Barbara L. Solow and Stanley L. Engerman (New York; Cambridge University Press, 1987), pp. 317-45.

40. "The Wealth of Jamaica in the Eighteenth Century," Economic History Review, 2nd Series, 18 (1965): 294.

41. "The Plantation Revolution and the Industrial Revolution," 5.

42. Melville H. Watkins, "A Staple Theory of Economic Growth," Canadian Journal of Economics and Political Science 29 (1963): 141 - 58.

43. "The Plantation Revolution and the Industrial Revolution," 25.

44. Robert Paul Thomas, "The Sugar Colonies of the Old Empire: Profit or Loss for Great Britain?," Economic History Review, 2nd Series, 21 (1968): 30.

45. F. J. Fisher, "The Sixteenth and Seventeenth Centuries," p. 183.

46. Thomas C. Cochran, "Economic History, Old and New," American Historical Review 74 (1969): 1561.

47. Elias H. Tuma, Economic History and the Social Sciences: Problems of Methodology (Berkeley and Los Angeles: University of California Press, 1971), p. 227.

48. "An Interview with Richard Sheridan," p. 35.

49. "The Wealth of Jamaica in the Eighteenth Century: A Rejoinder," Economic History Review, 2nd series, 21 (1968): 47.

50. Ibid.

51. Ibid., p. 60.

52. "Comments on Papers by Jones, Shepherd, Walton, and McCusker, Annual Meeting of the Economic History Association, Atlantic City, New Jersey, September 8-10, 1971," Journal of Economic History 32 (1972): 161.

53. "The Domestic Economy" in Colonial British America, eds. Greene and Pole, p. 78.

54. The phrase is Thomas C. Cochran's, "Economic History, Old and New," p. 1571. 
55. The Development of the Plantations to 1750 [and] An Era of West Indian Prosperity. 1750-1775. In a prefatory note, the editors stated: "We hope to achieve a regional approach as far as the diverse histories of the various territories permit, and we believe that the work can greatly stimulate research and writing throughout the area." See p. 6.

56. Ibid., p. 26.

57. Ibid., pp. 19-20.

58. Ibid., p. 70. For useful discussions of the work of the New World Group of economists see Denis M. Benn, "The Theory of Plantation Economy and Society: A Methodological Critique," Journal of Commonwealth and Comparative Politics 12 (1974):249-60; Hilary McD. Beckles, "'The Williams Effect': Eric Williams's Capitalism and Slavery and the Growth of West Indian Political Economy," in British Capitalism and Caribbean Slavery, ed. Solow and Engerman, pp. 303-16.

59. Although this book was based on Sheridan's doctoral thesis, additional research had, as he pointed out, "extended both the topical and time dimensions of my history of Britain's Caribbean empire." Sugar and Slavery, p. xi.

60. Jack P. Greene, "Society and Economy in the British Caribbean During the Seventeenth and Eighteenth Centuries," American Historical Review 79 (1974): 1506.

61. Canoe Press University of the West Indies commemorated the twentieth anniversary of the publication of Sugar and Slavery by republishing it with a foreword by Hilary Beckles.

62. Sugar and Slavery, p. xii.

63. Quoted in Sugar and Slavery, p. 363.

64. Ibid.

65. "The Domestic Economy" in Colonial British America, ed. Greene and Pole, p. 50.

66. Sugar and Slavery, p. 338.

67. For the points of difference in their approaches see Richard B. Sheridan, review of Yankees and Creoles: The Trade between North America and the West Indies before the American Revolution, by Richard Pares, in William and Mary Quarterly, 3rd series, 13 (1956): 416.

68. B. W. Higman, Slave Population and Economy in Jamaica, 1807-1834 (New York and Cambridge: Cambridge University Press, 1976), p. 16.

69. "A Rejoinder," 61.

70. Philip D. Curtin, The Atlantic Slave Trade: A Census (Madison: University of Wisconsin Press, 1974).

71. David Brion Davis, "Slavery and the Post-World War II Historians," in Slavery, Colonialism, and Racism, ed. Sidney W. Mintz (New York: W. W. Norton, 1974), pp. 6-7.

72. Robert W. Fogel and Stanley L. Engerman, Time on the Cross: The Economics of American Negro Slavery (Boston: Little, Brown, 1974).

73. "Africa and the Caribbean in the Atlantic Slave Trade," American Historical Review 77 (1972): 15-35; "The Guinea Surgeons on the Middle Passage: The Provision of 
Medical Services in the British Slave Trade," International Journal of African Historical Studies 14 (1981): 601-25.

74. "Mortality and the Medical Treatment of Slaves in the British West Indies," in Race and Slavery in the Western Hemisphere: Ouantitative Studies, ed. Stanley L. Engerman and Eugene D. Genovese (Princeton: Princeton University Press, 1975), pp. 285-310.

75. "The Crisis of Slave Subsistence in the British West Indies During and After the American Revolution," William and Mary Quarterly, 3rd series, 33 (1976):615.

76. "'Sweet Malefactor': The Social Costs of Slavery and Sugar in Jamaica and Cuba, 1807-54," Economic History Review, 2nd series, 29 (1976):256-57. See also "Slave Demography in the British West Indies and the Abolition of the Slave Trade," in The Abolition of the Atlantic Slave Trade: Origins and Effects im Europe, Africa, and the Americas, ed. David Eltis and James Walvin (Madison: University of Wisconsin Press, 1981), pp. 259-85.

77. "The Jamaican Slave Insurrection Scare of 1776 and the American Revolution," Journal of Negro History 61 (1976): 290-308; "From Jamaican Slavery to Haitian Freedom: The Case of the Black Crew of the Pilot Boat Deep Nine," ibid., 67 (1982): 328-39.

78. Orlando Patterson, The Sociology of Slavery: An Analysis of the Origins, Development and Structure of Negro Slave Society in Jamaica (London: MacGibbon and Kee, 1967); "Slavery and Slave Revolts: A Socio-historical Analysis of the First Maroon War, 1655-1740," Social and Economic Studies 19 (1970): 289-325; Edward Brathwaite, The Development of Creole Society in Jamaica, 1770-1820 (Oxford: The Clarendon Press, 1971); Monica Schuler, "Akan Slave Rebellions in the British Caribbean," Savacou I (I 970): 8-31; "Ethnic Slave Rebellions in the Caribbean and the Guianas," Journal of Social History 3 (1970): 374-85.

79. Patterson, The Sociology of Slavery, p. 11.

80. Doctors and Slaves: A Medical and Demographic History of Slavery in the British West Indies, 1680-1834 (New York and Cambridge: Cambridge University Press, 1985).

81. Ibid., p. xvii.

82. Ibid., p. xv. This was a logical extension of Sheridan's demonstrated interest in the influence of geography on economic development.

83. For an extended discussion of environmental history in general and McNeill's ideas in particular see William A. Green, History. Historians and the Dynamics of Change (Westport, Connecticut, and London: Praeger Publishers, 1993), pp. 167-89.

84. Doctors and Slaves, pp. 328-29.

85. B. W. Higman, Slave Populations of the British Caribbeam, 1807-1834 (Baltimore and London: Johns Hopkins University Press, 1984), chapters 6 and 7.

86. See, for example, "The Doctor and the Buccaneer: Sir Hans Sloane's Case History of Sir Henry Morgan, Jamaica, 1688," Journal of the History of Medicine and Allied Sciences 41 (1986): 76-87; "Slave Medicine in Jamaica: Thomas Thistlewood's' Receipts for a Physick'," Jamaican Historical Review 17 (1991): 1-18. 
87. See "The Maroons of Jamaica, 1730-1830: Livelihood, Demograph.y and Health," in Out of the House of Bondage: Runaways, Resistance and Marronage in Africa and the New World, ed. Gad Heuman (London: Frank Cass, 1986), pp. 152-72; "The Condition of Slaves in the Settlement and Economic Development of the British Windward Islands, 1763-1776," Journal of Caribbean History 24 (1990): 142.

88. "Changing Sugar Technology and the Labour Nexus in the British Caribbean, 1750-1900, with Special Reference to Barbados and Jamaica," New West Indian Guide 63 (1989): 59-93.

89. "From Chattel to Wage Slavery in Jamaica, 1740-1860," in The Wages of Slavery: From Chattel Slavery to Wage Labour in Africa, the Caribbean and England, ed. Michael Twaddle (London: Frank Cass, 1993), pp. 13-40.

90. See, for example, Introduction to Pastmasters, ed. Cunliffe and Winks, p. xi.

91. Quoted in "Temperate and Tropical," 21.

92. T. S. Ashton, "The Relation of Economic History to Economic Theory," in The Study of Economic History, ed. Harte, p. 179.

73. The phrase is Ashton's. Ibid., p. 177. 


\section{2 \\ The Capture of the Blue Dove, 1664: \\ Policy, Profits and Protection in Early English Jamaica ${ }^{1}$}

NUALA ZAHEDIEH

The main battle in imperialism is over land, of course; but the issues of who possessed and settled the land were contested and often decided in what can inaptly be termed "no man's land," the sea. Trade and plunder were linked from the earliest days of European settlement in America but the boundary between the two, between the acceptable and the unacceptable, was blurred and shifting constantly. ${ }^{2}$ Spain's power crumbled in the seventeenth century and other nations became territorial powers in their own right, with their own claims to commercial monopoly, and their own needs for protection. Hence, the reformulation of old rules became particularly pressing. Predators at sea, beyond territorial jurisdiction, could not be eliminated given the reputed richness of the pickings in the Caribbean and the limited resources available to any nation for defence, but they did need to be tempered with and, if possible, managed. ${ }^{3}$ European governments expressed lofty views about what was desirable, and made pious statements to distance themselves from pillage, but their agents on the frontier had to work out a practical division of patronage between plunder, planting, and peaceful trade which would maximise security in the real world. ${ }^{4}$ The difficulties experienced at a local level were reflected in the policy vacillations of Thomas Modyford when appointed Governor of Jamaica in 1664, and highlighted in events soon after his arrival, surrounding the capture of the Blue Dove by the privateer, John Duglas. ${ }^{5}$ 
When John Duglas arrived in Jamaica in January 1664, the island had an atmosphere characteristic of frontier settlements-violent, vulnerable, and unstable, with leaders striving to impose discipline and order on a rowdy, restless, roving, mainly male population of four or 5,000 people (in October 1662 , there were 2,600 men, 645 women, 405 children, and 522 slaves). ${ }^{6}$ Opportunities for enrichment abounded, but risks were high, and Jamaica was "circled in with [the] enemies' territories," in Cuba, Hispaniola, and the Spanish mainland. ${ }^{7}$ The English had seized the island nine years earlier under Cromwell's auspices, but did not finally defeat their Spanish predecessors until 1660, and never succeeded in defeating internal resistance from Spanish runaway slaves, who formed the origins of the Maroon bands that remained troublesome in the eighteenth century. In 1660, Charles II was restored to the throne, and ended Cromwell's war with Spain, but retained his American conquest and, in 1662 , appointed a governor, Lord Windsor, to establish civil rule. ${ }^{8}$ But Windsor stayed in Jamaica only a few months, and the state provided little material support, and little in the way of defence forces for the infant settlement-there were never more than a couple of naval frigates at the island and, for most of the 1660s, none at all. Not surprisingly, fears of Spanish invasion, or a negotiated return remained real, and frequently rumoured, threats. ${ }^{9}$ After all, no other settled Spanish territory had been seized and retained in the past.

The settlers trying to secure England's frontier in Jamaica had to contend with not only the dispossessed Spaniards, but also swarms of men of many nationalities who might be said to have been living "beyond the frontier." The fabled riches of the Indies drew marauders to the region in hopes of plunder and many opted to make the reckless, savage existence a permanent way of life, committing themselves to the wild freedom and comradeship of cruising in the Caribbean islands, robbing passing traders, fishing, turtling, and hunting wild cattle for meat and hides. The vast tracts of unpopulated land in northern Hispaniola became a particularly popular resort for these "buccaneers" (so called because of their Indian style of curing meat, "viande boucanée") and the nearby island of Tortuga their main harbour and retreat. ${ }^{10}$

These wild men, "tied to no rules but some of their own by tradition," had to be reckoned with, and Doyley, who was acting commander-in-chief of Jamaica for most of the period of martial law, used the war with Spain to incorporate them into the island's defence force by offering commissions against the Spaniards. ${ }^{11}$ The policy gave the predators good port facilities and 
a convenient market for their prize goods while in return the island obtained additional security against the Spaniards and a degree of immunity from attack for its own infant commerce. The policy was successful and Port Cagway (later known as Port Royal) became the main centre for privateering in the Caribbean. When Charles II ended the war with Spain, a Jamaican council of war pondered the problems of changing its strategy and thereby alienating the privateers, and decided that it would prefer to use the long-standing maxim that there was "no peace beyond the line" to legitimate a continuation of business as usual. ${ }^{12}$ It was argued that, as the Spaniards would not allow freedom of trade or navigation in these waters, and treated all Englishmen who ventured there as pirates, any aggression against them was justified. The home government did not demur and, in 1662, the first royal governor, Lord Windsor, was instructed that if friendly overtures towards his Spanish neighbours were rebuffed he should "procure and settle a trade with [them] ... by force, and by doing any such acts upon or against them, as you and the council shall judge most proper to admit you to a free trade with them." ${ }^{13}$ After peremptory attempts to initiate commerce with Puerto Rico and Hispaniola were rebuffed, Windsor resumed war in the Indies launching an attack on Cuba, led by Christopher Myngs and manned by about 1,500 privateers. ${ }^{14}$ The plundering trade was put on a wellregulated and business-like footing, with old commissions called in, new ones issued, and an Admiralty Court set up to regulate prizes and ensure that public dues were paid. ${ }^{15}$

Sir Charles Littleton, who took over the government when Windsor left Jamaica in October 1662, reported that, by 1664, when Duglas arrived, there were between fifteen and twenty privateering frigates based at the island, containing about 2,000 men-almost as many as the entire male population of Jamaica, and about five times that of Port Royal (reported to have $\mathbf{4 0 0}$ men, 200 women, 90 children, and 50 slaves). ${ }^{16}$ Captains were mostly English, French, and Dutch, but crews were of many more nationalities, including Indians and even a few Spaniards. ${ }^{17}$ Turnover was rapid, given the high mortality rates in the Indies and the perils of privateering, but there were always enthusiastic new recruits, particularly among sailors and indentured servants in, or out, of their time. It seems that the advantages of a base in Jamaica, offering facilities for fitting ships and selling prize goods, were sufficiently attractive to persuade many predators that it was worth sacrificing a degree of their traditional freedoms, submitting to the Admiralty Court, and above all taking care to 
exempt the island's own trade from attack. The Admiralty Court records show that thirty-one commissions were issued between September 1662 and July 1663. Twenty-one vessels were condemned in the same period and recorded proceeds of prize sales were $\mathfrak{£} 7,534$, although other information makes it clear that actual proceeds were higher; embezzlement was condoned so as to reduce the share of prize money given to the King and the Admiralty who laid claim to a tenth and fifteenth part respectively. ${ }^{18}$

Duglas was thus one of many men owing no particular allegiance to the King of England, but attracted to Jamaica by the prospect of plunder. In October 1662, he was in Lisbon and obtained a commission against enemies of the King of Portugal (which included Spain), after which he set sail in the St John, a small bark with four guns. ${ }^{19}$ After months cruising in the Canaries without success, Duglas moved to the Caribbean, where he was attacked by a French privateer and wounded. He landed at Montserrat to rest and recuperate. By this time, his wooden boat was rotting and when Duglas moved on to try his luck at Jamaica in January 1664, he may well have been feeling fairly despondent; after fourteen months at sea, with all the attendant dangers and costs, he had not had the hint of a prize. This was not, in fact, untypical of a privateer's experience; the fabled riches were often more real in the prospect than the reality, but it would have been, like losing any lottery, disappointing none the less. When Duglas arrived in Jamaica he introduced himself to Littleton, who accepted the legitimacy of his commission and allowed him to buy, man, and arm a new ship for war against Spain, and issued him with a let-pass to leave port when ready. ${ }^{20}$ Although Jamaicans had had recent inklings that attitudes towards privateering were changing in England they had more or less ignored them: ${ }^{21}$ Port Royal bustled with the business of fitting out privateers, entertaining them ashore, and buying their loot. ${ }^{22}$ The atmosphere must have served to raise Duglas's flagging morale.

The proceeds of plunder proved to be an important source of capital in the infant colony. Privateering was an ideal start-up trade, needing a small investment and producing quick profits, but it was not, on its own, a good strategy for long-term growth because predators, limited by the amount of their prey, would inevitably experience diminishing returns. ${ }^{23}$ If the colony could control the marauders, however, privateering could provide the security that was an essential prerequisite for successfully emulating alternative strategies for longterm development, such as the Barbados model of planting valuable cash crops, 
or the Dutch model, established in Curaçao, of entrepot trade with the Spanish empire. ${ }^{24}$ Jamaica's size, fertility, and strategic location in the heart of the Spanish empire would make it ideal for both - provided island trade was secure.

Planting made slow progress under martial law since civilians proved unwilling to settle in such an insecure situation, and soldiers made reluctant farmers. But this work accelerated after the Restoration and, by October 1662 , almost 3,000 acres were cleared and planted. ${ }^{25}$ It required "much money and patience," however, before the pioneers reaped great rewards. ${ }^{26}$ One of the most successful of these pioneers was Lieutenant-Colonel Thomas Lynch, who had decided to "marry, send for his relations and make this his England" and, by 1664, he possessed the most promising plantation in Port Morant which was the "best and richest settlement." 27

Lynch had accumulated a labour force of five white servants and thirty-seven slaves with which he had cleared and planted forty-five acres out of his 1,000 acre tract. He had also built a handsome, well-furnished, two-storey plantation house and a splendid sugar works (one of only eighteen on the island) with a "new, firm and well-built" mill-house, curing house, boiling house and still house, and he was well-stocked with horses, cattle and other livestock. ${ }^{28} \mathrm{All}$ of

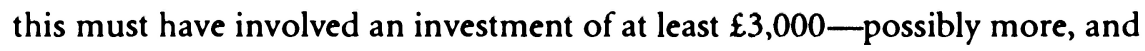
when he decided to leave Jamaica in 1665 , he leased the plantation for seven years at $£ 300$ per annum. ${ }^{29}$ Evidently, those who had money and patience would eventually receive a reasonable return, but only if the island could prevent invasion and ensure sufficient security in surrounding seas to maintain access to European markets.

Apart from being suitable for planting, Jamaica's location, in the midst of Spanish territory with easy access to Cuba, Hispaniola, and the mainland, made it an ideal base for contraband commerce with the rich Spanish empire. Spanish law required all trade with her colonists to be conducted via Seville and carried on the two supposedly-annual fleets, thus aiding both protection and revenue-raising. ${ }^{30}$ But since the fleet system left great areas of Spanish America poorly protected and lacking adequate commercial channels to Europe, it was fairly easy for other nations to gain direct access to Spanish American markets. ${ }^{31}$ The Dutch dominated this commerce and had established a base on the "little, barren and rocky island" of Curaçao which, because of its "neighbourhood to the great wealthy Spanish dominions," could act as a warehouse-receiving supplies from Europe and shipping them on to the Spaniards. ${ }^{32}$ The acquisition 
of Jamaica could enable the English to emulate and, given its superior location, even surpass this model although no-one expected the Spanish authorities to allow such trade unless "forced thereto by some unavoidable necessity. ${ }^{\text {"33 }}$

The opportunities for using Jamaica as a base for trade with the Spaniards were quickly recognized by Dutch Jewish merchants, who already had a strong foothold in contraband commerce at Curaçao, and well-developed networks of agents in America. William Beeston reported the arrival of six Jews in Port Royal in 1663, just one year after civil rule was established, bringing a rich cargo on the Great Gift, an English ship. ${ }^{34}$ They had dangled the temptation of gold before the King, claiming they knew the whereabouts of a lost mine which they would, in partnership with an Englishman, Sir William Davidson, the King's envoy in Amsterdam, open up and work for the crown in return for half the proceeds and letters of denizen. ${ }^{35}$ Beeston was sceptical and suspected the story was "barely a pretence for their design was only to insinuate themselves into the country for the sake of trade" for which they needed to be naturalized.

While the search for gold did, to the King's annoyance, prove fruitless, the Jews were able to set up shop in Port Royal and establish themselves in commerce. But, like the planters, the merchants' prosperity depended, above all, on the security of the seas surrounding the island. This was amply demonstrated in an incident taking place soon after Duglas's arrival in 1664. A ship called the Blue Dove, lightly manned with a crew of ten, bringing goods to Benjamin Moskett and Isaac Cordosa, Jewish merchants in Port Royal, was seized near Cuba by a prominent Jamaican privateer, John Morris, whose Virgin Queen carried sixty men and seven guns. ${ }^{36}$ Morris brought his prey into Port Royal to be tried in the Admiralty Court, claiming it was a Dutch ship, laden with Jewish-owned goods, that were intended for trade with the Spaniards and was thus, "lawful prize." In fact, the captain was English and had papers to show that, although the ship was loaded in Holland, it belonged to an Englishman, Sir William Davidson, partner of the Jewish merchants. Furthermore, after leaving Amsterdam, it cleared customs in Dover with goods consigned to Jewish merchants resident, and permitted to trade, in Jamaica. In other words, the Jewish merchants had taken great pains to comply with the letter of English law, and so could benefit from the immunities secured by Jamaican trade against marauders based on the island, which other valuable ships sailing in these dangerous waters did not share. ${ }^{37}$ Littleton declared that the Blue Dove was not lawful prize but was, in fact, "a free ship with liberty to trade as any other ship 
in the harbour," whereupon the Jewish merchants unloaded their cargo and sold the goods, leaving the disgruntled Morris and his sixty men emptyhanded. ${ }^{38}$ As the merchandise was described as "suitable for the Spanish trade" it probably found its way to Spanish markets on the island sloops which were already becoming practised in this risky, but highly profitable, illicit trade. As with planting, contraband trade offered Jamaicans tempting prospects of profit provided there was a reasonable degree of security in the surrounding waters. ${ }^{39}$

It might seem surprising that merchants involved in Spanish trade did not oppose Port Royal's patronage of plunder on grounds that it alienated their customers. But, in fact, there were numerous reasons why privateers and smugglers coexisted fairly happily. Firstly, smugglers benefited from the protection provided to island trade because predators who based themselves at Jamaica were obliged to confine their attention to others, and this had the very important side-effect of damaging their most important competitors, the Dutch. As demonstrated by John Morris, when he seized the Blue Dove, Dutch smugglers were regarded as legitimate prey and they were often soft targets, sailing alone, away from the main ports in less populous bays and creeks, and seizure required more cunning than brute force. Examples abound: in 1661, George Freebourne and James Risby in the Pearle and Betty met Henry Hambrouck in the St Peter of Amsterdam which, "under cover of a license to wood and water," was trading along the coast of Cuba. The Englishmen recommended a convenient place to careen and watched the Dutch ship unload. It was Christmas soon after, and the three ships' companies sat drinking together on the beach all day until, towards evening, when the Dutch crew was completely inebriated, the Englishmen were able to seize all their goods, with little opposition. ${ }^{40}$ Thus, the heavy risk of falling foul of the numerous Jamaican privateers raised Dutch risks and costs. Furthermore, privateering acted as a training ground for the ships, shipbuilding, and seamen involved in the Jamaica-based contraband trade. Finally, the conviction that the English would never gain entry to Spanish markets except by force, through pillage and plunder, was held deeply, sincerely, and with strong reason. ${ }^{41}$

The Spaniards did hold out one key to unlock their doors to foreign traders. This was the asiento, or license to supply slaves. Despite their high demand for labour, the Spaniards never attempted to enter the slave trade themselves, and depended on foreign suppliers-first the Portuguese and, by the mid-seventeenth century, the Dutch. ${ }^{42}$ The asiento was a glittering prize, because not only 
was the slave trade very lucrative, but also, by opening access to the major Spanish ports, it provided opportunities to supply dry goods covertly.

England was slow to enter the slave trade in a serious fashion, partly because of the distractions of the Civil War. After the Restoration, with an established market for slaves in Barbados, and the promise of new markets in the other islands, there was a fresh attempt to set up an English African company which involved all the major figures at court. ${ }^{43}$ Not surprisingly, the company also hoped to sell slaves in Spanish colonial markets and Thomas Modyford, a planter in Barbados and agent for the company, sent enthusiastic reports about Spanish willingness to make purchases from the English, and the high prices they would pay. ${ }^{44}$ It was clear to all, however, that Jamaica's wholehearted patronage of privateering was unlikely to endear them to their potential customers. Consequently, the King decided to make Modyford Governor of Jamaica, and he issued him with strict instructions to put an end to all depredations on subjects of the King of Spain. ${ }^{45}$

Modyford arrived in Jamaica on 1 June 1664 and, on 11 June, he issued a proclamation declaring that the King:

doth strictly charge and command all his loving subjects after notice hereof to treat all the subjects of the Catholic Majestie wheresoever they shall meet them whether by sea or land, as friends and allies, and not to make prize of any of the ships or goods by virtue of a commission heretofore granted, or under any other colour or pretence whatsoever, until His Majestie's pleasure concerning the promises be further known, any former powers, commissions, customs or usages to the contrary hereof notwithstanding. ${ }^{46}$

A Jamaican merchant reported that the privateers were "a little discouraged" by this unequivocal peace and only three of the twenty or more based at the island brought in their commissions; one was captured by HMS Westergate; one came in with a prize; and the third, Captain Swart, came in without men or money, "his vessel impossible to go to sea and must have been broken up. ${ }^{\text {"47 }}$ The indifference to the King of England's orders was not entirely surprising. After all, a high proportion of the captains and crews who had been operating out of Port Royal were not English subjects, and those who were did not much care about the King's disapprobation, particularly as he had little power to demonstrate his displeasure. All commentators warned that the King would need a strong and effective naval force to reduce the privateers to obedience. ${ }^{48}$ The navy, however, was in dire financial straits after the Restoration. ${ }^{49}$ More- 
over, it was expensive to keep ships in the Caribbean (the cost being about $\mathfrak{E} 6,000$ a year for a fifth rate and $\mathfrak{E} 10,400$ for a fourth rate), while sea conditions there required that the vessels' wooden hulls be regularly replaced. ${ }^{50}$ This left little scope for defending Jamaica, and the Governor did not receive sufficient naval support to eliminate piracy and privateering, and these predators, now unwelcome at Jamaica, merely moved elsewhere, notably to Tortuga. ${ }^{51}$ This small island off Hispaniola had long been a favourite haunt for buccaneers and, after attempts by Doyley to establish English control in the 1650s, had been taken over by the French who provided patronage for privateering in much the same way as had the English at Jamaica. Although slightly less convenient than Port Royal, if the latter were closed, Tortuga provided a quite acceptable alternative. $^{52}$

Jamaican settlers were as dismayed as the privateers by the prospect of peace. Fitting the buccaneers and selling their prize was a major source of income and exchange. But the new policy did more than threaten short-term prosperity; it also placed the strategy for long-term development in jeopardy. Planting and marketing cash crops, or contraband commerce with the Spaniards, both required a reasonable level of security for island territory and shipping. But if the privateers were alienated they could turn on the island's own commerce, and even perhaps assist the Spaniards or French in capturing the island, which was thinly populated and weakly defended. John Duglas quickly demonstrated the seriousness of the threat.

Duglas had been fitting a ship for a cruising voyage before Modyford's arrival but, as he had a Portuguese commission, he felt no obligation to heed the Governor's proclamation of peace except in that it opened up a new opportunity. While he was in Port Royal he had watched Jewish merchants load the Blue Dove with a valuable cargo containing sugar, cocoa, quicksilver, gold, jewels and other riches, worth $\mathfrak{E 5 , 0 0 0}$ to $\mathfrak{E 6 , 0 0 0}$, and since Jamaica had withdrawn patronage of privateering he did not feel any need to hesitate in plundering the island's own shipping.

Duglas used the let-pass issued by Littleton to leave Port Royal, taking a crew of twenty-six men of the usual mixed nationalities-twelve English, four French, two Dutch, two Belgian, one Spaniard, and three described as West Indians. They hovered around Bluefields Bay, where most ships sailing westwards out of Port Royal paused to wood and water, waiting for the Blue Dove, which arrived a few days later, accompanied by the Lucretia. After dark, Duglas 
sent a couple of men to talk to the crew of the Lucretia and distract their attention while, with the rest, he paddled over to the Blue Dove, hoping to secure his prize by relying on the privateers' usual mixture of cunning, surprise, and overwhelming numbers. When they approached, the ship's watch hailed them and they made a friendly reply. Then, when they got right up alongside the Blue Dove, some twenty of Duglas's men jumped on board, fired just one shot, hitting the arm of the ship's captain, Robert Cook, and frightening his nine hopelesslyoutnumbered men, into immediate submission. Cook and his crew were locked in the hold, then Duglas cut the ship's cables and sailed away, leaving the Lucretia behind. At Point Negril, the privateers met a small bark heading to Port Royal from the Caymans, and Duglas persuaded its captain to take Cook and most of his crew aboard, allowing them nothing but the clothes on their backs, some victuals and a cask of spirits. ${ }^{53}$ Thus, they returned home safe, though much poorer. ${ }^{54}$

Duglas could not sell the Blue Dove in Jamaica but there were plenty of other ports available. He decided to make for New England, which was known to welcome privateers bringing tropical goods for sale, and he arrived in Piscataya Bay in July 1664. After showing both his Portuguese commission and a number of depositions taken from passengers and crew on board the Blue Dove that avowed the ship was owned and freighted by Jews, who were "enemies of the King of Portugal," he claimed that she was lawful prize which he was taking home to be condemned in Europe. Meanwhile he requested permission to sell some of the prize goods to pay for provisions - a convenient, commonly-used ploy that would allow him to sell as much as he could of the cargo. ${ }^{55}$ Permission was granted and goods were sold, although probably not for their full value of $£ 5,000$ to $£ 6,000$. Nevertheless, Duglas and his crew would have had good reason to be satisfied with the return on their expedition.

While Duglas was disposing of the prize goods, however, Captain Hadsall of the Lucretia arrived in Boston, and reported the capture of the Blue Dove to Sir Francis Willoughby, son-in-law of one of the vessel's owners. At about the same time, news came that the Blue Dove had put into Portsmouth, New Hampshire. ${ }^{56}$ The governor immediately commissioned James Oliver and Edward Hutchinson to seize the Blue Dove, and they carried out their order on 18 July. The ship was brought to Boston, its hatches were sealed, and its papers were handed over to the authorities. ${ }^{57}$ The case was tried before colonial officials in August, while all goods remaining aboard the prize had been inventoried, with 
the damaged or perishable goods being sold to pay the costs arising from the seizure and trial.

At the trial, Duglas, like Morris in Port Royal, based his case on the assertion that the ship was freighted to and from Amsterdam, and the goods aboard belonged to Jews. But letters from the King on behalf of Sir William Davidson carried more weight. The General court determined that the "said ship Blue Dove was illegally seized by the said Duglas, his said commission not warranting the same," and the ship would be restored to its owners when they presented proper proof of their claim. It seemed that justice was done to the owners who nevertheless had to pay all charges arising from the action. ${ }^{58}$

The Blue Dove's crew were bound over for appearance at the next meeting of the Court. Duglas made bond for $\mathfrak{E} 1,000$ and was to be held in the county jail, while his men were boarded at Widow Thomas's home on King's Avenue after making bond of $£ 20$ each. Officials set about reclaiming goods sold at Piscataya, and repaid buyers the amount of Captain Cook's original outlay plus their charges for freighting the goods to Boston. ${ }^{59}$ The General Court met again in December, and Sir Francis Willoughby presented a power of attorney from Davidson and received custody of the Blue Dove. On the following day, the Court met again and held that if Duglas and his men did not appear before the bar at the next meeting of the county court, their bonds would be forefeited. Warrants were also issued for them on the grounds that some of the crew had "condemned and villified the actions of the General Court." Duglas had been released from jail in order to save the state money, and officials must have turned a blind eye to his activities, because on 31 January 1665, it was reported (without explanation) in the county court that all of the defendants had disappeared, sacrificing their bonds but walking away free. ${ }^{60}$ Thus, even with royal support, Davidson and his co-owners were unable to obtain full restitution or revenge.

The plight of the Blue Dove, which had managed to trade unmolested while Jamaica was under Littleton's pro-privateering regime, but was seized by predators as soon as Modyford changed policy, illustrated the problems in eliminating privateering. The reality of the frontier was that there were swarms of marauders, of many nationalities, who were committed to plunder as a way of life and always welcome somewhere. With the very scant defence forces available, it was important that the Governor of Jamaica achieve some measure of collusion, or incorporation, of these "wild, dissolute and tattered fellows" 
into the island economy, since neither the planting of cash crops, nor contraband trade, could make substantial progress if the island's own commerce were vulnerable, or if privateers joined with the French or the Spaniards to attack the island. ${ }^{\text {.1 }}$

Thus Modyford, who was an experienced frontiersman, having made his fortune in Barbados, as well as a harsh realist, quickly changed his mind about policy towards the privateers. On 30 June 1664, after reporting the loss of the Blue Dove, he wrote home that it would be "prudent to do by degrees and moderation what he had resolved to execute suddenly and severely." ${ }^{62}$ By July, he had renewed patronage in a quiet way, and in the autumn was pleased to receive orders that the privateers should be handled "gently." ${ }^{63}$ The outbreak of war with Holland in 1665 allowed him to issue commissions against Dutch shipping, although war also put paid to England's hopes of an immediate footing in the slave trade. With prospects fading of persuading the Spaniards to become customers, the old inclination to allow the rovers to resume plundering their preferred foes reasserted itself in England as well as the Caribbean. In 1666, Modyford created an elaborate list of reasons why war with Spain in the Indies was allowable, and began to issue commissions against her ships and territories, putting a legal gloss on what was already happening in practice: he pursued this policy with only one short break until the end of his government in $1671 .{ }^{\text {ot }}$

Patronage of privateering proved profitable; there was a "universal change [on the] faces of men and things, ships that were laid up presently a repairing, great resort of workmen and labourers to Port Royal, many returning that were gone and those fixed that were going, many [debtors] released out of prison. ${ }^{\text {n65 }}$ It also provided the island with necessary protection for its own infant commerce. But extracting these benefits required the Governor to exert firm control, and enforce strong discipline, over unruly men. This was achieved by instituting strict rules, and imposing severe penalties for ignoring them. Captains were expected to have a commission of some sort; articles of association outlined the rights and obligations of owners, creditors and crews; prizes were condemned in court and dues were paid; but, above all else, what defined the line between acceptable and unacceptable behaviour, between "piracy" and "privateering," was adherence to the rule that the island's own commerce should be immune from attack. Those who obeyed the regulations were able to use Jamaica's excellent harbour and port facilities-fitting and repairing ships, 
selling prizes and relaxing with "strumpets and wine" in the numerous taverns and brothels. ${ }^{66}$

Those who broke the rules, especially concerning the immunity of island trade, were treated as pirates and, if captured and tried, they were liable to be hanged. John Moreau, who obtained a commission in Jamaica in December 1663, responded to Modyford's June proclamation by "turning pirate." ${ }^{67} \mathrm{He}$ seized the Prosperous an English ship trading at Jamaica, and "inhumanely" turned all the ship's company ashore amongst the woods in Hispaniola without any provisions. ${ }^{68}$ Modyford sent Captain Ensome in HMS Swallow in pursuit, and Moreau was killed in the chase. His crew were captured, tried, and six were condemned to death. ${ }^{69}$

Predators, operating "beyond the frontier" at sea, and men attempting to settle and plant England's frontier territories in the Caribbean, perceived mutual benefits in a code of conduct which provided reciprocal immunities; this was reflected in the code's continuation long after English governments had turned their backs on support for commissioning plunder. The traditional rhetoric about forcing Spain to allow freedom of the seas retained sufficient purchase to justify violence against the Spaniards long after the Treaty of Madrid in 1670 proclaimed peace between the two nations in the Indies. Indeed, Edward Long still employed it as late as 1774 in his History of Jamaica. ${ }^{70}$ In Jamaica, it was impossible to secure a conviction against marauders who confined themselves to preying on the Spaniards, as Governor Molesworth complained in 1686, after William Coxon, a leading privateer of twenty-years standing, was helped to escape from prison. ${ }^{71}$ When a notorious villain, Peter Johnson, was hanged without trial by Lynch in 1671, he was lamented as if he was "as pious and innocent as one of the primitive martyrs. ${ }^{72}$ Vaughan remarked in 1679 that after Johnson, no more privateers were executed in Jamaica, despite all the violence committed against the Spaniards. ${ }^{73}$ But those who turned against the island's own trade were perceived as being "lifted in the service of the Devil" and, like him, at war with all mankind and treated accordingly. ${ }^{74}$

Thomas Modyford's skill in reaching an accommodation with the hordes of predators in the Caribbean no doubt made him rich-he was able to use his position to secure a substantial share of the plunder. ${ }^{75}$ But the policy was also an essential element in the English colony's survival and prosperity. The seas surrounding the island belonged to no-one and swarmed with wild men, like John Duglas, in search of treasure and excitement. No nation could count on 
21. In April 1663 the King sent orders to Charles Littleton, the acting Governor of Jamaica, signifying his dislike of "such undertakings as have already been set on foot and are yet pursued ... and commands that no such be pursued for the future." King to Charles Littleton, 28 April 1663, CO 1/17, fol. 51b, PRO. Littleton interpreted the orders to extend only to depredations on land and not at sea, Littleton to Arlington, 15 October 1663, CO 1/17, fol. 209.

22. "Beeston's Journal."

23. N. Zahedieh, "A Frugal, Prudential and Hopeful Trade: Privateering in Jamaica, 1655-89," Journal of Imperial and Commonwealth History 18 (1990): 145-68.

24. Surveys of economic and social development in the English Caribbean include Richard S. Dunn, Sugar and Slaves: The Rise of the Planter Class in the English West Indies, 1624-1713 (Chapel Hill, N.C: University of North Carolina Press, 1973); Richard B. Sheridan, Sugar and Slavery: An Economic History of the British West Indies, 1623-1775 (Barbados: Caribbean Universities Press, 1974). The Dutch experience is treated in Cornelius C. Goslinga, The Dutch in the Caribbean and on the Wild Coast, 1580-1680 (Gainesville: University Press of Florida, 1971); Johannes M. Postma, The Dutch in the Atlantic Slave Trade, 1600-1815 (Cambridge: Cambridge University Press, 1990).

25. "An Account of the Inhabitants of the Island of Jamaica."

26. Lynch to Cornbury, 29 March 1672, Add. MSS 11,410, fol. 532, British Library.

27. Lynch to Bennet, 12 February 1665, CO 1/19, fol. 31, PRO; "Littleton's Account."

28. "Lease of Lynch's Plantation," Deeds O.S.1, fols. 5-7, Island Record Office, Spanish Town, Jamaica (hereafter IRO).

29. Ibid.

30. Haring, Trade and Navigation; Jose de Veitia Linaje, The Spanish Rule of Trade to the West Indies, trans. Capt. John Stevens (London: S. Crouch, 1702).

31. K. R. Andrews, The Spanish Caribbean.

32. "Some considerations why His Majesty should keep and supply Jamaica," Harley MSS 3,361, fol. 50b, British Library; Goslinga, The Dutch in the Caribbean.

33. Harley MSS 3,361, fol. 50.

34. "Beeston's Journal."

35. Egerton MSS 2,551, fols. 152b-158b, British Library; W. S. Samuel, "Sir William Davidson, Royalist, (1616-1689) and the Jews," Transactions of the Jewish Historical Society of England 14 (1936): 39-79.

36. John Morris, Captain of the Virgin Queen, obtained a commission valid for twenty-three months in October 1662, and appears in the list of privateers based at Jamaica in 1663 (HCA 49/59, fol. 84, PRO; Add. MSS, 11,410, fol. 10, "List of Privateers," British Library). Morris later accompanied Henry Morgan in an expedition in the Bay of Mexico in 1664-65, Portobello in 1668, and Panama in 1671 (W. Noel Sainsbury, et al., eds., Calendar of State Papers, Colonial Series, America and West Indies, 20 vols. \{London: H. M. Stationery Office, 1860-1912\}, 5: nos. 1142 and 1838; "List of Ships under Admiral Morgan," CO 138/1, fol. 105, PRO.) 
After Thomas Lynch proclaimed peace in the Indies in 1671, and Morris lost his ship, he went into the service of the state and was despatched by Lynch to hunt "pirates" (Add. MSS, 11,410, fols. 465, 479-80, British Library). Morris later returned to his old ways with patronage from Henry Morgan as deputy Governor (CO 140/3, fols. 473, 479, PRO).

37. The skill with which Jewish merchants managed to comply with English regulations, and their success in commerce, combined to cause resentment. S. Hayne, $A n$ Abstract of all the Statutes made Concerning Aliens Trading in England with Observations Thereon (London: Printed by N. T. for the author, 1685).

38. "Papers relating to the Blue Dove," fols. 224, 225, 227; Court of Admiralty, 25 January 1664, HCA 49/59, fol. 55, PRO. The official court records are discreet about lewish involvement, "Robert Cooke being sworne in court made oath that the Blue Dove of London belongs to English owners and that no foreigners hath any part in her that she was bound for the island and consigned to Mr Jacob Watson; that his ships company are in all 10 of which 4 are Scotch men and that the certificates for clearing the ship and making her free are real and lawful procured by him."

39. Depositions taken in the Court of Admiralty, January 1664, HCA 49/59, fols. 51b-52, PRO. For a more detailed account of Spanish contraband commerce in the seventeenth century, see N. Zahedieh, "The Merchants of Port Royal, Jamaica, and the Spanish Contraband Trade, 1655-92," William and Mary Quarterly, 3rd ser., 43 (1986): 570-93.

40. Court of Admiralty, 24 September 1662, 28 October 1662, 13 November 1662, 22 January 1662, HCA 49/59, fols. 21-25b, PRO.

41. "Some Considerations why the King should keep Jamaica in his Possession," Egerton MSS, 2,395, fol. 615, British Library.

42. K. G. Davies, The Royal African Company (London: Longmans, 1957), Introduction; Postma, Dutch in the Atlantic Slave Trade.

43. Calendar of State Papers, No 407, "Proposals for the re-settlement of the Royal (African) Company."

44. Thomas to James Modyford, 30 March 1663, CO 1/17, fols. 28-9, PRO; Minute Book of the Royal Adventurers, 20 June 1663, T 70/75, fol. 11, PRO.

45. "Instructions to Col. Modyford," 18 February 1664, CO 138/1, fols. 29-36, PRO.

46. Minutes of Council of Jamaica, 11 June 1664, CO 140/1, fol. 92, PRO.

47. Joseph Martyn to Arlington, 26 June 1664, Edward Morgan to Arlington, 28 June 1664, CO 1/18, fols. 171, 175, PRO.

48. "The calling in the privateers will be but a remote and hazardous expedient and can never be effectually done without 5 or 6 men of war." Lynch to Arlington, 25 May 1664, CO 1/18, fol. 153, PRO.

49. Pepys was eloquent on this subject. In 1663, he exclaimed "God knows the King is not able to send out five ships at this present without difficulty we having neither money, credit nor stores." A. W. Tedder, The Navy of the Restoration (Cambridge: Cambridge University Press, 1916), p. 46. The second Dutch War made the situation much worse (ibid., p. 190). 
50. Pepys, "Estimate for Monthly Charges for Maintaining at Sea . . Men-of-War for the Security of the Leeward Islands," 12 May 1679, Calendar of State Papers, No. 988.

51. In 1667 the Lord High Admiral was instructed to limit the navy's annual expenditure to $\{200,000$, of which half would be for construction of new ships. E. A. Cruickshank, The Life of Sir Henry Morgan (Toronto: MacMillan, 1935), p. 96.

52. "A BriefiAccount of the Island Tortuga," "Mr Worsley's Discourse of the Privateers of Jamaica," Add. MSS, 11,410, fols. 320, 623, British Library.

53. "Papers Concerning the Blue Dove."

54. Despite the privateers legendary cruelty described in sensational accounts there is often surprisingly little blood-curdling violence in the privateers' frequently prosaic exploits. See Exquemelin, Bucaniers; D. Defoe, A General History of the Pyrates, From Their first Rise and Settlement in the Island of Providence, to the present Time (London: Printed for, and Sold by T. Woodward, 1724).

55 "Papers Concerning the Blue Dove," fols. 271-73.

56. Ibid., fol. 259.

57. Ibid., fols. 220, $221,226$.

58. Nathaniel B. Shurtleff, ed., Records of the Governor and Company of Massachusetts Bay in New England, 5 vols. (Boston: W. White, printer to the commonwealth, 1853-1854), 3:127.

59. Ibid.

60. "Papers Concerning the Blue Dove," fols. 75, 236a, 257, 259, 262, 262a, 264, 265, 269.

61. "Mr Worsley"s Discourse of the Privateers of Jamaica."

62. Modyford to Arlington, 30 June 1664, CO 1/18, fol. 176, PRO.

63. Modyford to Arlington, 20 February 1665, CO 1/19, fol. 47, PRO.

64. "Beeston's Journal."

65. "Reasons for Letters of Marque," 22 February 1666, CO 1/20, fols. 45-46b, PRO; Minutes of Council of Jamaica, February 1666, CO 140/1, fols. 143-7, PRO.

66. Exquemelin, Bucaniers, p.106.

67. Commission to John Moreau, 19 December 1663, HCA 49/59, fol. 84b, PRO.

68. "Reasons why the Private Men of War are Advantageous to Jamaica," CO 1/20, fol. 242, PRO.

69. Thomas Modyford to Arlington, 20 February 1665, CO 1/19, fol. 38; Court Martial, 1 March 1665, COl/19, fols. 43-43b, PRO; "Beeston's Journal."

70. Edward Long, The History of Jamaica, 3 vols. (London: Printed for T. Lowndes, 1774), 1:292-94.

71. Molesworth to Blathwayt, 16 January 1685, CO 138/5, fol. 135, PRO; Molesworth to Blathwayt, 2 November 1686, CO 138/6, fol. 211, PRO.

72. Lynch to Slingsby, 9 October 1672, CO 1/29, fol. 92, PRO.

73. "Report on the State of Jamaica by Lord Vaughan," MSS 159, fol. 20, Institute of Jamaica, Kingston. 
74. D. Defoe, The King of Pirates (London: A. Bettesworth, 1720), p. 5.

75. Modyford tried to play down his gains but there is ample evidence of him buying prize vessels and goods at low prices (CO 138/1, fols. 56, 134, CO 1/24, fol. 145, CO 1/19, fols. 253-55, PRO).

76. "The Governor of Jamaica's Answer to the Inquiries of His Majestie's Commissioners," CO 138/1, fol. 100, Public Record Office (PRO), London. 
their obedience but neither could they be ignored. Sweeping proclamations prohibiting plunder had little impact beyond alienating the predators and encouraging them to move their centre of operations. No state was willing or able to expend the sums needed to police the seas effectively and reduce the privateers. The survival strategy pursued by the state's agent, Modyford, depended on incorporating the marauders into the island economy and diverting their violence away from English trade and, as far as possible, against others. Success was reflected in the retention of Jamaica. Even though the island was situated in the heart of Spanish territory, "circled in with enemies," it remained in English hands and flourished, as both plantation and commercial centre, beyond the most optimistic projectors' dreams. ${ }^{76}$

\section{NOTES}

1. I would like to thank the British Academy for a grant that funded research in the United States and the Caribbean.

2. Violet Barbour, "Privateers and Pirates of the West Indies," American Historical Review 16 (1911): 529-66; K. R. Andrews, The Spanish Caribbean: Trade and Plunder, 1530-1630 (New Haven, Conn: Yale University Press, 1978).

3. The wealth of Spanish America, with its gold and silver mines, was legendary. Spaniards, well aware that this rich commerce aroused general covetousness, devoted the bulk of the resources earmarked for the defence of America to the protection of the treasure. Trade and territory outside the bullion routes were neglected. P.E. Hoffman, The Spanish Crown and the Defense of the Caribbeam 1535-1589 (Baton Rouge, Louisiana: Louisiana State University Press, 1980); R. D. Hussey, "Spanish Reaction to Foreign Aggression in the Caribbean to about 1680, "Hispanic American Historical Review 9 (1929): 289-302; C. H. Haring, Trade and Navigation between Spain and the Indies in the Time of the Hapsburgs (London and Cambridge: Harvard University Press, 1918).

4. A propaganda shift is reflected in contemporary literature which was by the late-seventeenth century trying to distance the buccaneers from civilized society by $\mathrm{d}$ welling on their barbaric cruelty and rendering them scarcely human. The legality of their activities is challenged and they were labelled "pirates" even when operating with commissions. Even Henry Morgan, who had been perceived as national hero, was being recast as brutal villain. See A. O. Exquemelin, The Bucaniers of America (London: for W. Crooke, 1684). 
5. "Papers Relating to the Blue Dove," Archives of Massachusetts, 1622-1799 (hereafter A. Mass.), 60, Massachusetts State House, Boston (hereafter M.S.H.). Some of these documents have been printed in J. F. Jameson, Privateering and Piracy in the Colonial Period (New York: Macmillan, 1923), pp. 27-40. The incident is described in J. G. Lydon, "Capt. John Douglas and the Blue Dove," New England Quarterly, 38 (1965): 54-64.

6. "An Account of the Inhabitants on the Island of Jamaica as it was taken and given in at my Lord Windsor's Departure from Said Island 28 October 1662," Add. MSS 11,410, fol.12, British Library, London.

7. "The Governor of Jamaica's Answer to the Inquiries of His Majestie's Commissioners," CO 138/1, fol. 100, Public Record Office (PRO), London.

8. S. A. G. Taylor, "The Western Design: An Account of Cromwell's Expedition to the Caribbean" (Kingston, Jamaica: Institute of Jamaica and Jamaica Historical Society, 1965); A. P. Thornton, West-India Policy under the Restoration (Oxford: Clarendon Press, 1956), pp. 67-72.

9. "A Journal kept by Coll. William Beeston from his first coming to Jamaica," Add. MSS 12,430, fol. 43, British Library.

10. C. H. Haring, The Buccaneers in the West Indies in the Seventeenth Century (London and Hamden, Conn.: Archon Books, 1910).

11. "Doyley's Journal," Add. MSS 12,423, fols. 58, 60-60b, 61b, 91, 101, British Library; Helen J. Crump, Colonial Admiralty Jurisdiction in the Seventeenth Century (London and New York: Longmans, 1931), pp. 95-102.

12. Doyley to Nicholas, March 1661, CO 1/15, fol.75, PRO.

A. MacFayden, "Anglo-Spanish Relations" (Ph.D. thesis, University of Liverpool, 1967). The line was the prime meridian passing through the Azores and the Tropic of Cancer. See G. Mattingly, "No Peace Beyond What Line?" Trans. of the Royal Historical Society, 5th ser., 13 (1963): 145-62.

13. "Additional Instruction to Lord Windsor," 3 May 1662, CO 138/1, fol. 20, PRO.

14. "Beeston's Journal."

15. "Condition of Jamaica at Lord Windsor's Departure," Add. MSS 11,410, fol. 6, British Library; "Beeston's Journal."

16. "Account of the Inhabitants on the Island of Jamaica," "A Brief Account of the State of Jamaica by Sir Charles Littleton," Add. MSS, 11,410, fols. 12 and 30, British Library.

17. "An Account of the Private Ships-of-War belonging to Jamaica and Tortudos in 1663," Add. MSS 11,410, fol. 10, British Library.

18. HCA 49/59, PRO.The Crown claimed a one-tenth share of all prizes and the Admiralty claimed one-fifteenth.

19. The commission was issued to Charles de Bils by Alfonso VI in 1658 and sold by him to John Duglas in 1662. See "Papers relating to the Blue Dove," fol. 215.

20. Ibid., fol. 271 . 


\title{
3 \\ The Taylor Manuscript and Seventeenth-Century Jamaical
}

\author{
DAVID BUISSERET
}

John Taylor, the son of Richard Taylor, was born in 1664 into a family long established around Chale, in the Isle of Wight. He was educated at home, and by the age of eighteen, after more than a year of special studies in mathematics and other "knotty sciences," he claimed that he had become "master of those branches of the Mathematics springing from Arithmatick and Geometry: viz., Navigation, Surveying, Dialling, Architecture, Fortification, Gunnery."

In October 168., Taylor went to live in Portsmouth, then a fast-developing naval base on England's south coast, within sight of the Isle of Wight. There he earned his living by giving lessons to the sons of the dockyard and naval officers. By the following year Taylor had moved to London, and was pursuing his mathematical studies there, but he became increasingly restless, and in June 1685, joined the royal army which was then being raised to counter the Monmouth Rebellion in the West of England. As Taylor put it, with no false modesty, "he betook himself to His Majesty's service with all the resolution and bravery imaginable."

The royal army marched into the west of England, and soon defeated Monmouth's scratch force at Sedgemoor. Taylor came back to London with his unit in July 1685, where at the end of August, the "wars being over," and Taylor "weary of this wild kind of life," he left the army and resumed his study of mathematics, to which he now added chemistry. Early in 1686, he met and married his wife, and in July published his Mathematical Treasury to favourable comment.' 
Later in the year, Taylor and his wife, who was by now pregnant and found that London did not agree with her, returned to the Isle of Wight. Taylor then became embroiled in a quarrel with his father-in-law, and this became so serious that he resolved to leave England in order to "seek his fortune abroad." He therefore sold some of his property to provide for his wife and mother as best he could, and went back to London, where his acquaintance Jeremiah Arnold, of the "Royal Company of Merchants trading to Jamaica," informed him of the opportunities available in that island. He gave Taylor letters of introduction to the Deputy Governor, Hender Molesworth, and Sir Francis Modyford, and advised him to buy a stock of cloth for sale in Jamaica. This Taylor did, and he also invested in three convicts from Newgate Prison. These three, Charles Gould, Ann Sharp and Susannah Caledon, had all been convicted of felony, and were available for sale as indentured servants. Taylor paid fees of $£ .6$ to the Newgate jailor, and undertook to pay $£ 18$ to transport the convicts to Jamaica on board the Saint George, then lying at London. He paid $£ 10$ for his own passage, and on 31 October the Saint George set sail for Jamaica. ${ }^{4}$

The first part of the voyage was full of incident; at one stage Turkish pirates pursued the ship, and a little later it was discovered that many of the convicts had cut their chains, and were waiting their chance to turn on the crew. Still, the Saint George reached Madeira on 29 November, Taylor noting that he "was in perfect health, but remain'd extremly mellancholly." They set out across the Atlantic on 3 December, making landfall on 25 December. The voyage was uneventful, except that the convicts broke into the liquor store, and became extremely drunk. By 29 December they were sailing past Santo Domingo, and on 1 January they arrived at Jamaica.

Taylor disembarked with the other passengers, and went to pay his respects to the Governor at Spanish Town; then he returned to Port Royal, where he rented lodgings and saw to the sale of his three servants; they fetched 145 dollars, leaving a positive balance of 45 dollars, but "not soe considerable a profitt as he expected." Taylor now had to find a job, or as he put it to "prosecute his employ," but on 18 January he fell gravely ill, and did not recover his strength until about the middle of April, some three months later. We cannot be sure what the illness was, but we do know that he had a high fever, that he was bled four times by the eminent Dr. Trapham, and that his recovery was helped by a dream. This illness consumed most of his slender capital, so when he was offered employment by Francis Blackmore he gladly consented. ${ }^{5}$ 
Blackmore and his wife lived in Clarendon, near Withywood, where they owned "two brave plantations for sugar and indigo." Taylor was taken on as a bookkeeper for Blackmore's and Thomas Sutton's estates, and was "mighty kindly used by that worthy gentleman and his good lady, whoe used him more as a son or brother than a stranger." On 18 April he "received his truncks of books etc. from Port Royall, which were brought to Witheywood by water, and from thence to Mr. Blackmore's in his wain." At this time he began composing his account of Jamaica, making it "his business to sirch and prie into the nature of all ye products of this island, and to collect their essence and natures."

Alas, early in May he again fell ill, this time with "the dry belly ache," and although he recovered after two weeks, doctors advised him to leave the country, since recurrences of the disease often led to paralysis. Taylor "therefore resolved to returne home to England, and to live there with his wife in that estate God had called him too." He said goodbye to the Blackmores, and took a sloop from Withywood Bay back to Port Royal, intending "at the first opportunity to return home to England." However, on 21 May he fell in with Captain Charles Talbot, commander of H.M.S. Falcon, and Talbot invited him to act as ship's clerk.

Taylor agreed, and on 26 May went on board the Falcon, where he "had a cabin provided for him in the steerage, and eat at the captain's table. And he was somewhat weak and discontented, but seemed as cherfull as possible." Now began an entirely new phase in Taylor's life, as he cruised the Caribbean with Captain Talbot, in search of pirates. ${ }^{6}$ They left Port Royal late in May, engaged the pirate Bannister, captain of the Golden Fleece, in the Gulf of Samana, and returned to Port Royal on 12 July. Taylor was now "in much better health, and stronger than when he went on board, for the sea agreed with him much better than the shore."

Falcon sailed again on 23 July, and after finding the remains of Bannister's ship returned to Port Royal on 4 September. Bannister himself avoided capture for a few months longer, but the following January H.M.S. Drake caught up with him, arriving back at Port Royal "with Banister, he and 3 of his partners hanged at the yards." Meanwhile Taylor continued to serve as clerk on the Falcon, which after several other cruises arrived back in England at the end of 1688. Presumably he then returned for a while to the Isle of Wight, but he eventually settled in Norfolk. His Almanack for... 1696 on the final page gives his address as being "my house near the Market-Place, Norwich." He published another Almanack in 1701, but we thereafter lose sight of him. ${ }^{7}$ 
From the time that he left England, Taylor kept a journal of all his doings, illustrating it with maps and drawings, a few of which are reproduced here; the maps merit a separate study. This journal, which fills three stout volumes, was once in the famous collection assembled by Sir Thomas Phillipps, and about twenty-five years ago was acquired by the National library of lamaica. ${ }^{8}$ The three volumes are paginated sequentially, which makes it relatively easy to grasp the extent of the work, and the importance accorded to each theme. The contents of the volumes are as follows:

V'olume I "Taylor's History of his Life and Travels"

p. 1 The Introduction or Preface /chiefly philosophical reflections about the work |

p. 19 Of his descent, and education

p. 42 Of our going to live in Portsmouth

p. 58 Of our living in London [October 1684-December 1685]

p. 106 Of all notable transactions ... [January-October 1686)

p. 145 An account of our travels in America [October-November 1686]

p. 161 Of our voyage from the islands of Madeira |December 1686-January 1687|

p. 176 Of our living in Jamaica |January-May 1687]

p. 196 Of our going on board H.M.S. Faulcon [May-July 1687]

p. 213 Of all notable actions. . . July 1687-September 1687)

Volume II "Taylor's present State of Jamaica"

p. 239 Of the discovery of Jamaica

p. 252 Of the taking of Jamaica by the English | 1655|

p. 304 Of the situation of Jamaica

p. 320 Of Jamaica: its towns, parishes etc.

p. 334 Of Jamaica: its products (beasts, birds, fishes, serpents, insects, stones, trees, shrubs, herbs, fruits, roots, seeds, flowers, barks and gums)

p. 491 Of Port Royal

p. 508 Of the situation of Saint Jago de la Vega

p. 519 Of the planting of sugar etc.

p. 536 Of the planter's usage towards his servants and slaves

p. 555 Of the laws and customs of Jamaica

p. 578 Of the reception of Albermarle

p. 588 Some particular directions [for intending settlers] 
Volume III "Multum in Parvo or Parvum in Multo"

p. 599 Of all notable actions [on H.M.S. Falcon,September 1687]

p. 605 Of all notable passages [September-October 1687]

p. 609 A geographicall description of the mainland of Peruana

p. 625 Of all notable occurences at Porta Bella [October 1687]

p. 634 Of all notable occurences [October-December 1687]

p. 681 A geographical description of ... Hispaniola

p. 711 Of all notable passages ... [January-May 1688]

p. 780 Of the King of Spain's Grand Flora

p. 810 Of all notable passages... [May-August 1688]

p. 854 Of our return home [1 September 1688-31 December 1688].

Although the manuscript gives an impression of homogeneity, being written in the same hand and apparently all at roughly the same time, it in fact consists of three separate literary types. From p. 1 to p. 144 it is in diary form, describing 'Taylor's early life and adventures. At p. 145 it takes on a new shape, that of the nautical log; this continues until the end of volume $I$ at p. 238, and also includes volume III, from p. 634 to the end. Volume II, called the "Present State of lamaica," offers a different stylistic form, providing a comprehensive description of the island as Taylor knew it.

The latter literary form had a long history. There were medieval European accounts, like that of Marco Polo, describing strange lands, but Taylor's "Present State" belongs to the stylistic type of "New World" descriptions composed by Spaniards in the sixteenth century, in works by authors like José de Acosta, Gonzalo Fernández de Oviedo, and Nicolás Monardes. ${ }^{9}$ The first English examples of the genre date from later in the sixteenth century, with the descriptions of the abortive Virginia colony; by the early seventeenth century there are abundant accounts of the area known as New England. ${ }^{10}$

The first English commentary on the Caribbean seems to have been written by Daniell Ellfryth in 1631, followed by such well-known works as Richard Ligon's A true and Exact History of the Island of Barbados (1657). ${ }^{11}$ The British seized Jamaica in 1655, and brief descriptions of the island began appearing shortly thereafter. Most of these remain in manuscript among the State Papers preserved at the Public Record Office and the British Library, though a few were eventually published in the first volume of the Journals of the House of Assem$b l y .{ }^{12}$ In fact, so many attempts were being made in England at this time to 
describe new territories, that in 1666 the Royal Society actually proposed the "General Heads for a Natural History of a Country," in an attempt to introduce some system into a rather chaotic situation. Taylor conformed only in a general sense to these recommendations. ${ }^{13}$

The first contemporary descriptions of lamaica were published in the early 1670s. Both John Ogilby's section on Iamaica in his America (London, 1671) and Richard Blome's A Description of the Island of Jamatca (London: 'T. Milbourn, 1672) were, however, quite short, merely summarising the island's "Situation," "Commodities" and history. At this time it had become fashionable to publish works entitled "The Present State of ...," with, for instance, works on France (1671), New England (1675), Carolina (1682) and England (1683) being named in this way. ${ }^{14}$

No more printed works on lamaica appeared between those of Blome and Ogilby, and the time when Taylor began his study, though Sir Hans Sloane was at work on his great "Natural History," which was published as part of $A$ Voyage to the islands Madera ... and Jamaica. "Indeed, the knowledge that Sloane had completed this work may have dissuaded Taylor from publishing his "Present State," for the manuscript shows every sign of having been carefully prepared for the printer.

Although Sloane has very little to say about the history or government of lamaica, his work on the island's natural history does closely parallel pp. 334 to 490 of Taylor's manuscript. Sloane used eight categories: plants, trees, insects, animals, fishes, birds, serpents, and stones. These are also Taylor's groupings, although he put them in a different order, and included eight sub-divisions under "plants." Sloane's descriptions are much drier and more professional than those of Taylor, who rarely mentions the Latin name for his subjects, and frequently interjects his own ideas, along with more or less fantastic pieces of folklore.

Vol. I, pp. 1-144, is written in diary form, and contains Taylor's account of his early life and intellectual formation; it provides the basis for a biographical reconstruction of his life. The sections cast in the form of a nautical log (Vol. 1, pp. 145-213 and Vol. Ill, pp. 599-854) offer material primarily of interest to maritime historians. They contain details of weather and sailing-times that reveal the sailing qualities of a small seventeenth-century warship. There are also accounts of wooding and watering, and taking on other kinds of supplies, that help our understanding of the logistical problems facing naval captains. 
WHST INIHS ACOONTS

When the Falan was at anchor in P'ort Royal, the log records ship arrivals and departures that complement information from the customs records. ${ }^{16}$ The logs also include lengthy descriptions of places visited by the Falcon; there are thus accounts of the city of Santo Domingo (p. 204) and of the Gulf of Samana (pp. 224.3(1).

However, it is the third literary type, comprehended in "The Present State of lamaica" (pp. 239-598), that offers material of greatest interest. It begins with an account of "the discovery of America by Don Christopher" (pp. 239-51) that most curiously reflects what the English then knew about that venture. Colum. bus, Taylor says, was born at Genoa in 1447 ( 1451 seems to be the correct date), and he goes on to make the unfounded assertions that the admiral was "of honourable extraction," and "sent to Rome and there by exquisite tutors instructed in all the liberal sciences." After proposing his voyage to the king of Portugal and being rebuffed, Columbus, according to Taylor, "redresses himself to Phillip, the king of Spain" (in reality to Ferdinand and Isabella), with whose support and two (sic) stout ships he set sail on 14 February 1492 (in reality 3 August), landed on "Hatie," which he renamed Hispaniola, and then returned home to his master, King Philip. Taylor next describes the second voyage, when Columbus called at lamaica, and then affirms that he died and was buried at seville in 1493; Taylor thus knew nothing of the third and fourth voyages, on the latter of which Columbus spent nearly a year marooned on Jamaica.

Taylor's account continues with a description of the Spanish settlement on the island, and of the Portuguese foundation of Saint Ann's Bay. In both these accounts useful information is mixed up with what seem to be fantastic rumours. However, since the earliest Spanish presence dated from over 150 years before Taylor's arrival on the island, some inaccuracies are not surprising.

His description of the British seizure and occupation of the island (pp. 252-67) probably used the testimony of eyewitnesses, and is remarkable both for its accuracy and for its originality, though some details are false. The fleet organized by "Oliver [Cromwell] that fell tyrant" did indeed fail before Santo Domingo, and then sail on to land in lamaica on 8 May 1655. The Spaniards on the island did retreat from their capital, burying their treasure, though we may doubt if these hiding places were "inchanted by magicque art." Taylor gives a credible account of the resistance of Juan de Bolas, and explains the failure of the Spaniards at Rio Nuevo in 1658 (which he erroneously dates to 1656). He goes on to describe the foundation of Port Royal, the settlement of the various 
regiments in different parts of the island, and the establishment of what he calls a lex methodica, or system of government with a governor, council and assembly.

The next section describes the sack of Panama by Sir Henry Morgan in 1671 (pp. 268-81), and the piratical ventures of Captain Bartholomew Sharp in the Pacific Ocean (pp. 281-95), ending with a description of "the care that hath allways bin taken by His Majesty of Great Britanie for the suppressing and distroying of pyrats in America" (pp. 295-303). It includes accounts of the fate of the pirates "Havine," Banister (also described in the earlier part of Taylor's work) and "Captain Bear, a man of good repute and an ancient trader in lamaica." Information about pirates is rare, and Taylor's account of Captain Bear's activities is probably unique.

The "Present State of Jamaica" really begins on p. 304. Taylor describes the geographical situation of the island, and then considers the influence of the winds, particularly those "northers" which not only refreshed the island, but also led to serious flooding at Port Royal. He claimed that Jamaica was more or less immune from "tempestuous hiroclidon or huricans," the last one having occurred in 1622, and he describes the drought of 1686.87 , as a result of which "those statly savanas, which before was farr greener than European medows, were now burnt up and looked like new fallowed ground." 'The slaves' provision grounds were also much damaged, Taylor adds, so that the planters were "forc't to maintain their Negro slaves with English and Irish provitions." Taylor concludes this section with some reflections on earthquakes; "a certain astroliger," he says, predicted an earthquake at Port Royal in March 1686, adding that "the Point should be swallowed up in the sea." This earthquake came to nothing (though some of the inhabitants fled in fear of it), but there was a strong one in February 1688 in which three houses at Port Royal were destroyed; Taylor experienced these tremors when he was on board H.M.S. Falcon in the harbour. These various alarums culminated, of course, in the disastrous earthquake of June 1692.

A general description of the island, taking in towns, forts, bays, rivers and so forth, begins on p. 320. Taylor lists numerous place-names from the era of Spanish settlement that subsequently fell into disuse. Curiously, he greatly overestimates the height of the mountains, which "by very often strick observations have been found to be somewhat more than six miles high" (that is about 35,000 feet; in reality, they reach about 7,400 feet). He makes tantalizing references to the state of the island in the days of the Spaniards and "Indians," 
speaking for instance of the "plesant savanas as of old the Indians' corn fields;" these savannahs, he adds, "are not allowed to be taken up or planted by any, but are common pastures for the adjacent inhabiteres."

Taylor next lists the "cheif and principall gentlemen and planters," and concludes the section with an account of the "inchanted places" on the island, where the Spaniards hid their treasure. These unverifiable tales, told for instance by "a gentleman who now lives at Saint Jago," perhaps contain a germ of truth, for the Spaniards did bury much specie in what they thought was a temporary flight, and through the years many such caches have been discovered in Jamaica.

A very long section devoted to the island's "products," ranging from creatures to plants and stones, begins on p. 334. Among the "beasts" were horses; Taylor describes an "aboundance of well-shap't horses of the Spanish breed, ranging in the spatious savanas;" so many, indeed, that it was common for planters to have " 4 or 500 horses, every man haveing a perticular mark for distinction sake." Cattle also abounded and were prized chiefly for their hides and tallow: "here they have noe dairies, nor do they make any considerable profit from the milke, for there is neither cheese nor butter made but only att two or three great plantations in the whole island." The hills sheltered wild cattle, too, and sometimes these were slaughtered and their flesh dried, "as we doe herings in Europe, which they call jercking." The small barkless dogs of the Arawaks could still be found, and wild dogs and cats roamed the woodlands.

Taylor marvelled at the variety of birds, including many parrots, and he particularly admired the Cuban parrot, "in my fancy the handsomest which I ever saw. . . these parrats will speak very loud and plain." He provides a long catalogue of large birds, including several which may now be extinct, and finds the humming-bird "the butifulst creature in the whole creation, for nature always appearth most glorious in its lesst workes." He confirms contemporary observations that "this bird is by the Indians preserved and dried and worn in their ears and nose as a choice jewell." The section on fish is as rich as the one on birds, and includes a good deal of information about turtles, then an important part of the islanders' diet. Taylor describes how, at Port Royal, huge jewfish are caught, fried and pickled; this fish is called "caveich" (the probable origin of today's "escovich"). ${ }^{17}$ He also notes the abundance of snapper, "a verey good frying fish."

Taylor's description of the Jamaican fauna predates the existence of a widespread plantation system, a time of abundant space and food for a great 
variety of creatures. These included not only survivors from the pre columbian period, but also the many animals imported by the Spaniards. The steady extension of the plantations, and mounting environmental pressures from Taylor's time to the present, have, of course, led to a steadv mpererishment of this marvellously diverse fauna.

The flora described by Taylor are readily recognized. Among the trees, he particularly admired the Spanish elm which, he wrote, makes cxcellent planks and "will cleave with great facility." He always listed the economic uses of the lamaican flora, noting for instance that the cotton tree is emploved "to make large boats called periaquer and canoas, some of which will carry seven or eight tunns of watter, they being full 8 foot broad and deep and nigh forty foot long." There were many "China and Sivilla orange trees" left over from the days of the Spaniards; under their shade, Taylor writes, "the painful planter and's farre Creolian ladies withdraw themselves from the schorching heat of Phoebus." In Spanish times there had also been many cocoa-walks, but Taylor notes that these were now mostly ruinate.

Among the shrubs, Taylor notes the "palmeto royall," adding that "the Burmodians make of these leaves hatts, capps, basketts, matts etc., and in great aboundance, which they themselves weve and bring to sell at lamaica." His section on plantains mentions that "the boonana tree is a shrub in all respects like the plantann," "whose inward part or pith made into a pectorall decoction cueres all obstructions of the splene." Taylor gives the therapeutic qualities of many other shrubs and plants-the "collalua" (callalloo), ${ }^{18}$ for instance - is an excellent pot herb ... . and is a great refiner of the blood"-thus revealing important insights into folk remedies and the current state of medical practice.

Taylor often contrasted the products of Jamaica with those of England, generally to the latter's disadvantage. Speaking of fruits, for instance, he notes that Jamaica has many which "the lady Europia never enjoyed." The pomegranates "are such in shape and growth which are daily sold in England, tho' much more delitious." The figs are "fare larger and better than any which grow either in Spain, France or England." The musk melons, too, are "much better and sweeter and quadruple as large" as those found in England. Although Taylor thus celebrates the bounty of Jamaica's fruits, he notes the deficiency of the island's flowers: "for here we find her green mantle voide of flowers, for Europe is the lady Flora's garden, which she hath array'd in her own livery, and these western parts she hath withheld hir favors from." 
In describing the island's products, Taylor provides invaluable information about the "native Indians," who use gourds as vessels for their drinks, and make "botles, cups, dishes, spoons and many other convenient utinsalls" from the calabash nut. Taylor records how the slaves use a good deal of maize, called "hommone after the Indian name;" they also make a drink from it, which "the Indians call cawwough." Taylor's work reveals a much more pervasive presence of the Indians than is usually ascribed them, although their identity remains problematic. Perhaps there were still Taino/Arawak survivors; after all, a nucleus of them had survived at least to 1611 , while Indians had also been brought as slaves from the Mosquito coast and from the North American mainland. ${ }^{19}$

The section on Jamaica's products ends on p. 490, and is followed by a twenty-page description of Port Royal, which gives an unrivalled account not only of the buildings on the Point, but also of the round of daily life. ${ }^{20}$ After this exceptionally full treatment of Port Royal, Taylor spends ten pages on the other settlements, beginning with Saint Jago, or Spanish Town, where, he notes, 1,300 Spanish houses survive from the original 5,000. These "low timber-work houses" are very different from "the brick buildings here erected by the English .. lofty and butiful as our buildings in London, and glazed with glass windows." Taylor's description thus confirms that the new settlers had not yet embarked upon a process of creolization, out of which would emerge a style of architecture both distinctive and more suitable for the tropics.

After Spanish Town, Taylor turns his attention to Liguanea, which he calls "the garden of Jamaica." He describes what is now central Kingston, around the parish church, as the "plesantest place on all the island, being continually plantable green and flourishing for seven miles together." ${ }^{21}$ Passage Fort he describes as having about thirty houses, and Old Harbour and Carlisle Town (near Alley) had about one hundred houses each; at the latter there were "many wealthy Jewes merchants." ${ }^{22}$ Taylor concludes this section by describing the "northside;" here in 1687 the plantations were indeed "not many, and those small and scattering."

Pp. 519-35 contain descriptions of how the island's main crops were produced. Although much of this information can be found elsewhere, some of it is original. Taylor records that indigo was often interplanted with maize, that rum was often re-distilled into brandy, that the Spaniards were expert cultivators of cocoa, and that Madame Greg had a thriving cotton plantation near "the Rock" (Rockfort). Taylor does not confine himself to the main crops, 
but offers details on the cultivation of maize, guinea corn, scotsgrass and cassava.

In the next section, "of the planter's useage towards his English servants, Indians and Negroa slaves on Jamaica, with an account of the strong carrage and anticque behaviour of those slaves, and of their many late insurrections and rebellions" (pp. 536-54), Taylor condemns the planters' hehaviour towards the indentured servants. When they are sick, he claims, "there is not half that car taken of 'em as over their Negros, and when dead no more ceremony at their funurals than if they were to bury a dogg." The Indians came from "Surinam, Florida, New England etc.," and used to be sold for slaves, though not many were now remaining; they received the same allowances as the English servants Taylor gives a long and interesting description of the treatment and life of the "Negroa slaves," including an analysis of their religious beliefs, origins and language (noting that they call Englishmen "bacarara"). He describes the well known rebellions of March 1682 (Madame Greg's), June 1683 (Colonel Ivy's) and December 1684 (Captain Duck's), and provides information about an otherwise unrecorded conspiracy discovered at Port Royal in December 1685. Taylor concludes with a description of the Maroons, who at this time were just beginning to gather strength in the mountains.

A description of the establishment of civil government (pp. 555-58) serves as an introduction to a long section on the laws of the island (pp. 558-77). Taylor sets out 60 laws, not all of which were enumerated in the Laws of Jamaica. ${ }^{23}$ Many of them concern the treatment of indentured servants and slaves, but they range widely, even covering such subjects as the protection of buzzards as scavengers.

The final two sections in "The Present State" concern the reception of the Duke of Albemarle, who arrived to govern the island on 20 December 1687 (pp. 578-87), and some advice for settlers (pp. 588-94). The "Joyful triumph of His Grace's reception" describes the festivities at Port Royal, incorporating scenes and characters that he had earlier depicted. Taylor's "particular directions" for settlers provide little practical advice. He does warn against the "treachery and perfidious dealing practice" that could be encountered when transacting business, but would by no means have been peculiar to Jamaica.

Taken as a whole, the "Present State" offers a remarkable and so far underexploited description of Jamaica in the 1680s; its very language contains many additions to the word-lists developed by the lexicographers. Taylor's 
work delineates the flora and fauna of the island immediately before the great expansion of the plantation system, which would change the island's ecology for ever, and it offers rich new evidence concerning both the Spanish occupation and the "Indian" presence. It is of interest not only to historians, but also to natural scientists, since Taylor's observations about natural processes and natural products, while often enmeshed in the errors of his time, contain valuable first-hand evidence. His style, though at first a little disconcerting, is well-suited to impart this information, for as he himself observed, "I allways love things concise and previous."

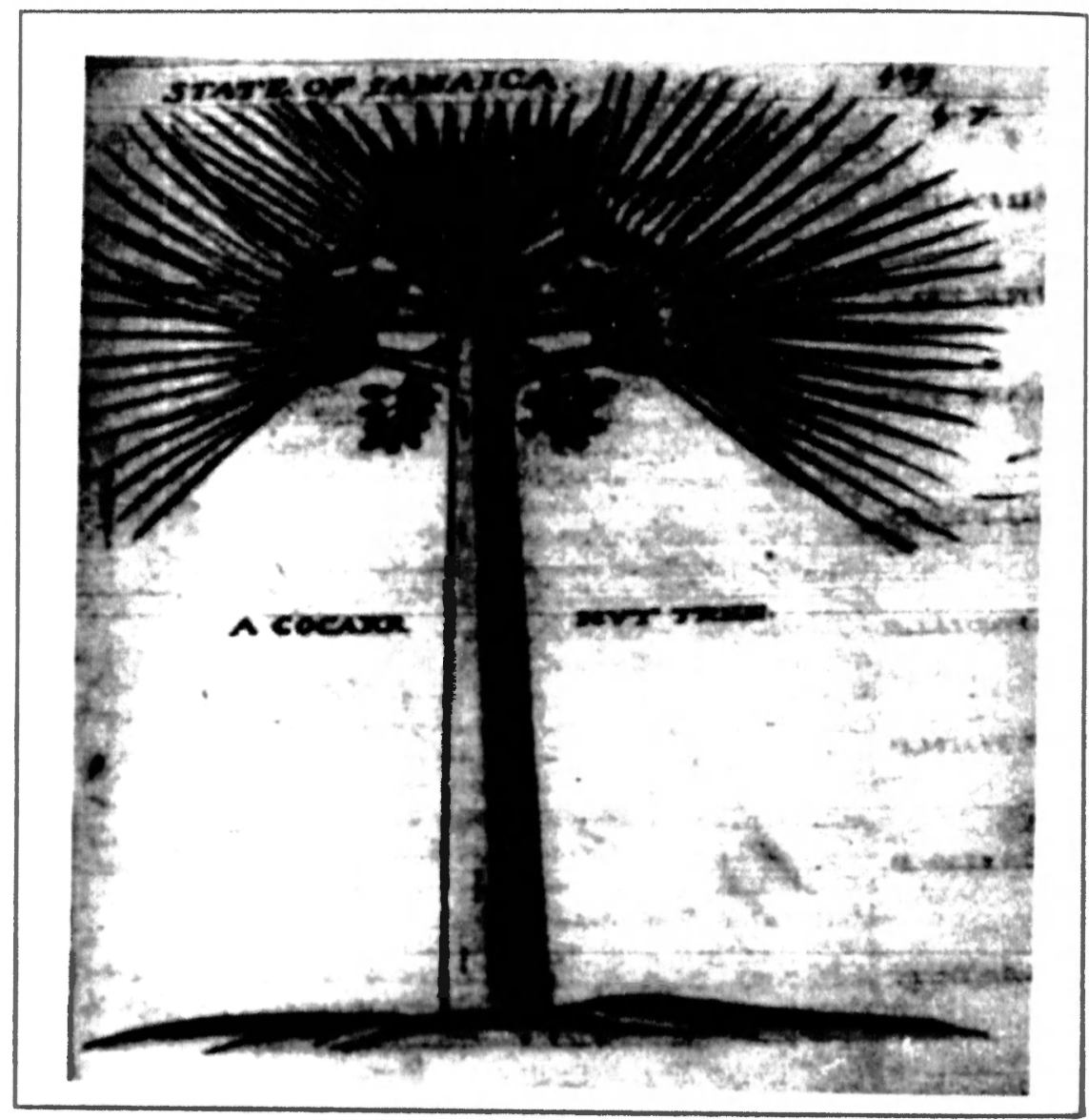

"A Cocarrnut Tree" 


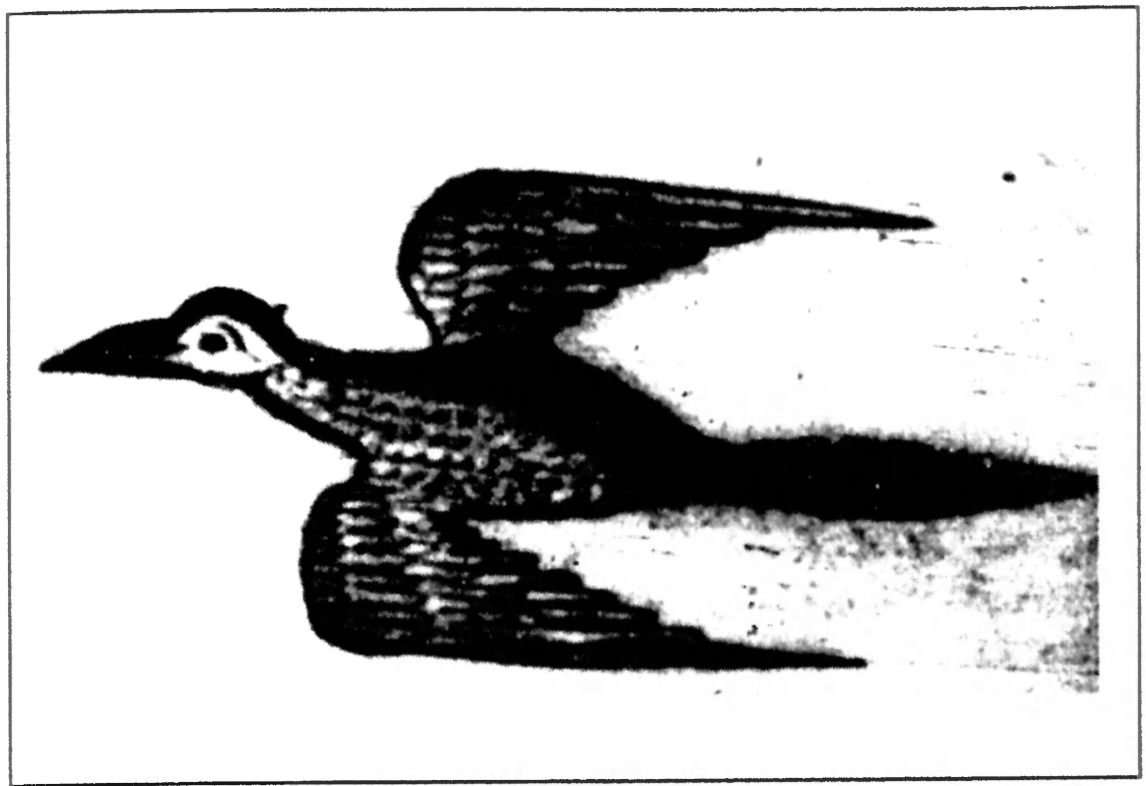

"A Tropick Bird"

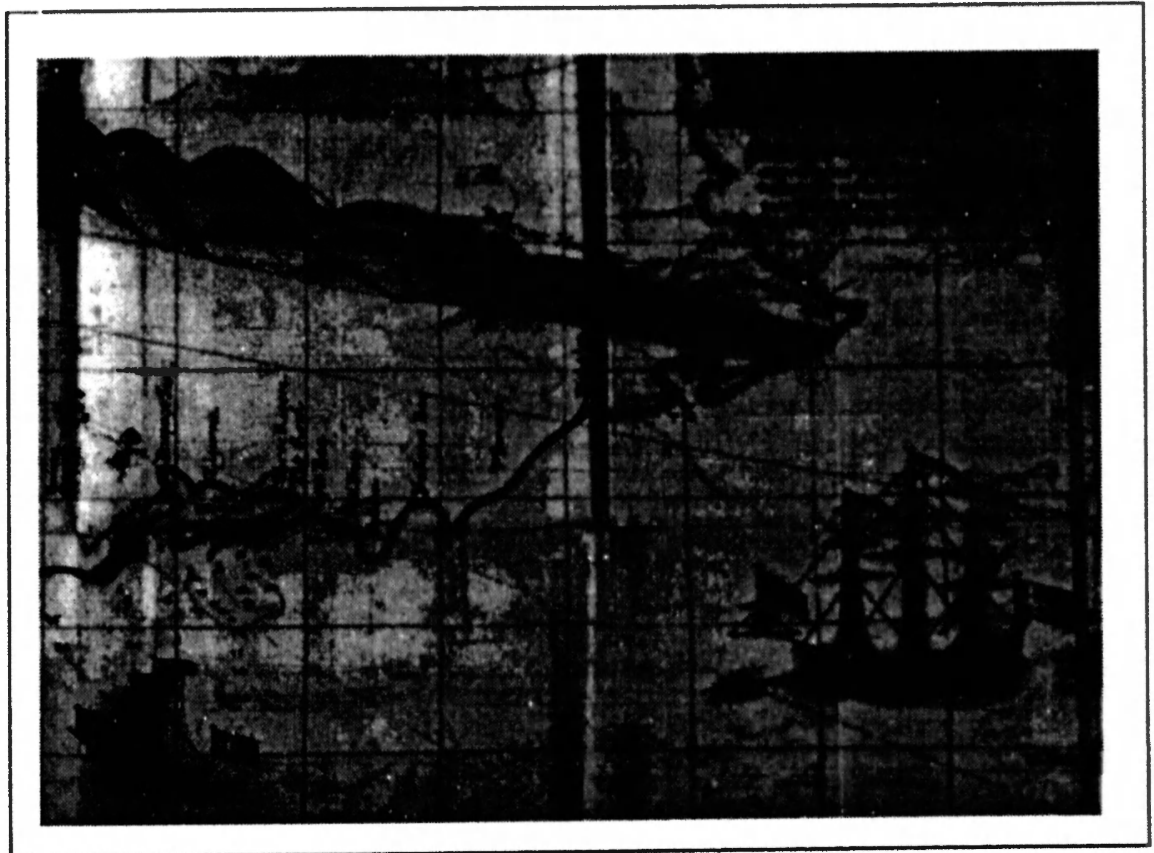

"Saint Jeromes Bay" Southeast Coast of Jamaica 


\section{Nolts}

I I have taken a gend alcal of advice about different aspects of the Taylor Manuscript. Two people whose help must be mentioned are Tony Gambrill of the Jamaican Historical Sin iety, who supported the transcription of the work, and Professor lan Stecle of the ('niversitv of Western Ontario, who read this article and made helpful suggestlons

: These and all other unascribed quotations throughout the article come from the manuscrupt of the Journal of John Taylor, MF 18, National Library of Jamaica. Kingston, Jamaica

3 There is a brief biographical notice in E. G. R. Taylor, The Mathematical Practitioners of Tudor and Stuart England (Cambridge: Cambridge University Press, 1954), P 237.38

4 Curiously, this voyage does not seem to be mentioned in the Customs Records (CO 142/13), Public Record Office (PRO), London. There, the only mention of the Saint George is for an earlier voyage in 1686, when she arrived at Port Royal on 3 May and left for London on 7 July.

5. We do not know much about Blackmore, but his will of September 1695 is cited by K. E. Ingram in Sources of Jamaican History, 1655-1838, 2 vols. (Zug: Inter Documentation Company, 1976) 1: 438.

6. Adm 51/345, PRO, contains the Falcon's log, "A journal kept by Lt. Thomas Smith on board H.M.S. Fulcon round England and Scotland and to the West Indies."

7. Almanack for... 1696 (London: Printed by H. Clark for the Company of Stationers, 1696): Almanack for . . 1701 (London: Printed by H. Clark for the Company of Stationers, 1701). I owe the references to Taylor's life after 1688 to the kindness of Robert Barker, formerly of Kingston, Jamaica, and now of London, England.

×. "John Taylor's Life and Travels 1686-8," in The Phillipps Manuscripts, ed. A. N. L. Munby (London: The Holland Press, 1968), No. 9251.

9. Jose de Acosta (1539?-1599), often referred to as "the Pliny of the New World," wrote Histona Natural y Moral de las Indias (Sevilla: Juan de Leon, 1590), Gonzalo Fernández de Oviedo (1478-1557) was the author of De la Natural Hystoria de las Indias (Toledo: Remo de Petras, 1526), and Nicolás Monardes (1483-1588) published De Simplicibus Medicamentis ex Occidentali India delatis (Antwerp: C. Plantin, 1574).

10. See, for instance, John Smith, A Description of New England (London: Humphrey Lownes, 1616) and Francis Higginson, New England's Plantation (London: M. Sparke, 1630).

11. Daniell Ellffryth's Guide to the Carbbean, 1631, ed. Stanley Pargellis and Ruth Lapham Butler (Chicago: The Newberry Library, 1945); Richard Ligon, A True and Exact History of the Island of Barbados (London: Humphrey Moseley, 1657). 
12. See, for instance, Egerton MSS 2395, Harlean MSS 3.361 and Additional Manu siripts 11410, British Library, Iondon, also numerous reterences in $W$ Noel Sainsbury, et al., eds., Calendar of Stute Pupers, Colonual Series, America and the West Indies, 20 vols. (London: H. M. Stationery ()ffice, 1860) 1912), referring to doxu ments in the PRO

13. For Boyle's "General Heads," see Charles Hutton, George Shaw and Richard Pearson, eds., The Philosophical Transactoons of the Royal Soucty, 18 vols. (I ondon C. and R. Baldwin, 1809) 1: 63.1. This reference came to me through the kindness of Rohert Bensen, of Hartwick College.

14. Pinson de La Martinière. The Present State of France (London I. Starkey, 1671), "A merchant of Boston," The Present State of New England (London: D. Newman, 1675); "RF," The Present State of Carolina (London: John Brmghurst, 1682); and Edward Chamberlayne, The Present Stute of England (London: William Whitweod, 1683). Professor lan Steele of the University of Western Ontario reminds me that there were similarly-titled descriptions of Virginia in 1705,1724 and 1727 .

15. Sir Hans Sloane, A Voyage to the Islands Madera ... and Jamatca, 2 vols. (London: Printed by B. M. for the Author, 1707, 1725)

16. Found in $\mathrm{CO} 142 / 13, \mathrm{PRO}$.

17. According to the Dictionary of lamuicun English, ed. F. C. Cassidv and R. B. Le Page (Cambridge: Cambridge University Press, 1980)

18. The word "callalloo" is thought by Cassidy to come from the Amerindian; see F. G. Cassidy, Jamuica Talk (Iondon: Macmillan, 1971)), p. 346

19. For the census of 1611 , see Frank Cundall and loseph Pieterst, Jamuica under the Spaniards (Kingston: Institute of Jamaica, 1912), pl. $34 \cdot 38$.

20. Various historians have used this section on Port Royal. They include Carl and Roberta Bridenbaugh, No Peace beyond the Line: The English in the Caribbean, 1624-1690(New York: Oxford University Press, 1972); Richard S. Dunn, Sugar and Slaves: The Rise of the Planter Class in the English West Indies, 1624-1713 (Chapel Hill: The University of North Carolina Press, 1972); Philip Mayes, Port Royal, Jamuica: Excavations, 1969-70 (Kingston: Jamaica National Trust Commission, 1972); and Michael Pawson and David Buisseret, Port Royal Jamaica (Oxford: Clarendon Press, 1975).

21. It is hard to recognize the Liguanea Plain in this description; the great expansion of the population has no doubt far outrun the early water supply.

22. The history of these once numerous lewish communities remains unwritten.

23. Published by A. Aikman at Spanish Town in 1792-93. 


\section{4 \\ English Quaker Merchants and War at Sea, 1689-1783}

IACOB M. PRICE

One of the most striking social transformations in late seventeenth and eighteenth century England was the evolution of the membership of the Society of Friends from a persecuted radical sect in the time of Charles II to a prosperous, most respectable, and more than tolerated community in the time of George II, a community whose members had access to the sympathetic attention of the most senior ministers of the crown. The Quakers, like other nonconformists, had benefited from the passage of the Toleration Act of 1689, but still suffered in a wordly sense from restrictions imposed upon them by their own religious principles. Among these was the absolute prohibition against taking oaths. This not only prevented Friends from serving on juries or testifying as witnesses in the Common Law courts but also prevented them from taking advantage of equity remedies available in the Court of Chancery or the equity side of the Court of the Exchequer. (In both equity courts, the bills and answers required by their written procedures had to be sworn to.) Since the equity courts were an important facility for settling quarrels between merchants, their inaccessiblity would have been an important disadvantage for would-be Quaker wholesalers and traders by sea. The Society of Friends preferred arbitration but that option was not always available. Thus, the passage of an Act of Parliament in 1696 permitting Quakers to "affirm" rather than swear in equity and other civil (not criminal) proceedings ${ }^{\prime}$ removed an important competitive disadvantage and made it less risky for Quaker merchants to enter into complicated 
contractual arrangements with non-Quakers, arrangements that might someday force them into the law courts.

Regardless of the greater or lesser importance ascribable to the Affirmation Act, there can be no question that in the decades following its adoption, some members of the Society of Friends prospered in overseas trade, wholesale commerce at home and banking. We naturally are not surprised to find Quaker merchants in London and Bristol active in the trade to the Quaker colonies of Pennsylvania and New Jersey. What is even more striking is the large number of Quaker names that turn up in the much more important trade to the Chesapeake: particularly in the firms of Adams, Barclay, Bland, Braine, Falconer, Freame, Grove, Hanbury, Higginson \& Bird, Hunt, Mildred \& Roberts, Osgood, Quare and Scarth in London, as well as Champion, Harford and Reeves in Bristol. ${ }^{2}$

Starting from a quite low level of importance in the Chesapeake trade, the Quaker merchants increased their share quite dramatically in the half century after the act of 1696. In the period between Michaelmas 1696 and Christmas 1699, London accounted for 52.6 percent of England's tobacco imports. ${ }^{3}$ About that time, although two Quaker merchants-Samuel Groome and Edward Haistwell-were among the top ten importers in London, the five identifiable Quakers accounted for only 8.3 percent of the capital's imports. ${ }^{4}$ By 1733 , a list of tobacco bonds outstanding in London shows five Quaker houses accounting for 13.3 percent of the total, ${ }^{5}$ while a similar list for 1747 showed four Quaker houses (led by the Hanburys) accounting for 19.2 percent. ${ }^{6}$ (Quakers then could not have been as much as one percent of the population of England or of greater London.)

Now the short century between 1688 and 1776 is associated not only with a very substantial increase in Britain's foreign trade but also with frequent major wars; particularly those of 1689-97, 1702-13, 1739-48 and 1756-63. These wars were all characterized by intense commerce raiding, with thousands of ships on each side captured in each conflict. ${ }^{7}$ But Quakers of course were historically committed to a rigid stand against war in all its manifestations. How then could Quaker merchants and the Society of Friends accommodate their strong antiwar sentiments with the apparent necessity of protecting commerce at sea? Did their principles permit them to arm ships for defensive purposes only? Was it allowable for non-Quaker masters of Quaker-owned ships to take out letters of marque? Did all Quaker merchants behave in the same way? 
The major part of this paper will explore the evolution of the attitude and discipline of the Society of Friends towards the participation by members in warlike acts at sea. At the end we shall look a little more closely at the relevant record of John Hanbury (1700-58), the most important Quaker merchant trading to North America at the opening of the Seven Years' War (1756-63).

In considering the approach of the Society of Friends towards war at sea or any other question, we must distinguish between doctrine and aspirations on the one hand and discipline on the other. Most matters of religious observance, including discipline, fell within the responsiblity of local (usually monthly) meetings. Several nearby monthly meetings consulted together in quarterly meetings. At the national level, London Yearly Meeting, including representatives from all local meetings, discussed matters of common concern and attempted to harmonize the outlook and activities of local Friends' meetings. London Yearly Meeting had a standing committee, the Meeting for Sufferings (dating from the years of persecution), whose individual members were severally charged with correspondence with lesser meetings in the British Isles and overseas.

Quakers placed great emphasis on thoughtful and prayerful discussion of difficult moral issues and strove for consensus before taking action. An important question would usually be carried from a local meeting to London Yearly Meeting. There the first discussion might end only with a resolution, a declaration of sentiment, that would not automatically be distributed to lesser meetings. As consensus became clearer, the subject of a resolution would be shaped into an epistle that would be sent to all local meetings. While an epistle guaranteed that a given subject would be called to the attention of the Society's membership, it did not automatically guarantee any action at the local level. The next step in encouraging behaviour recommended or enjoined in an epistle would be specific references to such behaviour in the queries sent to all local meetings with answers expected at the next Yearly Meeting. $\Lambda$ rather vague or general question often elicited somewhat vague or general answers. As consensus emerged calling for greater efforts in monitoring the behaviour discussed in the epistle, imprecise queries would be replaced by much more pointed questions requiring detailed responses. Finally, Yearly Meeting might send out an epistle requiring local meetings to name members to remonstrate "in the spirit of Truth and Love" with any Friends deviating from the new common policy and to "disown" any who refused to mend their ways. The actual "disownings" or separations would take place at the local level. 
The works of Gary Nash and lean Soderlund have shown how the hostility towards slavery of the Society of Friends in North America gradually evolved in the eighteenth century, with Pennsylvania taking early action against both the slave trade and slavery. ${ }^{8}$ A comparable evolution can be found among English Quakers. Thus, London Yearly Meeting in 1727 merely adopted a "sense of the meeting" resolution-not embodied in an epistle--"censuring" participation in the slave trade as "not a commendable nor allowed practice". This was progressively strengthened until a minute of 1761 called specifically for disowning any Quaker who persisted in that trade. (This would appear to have been slightly stronger than the Philadelphia Yearly Meeting's ruling of 1758 placing "under discipline" local Friends who imported, bought or sold slaves.) Finally, in 1772, a printed epistle from London Yearly Meeting condemned slavery as an "oppressive and unnatural bondage," commended the efforts of colonial Friends against the whole institution, and called for the total abolition of the slave trade."

A comparable evolution extending over many more years can be observed in the attitude of the Society of Friends towards violence at sea. Hostility towards war and warlike acts was one of the oldest and most fundamental characteristics of the Quaker movement, dating from its earliest days. This stand was embodied in a formal declaration of the movement as early as 1661 , which condemned "all outward War and Strife, and Fightings with outward Weapons, for any end, or under any pretence whatsoever". ${ }^{10}$ Such language was clearly broad enough to embrace actions on sea as well as on land, and to leave little scope for alleged self-defence.

A strict reading of the 1661 declaration posed particular problems for Quaker merchants and shipowners in the numerous wars of 1689-1815. If they were not to abandon all ventures by sea, how were they to face the urgent problem of protecting their vessels against enemy commerce raiders? NonQuaker merchants not only armed their vessels but very often also permitted ship captains in their employ to take out letters of marque and reprisal giving them legal authority to take enemy prizes. (The issuance to a master of letters of marque did not normally mean that his vessel was going out as a privateer, but simply that the captain and crew, who were prepared to risk their lives to defend the vessel, wanted the prospect of a share in a prize if their defensive actions led to the capture of an enemy raider.) But, what was a conscientious Quaker shipowner to do? He understood that he must refrain from privateer- 
ing, but could he arm his vessel defensively? Could he let the master take out letters of marque?

This first became a serious problem in the 1690 s. Friends now had toleration and the protection of the Affirmation Act, and a significant number of them now felt secure enough to undertake ventures by sea. Some obviously felt that the Society's strictures against warlike acts did not prohibit arming vessels and taking out letters of marque-all for defensive purposes, of course. Richard Gotley of Bristol was a generous subscriber to Friends' funds and was buried as a Friend when he died. Nevertheless, he provided shipping to carry William's army to Ireland in 1689 , for which he was paid almost $£ 4000$. In 1690 , he and Thomas Pope, another Bristol Quaker, were concerned in the ship Virginia Merchant for which letters of marque were issued. ${ }^{11}$ Such activity did not go unnoticed. Complaints were made to London Yearly Meeting in 1693 about Quaker-owned vessels carrying guns. A vaguely-worded epistle was sent out that year urging local meetings to appeal to the consciences of the offending shipowners. ${ }^{12}$ Despite this, Admiralty Court records show numerous examples during 1692-1712 of letters of marque being issued to Bristol Quakers and at least two to London Friends. At the Yearly Meeting of 1709, there were embarrassing protests about guns on Friends' ships but the assembly would do no more than call attention to the 1693 epistle. ${ }^{13}$

After the pacifist principles of the Society had been more explicitly reaffirmed in an epistle of 1730, the depths of commitment were severely tested by the wars of 1739-63. In 1744, an epistle of London Yearly Meeting deplored reports (primarily from Bristol) that some Friends were arming their vessels, taking out letters of marque and even engaging in privateering. Commending the Pennsylvania Friends' strong opposition to such practices, Yearly Meeting instructed local meetings in England to endeavor to persuade such deviators of their errors, and, if necessary, to expel them. ${ }^{14}$ A milder epistle of 1757 merely instructed local meetings to offer those in such errors "timely admonition and suitable counsel ... in the spirit of love and meekness". However, an epistle of 1782 specifically returned to the stronger language of $1744 .^{15}$

To attempt to understand how the Society might have influenced the decisions of individual merchants on the question of arming vessels, one must look at the records of local Quaker meetings in ports with significant Quaker populations, particularly London and Bristol. In Bristol, the seaborne arms problem seems to have been particularly disruptive for the Friends. There, 
however, separation was in fact available for use against deviant shipowners because the local meeting had experience with disownment of one-time Friends who had broken discipline by joining the army or navy, or taking oaths of office (whether as master in chancery or sheriff), or marrying outside the fold. ${ }^{10}$

In early 1744, the Bristol Men's Monthly Meeting was disturbed to learn that some Friends in the town were arming their vessels while others were actually engaging in privateering. Representatives were sent to interview the deviants. When they reported back that they had found the privateer owners quite obdurate, Bristol meeting referred the matter to the forthcoming Yearly Meeting. This brought forth the aforementioned very strong epistle in 1744, a document which clearly and fully presented the Society's strong feelings against the misdeeds of some maritime members.

It having been in pressing Terms represented \& Complained of to this Meeting, that notwithstanding We have look'd upon our Selves, as well as the primitive Christians to be included in that notable Prophecy, Isaiah.2. They shall beat their Swords into Ploughshares and their Spears into pruning hooks and Learn War no more, Agreeable to the Doctrine of our Blessed Lord \& Saviour lesus Christ, and his Apostles; to which our Ancient Friends abundantly bore Testimony, both in Doctrine and Practice, and suffered deeply for, and Confirm'd and ratify'd by several of our Yearly Meetings, particularly in the Years $1693,1709 \& 1730$, by the Express Declarations \& Testimonies against carrying Guns for Defending our Ships Persons \& Goods, and being under many Strong Engagements to Observe the same, from the particular Care of Providence over such as have been faithful to Our Testimony, particularly those of Our Friends in Pensylvania.

Nevertheless some professing to be of our Society have of late Slighted \& neglected their Ancient \& Christian Testimony to that Degree, as to be Concerned in Privateering, Or as Owners in Ships going with Letters of Marque, which is a flagrant and Lamentable Departure from our Peaceable Principle, which hath always been to Confide in the Protection of Providence of Almighty God, and not in Weapons of War, which Practice of theirs may be attended with Injustice Barbarity and Bloodshed.

This Meeting therefore having taken this Sorrowful and afflicting Case \& breach of our ancient Testimony into our Serious Consideration... 'tis the Unanimous sense of this Meeting, That all Quarterly and Monthly Meetings ought speedily to Deal with every Person found in the practice of such things, in the Spirit of Truth \& Love, in order to bring them from it, which if they cannot Do, then to Testify against them and to let them know, that we have no Unity or fellowship with Them. ${ }^{17}$ 
Though this admonition from Yearly Meeting was read at Bristol meetings along with a locally-drafted memorial, Friends there interested in privateers remained unmoved. (For example, surviving records indicate that Bristol Quaker Nehemiah Champion was the ship's husband and largest shareholder-3/16ths-in the corsair Townshend.) The privateer venturers were disowned but the Bristol meeting was left unhappy by this separation. The entire matter was reconsidered as soon as the war ended in 1748. Persuaded that they had acted improperly in expelling only the privateer owners and not those who had armed their vessels defensively -as they perhaps ought to have done if they had rigidly followed the letter of the epistle-the meeting voted to receive back into the fold the recently-disowned privateer venturers. ${ }^{18}$

By contrast, the Bristol Friends had much less trouble with the question of armed vessels and privateers during the ensuing Seven Years' War. In their reply to the Yearly Meeting's regular query, the Bristol Men's Meeting reported in 1756, "Upon Enquiry whether any of our Friends was concerned in Privateering or Letters of Marque, it doth not appear to this Meeting that any friends are concerned therewith and if any friends hear of any being concerned therewith they are desired to treat with them or lay it before this Meeting as the Nature of the case may require." Much the same was reported in 1759 and 1760 with the comment, "Whether there may be any particular concerned therein, we cannot yet Say.... ${ }^{n 19}$

During the War of the American Revolution (1775-83), the problem of armed vessels reěmerged to trouble Bristol Friends in a more open manner. In 1777, the local group could report to Yearly Meeting that "Friends are (as far as appears) faithfull in our Testimony against bearing Arms, or being in any wise concerned in the Militia, in Privateers, letters of Marque, or in dealing in Prize goods as such." However, by 1779 (after France had entered the war), they could only say, "Many Friends bear a faithful testimony against bearing Arms, or being in any manner concerned in the Militia, in Privateers, Letters of Marque, or armed Vessels or in dealing in Prize-goods as such; yet several are unfaithful in some of these respects, particularly in letters of Marque, Armed Vessels and the Militia, some of whom have been visited and the rest are under our care. ${ }^{\text {n20 }}$

The minutes of the Bristol local meeting now show considerable vigour in "caring" for the deviators, particularly in cases involving members of the extended Champion family. During the war, several members of the family were disowned for inappropriate marriages, suggesting that their relations with 
the local meeting were already quite strained. ${ }^{21}$ Richard Champion, "the potter", was charged with "being Concerned in fitting out an Armed Vessell." Though he cleared himself of this charge on assuring the meeting that he had "Disarmed" the vessell, he was disowned anyway for failing to submit another matter to arbitration. ${ }^{22}$ More serious was the case of George Champion, interested in several armed vessels and the reported sole owner of the Byron, 250 tons, 32 guns, 150 men, advertised for a "cruising voyage to lamaica." ${ }^{23}$ When visited in 1778 by members sent by the meeting, George Champion admitted "to be concerned in Vessels having Letters of Marque \& armed in a Warlike manner." When he failed to mend his ways, he was disowned in $1779 .{ }^{24}$ Not all were so stubborn. Nehemiah Champion, Ir., was associated with George Champion in a heavily-armed sloop in 1779, but, when threatened with disownment by the local meeting, agreed to get out of that venture. ${ }^{25}$ All in all, the Bristol local records would suggest that, however uncertain they may have been about enforcing the rules on defensively-armed vessels, the local Friends were by the time of the American War prepared to use disownment to check investments by local Quakers in anything that smacked of privateering. If such references are rarer in London, it is likely because there privateering was by mid-century (if not earlier) unambiguously considered beyond the pale.

The London and Middlesex Quarterly Meeting in effect consisted of two sub-meetings for London and Middlesex. London Quarterly Meeting in the 1740s consisted of five monthly meetings: Devonshire House, Gracechurch Street (originally Bull-and-Mouth), Peel, Southwark and Westminster. The first two were the most important, accounting for over sixty percent of the assessment revenues of the quarterly meeting. Even after a new sixth meeting was established in 1745 at Ratcliffe in the parish of Stepney in the East End, the two big meetings still accounted for fifty-five percent of assessments. ${ }^{26}$ The minutes for Gracechurch Street prior to 1789 have been lost, leaving only the minutes of Devonshire House and the metropolitan quarterly meeting for insights into the local role of the larger Quaker merchants. The importance of these eminent traders to the local Friends is perhaps suggested by accounts of London and Middlesex Quarterly Meeting indicating that eight large merchants and wholesalers contributing $£ 100$ each provided almost eighty percent of the subscriptions for the Friends Workhouse, 1754-57. ${ }^{27}$

Some hint of the tensions created by war for the London Friends can be detected in their changing answer to the queries sent out each year by Yearly 
Meeting to local meetings. Down to 1741 , these queries did not, as previously noted, contain any specific references to arming vessels. For some years the relevant query was only "How are the advices of the yearly meet[in]g put in practice?" A not unrepresentative answer was that given by Devonshire House Meeting in 1728: ". . the Yearly Meeting Advices are read in our Monthly Meetings and recom $/ \mathrm{m}$ lended to be put in Practice. A Testimony is maintained by several amongst us against the oppressive Yoak of Tythes and Church Rates so called, and we wish we could say Friends were more generally faithfull therein." ${ }^{28}$

In 1742, however, Yearly Meeting, now beginning to take more seriously the warlike armaments questions, altered the question to read: "Do you Beare a faithfull \& Christian Testimony against the receiving or paying Tithes [,] Priests demands \& those cal[1] ed Church Rates[,] bearing of Arms or paying Trophy money [a militia tax], and do you admonish such as are unfaithful therein? ${ }^{\text {29 }}$ Answering this in 1743 proved rather difficult for London and Middlesex Quarterly Meeting. The constituent Middlesex meetings could answer, "we know of no Friend who does bear Arms." But the London meetings could only say that "Friends generally stand faithfull . . . against Tithes, and bearing Arms: tho some, we fear, are not as Consistent ... in this Respect as we could desire. ${ }^{\text {30 }}$ Such replies were not satisfactory to Yearly Meeting which responded with the previously-mentioned strong epistle of 1744 giving an exceptionally full exposition of the Friends' objections to arming ships.

The language of the 1744 epistle was passionate; the threat of expulsion serious. Yet it should also be noted that its emphasis was on privateering and letters of marque, and not on arming vessels, the most common deviation from strict Quaker teachings. Maritime belligerency was not as acute an issue in London as in Bristol in the 1740s, but the 1744 epistle was directed towards a problem serious in the capital too. Though there are difficulties in identifying all Friends, assembling those readily identifiable suggests that the letters of marque question in London was more serious in the wars of 1739-48 than in the Spanish Succession War (1702-13). But the new epistle of 1744 had some observable effect there. Most of the London Friends' letters of marque in these wars were taken out during 1739-44, with relatively few applied for in the last years of hostilities, 1746-48. ${ }^{31}$

Even though they showed somewhat better discipline than the Friends at Bristol, the Londoners had no illusions that all was as it should be. In the years 
following the 1744 epistle, the minutes of London and Middlesex Quarterly Meeting continued to reveal problems in some of the London monthly meetings. Their representatives explained in 1746: "Many Friends among us are conscientiously concerned to maintain the Testimony ... against bearing Arms, or paying Trophy-money ... But as we canot say all have stood clear in that Respect, we hope those who have been faithful herein will be concerned in brotherly Love to exhort $\&$ admonish others as they have opportunity . . . ${ }^{32}$ The Londoners at Quarterly Meeting had to reply in this ambiguous fashion inasmuch as their constituent monthly meetings, particularly Devonshire House, were then reporting in much the same vein. ${ }^{33}$

The important Quaker merchant who must have created the greatest scandal among Friends on the issue of "bearing arms" was John Hanbury whom we shall discuss in the concluding section of this paper. Though he was a member of the Meeting for Sufferings and an important fighter for significant Quaker causes, the record is clear about his arming his ships and taking out letters of marque. ${ }^{34}$ But, immediately following his death in June 1758, Yearly Meeting in July adopted a new query on warlike acts: "Do you bear a faithful Testimony against bearing Arms and paying Trophy money, or being in any measure concern'd in Privateers, Letters of Marque or in dealing in Prize goods, as such[?]" During the remainder of the Seven Years' War, the answers from all the London local meetings insisted that almost all their members were conscientious in matters covered by the new query. Where specific deviations were admitted, they were confined to paying trophy money and hiring substitutes for militia duty. ${ }^{35}$ Even Devonshire House could reply in 1761, "We know of none amongst us concerned in Privateers or Letters of Marque, or that Deal in Prize Goods as such. ${ }^{\text {.36 }}$

When the War of the American Revolution commenced, all the London and Middlesex meetings insisted that their members generally adhered to the Society's strictures on "bearing arms" and related matters, though several, including Gracechurch Street in 1777, admitted that "some are unfaithful by paying Trophy-money, and hiring Substitutes for the Militia when called upon". ${ }^{37}$ As far as the war at sea was concerned, the atmosphere was rather different by 1778 for the American War was distinctly unpopular with dissenters generally, and with Friends in particular. Even so, while most of the London and Middlesex meetings reported total compliance in their answers to the queries on militia, privateers, letters of marque and armed vessels, Gracechurch Street had to admit throughout the war that "many are unfaithful in some of these Respects," 
without going into any details; and Devonshire House specified that year that "it is to be feared all are not clear respecting the Militia \& Armed Vessels; |and that | some Admonition has been given." In the remaining years of the war, Gracechurch Street would admit only to trouble over the militia, while Devonshire House became much less explicit; yet, as late as 1781, Quarterly Meeting again admitted that "there are exceptions with regard to the Militia, Trophy money, \& Armed Vessels, some of which are under Friends care. ${ }^{38}$

In summary, the London record suggests a gradual tightening of Friends' discipline on the matter of letters of marque and armed vessels (privateers only rarely being a problem in London). This tightening became more noticeable after the death of John Hanbury in 1758, yet during the American Revolutionary $W$ ar there were still recalcitrant individuals arming their vessels if not taking out letters of marque. It is striking, though, that-unlike in Bristol-nowhere in the London record is there any mention of disownment or expulsion on such account down to 1783.9

Can we go behind the pious sentiments of Yearly Meeting and the frequently imprecise answers of local meetings, and try to suggest quantitatively how member merchants responded to the teachings and discipline of the Society of Friends? Applied literally, adherence to the letter and spirit of Yearly Meeting's epistles most likely would have driven Quaker shipowners off the seas in time of war, though Quaker merchants would still have been able to ship some goods in vessels belonging to non-Friends. Since Lloyd's Register only survives from the later 1760s, we have no comprehensive listing of shipowners and the armament of their vessels for the wars of 1739-63. Even in the Register, we find only the name of the managing owner of a vessel that might have a dozen or more share-owners. Sometimes, though, multiple owners are listed in the declarations made by ship captains receiving letters of marque. Because such declarations also included the tonnage, number of guns and size of the crew, they give almost certain evidence of possible warlike intent-i.e., whether the letters of marque were simply a precaution or were in fact intended for a privateer. For example, letters of marque were taken out in 1742 for the armed merchantman King William of Bristol, 130 tons, 12 guns and 24 men; but when in 1744 her owners decided to convert her into a privateer, a new declaration changed her description to 18 guns and 155 men. In the absence of authoritative information, the size of the crew is the best available evidence of a privateer. ${ }^{t 0}$ 
For our present limited purposes, vessels with ninety or more sailors will be considered likely privateers.

In the Spanish Succession War, numerous (at least forty-five) letters of marque were issued to masters of Bristol vessels with Friends as part-owners, and at least two for London Friends. By contrast, in the wars of 1739-48, such activity by identifiable Friends in the two ports was more evenly balanced, with sixteen letters of marque issued to ships owned at least in part by Bristol Friends (particularly Nehemiah Champion, Jr., Charles Harford and William Recve), and about twenty-one letters of marque for sixteen London vessels with notable Quaker owners, including Joseph Adams, Henton Brown, James Collinson and particularly John Hanbury. (In both cases, most were taken out in the earlier years of the war, before the epistle of 1744.) There was, however, one conspicuous difference between the two ports. Of the sixteen Bristol letters of marque vessels, ten were definite or likely and two possible privateers, while of the sixteen London vessels with Quaker share-owners that received the twenty-one aforementioned letters of marque, only two were definite and another a possible privateer. ${ }^{41}$ Even with these vessels, from a Quaker viewpoint the situation in London was much less out of control than that at Bristol.

Over the full course of the ensuing war of 1756-63, there was a noticeable decline in total British privateering activity, owing to British maritime successes in the first years of the war and perhaps in part to the fact that Spain was not a belligerent until 1762, both phenomena reducing the pool of possible prizes. ${ }^{42}$ At Bristol in this war, about twelve letters of marque appear to have been issued to vessels with recognizable Quaker owners (much the same individuals as in the previous war) but only one of these was a definite privateer. At London in the same years, letters of marque were issued to only five vessels with known Quaker owners (the Hanburys, Jonathan Gurnell, William Neat and Elias Bland), none privateers. ${ }^{43}$ During the War of the American Revolution-particularly unpopular with the Society-hardly any letters of marque were issued to Friends, except, during 1778-79, to a few Bristol ships in which George and John Champion were part owners. ${ }^{44}$

To summarize: firstly, with a few exceptions in the 1740s, almost all the letters of marque issued to vessels with Quaker owners were for armed merchantmen and not privateers; and secondly, the number so issued was declining steadily between the 1690s and the American Revolution. Since the danger at sea remained very high through all the wars of $1689-1815$, the declining number 
of letters of marque issued to Friends would suggest that Quaker merchants were increasingly sensitive to the disapproval of other Friends. There were, however, stratagems for minimizing this disapproval. John Hanbury, the greatest Chesapeake merchant in London during the 1740s and 1750s, preferred wherever possible to charter freight space rather than use his own vessels. In one known case, where he did venture his own ship, he took out no letters of marque but authorized the captain to do so in Virginia. ${ }^{45}$ Even so, the downward trend in Friends' letters of marque is clear.

Some flesh and bones may be put on this study of "trends" by looking more closely at John Hanbury, the leading Quaker overseas merchant at the start of the Seven Years' War. He has presented something of a problem to historians in part because there were at least four or five John Hanburys active in London in his lifetime. First there was Friend John (1700-58), a Virginia merchant of Tower Street. Secondly there was his distant Anglican cousin, Major John Hanbury of Pontypool (1664-1734), big iron manufacturer and Member of Parliament. ${ }^{46}$ Thirdly, there was the unrelated John Hanbury (d. 1732), German merchant of London, governor of the Hamburg Company (the ofd Merchant Adventurers), director and deputy governor of the South Sea Cornpany. Fourthly, there was John Hanbury the younger, son of the preceding, who divided his time between Hamburg and London; and fifthly there was a John Hanbury, merchant of Bucklersbury (near the Mansion House), London, active in the 1740s and $1750 \mathrm{~s}^{47}$

John Hanbury, merchant of Tower Street, came of a respected Quaker family in Monmouthsire and married into the Osgood family, merchants of London prominent in Friends' affairs. He started in business as a Virginia merchant in the 1720 s and by 1747 was the leading tobacco importer in London. ${ }^{48}$ Although he was a member of the Friends Meeting for Sufferings from $1726,{ }^{49}$ he was long relatively obscure - particularly when compared with his cousin the M.P. or his namesake, the governor of the Hamburg Company. His name does not occur in the minutes of the Treasury before 1745, or the Board of Trade before 1748. He did, however, become much more conspicuous in the last decade of his life, particularly after he became in 1748 a partner in and London agent of the Ohio Company of Virginia. He and his cousin and partner Capel Hanbury had considerable influence among nonconformists in Bristol and helped manage and finance the 1754 return of Robert Nugent, a junior Lord of the Treasury, as Member of Parliament for that important city, thereby greatly increasing his 
access to the Duke of Newcastle and other ministers. He was the key Quaker figure who arranged with Lord Granville the compromise of 1756, under which the pacifist Quaker members of the Pennsylvania legislature voluntarily with drew for a time from that body, thus avoiding their disenfranchisement by an oath bill. His closeness to the ministry, his role in the Ohio Company, and the subsequent importance of his firm as government contractors during the Seven Years' War lent some credence to inflated charges that he was the eminence grise who had master-minded Braddock's ill-fated expedition in $1755^{\text {. }}$

In this paper, however, we are concerned only with Hanbury's activities as a Quaker shipowner in wartime. In the 1740s, his name first began to appear in government records in part because of his new connection with lohn Thomlinson, Sr. (d. 1767), a merchant/shipowner trading to New Hampshire and the West Indies and an important government contractor. Thomlinson, son of a prominent sugar planter in Antigua, had as a sea captain established useful connections in New Hampshire, whose agent he became after he settled in London as a merchant. ${ }^{51}$ High Court of Admiralty records show a good number of letters of marque issued in the 1740s for ships owned by John Hanbury, or by John Hanbury and John Thomlinson jointly (Table 1). The average tonnage of these vessels ranged from 362 for the Chesapeake trade, to 444 for the West Indian trade, and $\mathbf{5 5 0}$ for the East Indian trade. These were high tonnages by the standards of the early eighteenth century but the war danger and the threat of the Spanish guarda-costa in the West Indies made many merchants prefer larger vessels in the tobacco as well as in the more exposed West Indian trade. ${ }^{52}$ The very largest (e.g., the Heathcote, Harrington and Montague) appear to be ships originally built for the East India Company but which had already made the maximum four voyages permitted by the company for chartered vessels. Such ships may have been acquired by Hanbury and allies for special purposes, perhaps to fulfill contracts (in Thomlinson's name) for victualling or transport in the West Indies. ${ }^{33}$

Almost all the vessels in Table 1 appear to have obtained their letters of marque as armed merchantmen and not as privateers. This is consistent with Hanbury's position as a prominent if not strictly conforming Quaker. There is, however, a conspicuous exception to this generalization. In 1743, twenty-four London merchants with four associates in Bristol, Southampton and Worcester, joined in an "adventure" to send out on cruise two large privateers: the Fame, Captain Phillips Comyn (1,000 tons, 56 guns, $400 \mathrm{men}) ;$ and Winchelsea, 
Table 1: Letters of Marque isswed to Merchant Ships Owned in Whole or in Part by lohn Hanbury, 1740-56

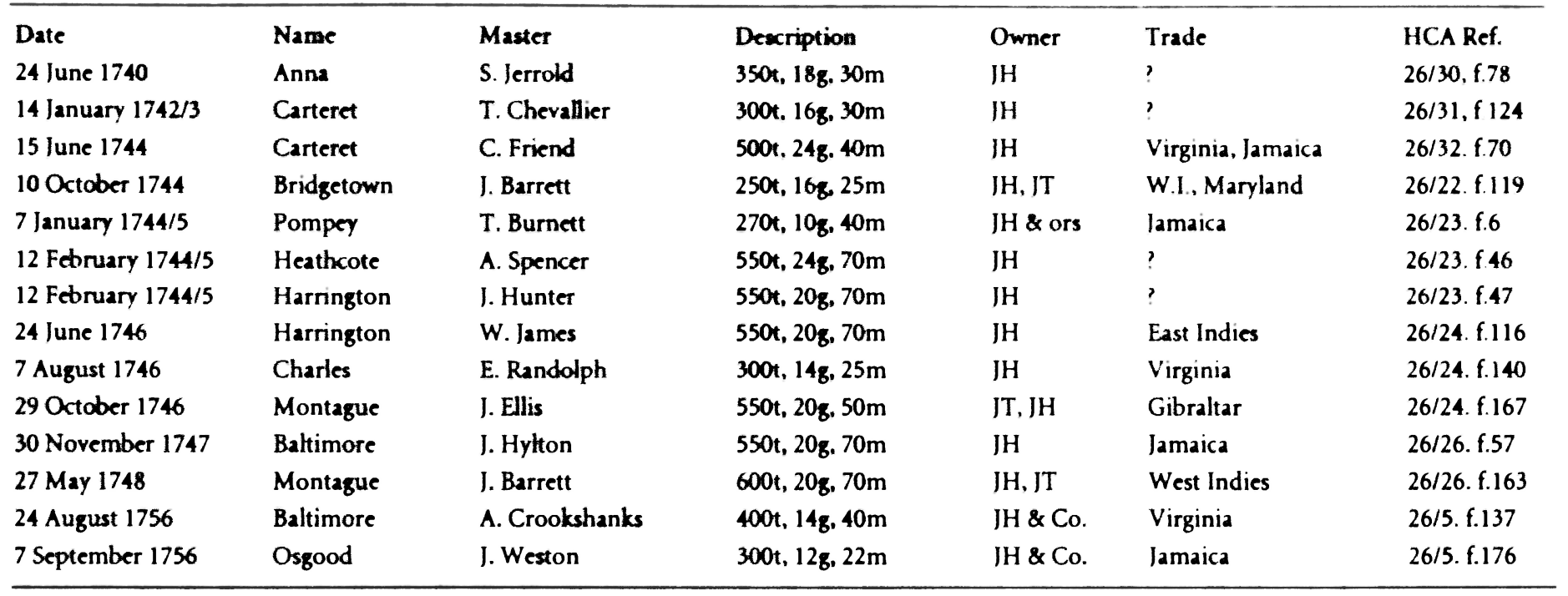

Owners: $J H=J o h n$ Hanbury; $J T=J o h n$ Thomlinson; ors = others. Description: $t=$ tons; $g=g$ uns; $m=$ men

Sources: HCA 26/4, 5, 22, 23, 24, 26, 30, 31, 32. Public Record Office, (folios specified in last column); and Lloyd's List. 1741.57

N.B. Eleven other co-owners were listed for the Pompey. The Osgood was listed as owned East India Company from 1707 to ... 1760 (London: printed for Charles Hardy. 1799) pp. by John and Capel Hanbury. In 1744, the Harrington and Heathcole returned from their 12-15. For William lames, master of the Harrington in 1746 (later a director of the East fourth and last voyages in the company's service to China and India. (The East India India Company. M. P. and baronet), see Sir Lewis Namier and lohn Brooke. The History Company then did not charter a vessel for more than four voyages.) Nothing found thus of Aarliament: The House of Commons 1754-1790, 3 vol. (New York: Oxford Lniversity far indicates how Hanbury used the Heathcote thereafter. The 1746 voyage of the Har. Press. 1964) 2672-73, H. B Wheatlev, ed, The Historical and the Posthumous Memoirs of rington to the East Indies under Capt. William James was apparently a non-company Sur Nathaniel William Wraxall. 1772-1784, 5 vois. (London: Bikers and Son, 1884) activity. OC. [Charles Hardy], A Register of Ships Employed in the Service of the Unived 1:167.90 
Captain lohn Gerald (550 tons, 30 guns, 180 men). The management of the venture was entrusted to four of their number: Thomas Hall, lohn Hanbury, lohn Thomlinson and lames Pearce (replaced on his death by Valens Comyn). The two privateers and a tender sailed from England in April 1744, with instructions to their "commodore", P. Comyn, to cruise first in the Atlantic approaches to the West Indies and off the coast of Brazil. If they had not taken enough prizes to justify a return to England, they were then to proceed into the Indian Ocean and head for the Straits of Sunda (between lava and Sumatra) to try to intercept the French China fleet returning from Canton. or perhaps the Spanish galleons bound from Acapulco to Manila. The commodore entered the Indian Ocean but failed in his assignments there; instead he put into Batavia ( modern lakarta). There he made an unauthorized contract with the governor of Batavia and other resident Dutchmen to use his two strong vessels "to Convoy some Dutch ships fitted out by the said Governour and other Persons at Batavia

. for a Private Trade with the Spaniards in the South Seas and for discovery of unknown lands to the East of Japan." These vessels reached Canton and Macao but, perhaps storm-damaged, were unable to proceed much further and returned to Batavia where P. Comyn, ill and dying, sold the Fame to the Dutch governor. Death also took the master of the Winchelsea and most of the other senior officers, but a junior officer was able to bring the Winchelsea back to London in $1747 .^{34}$

There cannot be any question that John Hanbury, manager of this ill-fated venture, was the Quaker merchant of Tower Street. In a Chancery suit arising from this unsuccessful adventure, one of its managers, lohn Hanbury, "affirmed" rather than swore to his answer - the most explicit evidence that he was a Quaker. Another manager, John Thomlinson, merchant of London, was Hanbury's frequent collaborator in the 1740s and 1750s."

There is also a significant chronological link between Hanbury's Asian adventure and the Friends' dilemma. The Fame and Winchelsea left England in April 1744. That summer London Yearly Meeting took an unprecedentedly strong stand against Friends having anything to do with privateering or letters of marque. Although the matter was brought to the meeting's attention by Bristol, there must have been many there who knew about John Hanbury's involvement with the two privateers. Thus the 1744 resolution and epistle can be viewed as a reproach as much to him as to the more obvious Bristol strayers from the path. Perhaps significantly, surviving evidence suggests that the Fame- 
Winchelsea episode was lohn l lanbury's first and last known involvement with privatecers.

Table 1 also suggests a more general retreat into virtue by the Hanburys. It shows lohn Hanbury of Tower Street involved in twelve letters of marque in the 1740s but only two in the opening years of the Seven Years' War-before his death in lune 1758. The last of those was taken out in September 1756. After his death in 1758, his firm (continued by his cousin Capel and son Osgood) does not appear in the register of letter of marque declarations. With the peace of 1763, some of their vessels are recorded without guns. ${ }^{-6}$ One cannot be sure of the motivation involved but it is possible that the Hanburys desisted after September 1756 because of the growing antagonism in the Society of Friends towards anything involving letters of marque. But they did not change the essential character of their business. In 1740, lohn had taken out letters of marque for his ship the Annu. In the Seven Years' War, his firm sent another Annu, also armed, to the Chesapeake without English letters of marque, though they permitted the captain to obtain such letters in Virginia. This shows some respect for the opinion of other Friends if not a decision to change their judgment of what their business required. ${ }^{57}$

In summary, the combination of the steady expansion of British overseas trade with the cycle of wars starting in 1689 created painful dilemmas both for individual Quaker merchants and for the whole Society of Friends, particularly in large ports. In principle, Friends were always opposed not only to violence, but also to any sort of activity that tended towards violence. Successive epistles from Yearly Meeting made this quite clear. However, only from the 1740 s did the Society experience a concerted disciplinary effort to correct or disown those who obviously deviated from these standards. Londoners generally avoided conspicuous involvement with privateers, but to end corsair investment at Bristol, disownments were necessary in the 1740s and again ca. 1780. Ordinary merchant ships created a more refractory problem. The arming of Friends' merchant vessels probably never ceased, but the taking out in England of letters of marque for ships owned by Friends, still common in the 1740s, had almost disappeared by the 1780 s.

The conspicuous career of lohn Hanbury thus falls into a period that witnessed the gradual tightening of Friends' discipline on belligerent acts. Though he was a particularly prominent Friend, in the management of his seaborne trade he frequently acted much as did other merchants. With one 
notable exception, he does not appear to have invested in privateers. Yet, if he was one of many who took out letters of marque in the 1740s, the fact that his firm took out none in London after September 1756 suggests that they were increasingly sensitive to the strong collective feelings of the Friends against such activity. His remittance and other war contracts fell into a category on which the Society had no clear position in his time. (Only in 1790 was munitions manufacture and sale prohibited. $)^{5 R}$ Thus, though they retreated on letters of marque, the Hanburys still acted as if contracting for military victuals or remittances was not inconsistent with Quaker teachings. When John was a member of the Meeting for Sufferings, it would have been difficult to argue otherwise.

\section{NOTES}

1. 788 William III c. 34: in Great Britain, Statutes of the Realm, 10 vols. (London Eyre, 1810-22) 7:152.

2. Merchants can be identified as Quakers by checking the vital records (particularly marriages and deaths) in the Friends House Library (FHL), London, as well as the London Monthly and Quarterly Meetings records there and (for Bristol) at the Bristol Record Office. See also notes 11 and 13. For a sketch of some leading Quaker trading families, see Jacob M. Price, "The Great Quaker Business Families of Eighteenth-century London", in The World of William Penn, ed. Richard S. Dunn and Mary Maples Dunn, (Philadelphia: University of Pennsytvania Press, 1986), pp. 363-99.

3. Customs 2, Public Record Office (PRO).

4. Printed bills of entry, London, for 1697 , Beineke Library, Yale University.

5. Cholmondeley (Houghton) MSS 29/22, Cambridge University Library.

6. T1/326/40, PRO.

7. For a general survey, see David J. Starkey, British Privateering Enterprise in the Eighteenth Century, Exeter Maritime Studies no. 4 (Exeter: University of Exeter Press, 1990).

8. Jean R. Soderlund, Quakers and Slavery: A Dividad Spint (Princeton: Princeton University Press, 1985); Gary B. Nash and Jean R. Soderlund, Freedom by Degrees: Emancipation in Pennsylvania and Its Aftermath (New York: Oxford University Press, 1991).

9. Extracts from the Minutes and Advices of the Yearly Meeting of Friends held in London ... (London: Society of Friends, 1783), pp. 227-28. For later actions, see 1802 ed., 
pp. 176-180. See also Soderlund, Quakers and Slawery, ch. 1, esp. pp. 30.31; and Anne Thomas Gary (afterwards Pannell). The Political and Economic Relations of English and American Quakers 1750-1785" (D.Phil. thesis, Oxford University, 1935). pp 194.221.

10. Richard L. Greaves, "Shattered Expectations? George Fox, the Quakers and the Restoration State, 16001 1685", Albion, 24 (Summer 1992): $248 \cdot 50$.

11. Russell Mortimer, ed., Minute Book of the Men's Meeting of the Society of Friends in Bristol 1686-1704. Bristol Record Society's Publications, no. 30. (Bristol: Bristol Record Society, 1977), pp. xxii, 257, 258. See also p. 261 for William Smith, part owner of the Bengal Merchant, with letters of marque in 1692.

12. Extracts from the Minutes (1783 ed.). p. 253; (1760 ed.), pp. 66-67; Gary, "English and American Quakers", pp. 101-115.

13. Forty four Bristol letter of marque vessels had Quaker shareholders between 1692 and 1712: I/ohn| W/illiam| Damer Powell, Bristol Privateers and Ships of War (Bristol and London: I. W. Arrowsmith, 1930), pp. 89-102. Identification of owners as Quakers can be confirmed in Mortimer, ed., Minute Book . . 1686-1704. For involvement of the Harford family of Bristol, see also HCA 26/2, f. 79 (1692); HCA 26/3, f. 39 (1695); HCA 26/16, f. 97 (1712), PRO. For London letters of marque involving Quakers Josh'sa Gee, John Osgood and lames Taykor (father-in-law of David Barclay) (1709), see HCA 26/14, f. 14; for Samuel Groome, see ibid., f. 73 (1709) and HCA 26/20, f. 166 (1705), PRO. For the 1709 discussion, Yearly Meeting, Minutes (1709), p. 62, FHL, and printed epistle following.

14. Extracts from the Minutes (1783 ed.), pp. 253.54.

15. Ihid., pp. 254-55. All such measure affected only Quakers in ports. More extreme was the position adopted by Yearly Meeting in 1790 against "fabricating or selling instruments of war." This potentially affected all Quakers in the iron trade and led to the suspension of Sampson Lloyd, III, of Birmingham, one of the founders of Uloyds Bank, when he defended another Quaker for such manufacture. Extracts (1802 ed.), pp. 203-04; Price, "The Great Quaker Business Families," p. 379.

16. SF/AI/7, f. 145, 158; SF/A 1/13, pp. 345, 352, 375, 419, 421-23, 426, 430, 435, 440. 444, 448, 451, 477, 540; SF/AI/15, pp. 14-15, 20, 34, 43, 53, 58, 63, Bristol Record Office.

17. London and Middlesex Quarterly Meeting, Minutes, vol. 5, pp. 138-39, FHL.

18. SF/A1/7, ff. 106, 110-12, 114-15a, 170-71a, 173a, Bristol Record Office. The accounts of the Townsend's third cruise $(1746)$ can be found in the Elton journal here. There were two Nehemiah Champions then active in Bristol: one managed the privateer; the other was on the committee that drafted the memorial of disownment.

19. SF/A1/9, ff. 67a, 108, 140, Bristol Record Office. In 1761, the reference to "any particular" was dropped. SF/A1/10, p. 31.

20. SF/A 1/13, Pp. 242, 324,417, 510-11, Bristol Record Office. 
pp. 176-180. See also Soderlund, Quakers and Slavery, ch. 1, esp. pp. 30-31; and Anne Thomas Gary (afterwards Pannell), "The Political and Economic Relations of English and American Quakers 1750-1785" (D.Phil. thesis, Oxford University, 1935), pp. 194-221.

10. Richard L. Greaves, "Shattered Expectations? George Fox, the Quakers and the Restoration State, 1660-1685", Albion, 24 (Summer 1992): 248-50.

11. Russell Mortimer, ed., Minute Book of the Men's Meeting of the Society of Friends in Bristol 1686-1704. Bristol Record Society's Publications, no. 30. (Bristol: Bristol Record Society, 1977), pp. xxii, 257, 258. See also p. 261 for William Smith, part owner of the Bengal Merchant, with letters of marque in 1692.

12. Extracts from the Minutes (1783 ed.), p. 253; (1760 ed.), pp. 66-67; Gary, "English and American Quakers", pp. 101-115.

13. Forty-four Bristol letter of marque vessels had Quaker shareholders between 1692 and 1712: J[ohn] W[illiam] Damer Powell, Bristol Privateers and Ships of War (Bristol and London: J. W. Arrowsmith, 1930), pp. 89-102. Identification of owners as Quakers can be confirmed in Mortimer, ed., Minute Book . . . 1686-1704. For involvement of the Harford family of Bristol, see also HCA 26/2, f: 79 (1692); HCA 26/3, f. 39 (1695); HCA 26/16, f. 97 (1712), PRO. For London letters of marque involving Quakers Josh'sa Gee, John Osgood and James Taylor (father-in-law of David Barclay) (1709), see HCA 26/14, f. 14; for Samuel Groome, see ibid., f. 73 (1709) and HCA 26/20, f. 166 (1705), PRO. For the 1709 discussion, Yearly Meeting, Minutes (1709), p. 62, FHL, and printed epistle following.

14. Extracts from the Minutes (1783 ed.), pp. 253-54.

15. Ibid., pp. 254-55. All such measure affected only Quakers in ports. More extreme was the position adopted by Yearly Meeting in 1790 against "fabricating or selling instruments of war." This potentially affected all Quakers in the iron trade and led to the suspension of Sampson Lloyd, III, of Birmingham, one of the founders of Lloyds Bank, when he defended another Quaker for such manufacture. Extracts (1802 ed.), pp. 203-04; Price, "The Great Quaker Business Families," p. 379.

16. SF/A1/7, ff. 145,$158 ;$ SF/A1/13, pp. $345,352,375,419,421-23,426,430,435,440$, $444,448,451,477,540 ;$ SF/A1/15, pp. 14-15, 20, 34, 43, 53, 58, 63, Bristol Record Office.

17. London and Middlesex Quarterly Meeting, Minutes, vol. 5, pp. 138-39, FHL.

18. SF/A1/7, ff. 106, 110-12, 114-15a, 170-71a, 173a, Bristol Record Office. The accounts of the Townsend's third cruise (1746) can be found in the Elton journal here. There were two Nehemiah Champions then active in Bristol: one managed the privateer; the other was on the committee that drafted the memorial of disownment.

19. SF/A1/9, ff. 67a, 108, 140, Bristol Record Office. In 1761, the reference to "any particular" was dropped. SF/A1/10, p. 31.

20. SF/A1/13, pp. 242, 324, 417, 510-11, Bristol Record Office. 
21. SF/A1/13, pp. 345, 352, 375, 422-23, 435, 540, Bristol Record Office. See also pp. $131,145,158,270$. William Champion, Jr., who did not attend meetings, was also encouraged to declare himself "not a Member" (pp. 469-70).

22. SF/A1/13, pp. 350, 376, Bristol Record Office. For Richard Champion's refusal to arbitrate in 1777, see SF/A1/13, pp. 376, 407, 427, 434. The "disownment" of Friend Richard Champion, "the potter", permitted him-when his pottery business turned bad-to become deputy to Edmund Burke as Paymaster-General of the Forces, 1782, 1783. On him, see Richard Champion and Hugh Owen, Two Centuries of Ceramic Art in Bristol (London: Bell \& Daldy, 1873), pp. 226, 259-62; Arthur Raistrick, Quakers in Science and Industry ... during the 17th and 18th Centuries (London: Philosophical Library, 1950), pp. 198-99, though misses the disownment on 10 August 1778; G. H. Guttridge, ed., The American Correspondence of a Bristol Merchant, 1766-1776: Letters of Richard Champion, University of California Publications in History, vol. 22, no. 1 (Berkeley: University of California Press, 1934).

23. Powell, Bristol Privateers, p. 254; see also pp. 250, 295.

24. SF/A1/13, pp. 436, 439, 460, 527, 541, 551, Bristol Record Office.

25. Powell, Bristol Privateers, 250; SF/Al/15, pp. 68, 81, 136-37, Bristol Record Office. In the last for "deceased" read "desisted." N. Champion did not die until 1782. Raistrick, Quakers in Science, pp. 190-200.

26. Devonshire House Monthly Meeting, Minutes vol. 5, pp. 283-84, FHL, and unpaginated entry for 5 December 1745.

27. London and Middlesex Quarterly Meeting, Minutes vol. 6, pp. 343-45, FHL.

28. Devonshire House Monthly Meeting, Minutes vol. 5, queries at beginning and p. 7 (3 February 1728), FHL. Cf. also pp. 24, 43, 63, 122, 140, 184, 204-05, 221, 238, 264.

29. Devonshire House Monthly Meeting, Minutes vol. 5, FHL, queries at beginning and pp. 283 (1 March 1745) and unpaginated (7 March 1746).

30. London and Middlesex Quarterly Meeting, Minutes vol. 5, pp. 93-96, FHL.

31. I have noted only four letters of marque (involving three Quaker firms) during 1756-58 and none thereafter in this war. HCA 26/5, 26/7, 26/8, PRO.

32. London and Middlesex Quarterly Meeting, Minutes vol. 5, pp. 93-94, 132-33, 160-61, 245-47, 283, 366-67, 479-81, FHL.

33. Cf. ibid., vol. 7, pp. 41-42, 120-21, 205-06, 279-80, 331-32, 517, 571.

34. For letters of marque, see Table I; for other evidence of Hanbury owning armed ships, see CO 5/1446 and 1447, passim, PRO.

35. London and Middlesex Quarterly Meeting, Minutes vol. 6, pp. 168-71, 199-202, 309-11, 314-15, 440-42, 444-49, 456-59, FHL.

36. Devonshire House Monthly Meeting, Minutes vol. 8, pp. 4-5, FHL. See also pp. 104 and 171; and vol. 7, pp. 672, 715; and vol. 9, pp. 30, 84, 138, 192.

37. London and Middlesex Quarterly Meeting, Minutes vol. 8, pp. 274-75, 286-88, 388-89, 420-22, 487-89, 492-93; vol. 9, pp. 1-2, 8, 33-34, FHL. 
38. London and Middlesex Quarterly Meeting, Minutes vol. 9, pp. 41-42, 94-98, 120-21, 225-30, 252-56, 360-63, 390-91, 475-78, 497-98; Devonshire House Monthly Meeting, Minutes vol. 9, pp. 238, 279-80, 333-34, 392, 453-54, 512-3; vol. 10 pp. 70-71, 158-60, FHL. The Virginia merchants Daniel Mildred and John Roberts were frequently on the committee that drafted the Devonshire House replies; they should have known what was happening. The opposition of Friends to the war was characteristically passive rather than active. Cf. John Sainsbury, Disaffected Patriots: London Supporters of Revolutionary America 1769-1782 (Kingston and Montreal: McGill-Queen's University Press, 1987), pp. 79-80.

39. Disownment did take place in London for other reasons. Osgood Hanbury, the son of John, was disowned by Devonshire House Meeting for possessing impropriated tithes (private rent rights originating in secularized tithes). However, he remained a member of the meeting at Coggeshall in Essex, where he owned property.

40. Powell, Bristol Privateers, p. 151.

41. For the wars of 1739-48, see declarations in HCA 26, vols. 4, 22-26, 30-32, PRO; and Powell, Bristol Privateers, passim. In this decade, the only London vessels with some Quaker owners that were definitely privateers were the Fame and Winchelsea to be discussed below. The possible privateer was the Real Galley with a crew of seventy to ninety men.

42. Cf. Starkey, British Privateering Enterprise, ch. 7.

43. For 1756-63, see HCA 26, vols. 5, 7, 9, 11, 27, 28, PRO; and Powell, Bristol Privateers, pp. 218-44.

44. HCA $26 / 33$, f. 84 ; HCA $26 / 36$, ff. 79,115 , PRO.

45. See below, n. 57 .

46. For Major John Hanbury of Pontypool (1664-1734), see Leslie Stephen et al., eds., Dictionary of National Biography, 63 vols. (London: Smith, Elder \& Co., 1885-1901) 61:379, which errs in describing him as a director of the South Sea Company; and Romney Sedgwick, ed., The History of Parliament: the House of Commons 17151754, 2 vols. (New York: Oxford University Press, 1970) 2:105 (which makes the same error). Rather full information on the leading Hanbury families can be found in Amy Audrey Locke, The Hanbury Family, 2 vols. (London: A. L. Humphreys, 1916).

47. See Kent's Directory and Baldwin's Complete Guide, London directories published under varying titles, for 1740s and 1750s; and Locke, Hanbury Family. The will of John Hanbury of Bucklersbury (proved 1769) is in Prob.11/953 (P.C.C. 419 Bogg), PRO. John Hanbury of Hamburg had an English residence at Greenwich.

48. T1/325/40, ff. 110-121, PRO, shows him with the highest total of tobacco bonds outstanding in London in 1747.

49. London Yearly Meeting, Minutes vol. 6, p. 379; vol. 11, p. 475, FHL.

50. For a general sketch of Friend John Hanbury, see Price, "Great Quaker Business Families," pp. 379-81. See also Francis Jennings, "Thomas Penn's Loyalty Oath," The American Journal of Legal History 8 (October 1964): 303-13; and idem, Empire 
of Fortune: Crown, Colonies and Tribes in the Seven Years' War in America (New York: Norton, 1986); Sir Lewis Namier and John Brooke, The History of Parliament: the House of Commons 1754-1790, 3 vols. (New York: Oxford University Press, 1964), 1: 283-84.

51. Sir Lewis Namier, England in the Age of the American Revolution, 2nd ed. (London: Macmillan, 1961), pp. 246-49.

52. Cf. Ralph Davis, The Rise of the English Shipping Industry In the Seventeenth and Eighteenth Centuries (London: Macmillan, 1962), pp. 280-86.

53. On Thomlinson as contractor, see the article on his son, John Jr., in Namier and Brooke, History of Parliament, 3: 522-23. For ships chartered by the East India Company, see [Charles Hardy], A Register of Ships Employed in the Service of the . . United East India Company from 1707 to . . 1760 (London: printed for Charles Hardy, 1799).

54. The most authentic account of the adventure thus far found is in the bill and answer in a related Chancery suit, Hallett v. Hall: C.11/1617/36, PRO. See also "A List of Privateers," Gentleman's Magazine, vol. 15 (January 1745): 49; Starkey, British Privateering Enterprise, pp. 46-48, 65, 131-32; Conrad Gill, Merchants and Mariners of the 18th Century (London: Edward Arnold, 1961), pp. 146-48. The names of the managers of the Fame-Winchelsea expedition are also given in a package of letters (1746-47) from Richard Taunton, one of the investors, to Thomas Hall, a manager, in C.103/130, PRO. Valens Comyn, another of the managers, subsequently took an active part in the larger "Royal Family" syndicate. On this, see Herbert S. Vaughan, ed., The Voyages and Cruises of Commodore /Georgel Walker (London: Cassell, 1928), esp. pp. xxxi-xxxii, 93-211. On V. Comyn, see also Sedgwick, History of Parliament, 1: 569.

55. In the letters of marque for the Winchelsea, a Thomas Hanbury is mentioned as owner but not a John Hanbury. All the owners need not have been listed, and Quaker John may have have preferred concealment. He had a cousin named Thomas in the Pontypool family but none of the other surviving documents allude to a Thomas as participant in the adventure. For the Winchelsea's letters of marque see HCA 26/31, f. 162 (5 September 1743) and HCA 26/4, f. 32 (2 April 1744), PRO, both mentioning Thomas Hanbury and John Thomlinson. For the Fame's see HCA 26/31, f. 164 (September 1743, cancelled), HCA 26/32, f. 5 (23 December 1743) and HCA 26/4, f. 31 (2 April 1744), PRO. The French declaration of war presumably made it necessary for the second to be superseded by the third. All three mention John Hanbury and John Thomlinson; but the description of the vessel changes from 900 tons, 54 guns and 350 men in the first two issues to 1,000 tons, 56 guns and 400 men in the third. It is not clear how literally these descriptions are to be taken.

56. Lloyd's Register of Ships (1764). Note the unarmed America and Britannia and the armed Hanbury and Palliser. 
57. Papers relating to the Anna, Captain James Esten, can be found in HCA 32/163, PRO. Other London Quakers trading to America in armed vessels included Thomas Hyam and Daniel Quare. For their armed ships, see (for 1735-39): C.O. $5 / 1446$ and 1447, PRO, passim. Privateering and armed ships are not discussed in Peter Brock, The Quaker Peace Testimony: 1660 to 1914 (York: Sessions Book Trust, 1990).

58. See n. 15. 


\section{5 \\ Edward Trelawny's "Grand Elixir": \\ Metropolitan Weakness and Constitutional Reform in the Mid-Eighteenth-Century British Empire}

JACK P. GREENE

Accompanying the conclusion of the War of the Austrian Succession and the assumption of power by Henry Pelham in 1748 was a significant change in the attitudes of British politicians toward the colonies. Increasingly impressed during the war years between 1739 and 1748 with both the growing economic and strategic importance of the colonies to Britain and with the looseness of metropolitan controls over them, the Pelham ministry put new emphasis upon colonial affairs symbolized in the appointment of George Dunk, Earl of Halifax, to the presidency of the Board of Trade in November 1748, and by a dramatic increase in the number of meetings the Privy Council devoted to colonial topics. Not since the early 1720s had either the Board of Trade or the Privy Council showed such a pronounced interest in the colonies. ${ }^{1}$

Especially for royal governors and other metropolitan representatives in the colonies, who had for decades been complaining about the weakness of metropolitan authority and the exorbitant power of local elites in the colonies, these changes brought hope that the metropolitan government was on the verge of undertaking important constitutional reform within the empire. From many colonies, they responded to these initiatives with elaborate critiques of existing constitutional arrangements and with proposals for changes that would bring the colonies under closer metropolitan control. Edward Trelawny, governor of the important colony of Jamaica and a client of Henry Pelham's, produced one of the most sweeping proposals for change in two letters he wrote to Pelham in 
April 1749. These letters are preserved among the Trelawny-Pelham Manuscripts in the National Library of Jamaica. ${ }^{2}$

By 1749, Trelawny was a hardened veteran of colonial administration. Born in 1699 to a prominent Cornish family who controlled at least three seats in Parliament, he had himself entered a Parliament for the borough of West Looe in 1724 at the age of twenty-five, and had sat for that borough or for East Looe for the next decade. He seems to have traded his family's parliamentary patronage for office, becoming a commissioner of customs in 1733 and governor of Jamaica in 1737, a post he took up the following year. His governorship was often stormy but, by contemporary standards, also highly successful. In April 1749, he was beginning the eleventh of a more than fourteen-year term as a colonial governor. ${ }^{3}$

The principal defect in British imperial governance, according to Trelawny, was structural. The "grand error in the first decoction of our Colony Government," he declared, in echoing the complaints of virtually every governor who held office in the early modern British Empire, was in the balance of power within colonial governments. While "too great power" was "lodged in the Assemblies," the governors, endowed with "pompous enough titles," effectively had very "little power." In the specific example of Jamaica, this situation made it possible for any assembly that was resentful at having been badly "us'd by their mother" government in London, or was stirred up by "a popular Assembly-man" who was "disoblig'd by the Governor," to make sure that the government would be "without mon[e]y, however necessary it may be for the Soldiers, \& forts." With no resources through which he could "perswade or terrify an assembly," a governor, Trelawny complained, was impotent against "the great power that comes to the Assembly from the sole right they assume of framing mon[e]y- bills." Moreover, in each colony the assembly represented the predominant property interest. For that reason, to place power in the assemblies was to lodge it, in Trelawny's words, "in the Planters themselves," a mistake that, he was persuaded, was "the Pandora's box from whence our evils have issu'd; hence," in Jamaica's case, "the engrossing of lands, the paucity of white inhabitants, the bad state of the Militia \&c \&c \&c."

To remedy these problems, Trelawny called for metropolitan officials to "consider our Colonies" not, as would "a Merchant or Planter," but "in a more general \& political sense." He made four specific proposals. First, like many governors before him, he repeated an earlier request he had made to the Board 
of Trade for the appointment to colony offices of metropolitans who were independent of the interests of local powerholders. Specifically, he called for the appointment of "a Chief Justice $\&$ an Assistant appointed from home" who would be both "great helps to a Governor" and, unlike the local planters, skilled in the law. Second, he suggested that "two Itinerant members" be "added to the Board of Trade," one to be resident in Jamaica and the other in the islands of the eastern Caribbean, "to serve as counterpoises \& check to" the power of the assemblies. As formal members of the island councils, " 8 in all things . . . consider'd as next to the Governor," such people, he predicted, would give those bodies strength "to withstand an Assembly, (who now carry all before them, \& ram things down the Council often much against their wills)."

As Trelawny admitted, however, these steps were "palliatives only." To get at the root of the problem of imperial governance in the British Empire, he advocated that "a State of the Colonies . . . be laid before the Parliament." Declaring that it was "high time" that the ministry take such a step, he argued "that unless there is an hearty \& steddy intent to go to the bottom of things, unless there is a resolution to consider fully the state of the Colonies \& make a thorough reformation to be settled by Act of Parliament, all other things will be ineffectual, productive of no lasting good, but a meer transitory amusement."

The most important element in that reformation, Trelawny made clear in setting forth his fourth and boldest proposal, was to take most of the revenueraising power out of the hands of the assemblies. "Whereas now a Colony Government is supported from year to year, as it were from hand to mouth, by annual bills rais'd by the Assembly, the standing revenue of the Island being very inconsiderable," he observed, "an Estimate should be made, (by a medium of former actual expenses for any numbers of years the Board of Trade should think proper) of what the future services of Government may be suppos'd to amount to, \& then, that those very funds, (as the duty on negroes, rum, \&c) which now are rais' $d$ annually should be setled perpetually by Act of Parliament to answer those services." Once "a proper \& ample Revenue [had been thus] settled by Parliament for the current \& ordinary services of the Country," Trelawny noted, governors would have "no need to trouble the Assembly for a supply but upon extraordinary occasions."

In Trelawny's view, such a measure, which he referred to as his "grand Elixir," could not fail to produce "unaccountable . . good": "all squabbles between Governors \& Assemblies would cease at once as it were by some charm. There 
will be an authority in a Colony Government, which will be rescued from the dependence on the humour of an Assembly, Who will then 'tis to be hop'd turn their thoughts from Politicks to Planting, $8 x$ to the real good of the Colony. It will not then be in the power of a popular man to blow the assemblies up into a flame, that they in their turn may fire the Clubs in the City, till the City it self is in a blaze, \& all Westminster to the very Palace under the greatest alarms." "Let this once be set right," he predicted, " 8 all other things will go right; Trade \& Planting will of course necessarily prosper."

In expressing his conviction that such an action by Parliament was "agre|e]able to the ancient constitution of England," a constitution whereby Parliament itself had met only to grant "aids upon extraordinary occasions," Trelawny was implicitly acknowledging that it was contrary to the tradition of active and regular parliamentary government that took shape in England-and in the colonies-during the seventeenth century and had been institutionalized during the Glorious Revolution. Whether colonial political leaders might have opposed such a drastic revision of existing governing arrangments seems not to have occured to him. But he was aware that it would be necessary to have their approval or acquiescence. To "induce them to consent to have an ample revenue settled ... perpetually for the Ordinary [expenses] of their respective Governments," he advocated that Parliament levy no new taxes but instead make existing ones permanent. For the same reason, he proposed that the Crown "generously" part with monies deriving from permanent revenues earlier voted by colonial assemblies to pay government expenses, such as the four and a half percent duties of Barbados and the Leeward Islands that, much to the displeasure of the legislators of those colonies, the Crown had long since diverted to its own ends.

Trelawny's letters to Pelham also discuss several related subjects. These include the potential for conflict with Spain over Spanish efforts to deny British traders access to Spanish American ports, and the early efforts of absentee West Indians in Britain to form a lobby that would make them, rather than the royal governors, the intermediaries between the metropolitan government and the colonies. But they are principally interesting for the insight they provide into the problem of imperial governance as perceived by royal officials in the colonies in the middle of the eighteenth century, and for the as yet relatively rare suggestion that those problems could only be resolved by the intervention of Parliament. The failure of metropolitan authorities to act on Trelawny's 
radical suggestion makes it impossible for us to know how colonial legislatures would have responded to such an action. Their explosive reaction to Parliament's much more tentative intervention in colonial affairs a mere fifteen years later strongly suggests that the response might not have been positive.

Full Text of Two Letters from Governor Edward Trelawny of Jamaica to First Minister Henry Pelham of Great Britain

$S[\mathrm{i}] \mathbf{r}$

I have been sometime in doubt whether I should trouble you with this, but my duty to his Majesty has got the better of other considerations, \& prompted me to this presumption; \& the great obligation you have conferr'd on me, \& the kindness you have honour'd me with, have made me choose to ad[d]ress my self to you rather than to any other Minister, \& I know not whether I should have prevail'd upon my self to write thus to any other.

There is great reason, I think to suspect that the Spanish Guarda-Costa's [sic] will be as insolent as ever they were before the war, \& full as much to imagine that our merchants will be crying out loud enough which may make an unpleasant noise in the city \& St. Stephens Chappel. There is no other way that I can see to prevent this, \& a war w[i]th Spain, or what is worse, insults abroad, \& uneasiness at home, but by keeping a good strong Squadron here, under a discreet \& honest Commander, \& that He, together with the Governor, \& the unanimous consent of his Majesty's Council of this Island, should have power to make Reprisals; if this had been done in 1736 or 1737 , we probably should have avoided the war; if it is not done, we probably shall have a war or worse sooner than may be lik'd. ${ }^{4}$

I flatter my self that you have a better opinion of my understanding, than to imagine that I propose this power in order to have a share of it my self. I know very well that it cannot be attended with either honour or profit, \& that it may effect the Commander at sea \& my self--in our characters \& perhaps in our fortunes, \& therefore it is that I propose the Council to be join'd w[i]th us, to screen us from that danger.

I had the honour you know, $\mathrm{S}[\mathrm{i}] \mathrm{r}[$,$] to be a member (with the two Admirals,$ $\&$ the two eldest Generals) of the Supreme Council of War in the West Indies; ${ }^{5}$ besides the honour of being a member, I know not any other that I got by it, I am sure I got no profit, \& I made Adm[ira]I Vernon ${ }^{6}$ my utter enemy, only by opposing, tho' w[i]th the utmost decency \& even submissions, his wild manner of proceeding at $\mathrm{Cuba}, \&$ by endeavouring to make him act honestly 
in the affairs of Panama, by either carrying it on rightly \& heartily, or by dropping it entirely. ${ }^{7}$ His friends \& partizans upon that became my enemies, their attacks upon me have occasion'd my attacks upon some of them. Animosities according to their nature have gone on spreading. Nor could the prejudices \& calumnies that have been rais'd against me have risen to that heighth [sic], or been so countenanc'd even by men of rank, as I have been inform'd, if his party had not join'd in the cry against me; I mention this only to show that I have no reason to be fond of a barren power; but neither am I to be deterr'd."

I perceive that I am to stay here, that is, if I go, I am to leave the Government in the hands of Mr Gregory, ${ }^{9}$ our eldest Councillor; I am glad, as thing have happen'd since, that it is so, for by what I can perceive of the workings of men[']s minds upon the Address of the Council \& Assembly ${ }^{10}$ which I now transmit to the Duke of Bedford, "I am apt to imagine that my stay here may be possibly usefull to those to whom I would be usefull tho' at the cost of my life \& every thing that is dear. There may be vanity in this thought, but this I am sure of, that tho' Mr Gregory may exceed me in ability, he doth not exceed me in honesty, \& tho' I may not be able to hinder improper ad[d]resses going home, yet I will not add the weight of the whole legislature's joining, as I have reason to believe $\mathrm{Mr}$ Gregory would, or any thing that was any way agre[e]able to $\mathrm{Mr} \mathrm{Wm}$. Beckford, ${ }^{12}$ whose abject tool I perceive him to be. This leads me to mention what I have observ'd for sometime, but reserv'd it as more proper for discourse, till I could have the honour to wait upon you, which now seems to be at some distance.

There is a scheme among the West Indians, or I am much mistaken, to make themselves formidable. As many as can are to get into the House \& keep together. All governors that will not be at their devotion are to be cried down; $\&$ none are to be made that will not be submissive to them. All representations from the Colonies are to be agre[e]able to their views, \& made when \& how they please. Of what consequence this may be to his Majesty's affairs \& to the Ministry, how easily the City is enflam/e]'d, I need not mention. But if you ask me why I trouble you w[i] th this, \& whether I have any remedy to propose, I answer that I think there may be a remedy, but that it will cost trouble, but I think it better to encounter an evil in its infancy, tho' $w[i]$ th trouble or even danger, than to let it grow to a strength not easily to be overcome. I think a State of the Colonies should be laid before the Parliament, a proper \& ample Revenue settled by Parliament for the current \& ordinary services of the Country, so that the Assembly need not be applied to but to give their Aids upon extraordinary occasions, w/hi]ch is more too according to the old Constitution of England. This would set the Governor not hors de Page[, $]^{13}$ as 
one of the French Kings said, but hors de Lacquay ${ }^{15}$ \& mesme d'esclave[, $]^{15}$ as he really is.

As it is now, if a popular Assembly-man is disoblig'd by the Governor, or takes it in his head without rime or reason the soldiers are to have no subsistence ( $\&$ the Governour is perhaps to be turn'd out for not having credit enough with them to get that subsistence). This has happen'd more than once formerly, \& had like to have happen'd once in my time, they having been affronted with the repeal of the law that divorced Mr Manning, \& had a mind to show that they would not be so us'd by their mother. ${ }^{16}$ It was got the better of; but more by luck than skill. I think that it is absolutely necessary that there should be a Chief Justice \& an Assistant appointed from home for this Island, as I have sometime agoe propos'd to the Board of Trade, for, (besides that Justice will never otherwise be duly administ[e]red in this Island, (a matter of the utmost importance in all governments) nor can it be expected that it should be duly administer'd by Planters however honest yet unskill'd in the law) these Gentlemen will be great helps to a Governor, who now stands alone, without any usefull power, tho' w[i]th much troublesome power, as Ordinary, Chancellor, \& President of the Court of Errors. And since the case is so, that Governor[s] have really in effect but little power, tho' their titles are pompous enough, I think it might not be a bad expedient, if two Itinerant members were added to the Board of Trade, the one to be at Jamaica, the other at the Windward [Leeward] Islands, ${ }^{17}$ at least till matters were settled by Parliament, which will take up time to prepare \& digest. They should be members of the Council, $8 x$ in all things be consider'd as next to the Governor. The Council headed by such a member would be able to withstand an Assembly, (who now carry all before them, $8 \mathrm{ram}$ things down the Council often much against their wills) \& might prevent many an improper \& inflammatory representation. (The Salary considering how dear everything is here could not be less than

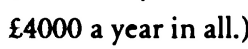

I mention these only as hints. The Board of Trade will digest the matter, \& think of other things that have escap[e]d me; I am from my soul convinc'd that something of this kind must be done, or you will find your selves much embar[r]ass'd from this part of the world, $8 \mathrm{r}$ the Islands themselves in the end very probably ruin'd.

I know the trouble I am bringing upon my self, (\& I like my ease as well as another man.) W. Beckford, whose interest \& that of his family are very powerfull in this Island, will, I have reason to fear, turn against me when he knows what opinion I have given. For it directly thwarts the view which he shows very plainly that he has, of making this country subservient to his designs, $8 \mathrm{r}$ represent things just as he has a mind. 
I mention'd that I could not help transmitting $\Lambda \mathrm{d}[\mathrm{d}]$ resses, tho' I could help joining in those I did not like, the reason is, that they do not oftimes present the $\mathrm{Ad}[\mathrm{d}$ /ress to me till the day, or the afternoon before the ship sails that is to carry it home, \& if I was to boggle, or take time to consider, they would be out of humour, (as I am threatened every now \& then they will be when I do not instantly, \& at their beck come into every thing they have a fancy for) \& so it might very probably have a bad influence on their supplies.

I had the honour of a letter from L[or]d Dupplin, ${ }^{18}$ for which I believe I am to thank you. I wrote his L/or]d/shilp in answer fully about the Chief lustice \& some other matters, but not about those I now trouble you with, having reserv'd them for conversation, but by what I observ' $d$ in the manner of carrying this $\Lambda d|d| r e s s$, as I mention above, I thought no time should be lost in acquainting you with what appears to be brewing here, nor could I omit it, I think, without failing in my duty to you \& to my country.

I am with all possible respect \& gratitude

S|i]r

Your most Devoted Servant

\section{Edw[ard] Trelawny}

PS 14th Ap/ril]

Two ad[d]resses are now prepar'd \& will both be presented to me I believe this day; the one is only congratulatory upon the Peace; the other sets forth their grievances. ${ }^{19}$ I will join in the former, but not in the other. I did not know of the congratulatory one when I wrote the above yesterday morning, nor was it thought of till the day before.

[To:] Right Honourable Mr Pelham.

\section{II}

\section{Ap[ril] 1749. Jamaica}

$S[\mathbf{i}] \mathbf{r}$

The last I troubled you with of the 13 \& 14th ins[tan]t was not sail'd away four hours, before I had the honour of your letter of 17 th Dec[embe]r which like all your others is full of kind condescension and goodness, for which I am so much obliged to you. As from my soul I think my leaving the Government in $\mathrm{Mr}$ Gregory's hands would be not only injurious to my friends but highly detrimental to his Majesty's service, I need say no more to show that I cannot do it. Could I serve you by it, (were I so vain as to hope to serve you) the dearest motive I could have, next to that on which I act, I could not do it. There is no harm in my staying either to Mr. Price ${ }^{20}$ of my self; he was with difficulty perswaded by me to consent to my recommending him, as I did my self the honour to acquaint you when 1 first took that liberty. As to my self, I have 
better health here than in England. It would indeed have been an excessive joy to me to have thank'd you in person for the great obligation you have conferr'd on me, $\&$ to have pour'd out the gratitude of my heart before you: $\&$ there are others whom I most ardently long to see, \& did actually flatter my self that I should see this summer. But a year or two will soon pass over, $\&$ in less time than that I perswade my self the calumnies with which Mr. Price has been aspers'd will be found to have no foundation, \& you will wonder at the false $\&$ impudent representations by which your self $\&$ other great persons have been impos'd upon.

As to my presence in England, which your great kindness \& preepossession [sic] in my favour have inclin'd you to think, might be of service in representing matters relative to this part of the world, tis certain, that all matters are better set forth by word of mouth than by writing, more explicitly, \& with greater dispatch, as doubts \& misapprehensions may be immediately clear'd \& set right \& objections answer'd. But again, on the other hand I take the liberty to say, that unless there is an hearty \& steddy intent to go to the bottom of things, unless there is a resolution to consider fully the state of the Colonies \& make a thorough reformation to be settled by Act of Parliament, all other things will be ineffectual, productive of no lasting good, but a meer transitory amusement. And if there really be such an intent in the Minister; (as w/i]th submission I think it is high time there should be) then, the Board of Trade may easily get all the information, from the papers \& materials they may command from the Colonies, that will be sufficient to guide their judgements in that matter.

I do not consider our Colonies as a Merchant or Planter. I consider them in a more general \& political sense. I consider their constitution, their form of Government, whether it is adapted to the nature of a Colony, so as not only to make that Colony flourish, but flourish in a manner the most agre[e]able to the interests of the mother-country. Let this once be set right, \& all other things will go right; Trade 8z Planting will of course necessarily prosper. Now, it is plain to me, that there has been a grand error in the first decoction of our Colony Governments, $8 \mathrm{x}$ what is unfortunate, is, that tho' it would be right, considering things abstractedly, $\&$ as they are in themselves, that this error should be absolutely done away; yet when you consider men's prejudices, \& tempers, it would be absurd not only to attempt but even to think of it. What I mean is the too great power that is lodged in the Assemblies, that is, in the Planters themselves. This is the Pandora's box from whence our evils have issu'd; hence the engrossing of lands, the paucity of white Inhabitants, the bad state of the Militia \&c \& \& \& as I could most easily prove. I therefore took the liberty to propose in my last that a Chief Justice \& his Assistant from England, $\&$ likewise a member of the Board of Trade should be resident here to serve as 
counterpoises $\&$ checks to this power. They will indeed be palliatives only, but it will be necessary to use such till my grand Elixir, which will take up time, is prepared. My Elixir is (which I touch'd upon in my last) that, whereas now a Colony Government is supported from year to year, as it were from hand to mouth, by annual bills rais'd by the Assembly, the standing revenue of the Island being very inconsiderable, an Estimate should be made, (by a medium of former actual expenses for any numbers of years the Board of Trade should think proper) of what the future services of Government may be suppos'd to amount to, \& then, that those very funds, (as the duty on negroes, rum, \& $\mathrm{c}$ ) which now are rais'd annually should be settled perpetually by Act of Parliament to answer those services; $\&$ then we shall have no need to trouble the Assembly for a supply but upon extraordinary occasions. This is agre[e]able to the ancient constitution of England; it is absolutely necessary. Without it, the Colonies will be undone, but not perhaps untill they have distracted their mother-country by the ferments which they will otherwise occasion.

Seldom any thing great can be done without some self-denyal; the $4 V_{2}$ per cent duty that is now paid to the Crown from Barbadoes $\&$ the Windward Islands ${ }^{21}$ must be parted with generously, to defray, according to its first intention, the expences of their respective Governments. This will be a vast advantage to them, \& cannot but gain them on our side, \& induce them to consent to have an ample revenue settled, (supposing that already settled not sufficient) perpetually for the Ordinary [expenses] of their respective Governments.

It is unaccountable what good such a regulation would do; all squabbles between Governors \& Assemblies would cease at once as it were by some charm. There will be an authority in a Colony Government, which will be rescued from the dependence on the humour of an Assembly, Who will then 'tis to be hop'd turn their thoughts from Politicks to Planting, \& to the real good of the Colony. It will not then be in the power of a popular man to blow the assemblies up into a flame, that they in their turn may fire the Clubs in the City, till the City it self is in a blaze, \& all Westminster to the very Palace under the greatest alarms.

I have almost set my self on fire, with my metaphor; you will forgive it; the country is very hot at present, the Sun almost vertical. I asure you I write in a morning, upon chocolate.

You will be pleas'd to observe by my I6[th] instruction, of which I inclose a copy, that the Board of Trade, or whoever advis'd that Instruction, were aware of the mischiefs that must flow from the great power that comes to the Assembly from the sole right they assume of framing mon[e]y-bills. ${ }^{22}$ But what remedy is propos'd? Why the Governor is to support the Council in their right of having an equal share in the framing of those bills. For G-od[']s sake! 
How shall he support them? Shall he use perswasion or terror? As to the former, I remember how merry people were with Hozier's perswasive orders, ${ }^{23} \&$ yet he had great guns by which the Spaniards have been persuaded by English Commanders[,] as S[i]r Charles Wager remark'd in the House. ${ }^{24}$ And what has a Governor to perswade or terrify an Assembly by? If the Instruction had added that if the Assembly would not agree to an Amendment made by the Council to a mon[e]y bill, that the bill nevertheless, if confirm'd by the Governor, should pass as amended by the Council, \& have the force of a law, there would have been some sense in that, but as that would have taken away the Assembly's negative as to that amendment, that could not be right neither. Which shows that it is ridiculous to think that such a right can be shar'd, \& at the same time it shows the necessity of the regulation I have humbly propos'd. Or else the Government here may often be without mon[e]y, however necessary it may be for the Soldiers, \& forts, if a popular Assemblyman takes it in his head to be disoblig'd, \& to show that he is not to be disoblig'd w[i]th impunity.

I hope I shall not have occasion to trouble you any more w[i]th Colony Affairs, having mention'd, in general in this \& the last, what is most material. If I find it necessary to add any thing further, I will take the liberty to trouble L[or]d Dupplin with it, if he does me the honour to continue the correspondence, \& some things I will write to Mr Gashry; ${ }^{25} \mathrm{Mr} \mathrm{Sharpe}^{26}$ \& $\mathrm{Mr} \mathrm{Baker}^{27}$ having oftimes acquainted me how much he [Dupplin] stirr'd in my affairs, I thought I was under an obligation to return him my thanks, to which his answer is very obliging, \& he promises me his assistance in all affairs of my own that may require it.

I am w[i]th all possible respect \& gratitude

$\mathrm{S}[\mathrm{i}] \mathrm{r}$

Your most devoted Servant

Edw[ard] Trelawny

[To:] Right Honourable Mr Pelham 
1. These developments are discussed in Jack P. Greene, "'A Posture of Hostility': A Reconsideration of Some Aspects of the Origins of the American Revolution," in Preachers 6 Politicians: Two Essays on the Origins of the American Revolution, ed. Jack P. Greene and William G. McLoughlin (Worcester: American Antiquarian Society, 1977), pp. 5-46.

2. Trelawny-Pelham Manuscripts, No. 306. These letters are published below in full for the first time, courtesy of the National Library of Jamaica. The quotations in the paragraphs below are from these letters.

3. On Trelawny's governorship, see George Metcalfe, Royal Government and Political Conflict in Jamaica, 1729-1783 (London: Longmans, 1965), pp. 58-108.

4. On the situation with regard to the guardacostas in the late 1730s, see Richard Pares, War and Trade in the West Indies, 1739-1763 (London: Frank Cass, 1963), pp. 1-64.

5. This Supreme Council, which operated during the early part of the War of Jenkins' Ear (1739-42), was composed of Admirals Edward Vernon and Sir Charles Ogle, Generals Wentworth and Balkney, and Trelawny.

6. Edward Vernon (1684-1757) became a vice-admiral in 1739 and was a principal actor in the West Indian theatre before he was struck off the list of flag officers in 1746.

7. The expeditions to Cuba and Panama in 1741-42 are briefly discussed in Pares, War and Trade in the West Indies, pp. 92-96.

8. Trelawny's quarrel with Vernon and Sir Charles Ogle may be followed in Frank Cundall, The Governors of Jamaica in the First Half of the Eighteenth Century (London: The West India Committee, 1937), pp. 184-86.

9. John Gregory had been a member of the Jamaica Council since 1717 , became its president in the 1730s, and three times served as acting governor. Trelawny succeeded in his efforts to prevent Gregory's appointment as lieutenant-governor. See Metcalfe, Royal Government and Political Conflict in Jamaica, p. 55. Cundall, Governors of Jamaica in the First Half of the Eighteenth Century, pp. 156-65, provides a brief public biography of Gregory.

10. This address complained of an additional duty levied by Parliament on sugar in 1748, pointed out the problems created by Spanish refusal to open West Indian ports to foreigners, and asked for an additional regiment for protection against slaves. It may be found in Journals of the Assembly of Jamaica, 4 (14 April 1749), pp. 155-56.

11. John, Fourth Duke of Bedford (1710-71) was Secretary of State for the Southern Department, 1748-51.

12. William Beckford (1709-70) was born in Jamaica and was the son of Peter Beckford, sometime speaker of the Jamaica Assembly. Educated in England and the Netherlands, he resided in England after the late 1740s, sitting in Parliament for Shaftesbury (1747-54), and for London (1754-70). He was elected Lord Mayor of 
London in 1762. While he resided in Jamaica in the 1740s, he had been a political ally of Trelawny's. See Metcalfe, Royal Government, pp. 21, 88.

13. One's own master.

14. Flunkey.

15. The same as a slave.

16. In May 1739, the Jamaica Assembly, at the request of Edward Manning (1700-56), one of the most prominent Kingston merchants, passed a law to enable him to divorce his wife Elizabeth, who had run off with Ballard Beckford, a member of the Assembly. The Privy Council disallowed this law on 16 July 1741. The Privy Council's actions may be followed in W. L. Grant and J. Munro, eds., Acts of the Privy Council, Colonial Series, 6 vols. (London: H. M. Stationary Office, 1908-12), 3: 681-83.

17. The Leeward Islands were to the windward of Jamaica.

18. Thomas Hay, Viscount Dupplin (1710-87) was a member of the Board of Trade and a political ally of Henry Pelham.

19. These petitions may be found in Journals of the Assembly of Jamaica, 4 (13 April 1749), pp. 155-56. The first is described in note 10 above. The second was an address of congratulations on the peace.

20. Charles Price (1708-72), a native of Jamaica, was a member of the Assembly after 1732. Speaker for most of the period from 1745 to 1763 , he was appointed to the Council and made a baronet in 1768. For biographical details, see Michael Craton and James Walvin, A Jamaican Plantation: The History of Worthy Park, 1670-1970 (Toronto: University of Toronto Press, 1970), 71-94.

21. The four and a half percent duty had been imposed by the Barbadian Assembly on all exported dead commodities in 1663 and by the Leeward, though not the Windward, Island Assemblies shortly thereafter. See Charles M. Andrews, The Colonial Period of American History, 4 vols. (New Haven: Yale University Press, 1934-38), 4: 135, n. 2.

22. This instruction may be found in Leonard W. Labaree, ed., Royal Instructions to British Colonial Governors, 1670-1776, 2 vols. (New York: D. Appleton-Century, 1935), 1: 205-06.

23. The British government sent Vice-Admiral Charles Hosier (1673-1727) to the West Indies in 1726 to try to bottle up the Spanish treasure fleet at Porto Bello and Cartagena, a task at which he failed. Max Savelle, The Origins of American Diplomacy: The International History of Anglo-America, 1492-1763 (New York: Macmillan, 1967), p. 318, and Cundall, Governors of Jamaica in the First Half of the Eighteenth Century, p. 125, briefly describe his activities.

24. Sir Charles Wager (1666-1743) had served on the Jamaica stations during the War of the Spanish Succession (1702-13), and was First Lord of the Admiralty in 1739-42. The speech to which Trelawny refers has not been identified. 
25. Francis Gashry (1702-62) was a Member of Parliament for Aldeburgh (1741) and for East Looe (1741-62). East Looe was a borough seat controlled by the Trelawny family. Gashry was Trelawny's London agent.

26. John Sharpe (1700-56), was a solicitor to the Treasury and well connected to West Indian merchants and absentees.

27. Philip Baker was agent to provide supplies and provisions for the independent company of British troops stationed in Jamaica under Trelawny's command. 


\title{
6
}

\section{Botanical and Horticultural Enterprise in Eighteenth-Century Jamaica}

\author{
DOUGLAS HALL
}

In 1770, Hinton East, a lawyer and sometime member of the Jamaica House of Assembly, began to establish a private botanical garden on his property "Spring Garden" in the "mountains of Liguanea (at Gordon Town)," and to import and export seeds and plants. In 1775, the House of Assembly acquired land and set up a public garden at Bath, in the parish of St. Thomas in the East. In 1777, that garden came under the management of Dr. Thomas Clarke, recently arrived from England. He was a medical man and botanist interested in medicinal and pharmaceutical plants, of which he was a collector. Another resident who had established a garden was Matthew Wallen. His was at "Cold Spring," about 4,000 feet above sea-level, near the borders of Portland and present-day St. Andrew. He was, like East, a member of the Assembly, and his garden was probably established in the early 1770s. Bryan Edwards, in his History of the West Indies (first published in 1793), mentioned both of these private gardens. ${ }^{1}$ That had all happened in eastern Jamaica.

Let us now look to the west. Riding home from Savanna la Mar, capital town of the parish of Westmoreland, on 11 January 1775, Thomas Thistlewood met John Cope, owner of Egypt sugar estate, and Thistlewood's erstwhile employer.

Going home met Mr. Cope who told me of a physic garden or Botanical Garden being intended to be established in Jamaica. That Matthew Wallen is one of the Commissioners; that the King of Spain has given leave to collect seeds, trees, plants \&c throughout his Dominions. ${ }^{2}$ 
It was interesting news. Thomas Thistlewood's garden, at Breadnut Island Pen, across the Cabaritta River from Egypt, had been started eight years before, in 1767, and by February 1768, he had imported and planted 139 varieties of trees, plants, and seeds from England. Many, as might be expected, had not survived, but he re-imported, replanted, and carefully tended those that did. In September 1770, he listed 136 plants "growing" in his garden. A second list, compiled in 1775 (perhaps in response to the news about Bath and Wallen) listed far more.

The second son of a farmer in Lincolnshire, England, Thomas Thistlewood, then twenty-nine years old, had arrived at Savanna la Mar in May 1750. For a year he had been employed as penkeeper on the Vineyard Pen, belonging to Florentius Vassall, a large proprietor of sugar estates and cattle pens in western Jamaica. Then for sixteen years he worked as overseer on Egypt sugar estate in Westmoreland. Like many others, he had come to Jamaica to make his fortune; but as he became increasingly familiar with the problems of sugar-planting and the costs of setting up as a sugar planter he ruled out that occupation. In mid-June 1765, he acquired his own property on the eastern bank of the Cabaritta River. It contained about 160 acres of limestone hills separated by alluvial depressions and morasses. He had also been buying slaves. By mid-1765 he owned twenty-two, and by the time of his move on to his own land in 1767, he had twenty-seven. Until then, as he acquired them, his slaves were employed in households in Savanna la Mar and in the Egypt cane fields, provision grounds, and garden; and, after June 1765, clearing bushes and helping hired carpenters to repair and refurnish the delapidated house on his own pen.

Breadnut Island Pen was not a "pen" in the current meaning of the word among the plantocracy. Verene Shepherd has noted contemporary descriptions:

Edward Long referred to "breeding-pens". Similarly, Barclay referred to his having "come into possession of a Pen (or grazing farm)" . . and Bryan Edwards, writing in 1793, mentioned that of "breeding farms (or, as they are commonly called in Jamaica, pens) the number is about 400." These pens were therefore not simply small temporary enclosures, but established livestock farms. ... Units which produced livestock as well as coffee, pimento and logwood were also styled pens, and in such cases stock-raising usually predominated. $^{3}$

Thistlewood had worked on such a pen at the Vineyard, and in the Westmoreland sugar belt he knew cattle pens associated with sugar estates such as Anglesea Pen and Carawina Estate, both owned by James Williams. 
Smaller properties, predominantly producing things other than sugar or livestock, went by a variety of names. Mr. Cope, for instance, had a "Polink" at Petherton in the hills east of Savanna la Mar; Mr. Roberts of George's Plain had a "Mountain": both terms signified a "provision-ground," or food-basket provision of root crops, plantains, vegetables, fruit, and perhaps a few livestock including poultry. Thistlewood himself would later describe his more elaborate enterprise as "a small Settlement, known by the name of Breadnut Island Pen." Similar nearby "settlements" would have been William Pommell's "The Wilderness," and John Scott's holding where there were "plenty of pot-herbs, bees, \&c." But none that we know of rivaled Thistlewood's in botanical and horticultural interest and performance.

The purchases of slaves and land had cost him close to $£ 1,500$ currency, ${ }^{4}$ but Thistlewood had several sources of income. There were his wages as overseer, although John Cope was often short of cash, and Thistlewood sometimes took rum and sugar in lieu of money. There were payments due to him from Cope and others who hired his slaves. And he also made money by importing goods for sale. In England, Henry Hewitt, a gardener on the outskirts of London, was his friend and agent. From him, on request, came garden seeds, plants, and other goods such as cloths, clothing, books, and foodstuffs, which Thistlewood retailed at a profit. Although he shipped rum in return, it seems that he sold it on board ship in Savanna la Mar and the purchaser-the ship's captain or purser-would re-sell in England (or North America) and eventually credit Thistlewood's account with Henry Hewitt. His accounts of various activities in April 1761 are illustrative.

[Monday, 6 April 1761:] called on board the Earl of Effingham, Capt. Bellamy, and received my bundle of trees marked TT No 1.

The next day, Dr. Gorse arrived at the pen:

let him have his trees according to account. Some of them seem to be alive.

[Thursday, 9 April 1761:] Received ... my cask garden seeds, box of ketchup, chest of books \& $\mathrm{c}$ and case of arms.

[Saturday, 11 April 1761:] carried my 4 puncheons of rum on board the Westmoreland, Capt. Hore.

The puncheons contained $\mathbf{4 4 4}$ gallons for which, after paying excise duty, Thistlewood received, or was credited with, $\mathfrak{E} 6614 \mathrm{~s}$.

[Monday, 13 April 1761:] Gave out my Scotch check handkerchiefs to Phibbah to sell for me. They are 28 inches square. 
Later in the month he sent catalogues of seeds to interested individuals and to local taverns for display. There were buyers, and his ketchup also went quickly at 3s. $9 \mathrm{~d}$. per pint bottle.

In April 1767, after delivering eight hogsheads of Mr. Cope's sugar to the Henry (Captain Richardson), he put on board four puncheons of rum marked TT. The total, 472 gallons net, brought him $\mathfrak{E} 532$ s. and the puncheons $\mathfrak{E} 610$ s. The rum in two of them was flavoured-he often added fruit, usually cashews or pineapples, when casking.

In the same month he was able to repay in sugar a remaining balance of $\mathfrak{E} 194$ 19s. $11 V_{4} \mathrm{~d}$. which he owed to Mr. Abraham Lopez, a merchant from whom he had borrowed in order to purchase his land. Breadnut Island Pen was now indisputably his, and on Tuesday, 1 September 1767, Thistlewood left Egypt and went onto his own land, although a few of his slaves remained temporarily on Egypt.

During his long tenure there, Thistlewood had done much to improve the Egypt garden, introducing new plants and increasing the varieties of vegetables, fruit, and flowers.

[Wednesday, 20 January 1762:] I have now a white narcissus in full flower in the garden, a pretty large bunch of 12 or 13 flowers in it. This is probably the first that ever flowered in this Island. ${ }^{5}$

His botanical interests had been greatly encouraged by Dr. Anthony Robinson, ${ }^{6}$ another of the medical botanists, who had frequently visited Thistlewood on Egypt in the 1760s and had taught him "in drawing birds, plants, \&c."

Thistlewood's slaves on Egypt had observed, and often worked on, his gardening activities there. They would have been little surprised, therefore, when in December 1766, he began planting on his pen. "In the valley before the house," they planted corn, peas, and flowers. In March 1767, work began on his "intended garden" in the same valley, and on a provision ground for his slaves. By the end of the month they had added lima beans, kidney beans, musk-melons, cucumbers, groundnuts, cho-chos, sunflowers and frangipani. Midmonth he reaped his first crop-"green black-eyed peas"-which he took back to Egypt for dinner.

At the end of March, after the arrival of a ship from England, Thistlewood extended the garden, and put in a variety of seeds and plants-stocks, pinks, asters, larkspurs, colombines, cabbages, savoys, broccoli, cauliflower, parsley, and many others. A horticultural showplace was in the making. By 1775, 
Breadnut Island Pen would be transformed from semi-ruinate land with a delapidated house, into a productive settlement containing two gardens in full cultivation, three provision grounds, two pastures, bee-hives, pens, sheds, and stables for livestock, as well as ponds and morasses which from October to January teemed with wildfowl. Labouring on it were his nearly thirty slaves; and in his household there was Phibbah. She was the only woman with whom Thistlewood ever had a stable relationship, though she was so frequently abused by his assaults on his own and other people's slave women. His association with Phibbah had begun in early 1754 , when she was a house slave and the property of the Copes. In June 1757, Thistlewood had asked them to sell her to him, but they had refused. Finally in November 1767, they had agreed to hire her to him at $\mathfrak{E} 18$ a year, so that she might live with him on the pen, and she became his "wife" and helpmate.

[Saturday, 2 January 1773:] Phibbah made me a present of $£ 10-18 \mathrm{~s}-1 \mathrm{~V}_{2} \mathrm{~d}$. all in silver; money she had earned by sewing, baking cassava, musk-melons and water-melons out of her ground.

That was only one of his many acknowledgements of her assistance.

At work on the pen, planting schedules were not entirely within Thistlewood's discretion. He knew the agricultural lore: for crops yielding above ground, sow or plant in the waxing of the moon; for crops yielding below the surface, plant in the waning of the moon. But there were other considerations. The arrivals of ships bringing his cases of seeds, bundles of trees, and boxes of seedlings, were not governed by appropriate seasons for planting, or by the phases of the moon. Seeds might be put by, but trees needed immediate attention. Sudden, unexpected weather, especially heavy rain which flooded his low-lying gardens, interrupted routine. The demands of sugar planters and others who wanted to hire his slaves did not always occur at times convenient for him; but that was a very important constituent of his annual income. And there were periods when one or another of his several ailments slowed him into comparative inactivity.

On the evening of Saturday, 30 January 1768, Captain Richardson brought the Henry into Savanna la Mar. Next evening, by previous arrangement, ten slaves went off, hired to Captain Arthur Forrest at Masemure Estate.

[Wednesday, 3 February 1768; ] Dick, Maria, Coobah and myself employed planting the English trees all day, doubt but few will grow.

[Thursday, 4 February 1768;] Received my remaining bundle of trees. 
And on the 5th:

Finished planting my trees, Negroes assisting \& c, as before.

His chest, cases and correspondence, had also been delivered. On 6 February 1768:

Transplanted granadillas, also planted 3 unknown bulbs, 16 white crocuses, 6 polyanthus narcissus, 16 Scotch crocuses, 6 narcissus of the sun, 16 blues crocuses 6 fine tulips, 16 yellow crocuses, 16 double jonquils, 9 double white narcissus, mixed annuals 50 , striped crocuses 20 , turkey ranunculus 50, 6 unknown roots, and where sticks stuck up besides. \& $\mathrm{cc}^{7}$

[Wednesday, 10 February 1768;] Planted lucern, red clover, timothy grass, white clover, French furze, saintfoin, melongena, turnip-cabbage, \&c. in the garden.

Employment of his slaves elsewhere obviously limited the availability of labour in the garden, where Thistlewood himself worked a good deal; but it more seriously affected the maintenance of provision grounds and pastures.

The first plantings had been done in the valley in front of the house where his garden would be made. In September 1767, he "Began to dig a pond in the garden before the door, $30 \mathrm{ft}$. long and 20 wide; but had some hands off doing sundry other work."

The first provision ground, which he appropriately named the Rock-Hole Provision-ground, lay just within his gate leading to the King's road. That ground was parcelled out among his slaves. Then, in mid-1768, he began to clear land and fence in another-the Lime-Kiln Provision-ground-so-called because of a kiln nearby. By the end of August, Lime-Kiln was ready for planting. During September, lima beans, peas, corn, cucumber, musk- and water-melons, tomatoes, and "sprouted cocoa-nuts" were put in. ${ }^{8}$ At first, the Lime-Kiln ground was not apportioned among the slaves. It was Thistlewood's preserve, intended to produce staple foodstuffs, fruit and vegetables, and also for experimental planting and transplanting from his garden.

About two years later, in October 1770, Lime-Kiln was divided between his slaves, and the original slaves' provision ground, Rock-Hole, became Thistlewood's. Then, in June 1772, work began on the Birch-Tree provision ground, which remained as another Thistlewood preserve until mid-July 1776, when it too was shared out among the slaves. At first, it was planted out in corn, peas, and beans. Finally, in early November 1772, workbegan on the second, or "new" garden. 
In January 1770, work on the pen was largely "make and mend." Thistlewood had to maintain an elaborate network of trenches to protect his garden beds from being washed away by heavy rain. The trenches were deepened and lined at the bottom with broken rocks. A bank was built around the garden pond; the grape vines were trimmed and cuttings from them and the fig trees were planted. Cumberland, the hired carpenter, mended the arbors, and leaves and trash were moved from the garden to the compost heap. ${ }^{9}$

At the beginning of February 1770, the Henry (Captain Richardson), came into port. On the 7th, Thistlewood received six plants each of gooseberries, raspberries, sweet briar, honeysuckle, and grape vines, and "all these were in excellent order, fresh, green, and growing." He planted them, and he also Planted 2 unknown seeds in provision-ground. Found the fruit in my garden, about as big as a lime, a pleasant pulp, enclosed three seeds of which those are two. The other opened.

In the next few days, back in the garden, he planted English peas, cuttings sent to him by Mr. Cope of the Burgundy, White Oblong Muscadine and Madeira Malmsey vines, and "from the box sent from England," walnuts, filberts, chestnuts, hazelnuts, cob-nuts, apricots, peaches, nectarines, plums, cherries, apple and pear kernels, and Spanish broom which seemed "decayed and spoiled." Some of the Spanish chestnuts were planted in the Lime-Kiln ground, while Rock-Hole ground was being hoed over for planting. At the end of February, sixteen of his slaves went off, hired to work on Friendship Estate, one of the properties of his first employer, Florentius Vassall.

The next heavy planting began at the end of April 1770-slips of sage, marjoram, thyme, rosemary, and wormweed. On the 23rd, Thistlewood noted: "I have a Sweet William now in flower and has been these 6 weeks past." In the next few weeks, until mid-June, during which time another shipment had arrived, there was another spate of planting: beans, peas, asparagus, cabbages, savoys, ochroes, cauliflowers, cucumbers, beets, parsnips, celery, broccoli, radishes, turnips, lettuce, borage, parsley, sorrel, rue, lavenders, marigolds, sweet williams, wallflowers, carnations, sunflowers, phlox, batchelor's buttons, pinks, hollyhocks, pineasters, labernums, cypresses, firs, pines, and cassia. Growing plants were trimmed or transplanted. And, as he went about his garden, he recorded with obvious satisfaction:

[15 May 1770:] Having 3 very large bushes of sage gathered, the greatest part of it. 
On 17 May 1770, he "Sowed a bed of Battersea asparagus seed," and transplanted out a bed of asparagus sown in 1768 . On the same day:

flowered an English pink (of a beautiful red) in my garden which is the first I have seen, or heard of, to have flowered in the island. The plant is flourishing and will have many flowers.

On 9 June 1770, the rose bushes on each side of his garden gate flowered "at last."

Nor were the fodder crops forgotten. In May 1770, he again sowed lucern, timothy grass, red and white clovers, sainfoin, trefoil, and French furze. On 11 June, with work in the garden becoming less demanding, his field slaves were sent off to clean the Lime-Kiln ground and trim the logwood fence around it. By the 21 st they had cleaned, hoed, and prepared it for planting.

[Monday, 25 June, 1770:] Planted the Lime-Kiln provision-ground with corn. Also planted musk-melon, cucumber, and cotton seed. Note! as I planted but 3 corn in a hole, and 29,700 grains [he had calculated that the 100 ears purchased on Saturday, 16 June, for 4 bitts would yield that number of plantable grains!] ought to be 9,900 holes planted. Began about sunrise, done at 11 AM. 6 made holes, \& 6 planted. Put Phoebe and Sally to keep the fowls out. ${ }^{10}$

Then, after the morning break, they cleared the pingwing fence around Rock-Hole ground and began to clean the pasture. The field gang had not had an easy day.

Since mid-May 1770, when there had been a heavy shower of rain, the weather had been dry. Most of the field slaves had been away for some time, working at Mr. Meyler's Cabaritta Estate. The able bodies left at home had been mainly occupied in the garden. As a result, provision grounds and pastures had been neglected, and food was scarce. Normally, the slaves' free time on the pen was Sundays and some Saturday afternoons. At those times they were free to work their allotted "grounds;" but labour for Thistlewood included the preparation and cultivation of undistributed provision grounds. These were also planted with some food crops for Thistlewood to provide his slaves, but now, even on them, there was not enough.

The hired gang had come back from Cabaritta on Saturday, 2 June 1770. On Monday the 4th, "Gave my Negroes today to look provisions." On Saturday the 9th they had the day again, on Saturday the 16th, the afternoon, on Saturday the 23 rd, the day, on Saturday the 30th, the afternoon, and on Saturday, 7 July, 
the day. In that month Thistlewood spent more money buying plantains, corn, and rice for his slaves than he earned by sales of produce from the pen.

[Saturday, 14 July 1770:] Gave the Negroes today as they are starving... Missed 3 water melons in the garden. Suspect Lincoln, Solon and Abba. Ditto Johnnie.

But he inflicted no punishments.

The scarcity was general in the Parish:

[Monday, 30 July 1770;] Phibbah walked to Three Mile River to look Bess and Damsel. All came home together in the evening. Waited for corn \&c. For 52 plantains, 4 bitts, \& for 100 corn, 4 bitts.

With more labour at hand, and a break in the weather, things seemed to improve; but there were always problems.

[Tuesday, 17 July 1770:] Never known so many caterpillars. Cabbages, savoys, broccoli, turnips, peas, cucumber, pumpkins, \&c, \&c, all eat to pieces by them. Even the grass and the bushes in the pasture full of them.

He tried to smoke them out.

Caterpillars were only occasionally a problem. Much more frequent, and more devastating, were the invasions of his provision grounds by birds and animals. There were occasions when his own livestock, or hogs from Samuel Say's adjacent pen, caused damage; but the chief offenders were cattle from Kirkpatrick Pen, across the morasses to the east. They provided a constant menace.

[Sunday, 29 July 1770:] AM. Bulleted a Kirkpatrick steer in Lime-Kiln provision- ground morass effectually.

[11 August 1770:] The cattle have trod and filled up a good deal of the trench against the Rock Hole provision-ground that otherwise would assist in draining the garden.

A few days later, he "had some discourse with Mr. George Leslie about his [Kirkpatrick] cattle in my land, \&c." As his own enterprises expanded, Thistlewood found he would have to deal with the other side of the problem. On Saturday, 2 December 1775, he recorded, "My cattle will not keep out of Mr. Wilson's land. Don't know what to do with them." ${ }^{11}$

During the second half of 1770 , although work continued in his garden, Thistlewood concentrated on his provision grounds. He sent for "a gallon or more of guinea-corn" given him by William Foot at Hertford, and prepared the Rock-Hole ground for planting it. 
[Friday, 24 August 1770:] Myself, Franke, Coobah, Phoebe and Mirtilla lining out as yesterday."

It was a "monstrous hot" day.

By the 28th they had finished the lining-out, and on

[Wednesday, 29 August 1770:] AM. Planted the Rock Hole provisionground with Guinea Corn, in rows 6 feet distant and about 3 feet from hole to hole in the rows, 15 or 20 corn spread in a hole. Note! It has soaked all night in water made very bitter with aloe. 36 rows from the far end are of the large white sort given me by Mr. Hughes.

On the same day he planted another quart of guinea corn in the Lime-Kiln ground among the "great corn" planted there on 25 June. Corn would give the quickest yield of food. On 2 September, he noted that "Some of the guinea-corn in the Rock-Hole provision-ground is peeping." Now was the waiting time, and the slaves were put to weed the garden.

Prospects of a good crop began to fade. The bitter aloes mixture had perhaps protected the corn seed, but the "peeping" shoots were being attacked by "vermin" which destroyed nearly all of them. Replanting began, and he put in some "great corn," musk- and water-melons, cucumbers and ochroes.

[Wednesday, 12 September 1770:] Mr. Hartnole, gave me some tar, and as the ants destroy many of the trees and plants in the garden, rubbed them with tar, by way of experiment, as the China pinks, sweet william, fennel, \&c. Citrons, cassia, justicia, shaddocks, black mulberrys, \&c.

Undeterred, next day he planted an "Abba or Mackaw Tree nut" in the garden, and another in the Rock-Hole ground, and he transplanted from the garden into the Lime-Kiln ground, on the side near the morass, "some asparagus, by way of trial." He had first planted asparagus seed in July 1768, and now the well-rooted plants would have to be transferred to permanent beds. In another year or so, the first small cropping might occur; then continuous and larger crops might be reaped from the same plants for a number of years.

On Friday, 9 October 1770, he reaped the great corn in the Lime-Kiln ground. It had promised well, but bad weather, caterpillars, and stealing, had resulted in "an indifferent crop." On 19 October, he shared that ground among his slaves, and "Gave the Negroes the rest of the day and tomorrow to plant and put their ground in order." In early December, he entertained the overseers of Egypt, Paradise and Sweet River Estates. 
"Mr. Parker, Mr. Limburner, and Mr. Ellis ... dined with me, and as we were walking in the garden in the evening perceived a swarm of bees upon a Fig tree leaf."

Next day he captured the swarm, but by mid-January 1771 , they had all been destroyed or flown off. Later, he would start again with much success and eventually add honey to his saleable produce.

From 8 a.m. until 2 p.m. on Christmas Eve, 1770, the slaves broke the great corn in the Rock-Hole ground. It yielded three cartloads. On Christmas Day, he distributed the usual extra rations of pickled fish and rum. Each slave got eight "jumpers," 12 and rum "according to status and age." On Wednesday the 26th, "Gave my Negroes today also." Things were looking up.

In the garden before his door, fruit and flowers thrived, and the wild fowl would, in a few more weeks, begin to flock his ponds and morasses. He "Sent Mrs. Cope 50 bunches of grapes, flowers and a pr. wild ducks ... Sent House Franke and Coobah, pr. Teal." ${ }^{13}$ Food and fodder were obviously coming into satisfactory supply. Towards the end of January 1771 , an entire day was spent reaping the guinea-corn in the Rock-Hole ground. The birds had made "sad havoc," but he "got very well." Anticipating a heavy yield, he had kept his field slaves at home for the day, though they should have gone to work on Friendship Estate. Two days later, he broke in his Barberry corn in the garden, which yielded less than he hoped for, but was not unsatisfactory. He sent some for $\mathrm{Mr}$. Cope and some for Mr. Say, and early in July, in response to a request from $\mathrm{Mr}$. Say, he was able to send him two bags of guinea corn (about 165 pounds).

1771 might be given two descriptive titles. In general, it could be called the "year of Thomas Thistlewood's social and economic establishment," and in very particular reference, it might be called the "year of the asparagus." By this time, Breadnut Island Pen was recognized in western Jamaica as a showpiece, owned and managed by a knowledgeable gardener. Thistlewood, owner of a mere 160 acres and fewer than thirty slaves, was now entertained by, and entertaining, the plantocratic elite and their womenfolk at his table. With clear satisfaction he recorded the dishes provided at these entertainments, perhaps to indicate that his provision was as rich as any other's; almost certainly with pride that his garden and grounds yielded in abundance. Roast goose and paw-paw sauce was a favourite, as well as roast pork and broccoli, roast mutton with broccoli, carrots and asparagus, stewed fish, crabs, and an abundance of fresh fruit, especially grapes, musk-melons and citrus. 
In April 1771, Captain Richardson came in. On board the Henry, along with the usual chests and boxes for Thistlewood, were two young men, William Thompson and Francis Scott. They were gardeners from Hexham in Northumberland, directed to Thistlewood by Henry Hewitt. They would soon go off to various employers, but Francis Scott remained in Westmoreland and became a frequent and welcome visitor to Breadnut Island Pen. Soon after the delivery of Thistlewood's cargo, there began the usual massive sowing and planting. The two young men gave a hand in the garden.

[Friday, 9 April 1771:] Mr. Scott grafted an orange upon

a pome-granate stock for me.

That was his first mention of grafting, and the attempt was apparently not successful. Five weeks later, "Mr. Scott whip grafted 3 orange grafts upon pome-granate stocks in my garden this evening."

Grafting seems not to have been an unknown practice in western Jamaica. In mid-January 1774, Thistlewood spent a day with William Henry Ricketts of Canaan Estate. Ricketts gave him several nuts and seeds, including canteloupe, melon seeds from Tours, France, and "shaddock seeds from Shaddocks upon pome-granate stocks," all of which Thistlewood planted. Ricketts had also lent him two books: Directions for bringing over seeds and plants from the East-Indies ... (London: L. Davis, 1770), and Some additional observations on the method of preserving seeds from foreign parts ... With an account of the garden at St. Vincent, under the care of Dr. George Young ${ }^{14}$ (London: W. Bowyer and J. Nichols, 1773), both written by John Ellis, F.R.S.

Whatever may have followed his attempts at grafting, Francis Scott's main contribution to Thistlewood's garden lay elsewhere.

[Friday, 19 April 1771:] In the morning Mr. Thompson and Mr. Scott planted me out a bed of asparagus, 5 rows in it. Look out to thin the other beds.

Some of the earlier transplants had begun to yield and he had "gathered a good mess" and sent gifts of asparagus and asparagus seeds to friends. Yields had so far been small, and he had not marketed any. In August and September he sold for the first time, with a modest return of about fifty bitts.

Mr. Scott (or Mr. Thompson) seems also to have given advice about gardening tools available in England. In May 1772, for the first time, Thistlewood "Cut, dunged and lighted up with my asparagus fork one of the small asparagus beds 
over the trench, by the sarsaparilla. Ground quite dry yet." In 1772 he sold 404 bitts worth of asparagus. He planted more and experimented:

[12 June 1773:] Planted some sweet orange seed in the garden, also a little asparagus seed, by way of trial, to see if it will grow without shading.

In late July 1771 , Thistlewood opened his "New" garden. He had been preparing the site for several months.

First began to plant in New Garden. Planted 6 rows of beans given me by Mr. Smith; 4 rows Hertfordshire white turnips; 4 rows early Dutch turnips; a bed of salmon radish, cardoon and spinach; a bed of Battersea cabbage, large English cabbage, sugar loaf [cabbage], green [and yellow] curled savoys. A bed of purple [and white] broccoli, turnip-cabbage, Reynolds turnip-rooted cabbage and best cauliflower.

And, in the next few days, more, including carrots, parsnips, and English peas from North America. But the most important was yet to come. On 9 August, Francis Scott arrived on a visit which would last five days.

[Monday, 9 August 1771:] Negroes begin to weed the Birch Tree Ground, but for the most part carrying lime, dung, \&c for asparagus beds in the new garden.

Under Scott's supervision there would be a large transplanting of rooted asparagus. It began on 13 August.

Mr. Scott finished 12 asparagus beds, 7 with lime and dung, and 5 with dung alone. [There had been insufficient lime.] The upper soil, to the yellow clay, is all neatly dug and took out, then the lime is laid at the bottom, some earth drawn upon it, then dug together. Upon this is laid a layer of dung, upon which is hawked the rest of the earth, then another layer of dung upon the earth, all well dug and mixed together, but not to disturb the lime. Those which had dung alone are only marked with a line, well dunged and dug in, then dug again at the top, and again well mixed and dug in among the earth. The beds are 40 feet long and 4 feet broad each having 4 rows of asparagus at 6 inches from the sides and 12 inches from each other.

On 14 August 1771, Francis Scott left, laden with gratitude and garden seeds.

Thistlewood apparently ordered more asparagus forks:

[19 May 1775:] Negroes dunging and forking up asparagus beds in New Garden. 
Francis Scott continued in his visits, assistance and advice. In May 1774, he recommended another gardening tool, "a garden spade of the best steel plate and of a moderate size, and about 4 shillings price."

Thistlewood was indefatigable in his gardening and proud of its results. Almost daily, he sent gifts of plants, seeds, fruit, flowers and vegetables. And those to whom he gave, slave and free, sent him presents in return.

He planted every slip and every seed, many of them "unknown," that came into his hands. He replanted, time and time again, trees, vegetables, and flowers. Though much of the replanting, especially of vegetables and flowers, was of annuals, there were many items with which, for various reasons, he had little success. English pears and peaches, for example, which might thrive in Matthew Wallen's garden up in the mountains, could hardly survive at a few feet about sea-level in the tropics. Surprisingly, a few actually showed false promise.

[8 June 1775;] Newington nectarine has above 30 blossoms on it, 8 the Catherine Peach is just going into blossom.

Other plants showed nothing at all.

[11 March 1774:] No sign of the artichokes, myrtles, or liquorice plants.

He would try again with them.

Thistlewood was not alone in western Jamaica in his botanical and horticultural interests and endeavours. There were many with whom he exchanged plants, literature, and the wisdom of experience.

[3 July 1767:] Sent to George Spence, Esq. near Lucea, about 30 sorts of garden seeds.

[6 May 1768:] Wrote to Dr. King ... and sent him some Euphorbia plants with the botanic characteristics of ditto.

[1 January 1773i] Mr. [John] Ricketts, Esq. of Ridgeland . . g gave me an advertisement of Trees, \&c sold by William Prince, near New York.

[19 August 1773;] Dr. Panton gave me some seeds (he says) of a curious plant from near the Mississippi.

In the next month he planted two mango seeds and twelve Bengal peach stones sent him by William Henry Ricketts of Canaan. This planting of mango seeds is of particular interest. The mango, and other exotics, are presently recorded as having been first brought to Jamaica in 1782 by Captain Marshall of Lord Rodney's fleet. More than a decade earlier, however, in October 1769, Thistlewood had heard that "Montague James, Esq. is introducing the mango 
into this island," and in January 1779, accompanied by Florentius Vassall's overseer, he

rode about a mile \& half to see the young mango tree. It is in a plantain walk considerably to the NE of Greenich works, in a fine rich soil, at about 20 feet distant from Cabaritta river. This young tree is now about $2 v_{2}$ feet high.

One of the medical botanists in Westmoreland was Dr. Robert Pinkney. In mid-October 1773, he sent Thistlewood a list of trees and other plants he wanted-presumably to be ordered through Henry Hewitt. He seems also to have lent a book:

[7 November 1773:] Returned [to Dr. Pinkney] Milne's translation of Linnaeus, and sent him some ripe seed of the adhatoda or prickly justicia, a pretty shrub bearing purple flowers which smell like violets. Also some ripe seed of a climbing plant growing in woodland belonging to LongPond estate, also in Ragged Savanna, near Little London.

In January 1774, he sent Mr. Ricketts "the description of the Sun Plant or Indian Lupine," and gifts of flowers, asparagus, and forbidden fruit. (His Indian lupines, just planted, flowered in March.) In return, Ricketts sent him "some Siberian barley and 2 Barbados cherries." As he always did, Thistlewood planted them, and by May, the barley was bearing.

[4 March, 1774:] [from Mr. Hayward, merchant and foundry owner] 2 junks of Sassafras, and a large paper of yappon, or South Sea tea, being the Cassine or Yerba de Camini. ${ }^{15}$

This was not the first time he had received such a gift. On a previous occasion, he had found some seeds among the leaves and planted them. He liked the tea, and had it in his garden.

About a week later, Captain Richardson of the Henry arrived. Among the books he brought were three which were perhaps of greater interest: The Art of Planting and Cultivating the Vine, by Louis de Saint Pierre (London: J. Wilkie, 1772); The Natural History of the Tea Tree, by John Coakley Lettsom, M.D., F.S.A., (London: E. \& C. Dilly, 1772); and A Treatise on the Venereal Disease, by N. D. Falck, Surgeon, (London: printed for the author, and sold by B. Law, 1772).

In early April 1774, Dr. Pinkney wrote asking for seeds "to send home." Thistlewood sent him sixteen parcels and listed the contents: the Helicteres; 
Screw Tree; Sweet Nut of Jamaica; Banisteria Laurifolia; Goerrfoea of Jacquin; Bastard Cabbage; Snow berry; Boarwood of Westmoreland; and a dozen others including two "unknown plants."

[13 October 1774:] About 9 AM. Mr. William Lock, and George Scott, Esq, the Receiver-General, came to my house and stayed till noon. Walked in the gardens. Mr. Scott offered me any service in his power [and] took memorandum to send to Peru for the Cherimoya, to the Mosquito Shore for the Vanilla, Sarsaparilla seed, and zebra-wood seed.

In January 1775, Thistlewood planted indigo in his new garden. For a time he experimented and, in the opinion of William Pommell, who had provided him with seeds from Georgia, produced small quantities of excellent indigo.

[18 January 1775:] [from Mr. Matthew Bowen] a great variety of flower seeds sent him from N. America by Mr. Gooden.

[7 May 1775:] Wrote to Richard Vassell, Esq. . . . . Sent to Mrs. Vassall some asparagus and flowers. Sent Mr. Vassall an account of plants growing in my garden, May 1st, 1775. With a list of desirable ones, chiefly from Mr. Ellis's Catalogue.

[14 August 1775:] [Mr. Parker, Mr. Cope's overseer] brought a leaf \& flower, seemingly a species of the Portlandia, but by his account grows upon a climbing withe that runs a great height; the antherae also different from those described by Brown or Jacquin.

At the end of August, there was another message from Alexander Parker, this time with "4 fine Egg Fruit, ${ }^{16}$ some cocos \&c, 5 young date plants \& 7 cuttings of the African rose. PM. Planted them in my garden." And, in December 1775:

Received from Dr. Panton, by the hand of Dr. Bell, 2 pieces of Vanilla, and some seeds, seemingly the musk-ochroe seed, though sent from St. Ann's for Vanilla seed.

The references have touched the parishes of Westmoreland, St. Elizabeth, Hanover, Kingston and St. Ann. The horticultural interest was widely spread through Jamaica, and it extended overseas. In that, the role of the sea-captains was obviously important.

Capital town of Westmoreland, and a busy seaport of a large sugar-producing area, Savanna la Mar provided home or hostelry for a large number of sea-captains. As carriers of goods and information, and as traders on their own account, they merit greater attention than they have hitherto received. 
[6 January 1775:] Capt. Charles Suttie says Mr. Edward Long has published a new History of Jamaica in 2 Vols. 4to Very dry. 3 Vols. 4to it seems. ${ }^{17}$

[23 May 1775:] In the evening sent down to Savanna la Mar, to Mr. Antrobus's Wharf, for Capt. Charles Suttie . . . a box of plants, vizt: The Clusea, or Balsam Tree; Hippomane, Manganeel [Manchineel] or Eve Apple Tree; Croton, wild rosemary; Caesalpinia Iprobably Barbados Pride]; Braziletto; Ironwood; Bignonia; Whitewood or Tulip Tree [Mountain Mahoe]; Dogwood; Paulinia, Supple Jack; Crabwood; Adhatoda or prickly justicia; Spathe or Maiden Plum Tree; a young rose-apple. Seeds of the justicia, and of the plant from the ruinate near Little London. Some punch strainers [luffa]; and a stem of Malpigia [cherry] with its ripe fruit on it.

With help from Lincoln and Chub, he had spent hours making up the collection. There is no mention of a consignee or of any payment. Perhaps Captain Suttie was to see what might be made of the plants.

[22 July 1775:] Sent Capt. Richardson ... a box in which is planted 2 wild Cinnamon; 2 rose apples; and some ripe sweet nuts . . . some ripe sweet nuts in a paper, also, made up "Western Universal Botanist", 3 Vols. 8vo [octavo], in a parcel, which he promises to deliver to Mr. Hewitt, to return to Mr. Nicoll.

Several of the sea-captains were also traders ashore. Late in February 1772, he paid Captain George Phillips, $£ 2$ 6s. 3d. for fifteen pounds of cheese (18s. 9d.), a keg of salmon (12s. 6d.) and a dozen cider (15s.). On 2 March 1774, "A Guinea-man came in this evening, said to be consigned to Captain Benjamin Wright." In mid-July 1774, he settled an account with Captain Benjamin Blake: $\mathfrak{1} 810$ s. total, for a barrel of Mess Beef ( $£ 5)$, a dozen steel hoes ( $£ 115 \mathrm{~s}$.) and a dozen best steel bills ( $\mathfrak{E 1} 15 \mathrm{~s}$.).

At the beginning of July 1774, twelve of his slaves had been sent to work on Retrieve Estate. This was the hardest form of labour they had to perform, back in the cane fields; and they had their preferences. Much earlier, on Sunday, 5 February 1769, "Many of my Negroes over from Blue Castle, praise it much, being easily worked." On the pen, the most strenuous work was probably the constant trenching and banking against heavy rainfall and invading livestock, and transporting sand and thatch into the gardens for preparing and shading seed beds. There was much bushing of logwood and billing of pastures. Lighter chores included livestock tending, hoeing and weeding in the gardens, and for some, fishing, shooting and higglering. 
Thistlewood's obvious curiosity and enthusiasm, and the fact that he actually worked in his gardens, perhaps modified the master/slave relationship. It is also possible that, in some measure, his slaves shared his gardening interest. At any rate, they learned a good deal about the cultivation of flowers, fruit, and vegetables.

[Saturday, 23 July 1774:] Gave my Negroes today.

Gave them plenty of cabbage, savoy, and broccoli plants to plant in their grounds,

which perhaps they would themselves consume; or perhaps they would take the produce to market. Nonetheless, when the water "came-down" in the rockholes and morasses, their diet was not entirely made up of herrings and shad.

[24 May 1774:] My Negroes get great quantities of snooks, tarpons, mudfish, \&c the morasses being full of new water. Plenty of crabs also run o' nights.

They sold these too, at home and abroad. Thistlewood had his own appointed fisherman for his table; but sometimes the fisherman failed (at his peril); and on occasion, there was special need. On 18 December 1772, "Paid my Negroes 7 bitts for fish and crabs I have bought of them since Mr. Smith [a visitor on business] has been with me."

Higglering for Thistlewood was normally the task of his house slavesJimmy (his waiting-boy), Bess (the laundress), and especially Damsel. Buyers sometimes came to his pen-house-slaves sent by their owners, and individual purchasers in their own right, slave and free. Usually, in addition to their purchases, they were sent away with gifts of flowers, pot-herbs and fruit, which, except for melons, Thistlewood seldom sold. In early April 1773, "Received for broccoli a bitt, savoys a bitt, and asparagus 2 bitts . . . also sent a little thyme and a few flowers."

Sales on his pen were secure: sales by higglering were not always so. For example, on Saturday, 8 June 1771, "Although I sent very fine radishes down [to Savanna la Mar] 14 for a bitt, yet Jimmy sold none." Fortunately, though his garden was his most cherished possession, it was not his most important source of income. Another, albeit seasonal, source of income was sales of wild fowl shot by Thistlewood himself, or by Lincoln, who was apparently at least an equal marksman. It was Thistlewood's opinion that Lincoln shot for himself too, and there can be little doubt that other slaves got the occasional duck. 
Though life and labour were far less onerous on the pen than on a sugar estate, and though Thistlewood's punishments of his slaves were mild compared with his excesses when overseer on Egypt, there was still much evidence of slave resistance. It is important to understand that slave resistance was directed against slave status, not against the whip. On his pen, Thistlewood experienced many forms of protest: running away, deliberately doing things the wrong way, maiming his livestock or letting them loose, blocking his gateway with stones, a suspected attempt to poison him, and others. There were also signs of recognized common interest: showing him a wild duck's nest, bringing him a strange plant or seed for his garden, protecting his and their provision grounds against strangers, and more.

In 1794, following the death of Hinton East, the Jamaica Assembly acquired Spring Garden, "with thirty-nine Negroes belonging to it, many of whom are valuable gardeners." ${ }^{18}$ Thomas Thistlewood died in 1786 . Following his death, Breadnut Island Pen was sold to his neighbour, George Robert Gooden. His thirty-three slaves, many of whom were experienced gardeners, were sold to others.

Their labours, so minutely recorded in Thistlewood's diaries, but until now untold, reveal that though Hinton East, Matthew Wallen, and Dr. Thomas Clarke, were undeniably important players in the development of botanical and horticultural interests in Jamaica, they were neither the only nor the earliest so involved. 


\section{APPENDIX 1}

"INDICATIONS OF REWARD"

An exact assessment of the profitability of Thistlewood's enterprises is impossible. To begin with, much of what he grew was not grown for monetary reward. His gardens were a source of enormous and unmeasurable pride and delight. He never sold a "poesy," but he prized his arrays of flowering plants and shrubs. He never sold a bunch of grapes. He gave gifts of flowers and fruit to all and sundry. He did not record every instance of money received, and many items were sold only on occasion, such as logwood, livestock, or grass, and from his gardens, a variety of vegetables, spices and fruit including broccoli, carrots, radishes, mint, parsley, papayas and granadillas. These, from the garden, are included below under "Sundries." He did not record the details of his account with Henry Hewitt, or monies spent on many occasional local purchases for his slaves or his gardens and grounds. We know that he spent annually, on taxes, amounts usually totalling under $£ 10$, on "year's cloth" for his slaves a bit less, and on sugar and rum about the same, totalling some $\mathfrak{£} 30$ or 960 bitts. Nonetheless, the following figures are not without interest.

In addition to earnings from sales of produce, Thistlewood received income from hiring slaves. (The amount for 1769 is, unfortunately, not available.) The figures given are gross earnings. For each "slave-day" he received 3 bitts ( 1 s. $10 V_{2} d$.). For a working week of five days he would get 15 bitts ( 9 s. $4 V_{2}$ d.). To each slave he gave a "subsistence" allowance of 2 bitts (1s. 3d.) per week, thus netting 13 bitts ( $8 \mathrm{~s}$. $1 V_{2}$ d.) per slave per week. In 1772, for example, when he grossed $£ 20710$ s., he would have netted just under $\mathfrak{1} 180$. As a rough indication, however, since so much else is unknown, the gross figures will do. As the overseer on Egypt he had earned "as good as an hundred pounds, sterling, per annum, all necessaries found me, and no expenses." $£ 100$ sterling was equal to $£ 140$ in local currency. 
Table 1: Earnings from Breadnut Island Pen, 1767-75

\begin{tabular}{|c|c|c|c|c|c|c|c|c|c|c|c|}
\hline ITEMS & 1767 & 1768 & 1769 & 1770 & $1771 \quad 1$ & 1772 & 1773 & 1774 & 1775 & $\begin{array}{l}\text { TOTAL } \\
\text { BITTS C }\end{array}$ & $\begin{array}{c}\mathfrak{E} \\
\text { CURRENCY }\end{array}$ \\
\hline ASPARAGUS & - & - & - & - & 53 & 404 & 405 & 501 & 425 & 1,788 & $£ 55: 17: 6$ \\
\hline $\begin{array}{l}\text { BEANS } \\
\text { wide variety }\end{array}$ & 10 & 107 & 29 & 64 & - & 54 & 135 & 190 & 113 & 702 & $£ 21: 18: 9$ \\
\hline $\begin{array}{l}\text { CABBAGES } \\
\text { wide variety }\end{array}$ & 25 & - & 10 & 1 & 64 & 59 & 50 & 37 & 21 & 267 & $£ 8: 6: 10 V_{2}$ \\
\hline $\begin{array}{l}\text { CASSAVA } \\
\text { root \& cakes }\end{array}$ & - & - & 21 & 35 & - & - & 1 & 38 & 92 & 187 & $£ 5: 16: 10 V_{2}$ \\
\hline CUCUMBER & - & 33 & 60 & 51 & 54 & 24 & 29 & 21 & 12 & 284 & $\mathfrak{E} 8: 17: 6$ \\
\hline $\begin{array}{l}\text { DOMESTIC } \\
\text { POULTRY \& } \\
\text { EGGS }\end{array}$ & 73 & 33 & 220 & 243 & 137 & 220 & 95 & 161 & 145 & 1,327 & $£ 41: 9: 4 V_{2}$ \\
\hline $\begin{array}{l}\text { FISH } \\
\text { fresh \& cured }\end{array}$ & 16 & 60 & - & - & - & - & - & 4 & 152 & 232 & $\mathfrak{E 7 : 5 : 0}$ \\
\hline HONEY & - & - & - & - & - & - & - & 34 & 146 & 180 & $\mathfrak{E} 5: 12: 6$ \\
\hline $\begin{array}{l}\text { MELONS } \\
\text { musk \& water }\end{array}$ & - & 9 & 67 & 39 & 103 & 29 & 54 & 2 & 7 & 310 & $\mathfrak{E 9 : 1 3 : 9}$ \\
\hline $\begin{array}{l}\text { OKRA \& } \\
\text { INDIAN KALE }\end{array}$ & 12 & 55 & 51 & 64 & 80 & 79 & 145 & 210 & 118 & 814 & 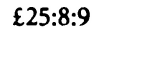 \\
\hline $\begin{array}{l}\text { PEAS } \\
\text { wude variety }\end{array}$ & 16 & 95 & 79 & 158 & 68 & 115 & 76 & 44 & 81 & 732 & $£ 22: 17: 6$ \\
\hline $\begin{array}{l}\text { PORK \& } \\
\text { GOAT FLESH }\end{array}$ & - & - & 34 & 66 & 49 & 336 & 166 & 273 & 210 & 1,134 & $\{35: 8: 9$ \\
\hline PUMPKINS & - & 12 & 30 & 11 & 2 & - & 1 & 2 & 1 & 59 & 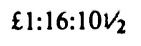 \\
\hline TURNIPS & - & 1 & 14 & 37 & 59 & 40 & 3 & 68 & 14 & 236 & $£ 7: 7: 6$ \\
\hline WILD FOWL & 59 & 121 & 100 & 267 & 258 & 126 & 90 & 336 & 158 & 1,515 & 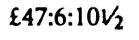 \\
\hline $\begin{array}{l}\text { PHIBBAH'S } \\
\text { SEWING }\end{array}$ & - & 128 & 39 & - & - & 14 & - & - & - & 181 & $\left\{5: 3: 1 V_{2}\right.$ \\
\hline $\begin{array}{l}\text { OTHER } \\
\text { SUNDRIES }\end{array}$ & 1 & 109 & 74 & 36 & 8 & 8 & 10 & 53 & 54 & 353 & $\left\{11: 0: 7 V_{2}\right.$ \\
\hline $\begin{array}{l}\text { TOTAL } \\
\text { (Bitts) }\end{array}$ & 212 & 763 & 828 & 1,072 & 935 & 1,508 & 1,260 & 1,974 & $1,749 \quad 1$ & 10,301 & $£ 321: 18: 1 V_{2}$ \\
\hline \multicolumn{12}{|c|}{ SUMMARY } \\
\hline $\begin{array}{l}\text { CURRENCY } \\
\text { f.s.d. }\end{array}$ & 1767 & 176 & & 1769 & 1770 & 1771 & & 772 & 1773 & 1774 & 1775 \\
\hline PRODUCE & $£ 6: 12: 6$ & 222816 & $6.101 / 2$ & :25:17:6 & $\{23: 10: 0$ & E29:4 & $: 41 / 2 \&$ & 47:2:6 & $£ 39: 7: 6$ & f61:13:9 & $\quad 65413: 16 / 2$ \\
\hline LABOUR & - & £109: & & $?$ & $\varepsilon 109: 7 \cdot 21 / 4$ & 14 f219: & & 160:7:6 & $£ 21622.2 V_{4}$ & $/ 4$ E196129\% & $y_{1} \quad \varepsilon 192: 3.51 / 4$ \\
\hline TOTALS & f6:12:6 & \{133: & $57 V_{2}$ & 1 & E1:0:172V/4 & 14 2014 & $A M 1 / 2 E$ & 200.100 & 62560:0/4 & 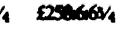 & /4 EX6) \\
\hline
\end{tabular}




\section{APPENDIX 2}

\section{THE GARDENS, EAST AND WEST}

The Hortus Eastensis compiled by Arthur Broughton, M.D., was published in Bryan Edwards' History of the West Indies, 5th ed., 5 vols. (London: G. \& W.B. Whittaker, 1819), 3: 367-407. It listed 521 "Exotic Plants" in Hinton East's garden at the time of his death, and showed for many of them the years in which they were supposedly first imported into Jamaica, and by whom. There were twenty-two persons named as importers, by far the most important being Hinton East himself, and Matthew Wallen, with Dr. Thomas Clarke a distant third. In many instances, however, Thomas Thistlewood recorded earlier plantings by himself and by others in western Jamaica.

In the Hortus Eastensis, the given dates of first importations range from a beginning in 1770 until 1790 . Of the 124 plants so dated, Thistlewood records an earlier planting of 78. Taking only some of the flowers planted on his pen in the three years 1767-1769 (and he had planted some before on Egypt) we can compare with the dates given in the Hortus Eastensis (in parentheses): Aster (1775), Stocks (1772), Lilac (1774), Crocus (1779), Narcissus (1773), Jonquil (1773), Larkspur (1774), Anemone (1773), Trumpet flower (1788), Painted Lady (1781), Amaranthus (1773), Labernum (1773), Lavender (1774), Cistus (1779), and Double-flowering Pomegranate (1774).

Not all survived, but some did, and he planted many more in attempts to see which varieties could thrive on his pen, a few feet above sea-level. Some flowered heavily, others such as the English Pinks and Sweet Williams (Thistlewood 1770, East 1772) seldom did. Thistlewood drew up two lists: one, in 1770, listed 136 plants "growing" in his garden; the other, in 1775, listed 332 plants in his gardens, provision grounds, pastures, ruinates and morasses.

Unlike the Hortus Eastensis which listed only exotics, "Thistlewood's catalogue of 1775 was really a botanical and horticultural survey of his pen. It named 200 plants growing in his gardens. Of the remaining 132, there were nine cultivated in his provision grounds: plantains, bananas, maize or "great" corn, guinea corn, scratch toyer, coco, cassava, peanuts and sugar cane. The rest included timber and fruit trees, vines and withes, wild flowers, wild spices and medicinal plants, logwood, fodder crops, and a host of other less useful but botanically interesting plants growing in his pastures, ruinates and morasses. 


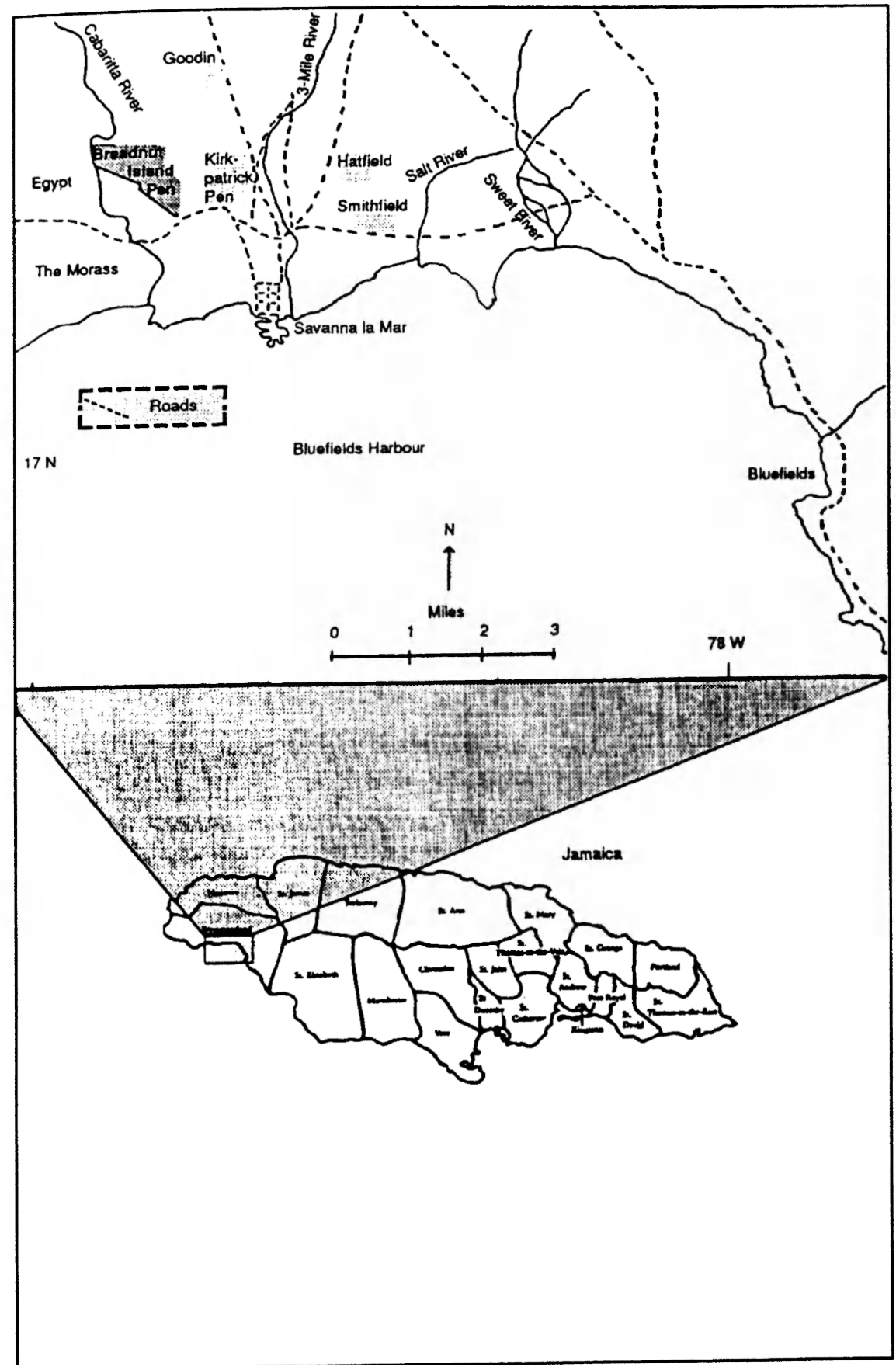

South-Central Westmoreland, around Savanna la Mar, in the late eighteenth century 
1. Bryan Edwards, History of the West Indies, 5th ed., 5 vols. (London: G. \& W.B. Whittaker, 1819) 1: xli, 1: 243, 3:367. See also, Douglas Hall, Planters, Farmers and Gardeners in Eighteenth Century Jamaica: The 1987 Elsa Goveia Memorial Lecture, (Mona: Department of History, University of the West Indies, 1990).

2. The Diaries of Thomas Thistlewood, 1767-1775, Monson Manuscript Deposit 31/1-37, Lincolnshire County Archives, Lincoln, England. Wherever I have quoted from the Diaries, I have indicated by date the location of the passage quoted. I am grateful to Lord Monson for his permission to use the Diaries in research and publication.

3. Verene Shepherd, "Pens and Penkeepers in a Plantation Society: Jamaica, 17401845" (PhD diss., Cambridge University, 1988), p. 11.

4. In Thistlewood's time, $£ 140$ Jamaica currency was the equivalent of $£ 100$ sterling.

5. It probably was. See Appendix B.

6. Dr. Robinson was then employed by the local Society of Arts to collect "curiosities" and remark generally on his findings: some of his drawings are now in the manuscript collection of the Jamaica National Library. One of his achievements was the preparation of a vegetable soap from the Coratoe or Maypole tree (see annotation to Thistlewood's catalogue of 1775). Much to Thistlewood's grief, Dr. Robinson died in early 1768.

7. "where sticks stuck up besides" probably refers to hard cuttings of plants, trees, or shrubs, which he would "stick" in the earth.

8. There is, in the contemporary literature, a possible source of confusion in the uses of the word "cocoa" in reference to both the cocoa (cacao) tree and its pod, or nut, and the cocoa (coco) nut tree. See F. G. Cassidy and R. B. LePage, eds., Dictionary of Jamaican English, 2nd ed. (London: Cambridge University Press, 1980), pp. 104, 111. But Thistlewood makes his reference quite clear: "[20 July, 1775:] Sent Mr. Cope 3 young cocoa nuts good only for their milk or water, whichever you call it."

9. Although he does not specify "compost" he refers to the removal of leaves and trash from his garden to go to the dung heap, and we know from his asparagus planting that he used lime.

10. If his calculations were even approximately correct, and assuming sunrise at 5:30 a.m., this would have meant one hole dug and planted, without a break, every 12 seconds, although they must have had some brief rest.

Though this schedule is possible in previously prepared land, it would have been demanding labour indeed. Four "bitts" were equal to thirty pence, Jamaica currency.

11. Wilson was now Thistlewood's neighbour on his southern boundary. Land originally owned by Samuel Say had passed, on his death, briefly to Mr. White, then to Wilson in 1775.

12. Another term for herrings. 
13. The Coobah here referred to was Phibbah's daughter (not by Thistlewood). House Franke was certainly a close friend and, though never so described, was probably Phibbah's sister. Both were house slaves at the Copes' residence.

14. Established in 1765 , this was the first botanical garden in the British West Indies.

15. The Cassine glauca is listed by C. D. Adams in Flowering Plants of Jamaica (Mona: University of the West Indies, 1972), as "an Asian plant at some time cultivated in Jamaica, has a lax inflorescence of hermaphrodite flowers and a 2-locular ovary" (p. 448). Thistlewood's "Yerba de Camini" is perplexing, as I can find no reference to "Camini." His script was not always clear, however, and "Camini" might in fact be "Camina," a place in northern Chile near the South Pacific; or "Camiri" a place in Bolivia near the border with northeast Paraguay. "Yerba-mate" (literally herbgourd/container) is Paraguayan tea, prepared from the leaves of the Ilex paraguariensis tree. In Flowering Plants of Jamaica (pp. 442-44), Adams lists several varieties of Ilex to be found in the island. I tend to favour Cassine glauca as the source of Thistlewood's tea. Otherwise, why would he not have simply written "yerba-mate?"

16. This is not the "Garden Egg" or "Egg Plant" (Solanum melongena), described in Cassidy and LePage, Jamaican English, p. 169. It is a "species of Pouteria, sometimes called Lucuma, and including the Canistal or Egg Fruit." See Adams, Flowering Plants of Jamaica, p. 575. It is not widely cultivated, but I know of a few trees in western Jamaica. Thistlewood certainly knew the difference: "[ 28 July 1772:] Sowed at the bottom of the parsley bed egg plant."

17. This entry indicates that Thistlewood received two volumes, quarto size, of Long's work, which either he or Captain Suttie thought "Very dry" reading. Thistlewood was indicating that the full set included a third volume, also quarto size, and indeed this was how the work had been published: Edward Long, The History of Jamaica, 3 vols. (London: T. Lowndes, 1774).

18. Journals of the Assembly of Jamaica, 9 (23 April 1796), p. 507. 


\section{7 \\ The West India Interest and the Crisis of American Independence}

ANDREW J. O'SHAUGHNESSY

The West India interest in Britain could have become a powerful natural ally of the North American lobby in opposing the policies that triggered the American Revolution. ${ }^{1}$ However, although some prominent West Indians spoke in favour of the North American cause, the two interests did not unite except briefly in reaction to the Stamp Act in 1765 and again, as war became imminent, in 1775. The West India agents, merchants, absentee planters and members of Parliament in Britain were divided in their response both to British colonial policies and to the rise of revolutionary resistance in North America. The activities of the West India interest actually helped isolate the North American lobby in Britain and created an impression among British policy makers of a divided colonial front.

The West India interest was well positioned to support the constitutional claims of the North American colonies against Britain. West Indians outnumbered North Americans in the House of Commons. Isaac Barré commented in 1765 that "there are gentleman in this House from the West Indies but there are very few who know the circumstances of North America. ${ }^{2}$ Only five North Americans sat in the Commons before 1775 compared to the seventy West Indians identified by Richard Sheridan. ${ }^{3}$ Absentee West Indian planters were integrated into British society through wealth, education, intermarriage, landownership and politics. They created a West Indian fraternity in Britain unparalleled among the North American colonies. ${ }^{4}$ 
The close ties between the island and mainland colonies, together with the similarities in their development, would lead one to expect an alliance between the West India and the North American interests. The political development of the island colonies was very similar to the mainland provinces. The rise of elected assemblies in the islands complemented the trend on the mainland. The island assemblies also attempted to increase their authority at the expense of the colonial executives and to "win the initiative" in the tradition of the British House of Commons. ${ }^{5}$ The islands nurtured a white political elite fully conversant in the discourse and rhetoric of the radical Whig opposition in both Britain and in North America. ${ }^{6}$ The island and mainland colonies were also closely related by informal social connections and most importantly by trade. ${ }^{7}$ The oceans acted often as highways, rather than barriers, in a period when most British North Americans lived along the coast of the mainland and their settlements extended no further than two hundred miles inland. Barbados and the Leeward Islands in particular depended upon provision imports from the continent. North America was a major source of shipping and a useful market for the produce of the islands. Jack Greene argues, for example, that the plantation systems of the British Caribbean and the southern mainland colonies had more in common than the latter with New England. ${ }^{8}$ Despite these similarities and connections, West Indian and North American interests did not unite to oppose British policies.

Some West Indians in Britain did indeed assume a prominent role in opposing the colonial policies that so alienated the mainland colonists. William Beckford and Rose Fuller, described by Richard Pares as "the two most important West India absentees in English politics," consistently opposed British policy towards America. ${ }^{9}$ Beckford, a mayor and alderman of London and an ally of Pitt the Elder in the House of Commons, played a leading role in opposing both the Stamp Act (1765-66) and the Townshend Duties (1767-70) upon principles common to the North American patriots. His premature death in 1770 "deprived the colonies of a warm and colourful friend" according to an agent for Massachusetts. ${ }^{10}$ Rose Fuller vigorously opposed the Stamp Act; he made a speech warning against the use of coercion in North America in 1769 and spoke in favour of the repeal of the tea duty in March 1770. Although nominally a supporter of the government after 1770 , he continued to dissent on questions relating to America. ${ }^{11}$ Jamaican Richard Pennant, in a speech in January 1769, criticized the taxing of North America. Antiguan Richard Oliver, 
an alderman and sheriff of London who replaced Beckford in representing the City, promised, in his electoral address of 1770 , to remove the "just" complaints of North America. ${ }^{12}$ He was associated with the London radical John Wilkes, a popular symbolic figure of liberty in America, and was imprisoned for his role with Wilkes in the famous printers' dispute between the City and the House of Commons. ${ }^{13}$ Oliver was adopted by the Society of West India Merchants in 1774 who promised to support his parliamentary candidacy for London and to recommend him to their "friends of the Livery. ${ }^{14}$ An anonymous correspondent of the Gentleman's Magazine cautioned the electorate of 1774 against unsuitable candidates including "West Indians, who publicly deny the legislative power of Great Britain over our American colonies, and for that reason chiefly want to be in the ensuing Parliament, that they may declare their opinion." ${ }^{15}$ Nine of the ten West Indian Members of Parliament (MPs), identified by Gerrit Judd, who sat continuously from the period of the Stamp Act (1765-66) until the end of the Revolutionary War (1783) opposed coercive policies against the North Americans. ${ }^{16}$

Although some prominent West Indians supported the North American cause, the West India interest tended to regard the North American lobby as a rival rather than an ally. The two interests had confronted one another in acrimonious debate over the passage of the Molasses Act in $1733 .{ }^{17}$ North Americans, especially in the mercantile New England colonies, actually blamed the West Indians for having connived with the British government in the first overt imperial tax in the colonies-the 1764 Revenue (Sugar) Act-which marked the culmination of a long antagonism between the two groups over the importation of French molasses into North America. ${ }^{18}$ The lobbies briefly buried their hatchet and united the following year.

The West India interest came closest to any kind of solidarity with North America during the Stamp Act crisis of 1765-66. ${ }^{19}$ Nevertheless, their response still differed significantly from the North Americans even at the height of their cooperation over the Stamp Act. The West India lobby characteristically avoided discussion of constitutional principles and based their stance on economic grounds. Stephen Fuller, the agent for Jamaica, willingly negotiated with the government to lessen the impact of the Stamp Act when the North American agents refused to make any agreement that would imply acknowledgement of , the right of Parliament to tax the colonies. ${ }^{20}$ At least ten members with considerable interests in the West Indies-about a third of the core group of West 
Indian MPs - actually voted against the repeal of the Stamp Act. ${ }^{21}$ Samuel Martin, Jr., supported the Stamp Act and voted against repeal, despite the chiding of his elderly father "the innovating sugar planter" of Antigua, owing to "apprehensions of the American tendency to independency."22

The 1765-66 Stamp Act alliance between the North Americans and the West Indians was short-lived thanks to the resurgence of their differences over the molasses and sugar trade with the French West Indies. The North American lobby proposed amendments to the 1764 Revenue (Sugar) Act in which they were opposed by the West Indian interest. In order to concentrate their full weight against the West India opposition, the North Americans briefly gave up their pursuit of other grievances against the imperial system including the amendment of the infamous currency laws. ${ }^{23}$ The two groups negotiated a temporary compromise, embodied in the 1766 Sugar Act, but the results satisfied neither side and the interests again split leaving a legacy of bitterness towards one another. ${ }^{24}$

Thereafter the West India interest failed to mobilize in response to British policies affecting North America until 1775 when war was already imminent. ${ }^{25}$ West Indians conspicuously failed to join the pamphlet campaign against Britain. Their silence was surely not the result of any intellectual incapacity since they produced a torrent of literature in the postwar abolition debate. ${ }^{26}$ Their response to the Townshend Duties (1767-70) was mute. William Beckford and Rose Fuller sought the total repeal of the duties in the House of Commons but we do not hear of a faction of West Indian members opposing the duties as they had done the Stamp Act. ${ }^{27}$ The correspondence of Stephen Fuller, the agent for Jamaica 1763-94, and other contemporary documents give no indication of the island agents actively lobbying for the repeal of the duties. The extant minutes of the Society of West India Merchants-beginning in 1769-make no reference to constitutional issues or to the question of imperial taxation.

The West India lobby further divided the colonial cause by campaigning successfully to exempt the islands from British policies towards America. Beeston Long, the chairman of the Society of West India Merchants, Rose Fuller, William Beckford and Richard Maitland, the agent for the island of Grenada, lobbied to shield the islands from the authority of the new Board of Commissioners of Customs in Boston (1767) and the four new Courts of Vice-Admiralty (1768)-which later played a crucial role in antagonizing colonial opinion, especially in Boston. ${ }^{28}$ Lord Hillsborough, the secretary of 
state for the American colonies, threatened to bring the affairs of both the assembly of Jamaica and the assembly of St. Kitts before Parliament in 1770 to "ascertain the Rights and Privileges of Provincial Assemblies in the future. ${ }^{\text {ng }}$ The West India lobby appear to have done nimble footwork to keep the assembly disputes out of Parliament and to soothe the tempers of concerned ministers. Some government ministers were partial to the special pleading of the West Indians and may have deliberately exploited the potential to divide the colonial lobbies. ${ }^{30}$

Imperial politics appeared so deceptively placid to the assembly of Barbados in 1772 that members debated reducing the agent's salary because "there is at this time so little for an agent to do," but their speaker, Sir John Gibbes Alleyne, warned that the possibility of another European war, "unusual and unconstitutional" imperial taxes, "new disturbances" in the mainland colonies or new British concessions to the North Americans (over the molasses trade) "to appease that powerful Body of Subjects by Indulgencies Granted them to the disadvantage of the Defenceless Inhabitants of these sugar islands" made an agent necessary:

to Distinguish when to join our Interest with our Northern Brethren in one common cause, or when to stand upon Seperate Ground for our advantages or to prevent an Injury ... at a time too when our Brethren of the Northern Continent have been zealous and happy enough to engage on their side not only a Franklyn but if the papers do not Misinform us a Burke and Barre in their service, men of the first Rate Political Abilities in the kingdom. ${ }^{31}$

The Society of West India Merchants actually lobbied the government in support of the drawback on tea in 1772 and "continuing the Exportation of Tea from Great Britain to Ireland, \& the Colonies as a national concern. ${ }^{\text {.32 }} \mathrm{An}$ anonymous correspondent in the Public Ledger (18 January 1773) criticized the West India interest for failing to be "alarmed sooner" by the situation of North America and for failing to take any action to prevent the "Destruction of the British Empire. ${ }^{33}$

The West India interest remained remarkably inactive and divided in response to the Coercive Acts of 1774-the series of laws, aimed at punishing Massachusetts for the Boston Tea Party of 1773, which triggered the American Revolution. The Society of West India Merchants met on 16 March 1774 to consider "the new regulations affecting Boston" but determined upon no other 
action than to instruct "Rose Fuller, Richard Pennant and Richard Oliver to inform the chairman [Beeston Long] of any further proceedings in Parliament which may in their opinion affect the interests of the sugar colonies, \& to use their best endeavours to get time allowed for the further consideration thereof. ${ }^{34}$ Rose Fuller, who had hitherto championed the North American cause in Parliament, was so outraged by the Boston Tea Party that he proposed

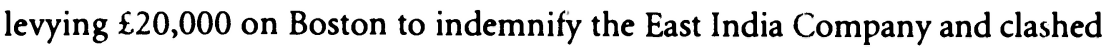
in a parliamentary debate with a fellow West Indian, Richard Oliver, who warned of the disastrous consequences of such a measure. ${ }^{35}$ Fuller nevertheless opposed the Coercive Acts and, on 19 April 1774, he moved for a repeal of the tea duty, but he was equivocating by the following year and eventually gave total allegiance to the government. ${ }^{36}$ William Bollan, the agent for Massachusetts' Council, had felt confident that the West Indian merchants would unite in support of the North Americans against the Coercive Acts but was disappointed by April that they were too divided to organize effectively. ${ }^{37}$ "Some West Indians" joined the North American representatives at the Thatched House Tavern in May to protest against the Boston Port Bill, closing the port of Boston to all commerce, but the interest was not united. ${ }^{38}$ Only twenty-four members of the Commons voted against the third reading of the Boston Port Bill on 6 May 1774. The correspondence of Stephen Fuller exemplifies the passive reaction of West Indians in London. Fuller wrote of the Massachusetts Regulating Act to the Jamaican Committee of Correspondence in June 1774 that "I consulted most of the Jamaica Gentleman upon the subject, and also the West India Merchants, who, are altho of various opinions in regard to several clauses of the Bill, did not chuse to step forth in opposition to it, as a matter not immediately affecting them. ${ }^{\text {"39 }}$ Fuller wrote the same day about the Quebec Act and the Revenue Act to Sir Charles Price, the owner of the Worthy Park plantation in Jamaica, that "The Quebec Act is just and fair and will not hurt us... As to the Revenue Act the Merchant and Planters tho' of various opinions all agreed not to act in it as not immediately affecting us." ${ }^{40}$ The passive behaviour of the West India interest in 1774 was typical of the London merchant community in general. ${ }^{41}$ Edmund Burke complained towards the end of the year that "the insensibility of the Merchants of London is of a degree and kind scarcely to be conceived. Even those who are the most likely to be overwhelmed by an American confusion are amongst the most supine. ${ }^{\text {n2 }}$ 
The West India interest sobered to grasp the urgency of the situation in North America. After December 1774, they belatedly attempted to intervene on behalf of the North Americans, for the first time since the Stamp Act (1765-66), to avert the impending crisis. Throughout January 1775 there were "various general meetings and committees of the West India Planters and Merchants. ${ }^{43}$ John Ellis of Jamaica became very active, according to Edmund Burke, in "bringing the West India merchants and planters to a right sense of their situation" and would have been even more effective but for "old withered Rose [Fuller]" who "within these few weeks, totally altered his hue." ${ }^{\text {"4t }}$ At the beginning of January, a group of absentee planters approached the Society of Merchants to suggest combined action in response to "the very alarming situation in which the West India Islands are now placed by the late American proceedings. ${ }^{.55}$ The merchants accepted the invitation and held a joint preliminary meeting with the planters on 5 January when they resolved to unite, along with the "merchants, traders \& $\mathrm{c}$ in the West India business residing at Bristol."46 At a well-publicized joint meeting on 18 January 1775, the merchants and planters decided on a petition to Parliament "as the only probable means of warding off impending ruin." ${ }^{47}$ Two members of the Society of Merchants, (John?) Willett and (Richard?) Atkinson, spoke against petitioning Parliament in what turned out to be an acrimonious meeting. Rose Fuller and Alderman Samuel Turner eventually carried a vote in favour of the petition but the wording of the final draft remained contentious. One speaker opposed the reference to Congress because it was not a body recognized by the British government and suggested that they should speak of "a meeting held at Philadelphia, called a Congress." Alderman Turner feared that this might appear "an oblique censure on the Americans" and advised them to avoid offending either the Americans or the British government. Rose Fuller suggested a compromise formula - "a meeting held at Philadelphia. ${ }^{\text {48 }}$ The final version of the petition simply spoke of "a Meeting held at the City of Philadelphia. ${ }^{49}$

At another meeting, on 25 January 1775, the merchants and planters delegated Richard Oliver to present their petition to the House of Commons and Rose Fuller to second the petition and that "all other members of parliament interested in, and immediately connected with the sugar colonies, be requested to support it. ${ }^{50}$ At the same time, they appointed Sir Philip Gibbes, a Barbadian planter, to chair a subcommittee to oversee the collection of signatures for the petition. Gibbes' committee posted the petition at the London 
Tavern, Bishopsgate, and then at the St. Alban's Tavern, Pall Mall, until the end of the month. ${ }^{51} \mathrm{~A}$ fourth meeting of the merchants and planters on the 7 February voted, on the recommendation of Barbadian George Walker and Philip Gibbes, to petition the Lords. ${ }^{52}$ The West India lobby also sent deputies to participate in the simultaneous meetings of the London North American merchants who also petitioned the House of Commons. The societies shared some members like Richard Neave, a member of the Society of West India Merchants and the London North American Merchants, and very likely acted in concert. ${ }^{53}$

The West India lobby now tried to mediate between the North Americans and the British government, in a belated attempt to avert war and to maintain the integrity of the British empire, by demonstrating the disastrous effects a war would have on the economy of the islands. Richard Oliver and Rose Fuller presented the petition of the merchants and planters to the House of Commons on 2 February.$^{54}$ The House of Commons referred the petition to a committee where the planters and merchants chose Richard Glover to present evidence in its support. Glover was a leading member of the merchant community and a former member of the Commons with no apparent ties to the West Indies. His experience of advocating merchant causes spanned some thirty years. He had represented the North Americans against the Mutiny Bill, only a decade earlier, and had represented the English linen merchants in March and April 1774. ${ }^{55}$ Glover was supported by the personal testimonies of George Walker, an absentee planter and agent for Barbados, and John Ellis, an absentee planter from Jamaica, who appeared before the committee. The West India merchants paid for two thousand copies of the original petition along with Glover's evidence to be published in a pamphlet, and distributed a copy to every member of Parliament. ${ }^{56}$ They voted one hundred guineas to buy a silver plate for Glover "in Testimony of their Respect \& Esteem," and also thanked their secretary, James Allen, for "diligent \& long attendance during the last session of Parliament on the Business of the West India Planters and Merchants. ${ }^{.57}$ But their activities were to no avail. The committee did not report and the petition was not debated. The petition met a same fate in the House of Lords. The West Indian attempt to mediate between Britain and North America was too little too late: war had broken out.

The intervention of 1775 was not the climax of a cumulative opposition movement, but rather a spontaneous reaction to the threat of losing provision 
imports to the West Indies from North America ${ }^{58}$ It was also in this context that the Jamaica Assembly sent a radical address to the King at the end of 1774 . The Jamaica Assembly and the West India lobby were motivated by economic self-interest more than scruples about constitutional propriety. The lobbying from January to March had coincided with a burst of activity among the London merchants. ${ }^{59}$ British ministers spoke openly in January of retaliation against the North American colonies with the possibility of military intervention and an embargo of North American trade. ${ }^{60}$ At the same time, news arrived from North America of the "Association" agreed by Congress, which imposed a ban on imports from Britain and her colonies (1 December 1774) and, of even greater concern, a ban on all exports (commencing 10 September 1775) to Britain and her colonies. The preamble of Glover's evidence actually stated that the "Association" occasioned the protests of the West India merchants and planters by creating such alarm for the very survival of the islands. ${ }^{61}$ Rose Fuller emphasized to the meeting of 18 January 1775 that they "grounded the necessity of a petition ... on the two resolves of Congress" and the actual petition began by explaining that "the planters and merchants are exceedingly alarmed at an agreement and association entered into by a Congress held at the City of Philadelphia in North America, on the 5th day of September $1774 .{ }^{162}$ The petitions and the evidence presented before the committee of the House of Commons avoided any discussion of the constitutional issues and instead concentrated upon the dire economic consequences that a war between Britain and North America would entail for the West Indies. They stressed, in an argument which would become very familiar, that the North American trade was vital to the very survival of the West Indies and that alternative sources of supply would be inadequate either for reasons of cost or insufficient quantities. It is significant that the agent for Barbados and absentee Barbadians featured more prominently in the lobbying activity of 1775 , rather than Jamaicans who traditionally gave the lead, because Barbados and the Leeward Islands depended more than Jamaica and the Windward Islands on imports from North America. George Walker warned that a war would lead to famine in Barbados and especially the Leeward Islands, and John Ellis connected the possibility of a famine with a slave revolt. ${ }^{63} \mathrm{Glover}$, in a summary of the evidence, predicted that a war would eventually lead to a famine in which as many as half the slaves of Barbados and the Leeward Islands would die. ${ }^{64}$ 
The interest rallied again in opposition to the proposed Prohibitory Bill of December 1775 in which the British government sought to prohibit all trade with the "rebel" colonies. The merchants and planters petitioned Parliament. ${ }^{65}$ George Walker and John Ellis again appeared and gave evidence in support of the petition. ${ }^{66}$ Nathaniel Bayly, an absentee Jamaican planter, distinguished himself during these debates on the Prohibitory Bill and subsequently became a prominent opposition speaker describing it as "madness" for the ministry to "put the nation to so immense an expense of blood and treasure" and, in an argument which foreshadowed a pamphlet of Samuel Estwick of Barbados, claimed that the ministry was going to war to enrich themselves. ${ }^{67}$ He repeatedly warned of the consequences for the West Indies: "In order to wreak the revenge of a vindictive ministry on the Americans," he told the Commons on 11 December, "you are now going to ruin all the plantations in the West-India islands, and to give their present produce up for plunder to your sailors, before the inhabitants can have any notice of your intentions. ${ }^{68}$ He returned to the charge in an ensuing debate of 21 December:

He was well informed, nay he was fully convinced, that the inhabitants of those islands must be starved; and though they should not, their crops must be left, as they had not nearly lumber enough to save the present; that being the case, the proprietors must be ruined, and the consequences would in the end reach the merchants, so as, he feared, to bring on a general bankruptcy among those in any manner concerned or interested in the West-India trade. ${ }^{69}$

The lobby still remained divided in 1775 in response to the growing crisis in North America. Aretas Akers, a merchant from St. Kitts, wrote from London in February 1775: "What astonishes me is to hear every day some West Indians supporting and approving the measures of Government, without considering the dependence that the sugar islands have on N. America. ${ }^{n 70}$ Many prominent West Indian Members of Parliament continued to support the government even after the outbreak of war with North America in April 1775. These included John St. Leger Douglas (St. Kitts), Sir William Gordon (Jamaica), Daniel Lascelles (Barbados), Edwin Lascelles (Barbados), Samuel Martin, Jr. (Antigua), Sir Ralph Payne (Antigua and St. Kitts) and Anthony Morris Storer (Jamaica). Stephen Fuller's nephew, John Fuller, his brother-in-law, William Dickinson, and (after 1775) his brother Rose Fuller, consistently supported the government. John St. Leger Douglas opposed Nathaniel Bayly, in his only 
speech in the House of Commons, saying that "though he had a considerable estate in the West Indies" he thought the Prohibitory Bill "a wise and salutary measure... It was better to suffer temporary inconveniences than sacrifice the British empire in America to the local interests of any of its constituent parts." ${ }^{.71}$ "Every West Indian, except Jack Douglas," wrote Anthony Morris Storer, "is in the utmost consternation." 72 Storer nevertheless remained a stalwart government supporter. Sir William Gordon spoke of "those canting hypocritical rebellious scoundrels of Bostonians" and, in his maiden speech of December 1777, advocated the continuance of force until "America had laid aside her claim to independence. ${ }^{73}$ Lord North, the leader of the government, thought Edwin Lascelles a "very useful friend to Government" and later praised his "considerable weight in the House of Commons and the country" along with his "constant and disinterested support to the Government. ${ }^{74}$ Lascelles' support for the war against the North Americans eventually cost him the allegiance of his Yorkshire constituents. Samuel Martin, Jr., hoped for "the subjugation of that insolent and cowardly people to their just obedience. ${ }^{.75}$ Sir Ralph Payne, who seconded the address to the crown when the ministry of Lord North assumed office, was closely associated with the government who rewarded him with a knighthood of Bath and the governorship of the Leeward Islands in $1771 .{ }^{76}$ Payne's inaugural speech to the legislatures of the Leeward Islands was rumoured by the Purdie and Dixon Virginia Gazette to have been written by none other than Lord North himself. ${ }^{77}$ Ministers of the government attended both his farewell dinner and his return dinner at the King's Arms in Cornhill. ${ }^{78}$ Fellow Antiguan Richard Oliver alone dissented from the toasts drunk to the "success of the Administration [the government]" at Payne's farewell. ${ }^{79}$ Payne re-entered Parliament in 1776 as the government candidate for Camelford and received the coveted sinecure of clerk of the Board of Green Cloth the following year. Horace Walpole wrote in 1779 that Payne was writing a defence of the government, with his Tory friend (and lexicographer) Samuel Johnson, which would be so verbose that it "must be printed in a pamphlet as large as an atlas." ${ }^{80}$

Sir Lewis Namier notes that on questions "of general constitutional significance, the West Indians divided according to their particular allegiances and connections, exactly as did other Members of Parliament. ${ }^{.81}$ Namier found, on the basis of his narrow definition of West Indian members, that "the majority of West Indians in Parliament opposed the Government on the American war: of those who sat in the Parliament of 1774-1780, eight voted regularly with the 
Opposition and only four with the Government, while the attitude of two others is doubtful ... Still, none of those who had been in Parliament before war broke out changed their political attitude when war came. ${ }^{82}$ Although Namier plays down the significance of "only four" supporters of the government these still represent a third of his sample. Furthermore, opposition to the government was not synonymous with sympathy for the American Revolution as the opposition parties, including even Lord Rockingham's supporters, consistently supported the notion of parliamentary sovereignty over the colonies. ${ }^{83}$ The proportion of West Indian members supporting the government is more impressive if we use the contemporary list of forty-nine West Indians, compiled by Stephen Fuller in June 1781, among whom half consistently opposed Lord North's government and the policy of war against North America but the other half began by supporting the government. ${ }^{84}$ Among the latter group, only four members eventually deserted the government for the opposition and another member remained neutral refusing to vote against the government. ${ }^{85}$

The West Indian opponents of the war became more vociferous as shortages on the islands became more acute, owing to the loss of the North American trade and the success of patriot privateers, and with no sight of the anticipated quick British victory. Samuel Estwick, the sub-agent for Barbados, published a pamphlet opposing the Revolutionary War in 1776. Estwick reiterated the now familiar theme of the economic consequences of the war upon the islands and the importance of the North American trade. He then went much further than any other West Indian author in supporting the principles of the American Revolution. He denied that Parliament had any right to tax the colonies and refuted Blackstone on parliamentary sovereignty which he believed to be circumscribed by the "fundamental rights" of the people. He went on to declare the war pointless accusing the ministry of conspiring to start the war to enrich themselves and the Scots! ${ }^{86}$ Estwick's pamphlet was a moderate success-it brought him to the attention of Lord Abingdon in whose interest he later entered the House of Commons in 1779..$^{87}$ An anonymous "West India Merchant", in a series of letters which appeared in the London Evening Post from January 1776 and in pamphlet form in 1778, similarly protested against the war although he did not enter the constitutional debate like Estwick. ${ }^{88}$ The author, a merchant trading with the Windward Islands, admitted that he failed to sign the petitions of 1775 pleading that he was deceived by the confident language of the government promising an early British victory. ${ }^{89}$ The thrust of the 
pamphlet emphasized the disastrous economic impact on the islands. He began by stressing the importance of the North American trade to the West Indies and concluded by showing the inadequacy of alternative sources of supplies. ${ }^{90} \mathrm{He}$ cautioned that the loss of the trade would lead to famine and even a slave rebellion and accused the ministry of ignoring the interests of the islands who stood to gain nothing from the war. ${ }^{91}$ His correspondence in the London Evening Post discontinued at the end of 1776 and resumed in 1778 upon a more forlorn tone. He ended by announcing that he had sold his business and gone to the Caribbean to salvage the remnants of his fortune.

The stance of the "West India Merchant" typified that of other West India opponents of the war who preferred to emphasize practical objections, especially the effect of the loss of the North American provision trade upon the islands, rather than constitutional arguments. ${ }^{92}$ In 1776, George Walker was alerting ministers to the danger of an impending famine in the islands if the war continued, but his efforts were undermined by the Governor of Barbados, Edward Hay (1773-79), who denied that the island was suffering from shortages and inflated prices. Both Lord North and Lord George Germain, the secretary of state for America, believed claims about scarcities exaggerated, while Governor Hay thought Walker embittered because of "the little attention that the House of Commons paid to his Long Dispositions before the House upon the effect which a rupture with North America would have." ${ }^{93}$ Walker met William Knox, an assistant to Germain, in September 1776, and left a petition pleading the plight of Barbados. ${ }^{94}$ Later the same month, he spoke with Germain and North. Walker was dismissed as agent the following January when Governor Hay refused to sign the bill renewing his appointment, and ironically the more radical Samuel Estwick replaced him as agent.

Even "moderate West Indians", Jamaican absentee Anthony Morris Storer confided in 1775, "foresee total ruin for themselves" and yet the interest did not unite in protesting the war's feared economic consequences on the islands. ${ }^{95}$ Stephen Fuller kept a remarkably low profile in the lobbying activities of 1775 and appears to have ducked the issue of scarcities caused by the loss of North American imports. The Society of West India Merchants engaged in some private negotiations with the government to supply the immediate needs of the islands but avoided public confrontation. As late as 1778, an anonymous pamphlet by "A West India Planter" contended that the war would not affect the economy of the islands nor lead to a famine. ${ }^{96}$ The writer disputed the 
importance of trade with North America arguing that the islands were now growing their own food crops and that they had lost the North American market long ago to foreign rivals. He admitted that the war would temporarily inconvenience planters but only the improvident ones would suffer. He even ridiculed the concerns for the security of the islands saying that any outcome of the American Revolution would not affect them. ${ }^{97}$ His view, although unlikely to be typical, shows that some planters at least remained optimistic about British success against North America and that some were almost immune from the worst effects of the war. Such an outlook would look unrealistic within the year when the French allied with the United States causing the war in the Caribbean to intensify. The American War eventually disrupted the economies of all the islands including Jamaica: Lowell Ragatz found high rates of inflation throughout the islands during the war and Richard Sheridan found pathetically high rates of mortality among the slave populations.$^{98}$ The failure of the West India interest to unite in protesting the economic impact of the war is explained by the unwillingness of some West Indians to embarrass the government, since it might appear to be a political attack upon the war in general.

The last serious prospects of a negotiated peace disappeared in 1778. The Society of West Indian Merchants dismissed the tempting offer of neutrality, extended by Congress to the islands in 1778 , on the grounds of impracticality. ${ }^{99}$ West Indians were more optimistic about the Carlisle Peace Commission in America in 1778 - the last attempt at a negotiated settlement between Britain and the United States until the British defeat at Yorktown. Anthony Morris Storer, an old school friend of Lord Carlisle, went as an assistant of the peace commission to North America in 1778-79. ${ }^{100}$ Sir Ralph Payne arranged for Governor George Johnstone, one of the peace commissioners sent to the United States, to obtain an introduction from William Manning, a London West India merchant of St Kitts, to Manning's brother-in-law, Henry Laurens, who was President of Congress. ${ }^{101}$ In deference to the delicacy of the negotiations, the West India interest made no attempt to include the islands in the terms of the treaty which promised both not to raise any imperial taxes within the colonies and to repeal the duty on tea. The final draft of the terms extended the benefit of these provisions to the islands but only thanks to the intervention of Governor Johnstone rather than their own agents or the Society of West Indian Merchants. ${ }^{102}$ 
The alliance of France and United States in 1778 intensified the war in the Caribbean. West Indian opponents of the government, now fearful of the loss of the islands to the French, became more militant in their criticism of the war. Samucl Estwick, the agent for Barbados after 1777, was outspoken in his opposition, and the interests of Barbados suffered accordingly. The formation of a separate organization of planters and merchants, which began to meet regularly after 1778 and started to keep its own minutes after 1780, may well have reflected dissatisfaction among absentee planters with the passivity of the existing Society of Merchants. In 1782, both the chairman of the new committee of planters and merchants, Nathaniel Bayly, and the deputy chairman, Richard Pennant, were absentee planters and opposition Members of Parliament who were outspoken critics of the war. ${ }^{103}$

Despite the realization of their worst fears with the French victorious in the Caribbean, the West India lobby remained divided over British conduct of the American War. Stephen Fuller actually admired Lord George Germain, the chief architect of the war, with whom he cooperated. The Society of West India Merchants provided shipping for British troops going to the Caribbean after 1779 enabling the government to free an estimated 15,000 tons of shipping for use in North America. ${ }^{104}$ The division of the West India interest was apparent when West Indian opponents of the war attempted to shame the government, in a Commons debate of February 1780, by calling attention to the defenceless state of Jamaica and producing a petition of the merchants and planters "interested in Jamaica" in support of their claims. Richard Pennant charged that the neglect of Jamaica was a sufficient grounds for the impeachment of Lord George Germain ("Lord North cried Impeach now"). The ploy of the opposition was foiled, in a triumph that any politician would relish, when Germain retorted that "the Petition did speak the Language of all the Planters; an Opposition had been made to it, which proved that all the Planters were not equally of Opinion with the Petitioners. ${ }^{n 105}$ Germain was referring to a counter-petition of sixtyone Jamaica planters and merchants placing "confidence in Lord George Germain's assurance of future protection. ${ }^{n 106}$ In the same debate, John Fuller exposed the opposition further, when he spoke in defense of Germain, asserting that "many other considerable Planters, as well as himself" refused to sign the original petition "satisfied that the Defense of Jamaica had not, and would not be neglected. ${ }^{n 107}$ Lord Rockingham's use of the original petition in the House of Lords similarly backfired when Lord Onslow replied that it was not "the 
unanimous Opinion of the Merchants concerned in the Object of it, he himself, in Concurrence with many very respectable Gentlemen, having signed a Protest, intimating the strongest Disapprobation of it." 108

Edmund Burke, looking back upon North American affairs in 1775, thought that the intervention of other groups in support of the North American lobby in 1773-75 might have averted the crisis and led to the adoption of more conciliatory policies. ${ }^{109}$ Despite the potential for a natural alliance, the West India interest showed no more sympathy for the North American cause than the rest of the London business community, and thereby contributed to the fatal isolation of the North American lobby in Britain. Apart from a brief alliance in opposition to the Stamp Act, the West India interest did not mobilise until 1775 when economic self-interest, rather than qualms about imperial constitutional issues, motivated their intervention to avert an imminent war. This belated entry into the imperial dialogue was too little too late while it did not represent an endorsement of republican principles. The interest remained divided in response to the Revolutionary War despite having nothing to gain and much to loose from the conflict. Their unwillingness to rally in support of the North American colonies is not simply explained by the historical rivalry between the two groups or by the desire of the West India interest to cultivate the British government. Their activities reflected the outlook of the white elites of the islands who wanted to maintain the integrity of the British empire and who exhibited little sympathy for the American Revolution. ${ }^{110}$ They sought the status quo of the pre-war era, an untenable position in 1774-76, and, once the independence of the United States became inevitable, they wanted to reopen the former trade with the mainland.

British statesmen thought in terms of an Atlantic empire in which the thirteen mainland provinces represented less than half the total number of colonies. The division of the West India lobby, the split among colonial interest groups, the behaviour of domestic commercial lobbies and the ambivalence of many North Americans is a vital context in which to understand the faith of the British government in the colonial policies of the revolutionary period. 


\section{NOTES}

1. The author wishes to thank Charles Cohen, Stanley Engerman, John Kaminski, Richard Leffler, John McCusker and members of the Early American History Group at the University of Wisconsin-Madison for their comments on an earlier draft of this paper. Paul Langford kindly lent copies of his notes on voting patterns of Members of Parliament. The University of Wisconsin-Oshkosh Faculty Development Fund provided a grant to do research in England in the summer of 1993 towards the completion of this project.

2. Quoted in Sir Lewis Namier and John Brooke, The History of Parliament. The House of Commons 1754-1790, 3 vols. (London: HMSO, 1964), 1:157; Michael Kammen, Empire and Interest. The American Colonies and the Politics of Mercantilism (Philadelphia: J.B. Lippincott Company, 1970), p. 133, notes that "advocates of the mainland colonies were less well-connected and organized, less well-financed and informed, less committed and, in several cases, less capable than their rivals, who knew what they sought, and how far they might go in achieving it. North America's political influence in no way equalled its economic importance;" Andrew J. O'Shaughnessy, "The Formation of a Commercial Lobby: the West India Interest, British Colonial Policy and the American Revolution" (forthcoming, Historical Journal, 1996) discusses the composition, organization and impact of the lobby during the revolutionary period.

3. Namier and Brooke, The House of Commons 1754-1790, 1:157; Richard B. Sheridan, Sugar and Slavery: An Economic History of the British West Indies, 1623-1775 (Aylesbury: Caribbean Universities Press, 1974), p. 60.

4. Derrick Knight, Gentlemen of Fortune: The Men who made their Fortunes in Britain's Slave Colonies (London: Frederick Muller Ltd, 1978); Richard B. Sheridan, "The British Sugar Planters and the Atlantic World, 1763-1775," Eighteenth Century Florida and the Caribbean, ed. Samuel Proctor (Gainesville: University of Florida Press, 1976), p. 4; Andrew J. O'Shaughnessy, "The Politics of the Leeward Islands, 1763-1783" (DPhil thesis, Oxford University, 1988), pp. 21-51; Michael Craton, "The Planters' World in the British West Indies," in Strangers within the Realm, ed. Bernard Bailyn and Philip D. Morgan (Williamsburg: Institute of Early American History and Culture, 1991), pp. 346-49.

5. Frederick G. Spurdle, Early West Indian Government (New Zealand: by the author, 1963).

6. Selwyn Carrington, "West India Opposition to British Policy: Barbadian Politics, 1774-82," The Journal of Caribbean History 17 (1982): 26-49; Andrew J. O'Shaughnessy, "The Stamp Act Crisis in the British Caribbean," William and Mary Quarterly, 3rd Series, 52 (1994): 206-07; Donna J. Spindel, "The Stamp Act Crisis in the British West Indies," Journal of American Studies, 2 (1977): 204-05.

7. Richard Pares, Yankees and Creoles: The Trade between North America and the West Indies before the American Revolution (London: Longmans, 1956). 
8. Jack Greene, Pursuits of Happiness: The Social Development of Early Modern British Colonies and the Formation of American Culture (Chapel Hill: University of North Carolina Press, 1988), p. 173.

9. Richard Pares, War and Trade in the West Indies, 1739-1763 (Oxford: Oxford University Press, 1936; new impression, London: Frank Cass \& Co., 1963), p. 219.

10. Michael Kammen, A Rope of Sand: The Colonial Agents, British Politics and the American Revolution (Ithaca: Cornell University Press, 1968), p. 245.

11. Namier and Brooke, The House of Commons, 2: 478-80.

12. [London] Public Advertiser, 12 July 1770.

13. Richard B. Sheridan, "Planters and Merchants: The Oliver Family of Antigua and London 1716-1784," Business History 13 (1971): 105.

14. Minutes of the Society of West India Merchants, 4 October 1774. Microfilm copies are held in the Royal Commonwealth Society in London and the originals are now in Trinidad.

15. Gentleman's Magazine, 44 (1774): 404-05, quoted in Sir Lewis Namier, England in the Age of the American Revolution, 2nd ed. (London: Macmillan, 1961), pp. 240-41.

16. Gerrit P. Judd, Members of Parliament, 1734-1832 (New Haven: Yale University Press, 1955). The nine were Charles Barrow, William Codrington, Henry Dawkins, Daniel Lascelles, Edward Lascelles, Edwin Lascelles, Edward Morant, Richard Pennant and Clement Tudway.

17. Richard B. Sheridan, "The Molasses Act and the Market Strategy of the British Sugar Planters," The Journal of Economic History 67 (1957):62-83.

18. John C. Miller, Origins of the American Revolution (London: Longmans, 1959), pp. 74, 180; Agnes Whitson, "The Outlook of the Continental American Colonies on the British West Indies," Political Science Quarterly 14 (1930):69, 70, 76; Namier, England in the Age of the American Revolution, p. 239; Frank W. Pitman, The Development of the West Indies (New Haven: Yale University Press, 1917), pp. vii-viii, 333-34, 353; Pares, War and Trade in the West Indies, p. 81; Eric Williams, Capitalism and Slavery, 5th ed.(London: André Deutsch, 1981), p. 117; Edmund S. Morgan and Helen M. Morgan, The Stamp Act Crisis, rev. ed. (New York: Vintage Books, 1963), p. 44; Kammen, Empire and Interest, pp. 124, 126; John L. Bullion, A Great and Necessary Measure: George Grenville and the Genesis of the Stamp Act, 1763-1765 (Columbia: University of Missouri Press, 1982), p.38.

19. O'Shaughnessy, "The Stamp Act Crisis in the British Caribbean," 203-25; Kammen, A Rope of Sand, p. 36.

20. O'Shaughnessy, "Stamp Act Crisis in the British Caribbean," 221.

21. The ten were Thomas Charles Bunbury, William Mathew Burt, James Edward Colleton, Thomas Earle Drax, Sir Alexander Grant, Sir James Lowther Fane, Samuel Martin, Jr., William Sharpe, Hans Sloane Stanley, and Sir Thomas Stapleton. Judd, Members of Parliament, 1734-1832, pp. 19-20, lists twenty-seven West Indian Members of Parliament at the time of the Stamp Act, of whom eight voted against repeal. The definition of a West India Member of Parliament poses prob- 
lems which are clarified in Barry Higman, "The West India Interest in Parliament, 1807-1833," Historical Studies 13 (1967): 1-19.

22. Samuel Martin, Sr., to Samuel Martin, Jr., 30 May 1766, Add. MSS 41347, fo. 226, British Library, London; Richard B. Sheridan, "Samuel Martin, Innovating Sugar Planter of Antigua 1750-1776," Agricultural History 34 (1960): 126-39.

23. Joseph A. Ernst, "The Currency Act Repeal Movement: A Study of Imperial Politics and Revolutionary Crisis," William and Mary Quarterly, 3rd Series, 30 (1968): 186-87, 188, 210.

24. Jack Sosin, Agents and Merchants: British Colonial Politics and the Origins of the American Revolution, 1765-1775 (Lincoln: University of Nebraska Press, 1965), pp. 81, 85, 98; Ernst, "The Currency Act Repeal Movement," 186.

25. Lillian M. Penson, The Colonial Agents of the British West Indies. 1924; reprint, London: Frank Cass, 1971), p. 203.

26. Roger Anstey, The Atlantic Slave Trade and British Abolition, 1760-1810 (London: Macmillan, 1975), p. 295, identifies forty-seven pamphlets published in defense of the slave trade.

27. Peter D. G. Thomas, The Townshend Duties Crisis (Oxford: Clarendon Press, 1987), pp. 119, 176.

28. Sosin, Agents and Merchants, p. 105, n. 29; Penson, Colonial Agents, p. 276.

29. Aretas Akers to Reverend James Ramsay, 29 October [1770?], Akers Papers, typescript in possession of Michael Wigan, Downham House, Downham, Billericay, Essex. The originals are possibly the missing Aretas Akers papers at the Institute of Jamaica. Lord Hillsborough to Governor William Trelawny of Jamaica, 12 June 1770, CO 137/65 fo. 151, Public Record Office (PRO), London; Same to Governor William Woodley of the Leeward Islands, 31 July 1770, CO 151/50, PRO.

30. O'Shaughnessy, "The Stamp Act Crisis in the British Caribbean," 224.

31. Minutes of the Assembly of Barbados, 3 June 1772, CO 31/36, PRO.

32. Minutes of the Society of West India Merchants, 3 March 1772.

33. Penson, The Colonial Agents, p. 204.

34. Minutes of the Society of West Indian Merchants, 16 March 1774.

35. "Debate of 23 March 1774," St. James Chronicle, 29 January 1774; Kammen, A Rope of Sand, p. 246.

36. Namier and Brooke, The House of Commons, 2: 480.

37. Bollan to John Erving, et al., 1 April 1774, Misc. Bound MSS, Massachusetts Historical Society, quoted in Kammen, A Rope of Sand, p. 294.

38. Arthur Lee to Samuel Adams, 16 May 1774, Adams MSS, New York Public Library; Kammen, A Rope of Sand, p. 291.

39. Fuller to the Committee of Correspondence, 25 June 1774, Fuller MSS, 265, fo. 267, Stephen Fuller Letter Books, Nicholas M. Williams Collection no. 6001, Boston College Library, Boston, Massachusetts.

40. Fuller to Price, 25 June 1774, ibid., fos. 266-67. 
41. Paul Langford, "The British Business Community and the Later Nonimportation Movements, 1768-1776," in Resistance, Politics, and the American Struggle for Independence, 1765-1775, ed. Walter H. Conser, Jr., et al. (Boulder, Colorado: Lynne Rienner Publishers, 1986), p. 281.

42. Kammen, A Rope of Sand, p. 294.

43. Minutes of the Society of Merchants, 7 February 1775. Douglas Hall, A Brief History of the West India Committee (Barbados and Edinburgh: Caribbean Universities Press, 1971), asserts that "these (minutes of meetings of merchants and planters in 1775] are important documents because they pin point the date on which the West India Committee, originating as a joint organisation of the merchant and planter bodies, can be said to have first been established" (p. 4).

44. The Gazetteer and New Daily Advertiser, 5 January 1775; Namier and Brooke, The House of Commons, 2: 81.

45. Minutes of the Society of West India Merchants, 3 January 1775; Hall, A Brief History of the West India Committee, p. 3. It is unclear whether these planters were derived from the old Planters' Club or whether they were simply an ad hoc society.

46. The Morning Chronicle and London Advertiser, 6 January 1775.

47. The London Chronicle, 17-19 January 1775.

48. Ibid.

49. Minutes of the Society of West India Merchants, 7 February 1775.

50. The Gazetteer and New Daily Advertiser, 16 February 1775.

51. Ibid.

52. The Morning Chronicle and London Advertiser, 8 February 1775; Sosin, Agents and Merchants, p.220, claims that the West Indians wanted Lord Dartmouth to present the petition to the House of Lords.

53. Langford, "The British Business Community and Later Nonimportation Movements, 1768 1776," in Resistance, Politics and the American Struggle for Independence, ed. Conser, p. 97; Sosin, Agents and Merchants, p. 220.

54. R. C. Simmons and P. D. G. Thomas, Proceedings and Debates of the British Parliaments Respecting North America, 1754-1783, 5 vols. (New York: Kraus International Publications, 1982-), 4: 342-43; William Cobbett, ed., Parliamentary History of England from the Earliest Period to 1803, 36 vols. (London, Hansard, 1806-22) 18: 219; Penson, The Colonial Agents, p. 205.

55. Kammen, A Rope of Sand, pp. 74-75; Namier and Brooke, The House of Commons, 2: 504-05.

56. The Evidence delivered on the Petition Presented by the West-India Planters and Merchants To The Hon. House of Commons, As it was introduc'd at the Bar, and summ'd up By Mr. Glover (London, no imprint, 1775); Minutes of the Society of West India Merchants, 4 April, 2 May 1775; The West India Merchant. Being a series of papers originally under that signature in the London Evening Post (London: J. Almon, 1778), p. 79.

57. Minutes of the Society of West India Merchants, 4 April 1775, 6 June 1775. 
58. Whitson, "The Outlook of the Continental American Colonies on the British West Indies," 86.

59. Kammen, $A$ Rope of Sand, p. 304; Langford, "The British Business Community and the Later Nonimportation Movements, 1768-1776," pp. 278-325.

(6). Ibid., p. 282.

61. The Evidence Delivered ... and summ'd up by Mr. Glover, p. 2.

62. The London Chronicle, 17-19 January 1775; The Gazetteer and New Daily Advertiser, 16 February 1775.

63. The Evidence Delivered . . and summ'd up by Mr. Glover, pp. 13, 15, 52.

64. Ibid., p. 71.

65. Simmons and Thomas, Proceedings and Debates, 6: 330.

66. Ibid., p. 343.

67. Namier and Brooke, The House of Commons, 2: 68; Simmons and Thomas, Proceedings and Debates, 6: 325.

68. Namier and Brooke, The House of Commons, 2: 68.

69. St. James Chronicle, 19-21 December 1775; Namier and Brooke, The House of Commons 1: 68.

70. Aretas Akers to Reverend James Ramsay, 20 February 1775, Akers Papers.

71. Simmons and Thomas, Proceedings and Debates, 6: 325; St. James Chronicle, 5-7 December 1775; Namier and Brooke, The House of Commons, 1: 158.

72. Namier and Brooke, The House of Commons, 2:332.

73. Ibid., p. 517

74. Ibid., 3: 23.

75. Ibid., p. 116.

76. Simmons and Thomas, Proceedings and Debates, 3: 169; Namier and Brooke, The House of Commons, 3: 254.

77. Virginia Gazette (Purdie and Dixon), 30 July 1772.

78. Payne's farewell dinner of 13 November 1771 and his return dinner of 23 October 1776. See Philip C. Yorke, ed., The Diary of John Baker. Barrister of the Middle Temple and Solicitor General of the Leeward Islands, (London: Hutchinson, 1931), pp. 225, 369.

79. Public Advertiser, 23 November 1771.

80. Namier and Brooke, The House of Commons, 3: 254.

81. Ibid., 1: 158.

82. Ibid., 1:158-59.

83. Paul Langford, "The Rockingham Whigs and America, 1767-1773," in Statesmen, Scholars and Merchants. Essays in Eighteenth Century History Presented to Dame Lucy Sutherland, ed. Anne Whiteman, John S. Bromley and Peter G. M. Dickson (Oxford: Oxford University Press, 1973); Paul Langford, "Old Whigs, Old Tories and the American Revolution," in The British Atlantic Empire before the American Revolution, ed. Peter Marshall and Glyndwr Williams (London: Frank Cass, 1980), pp. 106-30. 
84. "Colony Members of Parliament 1781 resident in Great Britain," Fuller MSS 265, fo. 305. Opponents of the government included Chaloner Archdeckne, William Baker, Sir Charles Bamfylde, Richard Beckford, Hon. William Bouverie, Sir Philip Clerke, Sir William Codrington, John Crewe, Sir Charles Davers, Henry Dawkins, George Dempster, Samuel Estwick, Richard Hill, Robert Ladbroke, Dudley Long, Sir James Lowther, Thomas Lucas, Hon. John Luttrell, Hon. Charles Marsham, Edward Morant, William Nedham, James Farrel Phipps, John Trevanion, Jacob Wilkinson.

85. Supporters of the government included John Bond, John Boyd, Mathew Brickdale, Lord Frederick Campbell, Sir James Cockburn, John Dawes, William Dickinson, John St Leger Douglas, Francis Eyre, John Fuller, Sir William Gordon, Joseph Gulston, Edwin Lascelles, David Robert Michel, Colonel George Onslow, Thomas Onslow, Sir Ralph Payne, Anthony Morris Storer, John Townson and the Hon. William Ward. Sir Patrick Blake, Thomas Charles Bunbury, John Nesbitt and Clement Tudway deserted the government for the opposition. William Woodley would not vote against the government but did not vote for them.

86. Samuel Estwick, A Letter to the Revd. Josiah Tucker, D.D. dean of Gloucester, in answer to his Humble address and earnest appeal. $\sigma$ c., with a postscript, in which the present war against America is shewn to be the effect, not the causes assigned by him and others, but of a fixed plan of administration, founded in system: the landed opposed to the commercial interest of the state, being as the means in order to the end (London: J. Almon, 1776), pp. 99, 101-05, 117, 119, 121, 124. The association of the Scots and ministerial corruption was fuelled by the premiership of Lord Bute (1762-63), a Stuart, whom many blamed for the excesses of George III. In A Letter to the Revd. Josiah Tucker ..., Estwick listed the senior officeholders in Jamaica to show that they were all Scots (p. 105).

87. Namier and Brooke, The House of Commons, 2:407.

88. The West India merchant.

89. Ibid., pp. 3-4.

90. Ibid., pp. 9, 121-24.

91. Ibid., pp. 86, 119, 146.

92. They would later employ the same tactics against the abolitionists arguing on the grounds of expedience rather than principle (cf., Anstey, The Atlantic Slave Trade, pp. 310-11).

93. Minutes of the Assembly of Barbados, 9 July 1776, C0 31/39; Edward Hay to Lord George Germain, 12 October 1776, C0 28/56 fo. 75, PRO.

94. Minutes of the Assembly of Barbados, 6 November 1776.

95. Namier and Brooke, The House of Commons, 2: 332.

96. "A West India Planter. "Remarks on the evidence delivered on the petition presented by the West India Planters and Merchants to the Honorable House of Commons, on the 16th March, 1775, as it was introduced at the bar and summed up by Mr. Glover, so far as the same respects Barbadoes and the Leeward Islands (London: H. S. Woodfall, for T. Cadell, 1777). 
97. Lowell I. Ragatz, A Guide For The Study Of British Caribbean History, 1763-1834 (Washington: US Government Printing Office, 1932), p. 267.

98. Lowell I. Ragatz, The Fall of the Planter Class in the British Caribbean, 1763-1833 (New York and London: American Historical Association, 1928; reprint ed. New York: Octogon Books, 1977),pp. 151, 187; Richard B. Sheridan, "The Crisis of Slave Subsistence in the British West Indies during and after the American Revolution," William and Mary Quarterly, 3rd Series, 33 (1976): 615-41; Selwyn Carrington, "The American Revolution and the British West Indies' Economy," Journal of Interdisciplinary History 17 (1987): 823-50; Carrington, The British West Indies During the American Revolution (Holland: Royal Institute of Linguistics and Anthropology/Foris Publications, 1988); Carrington, "The American Revolution and the Sugar Colonies, 1775-1783," in The Blackwell Encyclopedia of the American Revolution, eds. Jack P. Greene and Jack R. Pole (London: Basil Blackwell Ltd, 1991), pp. 508-18.

99. The Minutes of the Society of West India Merchants, 3 March 1778, imply that the idea was rejected without reference to the government, but the St. James Chronicle, 2-4 April 1778, reported that the merchants petitioned Lord North in favour of neutrality.

100. Dictionary of National Biography, eds. Sir Leslie Stephen and Sir Sidney Lee (London: Oxford University Press, 1937-38), 18: 1310; Namier and Brooke, House of Commons, 3:486.

101. Yorke ed., The Diary of John Baker, pp. 17, 447-48.

102. Fuller to the Committee of Correspondence, 3 March 1778, Fuller MSS 256, fos. 75-76.

103. Penson, "The London West India Interest in the Eighteenth Century," English Historical Review 30 (1921): 388-389, discusses the organizational changes.

104. David Syrett, "The West India Merchants and the Conveyance of the King's Troops to the Caribbean, 1779-1782," Journal of the Society for Army Research 14 (1967): 169, 170, 176; Syrett, Shipping and the American War 1775-1783 (London: University of London, Athlone Press, 1970), pp. 67, 69.

105. St. James Chronicle, 10-12 February 1780.

106. Petition to Chaloner Archdeckne, 7 February 1780, Fuller MSS 256, fo. 183.

107. St. James Chronicle, 10-12 February 1780.

108. Ibid.

109. Kammen, Empire and Interest, pp. 134-35.

110. Carl Lane, "The Roots of Jamaican Loyalism, 1760-1766" (Ph.D. dissertation, City University of New York, 1978); T. R. Clayton, "Sophistry, Security and Socio-Political Structures In The American Revolution: Or, Why Jamaica Did Not Rebel," Historical Journal 29 (1986): 319-44; O'Shaughnessy, "The Politics of the Leeward Islands, 1763-1783." I intend to explain the failure of the planters to support the North American cause in a forthcoming study, An Empire Divided: The American Revolution and the British Caribbean (working title). 


\title{
8 \\ The United States and the British West Indian Trade, 1783-1807.'
}

\author{
SELWYN H. H. CARRINGTON
}

The War of American Independence (1775-83) had brought significant hardships to British West Indian planters. The islands suffered in different ways and experienced varying levels of deprivation during the war. All emerged with weakened economies, however, and the planters must have had doubts as to their ability to continue sugar planting in a changed commercial environment.

The return of peace certainly did not satisfy the hopes and expectations which the planters had for the sugar industry. While they wished for better crops, they were not sanguine about the direction in which their businesses were heading. Many wanted the relations between the newly-independent United States and the West Indian colonies to be re-established on their pre-war commercial basis in order to promote and maintain the economic viability of the sugar islands, whose war-time experiences clearly demonstrated their dependence on United States trade. But planter preferences ran counter to the aims and goals of the British policymakers and pro-imperialist groups, such as the Canadian loyalists and the British shipping industry. Even the Committee of West India Merchants and Planters found a spokesman in Lord Sheffield who fervently supported the exclusion of North American ships, and some of their foodstuffs and lumber, from the West Indian trade. Hence, by Order-inCouncil of 2 July 1783, the United States was excluded from colonial markets on the principles of the Navigation Acts. Some articles such as salted beef, pork, fish and dairy products were prohibited, while the monopoly for supplying the 
islands went to the Irish and Canadians. After their war-time problems, the sugar islands encountered further insecurity, and the destabilization of the sugar industry continued.

The response to the post-war restrictions was critical. Most West Indian colonial governments supported the overall British policy, but were unhappy with its expected long-term impact on the islands. The only consolation discerned by David Parry, Governor of Barbados, was "that the advantages which may accrue to the Empire at large will highly compensate for the inconveniences His Majesty's West Indian islands must for a long time sustain." 2 All West Indian governors rejected the argument that Canada could supply the islands, and preferred to see the implementation of a strict, yet positive, trade arrangement between the United States and the West Indies. ${ }^{3}$ Some recommended the admission of United States vessels under one hundred tons for about three years, or until Canadian production could meet the demands of the islands. Planters were equally critical of British policy. Simon Taylor, who had looked forward to peace, now dreaded it and accused the British Government of entering "into a combination to Ruin" the islands "with their high duties and Prohibition of the American Trade. Indeed they seem to be tired of the islands and look on the inhabitants as their Gibionites," he wrote. ${ }^{4}$ Those who had expected relief from the large debts accumulated during the Revolutionary War, saw British policy as maintaining indebtedness by forcing them:

to pay a double price for their supplies which means their Debts to the Mother Country, which were considerable, before the capture of the island, instead of being diminished are greatly increased, to which is to be added a load of public debt for the payment of which such heavy taxes are about to be imposed on the People, as will almost be unsuperable in the present state of the reduced value of their produce, loaded with late additional duties imposed on it in the Mother Country, by which means the sugar yields but little to the Planter, and the high duty on Rum operates as a Prohibition to its Importation. While at the same time, from the present state of their commerce with America, they are in great measure deprived of the Benefits of the Market and likewise obliged to pay much higher than formerly for various Articles. indispensably necessary, which they chiefly depended on being supplied with, from that Quarter. ${ }^{5}$

British policy was formulated on the belief that the United States was unable or unwilling to take effective retaliatory action. Under-Secretary of State, John Knox, based his opinion on the fact that the United States was importing more 
and more manufactured goods from Britain in spite of the Proclamation of 2 July 1783 . He testified:

the orders from thence for our Manufactures are at this Time greater than at any period of the former Peace-And if they were inclined to enforce it ... they could not find the means. They were not able to do it in the height of the War - the United States have not ... but little Trade with any other Nation of Europe. ${ }^{6}$

Despite the optimism of British officials, the retaliatory measures adopted by many states in the new United States against British shipping and West Indian products had some effect. For example, Massachusetts, New Hampshire, and Rhode Island, prohibited British ships from loading any United States products, under penalty of seizure and condemnation. Maryland, North Carolina, and Pennsylvania, imposed an extra tax on British shipping, while the New England states placed an added charge on goods imported in British vessels. ${ }^{7}$ New Hampshire, Massachusetts, Rhode Island, Virginia, North and South Carolina, and Georgia, charged higher duties on British than on French West Indian sugar and rum, thus discouraging importation. ${ }^{8}$ These protective regulations, although without cohesion and probably not very strictly enforced, nevertheless adversely affected British shipping and the importation of West Indian staples into the United States. ${ }^{9}$

Imperial policy towards the United States trade created conditions which forced West Indians to adopt surreptitious practices for obtaining North American provisions and lumber. Some islands provided United States ships with British register, ${ }^{10}$ while most colonies allowed illegal entrances of United States ships, expediting their handling to avoid detection, while ships from Canada remained idle. ${ }^{11}$ British attempts to stop this trade by capturing the vessels involved resulted in the harassment of her naval officers by the colonists. $^{12}$

As efforts to trade with their United States counterparts in their own ports failed, British West Indian merchants resorted to free ports in the neighbouring French islands to buy North American supplies. ${ }^{13}$ This caused a massive depletion of the money supply from all the British islands, with an estimated

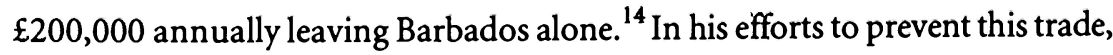
Parry issued a proclamation restating British policy, and encouraging British ships to go to the United States for supplies. 
Yet, on the whole, the operation of British policy did not achieve its goals. The prohibition on shipping did not lead to an increase of British seamen; rather, the number of slaves employed as sailors grew, especially on Bermudan vessels. ${ }^{15}$ Canada was unable to supply the necessary foodstuffs, or even lumber. For example, none of the vessels arriving in Dominica after the Order-in-Council of 2 July 1783 came from Canada. Governor John Orde told Lord Sydney: "as yet sorry am I to add, not a single vessel with any article of their produce had arrived." ${ }^{16}$ Instead, St. Eustatius, St. Pierre in Martinique, and several ports in St. Domingue, became entrepots for United States products destined for the British islands.

The restrictions on United States commerce gave rise to a circuitous trade that went through the foreign islands. Consequently, the largest quantities of most United States supplies of lumber and provisions prohibited by law reached the British West Indian sugar plantations this way. Canada could not supply the demands of the islands; more plantation supplies were reaching the British sugar colonies through the foreign West Indies than from Canada.

Moreover, the systematic smuggling which developed as a result of British policy meant that the British sugar colonies were relying on foreign islands for most of their supplies: Montserrat, St. Kitts, Nevis and St. Vincent, for example, imported most of their United States supplies from St. Eustatius. ${ }^{17}$ Table 1 gives the statistics illustrating trade between the United States, Canada, the foreign islands and the British West Indies, and shows that the quantities of most items imported from Canada were smaller than from the foreign islands, except for fish, and to a lesser extent, beef and pork. Although the quantities of some United States exports declined after 1785, combining the United States and the foreign figures, shows minimal, if any, decrease.

While goods from the United States were always in demand, the sugar planters suffered. The United States trade was simply "thrown into a new Channel, not destroyed by their separation from the Mother Country. ${ }^{18}$ The trade with the foreign islands was, however, subverting British monopoly of the commerce of the British West Indies, so in April 1787, Parliament passed an Act prohibiting the entry of flour, bread, wheat, rice and lumber from the foreign West Indies into the British colonies, except when governors, on advice from their Councils, were empowered to permit the importation of a list of enumerated goods for a limited time only, ${ }^{19}$ in cases of "real and very great necessity." 20 
Table: 1 Account of North American Provisions and Lumber imported into the British West Indies

\begin{tabular}{|c|c|c|c|c|c|c|c|c|c|c|c|c|c|c|}
\hline Year & Ships & Tonnage & $\begin{array}{l}\text { Flour } \\
\text { (Bbls.) }\end{array}$ & $\begin{array}{l}\text { Bread } \\
\text { (Bbls.) }\end{array}$ & $\begin{array}{c}\text { Rice } \\
\text { (Bbls.) }\end{array}$ & $\begin{array}{c}\text { Fish } \\
\text { (Hhds.) }\end{array}$ & $\begin{array}{l}\text { Beef \& } \\
\text { Pork } \\
\text { (Bbls.) }\end{array}$ & $\begin{array}{l}\text { Lumber } \\
(1,000 \mathrm{ft} .)\end{array}$ & $\begin{array}{l}\text { Staves } \\
\text { (No.) }\end{array}$ & $\begin{array}{c}\text { Disassembled } \\
\text { ("Shaken") } \\
\text { Hogshead }\end{array}$ & $\begin{array}{l}\text { Hoops } \\
\text { (No.) }\end{array}$ & $\begin{array}{c}\text { Corn } \\
\text { (Bushels) }\end{array}$ & $\begin{array}{l}\text { Horses } \\
\text { (No.) }\end{array}$ & $\begin{array}{l}\text { Oxen } \\
\text { (No.) }\end{array}$ \\
\hline \multicolumn{15}{|c|}{ THE UNITED STATES } \\
\hline 1785 & 635 & 49,021 & 82,887 & 14,834 & 6,415 & 449 & - & 12,497 & 27,201 & 3,572 & 258 & 132,451 & 1,667 & 176 \\
\hline 1786 & 502 & 38,421 & 100,033 & 21,106 & 7,239 & - & 18 & 6,851 & 17,368 & 1,284 & 206 & 192,163 & 573 & 76 \\
\hline \multicolumn{15}{|c|}{ BRITISH NORTH AMERICA (CANADA) } \\
\hline 1785 & 161 & 11,508 & 1,666 & 10 & 121 & 5,016 & 103 & 2,585 & 2,862 & 677 & 28 & 3,600 & 47 & 8 \\
\hline 1786 & 192 & 13,974 & 3,623 & 582 & 51 & 4,988 & 290 & 3,666 & 3,999 & 188 & 6 & 6,624 & 131 & 9 \\
\hline 1785 & - & - & - & - & - & - & - & - & - & - & - & - & - & - \\
\hline 1786 & 479 & - & 27,260 & 27,260 & 330 & 25 & 84 & 3,413 & 5,437 & 991 & 262 & 59,171 & 258 & 97 \\
\hline 1787 & 479 & 41,491 & 15,933 & 15,933 & 776 & - & 166 & 3,975 & 14,783 & 563 & 300 & 37,631 & 390 & 203 \\
\hline
\end{tabular}

Sources: A Comparative State of Trade between the West Indian Islands, the United States America from 1 October 1785 to 1 October 1787, showing No. of Vessels, Tonnages, and of America, the British Colonies in 1785-1786, Add. MSS. 38, 347, fos. 336-37, British their Cargoes, C.O. 318/1, fo. 135, Public Record Office, London.

Library, London; A Comparative State of Trade between the West Indies and North 
After the issuance of the Prohibitory Act in 1776, and the Order-in-Council of 1783 , the commanders-in-chief of every West Indian island were repeatedly requested to use the discretionary powers those measures allowed. In 1784, for example, when a severe gale did irreparable damage to property in St. Thomas in the East, residents there petitioned the Jamaican Assembly to request that the governor open the ports to United States provisions and lumber for six months. Initially, he refused, arguing that British shipowners should despatch their vessels to the United States for supplies. After being informed that there were no ships, and that he was bound to take the advice of the Council before refusing the petition, the governor conceded, and opened Jamaica's ports. His refusal may not have mattered, because some planters and merchants were in such a defiant mood over British policy that they were prepared to resort to unusual methods to secure supplies. Simon Taylor indicated:

if the importation is not allowed we must inevitably perish or bring in provisions without permission and indeed if some intercourse is not opened with America we must throw up the sugar estates into Provision Grounds and Penns or Migrate with our Negroes to the French Islands. Was Lyssons my sole property I would immediately throw it up for we are only labouring there to throw a Revenue into Britain without the least Benefit of ourselves. Indeed if the same rigorous Laws and high Dutys are continued I am determined to throw up my Properties. If I cannot sell them and move to some Government where the Laws will allow me to buy bread from Foreigners when I am starving. If we can get Provisions we may save the greatest part of our Negroes, if not they must be carried off with fluxes and Famine. ${ }^{21}$

British policy was not consistent with the continued development of a healthy sugar economy. The April 1787 Act (27 Geo. 111 C. 7) was passed to diminish the commercial importance of the foreign West Indies, and to reduce migration there from the Leeward and Windward Islands and Barbados. It also sought to restrain the commerce of the United States with the West Indies because, some British officials conjectured, commercial jealousy between the several states might limit united action against Britain. ${ }^{22}$ But the Act had hardly been proclaimed in the West Indies when its enforcement was suspended and the discretionary clause implemented. As Governor Shirley reported:

Soon after the receipt of the Act ... I found the immediate operation of it would have been attended with such ruinous and fatal consequences to the British islands that I ventured to permit the intercourse with the 
foreign islands to continue for a short time ... until the first day of October next, and I have also signified publicly that then the provisions of the Act will be strictly adhered to and carried into execution according to their full force. $^{23}$

Governors used their discretionary powers to open West Indian ports to United States trade throughout the period from 1782-1807. The general practice was for petitions to be made to the Assembly and/or Council to permit the importation of provisions and lumber from the foreign West Indian islands in British vessels. If governors rejected the Council Boards' advice, their members were usually supported by planters and merchants in the ensuing conflict. But a governor's refusal could at times signal division between groups on the island, being used, as the Council of St. Kitts noted, by "some designing Persons to serve their own particular Purposes regardless of the general good. ${ }^{24}$ The interpretation of the role of the Councils was also subjected to query on occasions when their recommendations were rejected. Since governors were obliged to take the advice of their Council Boards when considering requests for allowing United States trade, Council members believed that Parliament had placed its confidence in the Boards to judge such emergencies. Consequently, when their recommendations were disregarded, the members contended that this confidential trust had been violated. ${ }^{23}$

Claims of shortages and the clamour for opening the ports throughout the British West Indies were tied to interest groups. Early in the practice of suspending the Act and opening the ports, many merchants benefited from the trade, contrary to the interest of the planters, by re-exporting the goods to neighbouring islands, and reaping exorbitant profits. These merchants who had no commitment to the sugar industry, saw their businesses prosper from restrictions on the United States trade. In order to curb this practice, proclamations suspending the Act began to include a clause "obliging the importer to bond at entry" all goods and lumber, "and not to export without previous permission from the Governor. ${ }^{26}$ Different interest groups within the merchant class also adopted metropolitan alliances throughout the years, and became associated with efforts to control opening or closing of West Indian ports. In Barbados, for example, when Governor Seaforth closed the ports to United States trade on the petition of some merchants, public meetings were held at which Customs House Officers and other officials reportedly appeared in support of groups opposing his action. Several pro-United States sentiments 
were loudly voiced. One colonial official exclaimed: "Mother Country! America is the Natural Mother of these Colonies." Governors, on the other hand, by enforcing British policies, were usually linked with the imperialist faction. Governor Seaforth highlighted this conflicting situation:

in this manner I left the council not very easy in my mind for I knew that parties would not rest till they either drove me to some harsh measure or compelled me to give up the point. They imagined or effected to imagine that I was acting in contradiction to my orders from home and the Americans who were on the spot were not idle in assisting to increase the clamour against me by insinuating that if they were not allowed to sell their salt meat and fish they would sell nothing - they had even the impertinence to insinuate this to me. ${ }^{27}$

At times the governors must have felt that, irrespective of their decisions, they would face severe criticism. On occasion, some tried to steer a middle course by making exemptions in order to satisfy those groups not linked to the United States trade. This was particularly the case of Governor Nugent in Jamaica who, faced with general demands throughout the island for opening the ports to United States trade, acceded to the requests. He was equally conscious, however, of the need to pay "due attention to the interests of the British and Irish provision merchants and 'Graziers' as well as the fisheries by excluding the articles they supplied to Jamaica. ${ }^{n 28}$ The enforcement of the Act posed continued problems for all governors. British policy was from its inception seen as retrogressive commercial action. Governor Parry of Barbados was the first to point out this limitation:

The Dismemberment of the American Colonies from the British Empire, leaving them at perfect freedom to exercise their Talents and to improve the materials with which nature had supplied them for the purpose of Commerce, had in effect estranged the objects and circumscribed the Power of the Navigation Act. The Act being no longer capable of enforcing obedience to its restraints over so large a territory as it formerly controlled, the purpose for which it was passed are in a great measure defeated. ${ }^{29}$

The reinforcement of the Navigation Act by the April 1787 Act ( 28 Geo. $111 \mathrm{C}$. 7) caused ongoing tension and conflict in societies whose declining economic systems were linked to the exclusionist policy established by the 1783 Orderin-Council. The policy was occasionally evaded, and was unable to function smoothly, since it tried to suppress the interests of the very men who advised the governors. Thus, it created conflict between the merchant and the planter classes. 
By the 1790s, the operation of British policy became even more difficult to enforce. Governor Shirley of the Leeward Islands observed:

The Council Board appears to consider itself entitled to compliance whenever it represents the necessity of opening the ports, notwithstanding any other information which the Governor may have received. So that the Governor must either desert his duty to the Nation at large by constantly complying with the requisitions made by the Council to open the Ports or keep himself in disagreement with the Colony, by refusing to comply with requisitions when he had received information that there is not any necessity for opening the Ports... If the requisition for opening the Ports is always to be complied with when made by the Council the restrictions contained in the Act will be totally nugatory. ${ }^{30}$

Throughout the period of the French Wars (1789-1815), severe shortages, and depressed economic times resulted in repeated appeals from legislative bodies, merchants and planters for the reinstatement of all levels of United States trade with the West Indies, including the use of United States ships. Many members of the colonial interest groups viewed the continued policy of carrying on the trade in British ships as "fatal to the islands' " economic development. ${ }^{31}$

The justification for the continued practice of using the discretionary clause to open the ports to North American trade in United States ships was because of the trifling quantity of supplies, compounded by unreliable shipping, from Ireland, Britain, and Canada. ${ }^{32}$ The shortages which planters experienced during the American War of Independence were exacerbated by British exclusionist policy in the 1780s and by the French Wars during the 1790s and afterwards. Generally, the planters experienced grave hardships after 1776, and these continued beyond the first decade of the nineteenth century, with most of the British West Indies remaining almost totally dependent on regular supplies of foodstuffs and lumber from the United States. In addition there was a severe diminution of rum sales to the North American market.

Hence, in order to meet the quantities of provisions and lumber adequate to the local West Indian demand, proclamations were issued periodically permitting United States vessels to the trade, although these were directly contrary to the law. Consequently, Parliament passed Acts of Indemnity to protect the governors from being penalized for their actions. The permission for United States ships to enter West Indian ports by proclamations was for 
stipulated periods of time. In a few cases, such as Barbados, these were continued indefinitely, with succeeding commanders-in-chief simply reissuing the original document.

Consequently, the policy which was to be the exception became the rule. From 1794 on, Customs House Officers throughout the British West Indies annually admitted the entry of those articles which were listed in the original proclamation. Governors, however, were not allowed to include the importation of salted beef and pork, but since the quantity of these products imported from Britain, Ireland and Canada was very small, they were illegally brought with legitimate cargoes and landed either surreptitiously, or with the governors' permission, along with those articles allowed by proclamation. Not all colonial officials adhered assiduously to the tenets of British policy. Some governors refused to open the ports even when conditions of famine were apparent. Others simply turned a blind eye to the operation of the North American trade. Yet others adopted the recommendations of their Councils without question. This was especially the case when the governor was replaced by the President of the Council who acted as commander-in-chief. ${ }^{33}$

Opening the ports did not always achieve the intended results. In some instances as, for example, in 1794, there was only minimal response from United States traders because their government had imposed an embargo on trade with the West Indies because of the Royal Navy's impressment of United States seamen and its capture of United States ships. ${ }^{34}$ Furthermore, in some instances, the wrong goal was achieved, since opening the ports not only gave rise to a significant illegal trade, but also led to the exportation of sugar in United States vessels. The Colonial Office was incensed by this latter action, with West Indian officials offering as an excuse the refusal of the North Americans to take rum, or the lack of sufficient specie with which to pay them. The export of sugar in United States vessels defeated the British government's policy of forcing down sugar prices since imports to Britain would be reduced, thus maintaining or even forcing up prices on the London market. In spite of the British government's efforts, the United States became the chief neutral carrier of tropical products to Europe. This angered the Duke of Portland, Secretary of State for the Colonies, who wrote to Governor George Poyntz Ricketts of Barbados:

it is with concern ... that I feel myself under the necessity of representing to you how, materially, the interests of the island, and his Majesty's 
Property in general have been injured by the exercise of the liberty you have assumed, even exclusive of the National Evil arising from it -For it ought not to have escaped you that it is through this very channel and by these very means that Neutral Markets are supplied by American and other countries, and you should have recollected that exactly, in proportion as that supply is furnished them, the price of the Markets here must fall-it is impossible in this respect to separate the Public interest from that of the individuals - and I therefore cannot too strongly state to you my expectation that you will forthwith proceed to diminish the proportion of sugar now allowed to be exported, in return for American Produce, and that you would disallow it altogether as soon as possible. ${ }^{35}$

The practice of permitting North Americans to take sugar as barter for lumber and provisions became general throughout the British West Indies, and the objections of the Colonial Office did not seem to terminate it. Indeed, some commanders-in-chief objected to the Duke of Portland's criticism. Robert Thompson of the Leeward Islands was obviously upset and displeased with Portland's language, and his response got to the heart of the problem with British policy on trade between the United States and the West Indies. He replied:

If his Majesty"s Ministers would be pleased to take the Commercial Intercourse between the United States of America and the Islands into their consideration and to settle it upon some permanent basis, the Governors would then be exempted from all Solicitations for indulgences on the one hand, and from Censure on the other for that compliance with them. $^{36}$

In order to expedite their trade with the North Americans, Jamaica established a system of tariffs formalising exchanges to guide the Customs House officers. Whereas most of the islands were giving a part of their local produce to pay for North American supplies (for example, Barbados reduced its payment in local produce from $1 / 3$ to $1 / 4$ of the value of American goods ${ }^{37}$ ), the Jamaica Council Board recommended that the full value of the imports from the United States was to be paid in Jamaican products. Table 2 shows the rate of exchanges between American and Jamaican goods.

Numerous complaints from colonial officials and merchants involved in Irish, British and Canadian commerce with the islands, resulted in the termination of trade between the British West Indies and the United States. Lord Camden's directive of 5 September 1804 prohibited British West Indian governors from opening their ports to goods from the United states which were 
Table 2: Rates of Exchange at War Prices (1776-1782 for North American and Jamaican Products

\begin{tabular}{|c|c|c|c|c|c|c|c|c|}
\hline \multicolumn{4}{|c|}{ North Americian Produce } & \multicolumn{5}{|c|}{ Jamaican Produce } \\
\hline Item & Quantity & & rice & Item & Quantity & & Price & \\
\hline & & & s. d. & & & $\mathfrak{E}$ & s. & d. \\
\hline Staves & $(1,000 \mathrm{ft})$. & 40 & & & & & & \\
\hline Saltbeef & (bbl.) & 5 & & Sugar & (cwt.) & 3 & & \\
\hline Salt pork & (bbl.) & 7 & 10 & Coffee & (cwt.) & 5 & & \\
\hline Fish & (bbl.) & 3 & 10 & Rum & (gal.) & 4 & & 6 \\
\hline Salt Fish & (cwt.) & 25 & & Pimento & (lb.) & & & $7 V_{2}$ \\
\hline Superfine flour & (bbl.) & 7 & 10 & & & & & \\
\hline Inferior flour & (bbl.) & 6 & 10 & & & & & \\
\hline Cornmeal & (bbl.) & 3 & 10 & & & & & \\
\hline Corn & (bushel) & 13 & & & & & & \\
\hline
\end{tabular}

Source. Tariff at war prices of Americian produce imported into lamaica and of the produce of that island to be allowed to be taken away in return (no date). C.O. 137/106, Public Record Office, London.

not permitted by law, "except in cases of real and very great necessity." All commanders-in-chief also had to inform the Secretary of State when such cases arose, and provide justification. In essence, applications for relief now had to be made directly to the King through his ministers, and it was widely circulated "that the prohibitory order . . . would remain in force except his Majesty's pleasure should signify that it ought to be revoked. ${ }^{39}$

The reaction to British policy was swift and vociferous. The Assembly of Jamaica voiced serious opposition to Governor Nugent's order of 21 November 1804 terminating the trade between Jamaica and the United States as of 1 May 1805 , and the controversy spread throughout the sugar islands. ${ }^{40}$ West Indian interest groups in England also took up the matter. Lord Camden drafted an immediate response to West Indian governors:

I am now to acquaint you that the alarm which you state to have been excited in Jamaica has been extended to America, and to the Jamaica Merchants here; in consequence whereby a Meeting has been held at Mr. Pitt's upon the subject which was attended by the Duke of.Montrose, Mr. Rose and myself. ${ }^{41}$ 
Camden now assured the Jamaicans that the governors still had the power to open the ports to neutral shipping "in cases of urgent and real necessity," while in the United States, Congress threatened to retaliate to British exclusion by forcing all exports of provisions and lumber to be carried in United States vessels. $^{42}$

The British government was sensitive to the problems that its exclusionist policy caused in the United States, and sought to assure the North Americans that the policy was not discriminatory. The Colonial Office thus published a notice in the United States press that West Indian governors still retained the discretionary powers to relax, when necessary, "the rigid Provisions of the Navigation Laws," to allow the importation of provisions and lumber in North American or neutral bottoms, ${ }^{43}$ and Lord Musgrave, the Foreign Secretary, was directed to instruct the British representative in Washington that Lord Camden's letter was not intended to discriminate against the United States. On the contrary,

the British Administration had nothing in view but restoring the Trade with our Colonies as far as can conveniently be done, to the Provisions of the Laws which had been in force for a century and a half, a due attention to which had been interrupted only by the late [French Revolutionary] War, and that instead of having been made more strict they had of late years been very much relaxed. ${ }^{44}$

In its diplomatic communique, the imperial government recognised the dependence of the West Indian colonies on supplies of provisions and lumber from the United States. Consequently, the Board of Trade took up the question of North American trade with the West Indies, and ruled that it was necessary to continue the practice of allowing the importation of provisions and lumber into the islands in exchange for molasses and rum during the Napoleonic War, since there was not a sufficient number of British ships to go to the United States for supplies.

The Board recommended that the governors' discretionary powers be retained and that they be allowed to suspend the Navigation Laws for limited periods according to the necessity of each colony. West Indians who had long been frustrated by the attitudes of the British government, and who knew that United States lumber and provisions were needed for a profitable sugar industry, now pushed for a clearly defined policy. The Assembly of Jamaica stressed: 
the indispensable necessity which exists of the permanent establishment of an intercourse between the United States of America and the Island of Jamaica upon a liberal footing, and not to be rendered liable to the recurrence of an interruption, similar to that which has been recently experienced is established by referring to authentic documents. ${ }^{45}$

The dependency of the sugar colonies on the United States is nowhere more clearly highlighted than in the statistics giving the trade in provisions and lumber between each island and the United States between 1772 and 1806. The other revelation which the statistics show conclusively is that the imperial policy of restricting the transport of North American foodstuffs and lumber in British vessels did not work. It is also clear that overall, smaller quantities of all categories of goods were imported into the islands in the period after 1794 than in 1772.

The reduced supplies of North American provisions and lumber reaching the West Indies after the issuance of the Prohibitory Act in 1776, led to a marked increase in the prices of all articles. Hence, operating their estates became a severe burden to most planters after 1776. The price of lumber, for example, rose significantly during the War of American Independence and continued at a high level thereafter, and although the price declined in the 1780s and for some periods in the 1790s, it never again fell to pre-1775 levels.

The resumption of war with the outbreak of the French Revolution forced up prices of all supplies to new heights, especially since British policy prohibited the direct flow of goods between the United States and the West Indies. Herrings, the principal protein source for slaves, rose from $45 \mathrm{~s}$. per barrel in 1791 to 65 s. in 1793; shads were only a couple of shillings cheaper. Flour, which before 1775 was relatively cheap (thereby allowing managers to sell plantationgrown plantains at high prices and buy good quality flour for the slaves with the proceeds) rose by 220 percent, from $37 \mathrm{~s}$. $6 \mathrm{~d}$. to $\mathfrak{E} 6$ per barrel. The price of corn, the staple of the slaves' diet, increased dramatically on all the islands, rising from 7s. 6d.-8s. per bushel in 1790 to 10s.-14s. in 1792-93. ${ }^{46}$ The impressment of United States citizens by British captains deepened the crisis in Anglo-United States relations, and made life difficult for the West Indian planters, because the United States government retaliated by imposing an embargo on trade with the British West Indies. This further reduced supplies to the islands and corn prices soared to as much as $24 \mathrm{~s}$. $9 \mathrm{~d}$. per bushel early in $1797 .{ }^{47}$

In Barbados, prices of plantation supplies and lumber were 225 and 440 percent above pre-American Revolution prices, and while the Windward Is- 
lands were generally more self-sufficient in food supplies than the older sugar colonies, they too suffered from exceptionally high prices. In Dominica and St. Vincent, commodities such as salted pork and lumber cost 325-1220 percent more than they had before 1775, although in Grenada the level of increase was much lower. $^{48}$

All the sugar colonies needed vast quantities of North American lumber for making hogsheads and barrels to ship their sugar and rum. On the older islands, most of the woodlands had been cut down, but more importantly, tropical rain forests did not contain large quantities of lumber well-suited to shipping edible commodities. Hence the reliance on North America for supplying staves and hoops and even the lumber, shingles and frames for building houses. Lumber prices soared. Indeed, some colonies had no price quotations for lumber, because none was available. In other cases, lumber prices were from 600 to 1,200 percent higher than the 1775 figures. ${ }^{49}$

Such massive price increases, of course, significantly increased the costs of running a sugar estate and diminished its profitability. Moreover, there was no reciprocal trend in the price of rum. While sugar was central to the West Indian economy, the islands' profitability also depended on the production and sale of other crops, and of rum, whose value to eighteenth-century West Indian commerce cannot be overstated. The sugar planters used rum to procure supplies for their estates, bartering it with the North Americans for lumber and provisions, or selling it locally to meet the contingencies of the estates. Rum normally paid for all the local expenses of West Indian plantations, including the purchase of slaves, and the main consumers of West Indian rum were the North American colonies. But beginning with the American Revolution, and for the most part because of British policy, rum sales to this market were restricted. The British government's failure to allow the West Indies to establish reciprocal commerce with the United States weakened the islands' bargaining position in the rum trade, and the problems continued through the 1780s, worsening in the 1790s with the outbreak of the French Wars. Canada and Ireland, which were expected to replace the United States market, did not contribute in any meaningful way to relieving the islands' inability to dispose of their rum, although the destruction of the sugar industry in St. Domingue provided temporary relief.

The Haitian revolution rejuvenated the British markets on which the West Indians depended. The planters hoped the high prices that resulted from the 
revolution would persist, allowing them to meet their high food and lumber bills and repay their longstanding debts. Between 1795 and 1796, the average prices for rum in Jamaica increased from $5 \mathrm{~s}$. $6 \mathrm{~d}$. to $8 \mathrm{~s}$. $8 \mathrm{~d}$. Similar trends existed in St. Vincent, where the price of rum skyrocketed from 3s. $5 \mathrm{~d}$. per gallon in 1794 to 8 s. 3d. in 1796, although it fell to $7 \mathrm{~s}$. 7d. per gallon in 1797. The market was limited, however, and West Indian planters found themselves unable to dispose of their rum readily, and prices began to fall again. In Dominica, rum sold for 4s. 3d. to 4s. 6d.per gallon between 1804 and 1807, while the lowest prices were for Grenadian rum-2s. $9 \mathrm{~d}$. to $3 \mathrm{~s}$. $7 \mathrm{~d}$. per gallon in the years 1805-07. Jamaican rum did only marginally better, selling at $3 \mathrm{~s}$. $2 \mathrm{~d}$. to $3 \mathrm{~s} .8 \mathrm{~d}$. between 1805 and $1807 .{ }^{50}$

In the British West Indies, rum could not command satisfactory markets and sales. Moreover, changes in production were occurring throughout the world: the United States, for example, was now distilling its own products. Nor did Canada and Ireland, which were given the West Indian market for their lumber, fish, dairy products, beef and pork, reciprocate by purchasing West Indian rum, which now became a drug on local markets. By the abolition of the slave trade in 1807, conditions on the islands were precarious, and rum's traditional role in the economy of the British West Indies could no longer be maintained. In spite of warnings to the contrary, estate managers were forced to defy their absentee landlords and draw bills on them to make up the deficiency in rum sales and thus meet the contingency costs. This was a significant departure from the system that financed the operation of West Indian estates during the eighteenth century.

The dependence of the West Indian islands on external supplies was clearly evident in the years between 1783 and 1807, as the planters struggled to maintain the plantation system with only limited access to United States markets. Hence, the Council Boards seized every opportunity to open West Indies ports to North American trade. While not always in conformity with the Act of April 1787, and often at variance with the policies and expectations of the Colonial Office and even some local officials, the Boards' actions were imperative to the survival of the West Indian plantations. Consequently, attempts in 1804 to terminate the discretionary powers of the governors met with opposition from the legislatures of all the islands, and the British government was forced to continue the opening of West Indian ports, even though this was more closely monitored. 
It was clear that the profitability of the sugar economy and its continued economic benefits to Britain could not be maintained without unlimited trade with the United States. The results of the restrictions on British West IndianUnited States commerce were frequent and sometimes led to terrible sufferings in the sugar colonies. The conditions which had existed on the islands during the American War of Independence changed very little between 1783 and 1807 . The planters were forced to continue to grow provisions, and the colonies were repeatedly faced with periods of severe scarcity. The aspirations of the British merchants to establish their shipping as the major carrier did not succeed: their supplies to the West Indies were infrequent and unreliable. The North Americans continued to trade with the West Indies as British shipping made no major gains between 1783 and 1807. On the whole, the West Indian economy could not adjust to the new Atlantic commercial system and hence declined markedly, while the discriminatory duties imposed on West Indian products by some states in the United States reduced their consumption. ${ }^{51}$

The advantages to be derived by Britain from a healthy West Indian economy were potentially great, but were lost because of the restrictions contained in the order-in-council of July 1783 and the regulations embodied in the Act of 1787. The aim of the British government to bring the Canadian and Caribbean colonies closer together during this period failed, as the British sugar colonies remained dependent on the United States for their economic survival. ${ }^{32}$

NOTES

1. The research for the paper was funded in part from grants received in 1989 and 1993 from Dame Professor Lillian Penson Memorial Fund and from several grants made by the Research and Publication Fund of the St. Augustine Campus, University of the West Indies. Some of the information used in this chapter is incorporated in Selwyn H. H. Carrington, "The American Revolution, British Policy and the West Indian Economy, 1775-1808," Revista Interamericana 22 (1992): 72-108.

2. David Parry to Lord Sydney, 23 June 1784 and 7 September 1785, C.O. 28/60, fos. 104d and 158-160, Public Record Office (PRO), London.

3. Thomas Shirley to Lord Sydney, January 1785, C.O. 152/64, No. 95, PRO.

4. Simon Taylor to Sir John Taylor, 2 November 1783, Simon Taylor Letter Books, Vol. 1A, Institute of Commonwealth Studies (ICS), University of London. Tavlor 
appears to be referring to Gibeonites, the citizens of Gibeon in ancient Palestine, who were condemned to being hewers af wood and fetchers of water.

5. Alexander Winnett to Governor Mathews, 4 May 1874, C.O. 101/25, PRO.

6. "Minutes of the Privy Council for Trade," 18 March 1784, B. T. 5/1, fol. 43, PRO.

7. See Samuel Flagg Bemis, Jay's Treaty: A Study in Commerce and Diplomacy (New Haven and London: Yale University Press, 1962), pp. 32-33; and "Report of the Committee of the Privy Council for Trade and Foreign Plantations," 28 January 1791, PC 1/19/A24, pp. 14-15, PRO.

8. See The Committee of Merchants in the Trade between the Dominions of Great Britain and the United States (hereafter referred to as the Committee of Merchants), "Memorial to the Rt. Hon. William Pitt and the Rt. Hon. the Marquis of Camathan," 21 January 1786. B. T. 6/20, fos. 412-416, PRO; and The Committee of Merchants Trading to North America, "Memorial to the Committee at the Privy Council for Trade, 30 March 1787. B. T. 6/20, fos. 18-20d, PRO.

9. See"Answers to Questions to the Merchants of London, Bristol, Liverpool and Glasgow relative to the American Import and Tonnage Bill," 1789, B. T. 6/20, fos.373, 381, 383, PRO; and "Case of Messirs Spiers, Bownan and Company, Merchants in Glasgow, 1756. B. T. 6/51, fos. 6/81, fos. 248-249, PRO; Vernon G. Sester, "The Commercial Recipracity Policy of the United States 1774-1829 (Philadelphia: University of Pennsylvania Press, 1937), pp. 62-65; and Memo respecting American Duties, no date, B. T. 6/20, fol. 373, PRO.

10. Colonial Secretary to David Parry, 8 July 1785, C.O. 28/60, PRO; and Lord Sydney to Shirley, 2 June 1785, C O. 152/64, PRO.

11. Lord Sydney to David Parry, 5 August 1785, C.O. 52/64, PRO.

12. See Parry to Lord Sydney, 5 April 1786, C.O. 28/60, PRO; and David Parry to Lord Sydney, 14th October 1784, C O. 28/60, fol.172, PRO.

13. Parry to Lord Sydney, 15 November 1786, C.O. 28/61, fol.4, PRO.

14. Parry to Lord Sydney, 21 October 1787, C.O. 28/61, PRO.

15. Gov. Orde to Lord Sydney, 11 January 1785, C.O. 71/9, fol. 57, PRO.

16. See "An Account of Ships and their cargoes entered inwards in the British Islands, from the United States, British North America and the Foreign West Indies, " (no date), C.O. 318/1, fos. 142-148, PRO; and for Dominica see C.O. 318/1, fol. 264, PRO, and John Phillip Wise, "British Commercial Policy, 1794: The Aftermath of American Independence" ( $\mathrm{PhD}$ dissertation, University of London, 1972), pp. 74-75, 79.

17. Edward Lincoln to Lord Sydney, 1 December 1785, B. T. 6/85, fos. 185-186, PRO.

18. See Geo. 111. C. 7; and Lord Sydney to David Parry, 6 January 1787, C.O. 28/61, fos. 1-1d, PRO.

19. Shirley to Lord Sydney, 7 June 1787, C.O. 152/65, No. 169, PRO.

20. Simon Taylor to Jack (Sir John Taylor), 4 August 17, Simon Taylor Letter Books, Vol. $1 \mathrm{~A}$.

21. Shirley to Lord Sydney, 7 June 1787, C.O. 152/65, No. 169, PRO. 
1804 , fos. $22-23$, C.O, 28/71, fo. 205, PRO; C.O. $28 / 73,7$ May 1805 , fos. $4,15,34$, $80,81,96,197,198$, PRO; C.O. 28/74, February \& August 1806, fos. 42, 43, 81, 110 , PRO; C.O. 28/75, fos. $18,31,49$, PRO.

48. For Dominica, see Prices Current in Dominica, December 1786 - December 1808, C.O. $71 / 12,13,14,38,39,40,42,43$, PRO. For St. Vincent, see Extract of a Letter from a Planter in St. Vincent (no date), B. T. 6/77, PRO; The Prices of Lumber, Horned Cattle, Livestock and Indian Corn compared with the Average Prices Before and During the War [of the American Revolution], in Edward Lincoln to Lord Sydney, 8 January 1785, C.O. 260/7, No. 14, PRO; also see Prices Current, in C.O. 260/8, 9, 11, 13, 14, 15, 23, PRO. For Grenada, Answers to Queries 1st, 5th, and 6th of Heads of Inquiry, 1 January 1785, C.O. 101/26, PRO; Weekly Prices Current of the Produce, Provisions and Lumber exported and Imported from and to Grenada, August 1785-March 1790, C.O. 101/26, 27, 28, 29, 30, PRO; Prices Current, August 1805, C.O. 101/42, PRO; Prices Current 1806, C.O. 101/45, PRO; lanuary 1808, C.O. 101/47, PRO.

49. Ibid.; for increase in prices in Jamaica, see Prices Current in Kingston (1792 - 1810), C.O. 137/91, 95, 97, 114, 116, 117, 118, 121, 122, 124, 128, PRO; Prices in 1775 in Jamaica, Long Papers, Add. MS. 12, 404, British Library, London; Prices of Lumber at Kingston, 1772-1791, Journal of the Assembly of Jamaica 11 (no date), pp. 149-150, 436, University of the West Indies Library, Mona, Kingston, Jamaica.

50. Current Prices of the Market at Barbados, August, November 1785 \& March 1786, C.O. 28/60, PRO; C.O. 28/61, PRO; Prices in the Leeward Islands, C.O. 101/42, 43, PRO; Average Prices Current in St. Vincent, 1 October 1786-3 January 1787, C.O. 260/8, PRO; 5 April-5 July 1789, C.O. 260/9, PRO; see also the following C.O. 260/12-15, 23, PRO; Prices Current in Dominica for the years 1786-87, 1805-1808, (no dates), C.O. 71/12-14, 38-39, PRO; Wholesale Prices at Kingston, Jamaica, 5 January-5 July 1801; 5 December 1801, C.O. 137/105, vols. 114-118, 121-122, PRO. See also Van Keelen to Sir Joseph Barham, 24 July 1786, 24 July 1787, Barham Papers, Bodl. Mss. Clarendon, Dep. c. 357, Bun. 1, Bodelian Library, Oxford.

51. Statements made to the contrary by two historians are not, in my opinion, supported by their research. My manuscript, The Sugar Industry and the Abolition of the Slave Trade, 1775-1810, develops this theme fully, and provides ample statistical information to show that the greatest part pf the West Indian trade remained under the control of U.S. merchants. I also demonstrate the decline of the West Indian economy during the French Revolutionary and Napoleonic Wars. The contradictory conclusions are discussed in Seymour Drescher, Econocide: British Slavery in The Era of Abolition (Pittsburgh: University of Pittsburgh Press, 1977), and subsequent publications by him, and J. R. Ward, "The Profitability of Sugar Planting in the British West Indies, 1650-1834," Economic History Review, 2nd series, 31 (1978): 197-213.

52. Trade figures found throughout Colonial Office papers and plantation records testify to the dependence of the islands on supplies from the United States. 
22. Shirley to Lord Sydney, 24 July 1787, C.O. 152/65, No. 172, PRO.

23. "Minutes of A Meeting of the Council of St. Christopher," 31 December 1789, C.O. 152/69, fos. 5-5d, PRO.

24. "Minutes of A Meeting of the Council of St. Christopher," 31 December 1789, C.O. 152/69, fos. 5-5d, PRO.

25. John Nugent to Lord Sydney, 9 October 1788, C.O. 152/67, No. 12, PRO.

26. Lord Seaforth to the Earl of Camden, 12 December 1804, C.O. 28/71, fos. 198d-200, PRO.

27. John Nugent to the Earl of Camden, 19 May 1805, C.O. 137/114, PRO.

28. Parry to Lord Sydney, 16 June 1785, C.O. 28/42, fos. 88d-90, PRO.

29. Shirley to Lord Sydney, 13 January 1790, C.O. 152/69, fos. 3. 3d, PRO.

30. Stephen Fuller to John King, 23 August 1793, C.O. 137/93, fol. 275, PRO.

31. Major General Adam Williamson to Henry Dundas, 18 January 1794, C.O. 137/92, PRO.

32. See President Esdaile to the Duke of Portland, 20 September 1776, C.O. 152/78, 12-12d, PRO; and the Earl of Balcarres to the Duke of Portland, 11 May 1795, C.O. 137/95, PRO.

33. Lieutenant-Governor Williamson to Dundas, 23 June 1794, C.O. 101/33, PRO.

34. The Duke of Portland to George Ricketts, November 1799, C.O. 28/65, PRO.

35. Robert Thompson to the Duke of Portland, 3 September 1789, C.O. 152/79, PRO.

36. Ricketts to the Duke of Portland, 4 January 1800, C.O. 28/66, fol. 3. PRO.

37. See Barbados Mercury and Bridgetown Gazette, 8 April 1805, C.O. 28/72, fol. 9, PRO; and Lowell J. Ragatz, The Fall of the Planter Class in the British West Indies (New York: The Century Company, 1928), p. 299.

38. See Edward P. Lyon to the Earl of Camden, 7 March 1805, C.O. 137/115, PRO; and Edward Cooke to Edward P. Lyon, 13 March 1805, C.O. 137/115, PRO.

39. The Assembly of Jamaica to George Nugent, 7 December 1804, C.O. 137/113, PRO.

40. Lord Camden to George Nugent, 7 March 1805, C.O. 137/113, PRO.

41. Anthony Merry to Lord Harrowby, 25 January 1805, C.O. 137/ 115, PRO.

42. Extract of Despatch from Mr. Bond to Lord Musgrave, 3 June 1805, C.O. 137/115, PRO.

43. William Fawkner to Edward Cooke, 21 October 1805, C.O. 137/115, PRO.

44. William Fawkner to Edward Cooke, 21 October 1805, C.O. 137/115, PRO.

45. James Cragg to Henry Goulburn, 13 December 1793, Goulburn Papers, Acc 319, Box 53, Surrey Record Office, Kingston, England.

46. Samuel Eliot to Clement Tudway, 2 March 1797, Tudway Papers, DD/TD, Box 11/71, Somerset County Record Office, Somerset; see David Evans to Lord Penhryn (no date), Penhryn Mss. 1475, University of North Wales Library, Bangor.

47. For Barbados prices, see Comparative Prices for Provisions \& other Articles in Barbados, 26 December 1784, C.O. 28/60, fos. 183, 206, 243, 312, PRO; Average Prices at Barbados Market in January, February, March \& April 1787, 25 May 1787, C.O. 28/71, fo. 47, PRO; see also, Average Prices at Barbados Market for October 


\title{
9
}

\section{Property Rights in Pleasure:}

\author{
The Marketing of Slave Women's Sexuality in the West Indies
}

HILARY MCD. BECKLES

Visitors to Britain's West Indian plantations during the last decades of slavery frequently commented on what they considered the culturally endemic and morally regressive socio-sexual practices of white creoles. Comments reflecting aspects of the moral outrage that characterized popular anti-slavery literature, tended to focus on the values of domesticity within which racial groups were forging a new social sensibility. In general, they contained informed judgements on how the ethical character and aesthetic standards of creoles were shaped within the ideological sphere of the colonial mission, and highlighted the principal interest of slaveowners in maintaining and defending comprehensive property rights in persons.

Some proslavery practitioners, in addition, also seemed concerned by the extreme power held by slaveowners with respect to their right to intervene and manipulate the social world of the enslaved-especially its bio-social reproductive capacity. Ideologically, slaveowners understood well that they were entitled to commodify fully all the capabilities of slaves, as part of the search for maximum economic and social returns on their investment. Properly understood, this meant, among other things, the slaveowners' right to extract a wide range of non-pecuniary socio-sexual benefits from slaves as a legitimate stream of returns on capital, and an important part of the meaning of colonial mastery.

In real terms, then, slavery in the islands led to the legal and customary institutionalization of the slaveowners' right to unrestricted sexual access to 
slaves as an intrinsic and discrete product.' The circuitous route of capital accumulation within the slave system, furthermore, recognized no clear distinction between the slave-based production of material goods, and the delivery of sexual services. Production and reproduction oftentimes were indistinguishable within the market economy of slavery. With respect to slave women, then, household work, which ordinarily meant manual labor, also included the supply of socio-sexual services and the (re)production of children as a measurable marginal product that enhanced the domestic capitalization process.

An exploration into the dynamic, multidimensional system of slaveowning which focusses on slaveowners' property rights in slave sexuality is essential to a psycho-social and economic grasp of the accumulating mechanisms that emerged from slavery as a mode of (re)production. The contours of such an excavation and display, furthermore, are particularly relevant to any discursive journey into the "inner" worlds of enslaved women whose deeper integration into the market economy remains largely uncharted on account of the undeveloped discourse on the gender implication of slaveowning.

The outer sphere of this investigation touches upon the violent access to slave women's bodies by their owners, and the sale of their persons for money upon the sex market. Laws did not allow slaves to refuse social demands made by owner, but did provide for the punishment of recalcitrant, disobedient, rebellious and unruly slaves. Rape as a form, or degree, of sexual violation perpetrated against enslaved women by males-black, white, free or enslaved-was not considered a legal offense, and evidence of it does not appear in the litigation records.

Neither colonial statutes nor slave codes, then, invested slaves with any rights over their own bodies, but rather transferred and consolidated such rights within the legal person of slaveowners. This direct translation of legal entitlement into social power and authority meant that white men especially were located at the convergence where the racial, sexual, and class domination of slave women provided a totality of terror and tyranny. This judicial patriarchy supported and buttressed the ideological representation of white mastery, and illuminated the hegemonic maleness of the colonial enterprise.

The rape of the enslaved woman was first and foremost an attack upon her as a woman. Her powerlessness enters the scene of the offense only insofar as it serves as a confirmation of the totality of enslavement. It is for this reason that Orlando Patterson, attempting to compare violent rape with the coercive 
mechanisms of sexual manipulation, laid bare the social reality of plantation life when he stated that rape was often "unnecessary since the slave negress soon gave in to the overwhelming pressures and made the best of its rewards." ${ }^{2}$ This argument rises directly from the many assertions found in the tortured texts of slaveowners' narratives in which rape is rarely admitted but where clear prominence is given to slave women accepting offers they could not easily reject. ${ }^{3}$

The inner sphere of the investigation concerns the theme of the commercialization of slave women's sexuality as cash-receiving prostitutes. This subject also has several important implications for the way in which gender, race, and class relations are viewed within the market worlds of the slave mode of production. The roles of slaves as mistresses and concubines, and their use as prostitutes, is analyzed in connection with the formal institutional presence of "leisure houses"; these two processes in turn are considered against the general background of the passage and reform of slave laws and the complex ideological world of miscegenation.

Unlike the Antiguan colonial elite of the seventeenth century, Barbadian colonists did not legislate against miscegenation. In 1644, Antiguans passed a law which prohibited the "carnall coppullation between Christian and Heathen. ${ }^{4}$ Barbadians, however, hoped that the bio-social aspects of their white supremacy ideology, enshrined in the slave laws, would function as an adequate deterrent. The dominant ideological charge of the slave laws was that blacks were heathens and should not share the same psycho-social space as Christians. The use of dehumanizing animal analogies and demonisation references to blacks were common. Blacks, therefore, were not to be integrated into the emotional and sexual spheres of whites, either as domestic equals or as leisureseeking partners. ${ }^{5}$

Representations of racial inequality in this social idealism, however, could not find real-life roots in the colonial setting; here societal standards were being fashioned in a rather hurried and ad hoc manner. The social and demographic realities of plantation life oftentimes required pragmatic social approaches to race relations, which included, among other things, submission to the tendencies of human sexuality to transcend ideological boundaries, no matter how firmly established. Consequently, the earliest Barbadian slaveowners came to consider it their legitimate right and privilege to engage in sexual liaisons with blacks. According to Richard Dunn, seventeenth-century plantation records indicate that "the master enjoyed commandeering his prettiest slave girl and 
exacting his presumed rights from her." ${ }^{6}$ This tradition is further illuminated by John Oldmixon in 1708. Reporting on the domestic lives of slaveowners in Barbados, he noted that the "handsomest, cleanliest (black) maidens are bred to menial services" in order to satisfy their masters in "divers" ways. ${ }^{7}$

As the anti-slavery movement gained momentum towards the end of the eighteenth century, promoting its ideas by focussing upon the exploitation of black women and the destruction of slaves' family life, the moral authority of slaveowners came under intense scrutiny. Indicative of popular European opinion was the reaction of Colonel Hilton. A professional soldier, Hilton reported in 1816 being horrified at the sight, and by the moral implications, of a white woman in the slave market examining the genitals of male slaves "with all possible indelicacy." ${ }^{8}$ Likewise, F. W. Bayley, an English travel writer of the 1820 s, found organized slave prostitution in Bridgetown rather distasteful, but reported that white males considered the houses if "ill repute" socially indispensable. ${ }^{9}$ Mrs. E. Fenwick, an English schoolteacher living in Bridgetown during the 1810s, tried desperately but failed ultimately to accept a social culture in which young white males commonly underwent their sexual apprenticeship with domestic slaves and prostitutes "brought into the household solely and explicitly for the purpose of sex." Fearing for the moral character of her young nephew, she prepared to remove him to Philadelphia, but was defeated in the effort by a "raging fever" that took his life. ${ }^{10}$

Creole slaveowners seemed undisturbed by such searching critical comments on their social lives and personal struggles. In general, they considered it no evidence of degenerate taste to retain black or coloured female slaves as sexual partners. The evidence suggests, furthermore, that such social relations were popular in Bridgetown, while probably less so on the plantations, although estate owners and managers had social access to a larger number of slave women. In Bridgetown, organized prostitution, and the formal integration of slave mistresses into white households, were common enough, while on the sugar estates sexual access to slave women took more covert forms and was less visible to outsiders.

Urban society was influenced considerably by the maritime activity on which its economy depended. Here, prostitution was as much in demand as any social institution. The large, transient, maritime personnel expected to be able to purchase sex and the liberal values and ideological openness of urban society allowed for the proliferation of facilities that promoted slave prostitution. 
Claude Levy informs us that from the seventeenth century, Barbados was one of the region's busiest entrepots, and that slave prostitution was "an occupation which was more common at Bridgetown than in any other city in the British West Indies." "l With reference to Jamaica, B. W. Higman states: "Prostitution was common in the towns but rare on the plantations. No slaves were listed in the registration returns as prostitutes. But the inns and taverns of the towns were very often brothels as well, and the slaves attached to them were used as prostitutes as well as domestics." ${ }^{12}$ Prostitution was illegal in Barbados and Jamaica, but there is no evidence to show that the laws were enforced vigorously, a circumstance which suggests that this criminal activity was condoned if not encouraged by imperial and colonial officials.

Elizabeth Fenwick could find no significant reason to differentiate morally between urban slaveowners who engaged slave women as prostitutes and resident mistresses, and plantation owners who use them as "breeding wenches" in search of a greater labor supply. For her, these roles overlapped, because many prostitutes were often the kept mistresses of white males, who also encouraged them, from time to time, to have children so as to benefit financially from the sale of the child. In Fenwick's value system, slavery, in this specific context, was "a horrid and disgraceful" institution, and while she expressed a marked sympathy for "victimized" slave women, she was particularly disturbed by the manner in which slave prostitutes and resident mistresses (invariably housekeepers) constituted a sub-group within many white households - a kind of informal socio-sexual domestic service sector. According to her:

The female slaves are really encouraged to prostitution because their children are the property of the owners of the mothers. These children are reared by the ladies as pets, are frequently brought from negro houses to their chambers to feed and to sleep, and reared with every care and indulgence till grown up, when they are at once dismissed to labour and slave-like treatment.

Domestic arrangements that sought to conceal the practice of prostitution, she added, were "common" to both urban and rural white households, and not considered "an enormity." ${ }^{13}$

Plantation owners, however, consistently denied that female slaves were sexually abused or used for sex-related "immoral gain." They maintained that slave women were generally promiscuous, and pursued sexual relations with white males for their own material and social betterment. With respect to 
Newton Plantation in Barbados, the data for the late-eighteenth century show that female slaves feared, and sought to escape, sexual violence at the hands of white personnel. Slaveowners reports also indicate that domestic slaves sought sexual relations with white men, both on and off the estate. In 1796, Manager Sampson Wood informed the estate owner that one woman had fled the estate, charging sexual abuse by the overseer, but that most domestics "either have or have had white husbands, that is, men who keep them."

Dolly, the thirty-year-old daughter of Old Doll, the retired housekeeper, was the resident mistress of Wood's predecessor at Newton. Jenny, her twenty-eight year old sister, also had an intimate relation with the overseer, while Mary, her cousin, whom Wood described as "extremely heavy, lazy and ignorant," had a longstanding sexual relation with the white bookkeeper by whom she had a son. ${ }^{14}$ Yet, for this plantation the evidence of sexual coercion and rape is implicit in the same records, which show that all four field women listed in 1796 as having "mulatto" children, Membah Jubah, Fanny Ann, Jemenema and Little Dolly, were impregnated between the ages of thirteen and sixteen. ${ }^{15}$

The few cases in which slaveowners conceded the occurrence of rape and sexual violence they attributed such behavior specifically to whites whom they described as persons without "social breeding," such as dishonoured indentured servants, overseers, and other waged labourers. In 1822, for example, William Sharpe, a prominent Barbadian planter, informed a Committee of the Legislative Council:

illicit intercourse with the whites does sometimes take place, but it is principally confined to the inferior servants on the estates, who are young men whose circumstances in life will not admit of their marrying and supporting a family:- when a connexion of this kind takes place between them and the young black women, it is done by persuasion, and because they have it more in their power to gratify the vanity of the females in their fondness for dress; punishment however awaits the offender when his improper conduct is discovered, for he seldom escapes being turned out of the estates. A manager's moral conduct is a great recommendation of him: glaring instances of immoral conduct would not be tolerated. ${ }^{16}$

In Bridgetown, however, such rationalizations and apologies were considered unnecessary and irrelevant. White males, including planters who sometimes resided in town, made a gainful business by prostituting female slaves. William Dickson, an imperial administrator who lived in Barbados during the 1770 s and 1780s, found that men would often "lease out" their slave mistresses 
for the purpose of prostitution as a convenient way of obtaining cash. These women, he added, were "rented out" especially to visiting merchants, naval officers, and other such clients, for specified periods. ${ }^{17}$ The money paid to owners of slave women for sexual services frequently exceeded the slaves' market value.

During the period immediately after the sugar harvest the number of slave women placed on the urban market as prostitutes by rural slaveowners increased, as did the number of male artisans put out to sell their skills on a contractual basis. In both instances, slaveowners expected all, or a proportion of the money earned; the slaves, on the other hand, considered themselves fortunate to have a greater degree of "control" over the disposal of their time.

The question of slave prostitution was raised before the 1790-91 House of Commons inquiry into the slave trade. Evidence submitted showed that in spite of its illegality, it was "a very common thing" for "female slaves to be let out by their owners for purposes of prostitution." ${ }^{18}$ The Commissioners heard, furthermore, that rural slaves were sent to town, and town slaves were sent to the barracks at the Garrison, in order to raise money from prostitution. The evidence suggests that prostitution posed no major problems for colonial administrators, and may have been less widespread than in the cities of Europe. $^{19}$

Early nineteenth-century references to slave prostitution emphasized the distinction between the urban and rural contexts. In 1824, Thomas Cooper, looking at the wider Caribbean situation, stated that elite slaves on the estate, notably mid-wives, were frequently the suppliers of young girls to urban clients. ${ }^{20} \mathrm{~J}$. B. Moreton, however, noted in 1790 , that urban slave prostitutes were controlled by their mothers who arranged clients and received monies. He argued, furthermore, that coloured slaves "from their youth are taught to be whores" and to expect their living to be derived from immoral earnings. ${ }^{21}$

In support of his abolitionist position, Cooper attributed part of the failure of slave populations on the sugar colonies to reproduce themselves naturally to the prevalence of prostitution among young females-on the estates as well as in towns. Slaveowners, however, did not accept that prostitution had adverse effects upon slaves' domestic arrangements or their fertility. ${ }^{22}$ Edward Long, proslavery ideologue of late-eighteenth-century Jamaica, echoed the Barbadian planters' sentiments when he stated that black women were predisposed to- 
wards prostitution, and performed this function with efficiency and without moral reflection. ${ }^{23}$

The evidence is not always clear on the distinction in occupational terms, between slave mistresses, prostitutes, and housekeepers. Certainly, housekeepers were typically selected by white male householders via the sexual relation route, which suggests the inevitability of interchangeable functions. Captain Cook, a British military officer, giving testimony before the 1790-91 parliamentary committee, illustrated the many ways that Barbados' slaveowners prostituted female slaves. His knowledge of colonial society was derived from several visits to the colony in 1780 and 1782; he knew first hand the domestic culture of whites, and was attentive to the sexual practices of creole males. He described how enslaved domestics, black and coloured, were used as prostitutes in the colony's towns, and concluded that the purchase of sex by maritime crews "was a very common practice. ${ }^{\text {n24 }}$ Slave prostitutes, he stated, would go on board ships under special arrangements with port officials for the purpose of selling sex for money. He confessed to accepting this activity on board the ship under his command, since it was part of colonial maritime life, but seemed rather indignant when he discovered that a "negro girl" he knew well was "severely punished on her return home to her owner without the full wages of her prostitution. ${ }^{\text {.25 }}$

White creoles in Barbados never accepted that organized prostitution was of any economic importance. Slave women, they argued, were frequently given time to "work out," which meant that they were free to pursue whatever gainful employment they wished, and though many would enter the business of prostitution for quick and large sums of money, it was their own "voluntary" choice. Hiring slave women for multifarious social purposes, then, was considered part of the urban labour market in which slaves had some autonomy. Many free black and free coloured slaveowners, following the pattern set by white slaveowners, earned their living from the wages of hired-out female slaves; these worked formally as nannies, nurses, cooks, washerwomen, hucksters, seamstresses, and general labourers. The hiring-out of women specifically for sex ran parallel to this market, and the general expectation of white males who hired female slaves, under whatever pretence, was that sexual benefits, if needed, were included. Prices for hired women invariably reflected this dual function, even when it was not made explicit at the outset. 
The covert organization of slave prostitution was also a popular business activity of "well-to-do" white women-especially widows or those without influential or financially-sound husbands. White elite colonial society insisted on the projection of images of social respectability, and as such, distanced itself from formal association with prostitution as an enterprise. For financially-insecure white women, however, it was the best they could do, and they were described as displaying their involvement without shame or remorse. In 1806, for example, a British naval officer reported that he knew a respectable creole lady who, for a living:

lets out her negro girls to anyone who will pay her for their persons, under the denomination of washer woman, and becomes very angry if they don't come home in the family way. ${ }^{26}$

John Waller, an Englishman who visited Barbados in 1808, made a similar report on the relations between high "society" white women, slave prostitution, and the "hiring- out" labour system. He stated in his travel book:

In the family where I lodged, a respectable lady was regretting to the company at dinner, that a young female slave whom she had let out for several months was about to return as she would lose twelve dollars a month, the price of her hire, and besides, be at the expense of maintaining her. After dinner, I made inquiry respecting the subject of hiring slaves, and learned that the one in question had been let out to an officer in the garrison, with whom she had been living as a mistress. I felt extremely shocked at the idea of so strange a traffic; but I found, a few days later, this very slave advertised in the "Bridgetown Gazette," in the following curious terms: "To let, a Sempstress, a well-looking mulatto girl seventeen years of age, an excellent hand at the needle, etc. To prevent needless application -terms twelve dollars per month. Apply, etc." I had previously noticed advertisements of this description, and I believe that few weeks pass without them; they are, however, frequently intended only for the purpose literally expressed. ${ }^{27}$

The institutional framework of prostitution, however, centered on the taverns, bars, and inns of Bridgetown. By the late-eighteenth century many of these leisure houses were owned, or managed, by free black or free coloured women, who were more restricted occupationally than their white counterparts in the search for economic niches. Dr. George Pinckard who frequented Barbados during the 1790 s as a medical officer aboard a war vessel, provides us with insights into the practice of prostitution in Bridgetown's taverns: 


\begin{abstract}
The hostess of the tavern, usually, a black or mulatto woman, who has been the favoured enamorata of some backra [ white man] from whom she has obtained her freedom, and perhaps two or three slaves to assist her in carrying on the business of the house, where she now indulges in indolence, and the good things of life, grows fat, and feels herself of importance in society. It is to her advantage that the female attendants of her family should be as handsome as she can procure them. Being slaves, the only recompense of their services, is the food they eat, the hard bed they sleep on, and the few loose clothes which are hung upon them. One privilege, indeed, is allowed them, which is that of tenderly disposing of their persons; and this offers the only hope they have of procuring a sum of money, where with to purchase their freedom. ${ }^{28}$
\end{abstract}

Such taverns, according to Pinckard, were "commonly known by the names of the persons who keep them. ${ }^{29}$ The most frequented at Bridgetown were "those of Nancy Clarke, and Mary Bella Green; the former a black, the latter a mulatto woman." The white public, he intimates, would scarcely accept the terms "Mrs. Clarke," or "Mrs. Green," and so a "party is said to dine at Mary Bella Green's, or at Nancy Clarke's," the title Mrs. is reserved "solely for the ladies from Europe. ${ }^{\text {"30 }}$

In any of these taverns, Pinckard informs, a "bed may be had for halfa dollar per night, or three dollars per week; and, for an additional sum well understood, the choice of an attendant to draw the curtains." ${ }^{31}$ "Prostitute girls," he suggested, "were treated in the most cruel manner by their mistresses, whose objectives were to earn as much money from their duties as possible. My considered response to such treatment," Pinckard says, "was much tempered by the realization that these women" showed "neither shame nor disgrace" in their prostitution. Rather, he added, the one "who is most sought becomes an object of envy and is proud of the distinction shewn her. ${ }^{32}$

It was generally recognized that in these taverns, slave women were offered the boon of freedom as an incentive for maintaining their enthusiasm. For any category of slave, freedom was a legal status not easily rejected. ${ }^{33}$ There were freedwomen such as Sabina Brade who was described in 1807 as "an old, fat black woman;" Betsy Lemon, a well-known mulatto figure in Bridgetown; Betsy Austin, whose hotel was said to offer the best in "mental and corporeal" entertainment, though at exorbitant rates; Caroline Lee, Betsy Austin's diminutive mulatto sister, after whom the well-known Barbadian yellow sweet potato is named; and Hannah Lewis, arch-rival of Betsy Austin, also a "brown-skin 
lady. ${ }^{34}$ Dr. Walker, an Englishman who resided in Barbados during 1802-03, stated that these women possessed "considerable property, both in houses and slaves." He stated, furthermore:

Nor can they fail to amass large fortunes, as their houses are generally filled with strangers, who must submit to the most exorbitant charges for every article of eating, drinking, as well as for the accommodation of lodging and washing. These taverns are besides houses of debauchery, a number of young women of colour being always procurable in them for the purpose of prostitution. ${ }^{35}$

In 1837, when prominent English abolitionists Joseph Sturge and Thomas Harvey conducted their "emancipation" tour of the British West Indies, most hotels and taverns in Bridgetown were still considered "houses of debauchery where a number of slave women were kept for the purpose of prostitution. ${ }^{\text {n6 }}$ Most observers of slave prostitution in Barbados noted, like Sturge and Harvey, that coloured women, both slave and free, were more in demand than black women, and fetched higher prices for their services. Coloured women, however, were less available for this role than their black counterparts in Bridgetown, because they were more likely to be mistresses of white men or married to coloured men. The records attest to the favoured status of "yellow-skinned" women, most of whom operated from the more exclusive taverns and hotels. In 1804, for example, an English naval officer made reference to a white woman he knew who made "a round sum" by trafficking her prostitute "coloured" girls to Europeans as "housekeepers" in disguise, or as she preferred to call it, "marrying them off for a certain time." ${ }^{37}$

White men publicly displayed a preference for coloured women, though black women were more likely to bear the fruit of their secretive sexual exploits. The "mulatto" girl was paraded as the kept mistress, but the black housekeeper was more likely to be the "invisible lover." One contemporary explained that white men's mulatto preference resulted from their cohabiting with them "at a very early age," and few denied that the "brown" or "yellow" skin "coloured" women, outside of respectable family relations, were socially and sexually desired-more so than were white or black women. ${ }^{38}$

Bayley's observations in the 1820 s were perhaps representative of the white male's norm when he spoke of the sexual attractiveness of coloured women. He described them as having "captivated" with ease the "hearts of English, Irish, 
and Scotch" men on the island ${ }^{39}$ He added the following statement by way of personal judgement:

If I accord the palm of female beauty to the ladies of colour, I do not at the same time deteriorate the attractions of the fairer [white] creoles; the stately and graceful demeanour which calls upon us to admire the one, does not forbid us to be fascinated by the modest loveliness of the other; yet I will acknowledge that I prefer the complexion that is tinged, if not too darkly, with the richness of the olive, to the face which, however fair in its paleness, can never look as lovely as when it wore the rose-blush of beauty which has faded away. I know no prettier scene than a group of young and handsome colored girls taking their evening walk. ${ }^{40}$

From the comments of Bayley, Waller and Pinckard it seems that white elite males possessed a sexual typology in which white women were valued for domestic formality and respectability, coloured women for exciting socio-sexual companionship, and black women for less-structured covert sexual adventurism. Generations of black women, then, produced mulatto daughters who were priced higher on the market than themselves. Waller explained the forces which led to this differentiation:

A very respectable matron, who had shewn a kind of motherly affection for a young friend of mine who came over [from England] to settle here as a merchant, advised him in the most serious manner to look out for a young mulatto or Mustee girl for his housekeeper, urging that it would greatly increase his domestic comforts and diminish his expenses; and, in addition to this, she hinted very delicately, that, by being confined to one object, his health and reputation would be better secured, than by the promiscuous libertinism to which she seemed to consider every young man as habitually addicted. 41

North American abolitionists, J. A. Thome and J. H. Kimball, suggested that, during the 1830s, Europeans generally took this advice on "first going to the island." It was in vogue, they added, for new arrivants to engage "colored females to live with them as housekeepers and mistresses." Furthermore, "it was not unusual for a man to have more than one. ${ }^{\mathbf{4 2}}$ Bayley believed that this sexual culture arose principally from slavery, which corrupted the moral character of all who depended upon it, but he was not prepared to deny the sexual attractiveness of "the proud and haughty spirits of the coloured ladies themselves. ${ }^{413}$

Black women, whether slave or free, were generally not as successful in extracting socio-economic benefits from propertied white males as were col- 
oured women. Data for Bridgetown suggest that whereas black women remained in the "small-time" fringe for this illicit social culture, larger numbers of coloured women successfully fashioned their socio-ideological vision around the need to entertain white males, in return for social and material betterment. As free persons, coloured women's opportunities were severely limited, so this realization encouraged them to adopt a professional attitude towards the sex industry that brought them into intimate contact with propertied white males.

Social custom dictated that prominent white men should neither marry coloured women, nor allow them in any way to transcend white women in social respectability. In this way, coloured women's social ambitions could be kept in check without alienating their sexual usefulness. In spite of their intimacy and loyalty to eminent white males, coloured women could not be accepted as equal members of official elite society. When, for example, the newly-appointed Governor, George Ricketts, arrived at Barbados from Tobago in 1794 accompanied by his mulatto mistress, it caused a tremendous uproar among his councilors and assemblymen, although many had similar social relations. ${ }^{4}$

Illicit social relations with white men were considered the most rewarding option for coloured women, the recognition of which, some observers noted, frequently drove them to reject respectable domestic life with coloured men, and to consider black men socially unacceptable. A United States citizen resident in Barbados noted in 1814 that "colored parents educate their female children for this special purpose. ${ }^{\text {45 }}$ Likewise, Thome and Kimball, observing the social culture of urban whites and free coloureds, took the view that coloured women were "taught to believe that it was more honourable, and quite as virtuous, to be kept mistresses of white gentlemen, than the lawfully-wedded wives of coloured men. ${ }^{n 6}$ For Bayley, only the removal of civil disabilities that adversely affected the status of free coloured men would society be able to affect "the weakening of those motives which induce the colored women to live in immorality with a white protector. ${ }^{\text {"47 }}$ General emancipation, he argued, could bring about a slow "change in this system. ${ }^{\text {n88 }}$ Even then, he insisted, moral society would have to "contend with strong and established prejudices, and the mighty influence of long custom and habit. ${ }^{\text {"49 }}$

While the evidence points to whites and coloured women as the primary owners of slave prostitutes, occasional references to free black women and men suggest their marginal involvement. Free blacks were sometimes wholly dependent upon "immoral gains" to maintain their status. It was not uncommon 
to find runaway female slaves being harboured by such persons, who in turn arranged their prostitution in return for protection. It was at this end of the business that black owners of prostitutes were to be found in large numbers, often catering for black clients, both slave and free.

Some slave women gained legal freedom through the route of the overlapping roles of prostitution and concubinage. ${ }^{50}$ In these ways, they earned the necessary money to effect their manumission, or came in contact with clients who were prepared to assist them in doing so. Legal freedom, however, did not always result in a distancing from these roles. It was, therefore, very common to find freed women continuing as prostitutes and mistresses. In 1811, the Rector of the St. Michael Parish Church, commenting on the "very rapid" increase in the number of slaves freed by whites since 1802 , suggested that "out of every four at least three" were "females who obtained that privilege by becoming favorites of white men. ${ }^{51}$ He was supported by Joseph Husbands who claimed that in 1831:

By far the greater number of free colored persons in Barbados have either obtained their freedom by their own prostitution, or claimed it under some of their female ancestors who in like manner obtained it and have transmitted it to the descendants. ${ }^{52}$

Since the mid-eighteenth century, legislators seemed determined to restrain white males from manumitting their black and coloured favorites. In 1739, the manumission fee had been legally set at $£ 50$ plus an annuity of $£ 4$ local currency; the annuity was insisted upon by poor law officials as one way to prevent slaveowners from freeing old and infirmed persons who could not reasonably be expected to earn their subsistence. In 1774, a bill was introduced into the Assembly aimed at curtailing the number of females being manumitted. It was designed to raise the manumission fee to $£ 100$, but was rejected on the grounds that slaveowners should not be deprived of the right to assist the "most deserving part" of their slaves-"the females who have generally recommended themselves to our 'kindest notice."' It was defeated by a vote of eleven to five; opposition was led by Sir John Gay Alleyne who argued that female slaves who gave their loyalty, love, and service to masters should not be denied the opportunity to gain freedom. ${ }^{53}$

Barbadian whites debated the subject once again in 1801, following Governor Seaforth's proposed bill to limit female slave manumission, and to ensure that proper provisions were made by slaveowners for their manumitted slaves. 
The bill became law, and raised the manumission fee to $\mathfrak{\xi} 300$ for females and $£ 200$ for males. Slave women continued to be freed in significantly larger numbers than men for the rest of the slavery period (see Table 1), though the 1801 Act was repealed in 1816 following the Bussa Rebellion (14-17 April), and the $\mathfrak{\{} 50$ plus $\mathfrak{E} 4$ annuity fee for both sexes was re established.

Against this background, the Assembly continued to be notified that too many freed black women survived income derived from prostitution. Since the 1780s Joshua Steele had expressed concerned for free black women who were forced to subsist by "gallantry. ${ }^{\text {"4 }}$ He was supported by Governor Parry who was earlier informed by his Council that many freed women sustained "themselves by the prostitution of their persons." ${ }^{\text {"5 }}$ The Assembly, however, was aware that the urban economy provided few outlets for free black women, most of whom were unable to compete with slave labourers in the huckster trade, or as general labourers, housekeepers, seamstresses, and the like. It was difficult, then, for free black women to break out of the prostitute/mistress cycle, unless they were able to marry those few free black men who earned a steady income.

The socio-economic integration of slave women into the plantation system, therefore, allowed for their use at various points along the circuit of capital accumulation. Their contribution to the overall wealth creation process of slaveowners involved not only their roles as labourers, and reproducers of

Table 1: Slave Manumissions in Barbados, 1809-32

\begin{tabular}{lccccc}
\hline Years & No. Males & No. Females & Total & \% Male & \% Female \\
\hline $1809-11$ & 168 & 263 & 431 & 39.0 & 61.0 \\
$1812-14$ & 88 & 148 & 236 & 37.3 & 62.7 \\
$1815-17$ & 191 & 279 & 470 & 40.6 & 59.4 \\
$1818-20$ & 167 & 245 & 412 & 41.0 & 59.0 \\
$1821-23$ & 131 & 166 & 297 & 44.1 & 55.9 \\
$1824-26$ & 126 & 196 & 322 & 39.1 & 60.9 \\
$1827-29$ & 212 & 458 & 670 & 31.6 & 68.4 \\
$1830-32$ & - & - & 1,089 & - & - \\
\hline
\end{tabular}

Source: Jerome Handler, The Unappropriated Peopie: Freedmen in the Slave Society of Barbudos (Baltimore, Johns Hopkins University Press, 1974) p. 49. 
labour, but also as suppliers of socio-sexual services. The sex industry was an important part of the urban economy, and the relations of slavery, protected by slave codes, created societal conditions under which the maximum benefits offered by property ownership in humans accrued to slaveowners. The use of slave women as prostitutes, therefore, was another way in which slaveowners extracted surplus value and emphasized their status as colonial masters.

For the slave women, whether black or coloured, life as a concubine or prostitute was characterized by more than the omnipresent forces of relentless sexual exploitation at the hands of slaveowners. Their life chances were shaped by socially-complex and dialectically-changing circumstances. Some of them gained materially from the relations of sex in diverse ways. Many obtained legal freedom, which for slaves was the most important social commodity, and although few became slaveowners and tavern proprietors, more, perhaps, would have suggested that the lifestyle of a prostitute was more conducive to social mobility than that of plantation field gang women, who, according to the economic and pathological indicators, were the more dispensable and shortlived "beast of burden" in the productive sector. ${ }^{56}$

\section{NOTES}

1. See for example, George Pinckard, Notes on the West Indies, 3 vols. (London: Longman, 1806), 1: 245-46; John Waller, A Voyage to the West Indies (London: Richard Phillips, 1820), pp. 9-10, 20-21; J. Thome and J. Kimball, Emancipation in the West Indies (New York: Anti-Slavery Society, 1838), p. 79; J. Sturge and T. Harvey, The West Indies in 1837. (London: Hamilton and Adams, 1837), p. 1; William Dickson, Letters on Slavery (1789; reprint, Westport: Negro University Press, 1970), p. 39; F. W. Bayley, Four Years' Residence in the West Indies (London: William Kidd, 1833), pp. 496-97.

2. Orlando Patterson, The Sociology of Slavery (London: London University Press, 1967), p. 160. See also Hilary Beckles, Afro-Caribbean Women and Resistance to Slavery in Barbados (London: Karnak House, 1988), pp. 77-78. Most accounts of slavery in the West Indies comment upon the use of slave women as prostitutes but do not theorize the significance of this form of exploitation for an understanding of female slavery. For example, see Elsa Goveia, Slave Society in the British Leeward Islands at the end of the 18th Century (London: Yale University Press, 1965), pp. 216-17; Edward Brathwaite, The Develonment of Creole Society in Jamaica, 1770 - 
1820 (Oxford: Clarendon Press, 1971), p. 160; B. W. Higman, Population and Economy of Jamaica, 1807-1834 (Cambridge: Cambridge University Press, 1976). p. 42.

3. See, for example, the diary of Thomas Thistlewood, Jamaican slaveowner, for extensive references to this point, in Douglas Hall, In Miserable Slavery: Thomas Thistlewood in Jamaica, 1750-86 (London: MacMillan, 1989); also Hilary Beckles, Natural Rebels: A Social History of Enslaved Black Women in Barbudos (New Brunswick: Rutgers University Press, 1989), pp. 131-38.

4. See Leeward Islands MSS Laws, 1644-1673, CO 154/1, CO 154/1/49-50, Public Record Office (PRO), London.

5. The preamble to the 1661 Slave Laws of Barbados described blacks as "heathenish," "brutish," and a "dangerous kind of people." The 1688 Code described blacks as "of a barbarous, wild and savage nature, and as such render them wholly unqualified to be governed by the laws, customs and practices of [the white] nation." Acts of Barbados, 1645-1682, CO 30/2, CO 30/5, PRO. Richard Hall, Acts Passed in the Island of Barbados, 1643-1762 (London: Richard Hall, Jr., 1764), no. 42; also ff. 112-13. See also Richard Dunn, Sugar and Slaves: The Rise of the Planter Class in the English West Indies, 1624-1713 (Chapel Hill: University of North Carolina Press, 1972), pp. 240, 246.

6. Dunn, Sugar and Slaves, p. 253.

7. John Oldmixon, The British Empire in America, 2 vols. (London: Mapp, 1708), 2: 129 .

8. Colonel Hilton to Reverend John Snow, 16 August 1816, Codrington MSS, Barbados Accounts, 1721 to 1838, Lambeth Palace Library, London.

9. Bayley, Four Years' Residence, p. 497.

10. The Barbados Letters of Elizabeth Fenwick are to be found in A. F. Fenwick, ed., The Fate of the Fenwicks: Letters to Mary Hays, 1798-1828 (London: Methuen, 1927), pp. 163-207.

11. Claude Levy, Emancipation, Sugar and Federalism: Barbados and the West Indies, 1833-1876 (Gainesville: University of Florida Press, 1980), p. 30.

12. B. W. Higman, Slave Populations of the British Caribbean, 1807-1834 (Baltimore: Johns Hopkins University Press, 1984), p. 231.

13. Fenwick, Letters, p. 169.

14. Report on the Negroes at Newton Plantation, 1796, Newton Papers, M523/288, ff 1-20, Senate House Library, University of London, London.

15. Ibid.

16. Evidence of William Sharpe, in A Report of a Committee of the Council of Barbados, appointed to Inquire into the Actual Condition of the slaves of this Island (Bridgetown: W. Walker, 1822), pp. 5-6.

17. Dickson, Letters, p. 39.

18. Evidence of Nicholas Brathwaite, British Sessional Papers: House of Commons, 1791 (34), Vol. 42, p. 183. 
19. See Bryan Edwards, The History, Civil and Commercial, of the British Colonies in the West Indies, 3 vols. (1793; reprint, London: G. and W.D. Whittaker, 1801), 2: 23.

20. Thomas Cixoper, Facts Illustrative of the Condition of the Negro Slaves in Jamaica (London: Hatchard, 1824), p. 42.

21. I. B Moreton, Manners and Customs of the West India Islands (London: Richardson, 1790), p. 132.

22. See A Report of a Committee of the Council of Barbados, pp. 4-10.

21. Edward Long. The History of Jamaica, 3 vols. (London: T. Lowndes, 1774), 2: 436

24. Testimony of Captain Cook, British Sessional Papers: House of Commons, 1791 (34), Vol 42, p. 202.

25. Ibid

26. Major Wyvill, "Memoirs of an Old Officer, 1776-1807," p. 386, MSS Division, Library of Congress, Washington, D.C.

27. Waller, A Voyage to the West Indies, pp. 20-21.

28. Pinckard, Notes, 1: 245.46.

29. Ibid., p. 249.

30. Ibid

31. Ihid., p. 245.

32. Ibid., p. 137.

33. Neville Connell, "Hotel Keepers and Hotels," in Chapters in Barbados History, ed. P. F. Campbell (Bridgetown: Barbados Museum, 1986), p. 107.

34. Ibid., pp. 111-16.

35. Ibid., p. 108.

36. Sturge and Harvey, The West Indies in 1837, p. 1.

37. Major Wyvill, "Memoirs," p. 383.

38. Waller, A Voyage to the West Indies, p. 19.

39. Bayley, Four Years' Resudence, p. 493.

40. Ibid., pp. 493-94.

41. Walker, A Voyage to the West Indies, p. 20.

42. Thome and Kimball, Emancipation in the West Indies, p. 79.

43. Bayky, Four Years' Residence, p. 195.

14. John Poyer, The History of Barbados from the First Discovery of the Island in the Year 1605 till the Accession of Lord Seaforth 1801 (London: J. Mauman, 1808), p. 639.

45. Jerome Handler. The Unappropriated People: Freedmen in the Slave Society of Barbados (Baltimore: Johns Hopkins University Press, 1974), p. 199.

46. Thome and Kimball, Emancipation in the West Indies, p. 76.

47. Bayky, Four Years' Resudence, p. 497.

48. Ibid., p. 496.

49. Ibid.

50. Handler, The Unappropriated People, p. 137.

51. Evidence of Garnette Beckwith, December 5, 1811, Parliamentary Papers (PP), 1814-1815, Vol. 7, p. 478. 
52. Joseph Husbands, An Answer to the Charge of Inhabitants of Barbados (New York: Richardson, 1831), p. 19.

53. Minutes of the Barbados Assembly, 15 March 1744, Barbados Archives, Bridgetown, Barbados.

54. Joshua Steele's reply to Governor Parry, Parliamentary Papers (PP), 1789, Vol. 26, p. 33 .

55. See Handler, The Unappropriated People, p. 137.

56. Both terms - "worn out" and "beast of burden"-were used by William Dickson to describe the condition of slave women in the late-eighteenth century. See Dickson, Letters, pp. 6, 34. 


\title{
10
}

\section{The Story of Two Jamaican Slaves:}

Sarah Affir and Robert McAlpine of Mesopotamia Estate

\author{
RICHARDS. DUNN
}

\begin{abstract}
About sixty sugar estates were operating in Westmoreland parish at the western end of Jamaica in the late eighteenth and early nineteenth centuries, staffed by some thirteen thousand slaves. Mesopotamia was one of these estates, a largerthan-average sugar production unit, with a slave population that fluctuated from a low of 236 in 1744 to a peak of 421 in 1820. In August 1834, when the British government began to emancipate the Jamaican slaves, 316 slaves were attached to this estate. Mesopotamia was situated five miles inland from the port town of Savanna la Mar, on the winding Cabaritta River and in the shadow of the rugged Hanover Mountains. Today sugar is still grown on this land, but only a dilapidated stone gate post and twelve gravestones commemorate the white people who managed the estate in slavery times, while nothing memorializes the many hundred black people who lived and worked and died here. Yet much can be done to reconstitute the slave experience at Mesopotamia, because the owners of this estate kept the most detailed slave records yet discovered for any Jamaican plantation.

Mesopotamia was laid out around 1700, and was owned and operated for more than a century by four generations of the Barham family. The Barhams were absentee owners who lived in England, but two members of the familyJoseph Foster Barham (1729-89) and his son Joseph Foster Barham II (17591832) - took special interest in their slaves. They established a Moravian mission at Mesopotamia, at a time when most slaveholders on the island were
\end{abstract}


adamantly opposed to any form of religious instruction, and they required their bookkeepers to compile annual inventories (taken on 31 December or 1 January) so as to keep track of changes in the slave population. Eighty-five of these inventories, taken over a span of nearly a century between 18 April 1736 and 1 January 1832, survive among the Barham family papers in the Bodleian Library at Oxford, together with crop accounts, invoices of goods shipped from England to the estate, and extensive correspondence between the Barhams and their estate agents and sugar brokers. ${ }^{1}$ At first the Mesopotamia inventories merely list each slave by name, and occasionally by occupation or value, but from 1762 onward they supply annual births and deaths, and systematically record the age, occupation, and physical condition of each man, woman, and child. From 1774 onward they identify the mothers of all slaves born on the estate, and from 1780 onward they supply skeletal family data about most newly purchased slaves. Prosopographical information is thus most fully detailed for the years 17621831. By correlating the inventories for these years I have been able to reconstruct to some degree the individual life histories of all the 504 women and girls and 599 men and boys who lived on this estate over a span of seventy years, until the eve of emancipation in Jamaica.

To illustrate the character of the Mesopotamia evidence, let us consider the experiences of a slave mother and son. Affy, also known as Sarah Affir, appears on sixty-four and Robert McAlpine on thirty-eight of the inventories. They make an interesting pair: a black woman who spent the prime years of her life toiling in the sugar fields, and a mulatto man of more privileged ${ }^{2}$ status who worked as a cooper. Here is their story, pieced together from all of the references to them in the estate records.

\section{Sarah Affir.}

Affy was born at Mesopotamia in April 1767, one of three babies reported in that year ${ }^{3}$-a strikingly small total considering that the Mesopotamia slave community numbered 260 men, women and children at the time of her birth. One reason for the small number of newborns is that miscarriages, stillbirths, and neonates who died within a few days were generally not registered. When women were identified as pregnant in the inventories, only about half of them produced recorded live births during the following year, which suggests that a great many slave women aborted or miscarried their fetuses, or bore dead or 
dying infants whom the white record keepers ignored. The death rate was always much higher than the birth rate at Mesopotamia. During 1767 nine deaths were reported, and during Affy's lifetime nearly twice as many deaths as births were recorded. In consequence, the slave population was never self-sustaining. To maintain a viable work force at Mesopotamia, the Barhams imported 401 people to the estate between 1767 and 1832, buying 116 slaves from the African slave ships and 285 slaves from other Jamaican estates. Yet the population in January 1832, when the last inventory was taken, was 328-not a great deal larger than when Affy was born.

Neither of Affy's parents is identified in the birth register of 1767. The Mesopotamia bookkeepers only began to record the mothers of newborns in 1774, and they never recorded the fathers. Even Affy's name is problematic. Was it a real name chosen by her mother, or was it a book name imposed by the white record keeper? About fifteen percent of the names given to slave babies at Mesopotamia seem unlikely to have been selected by their mothers. These include British place-names like Aberdeen, Cambridge, Chelsea, Dorset, Dundee, Dublin, Edinburgh and Windsor; classical names like Brutus, Cato, Dido, Hercules, Juno, Jupiter, Neptune, Phoenix and Psyche; and comic names like Blackemoor, Bunny, Christmas, Danger, Goodluck, Prince of Wales and Trouble. Nearly seventy percent of the newborns received standard English names and nicknames or Biblical names. Only eight percent received African or pseudo-African names such as "Affy." In the annual inventories, her name was spelled several different ways, most often "Affy" but sometimes "Affie" or "Affry." Like all of the other Mesopotamia babies born at this time, she was given no surname in the record book.

From 1767 to 1773, Affy was annually listed among the other little girls on the estate, with no added comments about her occupation (since she had none) or her physical condition. Then at age seven she was put to work: the common pattern at Mesopotamia. Many of the boys and practically all of the girls began employment in the grass gang or third gang, a squad of about thirty youngsters aged six to sixteen who gleaned the fields and pastures, carried grass to the livestock pens, carried manure into the cane fields, and hoed the young sugar cane after it had been planted. Once these children began as field hands, they continued in the same line of work as adults, performing strenuous gang agricultural labour until their health broke down. For the boys at Mesopotamia, the odds of becoming a field hand were one in two; for the girls, the odds were 
five in six. ${ }^{4}$ But Affy escaped this scenario temporarily, and started to work as a domestic servant.

Affy's first employment supplies us with a hint as to who her mother may have been. There was another little seven-year-old girl named Doll who also started working as a domestic in 1774, and Doll's mother can be identified in the estate records as a woman named Lucy, who was a seamstress and washerwoman at the Great House. Five of the six other female domestics in 1774 were women in their forties and fifties, unlikely to have been Affy s mother, but thirty-five-year-old Amelia was of the right age, and she was the housekeeper for overseer Daniel Barnjum who occupied the Great House in the absence of Joseph Foster Barham I. Amelia was certainly in a good position to secure a favoured inside job for her young daughter. Affy served as a house girl for five years until 1779 , but was reassigned to field work when she was twelve years old. Amelia was still the overseer's housekeeper, and continued in this job until she died in 1784 when Affy was seventeen. But Amelia-supposing that she was Affy's mother-was unable to protect the girl any longer from sugar labour. Doll had already been sent into the cane fields the previous year.

The 1779 inventory lists Affy as a field worker without specifying what sort of agricultural labour she performed. There were 125 field workers at Mesopotamia in 1779, constituting half of the slave population, and they were organized into three large labour gangs, supervised by black drivers who kept the people in each squad working in regimented lockstep. About fifty-five men and women laboured in the great gang or first gang: these were the prime field workers, who performed the most strenuous tasks. The second gang was of somewhat smaller size, and was composed of teenagers not yet strong enough for first gang labour and adults in their thirties and forties who were beyond their working primes. The youngest hands were organized into the grass gang or third gang. Probably at age twelve Affy was assigned to the grass gang. If so, she was one of the older workers in this squad, and was bossed by a forty-eight-year-old slave woman named Peg, who was the children's driver.

After a year or so of field labour Affy contracted a bad case of the yaws, a cruel disease that produces disgusting ulcerating skin lesions and often causes disabling bone damage and permanent disfigurement. At least fifteen percent of the Mesopotamia slaves were seriously afflicted by the yaws during Affy $s$ lifetime, and seventeen people died of it according to the estate death registers. Youngsters were particularly susceptible; in over three-quarters of the recorded 
cases at Mesopotamia, boys and girls were first described as having the ulcers and scabs characteristic of the disease when they were between the ages of two and seventeen. 'Affy suffered from this highly contagious disease for at least four years, and may have spent some time in the plantation yaws house, where patients in the worst shape were quarantined from their fellow slaves on an isolated hill. By 1 lanuary 1785, when she was seventeen years old, Affy was finally on the mend, and the bookkeeper noted "Yaws Recovering" in the health status column after her name. From age eighteen to age thirty she was considered to be in gond health, and was always categorized as "able" or "healthy" in the annual inventories.

During the early 1780s, Affy was moved from the grass gang to the second field gang. Here she was drilled by Cuffee Tippo, an African-born man in his fifties who probably came from the Gold Coast. About half of Affy's fellow workers on the second gang were female, and about half of them were teenagers. She was now performing more strenuous tasks than in the grass gang. She cleaned the pastures and weeded canes, and during the sugar harvest she hauled the discarded cane tops to the cattle for fodder and the discarded cane leaves to the trash house to be dried and used as fuel. Then in the late 1780s, when Affy was around twenty, she was switched from the second to the first field gang. The policy at Mesopotamia in the 1800 s and 1810s, when every field hand was annually identified by gang, was to place almost all of the "able" hands in their twenties and thirties on the first gang, and to relegate almost all of the "weak" or "sick" hands in this age cohort to the second gang. If the same procedure was followed in Affy's case, she worked on the first gang for about a decade, from 1787 through 1797. Two drivers managed the great gang during Affy's time: a pair of men named Francisco and Hector. Francisco, the head driver, took charge of this gang in 1778 at the young age of twenty-seven and remained in command for twenty years until he died in 1798 . His colleague Hector had a remarkable forty-one-year tenure, serving as driver from 1775 when he was thirty to 1816 when he died at the age of seventy-one. And Hector must have been a formidable field boss. In 1797, when Affy was probably working in the first gang. Hector was charged with murdering a fellow slave. He scuffled so strenuously with a field cook named Cudjoe that Cudjoe burst a blood vessel in his brain and died. ${ }^{6}$

The women and men in the first gang were required to perform the most strenuous and hazardous labour on the estate. Working six days a week from 
sunrise to sunset, they did everything in unison and by hand, with no reliance on draft animals or on labour-saving tools. The hardest work of all came during the fall months when they started the next cane crop by excavating four-footsquare cane holes with hoes, and planted these holes with cuttings of old cane stalk. They worked in pairs, each couple digging up to one hundred holes per day, and the two drivers had the job of making sure that every pair kept pace with the work of the others. Once the cane was planted, they replanted cuttings that failed to sprout, and weeded and manured the rows of young shoots. The cane took more than a year to mature, and was harvested starting in January. At crop time the first gang hands cut the ripe canes-now towering three feet above their heads-with sharp curved knives called bills. And having trimmed the cut cane, they hauled it in bundles to the mill where they fed the canes through the mill rollers by hand in order to extract the cane juice from the stalks. This was dangerous work, where accidents and serious injuries were common. Then they stoked the furnaces that boiled the cane juice into crystallized sugar. During crop time, which lasted from four to six months, the first gang hands laboured up to ninety hours per week, including three nights of work per week, because the Mesopotamia mill and boiling house furnace were running twentyfour hours a day.

A good many of the Mesopotamia slaves decided that this taxing agricultural regimen was intolerable. The records identify 112 men and women who fled from the estate at least once between 1762 and 1831; all but eleven of them were field workers, and nine managed to escape permanently. A boy named Sam, who had worked in the overseer's kitchen when Affy was a house girl, began to abscond as soon as he was put into field work. After seven years of capturing and recapturing him, Barham's agents decided to get rid of Sam and sold him to the colony government for $\mathfrak{E} 40$ to be transported off the island as an incorrigible. But this was a drastic step: only three other slaves were sold off the estate during Affy's lifetime. And Affy herself seems not to have been a runaway-perhaps because she had a family of young children at Mesopotamia to care for and to love.

Affy was the mother of six children, and she probably conceived and bore the last five of them while she was a member of the first field gang. Her first child Princess was born in February 1785 when Affy was only seventeen. Then followed Hagar in October 1788, Davy in November 1790, Robert in April 1793, Ann in March 1796, and Rodney in February 1798. In her pregnancies for Hagar 
and Davy, Affy was cutting sugar cane during the first trimester, and in her pregnancies for Robert and Ann she was holing cane pieces during the first trimester. When the overseer discovered that a cane worker was pregnant, he would move her temporarily to the second gang, so that Affy escaped a good deal of the most strenuous labour as her six babies came to term. But she must have been an exceptionally strong woman. Almost half of the other women at Mesopotamia who lived into their thirties and forties had no recorded live births, and those who did become mothers averaged 3.5 births apiece. So Affy had an unusually large family by Mesopotamia standards. Her babies were spaced at intervals of forty-four, twenty-five, twenty-nine, thirty-five and twenty-three months, which suggests that she very likely lost another child between Princess and Hagar. Four of her children were sick with the yaws when young, but all six of them lived to adulthood-and this too was an unusual record at Mesopotamia.

Two of Affy's babies - Robert and Ann - were mulattoes, and the other four were black. This pattern was not unusual; twenty-three slave women at Mesopotamia bore forty-three children fathered by white men between 1762 and 1831 - over ten percent of the total births. In Affy's case, as we shall see, the white father of her son Robert can be identified. But unfortunately the father or fathers of Affy's four black babies cannot be traced. So while we know that Affy was pursued sexually by her white masters, we do not know whether she formed a steady marriage alliance with a slave husband.

Affy's four black children all followed their mother into field labour at a tender age. Princess was ill with the yaws from age two to five, but nevertheless joined the grass gang when she was eight years old, the second gang at twelve, and the first gang at nineteen. Hagar was sickly from birth and afflicted with the yaws at age eight, but she was put into the grass gang at ten, spent a year minding the fowl house (a job reserved for feeble workers), and at nineteen joined the second gang, where she spent the next two decades of her life. Davy, despite being afflicted with the yaws at age five, was in the grass gang at seven, moved on to the second gang at sixteen, and entered the first gang when he was twenty. And Rodney (who escaped the yaws as a young child) was in the grass gang at age six, served for two years as a house boy and eleven years as a cattle boy, and eventually at twenty-three joined the first field gang, where he stayed for the next decade or more. In sharp contrast, Affy's two mulatto children were automatically exempted from their mother's arduous toil as a field hand. The 
Jamaican planters assumed that slaves of white/black parentage were genetically superior to slaves of black/black parentage, and treated them accordingly. None of the fifty-two mulattoes and quadroons who lived at Mesopotamia between 1762 and 1832 ever had to hoe a cane piece or chop down a stand of mature cane. Both Robert and Ann were put to work a little later than their siblings, Robert at age eleven and Ann at ten. More important, Robert entered employment as a house boy and went on to become a skilled artisan in adulthood, while his sister Ann entered domestic service in 1806, and spent the rest of her recorded career working either in the Great House or in the overseer's house at Mesopotamia.

As her six children were entering into the workforce, Affy herself was wearing down in strength and health. In 1798, at age thirty-one, she was described as "weak" for the first time, and was soon shifted from the first gang back to the second gang. In 1801-02, Affy and her teenage daughter Princess were both working on the second gang, Princess on the way up the employment ladder and Affy on the way down. In 1803, Affy was removed from field labour; at age thirty-six she became a washerwoman at the Great House, one of three women employed in cleaning the eight or nine white people's household linen and clothing. Interestingly, another of these washerwomen was a slave we have already met named Doll, whose experiences at Mesopotamia paralleled Affy's to an almost uncanny degree. Both women were born in 1767, started work together as domestics at age seven, spent two decades in field labour, and were now consigned to the same laundry job. Like a great many other women at Mesopotamia, Affy and Doll went through a cyclical labour pattern in which they started relatively easy as children, worked desperately hard as young adults, and sank gradually back into the equivalent of child labour status as their health broke down.

For six years the bookkeepers listed Affy as a washerwoman, and then in 1809 she spent a year as a baby sitter for young children on the estate. With two other women, she operated a Mesopotamia-style day care center, looking after twenty little boys and girls aged two to five while their mothers were at work. These children, according to the estate agent, "are regularly brought up to the house two or three times a week to be inspected and each have had check [cloth] to make frocks for them. ${ }^{8}$ Thus part of:Affy's job was to sew up the costumes that her charges wore. At this date she had no children in her own family to care for. Her six daughters and sons-ranging in age from twenty-four to eleven-were 
all working twelve hours a day, and as yet she had no grandchildren. During 1810 Affy resumed her employment as washerwoman, and she continued to launder her white masters' linen for the next fourteen years, until 1824. There were two buildings at Mesopotamia where laundry was done: a combination cook room and washhouse measuring forty by twenty feet servicing the Great House, and another cook room and washhouse measuring forty by sixteen feet servicing the overseer's house and the bookkeepers' barracks. ${ }^{3}$ The cooks and washerwomen worked together because they could share a stove or stoves when heating their kettles and tubs. Thus Affy's workplace must have been oppressively hot. Throughout this span of years, from her forty-third birthday through her fifty-sixth birthday, Affy was continually described as being in a "weak" or "weakly" state of health.

It was during her washerwoman years that Affy entered the Moravian Church. Since 1760 , Moravian missionaries had been operating a station at Mesopotamia and teaching the slaves the United Brethren's mystical religion of the heart - to love and adore Our Saviour (as they addressed Jesus Christ) by identifying emotionally and physically with His blood, His wounds, and His sufferings on the Cross. ${ }^{10}$ From 1801 to 1808 , Brother Joseph and Sister Rachel lackson were the Moravian missionaries at Mesopotamia. About fifty slave men and women were baptized members of their congregation, though the Jacksons complained that attendance at chapel was very spotty during crop time. To judge by the letters that Brother Jackson wrote to Barham in England, he did his best to help the slaves without openly challenging Barham's attorney and overseer. " Like most Moravian missionaries, on Sundays he preached a doctrine of future rewards, urging the slaves to accept their present subjugation and to look forward to compensatory heavenly bliss in the next world. The Jacksons reported that they were baptizing a few slaves every year, and fortunately we can identify the men and women they brought into the church. During their tenure at Mesopotamia, they kept a fascinating conference bookso called because the missionaries recorded in it their spiritual conferences with Jesus Christ. ${ }^{i 2}$ Every month or so, the Jacksons met with the Saviour by praying and singing hymns to $\mathrm{Him}$, after which they proposed to Him various slave men and women as candidates for baptism or communion.

In June 1808, the Jacksons proposed Affy as a candidate for Holy Baptism. Very likely she was drawn to the plantation chapel because her teenage son Robert was serving as Brother Jackson's attendant in 1807-08. She was one of 
ten baptismal candidates - four slave men and six slave women-proposed by the Jacksons to the Saviour in 1808 . These people ranged in age from thirtyseven to fifty-six, and were mostly-like Affy-in poor health and marginally employed. Five had been born in Africa. And only one of them was actually baptized in 1808. Six waited for several years to be baptized, and three never became members of the Moravian Church.

The most distinctive feature of the Mesopotamia church admission process was that all decisions were made by lot, which the Moravians interpreted as the voice of the Lord. Their standard practice was to place three papers in a tube, one with a favourable message, another with a negative message, and a third that was blank. After mixing these papers, they drew out one of them, which was the Saviour's choice. When the Jacksons first proposed Affy's candidacy on 5 June 1808, they drew out a blank or negative message; the Saviour said "no" to Affy. ${ }^{13}$ Two months later, the Jacksons tried again, and once more the answer was "no". On 23 October 1808, they proposed her a third time, and this time the Saviour said "yes". Affy was now a candidate; the next step was to ask the Saviour for permission to baptize her. But the Jacksons never got this far, because Brother Joseph died in December 1808, and for over two years there were no replacement teachers at the Mesopotamia mission. Finally Brother and Sister Gründer arrived in April 1811. After spending considerable time getting acquainted with the communicants, baptized, and candidates for baptism on the estate, the Gründers on 19 May 1812 asked the Lord if Affy could receive Holy Baptism. The answer was "no". They asked again on 14 July 1812 and 24 February 1813 and 27 April 1813 and 22 March 1814, with the same result. The Gründers described Affy as a faithful attendant at the weekly meetings for candidates, which is doubtless why they kept trying. And finally when they asked for the sixth time on 17 May 1814, the answer was "yes". ${ }^{14}$ So Affy joined the Moravian Church at age forty-seven after six years of trying. She chose "Sarah Affir" as her baptismal name.

During the Gründers' eight year term of service at Mesopotamia, they secured the Saviour's approval for twenty-four new baptisms and fifteen new communicants. They never proposed Sarah Affir as a candidate for communion, perhaps because the Lord had voiced such repeated doubt about her baptism, or perhaps because she was no longer a faithful attendant. Surely the Christian promise of redemption was comforting to this victimized woman, yet most members of her family stood outside the Moravian Church. Among her 
six children and her five known grandchildren, only her son Robert and her granddaughter Jane were recorded as baptized Christians.

In June 1817, Sarah Affir was noticed for perhaps the only time by a record keeper from outside Mesopotamia. The British government directed the Jamaican authorities to compile a complete census of the slaves on the island, so Barham's attorneys provided the name, sex, age, colour, and origin of each slave living at Mesopotamia at this date. Whereas most slaveholders could only guess the ages of their people, Barham's attorneys had solid documentation, which they copied from the most recent inventory of 1 January 1817. But even the Mesopotamia age statements were not completely accurate, since the bookkeepers had neglected to add a year to everyone's age in 1800 and again in 1805 . In the Jamaica slave registration return for 1817, Sarah (identified as "Affy") was stated to be a Negro woman born in Jamaica, aged forty-seven, whereas she had actually just turned fifty. She was one of 321 slaves registered in Mesopotamia, one of 22,659 slaves registered in Westmoreland parish, and one of 345,252 slaves registered in Jamaica. ${ }^{15}$

By the mid-1820s, Sarah Affir had spent almost fifty years in drudge labour at Mesopotamia, mostly in the fields and in the washhouse. In 1824, at age fifty-seven, she became an invalid, incapable of any further work. She had contracted the ugly disease of scrofula, or tuberculosis of the lymphatic glands, and her neck was grossly swollen. In the parlance of the Mesopotamia inventories, Sarah was afflicted with the king's evil-the popular name for scrofula because it was believed that the king of England could cure this disease by touching the affected person's swollen glands.

Sarah's four black children were also wearing down. Princess, her oldest child, who had seemed to be strong like her mother, died very suddenly in June 1811 of the dry bellyache or dry gripes, a disease which produces excruciating cramps in the stomach and bowels. Princess, who had been in "able" health in January 1811, was twenty-six when she died, and in her eighth year of first field gang labour; she had no children. Sarah's second child Hagar was the next to go. While she had never been strong enough to work in the first gang, Hagar spent twenty-four years as a member of the second gang. From 1817 onward she was listed as "weak" rather than "able" in the annual inventories, and starting in 1824 at age thirty-six she began to run away from the estate at frequent intervals. Probably she didn't go very far, just into the wilderness slopes of the Hanover Mountains, where she could hide out for a few days or weeks and then 
return to receive a flogging and resume her labours. In January 1830 , she was discovered dead in a Negro hut. Her white supervisors suspected suicide, which would have looked very bad to the absentee owner, and also to the abolitionist critics of Jamaican slavery had they found out about it. So a jury considered the case and concluded soothingly that Hagar's death was "occasioned by the visitation of God." ió She died at forty-one, and like Princess was childless.

Sarah's two black sons failed more slowly. Davy worked in the first gang for sixteen years, starting in 1811 , but at the close of 1825 , at age thirty-five, he was described for the first time as "weak" rather than "able", and after another year was removed from field work. When the last Mesopotamia inventory was taken on 1 January 1832, Davy was employed as a mason and was "Weakly \& Diseased." He was forty-one years old. And his younger brother Rodney, although still a member of the first field gang in 1832 at age thirty-three, was characterized in the final slave inventory as "Weakly \& Hipshot" - meaning that his hip joint was dislocated. The records do not reveal whether Davy or Rodney had wives or children.

And Sarah Affir herself? She was a survivor. Although she became a permanent invalid in 1824, incapacitated with the king's evil, she was still alive in 1832. And in the final inventory the Mesopotamia record keepers belatedly recognized her by her Christian name. Barham's attorneys grumbled about the nuisance of identifying baptized slaves in the annual inventories, and for a long time they refused to do so. But finally on 1 January 1832 they listed the slaves by their "Original Names" and their "Christian Names" in parallel columns. Sixty-six of the 328 Mesopotamia slaves bore Christian names in the 1832 inventory, and Sarah was now identified both as "Affie" and as "Sarah Affir." Here her story abruptly breaks off. At last report, she was said to be sixty-two but was actually sixty-four. She was entering her ninth year of retirement from labour as an invalid at Mesopotamia, and her state of health was "Weakly."

\section{Robert McAlpine}

To turn from mother to son, the Mesopotamia birth register for 1793 contains the following entry: "April 1. Affie Deliver'd of a Mulatto Boy named Robert." ${ }^{\text {"18 }}$ There were ten births recorded during this year, compared with sixteen deaths, and three of the babies were mulatto. This was a strikingly high number 
sidering that 116 black men between the ages of eighteen and forty-five were living on the estate at the time of Robert's conception, and only seven white men. Though the birth register does not identify Robert's father, the boy evidently knew who he was. When Robert was baptized into the Moravian Church many years later, he chose "Robert McAlpine" as his baptismal name. And there was a white man living at Mesopotamia in the summer of 1792 by the name of McAlpin. One of many Scots who came to Jamaica in the late eighteenth century, Andrew McAlpin worked on the estate as a bookkeeper from July 1790 to November 1796 at the modest salary of $£ 30$ per annum. ${ }^{19}$ Interestingly, another Scot named Robert McAlpin (who was likely Andrew's brother) visited Mesopotamia for four months in 1793, arriving on 30 April and leaving on 30 August. ${ }^{20}$ But Robert McAlpin cannot have been the father, for he arrived a month after the baby's birth, so it appears to be mere coincidence that Affy named her baby "Robert". Or perhaps Andrew McAlpin chose this name; he was probably the clerk who entered the baby's birth into the Mesopotamia records.

Affy had just turned twenty-six when she bore Robert, and she was working in the first field gang. Her fourth child was a sickly little boy, with a very bad case of the yaws, which persisted from age six through nine. He was quarantined from the other slaves during 1801 and 1802, and lived with six fellow patients (five of them young children) in the plantation yaws house on an isolated hill. Here he was nursed by an African-born woman named Lydia, who died abruptly in November 1802 when Robert was probably still under her care. ${ }^{21}$ By the time he turned eleven Robert must have healed sufficiently so that he was presentable to his white masters, because his first job in 1804 was to wait on William Rodgers, who was Joseph Foster Barham II's attorney or estate agent and lived in the Mesopotamia Great House. Here, if not earlier, Robert encountered the facts of life about white power. Nine white people were living on the estate in 1804: the attorney, the overseer, the distiller, the pen keeper, the carpenter, two bookkeepers, the Moravian missionary, and the missionary's wife. Thirty-three slave servants attended them, and this number would have been even larger had the absentee owner been resident in Jamaica. Seven of the Mesopotamia slave servants in 1804 were men, twelve were women, ten were boys, and four were girls. The adults were mostly sickly or elderly and hence incapable of field work. Seven of the servants were mulattoes, mainly children like Robert. At the Great House, he joined a staff of seven domestics headed by 
a woman named Hannah, who had been the Barhams' housekeeper at Mesopotamia for twenty-five years. Robert's mother Affy was also working at the Great House in 1804, in the behind-the-scenes position of washerwoman.

In 1805, Robert had a new job description: "waiting upon the Doctor." He now attended the white doctor who physicked the slaves at Mesopotamia for an annual fee of $6 \mathrm{~s}$. $3 \mathrm{~d}$. per head. The name of this physician is unrecorded, but one hopes that he was more successful than his predecessor John Horsley, who had amputated the leg of a man named Abner, operated on the thorax of a man named Greenwich, and tapped the abdomen of a woman named Love-all three of whom died immediately after his procedures. ${ }^{22}$ The doctor who replaced Horsley was living at Mesopotamia in 1805, which explains why he needed a waiting boy. Robert served him for a year, and then in 1806 attended the overseer, a man named James Brodie Rose. At the overseer's house he joined four other slave domestics: three mulatto children and a black woman named Psyche who had been the Mesopotamia overseer's housekeeper for nearly a decade.

In March of 1806, just before his thirteenth birthday, Robert had a violent fight with a slightly older black boy named Tamerlane, a fourteen-year-old who was starting his apprenticeship training to become a cooper at Mesopotamia. Nothing is known about the circumstances of their quarrel, but Tamerlane (who had started working in the Mesopotamia grass gang at age seven) was very likely resentful of Robert's favored treatment. Both boys knew that the fifteen coopers and carpenters held the choicest slave jobs at Mesopotamia, because their skilled craft work was far less strenuous than field labour and permitted some measure of individuality. Tamerlane got his chance to become a craft apprentice through family connections (his older brother Richard was a carpenter), and he may have worried that mulatto Robert was going to steal his job away. Robert for his part probably saw Tamerlane as an inferior rival. Having served the white managerial elite at Mesopotamia for several years, he may have felt that he really belonged with them, rather than with his black mother and black siblings. When he was eight years old, two mulatto children at Mesopotamia had been manumitted by their father David Forrester, a former overseer, and when he was eleven, two more mulatto children had been manumitted by Patrick Knight, the white carpenter. Knowing of these manumissions, did Robert feel a special rage against his own white father for deserting him and thereby condemning him to a life of perpetual bondage? Whatever the 
reasons, when Robert and Tamerlane had their fight, Robert kicked Tamerlane in the intestines so hard that he killed him. ${ }^{23}$

The jury verdict on Tamerlane's death was that his assailant had committed manslaughter, not murder. Robert had acted unlawfully, but without premeditated malice: it was not a capital crime. But Robert was undoubtedly flogged for destroying valuable property. Slave floggings in Jamaica were frequent and severe. An estate manager named Thomas Thistlewood, who lived in Westmoreland parish a few miles from Mesopotamia from 1751 to 1786, recorded in his richly detailed diary that he flogged most adolescent and adult male slaves in his charge at least once a year, and many of the females as well. Thistlewood routinely ordered fifty lashes for a female slave who stole food, and one hundred lashes for a male slave who committed a similar minor misdemeanour. ${ }^{24} \mathrm{On}$ this scale Robert could have been given more than one hundred lashes for killing Tamerlane.

But Overseer Rose was evidently also interested in rehabilitating the boy, for he assigned him to attend the Moravian missionaries Joseph and Rachel Jackson at the plantation chapel, and there Robert stayed for the next two years. The Jacksons received a salary of $\mathfrak{E 5 0}$ per annum, and had the use of five slaves: three women, a girl, and a boy. In 1807, the women were all former field workers in broken health, and the girl, a twelve-year-old named Wonder, would soon be shifted into field labour. Robert, now age fourteen, was the only mulatto in this group of chapel slaves. Two of the chapel women were baptized, and Robert's mother, as we have seen, was proposed as a candidate for baptism in 1808. But the Jacksons almost never brought teenagers into the church, and they did not propose Robert. Brother Jackson may indeed have taught Robert to read; his successor Brother John Samuel Gründer reported in 1818 that he was keeping school at Mesopotamia with some of the mulatto children. ${ }^{25}$ But if loseph Jackson took an interest in young Robert, his support was brief because he died in December 1808.

After another year as a houseboy, Robert was deemed ready for adult employment in 1810 at age seventeen, and started his apprenticeship as a cooper-the craft he would practice for the remainder of his recorded career at Mesopotamia. When Robert started his apprenticeship, there were ten coopers at Mesopotamia: eight men and two boy apprentices. It was an experienced crew. Head Cooper Redriff had been making casks at Mesopotamia for twenty-seven years, mulatto Robin for seventeen, Chelsea for ten, and Plato for 
nine years. The coopers shared a workshop with the carpenters, of the same dimensions (forty by sixteen feet) as the washhouse and cook room where Robert's mother worked. ${ }^{26}$ Out of crop, the coopers spent some of their time constructing and repairing the fences on the estate, but they never did field labour. And their craft required real skill. Using oak staves imported from North America, Robert and his colleagues constructed huge hogsheads and smaller tierces for sugar containers, and puncheons for storing and shipping the plantation rum. They made hogsheads out of red oak staves and puncheons out of white oak staves. ${ }^{27}$ They steamed and bent the staves to curve properly, cut and bevelled them to join snugly, fastened the staves into grooved cask headings, and bound the assembled casks with iron hoops. In 1810, Mesopotamia produced a record crop, and Robert helped to construct 361 hogsheads and 164 puncheons to hold the sugar and rum shipped to England during that year. ${ }^{28}$ The average Mesopotamia hogshead weighed a little over a ton when filled with sugar, the average puncheon held a little over one hundred gallons when filled with rum. These bulging casks had to be built strongly so that they would not split open when carters and dock workers rolled, tumbled, hoisted or dropped them fully packed. And they had to be sealed tightly so that their contents would not leak out or spoil.

Robert worked mostly as a barrel maker for the next two decades. In 1812 and 1813 , he was switched temporarily to the carpenters' crew, but from 1814 onward he was back with the coopers. If he worked alone, he must have constructed nearly a thousand casks during the 1810 s and 1820s. Head Cooper Redriff died in 1816, and the other senior coopers also soon died or retired, so that Robert's crew was suddenly much younger and less experienced. In 1817, the eight coopers at Mesopotamia (half of them mulattoes) were on average twenty-five years old, with only five years' experience at cooperage. No one immediately replaced Redriff as supervisor; Robert was too junior for the post in 1816, and six years later he was passed over. In 1822, the overseer selected a twenty-five-year-old mulatto named William Prince as the new Head Cooper. Robert henceforth worked under the direction of a boss who was four years his junior and had started his craft training three years later.

In 1817, Robert was reported in the Jamaica slave registration return, like his mother. Identified by first name only, like all of the other Mesopotamia slaves, he was stated to be a mulatto man born in Jamaica, aged twenty-one, whereas he had actually just turned twenty-four. ${ }^{29}$ Unhappily, neither the 
Jamaican slave registration returns nor the Mesopotamia records tell us anything about Robert's personal life when he was in his young manhood. We do not even know whether he married or had children! The records tell us a little more about his mulatto sister Ann, who worked and perhaps lived from 1811 onward in the overseer's house. Unlike Princess and Hagar, Ann started having babies when she was very young. In May 1814, when she had just turned eighteen, she bore her first child, a girl named Jane who was categorized as a "quadroon", meaning that one parent was mulatto and the other white. When Jane was later baptized into the Moravian Church, she took the name "lane Ritchie", indicating that her white father was a certain Dr. Ritchie who doctored the slaves at Mesopotamia when she was conceived. Dr. Ritchie may well have also fathered Ann's second child, another quadroon named John, who was born in October 1816 when Ritchie was still employed on the estate. ${ }^{30}$ After a nearly five year interval Ann bore a mulatto girl named Mary in May 1821, an unnamed mulatto boy who died when nine days old in March 1824, a black girl named Selena in March 1825, and a black boy named Peter Foster in August 1828. The father or fathers of these last four children are unknown, and it is unclear why Ann chose the surname "Foster" for her last-born child; was it perhaps after her master, Joseph Foster Barham II, whom she had never seen? At any rate, Robert now had five nephews and nieces, who were all alive and well at last report in January 1832.

In 1826, Robert turned thirty-three. The spring and summer of this year was a time of exceptionally wet humid weather and debilitating sickness at Mesopotamia. In May and June more than one hundred slaves were hospitalized with influenza, pleurisy, and bowel cramps-a third of the population-and the cane fields were nearly deserted, so that the crop season dragged on much longer than usual. Whether Robert took sick is unknown, but nineteen slaves were buried in 1826, including the head driver and the head boiler. A watchman named Mingo was tried at the quarter sessions and ordered transported off the island as an incorrigible deserter. And one of the carpenters fell fifty feet from the coconut tree he was climbing and broke his neck. ${ }^{31}$ In July of this dismal year, Robert had another violent fight, this time with Head Distiller Peter, a thirty-seven-year-old black man. The two men quarreled over a debt of two bits that Peter owed Robert and had failed to pay. A bit was a Spanish coin worth approximately fourpence. Two bits was not a vast sum of money, even for a Mesopotamia slave. For example, Thomas Thistlewood, the diarist who re- 
corded the floggings administered to his slaves, generally paid one or two bits to a slave woman after fornicating with her-one bit to a woman from his own estate, and two bits to a neighbour's slave. A pregnant woman at Mesopotamia was paid a bonus of $\mathfrak{1} 1$, thirty times the value of two bits, if she delivered a live healthy baby. Robert and Peter probably both earned several pounds a year in tips or for extra work. So it seems likely that Robert's rage was triggered by something other than Peter's two bit debt. Perhaps both this quarrel and his clash twenty years earlier with Tamerlane were fueled by mulatto versus black hostility.

Robert attacked Peter with the handsaw he used to cut and trim barrel staves, struck him three times on the arm before he could be restrained, and appeared ready to kill the man. Barham's attorney reported that Peter was laid up in the crowded estate hospital, and his injuries proved to be so severe that he had to quit his distillery job and shift into the second field gang. Robert was incarcerated after this vicious assault, and brought to trial before the Westmoreland magistrates, who sentenced him to a flogging of thirty-nine lashes and a month of hard labour in the parish workhouse. ${ }^{32} \mathrm{He}$ was no doubt flogged publichy, in the presence of the entire Mesopotamia slave community. But this mould have been small consolation to Peter, who never recovered from his injuries, and died in 1827. For the second time, Robert McAlpine had caused the death of a fellow slave.

One wonders what Peter's brother, a black carpenter named Dundee, said to Robert after he was released from the workhouse. Or how he was greeted by his eight fellow coopers, seven of whom were black in 1826. Morale was deteriorating on the Mesopotamia coopers' crew. Cooper Toswell, who had run away for nine months in 1824, disappeared permanently in 1827. In this same year Cooper James also absconded for a while, and the bookkeeper noted that he was "ill disposed". Robert was never reported to be "ill disposed" by his white masters, and there is no indication that he ever ran away, but his workload was becoming increasingly burdensome in the late 1820 s. No new young apprentices had been recruited into the coopers' crew for many years, and by 1831 Robert and his colleagues were forty-four years old on average, whereas they had been only twenty-five years old back in 1817. All of them were still listed in "able" health as late as 1826 , but four of them were reported to be sick or weak by 1829 . Robert himself, having enjoyed continuous good health throughout his working career, began in 1827-at age thirty-four-to develop the skin 
ulcers and sores that had plagued him as a little boy. Once again he was coming down with the yaws.

Sometime between 1818 and 1832, Robert was baptized into the Moravian Church. There is no surviving record of his baptism, but he was listed among the sixty-six baptized slaves in the final Mesopotamia inventory of 1 January $1832 .{ }^{33} \mathrm{He}$ was identified by the "Original Name" of " $\mathrm{M}^{\mathrm{O}}$ Robert ${ }^{\mathrm{n} 34}$ and the "Christian Name" of "Robert McAlpine." Thus Robert announced his claim to the bloodline of the white father who had deserted him long ago. But doubtless he felt envious of Henry Patrickson, a mulatto carpenter twelve years his junior, whose father had been a bookkeeper at Mesopotamia. Around 1830, Patrick-

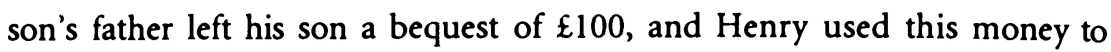
purchase his freedom from Joseph Foster Barham II in 1831, while Robert McAlpine remained a slave. ${ }^{35}$

At last report, on 1 January 1832, Robert was said to be thirty-six years old (actually thirty-eight), he was entering his twenty-first year as a cooper at Mesopotamia, and his health problem in one pithy word was "Sores." His thirty-five-year-old sister Ann was in better condition, still in "Able" health and still employed as a domestic servant in the overseer's house. Her two youngest children were not yet working, but ten-year-old Mary was serving in the Mesopotamia Great House, fifteen-year-old John was working alongside his mother in the overseer's house, and seventeen-year-old Jane Ritchie was an attendant in the Moravian chapel. These privileged slave children were repeating the pattern of their uncle Robert's youthful employment all over again.

As with Sarah Affir, here the story of Robert McAlpine abruptly breaks off. We know far too little about this mother and son, including their physical appearances, personal voices, relationships, beliefs, and hopes. Not to mention what happened to them-presuming that they were still alive in 1838-when the apprenticeship period initiated in 1834 came to an end, and the Jamaican slaves became fully free at last. But through the year-by-year skeletal outline of their careers at Mesopotamia, we can observe slavery in action on this sugar estate, and sense its harsh configurations. Though the bookkeepers' notations were always maddeningly formulaic and abbreviated, Sarah Affir's story clearly documents the brutal impact of sugar labour upon this strong woman and her four black children. Nothing came easy for Affy, including admission into the Moravian Church. And yet she exhibited remarkable powers of human endurance. Comparing mother with son highlights the differences between the career 
patterns available to black women and mulatto men. Robert McAlpine's story shows what it was like to be a "privileged" slave who spent his boyhood in personal attendance on his white masters, and was given the most attractive adult slave employment on the estate. Yet Robert reacted to his condition with acute frustration and blind rage. And small wonder. For even the most privileged slaves at Mesopotamia were trapped into a dehumanizing life of exhausting labour, debilitating disease, and demeaning social relationships. This was the essence of slave life on a sugar estate in Jamaica.

\section{NOTES}

1. The Barham Papers (hereafter cited as Barham) are filed in the Clarendon Manuscript Deposit, Bodleian Library, Oxford. The eighty-five Mesopotamia inventories are mixed among other business records in five boxes, itemized as $b$ 34-38. They are dated 1736, 1743-44, 1751-52, 1754-1820, 1822-32. Two inventories were taken in 1756, 1762, and 1802. 1 wish to thank the Earl of Clarendon for permitting me to use these Mesopotamia records.

2. The term "privileged" may seem inappropriate for any slave, but I use it in this essay to indicate that the white management at Mesopotamia systematically treated mulatto slaves differently from black slaves. Mulattoes were the only slaves eligible for possible emancipation; mulatto children were always employed as personal attendants to their white masters; and mulatto adults were always assigned to what the whites considered to be the most attractive adult slave jobs.

3. The Mesopotamia birth register for 1767 is included in the slave inventory dated 31 December 1767, Barham b 37. The record keepers missed a fourth infant, Nancy, also born in 1767, who lived on the estate until her death in 1819 .

4. I have described the agricultural regimen at Mesopotamia in two essays: "Dreadful Idlers' in the Cane Fields: The Slave Labor Pattern on a Jamaican Sugar Estate, 1762-1831," Journal of Interdisciplinary History 17 (Spring 1987): 795-822; and "Sugar Production and Slave Women in Jamaica," in Cultivation and Culture: Labor and the Shaping of Slave Life in the Americas, ed. Ira Berlin and Philip D. Morgan (Charlottesville: University Press of Virginia, 1993), pp. 49-72.

5. Mesopotamia males had a somewhat higher incidence of yaws than females, with 100 out of 166 recorded cases between 1762 and 1831. This was the standard pattern: see Richard B. Sheridan, Doctors and Slaves: A Medical and Demographic History of Slavery in the British West Indies, 1680-1834 (Cambridge: Cambridge University Press, 1985), pp. 83-85. 
6. Cudjoe's death is reported in the inventory for 1 January 1798 , Barham b 34 . The case was considered by a local jury who acquitted Hector of murder.

7. Of the twenty-nine women identified as running away from Mesopotamia at least once, twenty-one were childless and another seven had been brought to the estate late in life from other Jamaican plantations, after their children (if they had any) were grown. Just one woman is known to have abandoned her young child: Dido, who became "evil disposed" after she was sent to the workhouse in 1825 , left eight-year-old Georgiana behind when she fled Mesopotamia in 1831.

8. Annotated description of the Mesopotamia slave population, June 1802, Barham b 36. According to the inventory of 1 January 1810 (Barham b 36), there were sixteen working mothers on the estate with twenty-two young children aged two to five who needed looking after. Two of these children were cared for by their grandmother, and the other twenty by the three nurses.

9. The two kitchen-washhouses are described in "The Present State of the Buildings on Mesopotamia Estate," 1 June 1814, Barham b 34.

10. For background discussion of Moravian missionary efforts around the world, see J. Taylor Hamilton and Kenneth G. Hamilton, History of the Moravian Church: The Renewed Unitas Fratrum, 1722-1957 (Bethlehem, Pa.: Moravian Church in America, 1967).

11. Joseph Jackson to Joseph Foster Barham II, 7 November 1804, 6 May 1805, 17 December 1805, Barham c 378.

12. Minutes of Mesopotamia Conference, 1798-1818, Moravian Archives of Jamaica, Fairfield R/l, Jamaica Archives, Spanish Town. This book was kept by three successive pairs of Mesopotamia missionaries: Brother and Sister Brown in 1798 . 99, Brother and Sister Jackson in 1801-08, and Brother and Sister Gründer in 1811-18. Professor John W. Pulis of Dowling College found this minute book in the Jamaica Archives, and very kindly photocopied it for me.

13. While the standard Moravian practice was to use three papers, the Jacksons may have used only two, since forty-six percent of the answers they obtained between 1801 and 1808 were "yes". For discussion of the Moravian use and manipulation of the lot, see Gillian Lindt Gollin, Moravians in Two Worlds: A Study of Changing Communities (New York: Columbia University Press, 1967), ch. 3.

14. Minutes of Mesopotamia Conference, 1798-1818, pp. 35-36, 42-43, 45-46, 49-50.

15. The Mesopotamia return for 28 June 1817 is filed among the Westmoreland parish slave registration returns for 1817 in T71/178, Public Record Office, London. Barham's attorneys made subsequent slave registration returns in 1820, 1823, 1826, 1829 and 1832, but since these only list triennial births and deaths they provide no further information about Affy. For background on the Jamaican slave registration, see B. W. Higman, Slave Population and Economy in Jamaica, 1807-1834 (Cambridge: Cambridge University Press, 1976), pp. 45-46, 256.

16. So reported in the death register accompanying the 1 January 1831 inventory, Barham b 35. 
17. John Blyth and J. C. Grant complained to Joseph Foster Barham II on 17 October 1819 (Barham c 358) about the slaves' desire to have their "Christian" names recognized. The 1 January 1832 Mesopotamia inventory is in Barham b 35.

18. This birth register is in the inventory for 1 January 1794 , Barham $b 36$.

19. Andrew McAlpin (also spelled "McAlpine") is listed as a bookkeeper in the inventories of 1791-97 (Barham b 36), and his initial salary is reported in the plantation accounts for 1790-91 (Barham b 33). Andrew could also have fathered Affy's mulatto daughter Ann, since he left Mesopotamia eight months after her birth in March 1796. But Ann's father cannot be traced, because Ann never adopted a surname that surfaced in the estate records.

20. Robert McAlpin's short stay is recorded in the inventory for 1 January 1794 , but his employment (if he had any) is not stated.

21. A local jury explained forty-eight-year-old Lydia's death as "a visitation by God"the same verdict they reached when Robert's sister Hagar died in 1830 (see n. 16 above). Robert and the other inmates of the yaws house are identified in an unusually full and detailed description of the Mesopotamia slave population, drawn up in June 1802 (Barham b 36).

22. Horsley was paid $£ 136 \mathrm{~s}$. 8d. for these operations; he looked after the whites on the estate also, and was paid a total of about $£ 125$ per year for his medicines and attendance, according to the estate accounts for 1802 in Barham b 34 . See also William Rodgers to Joseph Foster Barham II, 5 July 1802, 11 March 1805, Barham c 357.

23. My interpretation of this episode is frankly conjectural. The Mesopotamia death register for 1806 reports that Tamerlane was kicked and killed "by a mulatto boy." Robert seems to me the most plausible candidate, but there were four other mulatto boys at Mesopotamia in March 1806 who could have done the deed. The oldest of them, Alexander, a seventeen-year-old carpenter, seems unlikely because he had been badly ruptured from the age of six. John, a twelve-year-old waiting boy, was likewise in poor physical shape and had recently been hospitalized with the yaws. Andrew, an eleven-year-old apprentice carpenter, was a lot younger than Tamerlane and hence an unequal combatant. And fourteen-year-old Thomas had attended Brother Joseph Jackson at the Moravian chapel for the past five years; if he imbibed any of the Moravians' pacifist teachings from Jackson, he too seems an unlikely candidate. Thomas traded places with Robert in 1807, Thomas moving to Robert's job in the overseer's house and Robert moving to Thomas's job at the Moravian chapel.

24. I derive these comments from my reading of the Diaries of Thomas Thistlewood, 1750-1786, Monson Manuscript Deposit 31/1-37, Lincolnshire County Archives, Lincoln.

25. Gründer claimed that three of his mulatto pupils at Mesopotamia "can read now pretty well"; John Samuel Gründer to Christian Ignatius Latrobe, 20 March 1818, Moravian Church House Archive, London. 
26. "The Present State of the Buildings on Mesopotamia Estate," 1 June 1814, Barham b 34; annotated description of the Mesopotamia slave population, June 1802, Barham b 36.

27. Between 1806 and 1811, Barham's attorney in Jamaica paid $£ 1,599$ for oak staves imported from America. When Barham objected to paying so much for imported lumber, the attorney explained that local Jamaican timber could not be coopered; it was too green when newly cut, and too brittle when dried. J. R. Webb to Joseph Foster Barham II, 27 July 1812, Barham c 358.

28. The Mesopotamia crop account for 1810 is in Barham b 34. The sugar and rum exported to England from the estate that year was valued at $£ 16,957$.

29. The Mesopotamia slave registration return for 28 June 1817, T71/178, Public Record Office, London.

30. Jane was probably baptized after she became an attendant at the Moravian chapel in 1830 . Her brother John had no recorded surname.

31. William Ridgard to Joseph Foster Barham 11, 17 February, 2 May, 10 May, 12 May, 9 June, 7 July 1826, Barham c 359. The death register for 1826 is in the 1 January 1827 inventory, Barham b 35.

32. William Ridgard to Joseph Foster Barham II, 4 August 1826, Barham c 359.

33. This inventory is in Barham b 35. A few months after this inventory was taken, Joseph Foster Barham II died, and his son John Foster Barham succeeded him as the absentee owner of Mesopotamia. But John never visited Jamaica and took little interest in his property there-which is why the slave records for the estate terminate in 1832. When John Barham died in 1836, his heirs sold Mesopotamia.

34. "M $\mathrm{Mm}$ is an abbreviation of "mulatto".

35. Patrickson was not fully liberated in 1831; he had contracted to pay $£ 140$ for his freedom and still owed $\{40$, so the estate attorney kept his manumission papers in escrow. William Ridgard and Duncan Robertson to Joseph Foster Barham II, 17 July 1830, Barham c 360; Ridgard and Robertson to John Foster Barham, 7 November 1832, Barham c 389. 


\title{
11
}

\section{Patterns of Exchange within a Plantation Economy:}

\author{
Jamaica at the Time of Emancipation
}

\author{
B. W. HIGMAN
}

The plantation-economy model has provided one of the central concepts of Caribbean historiography. As an organising paradigm it perhaps reached its peak in the 1960s, finding most complete expression in the work of Lloyd Best and George Beckford who used the data and ideas of historians to formulate an articulated econometric model. ${ }^{1}$ According to this model, the plantation was strictly monocultural and export-oriented, a total institution whose vital linkages were with the external, non-Caribbean world. Any forms of exchange within the colonial economies were seen as minor aspects of the system and, in any case, always ultimately directed towards production for trade with metropolitan markets rather than for local consumption. The history of consumption has in consequence developed around metropolitan themes, with little attention paid to what happened in the islands. ${ }^{2}$

This picture of plantation economy is now generally regarded as too constrained to illustrate accurately patterns of exchange within the Caribbean. The role of external trade remains central, of course, but historians have come to recognise a much more complex network of internal exchange, involving movement of commodities and people, and the construction of mechanisms governing such transactions that did not necessarily fall within the system of plantation accounting. ${ }^{3}$ One level of the system of internal exchange during the period of slavery directly involved independent production and consumption by the slaves, through the provision ground and internal marketing systems, 
creating what Richard Sheridan has termed a "dual economy." ${ }^{4}$ A second was the movement of plantation products to local merchants for internal sale. ${ }^{5}$ Third and equally important was exchange between planters and other rural landholders. Exchange at this level was in some cases a matter of reciprocal gift-giving, an extension of the hospitality of slaveowners one to another. ${ }^{6}$ In other cases exchange depended on the movement of commodities and people between different types of economic units, a trade designed to provide goods and services at market prices. This type of exchange worked in part to provide inputs for the production of plantation export staples, but it also served local consumption and offered possibilities for the development of a "creole economy." ${ }^{77}$ it this variety of internal exchange-the trading of rural landowners/slaveowners one with another-that provides the focus for the present paper. In isolating this topic for particular study, the linkages with other types of exchange are not meant to be diminished. All of the forms of exchange must be seen as part of an interlocking system, but the plantation-based level of the system has suffered relative neglect, to the extent that the "internal marketing system" has come to designate only a limited part of the whole pattern of internal exchange.

Jamaica was the Caribbean colony best known for all of these types of exchange. In part, this resulted from the island's relative size and environmental diversity. Thus sugar failed to cover the land in the way it did elsewhere in the region, and the variety of produce of the different ecological zones provided a basis for exchange. In 1832, immediately before the abolition of slavery, only slightly more than half of the slave population of Jamaica actually lived and worked on sugar estates, whereas fourteen percent were on coffee plantations, thirteen percent on livestock pens, seven percent on plantations producing minor staples (pimento, cotton, ginger), and eight percent lived in the towns. The labels estate and plantation had very specific meanings at this time: "estate" was used exclusively to name sugar-producing properties, and served to give them status, whereas "plantation" covered all other agricultural enterprises cultivating export staples. Land use patterns were strongly regionalised, but there was a significant spatial intermixing of the productive units, resulting in both long and short distance exchange within the island.

Much of the data available for the study of exchange within the Jamaican plantation economy is impressionistic, anecdotal or individual. Trade of this sort did not normally enter the official record, because it did not pass through 
customs-houses or become subject to state scrutiny. But Jamaica does possess what Richard Sheridan has rightly called "a remarkable body of materials for the study of colonial history," including the Accounts Produce or crop accounts. ${ }^{9}$ From 1740 to 1927 the agents of plantation owners who were absentees, minors, lunatics, heirs, or otherwise not directly managing their properties, were required to make annual returns to the Island Secretary, listing all goods and services sold within the island or shipped for sale, and the quantity of the year's output left undisposed at the date of the return. ${ }^{10}$ The value of these accounts thus varies from period to period, depending on the proportion of absentee-proprietorship. By the end of the eighteenth century, absenteeism was very common in sugar, so that a detailed picture can be obtained for that leading sector. In 1832, immediately before emancipation, the Accounts Produce of Jamaica included 960 properties on which lived fifty-eight percent of the island's rural slave population. ${ }^{11}$ Of these 960 properties, 540 were sugar estates accounting for roughly eighty percent of that sector. Thus the pattern of exchange derived from the Accounts Produce remains weighted towards sugar.

\section{Trade in livestock}

The best known form of exchange in the Jamaican plantation economy was that linking sugar estates with pens. Planters preferred to raise their own working livestock or at least to maintain a Guinea grass enclosure to feed their mules and serve as a nursery for reduced, lame or fattening stock. But some estates lacked land suited to grass and in such cases the planters generally looked for nearby sites, too poor for cane, to establish pens. These integrated or "satellite" pens were worked by the estates' slaves and the produce rarely entered the economy of account. ${ }^{12}$ In some cases estate and pen were separated by considerable distances. For instance, Rose Price owned both Worthy Park Estate in the parish of St. John and Spring Garden Pen more than ten miles to the south in St. Dorothy although on the main road from the estate leading through Guanaboa Vale (Figure 1). In 1832 there were 491 slaves at Worthy Park and 79 at Spring Garden; but there were 373 head of taxable livestock at the pen and none on the estate. (The "taxable livestock" included every horse, gelding, mare, colt, filly, mule-colt, and follower of breeding cows, and every young steer for sale; exempt were the working stock of estates and plantations-mules, spayed heifers and planter's steers). ${ }^{13}$ The pen sent forty steers and twenty-five spayed 


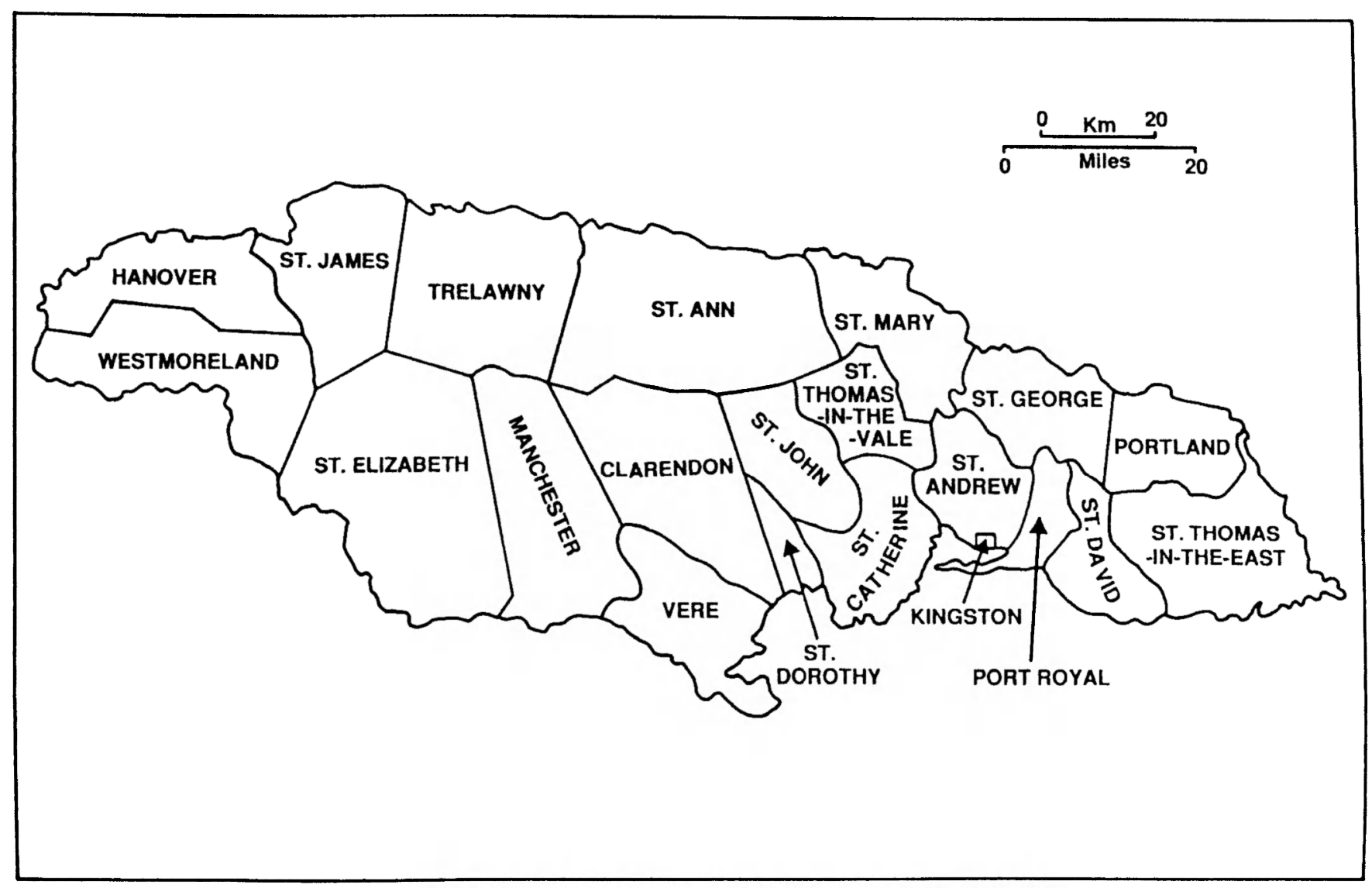


heifers to the estate, as well as sixty bushels of corn. In return the estate sent forty-six old cattle to the pen to fatten, and during the year the pen sold 106 fat cattle to butchers. Sugar and rum were sent from the estate for consumption on the pen. ${ }^{14}$ Worthy Park made 589 hogsheads of sugar and 248 puncheons of rum in 1832, an output equalled by only one or two estates, so the volume of estate/pen exchange was relatively large, as was the distance separating the two units. Normally, where planters owned both pen and estate the units were not much more than five miles apart.

Sugar planters who lacked viable pastures within the boundaries of their own estates and did not establish separate pens, generally purchased their working livestock (steers, spayed heifers and mules) from local penkeepers. By 1832, livestock imports were minor and directed mainly at the urban market for horses. ${ }^{15}$ Occasionally, working stock were moved from plantations to estates, but it was the movement from pen to estate or plantation that dominated the pattern of exchange, demonstrating a significant degree of specialisation. There was also some movement from pen to pen, but most of this involved breeding stock, especially stud bulls. ${ }^{16}$

A more complete understanding of the pattern of movement of working livestock can be obtained by mapping the 1832 Accounts Produce data for four parishes: St. James, Trelawny, St. Elizabeth and Manchester (Figure 2). These parishes were not representative of Jamaica as a whole, but they were diverse in terms of their physical environments and land use patterns. Sugar estates occupied the coastal zones of St. James and Trelawny, and the northern region of St. Elizabeth, whereas coffee dominated Manchester. The pattern of exchange shown in Figure 2 includes all of the properties located in the four parishes which sold working livestock in 1832; if the purchasers are not named in the records only the selling property is identified, and no attempt has been made to quantify the flows. Although much of the movement involved only short distances, a considerable number of cases extended more than ten miles. No major supply or demand regions seem to emerge. A great amount of line crossing occurs in Figure 2 and this may be used as an index of the complexity of the pattern: although the cost of moving working livestock was high, the estates and plantations generally chose to purchase from particular pens where the breeds and types they preferred were available. This applied especially in St. Elizabeth and Manchester, but on the north coast the pattern was much simpler. Here the planters purchased from relatively nearby pens, most of which were 


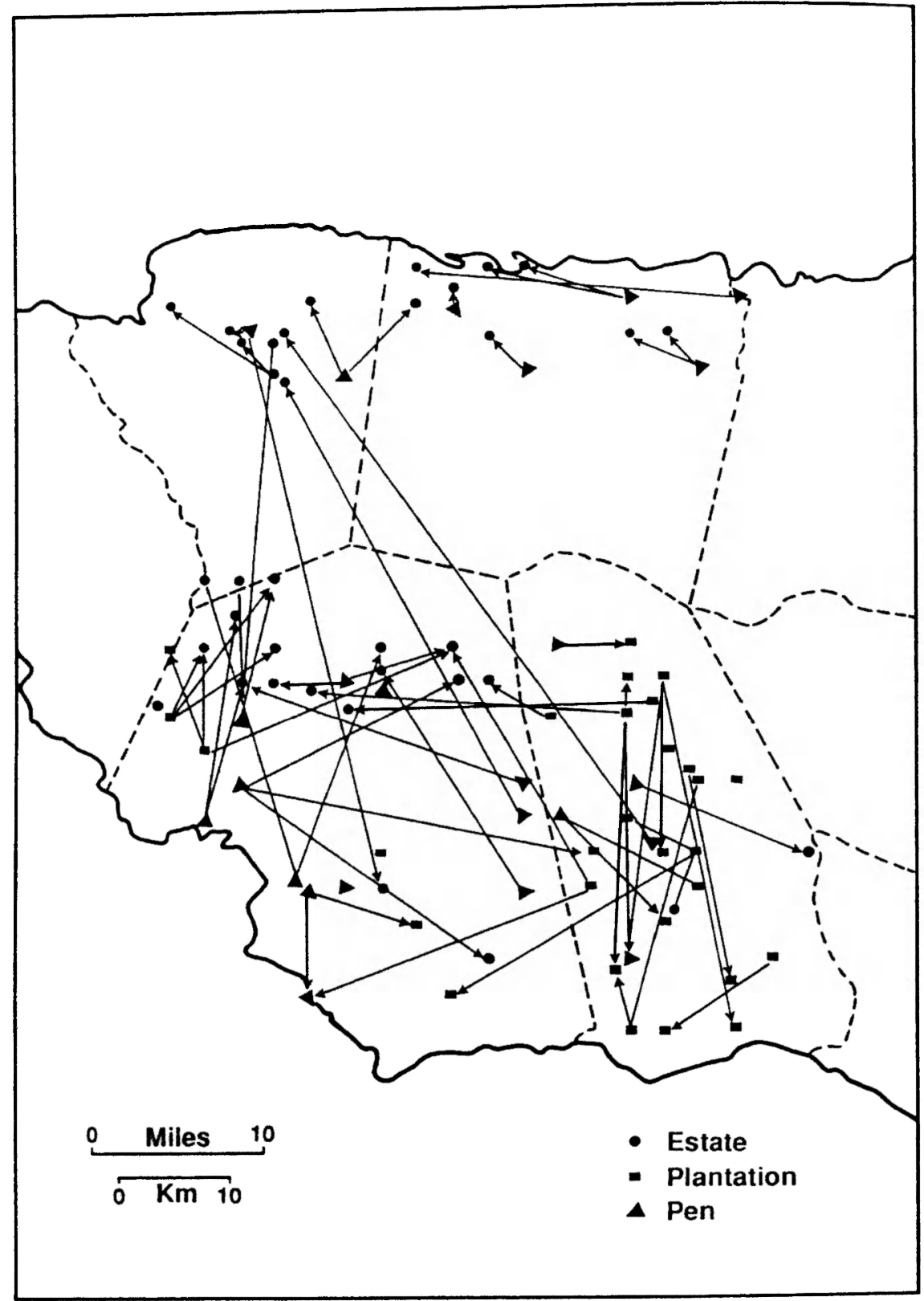

Figure 2: Sales of working livestock, 1832: St. James, Trelawny, St. Elizabeth and Manchester 
located in the poorer, elevated backlands. Whereas the purchase of livestock was common in St. Elizabeth and Manchester, the northern parishes had a much denser network of joint-owned pens thus reducing the demand through purchase. ${ }^{17}$ There is no doubt that the demand for working livestock was considerable in the northern sugar zone. Although some estates in Trelawny used wind and water power in their mills, the majority had auxiliary cattle mills, and all estates needed working stock to haul canes and sugar. Probably a good deal of this demand was satisfied by penkeepers in neighbouring St. Ann, avoiding the necessarily long routes around the impenetrable Cockpit Country of southern Trelawny. ${ }^{18}$ The movement of working livestock from independent pens to estates and plantations seems to have been at a maximum in the most diversified regions rather than forming a strong flow from stock-breeding regions to regions cropping export staples.

Old, lean or meagre cattle were sold by the estates, and occasionally by plantations, to pens which fattened the animals and then sold them to butchers. A map of these movements for the four parishes has been published elsewhere. ${ }^{19}$ In some cases the pattern was simpler, with the estates selling stock direct to the butchers; this was particularly common in Trelawny, giving further support to the view that the sugar estates in that parish were relatively self-sufficient in livestock production and maintenance. Some animals, such as sheep and vealers, never entered the system of exchange since they were bred and fattened on the pens specifically for the production of meat. Old mules, at the end of their working lives, could rarely find a purchaser. But for cattle, the end of the cycle generally came with the sale of their meat in the port towns or to the whites on the estates, and the export of their hides. Thus the typical pattern was as follows: the pens raised stock from their studs, some of which was killed for meat while young and some of which was sold to estates and plantations to work as beasts of burden or draught; when the working cattle became old or lame they were sold to pens where they were fattened and then sold to butchers who slaughtered them and retailed their meat and hides to estates and townspeople.

The spatial pattern of movement which resulted from the fattening and killing stages of this cycle was marked by some definite functional regions. The foci of these regions were pens, butcheries and towns. On the north coast in particular there were a number of pens which collected old stock from considerable numbers of estates. ${ }^{20}$ There was also a good deal of movement from Trelawny to pens in Manchester. Thus stock was often made to travel fairly long 
distances to the fattening pens, but once fat they were walked as little as possible. Consequently, whereas there was some line crossing in the movement of fattening stock, there was very little in the movement to butcheries. The supply areas of the butcheries approximated classical nodal regions, with fat stock moving to the nearest butchery in almost every case. Hence sellers of fat stock were faced with a limited number of potential purchasers and this often encouraged them to set up their own butcheries. ${ }^{21}$ The port towns were the most important markets for meat, since they contained the greatest populations of whites and provisioned shipping. These urban markets obtained a good deal of their livestock direct from estates, cutting out the fattening pens completely.

Between 1815 and 1832, the number of taxable livestock in Jamaica decreased from 218,306 to $138,527 .^{22}$ The penkeepers deplored this decline and attributed it to the freedom given to the entry of foreign cattle. In 1831, a duty was levied on all horned cattle imported for sale from countries other than Great Britain and Ireland. ${ }^{23}$ This effectively reduced the level of imports, but the planters claimed the measure gave an undue preference to the graziers and argued for "fair competition" in trade. The penkeepers, on the other hand, contended that the cattle farms and the livestock attached to estates and plantations produced a very considerable revenue for Jamaica, and believed

the prosperity of this island to depend most materially on the encouragement of the internal consumption of articles manufactured or reared therein, as the monies raised from the sale of such articles not only keep a circulating medium therein, and enriches its inhabitants, but enables them to purchase foreign manufactures, by which traders and merchants receive a corresponding advantage. $^{4}$

This statement clearly illustrates the competition between penkeeper, planter and merchant, as well the struggle between imperial and creole/colonial ideas, and the conflicting interests of residents and absentees. Contemporary observers aligned with the absentee-planter class regularly vilified the penkeepers, placing the internal trade of Jamaica in a context of fraud and deceit. Thus Benjamin McMahon, in his Jamaica Plantership published in 1839, claimed that the penkeepers were "generally either attorneys, or old overseers, who made their fortunes while in charge of properties belonging to their absentee proprietors. ${ }^{\text {"25 }}$ Once established on their pens, they entered into collusion with the attorneys in order to further line their pockets at the expense of the absentees:

This arrangement is made on a very liberal scale, to suit the interests of both the parties concerned. Some of the meagre working stock, belonging 
to the estates, have to be sold annually. The estates' attorney sells these to the pen-keepers at a couple of pounds under their intrinsic value; after which he purchases, from the same pen-keeper, cattle and mules for working on the estates under his charge; and for these he agrees to give two or three pounds more than their value ... Immediately after this, the worthy estate's attorney selects for himself some fine bred horses and draft mules. He takes them at the same price as what he paid for the common mules for the estates; and, in a month or two after, he sells them for three times the amount he paid for them . . . Such transactions are termed in Jamaica, "hand go, hand come;" meaning, if you assist me, I will assist you. ${ }^{26}$

There is no doubt that some absentees were concerned that their attorneys seemed to be buying large numbers of livestock. ${ }^{27}$ On the other hand, Thomas Roughley argued that many planters were parsimonious, rejecting the overseers' valid requests for new teams of cattle. ${ }^{28}$ The kind of horse and cattle trading described by McMahon may have been common but it was not the raison d'être of Jamaica's internal trade.

\section{Trade in goods}

In addition to the highly visible exchange of livestock, there was a significant internal trade in sugar, rum and coffee. Most transactions in these commodities involved sales by estates and plantations to urban merchants and shopkeepers, however, so that it is often difficult to identify and locate the final consumers. Apart from sales to the towns, ${ }^{29}$ most of the individual transactions were small, and even if it was possible to map them all, the result would be a complex maze of criss-crossing lines. An example of the pattern that would emerge is provided by Mexico and Oxford Estates in the Nassau Valley of St. Elizabeth (Figure 3). In 1832, Mexico exported 128 hogsheads of sugar but sold five within the island, exported forty-two puncheons of rum and sold nine locally; the locally-sold sugar and rum went to thirteen pens and plantations. Oxford exported 160 hogsheads of sugar and sold seven within Jamaica, and exported forty-one puncheons of rum and sold thirty-three locally, the local sales going to seventeen pens and plantations. Although the markets of the two estates overlapped considerably at their margins, they also had special areas to the east and west. These two estates were taking advantage of the diversity of land uses in their region, but even the sugar estates on the monocultural north coast sold a significant quantity of sugar and rum within the island. For example, Ironshore 


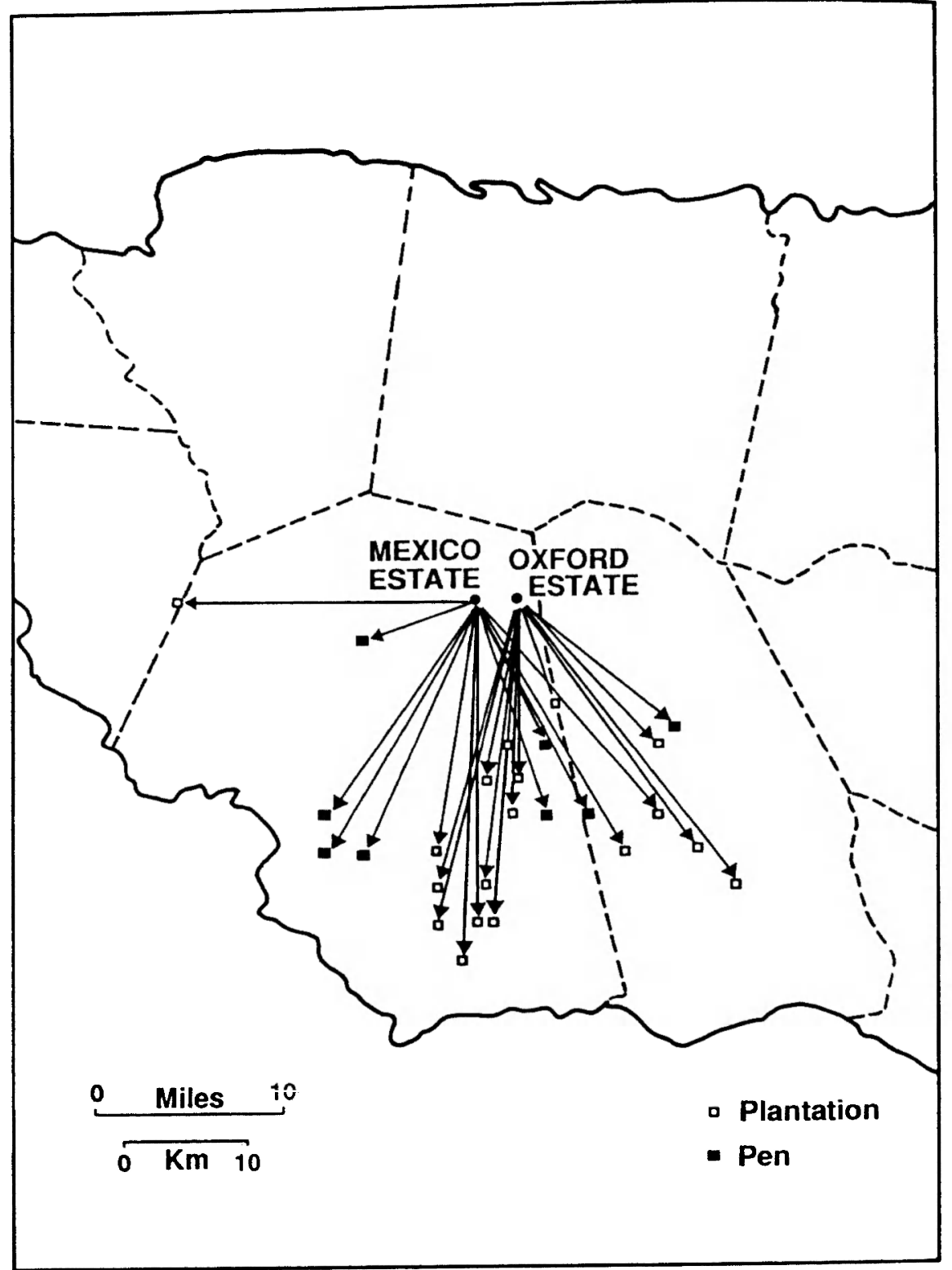

Figure 3: Sugar and rum sales, 1832: Mexico and Oxford Estates, St. Elizabeth 
Estate in St. James, close to Montego Bay, exported all of its sugar but sold all its rum within the island: the equivalent of thirty-four puncheons of rum were sold to a Kingston merchant, and seventy-three puncheons were disposed of in small lots to individuals, most of whom lived in Montego Bay. ${ }^{30}$ Less sugar than rum was sold within the island, but it is clear that the internal trade was substantial. In Trelawny, for instance, 45.5 percent of the rum produced in 1832 , and 1.9 percent of the sugar, was sold within the island, almost all of it for local consumption. ${ }^{31}$

Coffee was most often sold to merchants in the towns, rather than to estates or pens, but it is uncertain how much of this was subsequently exported, how much was consumed within the towns, and how much sold to estates and pens. Whereas planters gave rations of sugar and rum to their slaves, they do not seem to have used coffee in this way. It remained in the elite consumption culture.

Many other minor commodities were involved in internal trade. Grass pens were common close to the major towns, providing fodder for the large populations of riding animals, and producing substantial profits for their owners. One of the largest of these was Salt Pond Hut, ideally located in St. Catherine between Kingston and Spanish Town; in 1811 the pen sold a total of 177,706 bundles of grass. ${ }^{32}$ Timber, stone, wattles, bamboo and lime for building; shingles and thatch for roofing; firewood, sold by the cord and the bundle; ground provisions, fruits, coconuts, and other foods; all these and more entered the "formal" commodity market of Jamaica in the early nineteenth century. And it was at these margins that the tradable products of planters, penkeepers, merchants, shopkeepers, and higglers, slave and free, came to overlap and intermingle, with the "informal" exchange of the "internal marketing system" sharing many of the characteristics of the formal plantation economy.

\section{Trade in slaves}

Beyond the exchange of things in the internal market, there was a trade in people, the commodified slave population. Slaves were sold from owner to potential owner within the island, sometimes being moved to new locations in consequence and sometimes remaining where they were. Income from the sale of slaves was only rarely included among the receipts of the Accounts Produce, a fact that in itself invites interpretation in terms of the slaveowners' concepts of production and reproduction. Information on the exchange of slaves, how- 
ever, does exist in relatively complete form in the Returns of Registrations of Slaves, covering the period from 1817 to 1832 . These data have been analysed in detail elsewhere. ${ }^{33}$ For present purposes it is necessary only to note that almost 5,000 slaves were moved to new parishes during the triennium 1829-32 and that, unlike the commodity trades discussed thus far, movement between rural and urban areas tended to dominate the long-distance pattern of exchange.

Parallelling the internal slave trade was a significant short-term movement of labour. Slaveowners traded the services of their slaves in three different ways. Firstly, and most commonly, male and female slaves were hired out as field labourers at daily rates ranging from $1 \mathrm{~s}$. $3 \mathrm{~d}$. to $3 \mathrm{~s}$. per day depending on the task performed (cleaning canes and cane hole digging being at the two ends of the scale). As well as performing manual labour on estates, slaves were often worked on the parish roads, generally at a rate of $2 \mathrm{~s}$. $1 \mathrm{~d}$. per day. Secondly, slave tradesmen (masons, carpenters, coopers, coppersmiths, blacksmiths and plumbers) were hired at $3 \mathrm{~s}$. 9d. to $5 \mathrm{~s}$. per day. Thirdly, tradesmen were hired at yearly rates (usually $£ 30$ per year) as were female domestics. ${ }^{34}$

The demand for jobbing depended on the soil and climate of estates, especially the need for cane hole digging. William Taylor, attorney for estates in Clarendon, Vere and St. Andrew, believed jobbing was less in demand in the lowlands than in the upland areas where the soil was heavier and stiffer. But in upper Clarendon, he said, "it is a profitable species of traffic; and many men who have acquired property prefer buying jobbing gangs, and those jobbing gangs abound, and at certain seasons any number can be got at a day's notice." ${ }^{135}$ Such specialised jobbing gangs rarely appear in the Accounts Produce, however, since the owners were usually residents. In 1825, the planter-geologist Henry De la Beche argued that jobbing was by then "principally performed by persons who own more negroes than they can find employment for on their own properties. ${ }^{136}$ The Accounts Produce for 1832 do indicate a significant movement of labour from estates, plantations and pens, but it is impossible to test these data against the role of specialised jobbing gangs in quantitative terms.

Of all the properties which obtained income from day field labour in the four sample parishes-St. James, Trelawny, St. Elizabeth and Manchesteronly two can be classified as "jobbing gangs" (Figure 4). These earned no significant income from any source other than jobbing. But there were sugar estates which sent jobbers to pens, plantations and estates, pens which sent them 


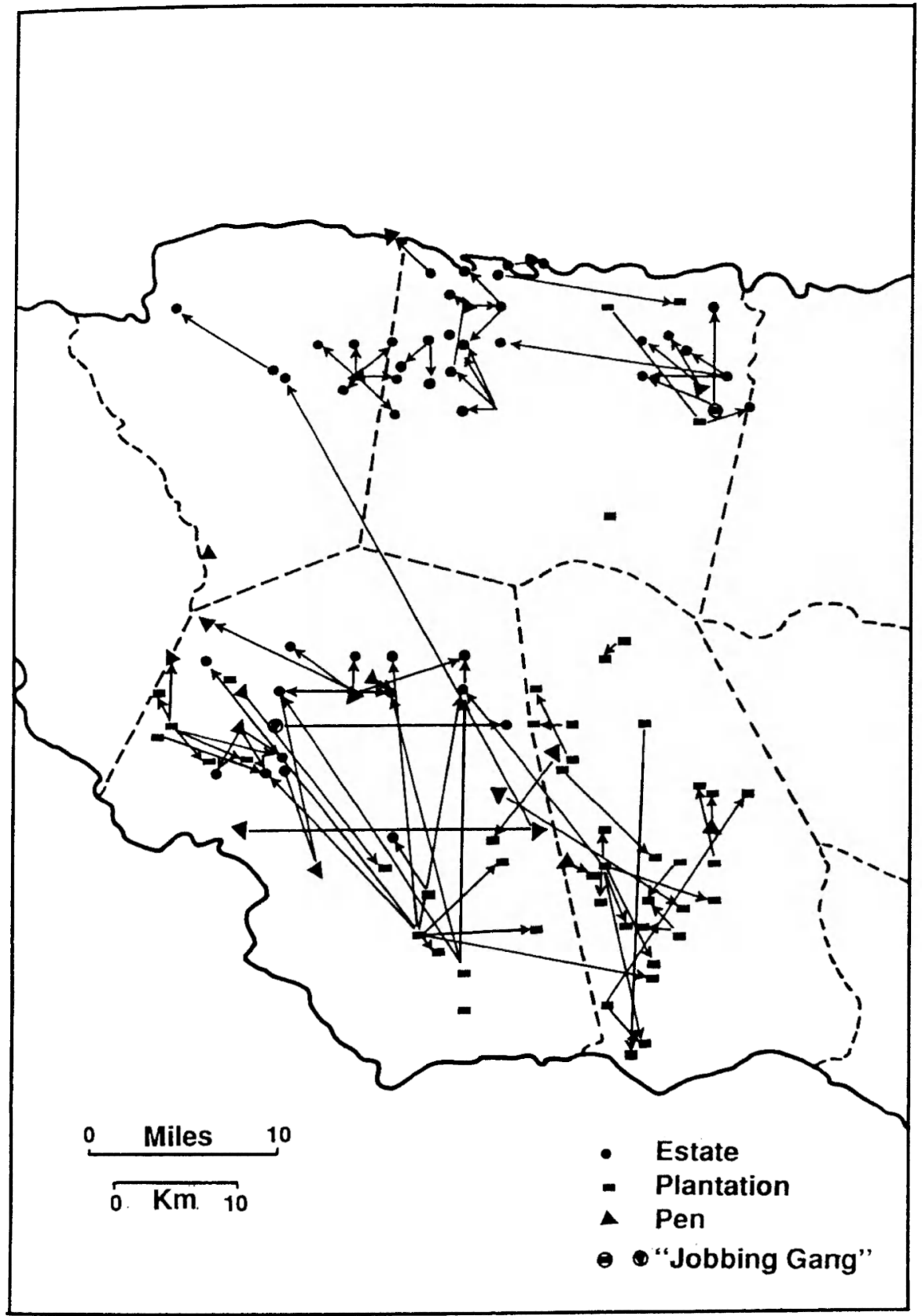

Figure 4: Jobbing of daily rate field labour, 1832: St. James, Trelawny, St. Elizabeth and Manchester 
to pens, plantations and estates, and plantations which sent them to pens, plantations and estates. In St. Elizabeth none of the estates sent out jobbers, but in St. James and Trelawny, where most of the demand came from estates, this was common. In Manchester, most of the links were confined to plantations. On the north coast most of the labour came from pens; here the pattern of movement was fairly simple, with jobbers generally moving short distances and rarely crossing the lines of other links. The demand in this region was largely for cane hole digging, hence the nearest labour was usually the cheapest. In St. Elizabeth the links of the sugar estates were fairly simple, but the plantation movements covered greater distances and tended to overlap, suggesting that it was in fact more difficult to obtain jobbing gangs.

The movement of slave tradesmen was relatively complex. They travelled further and their links crossed one another more frequently (Figure 5). The basic cause of this contrast with day field labour was that the skills of the tradesmen were more particular and scarcer, hence they could not always be found close at hand. Hirers were willing to underwrite heavier transaction costs in order to find such skilled labour. The sugar estates tended to have the largest populations of skilled slaves, so there was a considerable movement from estates to all types of properties, especially in the hinterland of Falmouth.

Slaves hired for an entire year were sometimes domestics (often specified as being coloured) or tradesmen, but in many cases they belonged to small groups attached to estates whose owners were dead, or pens and wharves which had been rented out. These hired slaves were often made to travel long distances, even as far as Kingston, more than 100 miles away. On the other hand, in some cases the Accounts Produce do not record an actual move, and the many examples of this in Trelawny and St. James suggest that these domestic slaves were hired to whites living on the same estates.

\section{Integrated exchange}

All of these types of exchange - of commodities, livestock, and slaves-were to some extent constrained by the structure and condition of Jamaica's internal transportation network, the efficiency of the marketing or monetary systems, and the ability to communicate information. These are topics which remain poorly understood. The speed with which messages could be transmitted by courier, post and newspaper, has not been studied systematically, so that it is 


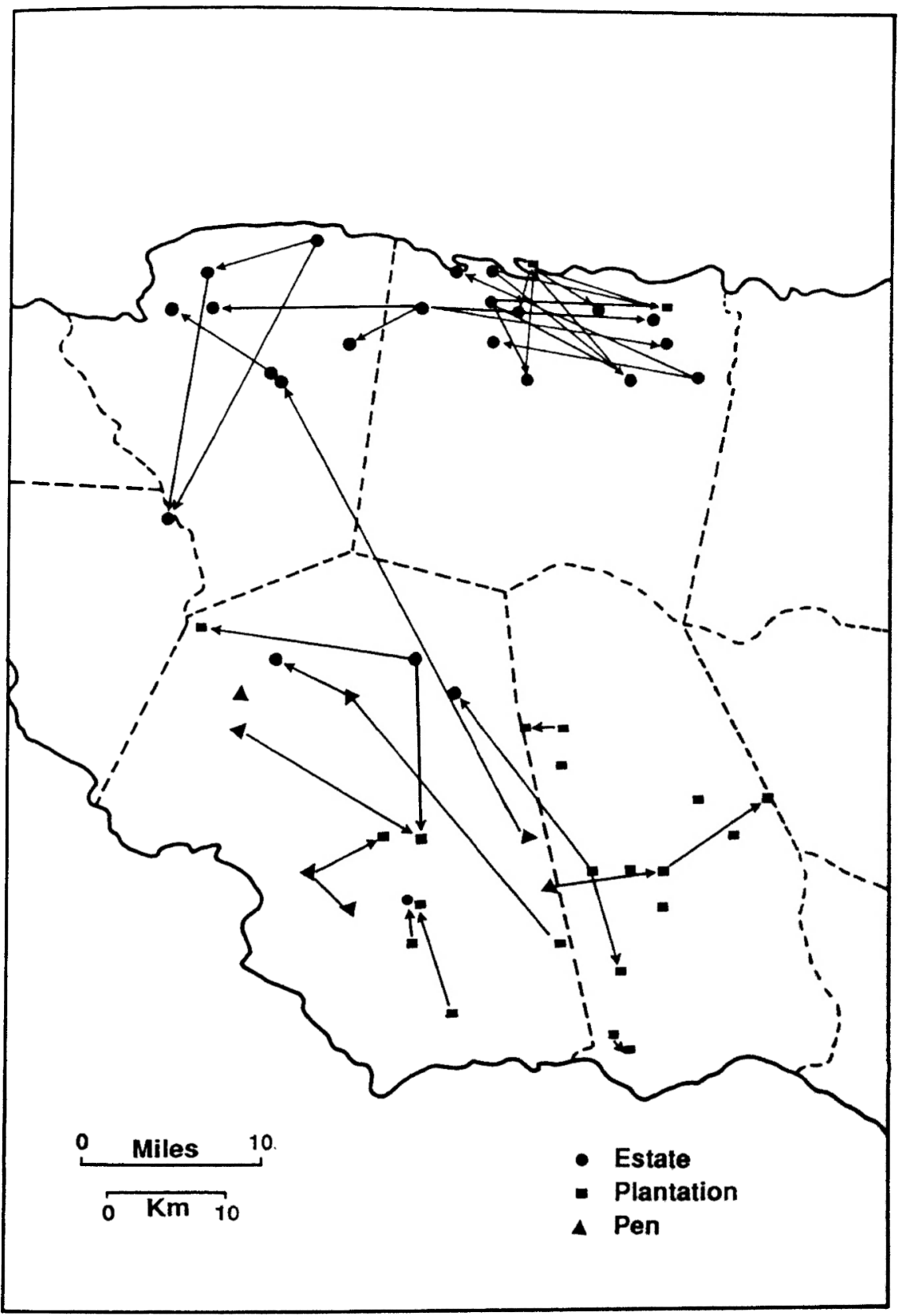

Figure 5: Jobbing of daily rate field tradesmen, 1832: St. James, Trelawny, St. Elizabeth and Manchester 
difficult to estimate the transaction costs involved. ${ }^{37}$ Carriage and bridle roads carried most goods, people and information, but there was also a very important coastal movement by sea and a small amount of river traffic. ${ }^{38}$ Long distance trade was cheaper by water than land, and the pattern of internal exchange therefore tended to emphasise small-scale, local movements, integrating the units within relatively small regional niches.

An illuminating example of the degree of integration that could be achieved at the local level, within the plantation economy, is provided by the Accounts Produce data for the properties under the attorneyship of William Tharp in the parish of Trelawny. Tharp was attorney for seven estates and two pens, all of which belonged to the heirs of John Tharp and were managed by overseers. These nine units were located in the hinterland of Falmouth, along the Martha Brae River (Figure 6). The furthest inland was Windsor Pen on the very edge of the Cockpit Country, about ten miles south of Falmouth, whereas Merrywood Estate was only about three miles inland. The estates, with slave populations ranging from 168 to 439 , produced sugar and rum most of which was exported to London and Bristol, though all of the rum produced on Good Hope, Merrywood and Wales ( 350 puncheons) was sold within the island. The estates were the foci of the system which the pens were designed to serve, and it is notable that there was no evidence of exchange between the estates themselves. The two pens also served separate functions. Windsor in the interior was organised to maintain the herds of working livestock on the estates, while Top Hill close to Falmouth served to fatten the old stock. At Windsor Pen there were 219 slaves and 467 taxable livestock; at Top Hill there were 65 slaves but no taxable livestock. The only traffic into Windsor was estate livestock requiring pasturage to restore them as working stock, and a puncheon of rum from Wales. No record is given in the Accounts Produce of Windsor supplying the estates with working stock but this was probably its chief function. ${ }^{39}$ Windsor also supplied timber to most of the estates. Top Hill's function was to fatten the old cattle which came from the estates, a total of 173 head in 1832, and to sell fat cattle (124 head in 1832) to butchers in Falmouth. Top Hill also sold some hides. This, then, was a closely integrated group of properties in which an attempt was made to maximise the return from land, labour and livestock, exploiting the diversity of natural resources within a small region through a planned system of exchange. 


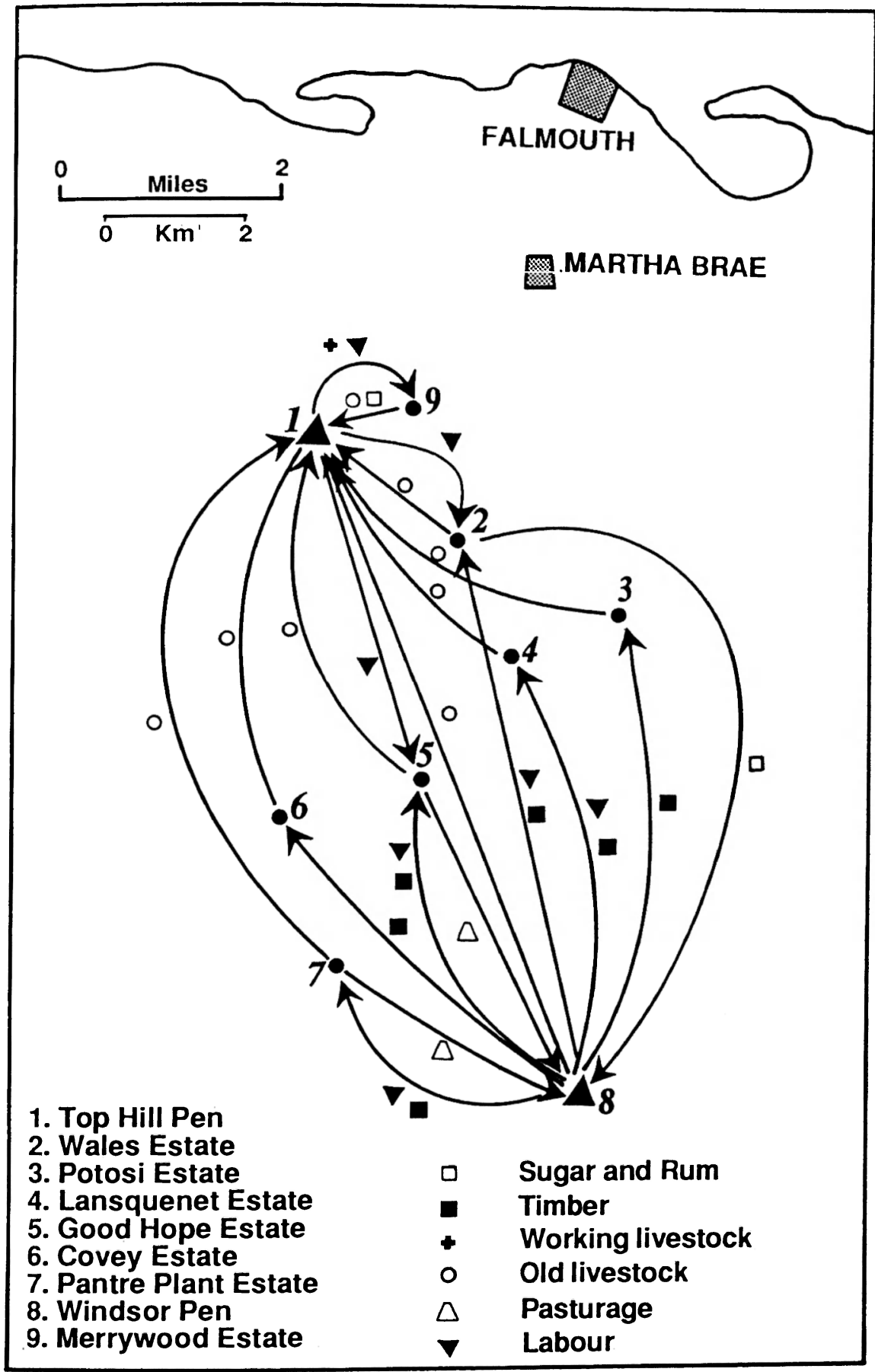

Figure 6: William Tharp's attorneyship, Trelawny, 1832 


\section{Conclusion}

Patterns of exchange within the plantation economy of Jamaica took a variety of forms. In some cases, a small region became the domain of a single planter or attorney. More often, planters traded with one another, and with other rural landholders and merchants, from one end of the island to the other. The extent of such exchange was limited only by the value and transaction costs involved in moving goods, people and information. This trade created an "internal marketing system" parallel to that rooted in the slaves' provision grounds.

These two internal marketing systems were not completely separate. Planters sometimes purchased from slaves goods and services which were the same as those traded in the planters' own system, such as livestock and the labour of tradesmen. Generally, however, the planters sought to distinguish the commodities of the two internal markets, by attempting to exclude slaves from trade in items of export production, imported goods, and status-linked commodities. ${ }^{40}$ In addition to this segmentation of the market through product differentiation, the two systems of internal marketing were characterised by contrasting monetary and accounting mechanisms. The internal marketing system of the slaves depended on verbal negotiation and payment in coin. Indeed the slaves came to control the island's supply of coin to an extent considered dangerous by the planter and merchant classes. The internal marketing system of the planter class was, on the other hand, most often dependent on written agreements, the exchange of paper, and formal accounting records. One mechanism of exchange, namely barter, was shared by the two systems, but this seems to have been relatively unimportant by the early nineteenth century and both markets were fundamentally monetised. ${ }^{41}$ Finally, the traders themselves were distinguished not only by slave or free status but also by gender. The planters' internal marketing system was dominated by males whereas the archetypal trader of the slaves' system was the black woman.

Sidney Mintz has argued that the internal marketing system of the slaves can be seen as standing "in violent contradiction to the slave regime itself." ${ }^{42}$ While the internal marketing system of the colonial planter/penkeeper/merchant class of Jamaica cannot be characterised in such radical terms, it did constitute a breach in the plantation economy insofar as production and exchange were directed away from an external/metropolitan orientation towards local/creole consumption. ${ }^{43}$ 


\section{NOTES}

1. See Lloyd Best, "Outlines of a Model of Pure Plantation Economy," Social and Economic Studies 17 (1968): 283-326; George L. Beckford, Persistent Poverty: Underdevelopment in Plantation Economies in the Third World (New York: Oxford University Press, 1972); Alex Dupuy, "Slavery and Underdevelopment in the Caribbean: A Critique of the 'Plantation Economy' Perspective," Dialectical Anthropology 7 (1983): 237-51; Hilary McD. Beckles, "The Williams Effect': Eric Williams's Capitalism and Slavery and the Growth of West Indian Political Economy," in British Capitalism and Caribbean Slavery: The Legacy of Eric Williams, ed. Barbara L. Solow and Stanley L. Engerman (Cambridge: Cambridge University Press, 1987), pp. 303-16.

2. Sidney W. Mintz, Sweetness and Power: The Place of Sugar in Modern History (New York: Viking, 1985)

3. Douglas Hall, "Incalculability as a Feature of Sugar Production during the Eighteenth Century," Social and Economic Studies 10 (1961): 340-52; idem., Planters, Farmers and Gardeners in Eighteenth Century Jamaica: The 1987 Elsa Goveia Memorial Lecture (Mona: Department of History, University of the West Indies, 1990).

4. Richard B. Sheridan, "From Chattel to Wage Slavery in Jamaica, 1740-1860," Slavery and Abolition 14 (1993): 13. See also S. W. Mintz and Douglas Hall, "The Origins of the Jamaican Internal Marketing System," Yale University Publications in Anthropology, No. 57 (1960).

5. B. W. Higman, "Jamaican Port Towns in the Early Nineteenth Century," in Atlantic Port Cities: Economy, Culture, and Society in the Atlantic World, 1650-1850, ed. Franklin W. Knight and Peggy K. Liss (Knoxville: The University of Tennessee Press, 1991), pp. 117-48.

6. See Douglas Hall, In Miserable Slavery: Thomas Thistlewood in Jamaica, 1750-86 (London: Macmillan, 1989); Alan L. Karras, Sojourners in the Sun: Scottish Migrants in Jamaica and the Chesapeake, 1740-1800 (Ithaca: Cornell University Press, 1992).

7. Edward Brathwaite, The Development of Creole Society in Jamaica, 1770-1820 (Oxford: Clarendon Press, 1971), pp. 80-95.

8. B. W. Higman, Slave Population and Economy in Jamaica, 1807-1834 (Cambridge: Cambridge University Press, 1976), p. 16. Cf. Richard Sheridan, "The Wealth of Jamaica in the Eighteenth Century," Economic History Review 18 (1965): 303.

9. Sheridan, "Wealth of Jamaica," pp. 293-94. See also Richard Pares, Merchants and Planters, Economic History Review Supplement, No. 4 (1960), p. 70.

10. Higman, Slave Population, pp. 9-10.

11. For the overall pattern in 1832, see Higman, Slave Population, pp. 9-42.

12. Verene A. Shepherd, "Livestock and Sugar: Aspects of Jamaica's Agricultural Development from the Late Seventeenth to the Early Nineteenth Century," The Historical Journal 34 (1991): 627-43; idem., "Alternative Husbandry: Slave and Free Labourers on Livestock Farms in Jamaica in the Eighteenth and Nineteenth Cen- 
turies," Slavery and Abolition 14 (1993): 41-66; B. W. Higman, "The Internal Economy of Jamaican Pens, 1760-1890," Social and Economic Studies 38 (1989): 61-86; Thomas Roughley, The Jamaica Planter's Guide (London: Longman, Hurst, Rees, Orme and Brown, 1823), pp. 142, 155.

13. Higman, Slave Population, p. 25.

14. Accounts Produce, Liber 73, ff. 122 and 133, Jamaica Archives, Spanish Town; Returns of Registrations of Slaves, Liber 141, ff. 6-8, Jamaica Archives, Spanish Town; Liber 128, f. 183; Jamaica Almanack (Kingston: 1833); Michael Craton and James Walvin, A Jamaican Plantation: The History of Worthy Park, 1670-1970 (London: W. H. Allen, 1970).

15. Between 29 September 1831 and 29 September 1832, Jamaica imported only 591 head of cattle, 1,323 horses, 618 asses, and 608 mules. Jamaica House of Assembly Votes (Jamaica: 1832), p. 481.

16. Accounts Produce, Liber 72, f. 199; Liber 73, f. 103.

17. See B. W. Higman, Jamaica Surveyed: Plantation Maps and Plans of the Eighteenth and Nineteenth Centuries (Kingston: Institute of Jamaica Publications, 1988), p. 266.

18. Reverend Samuel H. Stewart, "A Statistical Account of the Parish of Manchester," Jamaica Almanack, 1840, p. 145.

19. Higman, "Jamaican Port Towns," p. 129.

20. Accounts Produce, Liber 74, f. 29.

21. Journal of Benjamin Scott Moncrieffe, 1828-1840, p. 27, Jamaica Archives, Spanish Town.

22. Jamaica Almanack, 1816-1833.

23. $1 \mathrm{Wm} . \mathrm{IV}$, c. 23.

24. Jamaica House of Assembly Votes, 1833, p. 49.

25. Benjamin McMahon, Jamaica Plantership (London: Effingham Wilson, 1839), p. 172.

26. Ibid., pp. 173-74.

27. R. Alston to C. Scott, 29 October 1832, and R. Roy to R. Alston, 15 December 1832, Georgia Estate Letterbook, Vol. 3, National Library of Jamaica, Kingston.

28. Roughley, Jamaica Planter's Guide, p. 154.

29. See Higman, "Jamaican Port Towns," pp. 128-35.

30. Accounts Produce, Liber 72, f. 208.

31. Higman, "Jamaican Port Towns," p. 128.

32. Accounts Produce, Liber 34, f. 46. For further examples of these types of minor internal trade, see Higman, Jamaica Surveyed, chapters 4-7.

33. See Higman, Slave Population, pp. 45-50, 63-68.

34. Ibid., pp. 41-42.

35. "Report from the Select Committee on the Extinction of Slavery throughout the British Dominions," British Sessional Papers: House of Lords, 1832 (127), Vol. 1, pp. 625-27. 
36. H. T. De la Beche, Notes on the Present Condition of the Negroes in Jamaica (London: T. Cadell, 1825), p. 34.

37. Cf. Richard D. Brown, Knowledge is Power: The Diffusion of Information in Early America, 1700-1865 (New York: Oxford University Press, 1989); Ian K. Steele, The English Atlantic, 1675-1740: An Exploration of Communication and Community (New York: Oxford University Press, 1986).

38. Higman, "Jamaican Port Towns"; Edward Long, The History of Jamaica, 3 vols. (London: T. Lowndes, 1774), 2:183.

39. Perhaps Tharp found it convenient for accounting purposes to exclude these transactions. He is named as an example in the critique by McMahon, Jamaica Plantership, p. 164.

40. Cf. B. W. Higman, Slave Populations of the British Caribbean, 1807-1834 (Baltimore: Johns Hopkins University Press, 1984), pp. 237-42; Woodville K. Marshall, "Provision Ground and Plantation Labor in Four Windward Islands: Competition for Resources during Slavery," in Cultivation and Culture: Labor and the Shaping of Slave Life in the Americas, ed. Ira Berlin and Philip D. Morgan (Charlottesville: University Press of Virginia, 1993), pp. 212-13.

41. For a full discussion of the production and marketing strategies of.Jamaican slaves, see Roderick A. McDonald, The Economy and Material Culture of Slaves: Goods and Chattels on the Sugar Plantations of Jamaica and Louisiana (Baton Rouge: Louisiana State University Press, 1993), chapter 1.

42. Sidney W. Mintz, "Caribbean Marketplaces and Caribbean History," Nova Americana 1 (1978): 337.

43. Cf. Verene A. Shepherd, "Livestock Farmers and Marginality in Jamaica's SugarPlantation Society: A Tentative Analysis," Social and Economic Studies 41 (1992): 183-201. 


\title{
12 \\ Planter Profits and Slave Rewards:
}

\author{
Amelioration Reconsidered
}

MARY TURNER

When Henry Goulburn, prominent Tory politician and absentee slaveowner stood as candidate for Cambridge University in 1831, the Anti-Slavery Society campaigned against him. It circulated a broadsheet, "Address to the Electors of Cambridge University," charging that he had completely failed to improve conditions for the slave workers on his Jamaican estate, despite his own government's commitment to reform the slave system. ${ }^{1}$

The attack on Goulburn was part of a nationwide campaign to prevent the election of all candidates who were West India proprietors and merchants-the formidable West India interest-and of all who were not pledged to slave abolition. The Society was driven to this course by hard experience. Since the 1780 s the West Indian planters' response to its attacks was to project themselves as reformers and exert themselves from time to time, for example, by revising the slave codes. In 1823, the imperial government outlined a reform programme drawn up in close consultation with the Committee of West India Planters and Merchants. This involved revising the laws which regulated the extraction of slave labour, investing the slaves with basic legal rights (including the right to own property) and exposing them to religious instruction. The Colonial Office defined new laws for the Crown Colonies, and pressured colonies with representative Assemblies to define their own. It was an ambitious attempt to liberalise the slave regime and effect, over an unspecified period of time, a legally-regulated abolition of slave status. 
By 1831, the Anti-Slavery Society was convinced that the amelioration programme had failed. Absentees like Goulburn, who owned eighty percent of West Indian slaves, had not introduced on their estates the reforms which lay within their power as proprietors, and those, like Goulburn, who commanded political influence, had not fully supported parliamentary efforts to change the system. Eight years' experience had "furnished additional evidence of the criminality and incurable inhumanity of Slavery" and, as the 1831 General Meeting of the Society expressed it, made abolition the only effectual solution. ${ }^{2}$

This contemporary political judgement is reversed in J. R. Ward's study, British West Indian Slavery, 1750-1834: The Process of Amelioration. ${ }^{3}$ Goulburn, his fellow absentees, and their agents, are rehabilitated as significant innovators whose technical and managerial developments, intended primarily to improve productivity, also improved slave workers' material conditions. Ward calculates that between 1750 and 1834 the share of West Indian estate income applied to the slaves' maintenance increased, and the costs of more generous management were fully repaid through improved natural reproduction and labour efficiency. While Goulburn's Amity Hall does not precisely exemplify this trend, since its productivity declined, its owner qualifies for rehabilitation on the grounds that he tolerated a severe decline in his revenues in order to promote reproduction and "Amity Hall's slaves eventually maintained their numbers." Goulburn was, apparently, prepared to reverse traditional priorities and put reproduction before production, wages (in terms of slave worker maintenance standards) before profits. ${ }^{4}$

Ward perceives amelioration as a process motivated primarily by the planters: the Anti-Slavery Society monitored the implementation of a programme defined by the imperial government and sanctioned by the West Indian lobby. The process he perceives focused on the slaves' material condition in terms of food supplied; the government's programme assumed that the slaves were adequately fed, and focused on hours and terms of work and civic rights, in particular religious education. For both Ward and the Anti-Slavery Society, however, a key measure of the success of amelioration was the reproduction of the workforce. Reproduction clearly reflected nutrition, levels of labour extraction, methods of punishment and partnership patterns. The key difference between the two viewpoints is political. Ward considers reform a natural by-product of the planters' engagement with market forces, eked out, where necessary, with voluntary redistribution of their profit margins to promote 
slave worker welfare. The Anti-Slavery Society, by contrast, considered reform to mean regulations that curbed the planters' extraction of labour and invested the slaves with basic legal rights. The ultimate reform was to replace an antique, brutal and inefficient method of labour extraction, with the efficient, rational wage work system which characterised the metropolitan economy.

This article reviews Goulburn's record as an absentee owner in greater detail than the scope of Ward's work or the scale of an election broadsheet permits, to ascertain whether he qualifies on any count as an ameliorator. Does Zachary Macaulay, who wrote the broadsheet, or J. R. Ward, characterise the Right Honourable Henry Goulburn's conduct correctly? And what light does his record as owner of Amity Hall throw on both the process and the programme of amelioration? The interest in his case derives in part from his political position: Tory Member of Parliament from 1808 and increasingly prominent officeholder. As under-secretary in the Colonial Office (1812-21), he was familiar with colonial legislation, actively involved in formulating policy and dealt directly with the anti-slavery and the West India interests in the House of Commons as a government spokesperson. His continuous involvement in government at cabinet level ensured, moreover, that he remained well informed about West Indian affairs. So the questions arise, what influence did imperial policies for the reform of slavery exert on a slave-owning member of the government, and what efforts did he make to implement the 1823 amelioration policy?

Goulburn, in common with most absentees of his generation, inherited his slave property. Amity Hall in Vere parish, Jamaica, was developed by his father who subsequently settled and married in England. Goulburn's knowledge of the estate derived almost entirely from correspondence with its managers and from the yearly accounts. From 1805 to 1818 , day-to-day management was in the hands of William Samson, a resident working attorney, one of the strata of professional managers who emerged as estate owners and retired to England to live on their profits. A significant number of these professionals were Scotsmen like Samson. Until 1818 Goulburn found Samson a satisfactory manager who concentrated on maximising production and, hazards of drought and hurricane aside, consistently produced good returns —on average 300 hogsheads a year. Goulburn followed Samson's advice in particular on technological innovations: a waterwheel replaced the cattle mill in 1808 , and a steam-engine was introduced in $1818 .^{5}$ The capital outlay in both cases aimed to increase sugar production and decrease the number of hands engaged at the mill. 
While the productivity of Amity Hall was satisfactory, the slave population persistently declined. The labour supply problem had engaged the attention of Jamaican owners and managers more or less acutely since the 1780s, when their access to African labour reserves was first opposed. The sugar estates in particular depended on slave worker imports to sustain numbers. A pro-natalist policy was ofticially endorsed by the Jamaican Assembly in 1788, and the 1816 Slave Code proposed to reward mothers of six live children with exemption from field work. Some owners designed their own incentive schemes such as distributing money, medals, special food and clothing, to women who had children. ${ }^{6}$ Goulburn, however, was not one of them. On the contrary, he encouraged his manager to replenish the work force from the internal slave trade, and in 1818 sold land in Manchester parish to finance purchase of forty-two new slaves (adults and children) for $£ 3,000$. $^{7}$

This new investment in slave labour complemented the investment in the steam engine which, while decreasing the number of hands needed at the mill, was predicated on maintaining labour supplies. This double investment prompted Goulburn to invite his brother, Major Archibald Goulburn, to supervise the installation of the steam engine and review Samson's management. Major Goulburn, after only twelve days' residence, concluded that the estate was badly managed in every respect. The crop was thin, stunted, and plundered by slaves who were inadequately fed, miserably housed and manifestly discontented with their manager. ${ }^{8}$ Slave workers at Amity Hall, as in the rest of Vere, depended largely on estate-distributed staple and protein rations (customarily imported salt herring and home-grown corn), supplemented by vegetables grown on their allotments and house plots. Samson allowed eight pints of corn per adult for seven months of the year only. To Major Goulburn the very appearance of Amity Hall slaves contrasted sharply with those on neighbouring Bog estate, whose attorney, George Richards, argued that the solution to the slave reproduction problem was to supply more food and demand less work. This formula, he declared, did not necessarily reduce production; he claimed that he had halved the acreage in cane and produced more sugar, while the slave population had increased from 300 to $430 .^{9}$

On the strength of this promise to increase reproduction and maintain production, Goulburn changed managers: Richards took over from Samson in August 1818. Goulburn took no steps, however, despite Richards' insistence that reproduction patterns were contingent on good feeding, to increase 
the quantity of herring sent to the estate. Improved food production was to take place together with sustained cane production, a combination facilitated by the fact that Amity Hall had more land available for cane than the workforce could harvest and manufacture. Richards allowed the slaves thirteen acres of disused cane land for allotments and planted more corn to increase the ration to fourteen pints a head for eight months. While this could be considered an amelioration of slave conditions at Amity Hall, the change simply brought the estate into line with standards customary for ration-fed slaves on other estates. ${ }^{10}$

Goulburn, a regular Anglican churchgoer, did, however, briefly consider the utility of sending a Moravian missionary to live on the estate-a practice first followed by absentee Jamaican owners in the mid-eighteenth century. The slaves' need for Christian instruction had been canvassed since that date by the West India Committee and the imperial government, as well as by the anti-slavery interest, and resident planters in their capacity as magistrates were currently licensing dissenting missionaries to work among the slaves. Moreover, the slaves' infertility was commonly attributed, by both planters and their opponents, to the slaves' "licentiousness" and want of marriage sacraments. In the upshot, however, Goulburn decided he could not afford a $£ 200$ per annum expenditure on Christian instruction, since his revenues from Amity Hall were declining. ${ }^{11}$

Goulburn made it clear at every turn that expenses needed to be offset by earnings. He did not tolerate losses, he strove to avoid them. When revenue diminished under Richards, he necessarily sustained the loss, but did not adjust his expectations. The expense of an additional service for the slaves could only be countenanced by an equivalent earning. The slaves had to pay for their spiritual welfare by their productivity; Goulburn did not re-balance the books and redistribute profit to promote either reproduction, or religious instruction.

In 1823, however, pressure for abolition intensified. The Anti-Slavery party whipped up a campaign, led by Wilberforce, to demand a government commitment to abolition. In response, the government drew up the 1823 programme which incorporated substantial reforms proposed by a Special Committee of West India Planters and Merchants. This committee, which was dominated by Members of Parliament and chaired by the influential absentee Jamaican owner, Charles Ellis, proposed some reforms which estate managers could immediately implement, on the instruction of owners. These included the abolition of flogging for women, the disuse of the whip as a symbol of 
authority in the field, and the administration of flogging only in the presence of the overseer, who would record and account for each instance. Among measures requiring legislation, the committee favoured abolition of Sunday markets, property and inheritance rights for slaves, the prohibition of slave sales for debt, removal of impediments to manumission, admission of slave evidence, and the expansion of magistrate powers to hear complaints-all measures incorporated in the imperial government's programme. But the West Indian interest did not stop there: it embraced even the government's central proposition that religious instruction was the key to the slaves' moral and civil improvement.

The imperial government, however, went still further and proposed the legalisation of slave marriages and the establishment of savings banks. Moreover, to back up its commitment to religious education, it promised funding to revitalise the Anglican church in the West Indies and turn it into an engine for slave instruction, on condition that Sunday markets be abolished. ${ }^{12}$

The West India Committee's participant-support of the amelioration policy simply carried to a new level the strategy it had adopted in the 1780 s of combatting the anti-slavery interest by responding positively to its criticism. Participation in reform was intended to ensure the continued legality of slave labour. Nevertheless, by assuming the mantle of reformers the West India Committee invited the anti-slavery interest to judge its members, and absentee proprietors in general, by this yardstick.

Goulburn's response, as a metropolitan politician, was to establish a high public profile in the cause of slave religious instruction. He joined clerics, absentees, and fellow Tory politicians to preside over the Incorporated Society for the Instruction and Religious Conversion of the Negroes. ${ }^{13}$ This society undertook, with the assistance of West India Committee funding, to supplement the manpower of the Anglican church in the West Indies with auxiliary curates appointed specifically to teach the slaves-recruits who complemented the stipendiary curates, whom the imperial government appointed in 1824, and paid to assist the Bishops of Jamaica and Barbados. Goulburn consequently assisted in sending to Jamaica a number of young men who injected a degree of missionary spirit into the elitist and moribund Jamaican Anglican church. They worked in six of Jamaica's thirteen parishes, and won easy access to the estates. Charles Ellis set an example by employing one on his St. James property, while in St. Thomas in the East a local branch of the Incorporated Society was 
formed and, assisted by locally recruited catechists, instructed some 1,000 slave children. ${ }^{14}$

No curate, however, was appointed to Vere parish, and Goulburn did not follow Ellis's example and employ one at Amity Hall. Nor did he implement any of the other reforms the West India Committee proposed. Change at Amity Hall was determined by the fact that production had declined, and so had the slave population (from 267 to 251), with the number of births remaining comparable with Samson's regime. Goulburn decided to dismiss Richards, who had plainly failed to deliver on his promises, and a new manager, Alexander Bayley, took over in March 1825.

The new appointment clearly provided Goulburn with an opportunity to implement some of the reforms advocated by his fellow-proprietors and sanctioned by the government he served. The opportunity was ignored. Goulburn simply voiced his general concern for slave welfare and its improvement, and Bayley's attention focused on reorganising work routines and workloads, and inducing cheerfulness, alacrity, care and attention in the work force. ${ }^{15}$

Management standards at Amity Hall became a political issue, however, when Goulburn first attempted to win the seat for Cambridge University in 1826. No broadsheet was issued, but the Anti-Slavery Society circulated a letter to the electors which drew attention to the fact that Goulburn was a slaveowner, that the "friends of the Negro" considered slaveowners and West India merchants ineligible to stand for election, and specifically charged Goulburn with failing, in both his public and private capacity, to improve slave conditions. The slaves at Amity Hall were without religious instruction, cohabited like brutes without the sacrament of marriage, worked together under the lash from morning to night (and in crop-harvest-time-half the night) and were denied the use of a plough. These charges were reinforced by the fact that "it was in [Goulburn's] power to have joined heartily in endeavouring to put a period to such an opprobrious state of things ... it was in his power to have brought the evils of the system before Parliament and to have proposed ... the appropriate remedies," more particularly since his official situation made it easy for him to do so. "It was in his power to have done much in the way of Colonial Reform." ${ }^{16}$

Alerted to this attack by one of the electors, Goulburn countered as best he could in a letter to the President of Queen's College. He declared his slaves were "the most happy and comfortable in the parish." His recent financial losses were turned to good political account; Goulburn projected himself as appointing 
Richards, in the face of local advice, because he was prepared "to make any sacrifice of income to secure the comfort of the Negro." The thirteen acres Richards divided up to make allotments were described as part of the estate being converted from cane to provision ground, and Richards' dismissal was attributed entirely to the continuing decrease of the population. Goulburn "believed" that night work during crop had been stopped, and claimed the plough had been substituted for the hoe. He did not respond directly to the charge that the slaves were without religious instruction, but asserted that if the slaves were ill-treated or inadequately instructed, it was without his knowledge, against his orders, and "in spite of a sacrifice of nearly 4/5ths of my income made for the express purpose of securing to them every comfort to which their situation admitted." ${ }^{17}$

Goulburn informed Bayley that adverse reports about slave management at Amity Hall were in circulation for political purposes, and invited the attorney to defend himself and his employer, particularly on the question of religious instruction. The request reached Bayley at an interesting moment. The ill-treatment of Amity Hall slaves at the hands of an overseer who tackled production problems during crop by flogging the workers for "indiscipline" had precipitated a strike. About fifty of the "most efficient people"-presumably the millworkers and the first gang-stopped work and went to the woods. Production recommenced only when the overseer was dismissed. (The strike leader was tried at the Slave Court and sentenced to four months in Clarendon Workhouse.) Bayley consequently wrote two letters, both dated 6 May 1826, one dealing with the strike (provoked by cruel and unjust punishments), and one to answer Goulburn's critics. ${ }^{18}$

Bayley firmly denied all charges of ill-treatment, though he had just dismissed an overseer whom he considered "more exacting in the execution of his duties than I wished him to be." While not answering directly the charges about night work and flogging, he testified warmly as to Goulburn's anxiety for the slaves' well-being, citing the time and money spent securing good supplies of corn. He handled the religious instruction question with care: there was no impediment to the slaves' religious instruction, and Vere parish church was nearby and attended by slaves from many estates. The late rector had considered attendance from Amity Hall to be better than from any other estate-testimony at once unclear and unverifiable-but the new rector was not yet in residence. Goulburn, as a member of the Incorporated Society, presumably knew that it 
was an uphill fight to get slaves to attend a church whose clergy traditionally ignored their existence, much as the English clergy ignored the heathen masses of industrial England. What Bayley could not disguise was the continuing decline in the estate's slave population; from 1818 to 1826 , deaths outnumbered births by ninety-two to seventy-six. ${ }^{19}$

In the meantime, Goulburn lost the Cambridge University election (which turned, in fact, on the Catholic question rather than on slave emancipation), and did not probe for more information. ${ }^{20}$ This experience, however, which had threatened publicly to sully his reputation as a keen promoter of slave religious instruction, prompted him to test Bayley's reactions to a set of regulations drawn up by West Indian proprietors in England for their managers "as desirable to be adopted as soon as circumstances will permit."21 The regulations were a watered-down version of the bold proposals made by the 1823 special committee, and included abolition of the whip as a symbol of authority, limitations to flogging, and some novel suggestions for promoting religious instruction. Women were to be punished with a switch used by a woman, and by confinement overnight in a dark room. All corporal punishment was to be recorded, and was to take place the day after the offence, preferably at breakfast. These regulations, while clearly compromising the West India Committee's and the imperial government's original proposal (to abolish flogging for women completely) promised some amelioration, as did the procedural innovations to regulate punishment by flogging of the male workforce.

Religious instruction for the slave population at large was to be encouraged by the "Gentlemen employed on the Estates" attending divine service wherever a church or chapel was within a reasonable distance, while slave children were to be regularly catechised. Marriage was to be encouraged "by every means where the parties appear qualified for it," and presents awarded by managers to slaves who attended to their religious duties. Moreover, to facilitate church attendance, as well as to minimise Sunday marketing in the absence of any laws to prohibit it, managers were to buy from the slaves all exportable produce (such as arrowroot, pimento, ginger, etc.) and consign it to the proprietor, with "the Negroes name to accompany it." 22

Bayley, naturally, regarded the innovations as disruptive of established routines, including his own, and wanted none of them. His reply was well considered. He acknowledged that the administration of corporal punishment ought to be regulated along these lines, and that the change in women's 
punishment should be enforced. The abolition of flogging for women, however, was a highly contentious issue; the Jamaica Assembly refused to outlaw it in successive slave code revisions (1826, 1827 and 1831), and Bayley clearly would have acted only on clear instruction to do so. He claimed, however, that he had already abolished "that kind of whip so much complained of" - the cat of nine tails-except in the case of male slaves where example required it. ${ }^{23}$

As to attending divine service himself, Bayley accepted no such obligation, and he placed full responsibility for religious instruction on the clergy. The clergy must teach the children and persuade the people to marry, and managers should not be exposed to charges of partiality by distributing presents. As to the slaves selling their produce to the proprietor, Bayley was prepared to propose it, but without any expectation that they would accede. If they did, they must be paid their asking price; managers were not prepared to bargain with people long accustomed to selling at market. ${ }^{24}$

Goulburn, however, did go so far as to suggest one innovation. It revealed not only how limited his knowledge of plantation business was, but also how determined he was to promote production while improving reproduction rates. To improve the birth rate, he suggested that women should be removed from field work with a view to becoming, not simply wives and mothers, but industrial workers. "If it were possible to devise any useful branch of industry in which they could be employed I am not certain that the produce of the industry would not more than compensate for their exemption from labour in the field." ${ }^{25}$ But sugar production at Amity Hall, as on most Jamaican sugar estates at this period, relied on female field labour. The first gang included thirty-nine women of childbearing age (forty years old and under), of whom fifteen had never produced children. ${ }^{26}$ There was, as Bayley commented, no cure for field labour since there were no men to replace the women and no industry for them to engage in. He could only promise to maximise the use of the plough. ${ }^{27}$

Goulburn continued to agitate this question, but in ways which sent Bayley contradictory signals. He urged in one letter "if you consider [the low number of births] to occur either from excess of labour, or deficiency of food, or other cause which is within your power to remedy, to take every measure for preventing its occurrence," while in another he queried the expense of Bayley's proposal to use hired labour. ${ }^{28}$ Goulburn's priorities, however, were clearly affirmed when Bayley proposed to reduce the cane acreage at Amity Hall from 280 to 
260 acres as the "utmost that can be kept up by the present work-force."29 Goulburn agreed, as long as production levels did not fall. "Production of labour is always an object more particularly on a West India Estate with ... a decreasing population," but, he reminded Bayley, "I cannot well afford a reduction of Income" (emphasis added). ${ }^{30}$

By this date (1829), Goulburn had already sustained a reduction in income, as production at Amity Hall fell from Samson's yearly average of 336 hogsheads to an average of 205 by his successors. ${ }^{31}$ These losses took place not because, as Ward suggests, Goulburn pursued an expensive pro-natalist policy; he clearly did not re-balance his books in order to improve work conditions. His participation in the amelioration process consisted at best in allowing his attorneys to improve home-grown or locally purchased staple rations to levels above underfeeding. Lowered productivity at Amity Hall can be traced more convincingly to a significant reduction in the workforce precipitated by Samson's dismissal. Samson took with him his jobbing gang, who had been fed at Goulburn's expense, but whose bought labour had expanded sugar production. Certainly one of the sources of contention between Bayley and the resident workforce was the supply of hired slaves, and it was a jobbing gang introduced in the aftermath of the strike which enabled Amity Hall to produce the highest crop of Bayley's administration (276 hogsheads). ${ }^{32}$ On the whole, Goulburn accepted Bayley's judgement that it was better to avoid innovations because of the "temper and disposition of the Negroes," and because, he claimed, the association of abolition and amelioration made it difficult to introduce reforms "without producing in the Negroes a disposition and a feeling toward their masters quite different to that of gratitude. ${ }^{33}$ Goulburn was stirred from comfortable reliance on Bayley's judgement, however, by another moment of adverse publicity for Amity Hall, provoked not by abolitionists, but, more alarmingly, from within the House of Commons. An unidentified Member of Parliament informed Goulburn that his slaves were subjected to "unnecessary severities," and as a result they had set fire to the estate. This fire had been reported by Bayley as an accident rather than arson, but charges of severities circulating in parliamentary circles extended the currency of election campaign propaganda, and provoked Goulburn to a more extensive enquiry. As he stressed to Bayley, such charges against West Indian proprietors were readily believed. "My first anxiety . . . is to have the people on my estate contented and happy and for this I am prepared to make great sacrifices. ${ }^{34}$ 
Bayley, obliged to defend his own stewardship as well as Goulburn's reputation, flatly denied the charges and supplied an impressive dossier of testimonials to support his case. The Custos (Chief Magistrate of the parish) declared no severity had taken place, because if it had he would have heard of it. The estate doctor expressed surprise at the charges; the sick were kindly treated and he was confident the slaves would have complained of any severities. More revealingly, a neighbouring planter testified that five or seven years previously, Amity Hall had a bad reputation throughout the parish, but declared that a great moral improvement had taken place in the last two years. He suggested, moreover, that the slaves themselves would not tolerate severities: "You dare not at your peril make a bad use of your authority." Sworn statements from the bookkeeper and a resident carpenter testified that they had never witnessed severe punishments and that the slaves were properly fed. And for good measure, the Rector reported Bayley had invited him to catechise the children (they were making good progress), and Amity Hall slaves attended church in numbers comparable to other estates. ${ }^{35}$ Goulburn accepted these assurances and no further mention was made of sacrifices to content the slaves.

It was the 1831 Anti-Slavery election broadsheet that forced Goulburn to act. Addressed to "Members of the University of Cambridge who are inclined to support Mr. Goulburn," it took the form of an unsigned letter which published the information circulated by private letter in 1826 , and charged that "the intervening years, at least down to January 1830 , the date of my latest intelligence, have produced no favourable change in the condition of Mr. Goulburn's slaves." Readers requiring further clarification were directed to write to 18 Aldermanbury Street, the headquarters of the Anti-Slavery Society.

The broadsheet proved an ineffectual bit of election pamphleteeringGoulburn was returned head of the poll-but the adverse publicity provoked a strong reaction. Goulburn at once required the name of the writer, ostensibly to make immediate inquiry into the case. When Zachary Macaulay, editor of the Anti-Slavery Reporter was named, however, Goulburn challenged him to produce the evidence for the accusations. He was particularly incensed by the charge that the condition of Amity Hall slaves was the same in 1830 as in 1826. He boldly (albeit falsely) refuted this, claiming that provision had in fact been made for the religious instruction of his slaves and that night work, during crop, had stopped long ago. He demanded an interview with Macaulay's informant, to which Macaulay acceded as long as the identity of the witness remained 
confidential so as to avoid any problems when he returned to Jamaica. Goulburn, however, promised confidentiality only if he judged the information to be true; otherwise he would "if possible punish him for his malignity or falsehood." Macaulay, shocked by this "vindictive aspect" stood his ground. "You possess in your own hands ample means of contradiction; but I know they [the charges] cannot be contradicted with truth."36

Goulburn presented himself as one who had been made the "peculiar object of a libellous and false attack. ${ }^{137}$ The letters to Macaulay, however, were shadow boxing. The broadsheet alerted him to the real weakness of his position as an absentee who depended for information about his property on his employee and on the witnesses his employee recruited. The Anti-Slavery Society, like his unnamed colleague in the House of Commons, commanded other sources. The abolitionists had been strengthened by the Whig election, and the formation of the Agency committee in June 1831 promised to intensify popular animosity against slaveowners. In these circumstances, while attempting to lay the onus of proof on the Anti-Slavery Society, Goulburn set about collecting information. He wrote to the Rector of Vere and the Bishop of Jamaica to check on the state of religious instruction, and he told Bayley he was not satisfied with the testimonies in his possession, and invited him to provide more substantial evidence on the provision of religious instruction, the number of marriages, and the use of the whip and the plough. ${ }^{38}$

Showing more initiative, Goulburn also contacted West India Committee member and fellow-Member of Parliament, J. B. Wildman, recently returned to England from a four-year residence in Jamaica, where he had reformed the management of his three estates-Papine, Low Ground and Salt Savannah. Wildman's first exposure to the day-to-day conduct of his estate, like Major Goulburn's at Amity Hall, shocked him profoundly. What Major Goulburn perceived as a management problem, Wildman characterised as "a System of ... oppression and licentiousness not only practised but maintained on principle by the Attorney and every individual under him down to the very children of the Blacks." He consequently determined to take over himself. The first complaints he dealt with shed a flood of light on the relationship between workplace discipline and the low number of live births. The overseer complained one of the women was idle and pretending to be pregnant. The woman in turn complained that she had lost three infants from the treatment she had experienced at the hands of the overseer, and the overseer acknowledged she 
had lost them. The solution was obvious--to abolish flogging as a punishment for women and substitute brief spells of imprisonment, from a few hours, to a day or two, as necessary. In due course, the whip was also removed from the drivers and used, not as an instrument to extract labour, but in cases of theft, neglect and repeated crime, only when ordered by the attorney, and duly recorded. Wildman claimed that the woman who drew his attention to the problem had become the mother of three healthy children before he returned to England. The control of the whip to extract slave labour was extended also to the extraction of animal labour-the long bamboo whips used to lacerate the oxen were replaced by light hand whips, reducing stock losses. ${ }^{39}$

Wildman's next substantial reform was to abolish night work. The combination of day work under a tropical sun, the dampness induced by cool night air, and the vapours produced in the mill, injured the slaves' health, particularly when they slept during shift work. At the same time, Wildman emphasized that as they huddled together before the stokehole fires, "the debauchery carried on among all ages exceeds all belief and is I consider the main reason of the decrease of their numbers on sugar estates." Night work in crop also facilitated robbery to the extent, Wildman claimed, that some slaves objected to its abolition. Under the new regime the mill stopped at 8 p.m. and the boiling house closed as soon as the last skips were removed; the fires started again at 4 a.m., thus allowing eight hours rest and eliminating the "long spell" of working all day and every second or, on large estates, third night. The new system affected production very little since the mill broke down less frequently in the day.

Religious education was Wildman's third innovation. A Church Missionary Society man and his wife were installed on each estate, and attendance at chapel was expected twice each Sunday, and monitored by roll-call, in return for Saturday halfdays free. The slaves were not very cooperative, however, until full Saturdays were allowed. Then roll-calling could be discontinued, "the negroes attending very regularly of their own accord." In the meantime, the children attended classes in the chapel every weekday in two-hour spells. To validate the slaves' religious education, Wildman was also obliged "to put a stop to the licentiousness of the White People." No employee was allowed to live with a coloured woman - one warning only was allowed before being discharged: "the abandoned character of the White People more hinders the improvement of the negroes than all the vicious habits they have themselves contracted." ${ }^{40}$ 
These reforms, in particular abolishing flogging and curtailing licentiousness, had increased the number of marriages, while on one estate, births had grown from three, to nine, to eleven, and currently, to thirteen a year. Wildman also stressed that winning the goodwill of the people had enabled him to effect a substantial re-deployment of his workforce without coercion or loss of life. He had successfully persuaded one hundred of his slave workers to move voluntarily from his estate near Kingston, with its accessible markets, to Low Ground, in the Clarendon mountains, some fourteen miles from the nearest market. He also recommended task work, first officially endorsed by the imperial government in 1823 . The slaves, he found, responded well to incentives, and Wildman thought that planters would save money by giving slaves cash payments in place of the supplies of salt meat and fish customarily sent out from Britain. ${ }^{41}$

Wildman's success story was bound to make an impression on Goulburn, both because Wildman had achieved Goulburn's highest ambition of maintaining production while increasing reproduction, and because he claimed he undertook the reforms in the spirit Goulburn notionally identified with as "suited to the feelings of an Englishman and a Christian. ${ }^{42}$ But Wildman's account inevitably lent weight to Zachary Macaulay's election broadsheet criticisms. Goulburn had, in fact, despite his claims to the contrary, effected no reforms at Amity Hall, and had failed in particular to provide means of religious instruction. He had proved, as the broadsheet expressed it, less "determined in his purpose" than "sincere in his wishes;" he had allowed himself to be turned from his intention by cost, using the excuse that his estate was situated near a church. While the broadsheet did not publicise Goulburn's position as VicePresident of the Incorporated Society, Macaulay took care to remind him of it in their private correspondence. ${ }^{43}$

It was only under the pressure of public exposure, with the threat of more to follow, and using Wildman's experience to guide him, that Goulburn finally, in August 1831, set about implementing reforms at Amity Hall. He cleared the way by first requiring Bayley to answer the election charges, which he claimed had circulated with much effect. But without waiting in his customary way for Bayley's reply, he then sent out not proposals and suggestions for change, but a set of rules "to which I require your strict adherence." Goulburn required first that the whites on the estate set a moral example. Connections with coloured women, or any other form of profligacy, would result in dismissal. Secondly, 
there was to be no corporal punishment of women, only confinement. Thirdly, night work was to be prohibited, not because it demanded excessive extraction of labour, but because of its moral corruption. Fourthly, managers were to promote marriage by rewarding married couples with practical indulgences, including better clothing and more time for recreation. These rules were subsidiary to the great object of moral improvement; only the truths of religion could impose any permanent restraint on the licentiousness of slave manners, and to this end, if the rector could not attend the estate, Bayley must employ a catechist. Thus Goulburn belatedly endorsed the fundamental tenet of the amelioration programme to promote reproduction. The decrease of the workforce, as he pointed out to Bayley, diminished further the pitiful rate of return he currently accrued from his investment. ${ }^{45}$

Even at this juncture, however, Goulburn modified Wildman's reforms. A catechist was no substitute for a resident missionary; and he imposed a limit on the slaves' working week during crop, but not throughout the year. As for the promotion of marriage, he relied on material rewards rather than, like Wildman, moral incentives. ${ }^{46}$ Goulburn perhaps recognised that his absence from Amity Hall necessarily limited the changes he could effect, but he clearly wanted to avoid spending money on a resident missionary. In the event, the Bishop licensed a catechist to teach the children twice weekly for $£ 25$ a year. ${ }^{47}$

The new rules precipitated management changes. Bayley undertook to supervise reform, though not to be answerable for any production shortfalls that resulted, but the overseer who had to effect them resigned. Confirmation that changes were necessary came from Wildman. He reported that the slaves at Salt Savannah refused to associate with the Amity Hall slaves because they were "very bad disposed people." They had been under overseers of very dissipated habits, who conducted the estate on the driving system where maximum immediate profit had priority over the proprietor's long term interest. "The people have been treated with extreme rigour and harshness such as you would not be induced to tolerate for an hour longer were it possible to present the facts to your own sight or within the hearing of your own ears." Wildman warned Goulburn, "that loss must attend an alteration of the present system, at first, I anticipated and felt, but a different system can be pursued with profit." ${ }^{48}$

Wildman's encouraging words in 1831 re-echoed the message George Richards had relayed to Major Archibald Goulburn in 1818: adjustment in management practices could improve reproduction and maintain production. 
But at Amity Hall, for thirteen years, this had not proved the case. In 1831, piqued by publicity, Goulburn allowed himself to respond once more to the same lure-reform with profit. Wildman's experience demonstrated, however, the fragility of this balance, since within months of his return to England, productivity on his estates fell catastrophically. Although Wildman blamed his attorney, who "seemed to throw up things altogether" despite the fact that he "wrote him folios," his experiences certainly validate Macaulay's 1826 judgement: "the vices of the system are not to be reformed by a mere change of agents, or by a few exhortations to moderate work, and adequate food." ${ }^{49}$

As a reformer, Goulburn was a minimalist. He participated in the amelioration process only when driven to do so by slave labour shortages, and by the expense and uncertainty of the internal slave trade. More importantly, he expected that routine short-term production and profit could be pursued in tandem with the long-term intent to maximise reproduction. He clearly did not intend to lose money creating conditions conducive to an increased birth rate. The obligation to promote population growth, moreover, was simply added to his attorney's responsibilities without so much as a compensatory salary increment. It is not surprising that Bayley's careful replies to Goulburn defended the status quo and his own role in it. The Anti-Slavery Society's election critiques of Goulburn's failure to participate in the amelioration programme were, moreover, well informed. The particular charges which Goulburn so hotly denied, that night work continued until January 1830 , and that there was no provision at that date for slave religious instruction, were proved accurate by the rules he drew up in 1831. Goulburn did not promote the amelioration programme on his estate until his failure to do so was made public. His prominence in the Incorporated Society for the Religious Instruction and Conversion of the Slaves served primarily as good political cover for his inactivity. All of this reflected the essentially irresponsible position of the absentee owner, and the lack of mechanisms to effect reforms.

Goulburn's attitude to the amelioration of slavery, by process or programme, reflects the attitude he brought to bear on efforts to raise the standards of West Indian institutions in general. As he told the House of Commons when opposing an inquiry into the abuse of justice in Tobago, he always felt difficulty with questions of this sort, because West Indian legislatures operated with diminished influence and diminished moral authority. They could not be judged "as if their acts had been commited in this country, but as happening in 
another where there was so different and inferior a mode of government." At the same time, the acrimony, lies and distortions, which characterise Goulburn's correspondence with Zachary Macaulay, indicate both the extent to which, by 1831 , the abolitionists had become a political force to be reckoned with, and the absolute determination of their enemies to fight them every step of the way.

As applied to slavery, the term "amelioration" is embedded in the literature because it cloaked for contemporaries the economic and political priorities of both slave owners and the imperial government. These were to induce new levels of technical and managerial efficiency, to maximise production, to perpetuate the slave labour force, and (on the government's part) to induce the material, civil, and moral development of the slaves in preparation for wage work. As applied in J. R. Ward's work, its usage serves to assert the primacy of slaveowners and the metropole in shaping West Indian history.

The impetus to improve work conditions, however, as detailed study of . worker/manager relations at Amity Hall demonstrates, was generated primarily at the workplace in recurrent conflicts over subsistence levels and workloạds. ${ }^{30}$ The slaves used absenteeism, overt and covert sabotage (arson and malingering), appeals for mediation, and, as recorded above, collective bargaining that involved strike action. The tradition of slaves bargaining within the work unit, occasionally recorded by managers like Bayley, surfaced to public view when negotiations broke down and public protests followed; or, as in 1831, when a general strike became a key component in a rebellion to claim free legal status and wages. It was this event which proclaimed more convincingly and wages. It was this event which proclained, more convincingly than the Anti-Slavery Society could, the failure of amelioration as process or programme. 


\section{NOTES}

1. Election Broadsheet addressed to "The Attention of the Members of the University of Cambridge who are inclined to support Mr. Goulburn," London, 28 April 1831, Box 33, Goulburn Papers, Surrey Record Office, Kingston.

2. "Address to the People of Great Britain and Ireland Unanimously adopted at the General meeting. .. 23 April 1831," The Anti-Slavery Reporter 4 (May 1831): 280.

3. J. R. Ward, British West Indian Slavery, 1750-1834: The Process of Amelioration (Oxford: Clarendon Press, 1988).

4. Ward, British West Indian Slavery, pp. 262-63, 94.

5. G. S. Ramlackhansingh, "Amity Hall 1760-1860: The Geography of a Jamaican Plantation" (M.Sc. Econ. thesis, University of London, 1966), pp. 69, 72, 86.

6. Ward, British West Indian Slavery, pp. 166-67.

7. William Samson to Henry Goulburn, 9 July 1818, Box 51, Goulburn Papers.

8. Samson to Goulburn, 20 February 1818; Major Archibald Goulburn to Goulburn, 22 February 1818, Box 51, Goulburn Papers.

9. Major Archibald Goulburn to Goulburn, 22 February 1818, Box 51, Goulburn Papers.

10. George Richards to Goulburn, 16 January 1819, Box 51, Goulburn Papers.

11. Goulburn to Reverend Dr. Godfrey, President of Queen's College, Cambridge, 15 May 1826, Box 33, Goulburn Papers.

12. Minutes of the West India Committee: Standing Committee 25, 29 June 1823 (microfilm), Institute of Commonwealth Studies, London University; L. J. Ragatz, Fall of the Planter Class in the British Caribbean, 1763-1833 (New York: Octagon Books, 1971), pp. 410-15.

13. The Society was originally founded by Beilby Porteous, Bishop of London from 1787 to 1808 .

14. Mary Turner, "The Bishop of Jamaica and Slave Instruction," Journal of Ecclesiastical History 24 (October 1975): 368-69.

15. Alexander Bayley to Goulburn, 14 April 1825, Box 54, Goulburn Papers.

16. Copy of letter addressed to Reverend Dr. Godfrey, President of Queen's College, Cambridge, February 1826, Box 33, Goulburn Papers.

17. Goulburn to Godfrey, 15 May 1826, Box 33, Goulburn Papers.

18. Bayley to Goulburn, 6 May 1826, Box 54, Goulburn Papers.

19. Bayley to Goulburn, 6 May 1826 (replying to Goulburn to Bayley, 10 March 1826), Box 54, Goulburn Papers.

20. Cambridge University re-elected pro-Catholic emancipation Palmerston with the help of Whig votes. Goulburn was returned for Amargh city, a safe No-Popery constituency until 1831. Elie Halevy, History of the English People in the 19th Century, Vol 2: The Liberal Awakening 1815-1830 (London: Ernest Benn, 1961) pp. 240-41; Dictionary of National Biography, ed. Sir Leslie Stephen and Sir Stephen Lee (Oxford: Oxford University Press, 1890) 8:284. 
21. Goulburn to Bayley, 5 July 1827; Enclosure, "Regulations intended to be submitted by West Indian Proprietors in England to their Managers in the West Indies as desirable to be adopted as soon as Circumstances will permit," Box 54, Goulburn Papers. The "Regulations" in this form are not found in the Minutes of the West India Commitee, although they clearly reflect its recommendations to the Colonial Office. They had been in circulation for some years, however, and probably date from 1823. Goulburn "believed" he had sent them to Richards, Bayley's predecessor, who was replaced in February 1825.

22. "Regulations," Box 54, Goulburn Papers.

23. Bayley to Goulburn, 29 September 1827, Box 54, Goulburn Papers.

24. Bayley to Goulburn, 29 September 1827, Box 54, Goulburn Papers.

25. Goulburn to Bayley, 5 July 1827, Box 54, Goulburn Papers.

26. Bayley to Goulburn, 29 September 1827, Box 54, Goulburn Papers; B. W. Higman, Slave Population and Economy in Jamaica, 1807-1834 (Cambridge: Cambridge University Press, 1976), p. 208.

27. Bayley to Goulburn, 29 September 1827, Box 54, Goulburn Papers.

28. Goulburn to Bayley, 24 November 1828 and 18 June 1829, Box 54, Goulburn Papers.

29. Bayley to Goulburn, 2 January 1829, Box 54, Goulburn Papers.

30. Goulburn to Bayley, 22 April 1829, Box 54, Goulburn Papers.

31. Ramlackhansingh, "Amity Hall," p. 86.

32. Ramlackhansingh, "Amity Hall," p. 99, 143, 155-56; Bayley to Goulburn, 2 September 1826, Box 54, Goulburn Papers; Accounts 1826, Box 59, Goulburn Papers.

33. Bayley to Goulburn, 29 September 1827, Box 54, Goulburn Papers.

34. Goulburn to Bayley, 26 June and 6 November 1830, Box 54, Goulburn Papers.

35. Bayley to Goulburn, n.d., September 1830; Enclosures, J. W. Holmes, Custos, 25 September 1830; A. Murchison, M.D., 25 September 1830; Malcolm MacLeod, 23 September 1830; William Mackie and Robert Miller, 25 September 1830; Reverend John Smith, 25 September 1830, Box 54, Goulburn Papers.

36. Goulburn to John Pringle, 19 and 20 May 1831; Goulburn to Zachary Macaulay, 20 July 1831; Macaulay to Henry Goulburn, 2 August 1831, Box 33, Goulburn Papers.

37. Goulburn to Reverend W. Cunningham, 1 June 1831, Box 33, Goulburn Papers.

38. Goulburn to Christopher Lipscomb, Bishop of Jamaica, 13 January 1832; Goulburn to Reverend J. Smith, Rector of Vere Parish, Box 33; Goulburn to Bayley, 30-31 July 1831, Box 54, Goulburn Papers.

39. J. B. Wildman to Goulburn, 31 June 1831, Box 33, Goulburn Papers.

40. Ibid.

41. Ibid.

42. Ibid.

43. Election Broadsheet; Macaulay to Goulburn, 1 November 1831, Box 33, Goulburn Papers. 
44. Goulburn to Bayley, 30-31 July and 17 August 1831, Box 54, Goulburn Papers.

45. Goulburn to Bayley, 17 August 1831, Box 54, Goulburn Papers.

46. Wildman to Goulburn, 31 June 1831, Box 33, Goulburn Papers.

47. Bayley to Goulburn, 29 December 1831, Box 54, Goulburn Papers.

48. Bayley to Goulburn, 29 December 1831, Box 54, Goulburn Papers; Wildman to Goulburn, 7 November 1831, Box 33, Goulburn Papers; Macaulay to Henry Goulburn, 2 August 1831, Box 33, Goulburn Papers.

49. Evidence of J. B. Wildman, "Report from the Select Committee on the Extinction of Slavery throughout the British Dominions," British Sessional Papers: House of Commons, 1831-32 (721), Vol. 20, pp. 515, 517.

50. See Mary Turner, "Slave Workers and Labour Negotiations," in The Slaves' Economy: Independent Production by Slaves in the Americas, eds. Ira Berlin and Philip D. Morgan, (Cass: London, 1991) pp. 92-106. 


\title{
13
}

\section{Abolition and Emancipation:}

\author{
Williams, Drescher and the Continuing Debate
}

WALTER MINCHINTON

Richard Sheridan and I first met at the London School of Economics in the early 1950s when we were both research students, and we have kept in touch since. In 1960, we both attended the American Historical Association conference in New York when Dick was a commentator at a session at which I read a paper on "Bristol and the Slave Trade of North America." ${ }^{11}$ Our academic interests became more closely linked following the publication of his essay on "The Commercial and Financial Organisation of the British Slave Trade, 1750-1807."2 Based largely on literary and descriptive material, Sheridan argued that slave vessels returned from the West Indies to England largely in ballast, an assertion which won wide acceptance. But using information contained in the British naval office shipping lists for colonial ports, I expressed my doubts about this generalisation. ${ }^{3}$ I found that, according to these records, comparatively few vessels cleared in ballast. This argument has now been generously accepted by Dick Sheridan who wrote in 1987 that "Minchinton supplies evidence that slave traders did largely avoid returns in ballast."4 Our paths also crossed at a conference held in Aarhus, Denmark, in 1970 to celebrate the jubilee of the university there at which I read a paper on "Williams and Drescher: Abolition and Emancipation, ${ }^{15}$ which covered ground subsequently traversed by Sheridan in his own essay on Eric Williams. ${ }^{6}$ Since then, our academic interests have gone different ways, but this tribute to Dick Sheridan enables me to make a further contribution to the debate about Williams and Drescher. ${ }^{7}$ 
Abolition is one of the great movements of the past whose ripples are still rolling up the beach of history. And the British case deserves attention because, just as Britain was the first industrial nation, so-though the Danish were first-Britain was early in the field of abolition too. Of the facts of the British situation, there is no doubt: the British slave trade was abolished in 1807 and the British Parliament passed an act to emancipate the slaves in 1833. It is the explanation for these two pieces of legislation about which there is a continuing and lively debate. Why did the British Parliament pass these two acts when they did, and what factors brought about first abolition and then emancipation? What part did economic, political, religious and humanitarian motives play?

In the 1930s, the received wisdom was that first abolition and then emancipation were achieved by the disinterested work of religious zealots and humanitarians who for entirely altruistic motives campaigned against man's inhumanity to man, and advocated bringing the "lesser breeds" within the law. This view was heir to a long tradition which stemmed from Thomas Clarkson, The History of the Rise, Progress and Accomplishments of the Abolition of the African Slave Trade by the British Parliament, and was espoused in Oxford by Reginald Coupland, whose The British Anti-Slavery Movement, was published in $1933 .^{8}$ Coupland's book was not entirely welcomed with approbation. While the Spectator opined that it told "an inspiring story of a great cause," Professor William Macmillan, writing in the New Statesman, wondered whether, compared with the economic motive for imperial expansion, the humanitarian movement was anything like so strong as Coupland would have his readers believe. Then Cyril L. R. James, like Williams a Trinidadian writer, commented in the bibliography of his book, The Black Jacobins, not only on The British Anti-Slavery Movement, but also on Coupland's biography of Wilberforce: "Both these books are typical for, among other vices, their smug sentimentality, characteristic of the official approach of Oxford scholarship to abolition. As the official view, they can be recommended for their thorough misunderstanding of the question." 9 These misgivings heralded the publication in 1944 of Capitalism and Slavery by Eric Williams, whose book came out of his 1938 Oxford doctoral thesis on "The economic aspects of the abolition of the British West Indian slave trade and slavery." ${ }^{10}$

The essentials of the Williams thesis with respect to abolition and emancipation have two main elements: first-the anti-Coupland proposition-that the role of the intellectual movements has been exaggerated; and second, that 
emancipation and abolition were achieved by economic rather than by intellectual, religious and humanitarian movements. Further analysis shows that there were two components to this second proposition: a) the long-run: that abolition and emancipation took place in the context of secular West Indian decline-a proposition which Williams took over from Lowell Ragatz, though the latter dated the decline from 1763, while Williams, following Adam Smith, took 1776 as his starting point; and b) the short-run: "overproduction in 1807 demanded abolition; overproduction in 1833 demanded emancipation." ${ }^{11}$

Because it was published during World War II, Capitalism and Slavery got a somewhat muted reception, but in the following twenty-five years, aided without doubt by the fact that his book was directly and compellingly written, the Williams thesis became widely accepted by historians. As importantly, it also provided powerful ammunition for politicians in the Third World, arguments which could be employed by the periphery against the metropolis.

Abolition: the role of the anti-slavery movements

The campaign to rehabilitate the importance of religious and moral factors in the achievement of abolition was led by Roger Anstey. ${ }^{12}$ Williams' argument had been that, while the moral awakening of which Coupland and his followers had written may have genuinely affected the behaviour of the individual supporters of abolition, the root cause of the abandonment of the slave trade and later of West Indian slavery had been a change in the bälanice of economic pressure groups. The anti-slavery movement, Williams suggested, was a group response of the middle-class to a decline in the relative power of the West India interest on the one hand, and a change in the needs of the increasingly industrialised society in which they lived on the other. "This study," Williams wrote, "has deliberately subordinated the inhumanity of the slave system and the humanitarianism which destroyed the system. To disregard it [the latter] completely, however, would be to commit a grave historical error and to ignore one of the greatest propaganda movements of all time." Williams acknowledged that "the greatest propaganda movements of all time." Williams acknowledged that "the
humanitarians were the spearhead of the onslaught which destroyed the West Indian system and freed the Negro." But, he weñt on, the importance of the Britush humanitarians in the abolition of the slave trade and of slavery "has been seriously misunderstood and grossly exaggerated by men who have sacrificed scholarship to sentimentality and, like the scholastics of old, placed faith before reason." 
Anstey's book built on the case which he had previously argued, that "the initial impulse for the abolition of the slave trade came from newly-awakened Christian conviction strengthened by the 'reasonableness' and philanthropy of the Enlightenment." While he rejected the view that abolition was brought about by economic factors - "the 'developing economic forces' . . were neither organized nor a self-conscious group, had no political influence and had no relevance to the abolition question"-he also agreed that the earlier Coupland view which "saw abolition in moral and religious terms of too rough-hewn a kind and in which, as Williams and Hochstetter pointed out, too many important questions were begged" also required modification. Anstey therefore concluded that:

one must take greater account of intellectual change in the eighteenth century and study in detail the interplay between the moral purpose of the political nation, muted as it was and long hamstrung by a deep-rooted sense of the national importance of the West Indies, and the high moral purpose, daunting perseverance and political skill, and for the most part warmly Christian inspiration of the abolitionists. ${ }^{14}$

But not everyone was convinced by Anstey's attempt to describe in more detail the links between anti-slavery and evangelical theology. "If there is a doubt," one commentator wrote, "that most abolitionists belonged to evangelical denominations this does not mean necessarily that they became abolitionists because of their religious beliefs. More probably the same reasons that drove them to revivalism drove them to different types of reform or to abolitionism." ${ }^{15}$ Moreover, it is clear that large segments of evangelical Christianity in Britain remained indifferent to, or tolerant of, slavery, while elsewhere in northern Europe, Protestant theology did not generate mass abolitionism. Nor was the anti-slavery movement in Britain confined to evangelicals or nonconformists. ${ }^{16}$ Anstey, wrote Christopher Fyfe, failed to offer "a new underlying general explanatory thesis" on the causes of British abolition of the slave trade. ${ }^{17}$

Anstey's discussion virtually ended with the achievement of abolition in 1807, but religion continued to be an element in the anti-slavery movement in the 1820s and 1830s. Though to state this is not, as James Walvin argued, "to return to the traditional interpretation which saw abolition as a triumph for evangelicalism ... we need to recall that religion itself had been transformed, more especially among the lower orders." ${ }^{18}$ 
Already before the publication of Anstey's book, other writers had begun to reassess the place of humanitarian motives in democratic secular movements. But the pace quickened in the late 1970s. Two areas of investigation proved especially fruitful. The first was concerned with anti-slavery activity in particular areas. E. M. Hunt, for example, argued that anti-slave trade agitation in Manchester provided an example of a rapidly-growing industrial town trying to influence political decisions in London and indeed at times giving an energetic and dynamic character to the agitation. ${ }^{19}$ Then, in different ways, the situation in Liverpool and Bristol showed that economic factors were of importance. Frank Sanderson not only documented the activities of the opponents of abolition in Liverpool, but also demonstrated that while the movement for abolition there followed the national pattern in microcosm, given the size and importance of the African trade in the town, the practical effects of their local campaign were minimal. ${ }^{20}$ Of Bristol, Peter Marshall stated that "the abolitionists had done much to stir consciences, but the economic crisis of $1793 \mathrm{had}$ fatally sapped the material strength of the slave trade from Bristol." ${ }^{21}$ Further, from an examination of three groups of writers in Scotland, C. Duncan Rice supported the hypothesis that slavery had become "an anomaly in an age that was prepared to assume a unity of moral and economic behaviour."22

A second strand of debate was concerned with the relationship between the campaign for abolition and other aspects of radical politics. James Walvin discussed the importance of the spoken and written word, and argued that the anti-slavery movement exercised a considerable influence on the evolution of English popular radicalism, both directly through the example of anti-slavery language and tactics, and indirectly through the two movements' shared constituency of plebian nonconformity and working class community. ${ }^{23}$ But this view has not gone unchallenged. While Patricia Hollis, a historian of popular radicalism, did not dispute that there was an early sympathy for the anti-slavery cause amongst Jacobins and reformers like Thomas Hardy and John Cartwright, she contended that by the early nineteenth century, working-class radicals had become hostile to abolitionism. Popular radical leaders like Henry Hunt, William Cobbett and Richard Oastler, supported by scathing editorials from Henry Hetherington and Bronterre O'Brien, denounced the anti-slavery movement because of its indifference to poverty and suffering at home. By Chartist times, Patricia Hollis argued, "breaking up an anti-slavery meeting had become a statement of class consciousness by working-class radicals." 24 
Betty Fladeland also noted that there was an intense hostility to the anti-slavery cause on the part of the early Chartists. She argued, however, that this hostility was gradually dissipated by the mutual political conversion of some prominent abolitionists and Chartists. In particular, the Chartists forced many abolitionists to widen their understanding of oppression to accommodate the condition of the working classes in Britain. ${ }^{25}$ In this discussion there is a need to compare the position of black slaves and white industrial labour in radical and working-class literature. ${ }^{26}$

As a result, historians committed to the idea of an abolitionist/popular radical nexus have become more tentative in their claims. Seymour Drescher, for example, stated that "it would be odd if English urban artisans had completely abandoned a component of the democratic ideology they forged at the end of the eighteenth century," but he admitted that "the older antagonistic tradition of Cobbett remained a staple but equivocal attitude of some of the radical working-class spokesmen into the mid-[eighteen] thirties." ${ }^{27}$

Then Iain McCalman provided an analysis of the case of Robert Wedderburn, a Jamaican-born black who became active in London anti-slavery circles. McCalman argued that a study of Wedderburn's evolution as an ultra-radical shows, "first, that anti-slavery, Nonconformist and radical ideas did converge in London's most plebian and extreme radical milieu, independent of the formal abolitionist movement; second, that anti-slavery ideas were widely disseminated in ultra-radical circles during the formative years, 1815-c1834, possibly with some cooperation from abolitionists; and, finally, that this antislavery/ultra-radical legacy was transmitted into the new mass radicalism of the 1830s and 1840s." ${ }^{28}$ McCalman concluded that "the attitudes of Cobbett, Hunt and some other radical spokesmen seem to signify less the emergence of a new, pervasive class-conscious hostility to abolitionism than a persistence of the old ideological diversity that was so characteristic of early nineteenth-century popular radicalism." He continued, "by Chartist times there were several schools of thought on anti-slavery, as on so many issues. It was up to abolitionists like Sturge and ultra-radicals like Harney and Cuffay to try to ensure that sympathy for anti-slavery became the dominant radical view." ${ }^{29}$

Such research demonstrated that there was a clear connection between anti-slavery and the general expansion of mass political activity. ${ }^{30}$ It also showed that the reason for the growth of the anti-slavery movement was "far more than 
a downward flow of ideology from elites to a nascent capitalist or evangelical middle class." ${ }^{31}$

Then a new dimension has been added to the discussion by the demonstration of the part played by black slaves in Britain in the struggle for abolition. ${ }^{32}$ As Douglas Lorimer argued, because blacks in eighteenth-century England were caught in a half-way stage between colonial slavery and English domestic servitude, they were able, out of the ambiguities of their position, to alter their status. Consequently, slavery came to an end in England between the 1760 s and the 1790s not from Lord Mansfield's judgement in the Somerset Case in 1772, nor through the efforts of Granville Sharp, nor from the 1833 Act, but from the activities of the slaves themselves. This was made possible by certain institutional elements in Britain - the traditions of household servitude, a popular libertarian political culture and the ideology of the rule of law, which provided a climate conducive to black resistance. Nonetheless, he concluded, the force which brought this combination of institutional elements into play came from the courageous acts of resistance by individual members of the black community. ${ }^{33}$ While Lord Mansfield and Granville Sharp had their parts to play, so did the blacks. The heroic has been replaced by the social explanation. Further, the links in Britain between the black slaves and the white working class from the 1770s helped to explain the depth and breadth of abolitionist support.

It is now also recognised that the black slaves in the British West Indies were not passive beneficiaries of white benevolence, but were important agents of their own emancipation. The series of black revolts from the 1770s on made their contribution to producing both a climate of opinion and an actual situation which made abolition and emancipation probable at some time. Already, before Williams had written Capitalism and Slavery, C. L. R. James had documented the uprising in Saint Domingue in $1792 .{ }^{34}$ Yet the importance of this example should not be exaggerated. The slave trade continued apace nonetheless, and the 1790s saw the second highest volume of slaves per decade transported in the whole history of the trade. What happened later was entirely different. The uprisings in Barbados in 1816, in Demerara in 1823 and in Jamaica in 1831-32, took place after the abolition of the British slave trade, and at a time when there was some evidence that the political power of the West Indian planters in Britain was in decline. ${ }^{35}$ Nonetheless these revolts were an essential ingredient in the campaign for emancipation. 
And the part played not only by blacks but also by women is now acknowledged. Though largely within the limits determined by their male contemporaries, the abolitionist cause gave many women their first taste of political activity. "Within the anti-slavery campaign women played a remarkably influential role as fund-raisers, in recruiting names to petitions, and as organisers of meetings and publications." By the mid-1820s, they were often undertaking "the tedious, unrewarding but necessary tasks which underpinned so much of the abolitionist campaign." ${ }^{\text {"36 }}$

Finally, historians are also concerned with the aftermath of emancipation but a consideration of what took place after 1833 would take us beyond the limits of the present paper. ${ }^{37}$

\section{The economic basis of abolition and emancipation}

The second aspect of the Williams thesis which has been challenged is the argument that abolition was primarily achieved by economic forces rather than by intellectual, religious and humanitarian movements, an argument which has two components, the long-run and the short-run.

\section{The doctrine of West Indies decline-a) the long-run:}

On the long-run position, the major salvo was fired by Seymour Drescher in 1977 with the publication of Econocide: British Slavery in the Era of Abolition. That the West Indies were less valuable to Great Britain in the 1820s than they had been fifty or sixty years earlier - the Ragatz/Williams decline thesis-is a view which has been accepted by a large number of historians, but it is a view which Drescher challenged. His argument, in short, was that "neither Imperial nor world economic and demographic trends indicated a British advantage in destroying, abandoning or neglecting her slave system between 1787 and 1807. ${ }^{38}$ Intended as a refutation of the Williams doctrine that the abolition of the slave trade (and later emancipation) occurred primarily because the slave trade and plantation slavery had become undervalued or less valued, Drescher argued that "from the vantage point of British trade, the potential of the slave system was greater in 1804-14 than it had been at the outset of the great public opinion campaigns against the slave trade between 1788-92 or at any other point in the eighteenth century." ${ }^{39}$ Moreover, it was the metropolis which decided on abolition, not the planters or merchants. 
The most lively controversy has been concerned with the first long-run period between 1783 and 1806. In an attempt to define the nature of "decline," several aspects have been addressed. The first issue is the question of planter profits. Since Econocide, additional evidence of profits has become available, which Drescher argued supports his view that profits rose between 1773 and 1791. But Selwyn Carrington, who believes that "the debate over the profitability of slavery and the state of the economies of the British West Indian islands has undoubtedly been further confused by the publication of Econocide,"40 argued that on the contrary, "beginning with the outbreak of the War of American Independence, the economy of the sugar islands went into decline." ${ }^{11}$ This he attributed first to the American Revolution and then to British policy in the decade after 1783 which retarded cane cultivation and so reduced sugar production. While sugar prices rose, Carrington asserted that costs rose faster, thus diminishing profits. It was not only the increase in production costs, in the price of foodstuffs and timber, in wages and salaries, but also the higher local taxes and the increase in marketing costs, in freight rates and in insurance rates, which caused problems for the planters. Moreover, David Richardson demonstrated that, as the profits of planters dwindled, they bought fewer slaves. ${ }^{42}$ Carrington also showed that, as a result, contrary to Drescher's thesis, the number of slaves retained in the West Indies at the end of the eighteenth century declined. ${ }^{43}$ In his "Decline Thesis" articl_, Drescher, who on the question of the profitability of sugar planting in the West Indies claimed John Ward ${ }^{44}$ as an ally, rejected all these points in toto and offered a different interpretation from a different range of statistics. ${ }^{45}$

The argument about decline is now largely confined to the fifteen years between 1783 and $1798 .{ }^{46}$ After that, Carrington ard Drescher are in agreement. Although the British islands were able to benefit from the revolution in Saint Domingue and profits rose on some estates during the early years of the French Revolutionary War and particularly between 1795 and 1798, sugar prices fell sharply between 1798 and 1807 . The older islands then experienced difficulties, particularly after 1800 . From 12 percent in the 1790s, profits fell to 6 percent in 1801-04, and to 3 percent in 1805 for well-run estates, ${ }^{47}$ falling further in 1806-figures accepted by both Drescher and Carrington. Compared with earlier, this was decline indeed. ${ }^{48}$ Drescher is right, Michael Craton commented:

to discount the planter's invariable tendency to plead impoverishment, but he should have inquired much more fully into the question of plan- 
tocratic debts, the demise of inefficient plantations, and the transfer of capital investment-not only from old to new colonies, but out of formal colonialism altogether, and into industrial enterprises. ${ }^{49}$

On the profitability of the slave trade, there has been continued debate. Drescher rejected Anstey's calculations that profits declined sharply from 13 percent in 1791-1800 to 3.3 percent in 1801-07 because they were only concerned with slaves carried on British ships and not under neutral flags, and because the returns on staples carried homeward were excluded. ${ }^{50}$ Drescher's view that slaving profits declined less sharply is now accepted by David Brion Davis. ${ }^{51}$ But it should be noted that Drescher did not contest the fact of declining profits, only the cause and extent of such decline. ${ }^{52}$ On the volume of the British slave trade, David Richardson suggested that the overall expansion of the British slave trade was confined "largely to the 1720 s and early 1730 s and to the third quarter of the eighteenth century," though displaying a surge after the American Revolution. ${ }^{53}$ This position, which appears now to be accepted by Drescher, obviously affects calculations about the economic position of the West Indies. And it should be noted that the number of slaves retained, which Carrington regarded as a more accurate indication of West Indian prosperity, fell. ${ }^{54}$ While the majority of historians accept that slave trade profits fell-and two of the three English slave-trading ports, Bristol and London, withdrew from the trade by 1800 because of this, leaving only Liverpool to carry on the trade-there has been a dissenting voice. Joseph Inikori argues that the levels of profits canvassed by historians is too low and "that recent work has generally tended to make the trade look much less profitable than it actually was." 55

Then there is the question of the importance of trade with the West Indies for Britain. While the British West Indian share of the total was greater in 1808-12 than in 1773-77, it is an exaggeration to say that the British West Indies were "far more valuable" to Britain than they had been previously. ${ }^{56}$ And after abolition, the importance of British trade with the West Indies declined. Though Drescher is right to say that 1821 was the last single year when "the West Indies accounted for more of British overseas trade in both imports and exports than they had fifty years before, ${ }^{157}$ if the five-year averages are used rather than the figures for a single year, imports were lower in 1818-22 than in 1768-72 (25.8 percent compared with 27.2 percent), while exports were exactly the same percentage. And to extend the comparison, Ralph Davis's figures show that, as a proportion of British trade, imports from the West Indies fell from 
22.3 percent in $1804-06$ to 11.3 percent in 1834-36, and British exports to the West Indies fell from 17.6 percent to 8.9 percent in the same period. ${ }^{58}$ Moreover, alternative markets were becoming available in what Vincent Harlow called "the turn to the East"-imports from Asia (mainly tea) quintupled in less than a decade (1783-91), while in the early nineteenth century Latin America became the main market for the British textile industry.

The third type of comment on the Drescher position that "at the time of abolition the West Indian plantation system was flourishing" takes a different line of defence of the Williams position. "It is not clear what has led interpreters of Williams's thesis to assume that his position hinges on the belief that the plantation system was in decline," William Darity wrote. "For the plantation system to have become a drag on metropolitan growth does not mean that the islands themselves were undergoing economic deterioration." With development, an asymmetry could emerge between the growth of the colonies and the metropolis. "Thus," Darity concluded, "the Anstey-Drescher observation that abolition occurred during a peak period of West Indian prosperity is in no way inconsistent with Williams's thesis." ${ }^{\text {"59 }}$

On the long-run situation in the second period between 1808 and 1833 there continues to be some disagreement, since the indicators do not all point in the same direction. Of the declining importance of British West Indian trade as a share of total British trade there is no doubt, and the decrease from 20.9 percent in the period 1808-12 to 12.3 percent in $1828-32$ (at which point Drescher's table ends) is beyond dispute. ${ }^{60}$ On the demographic trend, once the importation of blacks had ceased, there is now broad agreement. ${ }^{61}$ Michael Craton, Barry Higman and Richard Sheridan all assert that there was a net decrease of the slave population which became an absolute decrease from 1808 to $1834 .^{62}$ Then there is the question of sugar. In the opinion of John Ward: since the ending of the slave trade British West Indian sugar production had continued to grow, but at a much reduced rate, and only through the acquisition of some new and highly fertile colonies. At the same time the price received by planters for their sugar had been severely cut through general deflation, heavier taxation, foreign competition, and the restriction of market opportunities. The evidence for reduced West Indian prosperity seems quite clear . . . because of the disadvantage at which British planters were placed in relation to their foreign competitors through being unable to continue the import of slaves from Africa... the profitability of sugar planting in the older colonies was cut by about half in the $1820 \mathrm{~s}^{63}$ 
The consequence of economic depression, it has been argued, may have facilitated emancipation by making the planters more willing to accept the compensation terms offered. ${ }^{64}$ But John Ward disagrees. In his view:

the available evidence does not provide much support for the notion that Emancipation was in any sense a consequence of economic developments in the West Indies. British West Indian plantation slavery in the 1820 s seems to me to have been a fundamentally healthy economy, adjusting with considerable courage and success to new and difficult circumstances. By 1830, prospects for the future were good. ${ }^{65}$

The doctrine of West Indies decline-b) the short-run:

The further Williams proposition-the short-run proposition - that "overproduction in 1807 demanded abolition; overproduction in 1833 demanded emancipation" also came to be accepted by many historians. ${ }^{66}$ But this view was challenged by Roger Anstey. While he accepted that "overall Caribbean production was in excess of demand" in 1805, he went on to argue that the relationship between abolition and the national interest is very different from the proposition that "overproduction in 1807 demanded abolition. ${ }^{167}$ This argument David Brion Davis found less than compelling. "If the key to the understanding of British abolition is to be found specifically, as Anstey argued, in the nature and timing of the 1806 Abolition Act, why was the national interest cloaked in hidden humanitarian motives just at one point in time in 1806," Davis asked? If the 1806 measure, he continued, is "what turned the tide, then Professor Anstey has simply refined and rehabilitated part of the Williams thesis"-that "the political nation' . . . needed to be persuaded 'that the national interest would positively be furthered by what was presented as principally a politicoeconomic measure."'68 On this matter, Drescher took issue both with Anstey and Davis, arguing on the basis of an analysis of Parliamentary voting in 1806-07 and on archival evidence, that "the over-production thesis" applies neither to 1806 nor to $1807 .^{69}$

The explanation for the second short-run situation, for emancipation in 1833, with which Drescher is less concerned, has become more complex. It was not simply, as Williams held, that "overproduction in 1833 demanded emancipation;" other factors were involved. Certainly the economic situation was less healthy than it had been. The London price of sugar had fallen to a lower point than it had been for almost a hundred years, but it was also the destruction of their works in the Jamaican rebellion of 1831-32 which forced a number of West 
Indian merchants and brokers into bankruptcy. ${ }^{70}$ While it is now recognised that the Anti-Slavery Society did not apply "unrelenting and steadily increasing pressure, ${ }^{171}$ the news of the rebellion, which received considerable publicity in Britain through the activities of missionaries such as William Knibb and Thomas Burchell, strengthened the hands of the humanitarians and their supporters in persuading the reformed Parliament, where the West Indian interest had been almost halved, to get rid of slavery in 1833. Economic, political and humanitarian factors all played their part in the achievement of emancipation.

For decades the issues raised by Williams have been widely discussed and some revisions have taken place. ${ }^{72}$ For example, while Williams may have underestimated the role of the humanitarian movements, the nature of the various branches of the anti-slavery movement has been assessed in more detail. ${ }^{73}$ This has widened and deepened our understanding rather than restored the Coupland position of the humanitarian movements in these campaigns. In the Third World, Williams' succinct phrase that "the capitalists had first encouraged West Indian slavery and then helped to destroy it," has become part of the orthodox interpretation of the rise of Western economic power, but elsewhere the quantitative underpinnings of Williams' views are now regarded as insecure ${ }^{74}$ and, as Robin Blackburn has argued, in the end Williams' "dialectical" schema of capitalism using and discarding slavery has come to be seen as mechanical and unsatisfactory. ${ }^{75}$ David Brion Davis notes that various historians have shown that Williams exaggerated the role of the slave trade and slavery in accumulating capital for the industrial revolution, and added that Williams had been unfair to William Pitt and the abolitionists. ${ }^{76}$ But it is still agreed that it is difficult "to get around the simple fact that no country thought of abolishing their slave trade until its economic value had considerable declined... Williams' fundamental insight - even his severest critics now acknowledge-was correct: the advent of slavery abolition was a function of the rise of capitalism." 77

At the same time, the debate initiated by Drescher on the decline thesis-on "econocide"-has given rise to a burgeoning literature to which Drescher himself has been a frequent contributor. His and other contributions have helped to shift the context of the debate. "Perhaps the most telling indicator of the change since 1987," Drescher has written, "is how routinely historians now speak of 'econocide' in connection with the end of slavery, they no longer have to specify exactly what they mean. ${ }^{78}$ One other direction in which the debate has widened is by the inclusion of other countries within the scope of the discussion. ${ }^{79}$ 
Perspectives too have changed. Writers now support the argument that "slavery contributed to British industrialization, but only marginally, and that British abolition was, nevertheless, economically irrational,"ôv while Blackburn asserts that "slavery was not overthrown for economic reasons but where it became politically untenable." ${ }^{81}$

Finally, Thomas Bender has written:

As all seminal works ought to do, Williams' book stimulated decades of monographic response, but as is often the case with such works, the scholarship it called into existence did not sustain its thesis. It is not at all clear that the plantation economy was in decline, nor is the rather crude explication of interest that Williams employed any longer compelling. Yet the legacy of the work survives. If his formulation of the argument has proven vulnerable, the larger issue of identifying the relationship between the rise of capitalism and the decline of slavery has remained stimulating. ${ }^{82}$

And this view is echoed by Michael Craton who has suggested that enough problems remain to fuel the "Williams debate" for at least the rest of the century. ${ }^{83}$ While Dresher's "econocide" has provoked further research, Williams' "debate" will continue. ${ }^{84}$

1. Subsequently published as "The Slave Trade of Bristol with the British Mainland Colonies in North America 1699-1770," in Liverpool, the African Slave Trade, and Abolition: Essays to Illustrate Current Knowledge and Research, ed. Roger T. Anstey and Paul E. H. Hair (Widnes: Historical Society of Lancashire and Cheshire, 1976), pp. 39-59.

2. Economic History Review, 2nd series, 11 (1958): 249-63.

3. Walter Minchinton, "The Triangular Trade Revisited," in The Uncommon Market: Essays in the Economic History of the Atlantic Slave Trade, ed. Henry A. Gemery and Jan S. Hogendorn (New York: Academic Press, 1975), pp. 331-52.

4. Richard B. Sheridan, "Eric Williams and Capitalism and Slavery: A Biographical and Historiographical Essay," in British Capitalism and Caribbean Slavery: The Legacy of Eric Williams, ed. Barbara L. Solow and Stanley L. Engerman (New York: Cambridge University Press, 1987), pp. 317-45. 
5. Subsequently "Williams and Drescher: Abolition and Emancipation," Slavery \& Abolition: A Journal of Comparative Studies 4 (1983): 81-105.

6. Sheridan, "Eric Williams and Capitalism and Slavery."

7. An earlier version of this essay was published (in Spanish) in Esclavitud y Derechos Humanos: La Lucha por la Libertad del Negro en el Siglo XIX, ed. Francisco de Solano and Agustín Guimerá (Madrid: Consejo Superior de Investigaciones Cientificas, 1990), pp. 531-51.

8. Thomas Clarkson, The History of the Rise, Progress and Accomplishment of the Abolition of the African Slave Trade by the British Parliament, 2 vols. (London: Longmans, 1808); Reginald Coupland, Wilberforce: A Narrative (Oxford: Clarendon Press, 1923) and The British Antislavery Movement (London: Thornton Butterworth, 1933). Others followed, though the role of William E. H. Lecky, A History of European Morals from Augustus to Charlemagne (London: Longmans Green, 1869), in the succession, has been disputed by William Darity, "The Williams Abolition Thesis before Williams," Slavery \& Abolition 9 (1988): 29-41.

9. Cyril L. R. James, The Black Jacobins: Toussaint L'Ouverture and the San Domingo Revolution (London: Secker \& Warburg, 1938), p. 321.

10. See Ivar Oxaal, Black Intellectuals Come to Power (Cambridge: Schenkman, 1968), pp. 69-70. Williams was later to turn from scholarship to politics to become prime minister of Trinidad and Tobago, a post which he held until his death in 1981.

11. Eric Williams, Capitalism and Slavery (Chapel Hill: University of North Carolina Press, 1944), p. 152. The thesis which Williams set out in Capitalism and Slavery owed much to the work of three people, the German historian, Franz Hochstetter, the author of Die Wirtschaftslichen und Politischen Motiv für de Abschaffung des Britischen Sklavenhandels im Jahre 1806/1807 (Leipzig: Duncker and Humblot, 1905); Lowell Ragatz, author of The Fall of the Planter Class in the British West Indies 1763-1833 (New York: Century, 1928), to whom Capitalism and Slavery is dedicated; and his compatriot, Cyril L. R. James who in The Black Jacobins stated clearly and concisely the thesis which Williams was to elaborate in his book. There were other components to the thesis, particularly the hypothesis that the British industrial revolution was financed out of the profits of the slave trade and plantation slavery. See also Minchinton, "Williams and Drescher;" and Barbara Solow, "Caribbean Slavery and British Growth: The Eric Williams Hypothesis," Journal of Development Economics 17 (1985): 99-115.

12. Roger Anstey, The Atlantic Slave Trade and British Abolition, 1760-1810 (London: Macmillan, 1975).

13. Williams, Capitalism and Slavery, p. 178.

14. Roger Anstey, "A Re-interpretation of the Abolition of the British Slave Trade, 1806-1807," English Historical Review, 87 (1972): 331-32.

15. Comment by Emilia Viotti da Costa in Roots and Branches: Current Directions in Slave Studies, ed. Michael Craton (Waterloo, Ontario: Historical Reflections, Vol. 6, 1979), p. 175. 
16. Seymour Drescher, "The Historical Context of British Abolition," in Abolition and its Aftermath: The Historical Context, 1790-1916, ed. David Richardson (London: Cass, 1986), p. 13.

17. Review in Journal of African History 17 (1976): 139-40.

18. James Walvin, "The Propaganda of Anti-slavery," in Slavery and British Society, 1776-1846, ed. James Walvin (London: Macmillan, 1982), p. 65.

19. E. M. Hunt, "The Anti-Slave Trade Agitation in Manchester," Transactions of the Lancashire and Cheshire Antiquarian Society 79 (1977): 46-72.

20. Frank E. Sanderson, "The Liverpool Abolitionists," in Liverpool, the African Slave Trade and Abolition, ed. Anstey and Hair, pp. 196-238.

21. Peter Marshall, The Anti-slave Trade Movement in Bristol (Bristol: Bristol Branch of the Historical Association, 1968), p. 24.

22. C. Duncan Rice, "Enlightenment, Evangelism, and Economics: An Interpretation of the Drive towards Emancipation in British West India," in Comparative Perspectives on Slavery in New World Plantation Societies, ed. Vera Rubin and Arthur Tuden (New York: Annals of the New York Academy of Sciences, Vol. 292, 1977), pp. 123-31. See also C. Duncan Rice, The Scots Abolitionists, 1833-1861 (Baton Rouge: Louisiana State University Press, 1981).

23. James Walvin, "The Impact of Slavery on British Radical Politics: 1787-1838," in Comparative Perspectives, ed. Rubin and Tuden, pp. 343-55; and "The Rise of British Popular Sentiment for Abolition, 1787-1832," in Anti-slavery, Religion and Reform: Essays in Memory of Roger Anstey, ed. Christine Bolt and Seymour Drescher (Folkestone: Dawson, 1980), pp. 149-62.

24. Patricia Hollis, "Anti-slavery and British Working-class Radicalism in the Years of Reform," in Anti-slavery, Religion and Reform, ed. Bolt and Drescher, pp. 294-315.

25. Betty Fladeland, "'Our Cause being One and the Same': Abolitionists and Chartism," in Slavery and British Society, ed. Walvin, pp. 69-99.

26. Douglas A. Lorimer, "Black Slaves and English Liberty: A Re-examination of Racial Slavery in England," Immigrants \& Minorities 3 (1984): 148, n. 93.

27. Seymour Drescher, "Public Opinion and the Destruction of British Colonial Slavery," in Slavery and British Society, ed. Walvin, pp. 22-48.

28. Iain McCalman, "Anti-slavery and Ultra-radicalism in Early Nineteenth-century England: The Case of Robert Wedderburn," Slavery o Abolition 7 (1986): 100

29. McCalman, "Robert Wedderburn," p. 115.

30. See Drescher, "Historical Context," p. 13; and James Walvin, "The Public Campaign in England against Slavery, 1787-1834," in The Abolition of the Atlantic Slave Trade: Origins and Effects in Europe, Africa, and the Americas, ed. David Eltis and James Walvin (Madison: University of Wisconsin Press, 1981), pp. 63-79.

31. Drescher, "Public Opinion", p. 47. 
32. See, for example, Folarin B. Shyllon, Black Slaves in Britain (London: Oxford University Press, 1974), and Black People in Britain, 1555-1833 (London: Oxford University Press, 1977).

33. Lorimer, "Black Slaves and English Liberty", pp. 121, 142.

34. James, Black Jacobins.

35. Drescher, "Historical Context," p. 14.

36. Walvin, "Propaganda," pp. 61-63.

37. But see Drescher, "Historical Context"; William A. Green, "Was British Emancipation a Success? The Abolitionist Perspective," in Abolition and its Aftermath, ed. Richardson, pp. 183-202; David Eltis, "Abolitionist Perceptions of Society after Slavery," in Slavery and British Society, ed. Walvin, pp. 195-213; and Roger Anstey, "The Pattern of British Abolitionism in the Eighteenth and Nineteenth Centuries," in Anti-slavery, Religion and Reform, ed. Bolt and Drescher, pp. 19-42.

38. Draft of Seymour Drescher, Econocide: British Slavery in the Era of Abolition (Pittsburgh: University of Pittsburgh Press, 1977), as cited by Anstey, Atlantic Slave Trade, p. 52.

39. Draft of Econocide in Anstey, Atlantic Slave Trade, p. 52. Drescher has developed his thesis in "The Decline Thesis of British Slavery since Econocide," Slavery of Abolition 7 (1986): 3-24; and Capitalism and Antislavery: British Mobilization in Comparative Perspective (London: Macmillan, 1986). See also his "Paradigms Tossed: Capitalism and the Political Sources of Abolition," in British Capitalism and Caribbean Slavery, ed. Solow and Engerman, pp. 191-208.

40. Selwyn H. H. Carrington, "'Econocide'-Myth or Reality? -The Question of West Indian Decline, 1783-1806," Boletin de Estudios Latinoamericanos y del Caribe 36 (1984): 47-48. Drescher argued that, regarding the old colonies, Carrington inverts his statements. See Carrington, "Econocide," p. 18; and Drescher, "Econocide, Capitalism and Slavery: A Commentary," Boletin de Estudios Latinoamericanos y del Caribe 36 (1984): 50, and "Decline Thesis," p. 16.

41. Selwyn H. H. Carrington, "British West Indian Economic Decline and Abolition, 1775-1807: Revisiting Econocide," Canadian Journal of Latin American and Caribbean Studies 14 (1989): 56.

42. David Richardson, "The Slave Trade, Sugar, and British Economic Growth, 17481776," in British Capitalism and Caribbean Slavery, ed. Solow and Engerman, pp. 103-33.

43. Carrington, "British West Indian Economic Decline", pp. 33-59. See also Carrington, "The American Revolution and the British West Indies' Economy" in British Capitalism and Caribbean Slavery, ed. Solow and Engerman, pp. 135-62.

44. John R. Ward, "The Profitability of Sugar Planting in the British West Indies, 1650-1834," Economic History Review, 2nd series, 31 (1978): 197-213.

45. Drescher, "Decline Thesis," especially pp. 12-18. Criticism of Drescher's interpretation of events in the British West Indies has also come from David Geggus who 
stated that Econocide"tends to neglect the older islands and makes much use of the fortuitous influences of war and revolution" ("The British Government and the Saint Domingue Slave Revolt, 1791-1793," English Historical Review 96 \{1981\}:287, n. 1). In reply, Drescher argued that in his "Decline Thesis" article he factored out these influences. He also rejected Geggus's suggestion that slave prices were pushed up by panic-buying and so "Drescher's favourable index of the British West Indies' capital value, claimed to be independent of inflation, though based solely on 1790 slave prices and population, seems rather dubious" ("British Government and the Saint Domingue Slave Revolt," p. 287). In reply, Drescher stated that he also used values for 1775, 1807 and 1812 ("Decline Thesis", p. 18).

46. See Carrington, "'Econocide," p. 30; Drescher, "Decline Thesis," p. 18.

47. On planter profits, see, for example, Michael Craton, Search for the Invisible Man: Slaves and Plantation Life in Jamaica (Cambridge: Harvard University Press, 1978), pp. 135, 138-40, 178-79. This alters the view expressed by Michael Craton and James Walvin, A Jamaican Plantation: the History of Worthy Park, 1670-1970 (London: W. H. Allen, 1970), p. 118, that from the 1780s "an irreversible decline" in the profits of the Worthy Park estate seemed to have set in. See also Drescher, "Econocide, Capitalism and Slavery," p. 53, Table 2, and Carrington, "British West Indian Economic Decline," pp. 47-48.

48. Review by Barbara Solow in Journal of Economic Literature 17 (1979): 551.

49. Review in Canadian Journal of History 13 (1978): 296.

50. Econocide, p. 240, n. 21. For the effect of the lack of a return cargo on trading profits, see Walter E. Minchinton, "The Voyage of the Snow Africa," Mariner's Mirror 37 (1951): 187-96.

51. David Brion Davis, Slavery and Human Progress (London: Oxford Univeristy Press, 1984), p. 335, n. 121.

52. In a letter to me, Drescher stated that "his major thesis is that the Act of 1799, which imposed stricter conditions on slave carrying, was a blow to both volume and profits although probably less of a blow than Anstey's 'British flag' figures indicate. Ergo decline followed restriction" (personal correspondence, 18 December 1986).

53. Richardson, "The Slave Trade, Sugar and British Economic Growth," p. 106. Richardson stated that between 1762 and 1775 British vessels possibly carried more slaves from Africa than in any previous or subsequent period of thirteen consecutive years and added in a note that the next highest thirteen-year total was achieved from 1783 to 1795.

54. Carrington, "British West Indian Economic Decline," p. 56.

55. Joseph Inikori, "Market Structure and the Profits of the British Slave Trade in the Late Eighteenth Century," Journal of Economic History 41 (1981): 745-76; "Rejoinder," Journal of Economic History 43 (1983): 723; and "A Further Rejoinder," Journal of Economic History 45 (1985): 708-11.

56. Drescher, Econocide, p. 16. In his "British Government and the Saint Domingue Slave Revolt," p. 287, citing Public Record Office (London) Customs 17/7-11, 
Geggus argued that in the 1780 s the islands' share of total British trade was declining.

57. Drescher, Econocide, p. 19.

58. Ralph Davis, The Industrial Revolution and British Overseas Trade (Leicester: Leicester University Press, 1979), pp. 89, 91, 93.

59. William A. Darity, Jr., "A General Equilibrium Model of the Eighteenth Century Atlantic Slave Trade: A Least Likely Test for the Caribbean School," Research in Economic History 7 (1982): 291. See also Darity, "The Numbers Game and the Profitability of the British Trade in Slaves," Journal of Economic History 45 (1985): 693-703. But Drescher queried the existence of an asymmetry since he believed that "both Davis' data (The Industrial Revolution) and mine show the opposite" (personal correspondence, 18 December 1986).

60. The figures Drescher gave of the British West Indian share of total British trade for the five-year period 1768-72 are: imports-27.2 percent, exports- 9.7 percent, total-17.7 percent; and for 1818-22: imports-25.7 percent, exports-9.9 percent, total-16.1 percent. Econocide, Table 1, p. 19.

61. Michael Craton, "Jamaican Slave Mortality: Fresh Light from Worthy Park, Longville and the Tharp Estates," Journal of Caribbean History 3 (1971): 1-27; B. W. Higman, Slave Population and Economy in Jamaica, 1807-1834 (London: Cambridge University Press, 1976), p. 231; Richard B. Sheridan, "Sweet Malefactor: The Social Costs of Slavery and Sugar in Jamaica and Cuba, 1807-54," Economic History Review, 2nd series, 29 (1976) 236-57.

62. But John R. Ward argued on the contrary that "by the time of Emancipation the improvement of demographic rates in Jamaica had been sufficient to bring the slave population to the point of maintaining its numbers by natural reproduction" ("The Profitability and Viability of British West Indian Plantation Slavery, 1807-1834," unpublished paper, p. 31). Ward noted, however, that his disagreement with Higman is not so sharp as this statement suggests. He agreed, following Higman, "that there was a fairly steady decline of slave numbers in the British West Indies between 1807 and 1834, largely due to the high mortality among the last generation of Africans imported before the closure of the slave trade. Among locally-born slaves, births probably matched or slightly exceeded deaths by the early $1830 \mathrm{~s}$ (personal correspondence, 17 December 1986). And on this Drescher commented, "shouldn't the question about demographic trends be posed for the slave system as a whole. BWI slavery might have been approaching self-maintenance in 1832, but it clearly had not reached it. Is Jamaica alone in the system?" (personal correspondence, 16 December 1986).

63. Ward, "Profitability and Viability," p. 22. For an earlier discussion of this question, see R. Keith Aufhauser, "Profitability of Slavery in the British Caribbean," Journal of Interdisciplinary History 6 (1974): 45-67. See also Drescher, Econocide, pp. $142-61$. 
64. See P.F. Dixon, "The Politics of Emancipation: The Movement for the Abolition of Slavery in the British West Indies, 1807-33" (D.Phil. thesis, Oxford University, 1971), p. 340; and Robert W. Fogel and Stanley L. Engerman, "Philanthropy at Bargain Prices: Notes on the Economics of Gradual Emancipation," Journal of Legal Studies 3 (1974): 377-401.

65. Ward, "Profitability and Viability," p. 32.

66. See, for example. C. Duncan Rice who wrote, "Indeed, it is difficult to see how the thesis that economic change made abolition possible in 1807 and [brought about emancipation] in 1833 can be challenged in view of the obvious growing weakness of the West India planters by the end of the eighteenth century." ("Humanity Sold for Sugar!': The British Abolitionist Response to Free Trade in Slave-grown Sugar," Historical Journal 13 (1970): 403.)

67. Anstey, "Re-interpretation," pp. 316-18.

68. David Brion Davis, "The Ideology of Anti-slavery," Times Literary Supplement, 24 October 1975, p. 1263.

69. Drescher, Econocide, Appendix III, pp. 214-23; and "Decline Thesis," p. 19.

70. Higman, Slave Population, p. 230.

71. See William A. Green, "Caribbean Historiography, 1600-1900: The Recent Tide," Journal of Interdisciplinary History 7 (1977): 520-21.

72. Among recent summaries of historiographical trends, see Thomas L. Haskell, "Capitalism and the Origins of the Humanitarian Sensibility," American Historical Review 90 (1985): 339-61, 547-66; Robin Blackburn, The Overthrow of Colonial Slavery, 1776-1848 (London: Verso, 1988); Thomas Bender, ed., The Antislavery Debate: Capitalism and Abolitionism as a Problem in Historical Interpretation (Berkeley: University of California Press, 1992); and Seymour Drescher, "Whose Abolition? Popular Pressure and the Ending of the British Slave Trade," Past 6 Present 143 (1993): 136-66.

73. David Brion Davis, The Problem of Slavery in Western Culture (Ithaca: Cornell University Press, 1966), p. 153.

74. David Eltis, Economic Growth and the Ending of the Transatlantic Slave Trade (New York: Oxford University Press, 1987), pp. 4-5.

75. Blackburn, Overthrow of Colonial Slavery, p. 26.

76. Davis, Problem of Slavery, p. 153, n. 56.

77. Thomas C. Holt, "Explaining Abolition," Journal of Social History, 24 (1990): 377.

78. Personal correspondence, 18 May 1995. See, for example, Eltis, Economic Growth; Robert W. Fogel, Without Consent or Contract: The Rise and Fall of American Slavery (New York: Norton, 1989); and James Walvin, Black Ivory (London: Fontana, 1992).

79. See, for example, Pieter C. Emmer, "Anti-slavery and the Dutch: Abolition without Reform," in Anti-slavery, Religion and Reform, ed. Bolt and Drescher, pp. 80-98.

80. Letter by Seymour Drescher, New York Review of Books, 6 April 1995. 
81. Blackburn, Overthrow of Colonial Slavery, p. 520.

82. Bender, ed., Antislavery Debate, p. 2.

83. Michael Craton, "The Transition from Slavery to Free Labour," Slavery \& Abolition 13 (1992): 53. For a discussion of the legacy of Williams, see Solow and Engerman, eds., British Capitalism and Caribbean Slavery.

84. I am grateful to Seymour Drescher for bringing me up to date with recent contributions to this debate. 


\title{
14
}

\section{The Ambivalencies of Independency:}

The Transition out of Slavery in the Bahamas, c. 1800-1850 ${ }^{1}$

\author{
MICHAEL CRATON
}

The writing of the early social history of the Bahamas is not made easier by the near absence of personal documents from the ordinary people. Yet one of the rare surviving letters from the late slave period is among the most remarkable and revealing found anywhere in the British West Indies. This is the letter in the Brown papers at the New York Historical Society written on 30 May 1800 by the Bahamian slave Caesar Brown to Mrs. Sophia Brown of Perth Amboy, New Jersey, begging to be allowed to manumit himself rather than be sold out of his owner's family. ${ }^{2}$

Writing in his own hand, in a style not only literate but elegant, and signing his letter with a flourish, Caesar Brown is addressing the daughter-in-law of his recently deceased owners, to whom he has been bequeathed. Contrary to his expectations, and what he claims was a promise made, Caesar was not manumitted in his master's will, and when his mistress soon followed her husband to the grave, was ordered to be sold with the other slaves. To make matters worse, a valuation of five hundred dollars had been placed upon him, which, while flattering to his self-esteem, made self-manumission almost impossible.

Caesar Brown's plea is subtly double-tongued. As a first alternative, he asks Sophia Brown to retain him as her own slave, in which case, he quite convincingly promises to transfer happily to the United States and serve his new mistress "for ever." If, however, she intends to sell all her newly acquired slaves, he begs her to lower his price, so that he can purchase his own freedom "with 
the assistance of some friends" in Nassau. Indeed, he claims, Patrick Brown, the nephew of his former owners, has already promised to advance him "a little money" towards his manumission if Sophia Brown chose to part with him.

Unfortunately, we know nothing more about Caesar Brown than can be inferred from his letter-even whether he obtained either of his wishes. Yet, however exceptional both he and his case were, the letter does surely convey invaluable information, not just about the social condition of the Bahamas in 1800 but also about the psychology of the Bahamian slaves in that interim phase between the decay of cotton plantations and the ending of formal slavery. Indeed, Caesar Brown's letter may even justify a conclusion that Bahamian slaves, while wonderfully enterprising and resilient, valuing personal freedom above all, were pragmatically aware of the benefits of retaining some, if not all, of the ties of dependency.

In an even wider context, this invaluable fragment of evidence, in conjunction with all else we know of the nineteenth-century social history of the Bahamas may help us to test the belief that the Afro-Bahamian people emerging out of slavery exhibited an unique concatenation of self-reliance and dependency that, as much as material conditions and the sociopolitical hegemony retained by their former masters, both thrust them forward and held them back.

There were black slaves in the Bahamas from the beginning of English settlement, since the first settlers from Bermuda in the 1640s brought with them blacks who were technically their chattel possessions. Slavery had become instituted in Bermuda, though not because of strict economic need but more or less by accident, through convenience and the subsequent imperatives of social control. The first blacks there were merely "servants," but very soon parcels of blacks appropriated by Bermuda-based privateers from foreign slave traders or plantations were retained in the colony as slaves in the strictest sense. By the 1630s, Bermudian laws presumed that "Negro" and "slave" were virtual synonyms, and there were laws to fix the status of slaves, to restrict their geographical and social mobility, and to police and punish them. There were few if any clauses in the laws which protected the slaves, and as the proportion of slaves rose by new acquisitions and natural increase towards a majority of the Bermudian population, and especially in response to threatened insurrection, the language of the laws became increasingly racist and draconian-most 
notoriously decreeing the expulsion from the colony of all slaves upon being freed in $1730 .^{3}$

As in all slave colonies, however, custom rather than statutory enactments determined actual relations between white freemen and black slaves in Bermuda, being shaped above all by the absence of a plantation economy, by the smallness of slave units, and the employment of most slaves either as domestics or mariners. Consequently, in a seeming paradox that disguises a genuine ambivalence, "white" Bermudian historians have been able to argue convincingly the relative lenience of Bermuda custom, while "black" historians have more recently stressed with equal plausibility the persistent resistance of the Bermudian slaves. Most of the features of Bermudian slavery were replicated in the Bahamas during the pre-Loyalist period, with the subsequent phase of Loyalist slavery bringing into sharper relief the tensions and ambivalencies that have confused earlier historians of Bermuda and the Bahamas alike. ${ }^{4}$

Despite the nominal association between the Bahamas and the Carolinas during the proprietary period (1668-1718), slavery was merely incidental in the island colony until the second royal governor, George Phenney, attempted to start plantations in New Providence, imported 295 slaves direct from Africa, and immediately felt constrained to pass the first slave regulations in May 1723. These used Negro and slave as interchangeable terms, implied that slaves were mere property, and determined that all non-whites would be tightly bound to their masters, but were as much concerned with the socialising and "civilising" of the blacks as with policing and punishing them. ${ }^{5}$ Over the following decade, the proportion of slaves in the population rose from thirty to forty percent, and in 1734, the Carolinian governor Richard Fitzwilliam was able to use the pretext of a slave plot to have the Assembly pass the first true slave laws (as well as ordinances against the free coloureds), defending the harshest clauses of the slave laws as being "no more than what is agreeable to the Laws of our Neighboring Colonies in the Method of trying and punishing these Savages." As responses to further influxes of slaves through privateering activities in the War of the Austrian Succession (1740-48) and the Seven Years' War (1756-63), which raised the proportion of slaves in the Bahamas above fifty percent, and to news of slave plots and rebellions elsewhere, progressively more comprehensive and tighter slave codes were enacted in 1748 and 1767 . In the same period, a law was passed (remaining in operation from 1756 to 1824) defining precisely what constituted a white person, fully free before the law, which despite its 
stated liberalising purpose, had the effect of sharpening and perpetuating the dividing line between black and white, slave and free. ${ }^{7}$

Both the pre-Loyalist slave laws and Bahamian custom, however, reflected and entrenched a slave system that was more lenient, or rather, more subtly, one in which social relations were more ambivalent and reciprocal, than in the true plantation colonies further south. The very restrictions on manumission (for example, making the manumitter responsible for the ex-slave, and the ex-slave still dependent on the former owner), and on the status, privileges and duties of non-white free persons, betrayed the existence of a sizeable and growing intermediate class, with ties of patronage and dependency, as well as familial ties with persons on both sides of the ostensible lines of colour and status. Similarly, it was not only such provisions as allowed slaves to carry firearms in special circumstances and to roam the islands by boat with minimal supervision, but the very existence (as well as the subtle wording) of clauses attempting to control slave self-employment, farming and trading on their own behalf, even running away to better themselves-with quite severe fines for conniving whites-that betrayed the custom of the slaves to engage in such activities, with or without the co-operation of members of the master class. On the eve of the Loyalist influx, a German visitor familiar with the southern mainland plantation colonies, Johan David Schoepf, was surprised to note that in the Bahamas "even slaves were able to earn money for themselves in their free time, being left 'undisturbed in the enjoyment of what they gain by other work' on the payment of 'a small weekly sum' to their owners." ${ }^{8}$

It is worth pointing out at this stage that Caesar Brown was the slave of a pre-Loyalist "Old Inhabitant" of the Bahamas (albeit with close mainland connections) and was himself likely Bahamian born and bred, a generation or two removed from Africa, the beneficiary of a system that had, since the time of Governor Phenney, allowed a fortunate few domestic slaves to achieve literacy and become baptized. However, though it is commonly argued that the Loyalist incursion-in which the total population of the Bahamas almost tripled and the proportion of slaves rose from a half to three-quarters between 1783 and 1790 -represented a setback to the established pattern of master-slave relationships, it was in fact the old Bahamian pattern which came to predominate-with subtle modifications-once the Loyalist attempts to re-establish cotton plantations and mainland plantation society withered on the Bahamian rocks, with the help of the chenille bug and tumbling world cotton prices. ${ }^{9}$ 
The period between the end of the War of the American Revolution (177583) and slave emancipation saw two waves of immigration to the Bahamas which inevitably affected the existing structure of society and the relations between whites and blacks. Most notable was the sudden influx of almost 6,000 "Loyalist" blacks. But a more intermittent and prolonged (and hitherto less studied) process beginning in 1811 was the relocation in the Bahamas of Africans liberated from illicit slavetraders, totalling some 5,500 before the end of slavery and perhaps 6,500 by the time of the last arrivals in the $1860 \mathrm{~s}$. We must also not forget the effects on Bahamian social relations between 1800 and 1850 of two types of emigration; the steady remigration of Loyalist whites, most commonly without their slaves, and the relocation down to 1823 of something like 3,000 slaves from the Bahamas in other colonies, with or without their masters. ${ }^{10}$

The majority of the "Loyalist" blacks were the slave property of Carolinian and Georgian planters arriving by way of Florida, settled in their established groupings on the larger and more fertile uninhabited islands (incidentally raising the number of peopled islands from three to a dozen). Other blacks, though, came from New York, to be settled mainly on the mainland of Abaco and in New Providence. Some were unequivocally slaves, but many if not most claimed to have become free by having fled behind the Loyalist lines, and to be only nominally and voluntarily under the control of the accompanying whites.

The ideal of the transplanted Loyalist plantocrats was to replicate mainland conditions by producing sea island cotton on the virgin Bahamian soils with the labour of their slaves. Despite the heroic efforts of the slave gangs clearing thousands of acres of bush and working the meagre soils-labour at least initially more strenuous than on the mainland-annual cotton production never exceeded about 600 tons and drastically declined after 1800 . The more ambitious and exploitative owners, however, diversified or turned completely to solar salt production in the drier more southerly Bahamian islands-an industry probably as harsh as any in its effects on the slave labour force. ${ }^{11}$

Meanwhile, the Loyalist-infiltrated white oligarchy attempted to impose the conditions of mainland slavery throughout the Bahamas, as much in urbanised New Providence as in the cotton and salt-producing islands. For the most part they enjoyed the support between 1787 and 1796 of an intemperate Loyalist Governor, Lord Dunmore, who, though notorious as the last royal governor of Virginia who had authorised the arming of slaves against the rebels, was a 
slaveowning planter himself, increasingly concerned by the political eruptions in Saint Domingue. Dunmore supervised the suppression of armed runaway blacks claiming wrongful enslavement in Abaco, authorised a committee to investigate Loyalist blacks' claims to freedom which returned most claimants to slave status, firmly put down at least one "French-inspired" non-white plot, and presided over racist legislation that decreed (in 1789) that all free coloureds and blacks be registered and labour on public works, and culminated in the consolidated Slave Act of $1797 .^{12}$

Though, under rising metropolitan pressure, a third of the 1797 law was ostensibly concerned with the protection of the slaves' interests, these clauses did little more than enact customary provisions concerning food, clothing and holidays, and set limits on slave punishments that would be impossible to enforce in practice. The bulk of the Act remained concerned with controlling and policing the slaves, limiting their activities, physical movement and chances of manumission, on pain of penalties and fines that were almost as harsh towards friendly black freedmen as against slaves. For example, any "Free Negro Mulatto or Indian" who concealed a runaway or forged a ticket of leave was liable to lose his freedom and be transported, as well as to suffer any punishment the court decreed, "short of life or limb." Freedmen aiding runaways to escape by boat were to be transported, on pain of death if they returned. Conversely, in an unsubtle attempt to divide the slave community, slaves who returned runaways were rewarded in the same manner as free blacks, and those who served against rebel slaves were not only to be paid $£ 5$ for each rebel killed and $\mathfrak{E} 10$ for each captive, but were to be awarded "a Blue Cloth Coat with a red Cross on the right Shoulder" to distinguish their loyalty. ${ }^{13}$

The fading of the French and Haitian threat, the decline first of cotton and then of salt production, the migrations already mentioned and other demographic changes, coupled with changing imperial attitudes and a growing political sophistication among the slaves, conspired to thwart the Loyalist ideal for Bahamian society and to replace it with a pragmatic reciprocity that was more akin to the social situation found in the Bahamas before the American Revolutionary War. This can be deconstructed from the successively more liberal legislation forced on a reluctant white oligarchy by the metropole (beginning in fact with the Consolidated Slave Law of 1797), from the actions of the more clear-thinking whites such as the slaveowning Attorney-General 
William Wylly, and, above all, from the increasingly self-conscious and self-interested behaviour of the slaves themselves.

Bahamian slaveowners-including those like James Moss and Burton Williams who shipped all the slaves they could to the crueller regimes further south-cloaked their self-interest in paternalist rhetoric, just as the slaves were capable of professing undying loyalty when it suited their temporary convenience. Such contradictory reconciliations are first made manifest in the turbulent Bahamian career of William Wylly between 1815 and 1823, but are amplified in the equally well-documented cases of the Rolle and Farquharson slaves in formal slavery's last decade. ${ }^{14}$

William Wylly was a typical Loyalist planter in having the responsibility for a tightly-knit group of slaves rapidly growing in numbers because of favourable demographic conditions at the very time that plantation production was proving hopelessly uneconomic. He was atypical in his fervent conversion to the socialising functions of evangelical Methodism and, as Attorney General, having to implement and mediate to his fellow planters the increasingly ameliorationist directives emanating from London. In an 1815 set of regulations for his three small estates in western New Providence, Wylly provided what he obviously thought was a model for other Bahamian planters. In advance of legislation, he laid down standards for issues of food and clothing, housing and garden plots, and while many rules were decreed, punishments were fixed and there were incentives for living a respectable family life. Slaves were required to attend chapel, but their spiritual as well as secular oversight was largely in the hands of trusty slave headmen, who had the authority to administer the lash, could each keep a riding horse, and were even paid an allowance of $£ 12$ a year. ${ }^{15}$

Most remarkable and contentious of all, was William Wylly's dubiously legal 1818 plan to allow his slaves the option of extra time off to work their own plots and sell their surpluses in Nassau, in return for a reduction in the issues of food corn provided by their owner. Wylly's justification for this clearly self-interested measure was that a system of ordained issues promoted a demoralising dependency and was a disincentive to industry. Significantly excluded from the concession were certain slaves (including one called Caesar), who were labelled inveterate skulkers. They would get their issues of corn, but work for their owner six days each week, without choice. In times of scarcity, however, all slaves could opt to obtain corn from Wylly's storage barn, but at a price of four shillings a peck, repayable in labour at a rate of a shilling for each day's task. ${ }^{16}$ 
William Wylly's alleged softness towards his own slaves, coupled with decisions he made in slave cases as Attorney General, and a suspicion that he was a secret agent of abolitionist societies in London, made him very unpopular among his fellow planters, especially those in the Bahamian Assembly-a running battle that continued until he was transferred to St. Vincent as Chief Justice in 1823. At the height of the debates over a local slave registration bill, Wylly was accused of defaming the Bahamian legislators in correspondence with the African Association and his arrest was ordered by the Speaker of the House. But when the Sergeant-at-Arms went out to Clifton to seize Wylly and carry him to jail, he and his constables were met and turned back by the Wylly slaves with cutlasses and fowling guns. ${ }^{17}$

In the outcome, Wylly stayed out of jail through a writ of habeas corpus and the exasperated Governor dissolved the Assembly - after which Wylly was horsewhipped on Bay Street by one of his disgruntled opponents in the legislature. In due course not only was the registration bill enforced, but so also was a ban on the export of slaves. In addition, progressive amelioration legislation, including obligatory food and clothing issues which the planters regarded as overgenerous, was enacted. However, we should not exaggerate the role of Wylly or his slaves in this process, any more than we should romanticise their inter-relationship. What Wylly was granting was what suited him best, and what his slaves were defending was a way of life that was the best they could construct in an imperfect world. Besides the armed confrontation at Clifton gate we should remember the Wylly runaways, including the headman Boatswain and his family who absconded from Clifton in 1821 to join the Nassau Black Baptists and were hunted down by their Methodist master; those Wylly slaves who were shipped off without the option of choice in 1822 to serve Wylly in distant St. Vincent (four of whom were drowned in a wreck in the Crooked Island Passage); and the fact that Wylly's liberalism did not extend to manumitting his slaves, even in his will. When he died in 1828 , his slaves were sold-the once-trusted Boatswain and his family being bought by a planter called Henry Moss, previously convicted of ill-treating his slaves, who transported them from their familiar New Providence to the new Turks Islands, where they toiled at the saltpans till the end of slavery. ${ }^{18}$

The agitation among Bahamian Out Island slaves in slavery's last years, most notably by the largest group of all owned by Lord Rolle, is well known. But it has usually been described in terms of simple resistance at a time when slavery 
had become uneconomic for the slaveowners, bonds were being loosened by legislation, and the slaves perceived that they had allies in the metropole. ${ }^{19}$ Perhaps it should now be re-analysed in more complex terms; as the conscious and progressive exploration by the slaves of the potential of a symbiotic relationship, in which the benefits of a practical independence were balanced and qualified by remnants of dependency. In 1983, long before Nigel Bolland invented the term proto-proletarian, a Bahamian trade unionist familiar with my first work on the Rolle slaves and Pompey's "rebellion," told me that he viewed Pompey and his followers as the first Bahamian trade unionists. ${ }^{20}$ The characterisation is apt at least as an analogy. What are the functions of trade unionists but constantly to explore the potential of the dialectic between the classes of masters and workers? And what would the workers do (what indeed did the Rolle ex-slaves do) without that dialectic?

Another large body of evidence relating to the forms of Bahamian slave behaviour which prefigured post-emancipation relationships consists of the almost 500 slave and apprentice runaway advertisements found in the Bahamian press between 1784 and 1838 . These especially concern the behaviour, attitudes and relationships of the suburbanised blacks of New Providence who constituted the majority of the advertised runaways. The very paucity of the advertisements from the Out Islands (no more than a quarter of the total), where at least three-quarters of Bahamian slaves lived in the Loyalist era, testifies to the preference of the great majority of Out Island slaves for the ties of dependency, as long as they were not maltreated or worked too hard, lived in family units, and had access to land of their own. ${ }^{21}$

As a whole, moreover, the Bahamian slave runaway advertisements testify to something rather more subtle than the commonplace that any slave would attempt to escape from his or her bondage if a realistic chance of a preferable alternative offered itself. A fair proportion of the runaways were recently enslaved Africans not yet attuned either to the acceptable compromises which the system offered, or to the realities that made escape for them into a more comfortable alternative an impracticality. Others-such as the "young Negro Man called Cuffy, well known about Town for his wickedness," the "Mulatto Villain Jack, well known, as he has been, and still remains, a perfect Pest in the Neighbourhood," or Robin, formerly employed at the Ordnance Department, "a short thick Black fellow, chews a great deal of tobacco, is much addicted to 
strong liquor, and very insolent when drunk"-were simply such awkward characters who might be called misfits, deviants or criminals in any society. ${ }^{22}$

The great majority of Bahamian slaves who never ran away had adjusted themselves to the realities of the system - while at the same time energetically adjusting it to themselves as far as they could. Their epitome were the Bahamian slave mariners who, as William Wylly noted in 1815, had the best opportunities to run (or sail) away, but as a class were the least likely to do so-a phenomenon that Wylly attributed to the fact that they were treated almost the same as white crewmen by the boat-owners, and were allowed a percentage of the profits from their fishing and turtling. ${ }^{23}$ Much the same applied to that growing number of slaves, especially those with artisanal skills living in New Providence, who were virtually self-employed wage labourers, returning only part of their earnings to their owners; or to those slaves who were in a position both to produce surplus crops in their own time, and to sell them mainly or wholly for their own benefit. Yet even that five percent of the slave population that ran and stayed away long enough to be advertised for can be used actually to illustrate much the same principles.

Most Bahamian manumission cases-which greatly increased in numbers when legislation first reduced and then removed the ex-masters' bond (guaranteeing a degree of continued responsibility) during slavery's final phase-involved more obviously material concerns, though each doubtless involved psychological ambivalencies too. Masters and slaves alike participated in the transactional calculus whereby one side weighed the loss of mastery and unpaid labour against the freedom from obligations to feed and clothe their slaves and what might well be the last chance of a financial return on their human property; while the other weighed the benefits of legal freedom against the cost of buying their freedom, uncertainties of wage or self-employment, and the loss of statutory support and less tangible benefits of dependency. Not that the change and break were ever necessarily sudden or complete. Though by 1834 , ex-owners no longer had a legal responsibility towards their ex-slaves, ties between them often remained cemented by freedom purchase payments made by the ex-slaves in instalments, often spread over years, as well as by the general tendency of ex-slaves to continue in much the same occupations and job relationships as in their former status.

Whatever the causes and consequences, though, the numbers of Bahamian free coloureds and blacks hugely increased in the last phase of formal slavery, 
so that by August 1834 (including Liberated Africans) they were almost half as numerous as slaves, and not far short of the whites in numbers. Significantly, in the colonial capital they actually outnumbered the slaves 2,955 to 2,881 , and the 1,418 whites by more than two to one. Though we must interpolate the feelings of the recently manumitted for ourselves, this trend certainly explains the sentiments of the Legislative Council when commenting on the problems they posed as early as 1811 :

They are ever sure to be found only in town and populous settlements; where from the excess of their numbers few find regular employment and many are given to beggary and crime or both, to eke out a precarious subsistence for themselves and their families. A want of industry is certainly not a vice in people of colour, but those who cannot obtain employment in which they will engage are idle from a species of necessity. ${ }^{24}$

As throughout the British slave colonies, the Apprenticeship phase in the Bahamas (intended to last from 1834 to 1840 but in fact ending two years early) was designed to be a transitional period of mutual adjustment for masters and slaves embarking on the form of relationship already prevailing in England between, on the one hand, employers and landlords, and, on the other, wageearning employees and tenants. That the Apprenticeship period in the Bahamas passed quietly and was seen, in these respects, to be successful, was attributable both to the ways that such "master/servant" and "landlord/tenant" relationships had been anticipated before formal slavery ended, and to the canny ways in which the white Bahamian master class was able to shift its ground to preserve its class hegemony-forming in the process what Howard Johnson has termed an "agro-commercial bourgeoisie." ${ }^{25}$ Such continuities, however, also inevitably involved a continuance of the pattern of qualified dependency which we have traced in the peculiar history of Bahamian slavery. The ease of the transition out of slavery, and the entrenchment of habits and attitudes of dependency, were, moreover, facilitated in the Bahamas by the fact that the system of formal apprenticeship was introduced in the Bahamas more than two decades before 1834, in respect of those Africans liberated from foreign slavers and settled in the islands-who were to form a significant, almost normative, element in the Bahamian black population ever after. ${ }^{26}$

Within a year of the ending of the British slave trade, Orders in Council established the ground rules for the resettlement of Liberated Africans in any 
British colony. The exigencies of wartime decreed that the most suitable recaptives be encouraged to join either the Navy or the Army, and a good number of able-bodied Africans landed in the Bahamas were in fact recruited into the West India Regiment stationed in Nassau. As to those who did not join the armed forces, though, the colonial authorities, under the supervision of the Collector of Customs, were to "bind all such negroes ... whether male or female ... as apprentices to prudent and humane masters and mistresses . . . either in the same or other colonies, to learn such trades, handicrafts, or employments as they may seem most fit for, or most likely to gain their livelihood by, when their apprenticeship shall expire. ${ }^{27}$ They were thus formally accepted as imperial wards or dependents, though this was not quite the way that colonial white masters interpreted the situation.

Between 1811 and 1838, when Liberated Africans still apprenticed as well as ex-slave apprentices were given their full freedom, some 5,550 Africans released from foreign slave ships were settled in the Bahamas (to whom were added perhaps another 1,000 before 1860$).{ }^{28}$ The ablest of those who did not join the West India Regiment, many with useful native skills, provided Bahamian masters with an additional labour force that down to Emancipation was almost as constrained as slaves, and after 1838, represented a competitive segment of an expanded labour pool that helped to drive down wages as well as exacerbate divisions among the black proletariat. As Howard Johnson has discovered, even the notorious Bahamian truck system of the later nineteenth century may have had its origins in the exploitative way in which some Bahamian mastersmainly those engaged in salt production-combined their obligations to provide for their Liberated African apprentices with a commutation of the wages they were obligated to pay, in a way that tended to reduce them towards virtual debt peonage. ${ }^{29}$

Only a minority of Bahamian Liberated Africans however fell under the sway of such masters, many in effect had no master but the Bahamian government, and all tended proudly to stress their distinctiveness from slaves and former slaves. They also strove to maximise the benefits of the government's and masters' legal obligations towards them, in a manner that fell somewhere between beggary and the assertion of rights. At the time of their initial liberation, all Liberated Africans were totally dependent on government support for food and clothing, and the majority who neither joined the Army nor were taken on as apprentices, as well as those whose apprenticeships or army service 
had expired, were not only allocated land and the means to set up as subsistence farmers, but also continued under the supervision and protection of government superintendents, and received government handouts as need arose. With their distinctive settlements in the Nassau suburbs, in the outlying parts of New Providence, and on many of the nearer Out Islands, their vigorous Afro-Bahamian culture-which included the extra-capitalistic system of savings called asu-and their strong sense of identity reinforced by sub-ethnic (but government-sanctioned) cultural and self-help friendly societies and lodges, the Liberated Africans and their descendants both replicated and reinforced that sometimes uneasy dichotomy of independency and dependency that characterised Bahamian blacks who had once been slaves.

All Bahamians after the end of slavery demonstrated the traditional Bahamian qualities of ingenuity in seizing what fleeting chances of fortune or livelihood were offered successively by salt, pineapples, wrecking, blockade running, sponges, sisal, and (even before 1900) tourism. But the consequent "boom and bust mentality" of which some have written did not really apply to the emancipated slaves and Liberated Africans and their descendants. ${ }^{30}$ Whatever temporary profits were to be made accrued overwhelmingly to that class which was ever tightening its grip upon the economy, while the black majority, its numbers inexorably increasing, found itself caught in a descending spiral of economic dependency from which inter-island migration and, ultimately, emigration out of the Bahamas, seemed the only escape. Despite the achievements made before Emancipation and the qualified optimism of the first years after 1838, this process was already irreversibly in place by 1850 .

The prospects for wage earning were never high in a colony where the number of willing labourers and skilled artisans generally exceeded the demand, and where there was, moreover, a chronic shortage of cash in circulation. A large proportion of those persons released earlier than 1838 (especially Liberated African women whose apprenticeships had expired) ${ }^{31}$ aspired to follow marketing customs familiar from Africa by becoming "hucksters"; that is, small-scale itinerant vendors of peasant agricultural produce and retailers of imported provisions and manufactured items purchased from wholesalers. Competition among themselves, the control of prices by the wholesalers, and the chronic shortage of coin, however, reduced their profits to a marginal level and located them only slightly above the status of barterers. 
A more insidious influence was the will and ability of the wholesalers to control the terms of transaction and insist on the exchange of produce for goods at their own rate, rather than on cash transactions. This incipient "truck system" became endemic in all trading and labour relations between Bahamian whites and blacks. For example, those few black freedmen in Eleuthera and Cat Island who sought to cash in on the novelty demand for pineapples from 1840 by producing the fruit on their own or common lands, found that the trading schooners that came from Nassau or further afield were only prepared to take their crops for payment in imported goods at inflated prices, with eagerly proffered and willingly accepted advances inevitably leading to an indebtedness very difficult to reverse. ${ }^{32}$

The ability of small producers to ship their own produce to more lucrative markets, as of all black Bahamians tied to the soil to diversify their activities by engaging in maritime activity on their own account, was undercut by the increasing control of shipbuilding and shipowning by the mercantile class. Not only did Nassau (and to a certain extent Harbour Island and New Plymouth) merchants monopolise the building of larger vessels by their control of the necessary capital, but they obtained shares in or even ownership of most vessels built independently throughout the islands, through the system of necessary advances. Nearly all Out Island farmers were fishermen too, and at one stage in the 1850s more than half of the able-bodied men in the colony were licensed wreckers. ${ }^{33}$ But their share in the product of their labour was already compromised, quite apart from the way in which Nassau merchants controlled the price paid for their fish, turtles and salvaged goods. Governors condemned the demoralising effects of the salvaging trade, but the same system of maritime dependency and exploitation was to reach its nadir after lighthouses and steamships had ended the salvaging "boom," with the even more deleterious effects of the sponging trade of the 1880 s, as described so vividly by Louis Diston Powles in Land of the Pink Pearl ${ }^{34}$

The system of payment in "truck," exacerbated by advances against future earnings, extended into wage employment from the beginning and grew ever wider after mid-century. It probably began with the commutation of wages due to Liberated Africans working in the salt-pans during the 1820s (though there were surely equivalent arrangements with semi-self-employed slaves at much the same time), and it extended in time to contract stevedores on the steamships serving the Caribbean through the Bahamas and to migrant workers in Latin 
America and the U.S.A. in the 1880 s and $1890 \mathrm{~s} .{ }^{35}$ Such modes were obviously a grotesque development of the systems of conditional wages, qualified handouts and prototypical patron-client relations from the late slave period. But the system of dependency with the widest involvement and the most obvious links to the slavery era concerned land tenures.

Of the three basic types already anticipated in the late slave period, the achievement of commonage rights by certain ex-slaves in Exuma and Eleuthera would seem on the surface to be the most successful outcome; the product of a canny amalgam between a spirited independence and dependence on a largely mythical noblesse oblige donation. Unfortunately, though, the equation lost its force at the moment of success. After Emancipation, the commoners were truly on their own. As their numbers grew and pressed on the limited resources of their meagre soils, they were forced to migrate to other islands and became ever more subject to the false generosity of mercantile creditors. Even when conditions changed and Out Island land became once again valuable in the twentieth century, they were hamstrung by the very provisions of the Commonage Law that denied them the right to alienate or even effectively develop their land.

At the other extreme were those many ex-slaves like Charles Farquharson's, who chose to remain on their former owners' lands despite having to sign contracts either to continue to give their labour for part of the week or a share of their produce in return for their tenancy. Labour tenancies were decreasingly common as estates became less viable as large units, but sharecropping arrangements persisted for more than a century as an at least nominal relationship between landowners and tenants. The details of the unique surviving contracts for the Farquharson Estate from the 1860s suggests why these and similar sharecroppers chose to remain, despite the fact (reported by the Stipendiary Magistrate as early as 1842) that the ex-slaves occupying lots laid out in town for which they had not paid, or squatting on Crown Lands and abandoned estates, referred to sharecroppers as "slaves. ${ }^{36}$ In return for a third of their agricultural produce and sundry no doubt tedious regulations, the sharecroppers not only enjoyed virtual tenure on the relatively reliable lands on which their families had lived for generations, but also had a continuing clien relationship with a family that had a vested interest in their agricultural success for instance, in marketing their crops and stock. Other sharecroppers signe contracts that obliged the landowners to provide them with tools, seed and 
fertilizer; and all sharecroppers no doubt felt that they could turn to the landowner for relief in the inevitable periods of distress.

Often the line between sharecropping and squatting became an extremely tenuous one, with the relationship between owner and occupier sustained seemingly by little more than a familial inertia. The benefits were for long merely hypothetical; for the black peasants a tenure of subsistence lands practically uninterrupted and with purely nominal obligations, rarely enforced; and for the landowner the availability of provisions, occasional labour, even more occasional gifts, and the maintenance of ownership against a possible improvement in economic conditions - not to mention the intangible benefits of being a kind of lord of the manor with a beholden peasantry.

More narrowly, within the temporal compass of the present paper, whatever the form of Bahamian labour and landowner-tenant relations, and however skewed they became in favour of the agro-commercial bourgeoisie-whether straight wage labour, labour contracts, labour tenancies, sharecropping, even the ubiquitous truck system - their essence remained a reciprocal transaction, or dialectic, between habits of dependency and an ingenious individualism, born in slavery.

The persistent dialectic between habits of dependency and ingenious individualism that stemmed from the peculiar nature of Bahamian slavery can be plentifully illustrated from the century and a half which followed the emancipation of the slaves. Any scholar of the period could make a personal choice. For the present writer, three come quickly to mind. In the 1880s, an American tourist called William Drysdale wrote such an engaging account of the daily commerce of a Nassau suburban shop called Morley's that it was repeated almost verbatim by the radical critic of late nineteenth century Bahamian society, Louis Diston Powles, in Land of the Pink PearL One of Morley's habitués was an aged Congo woman, "black as a coal, with some scars on her face," who carried a bundle and a basket and "a tray on her head, piled up more than a foot high with bundles and bottles and cans." She caught sight of the white visitors, curtseyed, greeted them politely, and immediately begged for money, pleading "Times is so hard." The shopkeeper Morley intervened to suggest that if she really expected anything, "Aunty" should dance for the visiting gentlemen, to which she readily agreed. 
"There is something surprising about seeing a woman of her age drawing her scant skirts together in preparation for a dance," wrote Drysdale,

... but she is as erect as a girl of twenty and strong as a man, and almost before we know what is going on, she is dancing in the small open space in the middle of the floor-dancing to a strange tune which she hums herself, of which the short words come out in jerks. She throws herself about wildly, giving us one of the half-graceful, half-awkward Congo dances we have often seen before. When it is done, and she is not a bit tired from the exertion, she looks at us in a way that says plainly enough, "There now, what are you going to give me for that?"

Drysdale gave the old Congolese an American twenty-five cents, for which she thanked the men profusely, invoking blessings on their heads, before investing a "check" (that is, a $1 \mathrm{l} / 2 \mathrm{~d}$. in the local sterling currency) of the gift in tobacco, resuming her tray, bundle and pail, and proudly going on her way into the night. ${ }^{37}$

Much the same type of social transaction occurred in the often-described arena where visiting whites most obviously came in contact with ordinary Bahamian blacks; the piazza of what was then Nassau's only large hotel, the Royal Victoria. Among the local blacks who thronged to offer their produce, handiwork, entertainment or services, or who picturesquely tumbled in the dust in competing for the pennies the tourists threw, were the so-called "native" singers and dancers. "The voices of some were soft and musical," wrote the American visitor Charles Ives in 1880 , "they sang the religious songs which they had learned in 'the shouting meetings,' with perfect abandon, and with a fervour and zeal that glorified their dusky faces, swayed their bodies, and extended down their arms to the tips of their fingers." The star of the show, though, was a boy nicknamed "Sankey" after the renowned contemporary evangelist, who performed with a female cousin, called (after the more famous Sankey's partner) "Moody." This precocious pair-described as "two little dots of children"-performed a kind of "sacred waltz ... in the most cunning and comical manner imaginable, while they sang to the rhythm of the dance, ' $O$ it will be joyful' \&c." As Ives wrote, "When the miniature boy and girl near the close alternately approached each other and withdrew, ogling, twisting, bowing and coquetting, while they continued to sing with many repetitions-'Meet to part no more; meet to part no more,' the gravity of the audience was sure to give way in laughter and applause." ${ }^{38}$ 
Who was this Bahamian "Steppin' Fetchit" and his partner? The girl fades from sight, but some years later L. D. Powles ascertained that "Sankey" had been christened with the impressive name Thaddeus de Warsaw Toote. Besides having a singing, dancing and miming talent that Powles reckoned would bring certain success in London's West End, "Sankey" Toote possessed much the character of Dickens' Artful Dodger-or, more appositely, of Br' Rabby (Brer Rabbit), or Anansi the Spider. Already by 1886 he had almost given up the entertainment business and was engaged in odd jobs ("good or bad is all the same to Sankey" said Powles) for anyone who would employ him. Powles' opinion was that "In a civilized country he would probably rise to a good position, or go for a long term of penal servitude. In earlier times he might have concluded a short, but brilliant career on the gallows!"

In fact, as an adult T. W. Toote became one of the most successful black businessmen of his time, and was elected Member of the House of Assembly (MHA) for San Salvador and Rum Cay in 1928. More significantly yet, he was the father both of Thaddeus Augustus Toote, MHA, Councillor and, along with A. F. Adderley, one of Nassau's two chief black lawyers and spokesmen (albeit cautious) for non-white causes, and of Frederick Augustus Toote who, migrating to the very different sociopolitical climate of Harlem, New York, became in the 1920s, one of the most important lieutenants of the great radical black activist, the Jamaican-born Marcus Garvey. ${ }^{39}$

The third and final example is derived from personal experience. In the later 1950s, when the political grip of the white Bay Street oligarchy still seemed unassailable, a youngish Exumian subsistence farmer (his name might have been Caesar Brown but in fact, of course, it was Rolle) told me that "Young Mr. Symonette [the white local MHA who was Speaker of the Assembly] has my vote as long as he and I draw breath." A somewhat naive idealist, I asked him why he would not rather support the Progressive Liberal Party (PLP), the black opposition party which claimed uniquely to represent the interests of the oppressed majority. "Whenever I need anything," he replied, "seed corn, medicine, even money, all I have to do is to go see Mr. Symonette and he gives it to me. How in this world is a bunch of black men ever going to have the means to do the same for me?"

But, as we know, the world did turn, and pretty soon too. And in 1968, once the PLP itself had gained its unoverturnable lead, many Out Islanders like my earlier Exumian confidant also-if the pun be pardoned-suddenly changed 
their roles, becoming almost overnight "PLP All the Way." For many, if not all, this transformation was as successful as it was timely, and even predictable. It was a type of transformation that Caesar Brown in 1800 would have understood, approved, and relished; a dance to life's tune, indeed, we would like to think that Caesar Brown successfully performed himself, within the limits of his time and place.

NOTES

1. This paper is a somewhat abbreviated version of that delivered at the Twenty. fourth Annual Conference of the Association of Caribbean Historians in Nassau, Bahamas, in March 1992. It derives largely from the subsequently published first volume of a social history of the Bahamas written in collaboration with Gail Saunders, Islanders in the Stream: A History of the Bahamian People. Volume One: From Aboriginal Times to the End of Slavery (Athens: University of Georgia Press, 1992), and from the manuscript of the second and concluding volume, due for publication in 1996.

2. New York Historical Society. Misc. MSS. Brown J. Papers of John Brown and Family, New Providence Bahamas, 1761-1835. The letter is worth quoting entire:

Nassau N P May 30th. 1800

Mrs. Sophia Brown

Dear Mistress,

By the death of my late mistress, which I regret most sincerly, I find my self left your slave, notwithstanding the constant assurances of Mr. Brown my former Master \& his wife to the contrary, who really did promise to make me free at their death. All the slaves my self included are to be sold here or sent to you. They have all been apraised at a proper valuation, except me, on whom the[y] have fixed the immoderate price of 500 Dollars. My only motive for intruding this letter on you, is to beg that you will consider my Master's promise which you know to be true, you likewise know with what Zeal \& fidelity I have served him and his wife, and you must be convinced of my attachment to my young Master $\&$ you, indeed I am convinced that you will render me every service in your power \& endeavour to make my situation somewhat more independent than it has been hitherto. If it is your wish to have me in New York I will with pleasure 
go there and serve you for ever, but if on the contrary it is your intention I should be sold with the rest of the slaves, I beg you so far to indulge me as to lower the price at which I am valued and I will try to purchase my own freedom, with the assistance of some friends in this place. Master Patrick Brown has promised to advance me a little money towards processing my emancipation if you chuse to part with me. It is My dear Madam my wish to purchase my freedom and I hope you will have the goodness to consent to it and to moderate the present sum at which I am apraised. I must pray you to write me your determination-please to enclose your letter to Master P Brown.

I have the Honor

to be,

Dear Madam

Your Faithful Slave

Caesar Brown

3. Craton and Saunders, Islanders in the Stream, 1:63-91; "An Act for Extirpating all free Negroes, Indians, Mulattoes, Such as have been Slaves . . 1730," quoted in Michael Craton, James Walvin and David Wright, eds., Slavery, Abolition and Emancipation; Black Slaves and the British Empire: A Thematic Documentary (London: Longman, 1976), p. 180.

4. Craton and Saunders, Islanders in the Stream, 1: 63-73. For the early history of Bermuda in general, see John H. Lefroy, Memorials of the Discovery and Early Settlement of the Bermudas or Somers Islands, 1515-1685, 3rd. ed., 2 vols. (Toronto: Toronto U.P., 1981 (1879)); Vernon A. Ives, ed., The Rich Papers: Letters from Bermuda, 1615-1646 (Toronto: Bermuda and Toronto U.P., 1984); Henry C. Wilkinson, The Adventurers of Bermuda: A History of the Island from its Discovery until the Dissolution of the Somers Islands Company in 1684, 2nd. ed. (London: Oxford U.P., 1958 (1933)); Charles M. Andrews, The Colonial Period of American History, 4 vols. (New Haven: Yale U.P., 1934-38), 2:214-248; Wesley Frank Craven, "An Introduction to the History of Bermuda," William and Mary Quarterly, 17 (1937):176-215, 317-62, 437-65; 18 (1938):13-63; Cyril O. Packwood, Chained on the Rock: Slavery in Bermuda (Bermuda: Baxter's, 1975). In the above bibliography, Wilkinson represents the "white" or panglossian approach to slavery, Packwood the "black" or more realistic approach. For rather more extreme positions, also (for the first) see Terry Tucker, Bermuda's Story (Bermuda: Baxter's, 1957), and (for the second), James E. Smith, Slavery in Bermuda (New York: Vantage, 1976).

5. Craton and Saunders, Islanders in the Stream, 1:126-32; Bahamas Archives, Council Minutes, May 2, 1723; Philip Cash, Shirley Gordon and Gail Saunders, eds., Sources of Bahamian History (London: Macmillan, 1991), pp. 183-84.

6. C.O. 23/3, 123, Public Record Office (PRO), London. Craton and Saunders, Islanders in the Stream, 1:138-39. 
7. Craton and Saunders, Islanders in the Stream, 1:57-60, 151-56. Acts of the Bahamas, 19 Geo II (1748), C.O. 23/5, 141, November 2, 1748; 27 Geo II c. 43 (1756), Bahamas Archives, Manuscript Laws, 1729-1792, 43; 7 Geo III, January 4, 1767.

8. Johann David Schoepf, Travels in the Confederation, 1783-1784 (Philadelphia: Campbell, 1911); Craton and Saunders, Islanders in the Stream, 1:171-74.

9. Craton and Saunders, Islanders in the Stream, 1:179-212; Gail Saunders, Bahamian Loyalists and their Slaves (London: Macmillan, 1983); Michael Craton, "Hopetown and Hard Bargain: The Loyalist Transformation in the Bahamas," in Settlements in the Americas: Cross-Cultural Perspectives, ed. Ralph Bennett (Newark: Center for Renaissance and Baroque Studies and University of Delaware Press, 1993), pp. 252-82.

10. Peter T. Dalleo, "Africans in the Caribbean: A Preliminary Assessment of Recaptives in the Bahamas, 1811-1860," Journal of the Bahamas Historical Society 6 (1984):15-24; Craton and Saunders, Islanders in the Stream, 2: Chapter 1; Howard Johnson, "The Liberated Africans in the Bahamas, 1811-1860," Immigrants and Minorities 7 (1988):16-40; Michael Craton, "Changing Patterns of Slave Families in the British West Indies," Journal of Interdisciplinary History 10 (1979):1-35; Craton and Saunders, Islanders in the Stream, 2: Chapter 1.

11. Craton and Saunders, Islanders in the Stream, 1: 196-232.

12. Craton and Saunders, Islanders in the Stream, 1: 208-11; Consolidated Slave Law, 1797; Bahamas Archives, Manuscript Laws, 1794-97, 265-80.

13. Ibid., Clauses 17, 19, 21, 28, 32.

14. Craton and Saunders, Islanders in the Stream, 1:221-27, 291-96, 335-57, 381-86; Gail Saunders, Slavery in the Bahamas, 1648-1838 (Nassau: By the Author, 1985); Michael Craton, "Hobbesian or Panglossian? The Two Extremes of Slave Conditions in the British Caribbean, 1783-1834," William and Mary Quarterly 35 (1978):226-56; "We Shall Not be Moved: Pompey's Proto-Peasant Slave Revolt in Exuma Island, Bahamas, 1829-1830," Nieuwe Westindische Gids 57 (1983):19-35; Michael Craton and Gail Saunders, "Seeking a Life of their Own: Aspects of Slave Resistance in the Bahamas," Journal of Caribbean History, 24 (1990):1-27; Michael Craton and Gail Saunders, "On Slavery's Margins: Farquharson's Estate, San Salvador, Bahamas, 1831-2," Slavery and Abolition, 12 (1991): 49-72, 154.

15. William Wylly, Regulations for the Government of the Slaves at Clifton and Tusculum in New Providence (Nassau: Royal Gazette, 1815); Craton and Saunders, Islanders in the Stream, 1: 222, 297-303.

16. Ibid.; Wylly to overseer James Rutherford, 24 August 1818, , C.O. 23/67, 163, PRO.

17. Craton and Saunders, Islanders in the Stream, 1:223-24; C.O. 23/64, 59-91, 112-19, 229-32, PRO.

18. Craton and Saunders, Islanders in the Stream, 1:224, 302-03; Bahamas Archives, Register of Returns of Slaves, 1822-1834.

19. See, For example, Craton, "We Shall Not Be Moved."

20. Conversation with Anthony Carey, Treasurer of Bahamas Hotel Workers' Union, Nassau, 16 June 1983. 
21. Craton and Saunders, Islanders in the Stream, 1:358-91; Godwin L. Friday, "Fifty Years of Freedom: Runaway Slaves in the Bahamas, 1784-1834," unpublished University of Waterloo M.A. paper, 1984.

22. Bahama Gazette, 26 July 1799, 19 November 1785,27 February 1798,19 November 1785, 21 July 1797.

23. C.O. 23/63, 37-41, PRO. The prevalence of the share system among Bahamian mariners predictably led to them being prominent among those slaves who purchased their own manumission in the last years of slavery. "The greater part of the slave population here are seafaring People," wrote Governor Carmichael Smyth in March 1830 (with some exaggeration). "The crews in the wrecking vessels are in a great measure composed of slaves-These people are paid in shares, and they almost invariably work out their freedom." Quoted in Howard Johnson, "The Share System in the Bahamas in the Nineteenth and Early Twentieth Centuries," Slavery and Abolition 5 (1984):141-53.

24. Bahamas Archives, Petition of Legislative Council, 1811, in Cash, Gordon and Saunders, Sources of Bahamian History, 218. For manumissions in the Bahamas, Craton and Saunders, Islanders in the Stream, 1: 230-31, 238-42, 276-77.

25. Howard Johnson, "'A Modified Form of Slavery': The Credit and Truck Systems in the Nineteenth and Early Twentieth Centuries," Comparative Studies in Society and History, 28 (1986): 729-53.

26. Craton and Saunders, Islanders in the Stream, 2:Chapter 1; Dalleo, "Recaptives in the Bahamas, 1811-1860"; Johnson, "The Liberated Africans, 1811-1860."

27. Cited (from R. R. Kuczynski) by Johnson U. J. Asiegbu, Slavery and the Politics of Liberation, 1787-1861: A Study of Liberated African Emigration and British AntiSlavery Policy (New York: Africana, 1969), p. 27, n. 1.

28. Dalleo, "Recaptives in the Bahamas."

29. Johnson, "Credit and Truck System," p. 731.

30. But see John Trainor, "Boom or Bust? A Reconsideration of Bahamian History," unpublished paper, Seventeenth Annual Conference of Caribbean Historians, Nassau, Bahamas, 1985.

31. For example, see the selected list of twenty-one female slaves manumitted between 1815 and 1822, of whom ten were hucksters in 1822 . Of these, four had actually been hucksters as slaves, the remainder being categorised mainly as domestics; Cash, Gordon and Saunders, Sources of Bahamian History, p. 2

32. See, for example, the report of the Methodist missionary at Governor's Harbour, Eleuthera, in September 1873: The pineapples are sold here to certain parties on credit. The purchaser promising to pay immediately after he sells the fruit in America. But instead of bringing money to pay in cash, he imports provisions, cottons and anything else out of which he knows he can make a large profit. The result is that few can get any money at all, and many are forced to take things which they really do not want rather than lose their labour altogether. "The circulating medium is thus purposely withheld". Cash, Gordon and Saunders, Sources of Bahamian History, p. 240. 
33. Michael Craton, A History of the Bahamas, 3rd. ed. (Waterloo: San Salvador Press, 1986), pp. 225-27.

34. Louis Diston Powles, Land of the Pink Pearl (London: Sampson Low, 1888); Craton, History of the Bahamas, pp. 238-41; Craton and Saunders, Islanders in the Stream, 2: Chapter 8.

35. Johnson, "Credit and Truck Systems"; Craton and Saunders, Islanders in the Stream, 2: Chapter 3.

36. Stipendiary Magistrate William Heild to Acting Governor Nesbitt, June 1, 1842, C.O. 23/113, 142, PRO; Craton and Saunders, Islanders in the Stream, 2: Chapter 3.

37. Powles, Land of the Pink Pearh pp. 169-76.

38. Charles Ives, The Isles of Summer, Or Nassau and the Bahamas (New Haven, Connecticut: By the Author, 1880), pp. 69-78; Powles, Land of the Pink Pearh pp. 164-65; Craton and Saunders, Islanders in the Stream, 2: Chapter 6.

39. Craton and Saunders, Islanders in the Stream, 2:Chapter 10; Hartley Cecil Saunders, The Other Bahamas (Nassau: Bodab Press, 1991), pp. 125-50. 


\title{
15
}

\section{The Land and Labour Problem at the Time of the Legal Emancipation of British West Indian Slaves}

\author{
STANLEY L. ENGERMAN
}

Throughout his highly productive career of research and writing on the history of the British Caribbean, Richard Sheridan has concentrated his attentions mainly on the seventeenth and eighteenth centuries, the centuries including "the development of the plantations" and "an era of West Indian prosperity." His writings have been central to our knowledge of the evolution of the British colonies and the link between Sugar and Slavery, as well as to other topics related to slaves and slaveowners, including their medical care and health. He has less frequently dealt with the years of the nineteenth century, including the ending of the slave trade and slavery, the advent of apprenticeship, and the emergence of various forms of "free labour" (or at least of non-slave labour). In an article on the crisis of the sugar islands in the early 1830s and the events leading to emancipation, he described several key issues in the changing economic fortunes of the various islands, both before and after emancipation. ${ }^{1} \mathrm{He}$ is one of the few to note the significance of the act, effective in 1825 , limiting intercolonial trade in slaves, an act that also helped generate conflicts among the islands when the precise method of compensation came to be debated. ${ }^{2}$ In describing the policy debates about the creation of free labour in the aftermath of emancipation, Sheridan summarises Edward Gibbon Wakefield's plan for voluntary "American slave emancipation" as follows:

the government should raise the price of public lands so that only men of substance could afford the purchase price. Revenue from land sales should 
then be used exclusively to finance pauper immigration from Europe. The barrier of high land prices would thus force the pauper immigrants into combined and constant labour for wages. With the increased division of labour would come a higher level of productivity and rising land values, until a point would be reached when it would no longer be economical to employ Negro slaves. Slaves would then be set free voluntarily "without injury to any one, with the greatest benefit to all."

In a more recent article on the development of wage labour in Jamaica, Sheridan points to the complex influences on the free labour supply of controls over the level of rents on housing and provision grounds, and the influence these rents had on labour availability and labour mobility. ${ }^{3}$

In this paper, I wish to expand upon Sheridan's discussions of the expected and actual labour force adjustments that took place in the British Caribbean with the ending of slavery, and to make some comparisons with the discussions elsewhere on similar issues of labour supply, that had preceded the British debates of the 1830s. In particular, I want to re-examine some of the Colonial Office and parliamentary presentations regarding policies aimed at short-term and long-term benefits for ex-slaves, planters, and consumers of slave-grown commodities. The advocacy of strategies to influence labour supply, directly as well as indirectly, by land, immigration, and related policies, pre-dated discussions on slave emancipation; many of the same issues had arisen in earlier debates concerning economic growth and social development.

The establishment of policies to secure appropriate labour availability, in terms of the size of the labour supply and the types of work it would do, were central concerns under mercantilism, persisted with the emergence of new nations, no matter how laissez-faire they were in the implementation of labour policies or other economic strategies, and also influenced regimes with centrally-planned or directed economies. ${ }^{4}$ The first problem is creating a labour force, and often this was accomplished by inducing or coercing people-men, women, and children - to work, using mechanisms ranging from forced slavery to voluntary systems that are predicated on the ability to satisfy the workers' existing or created wants. The latter, voluntary, option is possible when potential workers want to consume goods and can see a relationship between their rewards from labour and their labour input. Pools of voluntary labour may come as a shift from leisure or from various forms of home production, with the subsequent focus of their work being the production of goods to be sold in markets. Mercantilism, of course, emphasized foreign and overseas markets. 
In terms of many economic targets, however, increasing the total labour supply is not the only issue. There is also the problem of directing the labour to activities most advantageous to the ruling elites, if not also to the workers. Thus elites would usually prefer labour policies that entailed labourers doing wage work for others, rather than working for themselves on small agricultural landholdings or in small household manufacturing establishments. The desire to enforce working for others - either on plantations or in factories-is generally based upon arguments of economies of scale in production. These require concentrations of labour within units of production even though, given a free choice, individuals might prefer to work on small, individually-owned units, despite the fact that they provided less financial income than wage work, since the more productive sectors, whether plantations or factories, might entail labour-intensive forms of production. Labour controls established by owners to achieve such levels of production were unattractive to the labourers. But since the output levels that could be achieved by concentrating labour exceeded what was possible with individual proprietorships or on family farms, social planners were faced with a dilemma.

While these problems of labour-force creation and allocation were frequently discussed in regard to adjustments expected with the ending of slavery, they have a long history in Europe in relation to the ending of serfdom, as well as in the European colonies and overseas possessions, although an important distinction has invariably been made between relatively unsettled, underpopulated areas, and relatively densely settled, overpopulated regions. ${ }^{5}$ Perhaps the clearest statement of the labour supply problems remains that of the eighteenthcentury mercantilist, Sir James Steuart, who asserted that labour can be obtained either by making people "slaves to others" or "slaves to their wants." Steuart's argument on the differences between these types of incentives went further, by distinguishing agriculture from industry, and differentiating between requirements needed to generate forced physical labour and voluntary industry. ${ }^{7}$ Nevertheless, the issue of the need for incentives that exploit the desire for goods, to generate a larger labour force in the absence of slavery, has become more central to historical studies, particularly with the recent historical literature on consumerism and consumer goods. ${ }^{8}$

European mercantilist literature on the so-called "backward bending supply curve of labour" made this issue of the impact of wants, and the relative availability of complementary factors, central to the discussion of economic 
policy. ${ }^{9}$ Similarly, in the second half of the eighteenth century, various North American commentators, including Benjamin Franklin and, decades later, Alexander Hamilton, raised some similar points. ${ }^{10}$ The importance of want creation and its link to labour input, and the need to limit the availability of land to place labour in conditions desired by the elite, were clearly argued prior to debates on ending slavery in the British colonies, as was the need for governments to provide measures to make such incentives known and acceptable to those upon whom they were to operate.

The primary literature on the issue of what types of work were to be done, has come to be dominated by what economists term "the Nieboer-Domar hypothesis," whose central arguments are based the ratio of land to labour. ${ }^{11}$ The availability of much "free" land that people could move to in order to avoid working for others, meant that a shortage of wage labour could occur in areas of earlier settlement. Diverse possibilities existed for obtaining labour to work for landowners in these early settlement areas. One was coercion by enslavement or enserfment, thus restricting the labour force's free mobility, by legally and politically accepted means. An alternative, consistent with a nominally-free labour force, was to reduce "free" land by restrictions on the availability of new land to wage workers. Similarly, restricting labour mobility out of the region, or instituting measures to permit or attract new immigrants, could also lead to a lowered effective ratio of land to labour, and hence induce labour for others even in a population of legally free labourers. Thus, restrictions on land accessibility and encouragement of immigration are policies that have long been attractive to landowners and capitalists; their implementation has long been advocated in areas both outside and within the Caribbean. ${ }^{12}$

Preventing an out-migration of labour from older areas of settlement involved instituting restrictions on labour mobility that were difficult to enforce, so the more frequent political strategy was to limit the amounts of available land, and to encourage immigration. The broad range of measures by which this could be accomplished can be seen by a brief examination of United States land policy, which was widely debated on issues of both economic efficiency and economic equity. ${ }^{13}$

If politically feasible, the first and most direct strategy was to control the pace at which land was made available for purchase and settlement. The terms of sales would themselves affect the pace of movement. Policymakers in the United States, for example, debated such issues as the minimum acreage to be sold and 
the minimum price per acre, whether the government could sell land for credit, the need for specific periods of settlement or the performance of specific actions before providing full title to the land, and whether nationality and citizenship constraints should be imposed concerning who could purchase land. Variants of these policies were, of course, discussed elsewhere. For example, the land tax proposed in the British West Indies to accompany slave emancipation was intended to raise the costs and increase the difficulties of land acquisition, as were the attempts, such as those in British Guiana, starting in 1836 and continuing until the end of the nineteenth century, to impose large acreage and high price minimums for Crown Land sales.

Thus, several distinct measures, besides explicit coercion, have been used in efforts both to increase the labour supply, and to influence the specific activities undertaken by labourers. There were controls over immigration in some societies and over emigration in others; immigration could be subsidized, indentured, or free; taxation levels and requirements for cash payments could lower individual incomes and thus encourage labour input; and land could be made more (or less) expensive and less (or more) available to purchasers. ${ }^{14}$ All of these measures could be (and were) used to influence the labour supply, although the effects on the overall level and structure of labour output, and on the distribution of income and wealth would vary significantly depending on the strategy (or combination of strategies) utilized.

Writing in the middle of the eighteenth century, Benjamin Franklin commented:

In Countries full settled, the Case must be nearly the same; all Lands being occupied and improved to the Heighth: those who cannot get Land, must Labour for others that have it. ${ }^{15}$

Because of the great availability of land in America:

it will require many Ages to settle it fully; and till it is fully settled, Labour will never be cheap here, where no Man continues long a Labourer for others. ${ }^{16}$

Yet this cheapness of land could lead to larger population, both by encouraging earlier marriage and childbearing among the population as well as by the attraction of immigrants. But, Franklin asserted, this easy access to land would mean that:

we can never rival the Artificers, or interfere with the Trade of our Mother Country. ${ }^{17}$ 
Hamilton, in his 1791 Report on Manufactures, claimed that the establishment of manufactures was not easily accomplished, because:

The desire of being an independent proprietor of land is founded on such strong principles in the human breast, that where the opportunity of becoming so is as great as it is in the United States, the proportion will be small of those, whose situations would otherwise lead to it, who would be diverted from it towards Manufactures. ${ }^{18}$

He supported manufacturing development as encouraging: the employment of persons who would otherwise be idle (and in many cases a burden on the community) either from a bias of temper, habit, infirmity of body, or some other cause, indisposing or disqualifying them for the toils of the Country. ${ }^{19}$

The employment of others referred, in particular, to women and children, but manufactures would also offer desired extra employment for those, who although otherwise employed, had a considerable number of hours or even full seasons of leisure, that could be put to productive employment, and hence provide them additional income. The prospects for a rapid advance of manufactures were, however, limited, in part because:

the constant allurements to emigration from the settled to the unsettled parts of the country-the facility, with which the less independent condition of artisan can be exchanged for the more independent condition of a farmer. ${ }^{20}$

Hamilton clearly expressed his belief in a trade-off between manufactures and agriculture resulting from this problem of land availability:

If the effect of manufactories should be to detach a portion of the hands, which would otherwise be engaged in Tillage, it might possibly cause a smaller quantity of lands to be under cultivation. ${ }^{21}$

Nevertheless, as befits a firm policy advocate, Hamilton went on to describe how agriculture would ultimately be benefited by the development of manufactures, in part because immigration promised to replace the labour that had left agriculture for manufacturing.

Before turning to the discussions in the 1830 s concerning the economic adjustments expected to accompany the ending of slavery in the British West Indies, it will be interesting to look briefly at economic policy proposals in the newly-formed United States. Hamilton prepared a number of reports, including those on Vacant Land, on Public Credit, and on a National Bank and its constitutionality, of which the Report on Manufactures is the most relevant. ${ }^{22}$ 
For Hamilton, the new nation first needed to establish a land policy, and determine the criteria for the in-migration of both slaves and free persons. As indicated above, Hamilton understood that to encourage manufacturing and industry, the older settled areas needed a larger labour supply. To achieve this, he argued for extensive foreign immigration. In addition, since increased incomes would induce more residents to enter the labour force, Hamilton emphasized the opportunities for the employment of women and children. He also advocated using restrictive land policies to limit westward movement, although even if there was free internal migration, the increasing numbers of European migrants would maintain, if not increase, the number of labourers in the eastern states. They would fill the low-income, unattractive jobs that the native-born workers avoided. ${ }^{23}$

The industrialists' drive for increased immigration and a more restrictive land policy was carried through to the Civil War, with the nascent labour movement of the era presenting a mirror image in its efforts to restrict immigration and liberalise land policy. ${ }^{24}$ The outcome of these conflicts depended on a number of political factors that reflected the relative strengths and preferences of different groups in society. The interests of manufacturers and landowners were adequate to explain why immigration (except of slaves) remained unimpeded, while the concerns of potential owners of small landholdings could explain why land policy became increasingly liberal over the first part of the nineteenth century.

In the United States, however, want creation was infrequently mentioned, and little consideration was given to generating it as a strategy for increasing the labour force. Wants, apparently, had existed since the colonial era, both for residents and for the new immigrants who presumably had come from Europe in search of better opportunity. Concerns over want creation, however, would be more frequently voiced in the United States only after the emancipation of the slaves, but even then the terms of discourse frequently were those used in the earlier European debates.

Thus, the general discussions that occurred in the nineteenth century in western Europe and North America on growth policy focused on those that would encourage labour immigration, and restrict the availability of land to potential labourers. These discussions often advocated the expansion of largescale units, at times in agriculture, but more frequently in manufacturing, and although not all nations adopted all of the policies, the same basic outlines could 
often be observed. Moreover, these policies were considered appropriate for black Americans and Africans as well as for white Europeans and white Americans; similar needs and goals were proposed, irrespective of the ethnicity or prior legal status of the labourers. In pointing to the need for labour policy, for example, British Colonial Office representatives suggested that, in similar circumstances, the behavior of white European and American workers would be analogous to that of the soon-to-be-ex-slaves. Thus, similar policies to those adopted in the British Caribbean would pertain wherever comparable labour conditions existed.

The policies suggested by the British Colonial Office representatives demonstrate that the basic propositions of what has come to be called the NieboerDomar arguments about relative labour and land scarcity were quite wellknown in the early nineteenth century. The relationships between land availability, prospective free labour input, and pre-emancipation slave prices, for example, informed the discussions among the colonial authorities in the British West Indies, as well as between them and the Crown. There was concern about how differences in land/labour ratios among the islands would affect the post-emancipation availability of hired labour. This issue emerged in discussions about the best means of dividing the slave compensation payments between the islands. ${ }^{25}$ The tripartite distinction within the West Indies, based upon relative land/labour ratios, familiar from the post-emancipation context (see Table 1) was well anticipated by colonial agents, Members of Parliament, and the Colonial Office, while the arguments for the policies to be introduced after emancipation reflected the ongoing debate. Wakefield's strategy for labour control through land policy, which targeted British overseas and white settler colonies, was later of great interest to Marx. ${ }^{26}$ As Table 1 indicates, the declines in sugar production with emancipation were larger on islands with high ratios of land to labour, and except for those areas with large amounts of indentured immigration after 1834, sugar production levels recovered slowly, if ever.

Henry Taylor and Lord Howick (Earl Grey), developed two major Colonial Office plans for the policies that would accompany emancipation. These plans had certain aspects in common. ${ }^{27}$ Both Taylor and Howick justified the need for their policies by arguing that ex-slaves' labour/leisure decisions, as well as their need to work as employees for others rather than on self-owned land, were similar to the circumstances of British, Irish, or North American labour, and rested on the common issue of land/labour ratios. Ex-slaves would take advan- 
Table 1: Slave Prices, Land/Labour Ratios, Changes in Sugar Production in the British Slave Colonies Prior to and After Emancipation, and Contract Labour Immigration

\begin{tabular}{|c|c|c|c|c|c|c|}
\hline & (1) & (2) & (3) & (4) & (5) & (6) \\
\hline & $\begin{array}{c}\text { Average } \\
\text { Slave } \\
\text { Prices } \\
1823-30 \\
(E)\end{array}$ & $\begin{array}{c}\text { Land/ } \\
\text { Labour } \\
\text { Ratio } \\
\text { (Square } \\
\text { Miles per } \\
\text { Thousand } \\
\text { Total } \\
\text { Population) }\end{array}$ & $\begin{array}{l}\text { Percentage } \\
\text { Change in } \\
\text { Average } \\
\text { Annual } \\
\text { Sugar } \\
\text { Production } \\
1824-33 \text { to } \\
1839-46\end{array}$ & $\begin{array}{l}\text { Period in } \\
\text { Which } \\
\text { Pre-Eman- } \\
\text { cipation } \\
\text { Level of } \\
\text { Sugar } \\
\text { Production } \\
\text { Regained }\end{array}$ & $\begin{array}{c}\text { Ratio of } \\
\text { Sugar } \\
\text { Production } \\
\text { in } \\
1887-96 \\
\text { to Sugar } \\
\text { Production } \\
\text { in } 1839-46\end{array}$ & $\begin{array}{l}\text { Contract } \\
\text { Labour } \\
\text { Immigration } \\
\text { 1834-1918 } \\
\text { (Gross } \\
\text { Inflow) }\end{array}$ \\
\hline 1. Antigua & 33 & 3.1 & $+8.7 \%$ & - & 1.5 & 2,600 \\
\hline Barbados & 47 & 1.7 & +5.5 & - & 3.5 & - \\
\hline St. Kitts & 36 & 2.9 & +3.8 & - & $2.7^{(3)}$ & $2,900^{(5)}$ \\
\hline 2. Trinidad & 105 & 47.7 & $+21.7^{(1)}$ & - & $3.0^{(2)}$ & 157,700 \\
\hline British Guiana & 115 & 832.4 & -43.0 & $1857-1866$ & 3.4 & 301,000 \\
\hline Mauritius & 70 & 8.0 & +54.3 & - & 3.1 & 451,800 \\
\hline 3. Dominica & 43 & 16.3 & -6.4 & $1847-1856$ & 0.7 & 6,000 \\
\hline St. Lucia & 57 & 15.5 & -21.8 & $1857-1866$ & 1.7 & 5,200 \\
\hline Nevis & 39 & 5.0 & -43.1 & $1867-1876$ & (3) & $(5)$ \\
\hline Montserrat & 37 & 4.6 & -43.7 & $1867-1876$ & 2.5 & - \\
\hline St. Vincent & 58 & 5.7 & -47.5 & never & 0.7 & 5,600 \\
\hline Tobago & 46 & 8.8 & -47.5 & (2) & (2) & - \\
\hline Jamaica & 45 & 12.2 & -51.2 & $1930 \mathrm{~s}$ & 0.6 & 53,900 \\
\hline Grenada & 59 & 6.3 & -55.9 & never & (4) & 6,200 \\
\hline
\end{tabular}

Notes:

1. Trinidad output did decline slightly after the end of the Apprenticeship, and it was not until 1845 that the 1834 level was regained.

2. Tobago data merged with Trinidad after 1891 . The $1877-86$ level of sugar production in Tobago was two-thirds that of 1824-33.

3. Nevis data merged with St. Kitts after $\mathbf{1 8 8 2}$.

4. No sugar output shown after 1888 , a year in which only 77 tons were recorded.

5. Includes Nevis with St. Kitts.

\section{Sources:}

Column (1): British Sessional Papers: House of Commons, 1837-38 (48), p. 329. The values of those slaves designated "praedial attached" present a somewhat similar ranking, although there are some differences. See the table in Herman Merivale, Lectures on Colonization and Colonies (1841; reprint, London: Longman, Green, Longman and Roberts, 1861), p. 333. See also p. 312. 
Table 1: Sources cont'd:

Column (2): Population from the statistical chart in the front of R. M. Martin, History of the Colonies of the British Empire (London: W. H. Allen, 1843). Areas from Worldmark Encyclopedia of the Nations (New York: World Press, 1960), pp. 1038, 1049, 1155. For the ratio of slaves per square mile in 1834, see William A. Green, British Slave Emancipation: The Sugar Colonies and the Great Experiment, 1830-1865 (Oxford: Clarendon Press, 1976), p. 193.

Column (3): Noel Deerr, History of Sugar, 2 vols. (London: Chapman and Hall, 1949-1950), 2:377. The periods are those shown by Deerr. Any alternative sets of years would show a similar comparison.

Column (4): Deerr, History of Sugar, 2:377, 199-200, 203-04. Again, the periods shown by Deerr were used, but any alternative sets of years would show a similar comparison.

Column (5): Deerr, History of Sugar, 2:377, 196, 199, 203-04. As before, the periods shown by Deerr were used, but any alternative sets of years would show a similar comparison.

Column (6): G. W. Roberts and J. Byrne, "Summary Statistics on Indenture and Associated Migration affecting the West Indies, 1834-1918," Population Studies 20 (1966):125-34, for the West Indies; and R. R. Kuczynski, Demographic Survey of the British Colonial Empire, 3 vols. (London: Oxford University Press, 1949), 2:797, for Mauritius.

tage of the availability of free land which, Taylor and Howick contended, would be to everyone's long-run detriment. Thus, without "coercion" created by the absence of free land, few ex-slaves would be willing to work for others. Moreover, although the ex-slaves' responses were not a reflection of their race or their prior slave status, the degradation of labour slavery generated among the enslaved, called for corrective policy measures.

The Taylor memorandum notes that contemporary observers held, depending on whether they were pro- or anti-slavery, contradictory expectations concerning the probable industry and conduct of the Negro when he became "a free agent," how much work he would do, and how he would decide between "employing himself for his own benefit" and "working for wages." ${ }^{28}$ Although Taylor did not expect the ex-slaves to work a full week, since they could meet their wants and even obtain some luxuries with fewer days of labour, he believed that work for others would occur with the creation of "a species of gentlemanlabourer which no form of society has heretofore presented, and which, perhaps, is scarcely likely to result from any natural state of things," it being a pattern not to be found in "the rural condition of life" in "all ages and countries. ${ }^{~}{ }^{2}$ Even if the ex-slave was willing to work longer days:

he must be expected in general to prefer working on grounds of his own, if that be in his choice, to hiring himself out for the harder labour of sugar cultivation. ${ }^{30}$ 
The "temperament" of the Negro and the impact of slavery would affect what could be expected after emancipation:

The experience of all under-peopled free countries seems however to show that mankind are affected, under such circumstances, with a strong propensity to scatter themselves over the earth, adopt a wild and isolated manner of living, and elect the occupation of hunting and shooting in the woods, in preference to any other mode of providing themselves with food. But even supposing that the peculiar dispositions of the Negro were sufficient to counteract the human propensity to wander, (and over the old at least the force of habit would probably have more influence than the allurements of novelty and a silvan life, ) still the Negro villages, though on such a supposition they might hold together, would present scenes of savage sloth, unstimulated by the motives of human nature in a cultivated state, unactuated by opinion, the great regulator of civilized societies, and perhaps interrupted only by such broils and acts of violence as idleness and the ardour of the Negro temperament might give birth to. ${ }^{31}$

Taylor discussed two policies aimed at moderating the problems expected with emancipation, one to be followed if emancipation were immediate, the other if gradual emancipation were implemented. The first, anticipating (if only to rebut) a related suggestion by Lord Howick was:

that of a tax upon land not cultivated in exportable produce. The object of this tax is to limit the means and aggravate the difficulties of subsistence; or, rather, to create difficulties where there are none, and thus to coerce the Negroes by the strong hand of necessity. In all unpeopled and fertile regions, the difficulty of procuring hired labour and inducing regular industry arises mainly from the facility of obtaining the necessaries of life without engaging or regularly persevering in labour for hire. To counteract this facility a policy, has for the last two years, been most successfully adopted in Australasia and the Canadas, of which the principle is, a tenacious reservation of new lands by the Crown until a certain minimum price per acre is offered for them, at which, as the upset price, they are sold by auction. By an adherence to this policy on the part of the Crown the value of land, whether still ungranted or in the hands of private proprietors, is enhanced; men without capital cannot acquire it; and, instead of squatting upon grants in the wilderness (which is always preferred if it can be done), they are obliged to hire themselves to labour for the land-owning capitalist. Thus society is condensed and civilized, where it would otherwise consist, on the one hand of capitalists shorn of their profits by the want of labour, and on the other of those who should be labourers, turning squatters and idlers, and living like beasts in the woods. ${ }^{32}$ 
The tax burden should serve the purpose of inducing labour:

This tax is to be levied, either immediately upon the Negroes who are the occupants of provision-grounds, or upon the Planters who are the owners, and who must, in that case, exact a proportionate rent from the Negroes. It is then anticipated, that, in order to pay this tax or this rent, the Negroes will be under the necessity of working for hire in the cane-field, as well as for subsistence in the provision-ground. ${ }^{33}$

Taylor argued, however, that because ex-slaves owned little property, and plenty of land was available for growing subsistence crops, the government would be unable to drive the price of land high enough. Thus a land tax "would fail in combining industry and the continued cultivation of sugar with freedom." 34

Taylor preferred to avoid "the evils and hazards of sudden emancipation" by combining the "exercise of [voluntary] industry" with "reaching total and ultimate emancipation" through a system whereby slaves purchased free days, and then, ultimately, their freedom: ${ }^{35}$

in being thus, to a great extent, the agent of his own redemption from slavery, he would have given undeniable proof of previous industry, and therefore, a preparation, in one particular at least, and that, perhaps, the most important of all, for the state to which, with the assistance essential in the first instance, he should have worked his own way. The more or less, and sooner or later, of freedom would be in the direct ratio of the good or bad use which he make of the portion first conferred upon him; and the operation of the measure would be in accordance with the great moral principle of the government of men, which would call their own powers and virtues into action for their own profit and advantage; and bring home to them the consciousness of a moral agency and responsibility by making the good and evil of their lives the result of their own conduct. ${ }^{36}$

This policy of deferred emancipation was not implemented, but its underlying logic included components that were to underpin arguments for periods of apprenticeship that would provide education for "appropriate" behavior in the labour market, and help solve the expected difficulties accompanying emancipation.

Lord Howick's basic aim of increased levels of labour input to foster higher levels of output in order to benefit the state, as well as the labourers, was presented in terms that would have sounded appropriate if they came from a late eighteenth-century English mercantilist. ${ }^{37}$ 
Such being the general outline of the plan, the great principle of personal freedom as contradistinguished from domestic slavery, would be established. Every man would receive the fair value of his own labour, and no one would be required to labour beyond his ability. On the other hand, the great principle of civil liberty, would not be infringed. The State is entitled to demand of all its members, that on receiving a fair equivalent, they shall perform such duties for the common good of society as they may be best qualified to discharge. Emancipation, properly understood, does not imply the right to be indolent when profitable labour is to be had, but only the right to labour moderately in obedience to a general law for a fair compensation, subject to such penalties for disobedience as the law may have prescribed, and as the Magistrate alone shall inflict. ${ }^{38}$

Howick proposed the rather traditional policy of imposing a tax on land used for provision grounds, from which two major results were to be expected: First, it would indirectly but inevitably induce the emancipated slaves to labour for wages. Secondly, it would yield a revenue at the expense of the same class of persons, adequate not only to supply the deficiency resulting from the repeal of other taxes, but to repay the principal and interest of the loans made by Great Britain to the different Colonies. ${ }^{39}$

The more crucial aspect of the tax appeared to be the former-solving the labour problem confronting underpopulated frontier areas. He stated:

Between the condition of the poorer classes of society in old and densely peopled countries, and their state in territories recently acquired and partially occupied, there exists a distinction which affects the whole system of social life. In the greater part of Europe, the soil is either appropriated to private owners, or reserved in very small quantities to the state for some specific purposes. It is all either brought into cultivation or devoted to some ends of public convenience. The mass of the population are wholly unable to draw an independent subsistence from the land. If occupied at all by the poor, as in Ireland, it is on condition of paying rents, high in proportion to the extreme competition which prevails for that which has there become a necessary of life. If occupied by capitalists, as in England, the poor depend for their maintenance altogether on the wages which they can earn in the service of their wealthy neighbors. An inexorable necessity compels the English cottager to labour in the fields for wages with which to purchase food. The same necessity urges the Irish peasant to labour for wages with which to pay the rent of the land on which his food is grown.

In countries recently settled, on the other hand, where the soil capable of cultivation would support a number of persons far more numerous than the actual inhabitants, large tracts of good land are either unappro- 
priated, or are permitted by the proprietors to remain in their natural wild state. The means of obtaining food are therefore within the reach of every man. By cultivating a sufficient quantity of ground on his own account, he can maintain himself and his family; and ground fit for that purpose is so redundant and cheap that in many situations the price is little more than nominal. Even those who are totally destitute of capital, may purchase on very easy terms and at a long credit, as many acres as will yield provisions for the consumption of a numerous household. The natural tendency and the invariable result of this state of things is to raise the wages of manual labour far beyond what may be termed the proper level. Men who can obtain an abundant, though rude maintenance, by working on their own account, will either not work in the service of another at all, or not without a very high remuneration. To descend into the class of hired servants, in husbandry or in manufactures, is to sacrifice the independence which, valuable as it is every where, is peculiarly esteemed in countries where great inequalities of fortune are unknown. The excitement and adventure of a rural life, in which the settler has the government of his own time and pursuits, must also be surrendered. He further renounces the indulgence of that desire by which mankind are so generally actuated, of being ranked amongst the class of landholders, and of exercising the various civil franchises incident to that character. Accordingly it is invariably found that, in such countries, men are content to forego the use of many articles which, in a more refined state of society, habit or example have rendered indispensable, even to the most indigent. The sacrifice is voluntarily made, to enable them to assert their won personal independence, and to gratify the tastes already mentioned. They are content to live in rude dwellings and to wear coarse clothing, assured at least of an abundance of food and fuel, and satisfied that the same resources will in their turn be enjoyed by their children. Thus, in the Western States of America; in the British North American Provinces; in the colony of the Cape of Good Hope, and in the Australian settlements, the facility of procuring land has invariably created a proportionate difficulty in obtaining hired labourers. Those countries all illustrate the preference with which men always regard the condition of detached agriculturalists, although accompanied by numerous privations, to that of workmen living upon wages amidst great comparative indulgence. ${ }^{40}$

After this general description of labour problems confronting all parts of the world, Howick discussed the specific circumstances of British West Indian slave emancipation. He compared the behaviour of the freed slaves with that of the Irish peasantry, focussing primarily on the impact of relative amounts of labour 
and land, which, he believed, was the primary influence on the behaviour of workers.

The emancipation of the slaves in Jamaica, Trinidad, and British Guiana, if unqualified by any corrective provisions, would at once bring them into the state already described as characteristic of the inhabitants of countries imperfectly settled. If at liberty to follow their own inclination, it may be confidently predicted that they would not be allured from the occupation of the land, to engage in the steady cultivation and manufacture of sugar, for any wages which the planter could offer them. A controversy has been long and warmly agitated as to the disposition of the negroes to labour for wages in the fields. On the one side, their reluctance to this mode of living has been ascribed to some generic distinction between the African and the European races; on the other hand, expectations have been cherished which would seem to proceed on the assumption that the negroes are gifted with a forethought and habits of self-control, of which it would be impossible to cite any other example. The simple truth, however, would seem to be sufficiently obvious. Free negroes are found to act differently from other free men; not because they differ from others in character, but because their circumstances are different; and just in proportion as they are brought within the reach of those motives by which Europeans are governed, will their conduct resemble that of the natives of Europe.

Why is the Irish peasant thankful to perform any labour, however severe, for any wages however trifling; while the Jamaica free negro refuses very large wages for services comparatively light? Is it because the wants of the one are few and simple, and those of the other numerous and artificial? Assuredly not; for the potatoes of the Irishman are, it is to be feared, less abundant and nutritious than the provisions of the negro, and his cabin is a less commodious residence than the hut of the other. Both alike then limit their desires to the first necessaries of life. Is the difference attributable to the industry of the peasant, and to the indolence of the manumitted slave? That supposition is unfortunately at variance with well-established facts. The same love of repose distinguishes the Irishman and the negro; or, more properly speaking, is characteristic of all men who are not living under the constant excitement of some habitual stimulus to exertion. The real cause of the anxiety of the one to earn wages, and of the indifference of the other on that subject, is that the first will lose the potato-ground, which is his sole dependence, if he cannot procure the means of paying his landlord's rent; while the other is free from every such anxiety. In the vast tracts of fertile and unoccupied ground amidst which he lives, the African or creole freed-man perceives an unfailing resource for the subsistence of his family and himself. The free negro, if transferred 
into a population as dense as that of Ireland, or the Irishman, if migrating to a country as thinly peopled as Jamaica, would each be found to reverse his present habits in this respect - the one anxiously seeking for the wages which he had previously refused, the other despising the hired service which he had formerly solicited. ${ }^{41}$

While the comparison of the Irish with the African may simply reflect white English upper-class arrogance, it should be noted that Howick's comparisons, within Europe, America and elsewhere, covered wider ground, and focussed on what he felt to be common aspects of human behavior, in influencing the desire to consume and thus to labour. ${ }^{42}$

Although various proposals addressed expected and realized post-emancipation labour problems, surprisingly little was said at that time about immigration, and particularly, given later developments, about indentured labour. Henry Taylor's major policy was gradual self-purchase, as a means of convincing slaves of the importance of labouring to achieve income for desired ends: after freedom, ex-slaves would continue wanting to work for others in order to acquire the means to purchase goods they desired. Lord Howick preferred a tax on land, thus increasing the difficulty of its acquisition. The tax would lower worker incomes, not only encouraging more labour, but also labour for others. Neither of these policies was adopted as proposed, nor, with the exceptions of the previously densely-populated islands of Barbados and Antigua, were there sufficient restrictions on land availability elsewhere to force ex-slaves onto plantations. $^{43}$

Debates on these policies were renewed in what was perceived as the chaotic aftermath of emancipation, with parliamentary hearings in 1842 and 1848, where many of the same arguments about labour supply and land availability were repeated. Subsequently, the major labour policy was expanded and codified, with the in-migration of contract labour, primarily from India. Contract labour, which had existed for several centuries in the British Empire, and accounted for about one-half of white migration to the pre-Revolutionary War United States, flourished soon after emancipation with the migration of Indian labour to the Indian Ocean islands of Mauritius and Reunion. The belated, and successful, adoption of indentured labour immigrants in some of the West Indies seems, therefore, to reflect the failure of the land and labour policies initially attempted with the ex-slaves already resident. For the other islands, the impact of land and labour policies was rather limited, and the attempt to use 
indentured workers was also unsuccessful, so that the plantation system effectively ended.

The discussion of emancipation era labour policy arguments returns us to the analysis of the rise and expansion of slavery, the topic to which Richard Sheridan has devoted so much of his scholarly life. The attempt to recompose the forms of labour organization that had characterized slavery, without the legalised coercion permitted under slavery, suggests the centrality of the labour issue to the settlement of the Americas. More labour was wanted to do particular types of work than was available voluntarily, especially given the scale of the productive unit that would yield high returns in the islands and parts of the mainland (it being believed that labourers working for themselves on small farms would not produce high levels of output). After emancipation, means were sought to have labour work voluntarily, on large-scale units, in the belief that society would profit by securing, under a different institutional form, the production benefits landowners and consumers achieved under slavery. The rather limited successes of the post-emancipation policies in maintaining sugar production and overall agricultural output, contrast markedly with the outcomes of labour policies in the seventeenth, eighteenth, and early nineteenth centuries, which generated high and increasing production of sugar and other goods.

The discussion of labour plans for the transition from slavery to freedom in the British West Indies also raises profound questions relating to economic growth. The design of policies for economic adjustment in the aftermath of serfdom in Europe, as well as for twentieth-century economic development, raises similar issues when evaluating factors on the increase of labour supply and analyzing measures that determine where and how people will work. ${ }^{44}$ Specific policies determining land use and availability, regulating access to foreign labour, and legislating the opportunities of labour, have long been contested by workers, landowners, and capitalists. A high level of measured output may appear desirable to some, but may not be so for others, while achieving short-term benefits may not be in everyone's long-term interests. The concerns with the labour and land problems elsewhere indicate that the importance of these issues was not unique to the post-emancipation Caribbean, and show how different approaches and resolutions have resulted in a diverse set of outcomes. 
1. Richard B. Sheridan, "The West India Sugar Crisis and British Slave Emancipation, 1830-1833," Journal of Economic History 21 (1961): 539-51.

2. This act was 5 Geo. IV, c. 113.

3. Richard B. Sheridan, "From Chattel to Wage Slavery in Jamaica, 1/40-1860," Slavery and Abolition 14 (1993): 13-40.

4. For a discussion of some of these issues, see Stanley L. Engerman, "Coerced and Free Labor: Property Rights and the Development of the Labor Force," Explorations in Economic History 29 (1992): 1-29.

5. For a discussion of the relatively-neglected proposals for the transition from serfdom to free labour in nineteenth-century Europe, see particularly Jerome Blum, The End of the Old Order in Rural Europe (Princeton: Princeton University Press, 1978), part 3.

6. Sir James Steuart, Principles of Political Economy. Vol. 1 of The Works, Political, Metaphysical, Chronological of Sir James Steuart, 6 vols. (1767; reprint, New York: Augustus M. Kelley, 1967) 1: 52.

7. Ibid. pp. 224-31 and 254-62. Steuart notes the compatibility of slavery with agriculture, and the difficulty free labour experiences in competing with slavery where the latter already exists. For an important examination of the choices made between "free" white and slave black labour in seventeenth and eighteenth-century Europe, see David Eltis, "Europeans and the Rise and Fall of African Slavery in the Americas: An Interpretation," American Historical Review 98 (1993): 1399-1423.

8. See, for example, the papers in John Brewer and Roy Porter, eds., Consumption and the World of Goods (London: Routledge, 1993), particularly those by de Vries, Appleby, Shammas, Weatherill, and Breen.

9. See, for example, the discussions in Jan de Vries, "Between Purchasing Power and the World of Goods: Understanding the Household Economy in Early Modern Europe," in Consumption and the World of Goods, ed. Brewer and Porter, pp. 85-132; A. W. Coats, "Changing Attitudes to Labour in the Mid-eighteenth Century," Economic History Review 11 (1958): 35-51; Peter Mathias, "Leisure and Wages in Theory and Practice," in his The Transformation of England: Essays in the Economic and Social History of England in the Eighteenth Century (New York: Columbia University Press, 1979), pp. 148-67; and Joyce Oldham Appleby, Economic Thought and Ideology in Seventeenth-Century England (Princeton: Princeton University Press, 1978). The basic work on this topic remains Edgar S. Furniss, The Position of the Laborer in a System of Nationalism: A Study in the Labor Theories of the Later English Mercantilists (New York: Houghton-Mifflin, 1919). See also J. E. Crowley, This Sheba Self: The Conceptualization of Economic Life in Eighteenth-Century America (Baltimore: Johns Hopkins University Press, 1974), on the United States. 
10. Benjamin Franklin, "Observations Concerning the Increase of Mankind," in The Papers of Benjamin Franklin, Volume 4: July 1, 1750 through June 30, 1753, ed. Leonard W. Labaree (New Haven: Yale University Press, 1961), pp. 225-34; and Alexander Hamilton, "Report on Manufactures, December 5, 1791," in The Reports of Alexander Hamilton, ed. Jacob E. Cooke (New York: Harper \& Row, 1964), pp. 115-205. Franklin describes "the proneness of human Nature to a life of ease, of freedom from care and labour," in explaining why the easy availability of the "Productions of Nature" have influenced the American Indians. See his Letter to Peter Collinson, 9 May 1753, in Papers of Benjamin Franklin, Volume 4, ed. Labaree, pp. 477-86.

11. See Evsey D. Domar, "The Causes of Slavery or Serfdom: A Hypothesis," Journal of Economic History 30 (1970): 18-32; and H. J. Nieboer, Slavery as a Industrial System, (1910; reprint, New York: Burt Franklin, 1971).

12. This point about the use of legal measures to induce desired labour force behaviour was noted in the 1842 and 1848 Parliamentary hearings on the problems of British West Indies. Mr. Hawes commented about the landowners' desire:

to reaquire that power by law which they had been deprived of by the Act of Emancipation. The loss of the lash was to be made up by the severity and subtlety of the law.

Great Britain, Parliament, Hansard's Parliamentary Debates, Third Series, Volume 99, 29 May to 13 June 1848 (London: G. Woodfall and Son, 1848), p. 1116.

13. See Paul W. Gates, History of Public Land Law Development (Washington, D.C.: Government Printing Office, 1968), as well as the sources cited below in note 24 .

14. The distinction between controls over out-migration or in-migration also raises a number of important issues for examining the abolition of forms of controlled labour, such as slavery and indentured labour. Thus, while the transatlantic migration of slaves to the Americas was ended by policies in the receiving countries, the migration of indentured labour from China and India was ended by the sending areas. Similarly, free migration was sometimes limited by the country of residence, and sometimes by the countries to which the migrants would go. The politics of these cases, if not the economic impacts, could differ.

15. Benjamin Franklin, "Observations," p. 227.

16. Ibid. p. 228.

17. Pennsylvania Assembly Committee, Report on the State of the Currency (19 August 1752), in Papers of Benjamin Franklin, Volume 4, ed. Labaree, pp. 344-50.

18. Alexander Hamilton, "Report on Manufactures," p. 139.

19. Ibid., p. 131.

20. Ibid., p. 117.

21. Ibid., p. 135.

22. See Reports of Alexander Hamilton, ed. Cooke.See also the discussion of the influential views of Tench Coxe in Jacob E. Cooke, Tench Coxe and the Early Republic (Chapel Hill: University of North Carolina Press, 1978), pp. 98-108, 182-200. 
23. See Hamilton, "Report on Manufactures."

24. See, for example, the discussions in Helene Sara Zahler, Eastern Workingmen and National Land Policy, 1829-1862 (New York: Columbia University Press, 1941), pp. 109-26, 184-87; Benjamin Horace Hibbard, A History of the Public Land Policies (New York: Macmillan, 1924), pp. 74-78, 548-60; Roy M. Robbins, Our Landed Heritage: The Public Domain, 1776-1936 (Princeton: Princeton University Press, 1942), pp. 13-19, 45-48; and Mary E. Young, "Congress Looks West: Liberal Ideology and Public Land Policy in the Nineteenth Century," in The Frontier in American Development: Essays in Honor of Paul Wallace Gates, ed. David Ellis (Ithaca: Cornell University Press, 1969), pp. 74-112.

25. These debates discussed whether compensation should be based on slave prices or on the number of slaves (and thus made on an equal per capita basis). There was also concern over maintaining land values on those islands where ex-slaves could not be kept on plantations. The Jamaica agents noted, on 18 July 1833, that the emancipation bill:

will be less mischievous to other colonies than ours. For instance, in Barbados and Antigua and several other islands the liberated slaves must work for wages or want the necessaries of life, those islands being so fully peopled and occupied that, as in England, the choice of the lower order lies between work and starvation.

And these Jamaica agents further noted (8 August 1833) that, in contrast with the easy availability of land in Jamaica:

the negros in the thickly settled islands must labour for wages at the end of the apprenticeship or starve. In the Crown Colonies they have either a strong and well organized police, or the negroes are kept in check and in terror of the aboriginal Indians.

Jamaica Agents Letter Books, 1784-1834, 1B/5, Jamaica Archives, Spanish Town

26. Edward Gibbon Wakefield, England and America: $A$ Comparison of the Social and Political State of Both Nations (New York: Harper and Brothers, 1834); and Edward Gibbon Wakefield, $A$ View of the Art of Colonization: In Present Reference to the British Empire (London: John W. Parker, 1849). See Karl Marx, Capital: A Critique of Political Economy (1906; reprint, New York: Modern Library, 1936), pp. 838-48. To Marx, Wakefield's policy to achieve "the manufacture of wage-workers in the Colonies," demonstrated that Wakefield had "discovered in the Colonies the truth as to the conditions of capitalist production in the mother-country."

27. The plans are "Paper on the Proposed Emancipation of Slaves by Mr. Henry Taylor, January 1833," CO884/1, Public Record Office; and "Heads of a Plan for the Abolition of Negro Slavery, and for the Continued Cultivation of the Estates by the Manumitted Slaves, 7 January 1833," CO 320/8, Public Record Office. An abstract from Lord Howick's proposal is reprinted in "Memorandum of Lord Howick [Extracts]," in Select Documents on British Colonial Policy, 1830-1860, ed. Kenneth 
N. Bell and W. P. Morrell (Oxford: Clarendon Press, 1928), pp. 383-89. For discussions of their context see Henry Taylor, Autobiography of Henry Taylor, 1800-1875, 2 vols. (New York: Harper \& Brothers, 1885), 1: 98-114; Charles C. F. Greville, The Greville Memoirs: A Journal of the Reigns of King George IV and King William IV, 3 vols., 4th ed. (London: Longmans, Green and Co., 1875), 2: 347-50, 359-60, 380-81; Earl Grey, The Colonial Policy of Lord John Russell's Administration, 2 vols. (London: Rich and Bentley, 1853), 1:54-61. For broader discussions of these emancipation proposals, see William Law Mathieson, British Slavery and its Abolition, 1823-1838 (London: Longmans, Green and Co., 1926), pp. 183-242; W. L. Burn, Emancipation and Apprenticeship in the British West Indies (London: Jonathan Cape, 1937), pp. 75-120; D. J. Murray, The West Indies and the Development of Colonial Government, 1801-1834 (Oxford: Clarendon Press, 1965), pp. 187-204; William A. Green, British Slave Emancipation: The Sugar Colonies and the Great Experiment, 1830-1865 (Oxford: Clarendon Press, 1976), pp. 54-95, 114-21; and Thomas C. Holt, The Problem of Freedom: Race, Labor, and Politics in Jamaica and Britain, 1832-1938 (Baltimore: Johns Hopkins University Press, 1992), pp. 42-53.

28. "Paper on the Proposed Emancipation," p. 36.

29. Ibid., p. 47.

30. Ibid., p. 48.

31. Ibid., pp. 54-55.

32. Ibid., pp. 71-72.

33. Ibid., p. 72.

34. Ibid., pp. 73-74.

35. Ibid., p. 75.

36. Ibid., pp. 75-76.

37. For other presentations by Howick on the problem of slave emancipation, see Grey, The Colonial Policy of Lord John Russell's Administration, 1: 50-199, as well as speeches in Parliament in 1833 and 1845 dealing with the labour issue. See Great Britain, Parliament, Hansard's Parliamentary Debates, Third Series, Volume 17, 2 April to 20 May 1833 (London: T. C. Hansard, 1833), pp. 1231-59; and Great Britain, Parliament, Hansard's Parliamentary Debates, Third Series, Volume 77, 4 February to 26 February 1845 (London: G. Woodfall and Son, 1845), pp. 1103-18. In 1842 , a select committee that included by-then Viscount Howick, compiled the first large report dealing with the problems of the post-apprenticeship West India colonies, and placed great weight on the desirability of taxes to raise the price of land and create a larger supply of labour. See "Report from the Select Committee on West India Colonies," British Sessional Papers: House of Commons, 1842 (9), pp. iii-v.

38. "Plan for the Abolition of Negro Slavery," p. 12.

39. Ibid., pp. 5-6.

40. Ibid., pp. 6-7. 
41. Ibid., pp. 7-8. Howick goes on to argue that "there is one commodity, if so it may be termed, in which the manumitted slaves would abound. It is leisure time" (p. 9).

42. Some of the debate on post-emancipation policies dealt with questions of possible differences in the treatment of Englishmen and of ex-slaves. In 1848, Henry Barkly claimed that the West Indian vagrancy laws were no different from those of England, it being the case that:

the very Act ... quoted as passed in St. Vincent happened to be the Vagrant Act of this country; and what was more natural than that the colonists called on to legislate in a hurry should transfer the laws under which they had been themselves brought up to their Statute-book (Hansard, Volume 99, p. 1330).

43. And these islands, such as Barbados, had their own proposed policies to ensure the desired land/labour ratio-the prohibition of emigration to other islands. See the discussion in G. W. Roberts, "Emigration from the Island of Barbados," Social and Economic Studies 4 (1955): 245-88. See also the reaction of J. P. Mayers, agent for Barbados, in his letter to the 1842 Committee, expressing a lack of interest in the issues of the inquiry, given Barbados's different problems, and arguing that free migration to other islands, as some had proposed, would represent an "evil" to "that population [the migrants], as well as the proprietors" ("Report from the Select Committee," p. 764).

44. The transition after serfdom posed at least one additional issue. Unlike ex-slaves, ex-serfs had often been given customary rights on the lands that would be made available to them for their ownership-but generally at some price. This price, however, often implied terms that imposed high costs on the ex-serfs. 


\title{
16
}

\section{Urban Crime and Social Control in St. Vincent during the Apprenticeship}

\author{
RODERICK A. MCDONALD
}

\begin{abstract}
Sir Benjamin Hawes, M.P.: $\quad$ "What is the state of crime in St. Vincent's?"
Hay McDowell Grant: $\quad$ "I should think it has rather increased; I do not think the actual amount of crime has increased, but that it is more taken notice of."

Hawes:

"There is more detection, more police?"

Grant:

"Perhaps more; the crimes which were before punished on the estate, are now brought forward to public view."
\end{abstract}

(Testimony before the House of Commons, 1842) ${ }^{2}$

St. Vincent's particular historical circumstances, especially the presence of an unassimilated, frequently hostile, indigenous Carib population, and the protracted Anglo-French imperial struggle for control of the island that preceded its ultimate incorporation into the British colonial system in 1783, delayed the ascendancy of sugar plantation slavery there. By the early nineteenth century, however, sugar production peaked at over 20,000 hogsheads in some years, while the slave population grew, reaching some 25,000 by 1808 , the year the slave trade was abolished, before declining to 22,250 on Emancipation Day, 1 August $1834 .^{3}$

These last years of slavery on the island witnessed an increased emphasis on the control of the slave population through the enactment of formal legal measures. Charles Shephard observed that "the old Slave Act of 1768, having been deemed inappropriate to the improved condition of the negroes, after 
several partial amendments, and particularly by an Act passed in $1813 \ldots$ it was entirely repealed in 1820 , and has been re-enacted every seven years, with gradual improvements." ${ }^{4}$ While these later acts granted slaves certain concessions consistent with the concept of amelioration that emerged in the quartercentury between 1808 and 1834, they functioned primarily to secure the dominance of St. Vincent's free white population over the island's enslaved peoples. ${ }^{5}$

Coinciding with the revised slave laws, penal institutions were constructed that reflected a similar emphasis on control rather than concession. Hence "An Act for building a Cage, and for establishing a Police in the Town of Kingstown," passed in 1821, followed six years later by "An Act for the establishment and regulation of a Treadmill in Kingstown."

Before emancipation, however, relatively little crime fell within the compass of the formal legal structure. In the last five years of slavery, the number of convicted prisoners held steady at some 300 people (female and male, slave and free, black, coloured and white), out of a total island population of about $26,550 .^{7}$ Crimes committed by rural and plantation slaves did not normally reach the courts, despite the fact that, as Shephard noted, "the government of the slave population, is chiefly under the control of the Magistrates, except in specified cases; two Justices sit in rotation at the Court House in Kingstown, twice each month, to hear and determine all petty offences; the punishments of slaves are regulated by a Slave Act, and recently, since the establishment of a treadmill, by the laws regulating the same." ${ }^{8}$ Rather, as St. Vincent sugar planter, Hay McDowell Grant, observed, slaves guilty of crimes, if detected, were usually punished by the owners or managers of the estates on which they lived. ${ }^{9}$ Apart from those charged with the most serious crimes, such as rebellion or murder, the only slaves likely to have fallen foul of St. Vincent's formal legal system with any regularity would have been the small number living in the island's urban areas, especially the capital, Kingstown. ${ }^{10}$ Since their residence and activities placed them in close physical proximity to the police and the courts, their alleged offenses would have come more readily to the attention of the authorities.

Emancipation eliminated the ex-slaveowner's option to adjudicate on the actions of his workers. Although all slaves over six years of age were required to continue labouring as apprentices for those who had held them in bondage, the St. Vincent Abolition Act prohibited former slaveowners from punishing a newly-freed "apprenticed labourer for any offence by him committed, or 
alleged to have been committed, by the whipping, beating or imprisonment of his person, or by any other personal or other correction or punishment whatever." ${ }^{11}$ Instead, in the proliferation of laws, personnel and institutions accompanying emancipation, metropolitan and island authorities incorporated new strategies to address the altered circumstances. These developments reflected the high priority given to controlling the apprentices. New definitions of crime and criminality, with accompanying mechanisms for the identification and punishment of transgressions, were instituted with, or followed fast on the heels of, slavery's abolition.

The Abolition Act included specific provisions to replace the slaveowners' prerogative to punish slaves. During the four-year Apprenticeship, a newly-created Special Magistracy exercised "sole and exclusive jurisdiction over ... all offences committed, or alleged to have been committed by any such apprenticed labourer, or by his employer in such their relation to each other." Indeed, the Special Magistrates had responsibility over "any question, matter or thing incident to or arising out of the relations subsisting between such apprenticed labourers and the persons respectively entitled to their services." 12

Thus, in rural areas, the jurisdiction of the Special Magistrates replaced planter justice during the Apprenticeship. Magistrates visited each estate within their judicial district at least once a fortnight, and convened courts to hear and adjudicate on the complaints brought before them by both apprentices and planters. The Abolition Act, and the accompanying "Act for Establishing a Police for the Regulation of Apprenticed Labourers," which both codified the obligations of the two parties and specified the consequences of any contravention, guided the decisions at these proceedings. ${ }^{13}$ Since the provisions of the Abolition Act likewise pertained to urban apprentices, Special Magistrates also held court in towns within their jurisdiction to rule on grievances between apprentices living there and those entitled to their labour.

Special Magistrates' responsibilities were limited to disputes between apprentices and employers. They had no jurisdiction over crimes that fell within the purview of St. Vincent's "superior courts of civil and criminal justice." ${ }^{14}$ Before 1834, most slaves who committed crimes such as assault and theft, would, if caught, have been punished by their owners, but during the Apprenticeship, responsibility for adjudicating on these acts fell to the criminal courts, a circumstance that would indeed, as Grant testified, have "brought forward to public view" more crimes. In addition, many apprentices were ensnared by new 
laws instituted to control the newly-freed population. ${ }^{15}$ Small wonder then, that by 1836 , the number of prisoners on the island-1,265-was over four times the annual pre-emancipation average, the increase coming primarily from the ranks of the apprentices, as whole areas of their lives were, in effect, criminalised. $^{16}$

During the Apprenticeship, criminality was redefined, while the mechanisms for prosecuting and punishing crime were overhauled. But these changes did not uniformly affect constituencies within the island population. Whites felt little impact, with the brunt of the changes being borne by free coloureds and apprentices. Moreover, a clear urban/rural division existed, as is evident by the marked differences in how the activities of town-based apprentices were criminalised, as compared to those of their counterparts working on the island's estates, plantations and pens.

Disparities between the urban and rural contexts reveal the priorities and values that guided the authorities' reconceptualisation of crime. The codification of laws experienced by agrarian apprentices, which were designed to control and extract work within the plantation gang system, reflected markedly different imperatives from those instituted to control town-based apprentices, whose patterns of residence and labour were so dissimilar to their rural counterparts. Moreover, differences in the offences and crimes which were reported and investigated, indicate how the locale - town as opposed to country-of the apprentices' continued (albeit altered) servitude, shaped their actions and responses. Hence, both the authorities' aspirations and the perpetrators' attitudes caused different crimes to predominate in these different milieus. ${ }^{17}$

Within St. Vincent's urban context, offences against private property and threats to the public peace, in the form of brawls, drunkenness and the like, were the dominant forms of apprentices' criminality. These characteristics were not shared by rural apprentices who, of course, were primarily labourers on sugar estates. Whereas theft predominated among offenses against private property in the urban setting, in the countryside, attacks on private property blamed on apprentices were as frequently destructive-sabotaging cane-fields, or arson, for example-as acquisitive. Rural apprentices were also accused of negligence, disobedience, impertinence, unwillingness to work, and a variety of other labour-oriented offenses, that were much less prevalent in the catalogue of urban apprentices' crimes. ${ }^{18}$ Moreover, rural criminality was frequently 
considered, and indeed punished, as a group or gang phenomenon, whereas crime and its prosecution in the urban context targeted individual perpetrators.

The urban and rural worlds did, of course, intersect, as increased numbers of apprentices traveled back and forth between them, exploiting the more ready accessibility of towns occasioned by the termination of slavery. During the Apprenticeship, planters and island authorities alike voiced increasing concern about the "contamination" of urban influences corrupting agrarian apprentices. But in the realm of crime and criminality, differences between the urban and rural contexts outweighed continuities.

Among the records providing information on crime in St. Vincent during the Apprenticeship, the Special Magistrates' reports are, of course, extremely useful. ${ }^{19}$ For understanding the urban situation, however, the returns submitted by one Special Magistrate in particular, John Anderson, are of singular importance, since Kingstown, the largest town on the island, fell within his jurisdiction. ${ }^{20}$ Moreover, Anderson kept a private journal which contains a wealth of salient information about his Special Magistrate's duties, as well as the unique perspectives on urban crime he derived from his 1836 appointment as Kingstown's Chief Police Magistrate and "ex officio a Justice of the peace... [with] power to adjudicate over all misdemeanours, breaches of the peace, $\&$ the like offences committed by any class." 21

A man hears every day of the necessity of establishments of police, and the
passing of vagrant and other severe restraining acts ...

(Major John B. Colthurst, St. Vincent Special Magistrate, June 1838). ${ }^{22}$

In 1831, Shephard claimed that "the police of the Island has been greatly improved of late years, and especially in the town of Kingstown; this is regulated by three Town Wardens [and] a Chief Constable." Consequently, law-breakers, whom Shephard identified as "the lower class of persons who occupy the towns ... principally seafaring persons," were being more readily apprehended, with the threat of punishment on the recently-installed treadmill helping to deter crime. ${ }^{23}$ Emancipation, however, undermined this optimistic view of the state of law and order that St. Vincent's white population held, and wrought signifi- 
cant changes in all four dimensions of the island's legal system-laws, personnel, institutions and punishments.

By 1836, Anderson lamented how Kingstown was being plagued with "numerous breaches of the peace." He noted the frequent occurrence of public brawls among free blacks and free coloureds, as well as apprentices, both male and female, which, moreover, "were often attended by crowds, who never interfered between the disputants, or sought to get them punished." The town's constabulary could not provide an effective deterrent to these activities because, Anderson observed, they were outmanned, even though by this time, the town constabulary had increased to "six Policemen and a Chief Constable," the additional men being "added to the Stipendiary Magistracy, for the capital, on the commencement of the apprenticeship." ${ }^{24}$

Anderson, a recent arrival in St. Vincent, had read Shephard, and was expecting to find a contingent of "admirable police" in Kingstown. Instead, what he disparagingly called "this so famed force," had just to stand by and watch rivals "fight out their dispute, without let or hindrance." One problem, according to Anderson, was that the four policemen who had been added to the constabulary in 1834 were "prohibited interfering with Freemen in their broils, [and] had to confine their care to the [apprenticed] Labourers," although he considered them "too few in number" to carry out even this responsibility effectively. ${ }^{25}$

The island assembly knew that an ineffective police force could jeopardize the white minority's control over St. Vincent's non-white freedpeople and apprentices, and passed legislation giving Special Magistrates the power to act as town constables. Furthermore, on Lieutenant-Governor George Tyler's recommendation, the local authorities moved to consolidate the police into a more efficient unit. By October 1836, a bill uniting "the Ordinary police, with the Stipendiary force, creat[ing] a body of nine policemen, \& a Serjeant, under the control of the Chief Police Constable," had become law. This legislation also created the post of Chief Police Magistrate to which Anderson was appointed. His duties required him to convene a court in Kingstown "three days in every week, from 10 A.M. to 2 P.M.," while for cases that needed a plurality of justices, two fellow magistrates joined him at a court held every two weeks. As Chief Police Magistrate, Anderson sought "to impose order and energy into the Police establishment-and to enforce a rigid attention to the laws," all the while fulfilling his responsibilities as Special Magistrate. ${ }^{26}$ 
Two facilities in Kingstown housed persons accused or convicted of crimes or misdemeanours - the town jail and the house of correction - with the latter being reserved exclusively for the incarceration of apprentices. The house of correction, which was located right in the centre of town and adjacent to the jail, contained a treadmill. ${ }^{27}$

This complex of "jail,_cage,-cells for solitary confinement, \& treadmill," was, according to Anderson, being "respectably conducted by a sailor, and superintendant. ${ }^{28}$ Andrew Parie had run the Kingstown House of Correction since 1825, and continued as superintendent through the Apprenticeship at the annual salary of $£ 150$ currency. He paid "Mr. Young, his assistant, one dollar or $4 \mathrm{~s}$. $2 \mathrm{~d}$. sterling weekly, and gives clothes occasionally," but since there was "no accommodation whatever" for the superintendent's assistant, Inspector of Prisons, Robert Sutherland, reckoned it was "impossible a trustworthy person would accept the office." Kingstown Jail was under the charge of John Bates who received a salary of $£ 100$ currency per annum and had no assistant. ${ }^{29}$

St. Vincent's Provost-Marshal-General oversaw the operations of the jail and appointed the jailer. The public treasury paid three shillings currency per day for the keep of each prisoner there, with the jailer's salary also being paid out of these funds. The facility's operations were monitored by the daily visits of the Provost Marshal, and with inspections conducted twice-yearly by the jurors of the Court of Grand Sessions. ${ }^{30}$

The House of Correction in Kingstown, like its two counterparts in Barrouallie and Colonarie, came under the jurisdiction of the Special Magistracy, as did the island's three treadmills. The local police sergeants ran the Barrouallie and Colonarie facilities for no extra compensation, but the island treasury disbursed Parie's salary. All three houses of correction received weekly visits from a Special Magistrate and, like Kingstown Jail, underwent the twice-yearly inspections by the jurors of the Court of Grand Sessions. ${ }^{31}$

Prisoners on the island could be sentenced to serve time on the treadmill. The machines at Barrouallie and Colonarie, like the houses of correction to which they were attached, were reserved exclusively for apprentices, while the Kingstown treadmill received inmates from both the jail and the house of correction. The Kingstown machine had been "constructed in England; length 10 feet, diameter 3 feet 7 inches, depth of tread 5 inches." It had "machinery to grind corn or oats attached; straps on the bar for the wrists," and when in 1838 Sutherland "saw it at work; its motion was regular; it revolved four times a 
minute." Sutherland was dissatisfied with the other two treadmills. They had both been built locally, but because of design and equipment problems the Barrouallie machine was "in bad order," while the "badly constructed" Colonarie treadmill was in his opinion "an unsafe mode of punishment" that did not "answer the purpose.". ${ }^{32}$

Crime and criminality feature prominently in the journal Anderson kept of his residence in St. Vincent. Although this preoccupation increased with his appointment as Chief Police Magistrate, the monthly reports he and his fellow Special Magistrates submitted reflect the frequency with which they confronted criminal conduct in arbitrating between the former slaves and the former slave owners.

Anderson differentiated among both crimes and criminals. He stressed the distinction between the urban and rural settings, and classed criminals within four basic categories: rural apprentices, urban apprentices, the urban free black and coloured population, and whites.

Neither he nor the other authorities expressed much interest in white criminality which, of course, they rarely perceived as threatening the hegemony enjoyed by whites on the island. Only when such conduct had the potential of inspiring a like response among the island's non-white population did it receive much comment or criticism. Anderson became particularly concerned with "various instances of neglect of duty, indolence, \& improper work" by some rural apprentices under his charge, to which he "attribute[d] the proximity of the Estates in this district, to Kingstown, and the facilities of communication with debauched characters thence, as the causes of these misdemeanours. ${ }^{33} \mathrm{His}$ condemnation of those he defined as urban miscreants (the same "lower class of persons who occupy the towns ... principally seafaring persons" identified by Shephard as Kingstown's criminal element) would have embraced any whites among them. ${ }^{34}$ Other white criminality-planters abusing or cheating apprentices, for example-did not preoccupy island authorities in the way that the criminality of non-whites, free and apprenticed, did.

Most of St. Vincent's free black and free coloured populations lived in Kingstown during the Apprenticeship. These four years witnessed a steady growth in the numbers of free non-whites, with their children, and the children of apprentices augmenting the ranks, along with ex-slaves who had succeeded in terminating their obligations as apprentices early. And as the free non-white population grew, so too did its urban concentration. The correlation that white 
authorities made between these developments and threats to their conception of public order resulted in heightened legislative and police activity targeting Kingstown's non-white residents.

Anderson observed that "by no class was greater opposition given to the working of the Police bill [of October 1836] than the coloured;-because upon many of them fell its first and heaviest weight." Since the act abolishing slavery and the accompanying legislation establishing a police force already stipulated the procedures for regulating the conduct of apprentices, it was control of what the apprentices would soon become-free people of colour-that received legislative priority. Fueled by concern over "offences against the excise,revenue,-public peace and private property" that Anderson claimed were being "committed by [free] coloured people," the 1836 Police Bill was anticipating full freedom in its efforts to circumscribe the activities of the non-white population. $^{35}$

Anderson, of course, recognized the honesty and reputability of many free non-whites, some of whom were "possessed of wealth, - a few are deservedly in offices of trust as Managers, \& confidential clerks: In their highest ranks, 一are persons of great respectability," and he noted in 1836 the first instance in the island's history of "a respectable, \& educated Coloured gentleman being elected a member of the Assembly." 36

Notwithstanding these exceptions, and, indeed, any potential community of interest with the free non-white elite, white Vincentians felt increasingly threatened by the free non-white urban population, and responded by criminalising activities that had previously been minor annoyances, and rigourously punishing contraventions. In so doing, whites were moving to establish control over what they regarded as an essentially monolithic and undifferentiated segment of island society, two years before full freedom would swell its numbers dramatically.

Anderson condemned the free coloured "shopkeepers, \& hucksters who exist by retail ... and a very mean expedient of huckstering by their servants." These small merchants complemented their legitimate trade by fencing goods stolen by apprentices, a problem the legislature confronted in 1836, when it outlawed the sale "of syrup and sugar" without a license. ${ }^{37}$

A few months later the Police Bill targeted another branch of petty commerce-the houses run by free coloured women that, according to Anderson, were hosting "nightly orgies \& dances, to which all visitors were welcome on 
paying for their reel, quadrille,-stimulants." Anderson complained of the problems these festivities caused-such as drunkenness, fights, gambling, disturbances of the peace, and the consumption and distribution of stolen property-and lamented that "app[rentice]d labourers, \& free blacks of both sexes" patronized the shebeens, which, he observed, were located in "a noted quarter of the town." 38

Before the Police Bill, the owners of these "abodes of vice, \& debauchery" were unlicensed, and according to Anderson, "the Police in years back, seem to have wink[ed]" at any problems occurring there. While slave laws controlled the masses of St. Vincent's non-whites, whites could afford to disregard the petty nuisances of the free coloured population, but demographic and legislative changes compelled whites to reevaluate the dimensions of their control over the affairs of the island. Not only was the growth (and, more importantly, the impending massive growth) of the free coloured population threatening the status quo, but also their activities were "infecting" the rural apprentices, who Anderson claimed, would travel considerable distances to attend dances "in these dens," before wearily "making their way back to their estates in time next morning for the six o' $\mathrm{C}$. bell;- -but in reality as may be imagined, incapable of work." ${ }^{39}$

After the Police Bill imposed a licensing requirement on these establishments, unlicensed premises were subjected to raids by the town constabulary. On 21 December 1836, one proprietor, Ann Greeg, wrote to Anderson in his capacity as Chief Police Magistrate, requesting "a permit to give a small hop know and then as the Hellerdays is so near." She particularly asked him to "let me always hold [the permit] myself so as to show it to any of the Constable when they come to Break up the Dance," and promised to "see and take care that theire shall be no noise or any incombrance. ${ }^{100}$ Although Greeg's concerns suggest some enforcement of the Police Bill by the constabulary, unlicensed shebeens continued to operate clandestinely, as witnessed by Anderson's complaint the following summer about the "debauched characters" in Kingstown, among whom were undoubtedly numerous free coloureds, he accused of causing apprentices to neglect their work. ${ }^{41}$

The detailed description Anderson provides of one of these gatherings illustrates the threat they posed to white control. In early 1838, with cholera prevalent in Kingstown and numerous fatalities putting whites "in the midst of universal gloom," free non-whites and apprentices "with their wonted levity, 
indulged in stolen 'hops', 8 r 'maroons," such as the "quadrille party," held on the evening of Friday, 23 February 1838, at the Back Street home of a free coloured woman, Miss Mary Sample. A "Club" of young apprentices, the domestic servants of prominent white merchants, organized the dance, which attracted "a promiscuous crowd of all colours," free and apprenticed. The club's president, Joseph Louis Debukes, and two stewards, Joe Patterson and William Aberdeen, had issued formal invitation cards, and rented Miss Sample's house, stealing from their employers to meet these expenses, to clothe themselves and their friends elegantly, and to provide the alcohol consumed at the fette, to which "married women were not admitted, only young ladies." One club member had "dressed himself in his master's shirt, silk stockings, and vest, — \& hung around his neck a Valuable Gold chain, \& eye glass," and before heading to the dance shared "a bottle of [his employer's] champaigne" with a friend, while another took "a basket full of wine, spirits, and foreign liquers ... knives, forks \& plates," appropriated from his employer, to the venue, where his girl friend, outfitted in a stolen "white satin gown, trimmed with white, and corresponding finery" presided as "mistress of the revels." At this "festive scene; the tambourine flourished,- - the fiddle scraped,-the triangles chimed,-and 'a gentleman' was just handing "port wine and Claret sangaree ... to the ladies" when the police, alerted to the theft of the alcohol and tableware, raided the house, where they confiscated "upwards of a dozen \& a half empty Champaigne bottles ... besides spirits,_-Various pairs of new shoes,- -stockings, —and candles," all stolen. At the ensuing trial, Anderson found it "impossible to calculate the extent of the plunder, or the period of its successful existence. ${ }^{42}$

Such events confirmed some of the white population's worst fears, while highlighting the inadequacy of their attempts at controlling Kingstown's black and coloured residents, among whom, apprenticed and free, a growing fraternity was unresponsive to whites' authority, preyed on their private property, disregarded their laws, disturbed their peace, and flouted their standards of morality and behaviour. Recognizing that the end of the Apprenticeship would likely exacerbate their plight, whites called for increased vigilance, harsher laws and stiffer penalties, a response that Anderson no doubt reflected in the "adequate punishment" he meted out to Debukes and his friends for their "wickedness \& effrontery," and explains why at this time Special Magistrate John Colthurst was hearing "every day of the necessity of establishments of police, and the passing of vagrant and other severe restraining acts." ${ }^{43}$ 
The white authorities could not, however, institute Draconian measures with impunity, as they found out in mid-March 1838 when a group of young free coloured men accused of assaulting the police faced trial. Anderson was one of the six specially-appointed magistrates who unanimously found two of: the men guilty, and sentenced them "to pay a fine, \& undergo ten days hard labour on the treadmill;" the others were fined for their involvement. Sentencing free coloureds to the treadmill was most unusual, and in doing so the white authorities were showing their response to changing power relations. The treadmill punishment, which until then had been reserved primarily for slaves and subsequently apprentices, "gave great offence to the [free] coloured population," according to Anderson, because it bracketed them with the apprentices, and it seems clear that this was the intent of the white authorities, although Anderson disingenuously observed that "white sailors and soldiers" had also been punished in this way. ${ }^{44}$ Whites could no longer hope to maintain control over Vincentian society while recognizing a distinction between free and apprenticed that, after all, full freedom would be eliminating within months. Instead, as the legislative and judicial record reflects, they tried to adopt an implacable and increasingly undifferentiated posture towards the island's nonwhites.

Thus, as legislation governing their activities increased, more free coloureds were falling foul of the law, and their contraventions received more zealous prosecution and more severe punishment. Free coloured opposition to these developments, which, as Anderson noted, dated from the passage of the Police Bill in 1836, escalated dramatically with the judgment that sentenced members of their community to the treadmill. A riot occurred, and with it the Apprenticeship era's most severe challenge to the island authorities' conceptions of law and order. That free coloureds, and not apprentices, organized the most concerted and coherent open resistance to the white establishment in these years, in no way suggests that the ex-slaves were accepting the continued oppression under which they lived and worked: it does, however, indicate how changes wrought by the Apprenticeship, and anticipated with full freedom, transformed the social construction of crime and control in St. Vincent's urban milieu, and polarized Kingstown's various constituencies.

The riot mobilized St. Vincent's free coloureds, with "not merely the refuse of Kingstown," Anderson was surprised to report, but "upwards of 1000 persons" among them "wealthy individuals" from the community demonstrating 
outside the jail, where they physically prevented the transferal of the two prisoners to the treadmill. The ensuing fracas lasted through the day. The gate to the jail was broken open, police were attacked, and the magistrates verbally abused and threatened, before Lieutenant-Governor Tyler agreed to receive a petition from a deputation of free coloured leaders urging him to dispense with the treadmill punishment for the two men. While the authorities deliberated, the crisis entered its second day. Again "the crowd assembled in great force" and, facing the threat of large-scale rioting, Tyler reversed the magistrates' sentence (a decision the jurists opposed) and released the men. ${ }^{45}$

Elated, the free coloured community "paraded these youths about in triumph [as] the news ran like wild-fire over the Colony ... that 'the Buckra was put down." ${ }^{\prime 46}$ The free coloured achievement, of course, had been to check efforts by the white establishment, escalating since the 1836 Police Bill, to deny them the particular (albeit often uncodified) niche they had been occupying within the framework of law enforcement on the island. ${ }^{47}$ The persistence of the free coloureds as a specific cohort, and their place in island society, depended on maintaining the distinctions between them and the apprentices that whites had been trying to eradicate. Tyler's appointment, within months of the riot, of "one of the ringleaders [as] Corporal of Police," indicates some early success for the strategy. ${ }^{48}$

Since Anderson had jurisdiction over the third judicial district, which included Kingstown as well as a number of sugar estates to the capital's west and north, he witnessed first-hand the involvement of apprentices in urban crime. Indeed, in his very first magistrate's report to Lieutenant-Governor Tyler, Anderson noted that "the offences committed on the estates are exceedingly few," but lamented that "the calendar is swelled up by cases from the town." Of course, many of these did not involve criminal conduct. Rather they were for the most part "disputes between seamen and their employers" over the terms of their apprenticeship as set down in the Abolition Act. Nevertheless, Anderson did indicate that "breaches of the peace" were occurring in town, although none were very serious. ${ }^{49}$

The following month, Anderson reiterated that, although he had "occasion to punish few offenders in the rural part of his charge," he had nevertheless dealt with a large number of cases. "These," he observed, were "mainly of a class which necessarily enters into the police reports of any capital," with breaches of the peace again featuring prominently. "The crime of theft" appeared several times 
in Anderson's April 1836 report, and by May, "breaches against the public peace, particularly robbery in various shapes" were occurring with such frequency in Kingstown that Anderson felt constrained to "call for the strict vigilance of the police" in his report that month. ${ }^{50}$

Selections transcribed by Anderson from his "Journal of Cases" indicate the principal concerns whites felt about criminality among urban apprentices, and the priorities they set in controlling it. ${ }^{51}$ The impact of theft on the island's commerce was apparently proving particularly troublesome. Anderson not only lamented its prevalence at the docks and aboard ships, but also worried about its organizational sophistication, offering as evidence the resourcefulness of the perpetrators, and the existence of complex, efficient fencing operations to facilitate the disposal of stolen goods.

When "J- \& A- apprentice seamen to Messrs. T-, were accused of plundering the drogher in which they were serving, of sugar," Anderson indicated that "this is a crime of daily occurrence; \& one, in which the Black, \& Coloured hands are so expert under the eye of even the most attentive skipper, as to occasion the destruction of property to an immense amount." Prosecution proved difficult, with Anderson holding out "little hope of discovering the depredators," since "a species of freemasonry among Negroes whenever 'Buckra' is concerned," meant that apprentices refused to cooperate with any investigation. Detection was further hampered by the perpetrators "hav[ing] their scouts in Kingstown who receive the stolen wares whether canes, sugar, melasses, cotton, iron, etc." The authorities tried to curb these fencing operations by tightening the laws: "with a view of checking the guilty, the Legislature in June 1836, made it imperative on retailers of syrup and sugar, to provide themselves with licenses." ${ }^{\text {52 }}$ The free coloured petty "shopkeepers and hucksters" about whom Anderson complained elsewhere would have been prominent among the fencing fraternity, thus extending "the freemasonry among Negroes," and cementing precisely the kind of bond between apprentices and free coloureds most feared by whites. ${ }^{53}$

Anderson recalled how the captain of another vessel took extraordinary steps "to prevent the possibilty of his men attacking" a cask of brandy he was transporting:

he had it wrapped in a sail cloth,-upon which he lay down himself on the deck. In this situation, he fell asleep,- the cunning rogues watching their opportunity, gently bored a hole thro the sail, $\&$ wood, $\&$ drew off about 
a gallon;-filling the vacant space up with water, \& carefully closing the aperture. $^{54}$

Similarly, "butter, — salt fish, —all estate stores," Anderson averred, are "easily attainable" by apprentices at the docks.

The former the depredators suck off, (after starting a hoop of the keg containing it,) by introducing a quill \& then letting it run; - and into the fish barrel they pour salt water, which swells up the fish, exposed to the heat of a strong sun; still further, to destroy all traces of their guilt, they contrive when landing their cargo, to ship a sea. Thereupon they repair to the manager-inform him, that the hoghshead has been accidentally wet, $-\&$ recommend an immediate distribution of its contents among the labourers to prevent total loss if kept in hand.

Anderson complained that this "stratagem too frequently succeeds." ${ }^{55}$

As with depredations against commerce, theft occurring within their households particularly annoyed white town-dwellers, who accused the apprentices they employed as domestics of a propensity for this crime. "These retainers," Anderson asserted, "must be watched, to a degree that is painful ... and more especially he who has the distribution of your horse's provinder otherwise he will purloin the same." ${ }^{56}$ Not only did these "misnamed grooms ... steal, \& sell the food meant for your horses," but also, Anderson indignantly reported that, without permission, they "ride these at night." 57

But despite indicting apprentices for their "proneness to picking and stealing, [Anderson] never heard of a highway robbery. One may traverse the entire length of St. Vincent, in the dead of night, without fear of personal violence." Moreover, since "burglary [was] equally uncommon," white homeowners needed to take few precautions for securing their dwellings. ${ }^{58}$

On the other hand, apprentices who threatened public order did worry the white community, and were policed with increasing rigour. As noted above, legislation enacted in 1836 augmenting the police force and requiring taverns to be licensed, sought to check what whites considered the most egregious problems-frequent brawls in the streets of Kingstown, drunkenness in numerous taverns and illicit shebeens, debauchery in the capital's "abodes of vice," fettes and parties where stolen goods were worn and consumed-all of which involved the apprentices of the town, as well as free coloureds. ${ }^{59}$

Severe criminal penalties and grim penal conditions complemented the legislative activity. As Chief Police Magistrate, Anderson, eagerly imposed harsh 
punishments on transgressors. In one instance, he was called to adjudicate on a complaint "by an apprentice against a fellow Labr.; - that the other had insulted him by cutting in before him at a quadrille party, when he was pirouetting; he, the accused being at the time, clad in a fine linen shirt over his trowsers, (by way of shewing it off) with a sword bound round his waist. "When Anderson discovered that the sword had been "abstracted from a Police Constable," he shifted his attention away from the original grievance, focusing instead on the complainant: "the rigid statute of the colony, forbidding any app[renti]ce to have arms in his possession under severe penalties left me no alternative, - but to order the tonsure to his wooly head, \& a Dance to other movements at the Tread[mill] in the Cage. ${ }^{160}$ Here, Anderson appears to have exploited an innocuous incident-the apprentice, after all, had brought the original suit, and he was wearing the sword as a fashion accessory, not to foment armed insurrection--to impress the non-white community with the power and resolve of whites, by imposing a penalty disproportionate to the crime. A clear expression of this motive was his vindictive order to have the apprentice's hair cut off, a punishment that was designed to embarrass and degrade. Elsewhere he heartily approved of the House of Correction regulation requiring inmates to have their heads shaved: "this was found a most efficacious punish [men]t the terrors of which were dreaded by both blacks \& coloured ... more than any other." 61

Convicts incarcerated in St. Vincent's jails endured brutal conditions-meagre rations, unsanitary and uncomfortable accommodations, and a strict regimen. The construction of the treadmill meant that prisoners "no longer worked in chains in Kingstown," while Anderson indicated that whites opposed the "penal gangs who labour on the public highways," preferring that convicts be "confined to hard labour within the prison walls." ${ }^{\text {62 }}$ Since metropolitan authorities also considered the employment of convicts "out of prison on public works, repairing roads, cleaning the streets, \&c., in gangs, and wearing shackles ... [or] let out for hire, to dig cane holes ... highly objectionable," those not sentenced to the treadmill toiled within the prison "breaking stones for the repair of roads." ${ }^{63}$

But Anderson's frustrations indicate that many apprentices avoided punishment through their facility in manipulating the legal system. He conceded that apprentices "excel in 'spinning a yarn," complaining that "any one who has served as a Magistrate must know this to the cost of his time, \& patience; - to 
say nothing of the utter disregard of all truth, which he must be compelled to hear sworn to." According to Anderson, apprentices "appear to consider it meritorious to bamboozle, instead of enlightening their Judge, \& he will require a sharp eye $\&$ ear to detect their byeplay, and fallacies. Every look, \& word of his are watched before the cautious negro gives response." ${ }^{64}$ This led Anderson to acknowledge ruefully that "a negro wd. make a capital special pleader." ${ }^{65} \mathrm{He}$ did, however, recognize "the general respectful demeanour,-and propriety of conduct, and attire, - evinced by the labouring population at the Courts held for enquiring into their grievances, - particularly in town;" and this attitude no doubt also pertained to criminal proceedings. ${ }^{66}$

Hay McDowell Grant erred when he told a House of Commons committee in 1842 , "I do not think the actual amount of crime has increased" in St. Vincent. ${ }^{67}$ During the Apprenticeship, a proliferation of legislation had combined with increased law enforcement, policing and prosecution, to swell the island's crime statistics and prison inmate population. ${ }^{68}$ Apprentices, both urban and rural, along with the free non-white community, were the principal targets as tougher criminal codes were being more stringently applied. The rationale, of course, was the desire of the authorities and, by extension, the white elite, to continue controlling these "lower orders" after the abolition of slavery. In the urban context, this control sought to cement white hegemony by eliminating the possibility of rebellion, protecting private property, instilling white values of morality and behaviour, maintaining the public peace, and inculcating the non-white community with sober and industrious work habits. During the Apprenticeship, much of the legislative activity addressed these issues.

Throughout the slavery era, the omnipresent fear of slave rebellion resulted in laws prohibiting slaves from carrying arms, and emancipation did not eliminate white trepidations about revolt, as Anderson indicates by his mention of the statute "forbidding any app [rentice] to have arms in his possession under severe penalties." ${ }^{69}$ Meanwhile, whites expressed concern that emancipation, and then full freedom, threatened their wealth and property (they, of course, owned most of both on the island), and they sought protection. A Barbadian newspaper reported from St. Vincent on Saturday, 31 March 1838, that:

a petition was presented to the Legislature from the inhabitants of Kingstown for a more effective Police, the present being reduced to a serjeant 
and three men, for both day and night duty. The petitioners mention that stores of merchants had been broken open, and plundered to a great extent - and they expect, very naturally, that such disorders will increase, when the non-praedials become free. ${ }^{70}$

Legislation proscribing drunkenness, debauchery, gambling, and the like, not only propagated the moral codes whites thought desirable for the non-white community (though not necessarily for themselves!), but also would check breaches of the peace and petty crimes associated with such licentious activities. Moreover, intemperance, whites felt, resulted in "neglect of duty, indolence, \& improper work," both by urban workers, and by estate labourers who indulged when visiting town. ${ }^{71}$

Exploiting their power to legislate, whites tried to pre-empt challenges to their dominance in island affairs, and create among non-whites, a tractable, disciplined labour force, and a docile, subservient community. The history of St. Vincent during the Apprenticeship, and after full freedom, testifies to the inadequacy of this strategy for social control.

\section{Postscript}

In June 1841, the Barbados Mercury and Bridgetown Gazette reprinted a report from the St. Vincent Gazette on the "disgraceful and most unprovoked riot" that had occurred in Kingstown on the evening of Monday, 24 May 1841. Three privates from the militia, who some hours previously had been cautioned by police constables for having "discharged their fire-arms in the market place" were charged with "riotous conduct at the lower part of the town." When they were "apprehended by the police and committed to the station-house," however, "a large concourse of persons assembled, and an attempt to release the prisoners was made." Even the subsequent release of the three men on bail, did not satisfy

the mob, [and] their riotous conduct continued, and was increased ... in consequence of a woman having been knocked down senseless by one of the police, which led to a report that she was killed. The mob first destroyed the stocks-pushed the police boat into the sea-forced an entrance into the station-house-expelled the police officers-destroyed the barrier to the place of confinement - threw the arms and part of the hose of the fire engine into the sea-and were proceeding with the demolition of the building - when the interference of the Attorney General, and also of a Magistrate, an application for military assistance, and their subsequent 
appearance, put an end to these most outrageous proceedings, which continued for three hours!!! The Serjeant and several policemen were severely beaten, and were driven to take refuge in the Gaol.

The report credited Colonel Winchester and a company of the 92nd Regiment with ensuring "the safety of the town from further violence . . . and restor[ing] tranquillity" there, but indicted "the inefficiency of the police force-the apathy and culpable supineness of the respectable portion of the inhabitants (householders and others who have large property at stake) - [and] the reckless and outrageous conduct of the lower orders." In conclusion, the newspaper provided details of the investigation into the incident, and the ensuing court proceedings. ${ }^{72}$

Echoes of the March 1838 riot in Kingstown can be clearly discerned in this incident, indicating the deficiencies of the strategies implemented in anticipation of full freedom, to control St. Vincent's non-white urban population, and to secure the position of the island's white community. ${ }^{73}$ Emancipation had not eradicated, but rather had transformed the social tensions and conflicts created by slavery. ${ }^{74}$ The Apprenticeship provided the initial forum for their expression, and was the harbinger of a struggle that would continue in freedom.

\section{NOTES}

1. The research and writing of this article were supported by grants from the Harry Frank Guggenheim Foundation (1992-93 Research Fellowship) and Rider University (1994 Summer Research Fellowship). I am also grateful to the Philadelphia Center for Early American Studies at the University of Pennsylvania, Richard Dunn, Director, Wayne Bodle and Donna Rilling, Acting Directors, for the research facilities I enjoyed as a Visiting Fellow.

2. British Sessional Papers: House of Commons, 1842 (Vol. 13), p. 29.

3. Robert Montgomery Martin, History of the Colonies of the British Empire (London: William Allen and George Routledge, 1843), pp. 54, 59.

With the advent of the Apprenticeship, 15,309 slaves were classified as praedials, 2,793 as non-praedials, with another 1,189 described as "aged, diseased or otherwise non-effective." Under the terms of the emancipation act, 2,959 children under six years of age became free on 1 August 1834 (British Sessional Papers: House of Commons, 1835 \{Vol. 50\}, p. 685). 
4. Charles Shephard, An Historical Account of the Island of St. Vincent (London: Ridgway and Sons, 1831), pp. 199-200.

The 1813 Act, Shephard noted, "gave slaves the advantage of a trial by jury, the same as free persons in all capital offences, with the additional benefit of being defended by Counsel" (pp. 199-200).

5. Martin, History of the Colonies, p. 54, used the figure given in Shephard, Historical Account of St. Vincent, Appendix IV, p. iv, in estimating that there were 1,301 whites in St. Vincent in 1825; Hymie Rubenstein, Coping With Poverty: Adaptive Strategies in a Caribbean Village (Boulder, Colorado: Westview, 1987), p. 39, gives a figure of 1,300 whites on the island in 1834; and John Davy, The West Indies, before and since Emancipation (London: W. and F. G. Cash, 1854), p. 176, said that in 1844 the white population of St. Vincent stood at 1,268.

Calling "the returns of the general population ... very defective" (p. 14), Shephard put the free colored population of the island at 2,824 in 1825 (Appendix IV, p.iv). Martin (p. 54) cited this figure, as did B. W. Higman, Slave Populations of the British Caribbean, 1807-1834 (Baltimore: Johns Hopkins University Press, 1984), p. 433, while Rubenstein estimated that there were 3,000 free coloureds in St. Vincent and the Grenadines in 1834 . Neither of these population figures distinguishes between free coloured and free black.

Thus St. Vincent's population at the time of emancipation numbered approximately 26,550 - 22,250 slaves, 1,300 whites and 3,000 free coloureds.

6. British Sessional Papers: House of Commons, 1839 (Vol. 37), p. 703.

7. Martin, History of the Colonies, pp. 54-55.

8. Shephard, Historical Account of St. Vincent, p. 199.

9. British Sessional Papers: House of Commons, 1842 (Vol. 13), p. 29.

10. Of the 22,250 slaves in St. Vincent in 1834 , only $2,793(12.5 \%)$ were not engaged in the cultivation and processing of sugar, or in other agrarian activities, if capable of work. These non-praedials, however, did not all live in town. Indeed, many of them would have been employed as domestics in the great houses of the sugar estates, and as servants in other rural residences occupied by whites. A much smaller number-perhaps no more than 1,000 or 1,500 -would have been townbased. These would have included most of the 382 slaves "employed on wharfs, shipping or other vocations," and the 212 non-praedial tradesmen, as well as those of the island's 2,199 domestic slaves who were attached to the households of the urban white population, and some proportion of the nearly 2,000 slaves classified as "aged, diseased or otherwise non-effective." (British Sessional Papers: House of Commons, 1835 \{Vol. 50\}, p. 685.)

11. "An Act for the Abolition of Slavery in the Island of St. Vincent and its Dependencies, in consideration of Compensation, and for promoting the Industry and good conduct of the Manumitted Slaves" (Clause 30), British Sessional Papers: House of Commons, 1835 (Vol. 50), pp. 378-87.

Under the terms of the Act, only slave children under six years of age were immediately granted their freedom; all others had to continue working for their former owners through a period of Apprenticeship that lasted until 1 August 1838. 
12. St. Vincent Abolition Act, Clause 29.

13. "An Act for establishing a Police for the Regulation of Apprenticed Labourers, and for carrying into effect certain provisions of an Act, intituled, 'An Act for the Abolition of Slavery in the Island of St. Vincent and its Dependencies, in consideration of Compensation, and for promoting the Industry and good conduct of the Manumitted Slaves," passed on 23 June 1834, a month and a half after the passage of the Abolition Act.

14. Ibid.

15. British Sessional Papers: House of Commons, 1842 (Vol. 13), p. 29. In 1833, and again in 1838, for example, the St. Vincent legislature passed Acts for the "Punishment of Idle and Disorderly Persons, Rogues and Vagabonds." British Sessional Papers: House of Commons, 1839 (Vol. 36), p. 450.

16. Martin, History of the Colonies, p. 55.

17. The "aspirations" of the authorities, of course, would not necessarily have been undifferentiated since they could incorporate the not always identical interests of metropolitan authorities, island authorities, and various social groups and classes, as well as the actual or potential victims, and even the perpetrators of crimes. In the context of the Apprenticeship in St. Vincent, however, legal codes pertaining to the apprentices responded primarily to the interests of the former slaveownersthe white planter and merchant elite.

18. Many of these work-related offenses, of course, were breaches of the labour obligations mandated by the Apprenticeship, rather than criminal acts, but the line between the two was blurred, and some Special Magistrates apparently had difficulty making distinctions. A letter from the Colonial Office to Sir Evan Murray MacGregor, Governor of Barbados and the Windward Islands, observed that one St. Vincent Magistrate, John Anderson, had been "in the habit of exercising summary jurisdiction, as Special Magistrate, in cases ... cognizable only by the ordinary Criminal tribunals." (Letter from J. M. Spedding, Colonial Office, to MacGregor, Government House, Barbados, 31 May 1838, C.O. 260/56, St. Vincent, Correspondence, Original-Secretary of State, Despatches, Colonial Office Series, Public Record Office, London.)

19. The monthly reports submitted by St. Vincent's Special Magistrates are contained in C.O. 260/54-57, St. Vincent, Correspondence, Original-Secretary of State, Despatches.

20. Anderson's reports made frequent and stark distinctions between crimes committed in the urban and rural sections of his district.

21. The Journal of John Anderson, St. Vincent Special Magistrate, 1836-1839, pp. 122-23. The 55,000 word manuscript of Anderson's journal is located in the Department of Archives and Special Collections of the University of Aberdeen, Aberdeen, Scotland. Citations are to the 190-page typescript of my transcription of the journal. Anderson had jurisdiction over the 3,195 ex-slaves ("1587 apprentice males \& 1608 apprentice females ... exclusive of children") in St. Vincent's Third 
District, which encompassed the towns of Kingstown and Edinboro, as well as thirteen estates (pp. 92-93). Anderson's journal too is replete with references to the urban/rural disparity vis-d-vis crime.

22. Woodville K. Marshall, ed., The Colthurst Journal: Journal of a Special Magistrate in the Islands of Barbados and St. Vincent, July 1835-September 1838 (Millwood, New York: KTO Press, 1977), p. 206.

23. Shephard, Historical Account of St. Vincent, pp. 203-04.

Shephard recorded that in 1829 , the Chief Constable received an annual salary of $£ 300$ currency, while the Wardens, or Constables, were each paid $£ 100$ currency (Appendix XIV, p. xxxvi).

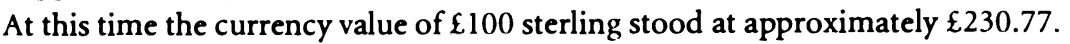

24. Anderson, Journal, p. 28.

25. Anderson, Journal p. 28.

26. Anderson, Journal, pp. 28, 122-23.

27. British Sessional Papers: House of Commons, 1839 (Vol. 37), pp. 701-11.

Two other houses of correction, one on the west coast at Colonarie, and the other in the east at Barrouallie, had been built at the commencement of the Apprenticeship, and also housed only apprentices. They both had a treadmill.

28. Anderson, Journal, p. 20.

29. Sutherland conducted his inspection at the end of the Apprenticeship, and his "Report on Prisons" was included in the "Papers on the Condition of the Labouring Population of St. Vincent," British Sessional Papers: House of Commons, 1839 (Vol. 37), pp. 703-11.

30. Sutherland, Report on Prisons, pp. 703-09.

One shilling and three pence supplied each prisoner with the daily ration of 1.5 pounds of bread or yams, or a quart of farina, and .5 pounds of fish.

31. Sutherland, Report on Prisons, pp. 703-11.

The two sergeants, whose police salary was $£ 200$ currency per annum, were, however, entitled to two shillings and sixpence for every prisoner released or

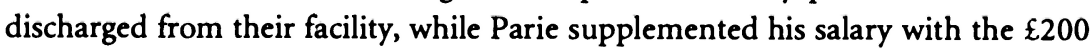
currency he was paid annually as town overseer and superintendent of water-tanks, pipes and streets.

At all three facilities, one shilling currency paid for the meal or yams and fish supplied each inmate daily. The meagre Kingstown rations comprised 1.5 pints of corn, meal or farina per day, or the equivalent in yams, as well as a herring, half a shad, or 2.5 pounds of salt fish a week.

32. Sutherland, Report on Prisons, pp. 705-10.

33. Anderson Report, 30 June 1837, C.O. 260/55.

34. Shephard, Historical Account of St. Vincent, p. 204.

35. Anderson, Journal, pp. 123-24.

36. Anderson, Journal, pp. 42, 110.

37. Anderson, Journal pp. 40, 69-70. 
38. Anderson, Journal, pp. 123, 165.

39. Anderson, Journal, p. 111.

40. Anderson, Journal, p. 125.

41. Anderson Report, 30 June 1837, C.O. 260/55.

42. Anderson, Journal, pp. 165-67.

43. Anderson, Journal, p. 167; Marshall, The Colthurst Journal, p. 206.

44. Anderson, Journal, p. 168.

45. Anderson, Journal, pp. 168-69.

If, as Anderson estimated, "upwards of 1000 persons" participated, the demonstration involved about one-third of all free coloureds on the island.

46. Anderson, Journal, p. 170.

47. Note that it was not the trial, the verdict, nor the fine, but the treadmill-an apprentice's punishment-to which the free coloured population objected.

48. Anderson, Journal, p. 168.

49. Anderson Report, 10 February 1836, British Sessional Papers: House of Commons, 1836 (Vol. 49), p. 430.

50. Anderson Reports, 1 March, 4 April and 3 May 1836, British Sessional Papers: House of Commons, 1836 (Vol. 49), pp. 431, 433, 434.

51. Anderson, Journal, p. 38.

52. Anderson, Journal, p. 40.

53. Anderson, Journal, pp. 40, 69.

54. Anderson, Journal, p. 50.

55. Anderson, Journal, p. 51.

56. Anderson, Journal, p. 45.

57. Anderson, Journal, p. 72. Whites residing in the countryside, of course, voiced similar complaints about the apprentices working for them as domestics, grooms and other household servants.

58. Anderson, Journal, p. 113.

59. Anderson, Journal, p. 111.

60. Anderson, Journal, p. 69.

61. Anderson, Journal, p. 96.

62. Anderson, Journal, p. 115. The descriptions and regulations for Kingstown Jail, Kingstown House of Correction and Treadmill, and St. Vincent's other prisons, attest to the grim conditions experienced by inmates. (See British Sessional Papers: House of Commons, 1839 \{Vol. 37\}, pp. 701-09.)

63. "Remarks on the Colonial Prisons," British Sessional Papers: House of Commons, 1837 (Vol. 53), p. 21; British Sessional Papers: House of Commons, 1839 (Vol. 37), pp. 707-09.

64. Anderson, Journal, p. 81.

65. Anderson, Journal, p. 113.

66. Anderson, Journal, p. 29.

67. British Sessional Papers: House of Commons, 1842 (Vol. 13), p. 29. 
68. As mentioned above, Robert Montgomery Martin noted a fourfold increase in the island's prison population during the Apprenticeship (History of the Colonies, p. 55).

69. Anderson, Journal, p. 69.

70. The Barbadian, 31 March 1838, p. 2.

71. Anderson Report, 30 June 1837, C.O. 260/55.

72. Barbados Mercury and Bridgetown Gazette, 15 June 1841, p. 2.

73. Complementary strategies to control St. Vincent's rural ex-slave population and provide the large, white-owned, sugar estates with a stable and obedient agrarian labour force made up of ex-slaves (a subject that I intend to examine elsewhere) also foundered, as evidenced by the series of rural labour disputes $(1838,1839$, 1847-48 and 1854) that culminated with the "Vox Populi" riots of 1862. (See Woodville K. Marshall, "'Vox Populi': The St. Vincent Riots and Disturbances of 1862," in Trade, Government and Society in Caribbean History, 1700-1920: Essays Presented to Douglas Hall, ed. B. W. Higman (Kingston: Heinemann, 1983), pp. 84-115.

74. Throughout the British West Indies, redefinition of criminality accompanied the abolition of slavery, and framed the protracted struggles between these societies' various constituencies that would persist into the twentieth century. In Crime in Trinidad: Conflict and Control in a Plantation Society, 1838-1900 (Knoxville: University of Tennessee Press, 1986), David Trotman documents such developments. His evidence complements the findings for St. Vincent, while suggesting that particular strategies to reconstitute a sugar plantation economy (by, for example, importing indentured labour or limiting access to land) caused variations in the definition and commission of crime. 


\section{7 \\ "Repression is not a Policy": \\ Sydney Olivier on the West Indies and Africa ${ }^{l}$}

RICHARD A. LOBDELL

The aftermath of emancipation in the West Indies has been the subject of much scholarly research. Quite properly, this research has been concerned with the variety and commonality of experience within the West Indies during the century following emancipation. Although we are far from a complete, or perhaps even a satisfactory, understanding of the post-emancipation period, a great deal has been learnt about significant developments during that period: the circumstances and processes by which a peasantry did or did not emerge; the growth and significance of villages and small towns; the economic and social ramifications of production for inherently unstable export markets; the complex relationships between immigration, emigration, and local labour markets; the episodic expression of popular unrest and protest; the evolution of political constitutions and the formulation of economic and social policy.

This paper looks at the aftermath of emancipation from a different perspective. The premise is that West Indian experience following emancipation served, after the turn of the twentieth century, to inform a powerful critique of British policy in the "new" colonies of Southern and East Africa. A major proponent of that critique was Sydney Olivier, who believed that developments in the West Indies following emancipation had been, on the whole, both economically productive and socially beneficial. In a series of books, essays, and speeches, Olivier severely criticized British policy in Africa, and argued that experience gained in the West Indies was a reliable guide to the formulation of public policy 
in Africa. The purpose of this paper is to examine, in an exploratory and summary fashion, Olivier's interpretations of post-emancipation West Indian history and their implications for British policy in Africa. ${ }^{2}$

\section{Olivier's official career ${ }^{3}$}

Sydney Haldane Olivier was born into the relative prosperity of a country clergyman's family in 1859. He was schooled at Tonbridge and then at Corpus Christi College, Oxford, where he developed a strong affinity for the positivism of Auguste Comte. Having been reared in a family which "never regarded buying cheap and selling dear as a beneficial activity," ${ }^{4}$ Olivier faced the task of finding suitable employment after completing his degree in 1881 , and so decided, largely by chance he later claimed, to write the Civil Service competitive examination in 1882. He was ranked first among the successful candidates and joined the Colonial Office where one of his colleagues was the young Sidney Webb, who had ranked second in the previous year's examinations.

By the normal criteria of his time, Olivier had a distinguished career within the Colonial Office, where his work both impressed and provoked his superiors. From 1882 to 1890 , he was attached to the West India department as a second-class clerk. In late 1890 , he was sent to British Honduras to serve as acting colonial secretary, an unusual appointment for a relatively junior member of the Office. During 1891-95, Olivier laboured in the South Africa department, and thus had opportunity to observe the growing conflict between British ambition and Boer resistance. For several months in 1895, Olivier was again in the Caribbean, this time serving as acting auditor-general of the Leeward Islands. Thereafter, he served as secretary to the West India Royal Commission of 1896-97, and was largely responsible for writing the Commission's impressive Report. ${ }^{5}$ A year later, Olivier was sent to Washington to assist with negotiations concerning American tariffs on West Indian exports. In late 1899, Olivier was appointed colonial secretary in Jamaica, in which post he served until 1904. During 1904-07, he was principal clerk at the Colonial Office for the West Indies and West Africa. Following a contretemps between Governor Swettenham and the U.S. Navy in the aftermath of the Jamaica earthquake of 1907, Olivier was appointed Governor of Jamaica in which post he served until his resignation in 1913. 
Olivier's official career was not limited to colonial affairs. During 1913-17, he was permanent secretary to the Board of Agriculture and Fisheries in London, after which he served in the Exchequer as assistant-comptroller and auditor-general until his retirement in 1920. In 1924, Olivier became the first baron created by the Labour Party government of Ramsay MacDonald in whose cabinet he served as Secretary of State for India. When Labour formed its second government in 1929, Olivier was appointed chairman of the West India Sugar Commission - and quarrelled unceasingly with the Secretary of State for the Colonies, his old friend Sidney Webb, by now Lord Passfield. And for nearly twenty years before his death in 1943, Olivier was one of the very few members of the House of Lords actively interested in imperial affairs.

It was an impressive career, but others in the public service might have claimed as much. What distinguished Olivier from his official colleagues was his early conversion to socialism, and his outspoken criticism of government policy both in Britain and in the Empire. In 1885, he joined the recently founded Fabian Society, which for many years thereafter was dominated by Sidney Webb, Bernard Shaw, Graham Wallas, and Olivier. It was an exciting intellectual adventure, and the Fabians threw themselves into furious public debate with nascent Marxists, social democrats, anarchists, and reformers of varied hue. In 1889, the Society published Fabian Essays in Socialism, to which Olivier contributed a chapter entitled, "The Moral Basis of Socialism." It was an immediate and surprising success; thus encouraged, the Society published a wide variety of tracts, essays, and pamphlets. Olivier worked on many of these, and was the principal author of Capital and Land, ${ }^{6}$ which boldly advocated the nationalization of both land and capital in Britain. Throughout the 1880s and 1890 s, Olivier regularly contributed articles on socialism and anarchism to the most prominent radical journals. He attended, spoke at, and wrote about, various international socialist congresses. In London and its environs, he was a regular public lecturer for the Society on various aspects of socialism. In Jamaica during 1901, whilst colonial secretary, Olivier gave a series of public lectures on socialism, for which he was severely reprimanded by Joseph Chamberlain. ${ }^{7}$ That there might have been something peculiar, something even personally dangerous, in being simultaneously an outspoken socialist and a high ranking civil servant seems never to have occurred to Olivier.

Although in private correspondence and at Fabian Society meetings Olivier strongly opposed what he considered the excesses of the "new" imperialism, he 
published nothing on colonial policy before 1906. In that year the Independent Labour Party published his White Capital and Coloured Labour. ${ }^{8}$ In addition to the presentation of his (for the times) advanced views on race, and his disdain for "commercial imperialism," the book sets forth Olivier's argument, based on his understanding of West Indian affairs, that British and colonial government policy in Southern and East Africa was mistaken. In succeeding years, Olivier regularly returned to his basic thesis: if disaster were to be avoided in Africa, policy would have to be modelled on West Indian experience.

\section{Olivier on the West Indies}

With characteristic self-assurance, Olivier wrote to his old friend H.G. Wells in August 1942: "Since the Emancipation I know more than anyone else about the

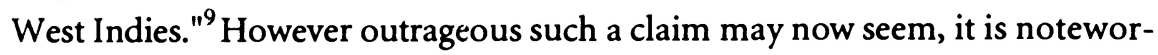
thy that Eric Williams considered Olivier the best informed and most sympathetic of British writers on the West Indies. ${ }^{10}$ More recently, Gordon K. Lewis

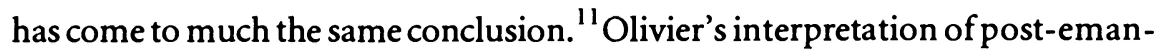
cipation West Indian history is most conveniently summarized in his 1936 book, Jamaica: The Blessed Island, although it was an interpretation which evolved over the much longer period, 1890-1943. ${ }^{12}$

Economic issues absorbed the greatest share of Olivier's attention. In view of the long-term deterioration of the sugar industry, the central economic problem during the post emancipation period was, for Olivier, the changing patterns of land ownership and use. In those colonies or districts where a monopolization of land had been, or could be, effectively maintained by the estates, Olivier saw little prospect for sustained economic progress. On the other hand, if land had been, or could be, acquired by small cultivators through purchase or secure rental agreements, then the possibility emerged of a diversified economy based on small settler ("peasant") cultivation. For Olivier, this latter development was vital. Through the production of new export crops and the cultivation of food for domestic consumption, peasants would and did significantly contribute to government revenues, and generally increase the overall standard of living. Moreover, in Olivier's view, the peasantry was a useful offset to the debilitating features of the plantation system: freed from the tyranny of dependence on wage labour, peasants had become economically innovative, and made valuable contributions to social and political stability. 
Olivier also argued that a vibrant peasantry actually strengthened the estate sector through the provision of occasional wage labour on a more willing, and hence more productive, basis. In short, Olivier was convinced that public policy ought to nurture the peasantry where it had emerged; where it had not, colonial policy ought to seek its establishment.

These considerations led Olivier to emphasize the active participation of the state in economic affairs. He praised the initiatives of Blake and Norman who, as governors of Jamaica, had undertaken significant public expenditures to improve transport, education, and agriculture. During his years as an official in Jamaica, Olivier provided government support for the shipping and marketing of peasant-grown bananas, for cooperative ventures to establish modern sugar factories, and for the establishment of certain manufacturing enterprises in Kingston. Today, these might be thought weak and ineffectual initiatives; by the standards of his time, Olivier's advocacy of state intervention must have seemed to others eccentric, if not positively dangerous, characteristics in a colonial administrator. Despite considerable criticism, Olivier believed that economic progress in the past, and certainly in the future, depended upon state policies designed to diversify the West Indian economies.

Social developments during the post-emancipation period were also of great importance to Olivier. Indicative of the growth of personal aspirations which characterized the period, was the high value attached to formal education by ordinary West Indians who pressured colonial governments to expand the number of school places. In Olivier's view, these aspirations owed much to the work of evangelical churches which, unlike the established Anglican church, provided practical assistance to emancipated slaves, and thereby thwarted the efforts of planters to maintain their accustomed positions of economic supremacy and social privilege. As a result, West Indian social relations had progressively come to be based on class rather than racial differences. In Olivier's opinion, such antagonisms and social conflicts as existed towards the end of the nineteenth century arose from contending class interests which, although inevitable within a system of capitalism, might in principle be moderated if the economic system could be diversified and reformed. Olivier recognized that social development in the West Indies had been far from ideal during the post-emancipation period. But, compared with social relationships in other racially-mixed communities such as those in the United States, the West Indies seemed to him a model of good feeling and common sense. Contributing to 
this social development, in Olivier's judgement, had been the relative absence in the West Indies of crude racial theories of white supremacy. Thus, a distinction between race and class was central to Olivier's interpretation of post-emancipation social development.

With respect to political developments, Olivier believed that constitutional advancement had been correctly subordinated to the higher requirements of social justice and economic progress. He accepted-indeed, he was one of the principal architects of-the late-nineteenth-century Colonial Office doctrine that the most effective guarantor of the rights and interests of "native peoples" was some form of crown colony government, which ensured that public policy was within the control of the governor and Whitehall. In this view, past forms of representative government in the West Indies had consistently elevated planter and mercantile interests over those of small farmers and labourers. The most glaring example of the resulting social injustice was the legislation with respect to land ownership and conditions of labour enacted by various assemblies immediately following emancipation. Furthermore, crown colony government permitted the governor to institute fiscal and structural reforms which otherwise would have been blocked by local special interests. In short, social justice and economic progress could not be entrusted to "representative" governments which would inevitably be dominated by the narrow interests of a few. Such constitutional advances as had occurred in the 1880 s and 1890 s were permissible, in Olivier's opinion, because the ultimate authority of the governor had not been weakened, and because the electoral franchise had been widened without becoming irresponsibly broad. Olivier's was the typical Fabian distrust of narrowly representative governments, which he believed everywhere and always were susceptible to dominant class interests and opportunism.

By way of summary, Olivier believed that post-emancipation developments in Jamaica, and throughout the West Indies generally, had been largely beneficial and progressive. The Jamaican economy had been diversified after 1880 largely through the rise of an independent peasantry. Social relationships had become increasingly based on class rather than racial differences, though this process was far from complete. The colonial government had come to play a significant role as guarantor of social justice and the initiator of economic progress. For Olivier, these were significant lessons learnt during the aftermath of emancipation, lessons which might with profit be applied to imperial policy elsewhere. 


\section{Olivier on Africa ${ }^{13}$}

At the turn of the twentieth century, Britain claimed imperial authority over large tracts of Africa, notwithstanding the prolonged war against the Boers in South Africa. After World War I, African territories formerly claimed by Germany came under British authority as mandated territories of the League of Nations. The "new" imperialism, dating from the early 1880 s, had not only doubled the size of the empire; it signalled, at least in the eyes of some, a novel and dangerous mode of colonial administration and imperial control. Thus, during the first quarter and more of the twentieth century, debate over British policy in Africa was heated and often bitter.

Among critics of imperial policy in Africa, Olivier was not especially wellqualified. He had neither worked in nor visited Africa. His information was based on administrative work in the Colonial Office before 1907, and on the testimony of more informed critics such as Leonard Woolf, Norman Leys, and fellow members of the Anti-Slavery and Aborigines Protection Society. And yet, Olivier brought to the debate a new perspective. While others offered criticism on the basis of economic or moral considerations, Olivier pragmatically claimed that British policy in Africa was ineffectual and counterproductive. The basis for this claim was his unique understanding of those policies which had, and those which had not, worked well in the West Indies following emancipation.

In view of Olivier's claims for the positive role of the peasantry in Jamaica, it is not surprising that he was highly critical of land policy in Southern and East Africa. The establishment of large farms by European settlers had presumed that Africans would supply labour at wages to be determined by white employers. Not surprisingly, this proved not always to be the case. Accordingly, at the insistence of European farmers, colonial regimes pursued two general policies: a series of taxes was devised to force Africans to undertake at least some wage labour, and African ownership of land was greatly restricted. To clothe these policies in some form of respectability, colonial governments and settler apologists argued that wage employment, however it might come about, was essential for the "civilization" of Africans.

To Olivier these policies were but a repetition of the immediate post-emancipation attempts by West Indian planters to control labour by force of law. Not only had great social evil resulted, but these attempts on the whole had been counterproductive in terms of output and profit. Olivier expected that the 
application of such policies in Africa would be even less successful because private property in land, which had long been established in the West Indies, was not a socially accepted concept in much of Southern and East Africa. The result, Olivier believed, would be at best unproductive; more likely, Africans would openly oppose such policies and the result would be violent confrontation. As to the claim that forced labour would somehow "civilize" Africans, Olivier dismissed it as self-serving cant. In Olivier's view, the objective of these policies in Africa, as it had been in the West Indies, was to concentrate land ownership in the hands of a European elite; a more productive and desirable policy in Africa, as in the West Indies, was the creation of an independent peasantry by the colonial government.

A second and closely related issue of concern to Olivier was the racial basis of economic and social relationships in Southern and East Africa. Africans and Indians were restricted with respect to land ownership and place of residence. Even more disturbing was the Colour Bar legislation in South Africa which forbade the employment of non-whites in a wide variety of occupations; during the 1920s it appeared that similar legislation might be adopted in Rhodesia. Beyond this, administrative and judicial proceedings often were determined by racial considerations, and racial prejudice tended to permeate all aspects of social relationships.

In Olivier's view, these were outrageous perversions of long established imperial ideals. Nowhere in the West Indies-indeed, hardly anywhere in the Empire-had it been thought necessary, let alone desirable, to regulate such matters on the basis of race or colour. That social and economic relationships would be based on class considerations seemed to Olivier a regrettable inevitability of capitalism; that the latter should degenerate into racism was plainly unacceptable. If social relationships in Africa were to become regulated by something like the "Jim Crowism" of the United States South, then violence and rebellion seemed to Olivier the unavoidable outcome. If the British empire in Southern and East Africa were to be redeemed and made progressive, the example of social relationships found in the West Indies would have to be embraced by colonial governments. But in this regard, Olivier believed that political and constitutional developments had been dangerously disappointing, because the political franchise had been largely restricted to Europeans, and consequently colonial assemblies were dominated by these special interests. The result had been racially-biased social and economic legislation which, in 
Olivier's view, threatened social stability and economic progress, and cast in doubt the efficacy of British imperial policy throughout Africa.

Here Olivier faced a dilemma in suggesting reform. On the one hand, the attitudes of European residents clearly disqualified them as trustees or guardians of colonial society. On the other hand, extending the political franchise would in all probability give rise to demagoguery with all its attendant iniquities. Based on his understanding of post-emancipation developments in the West Indies, Olivier urged the establishment of strong crown colony administrations in Africa, freed from the narrow interests of local factions and subject to enlightened imperial supervision from Whitehall. But in Olivier's judgement, the Colonial Office after World War I had itself adopted the basic tenets of what he called "commercial imperialism," the doctrine that British economic interests were paramount in colonial policy. If local control were untrustworthy and if imperial supervision had become suspect, how best could colonial affairs be managed so as to ensure social justice and economic progress? It was a dilemma which Olivier never came fully to resolve.

British policy in Southern and East Africa thus was seen by Olivier as misguided and ineffective. The practices of European residents and the policies of colonial governments with respect to land and labour were calculatedly repressive. Social relationships had degenerated into vulgar racism which must undermine social stability and obstruct economic progress. The abandonment of principled policy by imperial authority and the rise of white-dominated colonial regimes in Southern and East Africa seemed to Olivier a repudiation of all that had been learnt concerning the successful administration of raciallymixed communities. Unless these practices and policies were reformed along lines suggested by West Indian experience, Olivier argued, government action in Africa would of necessity become increasingly repressive and counterproductive. Indeed, the danger was even greater than inefficiency and injustice: the British empire in Africa might simply disintegrate.

\section{Conclusion}

During more than half a century's connection with the West Indies, Sydney Olivier developed a distinctive and comprehensive interpretation of the region's history and contemporary situation. The issues he analyzed and the patterns he described remain at the core of modern discussions of West Indian 
history. That some of his facts and inferences have proved inaccurate or unsatisfactory cannot diminish his achievements as an historian.

Nonetheless, Olivier was primarily concerned with practical problems of colonial administration. Although his contact with African affairs was indirect, he was convinced that the problems of colonial administration in Southern and East Africa might be solved by reference to the lessons he had discerned from the aftermath of emancipation in the West Indies. Policies designed to broaden land ownership and to diversify the economy, efforts to restrain and eliminate racial distinctions and conflicts, firm commitments to the maintenance of strong crown colony government -all these, Olivier believed, had been helpful in the West Indies. But in Africa, such policies had been not only discounted, they had been inverted: land had been monopolized, racial prejudice permeated the social order, and political control had passed from Whitehall to a self-interested European elite. In Olivier's view, the result would be economic inefficiency, social unrest, and the end of Britain's African empire unless imperial policy were reformed along lines indicated by the post-emancipation experience of the West Indies.

Olivier's critique of African policy was largely disregarded by successive British governments. Why his advice was ignored or rejected is a question of some interest, for it would shed additional light on the forces at work in the formulation of imperial policy after the turn of the twentieth century. Also of interest is the question of whether Southern and East Africa would have been better served had Olivier's views been taken seriously and acted upon. Although these and similar issues remain unresolved, Olivier's interpretation of the aftermath of emancipation in the West Indies nonetheless formed an important critique of British imperial policy in Africa during the early twentieth century. 


\section{NOTES}

1. Quotation from Sydney Olivier, The Anatomy of African Misery (London: L. and V. Woolf, 1927), p. 229.

2. There is an enormous scholarly literature on the general topic of European imperialism and anti-imperial thought. Sources which have been especially helpful to this article include: Philip D. Curtin, ed., Imperialism (New York: Harper and Row, 1971); J. A. Hobson, Imperialism: A Study (London: Archibald Constable, 1905); Edward W. Said, Culture and Imperialism (New York: Knopf, 1993); Joseph A. Schumpeter, Imperialism and Social Classes (New York: A. M. Kelley, 1951); Bernard Semmel, Imperialism and Social Reform: English Social-Imperial Thought, 1895-1914 (Cambridge, Mass.: Harvard University Press, 1960).

3. Biographical materials on Olivier are scattered. Among the most helpful and accessible are: Francis Lee, Fabianism and Colonialism: The Life and Political Thought of Lord Sydney Olivier (London: Defiant Books, 1988); Norman and Jeanne MacKenzie, The First Fabians (London: Weidenfeld \& Nicolson, 1977); M. Olivier, ed., Sydney Olivier: Letters and Selected Writings (London: George Allen \& Unwin, 1948); Paul Rich, "Sydney Olivier, Jamaica, and the Debate on British Colonial Policy in the West Indies," in Labour in the Caribbean, ed. Malcolm Cross and Gad Heuman (London: Macmillan Caribbean, 1988), pp. 208-33.

4. M. Olivier, Sydney Olivier, p. 30.

5. Report of the West India Royal Commission (C. 8655) (London: H.M.S.O., 1897).

6. Sydney Olivier, Capital and Land, Fabian Society Tract No. 7 (London: The Fabian Society, 1888).

7. CO 137/626, January 1902, Public Record Office (PRO), London.

8. Sydney Olivier, White Capital and Coloured Labour (London: Independent Labour Party, 1906).

9. M. Olivier, Sydney Olivier, p. 181.

10. Eric Williams, British Historians and the West Indies (London: André Deutsch, 1966), pp. 208-09.

11. Gordon K. Lewis, The Growth of the Modern West Indies (London: MacGibbon and Kee, 1968), p. 109.

12. The discussion in this section draws on the following major works by Olivier: White Capital and Coloured Labour, "Master and Man in the Tropics," in Western Races and the World, ed. F.S. Marvin (London: Oxford University Press, 1922), pp. 229-48; "Constitutional Development in the West Indies," New Statesman 19 (24 June 1922): 316-17; "Mr. Wood on the West Indies," Contemporary Review 122 (August 1922):152-60; "Progress of a Negro Peasantry," Edinburgh Review 249 (January 1929): 105-16; "The Government and Our Sugar Colonies," Nineteenth Century and After 108 (July 1930): 56-61; The Myth of Governor Eyre (London: L. \& V. Woolf, 1933); Jamaica: The Blessed Island (London: Faber \& Faber, 1936); "The Scandal of West Indian Labour Conditions," Contemporary Review 153 
(March 1938): 282-89; "Truth About the West Indies," Nineteenth Century and After 124 (July 1938):1-19; "Freedom Day," Contemporary Review 154 (August 1938): 154-62.

13. This section draws on the following major writings of Olivier on Africa: White Capital and Coloured Labour, "The Government of Colonies and Dependencies," in Papers on Inter-Racial Problems communicated to the First Universal Races Congress held at the University of London, July 26-29, 1911, ed. G. Spiller (London: P.S. King, and Boston: The World's Peace Foundation, 1911), pp. 293-301; The League of Nations and Primitive Peoples (London: Oxford University Press, 1918); "Are We Going to Act Justly in Africa?" Contemporary Review 118 (August 1920):198-206; "Colour Prejudice," Contemporary Review 124 (October 1923):44857; "Native Land Rights in Rhodesia," Contemporary Review 130 (August 1926): 145-51; The Anatomy of African Misery, "Government of Nations in Africa," The Nation 126 (30 May and 6 June 1928): 621-22; Imperial Trusteeship, Fabian Society Tract No. 230 (London: The Fabian Society, 1929); "Settled Policy in East Africa," Contemporary Review 140 (December 1931): 694-701. 


\section{Bibliography}

A full list of Richard B. Sheridan's publications appears in the prefatory matter ( $\mathrm{pp} \mathbf{x}$-xvi)

\section{ARTICLES}

Allen, H. C., "Samuel Flagg Bemis." In Pastmasters: Some Essays on American Historians, edited by Marcus Cunliffe and Robin W. Winks. New York: Harper and Row, 1969.

Andrews. K. R., "The Pattern of British Abolitionism in the Eighteenth and Nineteenth Centuries." In Anti-slavery, Religion and Reform: Essays in Memory of Roger Anstey, edited by Christine Bolt and Seymour Drescher. Folkestone: Dawson, 1980.

Anstey, Roger T., "A Re-interpretation of the Abolition of the British Slave Trade, 1806-1807." English Historical Review 87 (1972).

Ashton, T. S., "Richard Henry Tawney, 1880-1962." Proceedings of the British Academy 48 (1962).

"The Relation of Economic History to Economic Theory." In The Study of Economic History, edited by N. B. Harte. London: Frank Cass, 1971.

Aufhauser, R. Keith, "Profitability of Slavery in the British Caribbean." Journal of Interdisciplinary History 6 (1974).

Barbour, Violet, "Privateers and Pirates of the West Indies." American Historical Review 16 (1911).

Beckles, Hilary McD., "'The Williams Effect': Eric Williams's Capitalism and Slavery and the Growth of West Indian Political Economy." In British Capitalism and Caribbean Slavery: The Legacy of Eric Williams, edited by Barbara L. Solow and Stanley L. Engerman. New York: Cambridge University Press, 1987.

Benn, Denis M., "The Theory of Plantation Economy and Society: A Methodological Critique." Journal of Commonwealth and Comparative Politics 12 (1974).

Best, Lloyd, "Outlines of a Model of Pure Plantation Economy," Social and Economic Studies 17 (1968).

Carrington, Selwyn H. H., "The American Revolution and the British West Indies' Economy." In British Capitalism and Caribbean Slavery: The Legacy of Eric Williams, edited by Barbara L. Solow and Stanley L. Engerman. New York: Cambridge University Press, 1987.

"West India Opposition to British Policy: Barbadian Politics, 1774-82." The Journal of Caribbean History 17 (1982).

, "British West Indian Economic Decline and Abolition, 1775-1807: Revisiting Econocide." Canadian Journal of Latin American and Caribbean Studies 14 (1989). 
, "The American Revolution and the Sugar Colonies, 1775-1783." In The Blackwell Encyclopedia of the American Revolution, edited by Jack P. Greene and Jack R. Pole. London: Basil Blackwell Ltd, 1991.

"The American Revolution, British Policy and the West Indian Economy, 1775-1808." Revista Interamericana 22 (1992).

Clayton, T. R., "Sophistry, Security and Socio-Political Structures In The American Revolution: Or, Why Jamaica Did Not Rebel." Historical Journal 29 (1986).

Coats, A. W., "Changing Attitudes to Labour in the Mid-eighteenth Century." Economic History Review 11 (1958).

Cochran, Thomas C., "Economic History, Old and New." American Historical Review 74 (1969).

Cole, Arthur H., "Economic History in the United States: Formative Years of a Discipline." Journal of Economic History 28 (1968).

Connell, Neville, "Hotel Keepers and Hotels." In Chapters in Barbados History, edited by P. F. Campbell. Bridgetown: Barbados Museum, 1986.

Corfield, P. J., "F. J. Fisher and the Dialectic of Economic History." In F. J. Fisher, London and the English Economy, 1500-1700, edited by P. J. Corfield and N. B. Harte. London: The Hambledon Press, 1990.

Craton, Michael, "Jamaican Slave Mortality: Fresh Light from Worthy Park, Longville and the Tharp Estates." Journal of Caribbean History 3 (1971). "Hobbesian or Panglossian? The Two Extremes of Slave Conditions in the British Caribbean, 1783-1834." William and Mary Quarterly 35 (1978). "Changing Patterns of Slave Families in the British West Indies." Journal of Interdisciplinary History 10 (1979). "We Shall Not be Moved: Pompey's Proto-Peasant Slave Revolt in Exuma Island, Bahamas, 1829-1830." Nieuwe Westindische Gids 57 (1983). "The Planters' World in the British West Indies." In Strangers within the Realm, edited by Bernard Bailyn and Philip D. Morgan. Williamsburg: Institute of Early American History and Culture, 1991.

, "The Transition from Slavery to Free Labour." Slavery \& Abolition 13 (1992). , "Hopetown and Hard Bargain: The Loyalist Transformation in the Bahamas." In Settlements in the Americas: Cross-Cultural Perspectives, edited by Ralph Bennett. Newark: Center for Renaissance and Baroque Studies and University of Delaware Press, 1993.

Craton, Michael, and Gail Saunders, "Seeking a Life of their Own: Aspects of Slave Resistance in the Bahamas." Journal of Caribbean History 24 (1990). "On Slavery's Margins: Farquharson's Estate, San Salvador, Bahamas, 1831-2." Slavery \& Abolition 12 (1991).

Craven, Wesley F., "An Introduction to the History of Bermuda." William and Mary Quarterly 17 (1937).

Dalleo, Peter T., "Africans in the Caribbean: A Preliminary Assessment of Recaptives in the Bahamas, 1811-1860." Journal of the Bahamas Historical Society 6 (1984). 
Darity, William A. Jr., "A General Equilibrium Model of the Eighteenth Century Atlantic Slave Trade: A Least Likely Test for the Caribbean School." Research in Economic History 7 (1982).

,"The Williams Abolition Thesis before Williams." Slavery \& Abolition 9 (1988).

"The Numbers Game and the Profitability of the British Trade in Slaves." Journal of Economic History 45 (1985).

Davis, David Brion, "Slavery and the Post-World War II Historians." In Slavery, Colonialism, and Racism, edited by Sidney W. Mintz. New York: W. W. Norton, 1974.

"The Ideology of Anti-slavery." Times Literary Supplement, 24 October 1975.

de Vries, Jan, "Between Purchasing Power and the World of Goods: Understanding the Household Economy in Early Modern Europe." In Consumption and the World of Goods, edited by J. Brewer and R. Porter. London: Routledge, 1993.

Dixon, P.F., "The Politics of Emancipation: The Movement for the Abolition of Slavery in the British West Indies, 1807-33". DPhil thesis, Oxford University, 1971.

Domar, Evsey D., "The Causes of Slavery or Serfdom: A Hypothesis." Journal of Economic History 30 (1970).

Drescher, Seymour, "Public Opinion and the Destruction of British Colonial Slavery." In Slavery and British Society, 1776-1846, edited by James Walvin. London: Macmillan, 1982.

"The Decline Thesis of British Slavery since Econocide." Slavery $\downarrow$ Abolition 7 (1986).

,"The Historical Context of British Abolition." In Abolition and its Aftermath: The Historical Context, 1790-1916, edited by David Richardson. London: Cass, 1986.

"Paradigms Tossed: Capitalism and the Political Sources of Abolition."

In British Capitalism and Caribbean Slavery: The Legacy of Eric Williams, edited by Barbara L. Solow and Stanley L. Engerman. New York: Cambridge University Press, 1987.

"Whose Abolition? Popular Pressure and the Ending of the British Slave Trade," Past \& Present 143 (1993).

Drescher, Seymour, and John R. Ward, "The Profitability of Sugar Planting in the British West Indies, 1650-1834." Economic History Review, 2nd series, 31 (1978).

Dunn, Richard, "'Dreadful Idlers' in the Cane Fields: The Slave Labor Pattern on a Jamaican Sugar Estate, 1762-1831." Journal of Interdisciplinary History 17 (1987).

"Sugar Production and Slave Women in Jamaica." In Cultivation and Culture: Labor and the Shaping of Slave Life in the Americas, edited by Ira Berlin and Philip D. Morgan. Charlottesville: University Press of Virginia, 1993.

Dupuy, Alex, "Slavery and Underdevelopment in the Caribbean: A Critique of the 'Plantation Economy' Perspective," Dialectical Anthropology 7 (1983).

Eltis, David, "Abolitionist Perceptions of Society after Slavery." In Slavery and British Society, 1776-1846, edited by James Walvin. London: Macmillan, 1982.

"Europeans and the Rise and Fall of African Slavery in the Americas: An

Interpretation." American Historical Review.98 (1993). 
Emmer, Pieter C., "Anti-slavery and the Dutch: Abolition without Reform." In Anti-slavery, Religion and Reform: Essays in Memory of Roger Anstey, edited by Christine Bolt and Seymour Drescher. Folkstone: Dawson, 1980.

Engerman, Stanley L. "Coerced and Free Labor: Property Rights and the Development of the Labor Force." Explorations in Economic History 29 (1992).

Ernst, Joseph A., "The Currency Act Repeal Movement: A Study of Imperial Politics and Revolutionary Crisis." William and Mary Quarterly, 3rd series, 30 (1968).

Fisher, F. J., "The Sixteenth and Seventeenth Centuries: The Dark Ages in English Economic History?" In The Study of Economic History: Collected Inaugural Lectures 1893-1970, edited by N. B. Harte. London: Frank Cass, 1971.

Fladeland, Betty, "'Our Cause being One and the Same': Abolitionists and Chartism." In Slavery and British Society 1776-1846, edited by James Walvin, pp. 69-99. London: Macmillan, 1982.

Fogel, Robert W., and Stanley L. Engerman, "Philanthropy at Bargain Prices: Notes on the Economics of Gradual Emancipation." Journal of Legal Studies 3 (1974).

Franklin, Benjamin, "Observations Concerning the Increase of Mankind." In The Papers of Benjamin Franklin. Vol. 4, July 1, 1750 through June 30, 1753, edited by Leonard W. Labaree. New Haven: Yale University Press, 1961.

Friday, Godwin L., "Fifty Years of Freedom: Runaway Slaves in the Bahamas, 1784-1834." MA paper, University of Waterloo, 1984.

Geggus, David, "The British Government and the Saint Domingue Slave Revolt, 1791-1793." English Historical Review 96 (1981).

Greaves, Richard L., "Shattered Expectations? George Fox, the Quakers and the Restoration State, 1660-1685." Albion 24 (1992).

Green, William A, "Caribbean Historiography, 1600-1900: The Recent Tide." Journal of Interdisciplinary History 7 (1977).

, "Was British Emancipation a Success? The Abolitionist Perspective." In Abolition and its Aftermath: The Historical Context, 1790-1916, edited by Daivd Richardson. London: Cass, 1986.

Greene, Jack P.,"Society and Economy in the British Caribbean during the Seventeenth and Eighteenth Centuries." American Historical Review 79 (1974).

"'A Posture of Hostility': A Reconsideration of Some Aspects of the Origins of the American Revolution." In Preachers 6 Politicians: Two Essays on the Origins of the American Revolution, edited by Jack P. Greene and William G. McLoughlin. Worcester: American Antiquarian Society, 1977.

Hall, Douglas, "Incalculability as a Feature of Sugar Production during the Eighteenth Century," Social and Economic Studies 10 (1961).

Hamilton, Alexander, "Report on Manufactures, December 5, 1791." In The Reports of Alexander Hamilton, edited by Jacob E. Cooke. New York: Harper \& Row, 1964.

Haskell, Thomas L., "Capitalism and the Origins of the Humanitarian Sensibility." American Historical Review 90 (1985). 
Higman, B. W., "The West India Interest in Parliament, 1807-1833," Historical Studies 13 (1967).

"American Influences on the Development of British West Indian Historiography." Paper presented at Department of History seminar, University of the West Indies, Mona, February 1976.

"The Internal Economy of Jamaican Pens, 1760-1890," Social and Economic Studies 38 (1989).

"Jamaican Port Towns in the Early Nineteenth Century." In Atlantic Port Cities: Economy, Culture, and Society in the Atlantic World, 1650-1850, edited by Franklin W. Knight and Peggy K. Liss. Knoxville: The University of Tennessee Press, 1991.

Hollis, Patricia, "Anti-slavery and British Working-class Radicalism in the Years of Reform." In Anti-slavery, Religion and Reform, edited by Christine Bolt and Seymour Drescher. Folkstone: Dawson, 1980.

Holt, Thomas C., "Explaining Abolition." Journal of Social History 24 (1990).

Hunt, E. M. "The Anti-Slave Trade Agitation in Manchester." Transactions of the Lancashire and Cheshire Antiquarian Society 79 (1977).

Hussey, R. D., "Spanish Reaction to Foreign Aggression in the Caribbean to about 1680." Hispanic American Historical Review 9 (1929).

Inikori, Joseph, "Market Structure and the Profits of the British Slave Trade in the Late Eighteenth Century." Journal of Economic History 41 (1981).

, "Rejoinder." Journal of Economic History 43 (1983).

"A Further Rejoinder." Journal of Economic History 45 (1985).

Jennings, Francis, "Thomas Penn's Loyalty Oath." The American Journal of Legal History 8 (October 1964).

Johnson, Howard, "The Share System in the Bahamas in the Nineteenth and Early Twentieth Centuries." Slavery \&Abolition 5 (1984).

, "A Modified Form of Slavery': The Credit and Truck Systems in the Nineteenth and Early Twentieth Centuries." Comparative Studies in Society and History 28 (1986).

"The Liberated Africans in the Bahamas, 1811-1860." Immigrants and Minorities 7 (1988).

Johnson, Richard R., "Charles McLean Andrews and the Invention of American Colonial History." William and Mary Quarterly, 3rd series, 43 (1986).

Lane, Carl, "The Roots of Jamaican Loyalism, 1760-1766." PhD diss., City University of New York, 1978.

Langford, Paul, "The Rockingham Whigs and America, 1767-1773." In Statesmen, Scholars and Merchants. Essays in Eighteenth Century History Presented to Dame Lucy Sutherland, edited by Anne Whiteman, John S. Bromley and Peter G. M. Dickson. Oxford: Oxford University Press, 1973. 
, "Old Whigs, Old Tories and the American Revolution." In The British Atlantic Empire before the American Revolution, edited by Peter Marshall and Glyndwr Williams. London: Frank Cass, 1980.

, "The British Business Community and the Later Nonimportation Movements, 1768-1776." In Resistance, Politics, and the American Struggle for Independence, 1765-1775, edited by Walter H. Conser, Jr., et al. Boulder, Colorado: Lynne Rienner Publishers, 1986.

Lorimer, Douglas A., "Black Slaves and English Liberty: A Re-examination of Racial Slavery in England." Immigrants \& Minorities 3 (1984).

Lydon, J. G., "Capt. John Douglas and the Blue Dove." New England Quarterly. 38 (1965).

MacFayden, A., "Anglo-Spanish Relations." PhD thesis, University of Liverpool, 1967.

Main, Gloria L., "Probate Records as a Source for Early American History." William and Mary Quarterly, 3rd series, 32 (1975).

Marshall, Woodville K., " 'Vox Populi': the St Vincent Riots and Disturbances of 1862." In Trade, Government and Society in Caribbean History, 1700-1920: Essays Presented to Douglas Hall, edited by B. W. Higman. Kingston: Heinemann, 1983.

, "Provision Ground and Plantation Labor in Four Windward Islands: Competition for Resources during Slavery." In Cultivation and Culture: Labor and the Shaping of Slave Life in the Americas, edited by Ira Berlin and Philip D. Morgan. Charlottesville: University Press of Virginia, 1993.

Mathias, Peter, "Leisure and Wages in Theory and Practice." In The Transformation of England: Essays in the Economic and Social History of England in the Eighteenth Century, edited by P. Mathias. New York: Columbia University Press, 1979.

Mattingly, G., "No Peace Beyond What Line?" Trans. of the Royal Historical Society, 5th ser., 13 (1963).

McCalman, Iain, "Anti-slavery and Ultra-radicalism in Early Nineteenth-century England: The Case of Robert Wedderburn." Slavery \& Abolition 7 (1986).

Minchinton, Walter, "The Triangular Trade Revisited." In The Uncommon Market: Essays in the Economic History of the Atlantic Slave Trade, edited by Henry A. Gemery and Jan S. Hogendorn. New York: Academic Press, 1975.

, "The Slave Trade of Bristol with the British Mainland Colonies in North America, 1699-1770." In Liverpool the African Slave Trade, and Abolition: Essays to Illustrate Current Knowledge and Research, edited by Roger T. Anstey and Paul E. H. Hair. Widnes: Historical Society of Lancashire and Cheshire, 1976.

, "Williams and Drescher: Abolition and Emancipation." Slavery \& Abolition: A Journal of Comparative Studies 4 (1983).

Mintz, S. W., "Caribbean Marketplaces and Caribbean History." Nova Americana 1 (1978).

Mintz, S. W., and Douglas Hall, "The Origins of the Jamaican Internal Marketing System." Yale University Publications in Anthropology, no. 57 (1960). 
Olivier, Sydney, "The Government of Colonies and Dependencies." In Papers on Inter-Racial Problems communicated to the First Universal Races Congress held at the University of London, July 26-29, 1911, edited by G. Spiller. London: P.S.

King, and Boston: The World's Peace Foundation, 1911.

, , Are We Going to Act Justly in Africa?" Contemporary Review 118 (August 1920).

, "Constitutional Development in the West Indies." New Statesman 19 (24 June 1922).

, "Master and Man in the Tropics." In Western Races and the World, edited by F. S. Marvin. London: Oxford University Press, 1922.

, "Mr. Wood on the West Indies." Contemporary Review 122 (August 1922).

, "Colour Prejudice." Contemporary Review 124 (October 1923).

, "Native Land Rights in Rhodesia." Contemporary Review 130 (August 1926).

, "Government of Nations in Africa." The Nation 126 (30 May \& 6 June): 621-22.

, "Progress of a Negro Peasantry." Edinburgh Review 249 (January 1929): 105-16.

, "The Government and our Sugar Colonies." Nineteenth Century and After 108

(July 1930).

, "Settled Policy in East Africa." Contemporary Review 140 (December 1931).

, "Freedom Day." Contemporary Review 154 (August 1938).

, "The Scandal of West Indian Labour Conditions." Contemporary Review 153

(March 1938).

"Truth about the West Indies." Nineteenth Century and After 124 (July 1938).

O'Shaughnessy, Andrew J., "The Politics of the Leeward Islands, 1763-1783." DPhil thesis, Oxford University, 1988.

,"The Formation of a Commercial Lobby: the West India Interest, British Colonial Policy and the American Revolution." Historical Journal (forthcoming).

Penson, Lilian M., "The London West India Interest in the Eighteenth Century." English Historical Review 30 (1921).

Phillips, U. B., "A Jamaica Slave Plantation." American Historical Review 19 (1914).

Phillipps, Sir Thomas, "John Taylor's Life and Travels 1686-8." In The Phillipps

Manuscripts, edited by A. N. L. Munby, no. 9251. London: The Holland Press, 1968.

Pitman, Frank W., "The Settlement and Financing of British West India Plantations in the Eighteenth Century." In Essays in Colonial History Presented to Charles McLean Andrews by His Students. New Haven: Yale University Press, 1931.

Price, Jacob M., "The Transatlantic Economy." In Colonial British America: Essays in the New History of the Early Modern Era, edited by Jack P. Greene and J. R. Pole. Baltimore: Johns Hopkins University Press, 1984.

Ramlackhansingh, G. S., "Amity Hall 1760-1860: The Geography of a Jamaican Plantation." MSc Econ. thesis, University of London, 1966.

Rice, C. Duncan, 'Humanity Sold for Sugar!': The British Abolitionist Response to Free Trade in Slave-grown Sugar." Historical Journal 13 (1970). 
"Enlightenment, Evangelism, and Economics: An Interpretation of the Drive towards Emancipation in British West India." In Comparative Perspectives on Slavery in New World Plantation Societies, edited by Vera Rubin and Arthur Tuden. New York: Annals of the New York Academy of Sciences, Vol. 292 (1977).

Rich, Paul, "Sydney Olivier, Jamaica, and the Debate on British Colonial Policy in the West Indies." In Labour in the Caribbean, edited by Malcolm Cross and Gad Heuman. London: Macmillan Caribbean, 1988.

Richardson, David, "The Slave Trade, Sugar, and British Economic Growth, 1748-1776." In British Capitalism and Caribbean Slavery: The Legacy of Eric Williams, edited by Barbara L. Solow and Stanley L. Engerman. New York: Cambridge University Press, 1987.

Roberts, G. W., "Emigration from the Island of Barbados." Social and Economic Studies 4 (1955).

Roberts, G.W., and J. Bryne, "Summary Statistics on Indenture and Associated Migration affecting the West Indies, 1834-1918." Population Studies 20 (1996).

Samuel, W. S., "Sir William Davidson, Royalist (1616-1689) and the Jews." Transactions of the Jewish Historical Society of England 14 (1936).

Sanderson, Frank E., "The Liverpool Abolitionists." In Liverpool, the African Slave Trade and Abolition: Essays to Illustrate Current Knowledge and Research, edited by Roger T. Anstey and Paul E. H. Hair. Widnes: Historical Society of Lancashire and Cheshire, 1976.

Sayers, R. S., "Thomas Southcliffe Ashton, 1889-1968." Proceedings of the British Academy 55 (1970).

Shepherd, Verene, "Pens and Penkeepers in a Plantation Society: Jamaica, 1740-1845." PhD diss., Cambridge University, 1988.

"Livestock and Sugar: Aspects of Jamaica's Agricultural Development from the Late Seventeenth to the Early Nineteenth Century," The Historical Journal 34 (1991) "Livestock Farmers and Marginality in Jamaica's Sugar-Plantation Society:

A Tentative Analysis." Social and Economic Studies 41 (1992).

"Alternative Husbandry: Slave and Free Labourers on Livestock Farms in Jamaica in the Eighteenth and Nineteenth Centuries." Slavery \& Abolition 14 (1993).

Solow, Barbara, "Caribbean Slavery and British Growth: The Eric Williams Hypothesis." Journal of Development Economics 17 (1985).

Stewart, Revd. Samuel H., "A Statistical Account of the Parish of Manchester." Jamaica Almanack (1840).

Syrett, David, "The West India Merchants and the Conveyance of the King's Troops to the Caribbean, 1779-1782." Journal of the Society for Army Research 14 (1967).

Thomas, Robert Paul, "The Sugar Colonies of the Old Empire: Profit or Loss for Great Britain?" Economic History Review, 2nd series, 21 (1968).

Trainor, John, "Boom or Bust? A Reconsideration of Bahamian History." Paper presented to the seventeenth annual Conference of Caribbean Historians, Nassau, Bahamas, 1985. 
Turner, Mary, "The Bishop of Jamaica and Slave Instruction." Journal of Ecclesiastical History 24 (October 1975).

"Slave Workers and Labour Negotiations." In The Slaves' Economy: Independent Production by Slaves in the Americas, edited by Ira Berlin and Philip D. Morgan. Cass: London, 1991.

Walvin, James, "The Impact of Slavery on British Radical Politics: 1787-1838." In Comparative Perspectives on Slavery in New World Plantation Societies, edited by Vera Rubin and Arthur Tuden. New York: Annals of the New York Academy of Scences, Vol. 292 (1977).

, "The Rise of British Popular Sentiment for Abolition, 1787-1832." In Anti-slavery, Religion and Reform: Essays in Memory of Roger Anstey, edited by Christine Bolt and Seymour Drescher. Folkestone: Dawson, 1980.

, "The Public Campaign in England against Slavery, 1787-1834." In The Abolition of the Atlantic Slave Trade: Origins and Effects in Europe, Africa, and the Americas, edited by David Eltis and James Walvin. Madison: University of Wisconsin Press, 1981.

, "The Propaganda of Anti-slavery." In Slavery and British Society, 1776-1846, edited by James Walvin. London: Macmillan, 1982.

Watkins, Melville H., "A Staple Theory of Economic Growth." Canadian Journal of Economics and Political Science 29 (1963).

Whitson, Agnes, "The Outlook of the Continental American Colonies on the British West Indies." Political Science Quarterly 14 (1930).

Young, Mary E., "Congress Looks West: Liberal Ideology and Public Land Policy in the Nineteenth Century." In The Frontier in American Development: Essays in Honor of Paul Wallace Gates, edited by David Ellis. Ithaca: Cornell University Press, 1969.

Zahedieh, N., "The Merchants of Port Royal, Jamaica, and the Spanish Contraband Trade, 1655-92." William and Mary Quarterly, 3rd ser., 43 (1986).

"A Frugal, Prudential and Hopeful Trade: Privateering in Jamaica, 1655-89." Journal of Imperial and Commonwealth History 18 (1990).

\section{BOOKS}

"A merchant of Boston," The Present State of New England. London: D. Newman, 1675.

"A West India Planter." Remarks on the evidence delivered on the petition presented by the West India Planters and Merchants to the Honorable House of Commons, on the 16th March, 1775, as it was introduced at the bar and summed up by Mr. Glover, so far as the same respects Barbadoes and the Leeward Islands (London: H. S. Woodfall, for T. Cadell, 1777).

Adams, C. D., Flowering Plants of Jamaica. Mona: University of the West Indies, 1972.

Andrews, Charles M., The Colonial Period of American History. 4 vols. New Haven: Yale University Press, 1934-38. 
BIBLIOGRAPHY

Andrews, K. R., The Spanish Caribbean: Trade and Plunder, 1530-1630. New Haven, Conn: Yale University Press, 1978.

,The Atlantic Slave Trade and British Abolition, 1760-1810. London: Macmillan, 1975.

Anstey, Roger T., and Paul E. H. Hair, eds., Liverpool, the African Slave Trade and Abolition. Widnes: Historical Society of Lancashire and Cheshire, 1976.

Appleby, Joyce Oldham, Economic Thought and Ideology in Seventeenth-Century England. Princeton: Princeton University Press, 1978.

Asiegbu, Johnson U. J., Slavery and the Politics of Liberation, 1787-1861: A Study of Liberated African Emigration and British Anti-Slavery Policy. New York: Africana, 1969.

Bailyn, Bernard, and Philip D. Morgan, eds., Strangers within the Realm. Williamsburg: Institute of Early American History and Culture, 1991.

Bayley, F. W., Four Years' Residence in the West Indies. London: William Kidd, 1833.

Beckford, George L., Persistent Poverty: Underdevelopment in Plantation Economies in the Third World. New York: Oxford University Press, 1972.

Beckles, Hilary McD., Afro-Caribbean Women and Resistance to Slavery in Barbados. London: Karnak House, 1988.

, Natural Rebels: A Social History of Enslaved Black Women in Barbados. New Brunswick: Rutgers University Press, 1989.

Bell, Kenneth N., and W. P. Morrell, eds., Select Documents on British Colonial Policy, 1830-1860. Oxford: Clarendon Press, 1928.

Bemis, Samuel Flagg, Jay's Treaty: A Study in Commerce and Diplomacy. New Haven and London: Yale University Press, 1962.

Bender, Thomas, ed., The Antislavery Debate: Capitalism and Abolitionism as a Problem in Historical Interpretation. Berkeley: University of California Press, 1992.

Bennett, Ralph, ed., Settlements in the Americas: Cross-Cultural Perspectives. Newark: Center for Renaissance and Baroque Studies and University of Delaware Press, 1993. Berlin, Ira, and Philip D. Morgan, eds., Cultivation and Culture: Labor and the Shap ing of Slave Life in the Americas. Charlottesville: University Press of Virginia, 1993.

Blackburn, Robin, The Overthrow of Colonial Slavery, 1776-1848. London: Verso, 1988.

Blum, Jerome, The End of the Old Order in Rural Europe. Princeton: Princeton University Press, 1978.

Bolt, Christine, and Seymour Drescher, eds., Anti-slavery, Religion and Reform: Essays in Memory of Roger Anstey. Folkstone: Dawson, 1980.

Brathwaite, Edward, The Development of Creole Society in Jamaica, 1770-1820. Oxford: Clarendon Press, 1971.

Brewer, John, and Roy Porter, eds., Consumption and the World of Goods. London: Routledge, 1993.

Bridenbaugh, Carl, and Roberta Bridenbaugh, No Peace beyond the Line: The English in the Caribbean, 1624-1690. New York: Oxford University Press, 1972. 
Brock, Peter, The Quaker Peace Testimony: 1660 to 1914. York: Sessions Book Trust, 1990.

Brown, Richard D., Knowledge is Power: The Diffusion of Information in Early America, 1700-1865. New York: Oxford University Press, 1989.

Bullion, John L., A Great and Necessary Measure: George Grenville and the Genesis of the Stamp Act, 1763-1765. Columbia: University of Missouri Press, 1982.

Burn, W. L., Emancipation and Apprenticeship in the British West Indies. London: Jonathan Cape, 1937.

Carrington, Selwyn H. H., The British West Indies During the American Revolution. Leiden: Royal Institute of Linguistics and Anthropology/Foris Publications, 1988.

Cash, Philip, Shirley Gordon, and Gail Saunders, eds., Sources of Bahamian History. London: Macmillan, 1991.

Cassidy, F. G., Jamaica Talk. London: Macmillan, 1971.

Cassidy, F. G., and R. B. Le Page, eds., Dictionary of Jamaican English. 2nd ed. London: Cambridge University Press, 1980.

Chamberlayne, Edward, The Present State of England. London: William Whitwood, 1683.

Champion, Richard, and Hugh Owen, Two Centuries of Ceramic Art in Bristol. London: Bell \& Daldy, 1873.

Clarkson, Thomas, The History of the Rise, Progress and Accomplishment of the Abolition of the African Slave Trade by the British Parliament. 2 vols. London: Longmans, 1808.

Cobbett, William, ed., Parliamentary History of England from the Earliest Period to 1803. 36 vols. Londo: Hansard, 1806-22.

Coleman, D. C., History and the Economic Past: An Account of the Rise and Decline of Economic History in Britain. Oxford: The Clarendon Press, 1987.

Colley, Linda, Lewis Namier. London: Weidenfeld and Nicolson, 1989.

Conser, Walter H. Jr., et al., eds., Resistance, Politics, and the American Struggle for Independence, 1765-1775. Boulder, Colorado: Lynne Rienner Publishers, 1986.

Cooke, Jacob E., Tench Coxe and the Early Republic. Chapel Hill: University of North Carolina Press, 1978.

Cooke, Jacob E., ed., The Reports of Alexander Hamilton. New York: Harper \& Row, 1964.

Cooper, Thomas, Facts Illustrative of the Condition of the Negro Slaves in Jamaica. London: Hatchard, 1824.

Corfield, P. J., and N. B. Harte, eds., F. I. Fisher, London and the English Economy, 1500-1700. London: The Hambledon Press, 1990.

Coupland, Reginald, Wilberforce: A Narrative. Oxford: Clarendon Press, 1923.

, The British Antislavery Movement. London: Thornton Butterworth, 1933.

Craton, Michael, A History of the Bahamas. 3rd ed. Waterloo: San Salvador Press, 1986. 
Craton, Michael, ed., Roots and Branches: Current Directions in Slave Studies. Waterloo, Ontario: Historical Reflections, Vol. 6 (1979).

Craton, Michael, and James Walvin, A Jamaican Plantation: The History of Worthy Park, 1670-1970. Toronto: University of Toronto Press, 1970.

Craton, Michael, and Gail Saunders, Islanders in the Stream: A History of the Bahamian People. Vol. 1, From Aboriginal Times to the End of Slavery. Athens: University of Georgia Press, 1992.

Craton, Michael, James Walvin, and David Wright, eds., Slavery, Abolition and Emancipation; Black Slaves and the British Empire: A Thematic Documentary. London: Longman, 1976.

Cross, Malcolm, and Gad Heuman, eds., Labour in the Caribbean. London: Macmillan Caribbean, 1988.

Crowley, J. E., This Sheba Self: The Conceptualization of Economic Life in EighteenthCentury America. Baltimore: Johns Hopkins University Press, 1974.

Cruickshank, E. A., The Life of Sir Henry Morgan. Toronto: Macmillan, 1935.

Crump, Helen J., Colonial Admiralty Jurisdiction in the Seventeenth Century. London and New York: Longmans, 1931.

Cundall, Frank, The Governors of Jamaica in the First Half of the Eighteenth Century. London: The West India Committee, 1937.

Cundall, Frank, and Joseph Pietersz, Jamaica under the Spaniards. Kingston: Institute of Jamaica, 1912.

Curtin, Philip D., ed., Imperialism. New York: Harper and Row, 1971. ,The Atlantic Slave Trade: A Census. Madison: University of Wisconsin Press, 1974.

Davies, K. G., The Royal African Company. London: Longmans, 1957.

Davis, David Brion, The Problem of Slavery in Western Culture. Ithaca: Cornell University Press, 1966.

Slavery and Human Progress. London: Oxford Univeristy Press, 1984.

Davis, Ralph, The Rise of the English Shipping Industry in the Seventeenth and Eighteenth Centuries. London: Macmillan, 1962.

The Industrial Revolution and British Overseas Trade. Leicester: Leicester University Press, 1979.

Davy, John, The West Indies, before and since emancipation. London: W. and F. G. Cash, 1854.

de Acosta, José, Historia Natural y Moral de las Indias. Sevilla: Juan de León, 1590.

Deerr, Noel, History of Sugar. 2 vols. London: Chapman Hall, 1949-1950.

Defoe, D., The King of Pirates. London: A. Bettesworth, 1720.

, A General History of the Pyrates, From Their first Rise and Settlement in the Island of Providence, to the present Time. London: Printed for, and Sold by T. Woodward, 1724.

De la Beche, H. T. Notes on the Present Condition of the Negroes in Jamaica. London: T. Cadell, 1825. 
de la Martinière, Pinson, The Present State of France. London: J. Starkey, 1671. de Solano, Francisco, and Augustín Guimerá, eds., Esclavitud y Derechos Humanos: la Lucha por la Libertad del Negro en el Siglo XIX. Madrid: Consejo Superior de Investigaciones Científicas, 1990.

de Veitia Linaje, José, The Spanish Rule of Trade to the West Indies. Translated by Capt. John Stevens. London: S. Crouch, 1702.

Dickson, William, Letters on Slavery. 1789. Reprint, Westport: Negro University Press, 1970.

Drescher, Seymour, Econocide: British Slavery in the Era of Abolition. Pittsburgh: University of Pittsburgh Press, 1977. Capitalism and Antislavery: British Mobilization in Comparative Perspective. London: Macmillan, 1986.

Dunn, Richard S., Sugar and Slaves: The Rise of the Planter Class in the English West Indies, 1624-1713. Chapel Hill: University of North Carolina Press, 1973.

Edwards, Bryan, The History, Civil and Commercial, of the British Colonies in the West Indies. 3 vols. 1793. Reprint, London: G. \& W. B. Whittaker, 1801.

Ellis, David, ed., The Frontier in American Development: Essays in Honor of Paul Wallace Gates. Ithaca: Cornell University Press, 1969.

Eltis, David, Economic Growth and the Ending of the Transatlantic Slave Trade. New York: Oxford University Press, 1987.

Eltis, David, and James Walvin, eds., The Abolition of the Atlantic Slave Trade: Origins and Effects in Europe, Africa, and the Americas. Madison: University of Wisconsin Press, 1981.

Engerman, Stanley L., and Eugene D. Genovese, eds., Race and Slavery in the Western Hemisphere: Quantitative Studies. Princeton: Princeton University Press, 1975.

Exquemelin, A. O., The Bucaniers of America. London: for W. Crooke, 1684.

Fenwick, A. F. ed., The Fate of the Fenwicks: Letters to Mary Hays, 1798-1828. London: Methuen, 1927.

Fogel, Robert, Without Consent or Contract: The Rise and Fall of American Slavery. New York: Norton, 1989.

Fogel, Robert, and Stanley L. Engerman, Time on the Cross: The Economics of American Negro Slavery. Boston: Little, Brown, 1974.

Furniss, Edgar S., The Position of the Laborer in a System of Nationalism: A Study in the Labor Theories of the Later English Mercantilists. New York: Houghton-Mifflin, 1919.

Gates, Paul W., History of Public Land Law Development. Washington, D.C.: Government Printing Office, 1968.

Gemery, Henry A., and Jan S. Hogendorn, eds., The Uncommon Market: Essays in the Economic History of the Atlantic Slave Trade. New York: Academic Press, 1975.

Gill, Conrad, Merchants and Mariners of the 18th Century. London: Edward Arnold, 1961. 
Gollin, Gillian Lindt, Moravians in Two Worlds: A Study of Changing Communities. New York: Columbia University Press, 1967.

Goslinga, Cornelius C., The Dutch in the Caribbean and on the Wild Coast, 1580-1680. Gainesville: University Press of Florida, 1971.

Goveia, Elsa, Slave Society in the British Leeward Islands at the end of the 18th Century. London: Yale University Press, 1965.

Grant, W. L., and J. Munro, eds., Acts of the Privy Council, Colonial Series. 6 vols. London: H. M. Stationery Office, 1908-12.

Green, William A., British Slave Emancipation: The Sugar Colonies and the Great Experiment, 1830-1865. Oxford: Clarendon Press, 1976.

Greene, Jack P., Pursuits of Happiness: The Social Development of Early Modern British Colonies and the Formation of American Culture. Chapel Hill: University of North Carolina Press, 1988.

Greene, Jack P., and William G. McLoughlin, eds., Preachers \& Politicians: Two Essays on the Origins of the American Revolution. Worcester: American Antiquarian Society, 1977.

Greene, Jack P., and J. R. Pole, eds., Colonial British America: Essays in the New History of the Early Modern Era. Baltimore: Johns Hopkins University Press, 1984. , eds., The Blackwell Encyclopedia of the American Revolution. London: Basil Blackwell Ltd., 1991.

Grey, Earl, The Colonial Policy of Lord John Russell's Administration. 2 vols. London: Rich and Bentley, 1853.

Greville, Charles C. F., The Greville Memoirs: A Journal of the Reigns of King George IV and King William IV. 3 vols., 4th ed. London: Longmans, Green, and Co., 1875.

Guttridge, G. H., ed., The American Correspondence of a Bristol Merchant, 1766-1776: Letters of Richard Champion (University of California Publications in History, vol. 22, no. 1). Berkeley: University of California Press, 1934.

Hall, Douglas, A Brief History of the West India Committee. Barbados and Edinburgh: Caribbean Universities Press, 1971.

, In Miserable Slavery: Thomas Thistlewood in Jamaica, 1750-86. London: Macmillan, 1989.

, Planters, Farmers and Gardeners in Eighteenth Century Jamaica: The 1987. Elsa Goveia Memorial Lecture. Mona: Department of History, University of the West Indies, 1990.

Hall, Richard, Acts Passed in the Island of Barbados, 1643-1762. London: Richard Hall, Jr., 1764.

Hamilton, J. Taylor, and Kenneth G. Hamilton, History of the Moravian Church: The Renewed Unitas Fratrum, 1722-1957. Bethlehem, Pa.: Moravian Church in America, 1967.

Handler, Jerome, The Unappropriated People: Freedmen in the Slave Society of Barbados. Baltimore: Johns Hopkins University Press, 1974. 
[Charles Hardy], A Register of Ships Employed in the Service of the .. . United East India Company from 1707 to . . 1760. London: printed for Charles Hardy, 1799.

Haring, C. H., The Buccaneers in the West Indies in the Seventeenth Century. London and Hamden, Conn.: Archon Books, 1910.

, Trade and Navigation between Spain and the Indies in the Time of the Hapsburgs. London and Cambridge: Harvard University Press, 1918.

Harte, N. B., ed., The Study of Economic History: Collected Inaugural Lectures 1893-1970. London: Frank Cass, 1971.

Hayne, S., An Abstract of all the Statutes made Concerning Aliens Trading in England with Observations Thereon. London: Printed by N. T. for the author, 1685.

Heuman, Gad, ed., Out of the House of Bondage: Runaways, Resistance and Marronage in Africa and the New World. London: Frank Cass, 1986.

Hibbard, Benjamin H., A History of the Public Land Policies. New York: Macmillan, 1924.

Higginson, Francis, New England's Plantation. London: M. Sparke, 1630.

Higman, B. W., Slave Population and Economy in Jamaica, 1807-1834. Cambridge:

Cambridge University Press, 1976.

Slave Populations of the British Caribbean, 1807-1834. Baltimore: Johns

Hopkins University Press, 1984.

, Jamaica Surveyed: Plantation Maps and Plans of the Eighteenth and Nineteenth

Centuries. Kingston: Institute of Jamaica Publications, 1988.

Higman, B. W., ed., Trade, Government and Society in Caribbean History, 1700-1920:

Essays Presented to Douglas Hall. Kingston: Heinemann, 1983.

Hobson, J. A., Imperialism: A Study. London: Archibald Constable, 1905.

Hoffman, P. E., The Spanish Crown and the Defense of the Caribbean, 1535-1589.

Baton Rouge: Louisiana State University Press, 1980.

Holt, Thomas C., The Problem of Freedom: Race, Labor, and Politics in Jamaica and Britain, 1832-1938. Baltimore: Johns Hopkins University Press, 1992.

Husbands, Joseph, An Answer to the Charge of Inhabitants of Barbados. New York: Richardson, 1831.

Hutton, Charles, George Shaw, and Richard Pearson, eds., The Philosophical Transacions of the Royal Society. 18 vols. London: C. and R. Baldwin, 1809.

Ingram, K. E., Sources of Jamaican History, 1655-1838. 2 vols. Zug: Inter Documentation Company, 1976.

Innis, Harold Adams, The Cod Fisheries: The History of an International Economy. New Haven: Yale University Press, 1940.

Ives, Charles, The Isles of Summer; Or Nassau and the Bahamas. New Haven, Connecticut: By the Author, 1880.

Ives, Vernon A., ed., The Rich Papers: Letters from Bermuda, 1615-1646. Toronto: Bermuda and Toronto University Press, 1984.

James, Cyril L. R., The Black Jacobins: Toussaint L'Ouverture and the San Domingo Revolution. London: Secker \& Warburg, 1938. 
Jameson, J. F., Privateering and Piracy in the Colonial Period. New York: Macmillan, 1923. Jennings, Francis, Empire of Fortune: Crown, Colonies and Tribes in the Seven Years' War in America. New York: Norton, 1986.

Kammen, Michael, A Rope of Sand: The Colonial Agents, British Politics and the American Revolution. Ithaca: Cornell University Press, 1968.

Empire and Interest. The American Colonies and the Politics of Mercantilism. Philadelphia: J.B. Lippincott Company, 1970.

Karras, Alan L., Sojourners in the Sun: Scottish Migrants in Jamaica and the Chesapeake, 1740-1800. Ithaca: Cornell University Press, 1992.

Knight, Derrick, Gentlemen of Fortune: The Men who made their Fortunes in Britain's Slave Colonies. London: Frederick Muller Ltd., 1978.

Knight, Franklin W., and Peggy K. Liss, eds., Atlantic Port Cities: Economy, Culture, and Society in the Atlantic World, 1650-1850. Knoxville: The University of Tennessee Press, 1991.

Kuczynski, R.R., Demographic Survey of the British Colonial Empire. 3 vols. London: Oxford University Press, 1949.

Labaree, Leonard W., ed., Royal Instructions to British Colonial Governors, 1670-1776. 2 vols. New York: D. Appleton-Century, 1935.

Lecky, William E. H., A History of European Morals from Augustus to Charlemagne. London: Longmans Green, 1869.

Lee, Francis, Fabianism and Colonialism: the Life and Political Thought of Lord Sydney Olivier. London: Defiant Books, 1988.

Lefroy, John H., Memorials of the Discovery and Early Settlement of the Bermudas or Somers Islands, 1515-1685. 3d ed., 2 vols. 1879. Reprint, Toronto: Toronto University Press, 1981.

Levy, Claude, Emancipation, Sugar and Federalism: Barbados and the West Indies, 1833-1876. Gainesville: University of Florida Press, 1980.

Lewis, Gordon K., The Growth of the Modern West Indies. London: MacGibbon and Kee, 1968.

Ligon, Richard, A True and Exact History of the Island of Barbados. London: Humphrey Moseley, 1657.

Locke, Amy Audrey, The Hanbury Family. 2 vols. London: A. L. Humphreys, 1916.

Long, Edward, The History of Jamaica. 3 vols. London: Printed for T. Lowndes, 1774.

Marin, R.M., History of the Colonies of the British Empire. London:

W.H. Allen, 1843.

Marshall, Peter, The Anti-slave Trade Movement in Bristol. Bristol: Bristol Branch of the Historical Association, 1968.

Marshall, Peter, and Glyndwr Williams, eds., The British Atlantic Empire before the American Revolution. London: Frank Cass, 1980.

Marshall, Woodville K., ed., The Colthurst Journal: Journal of a Special Magistrate in the Islands of Barbados and St. Vincent, July 1835-September 1838. Millwood, New York: KTO Press, 1977. 
Martin, Robert M., History of the Colonies of the British Empire. London: William Allen and George Routledge, 1843.

Marvin, F. S., ed., Western Races and the World. London: Oxford University Press, 1922.

Marx, Karl, Capital: A Critique of Political Economy. 1906. Reprint, New York: Modern Library, 1936.

Mathias, Peter, ed., The Transformation of England: Essays in the Economic and Social History of England in the Eighteenth Century. New York: Columbia University Press, 1979.

Mathieson, William L., British Slavery and its Abolition, 1823-1838. London: Longmans, Green and Co., 1926.

Mayes, Philip, Port Royal, Jamaica: Excavations, 1969-70. Kingston: Jamaica National Trust Commission, 1972.

McCusker, John J., and Russell R. Menard, The Economy of British America, 1607-1789. Chapel Hill: University of North Carolina Press, 1985.

McDonald, Roderick A., The Economy and Material Culture of Slaves: Goods and Chattels on the Sugar Plantations of Jamaica and Louisiana. Baton Rouge: Louisiana State University Press, 1993.

McKenzie, Norman, and Jeanne MacKenzie, The First Fabians. London: Weidenfeld \& Nicolson, 1977.

McMahon, Benjamin, Jamaica Plantership. London: Effingham Wilson, 1839.

Meier, Gerald M., and Dudley Seers, eds., Pioneers in Development. New York and Oxford: Oxford University Press, 1984.

Merivale, Herman, Lectures on Colonization and Colonies. 1841. Reprint, London: Longman, Green, Longman and Roberts, 1861.

Metcalfe, George, Royal Government and Political Conflict in Jamaica, 1729-1783. London: Longmans, 1965.

Miller, John C., Origins of the American Revolution. London: Longmans, 1959.

Mintz, Sidney W., Slavery, Colonialism, and Racism. New York: W. W. Norton, 1974. , Sweetness and Power: The Place of Sugar in Modern History. New York: Viking, 1985.

Monardes, Nicolás, De Simplicibus Medicamentis ex Occidentali India delatis. Antwerp: C. Plantin, 1574.

Moreton, J. B., Manners and Customs of the West India Islands . London: Richardson, 1790.

Morgan, Edmund S., and Helen M. Morgan, The Stamp Act Crisis. Rev. ed. New York: Vintage Books, 1963.

Mortimer, Russell, ed., Minute Book of the Men's Meeting of the Society of Friends in Bristol, 1686-1704 (Bristol Record Society's Publications, no. 30). Bristol: Bristol Record Society, 1977.

Murray, D. J., The West Indies and the Development of Colonial Government, 1801-1834. Oxford: Clarendon Press, 1965. 
Namier, Sir Lewis, England in the Age of the American Revolution. 2nd ed. London: Macmillan, 1961.

Namier, Sir Lewis, and John Brooke, The History of Parliament. The House of Commons 1754-1790. 3 vols. New York: Oxford University Press, 1964.

Nash, Gary B., and Jean R. Soderlund, Freedom by Degrees: Emancipation in Pennsylvania and Its Aftermath. New York: Oxford University Press, 1991.

Oldmixon, John, The British Empire in America. 2 vols. London: Mapp, 1708.

Olivier, M., ed., Sydney Olivier: Letters and Selected Writings. London: George Allen \& Unwin, 1948.

Olivier, Sydney, Capital and Land (Fabian Society Tract No. 7). London: The Fabian Society, 1888.

, White Capital and Coloured Labour. London: Independent Labour Party, 1906.

, The League of Nations and Primitive Peoples. London: Oxford University Press, 1918.

, The Anatomy of African Misery. London: L. and V. Woolf, 1927.

Imperial Trusteeship (Fabian Society Tract No. 230). London: The Fabian Society, 1929.

, The Myth of Governor Eyre. London: L. \& V. Woolf, 1933.

, Jamaica: The Blessed Island. London: Faber \& Faber, 1936.

Oxaal, Ivar, Black Intellectuals Come to Power. Cambridge: Schenkman, 1968.

Packwood, Cyril O., Chained on the Rock: Slavery in Bermuda. Bermuda: Baxter's, 1975.

Pares, Richard, $A$ West-India Fortune. London: Longmans, 1950.

Yankees and Creoles: The Trade between North America and the West Indies before the American Revolution. London: Longmans, 1956.

War and Trade in the West Indies, 1739-1763. 1936. New impression, London:

Frank Cass 8x Co., 1963.

Merchants and Planters. Economic History Review, supplement no. 4 (1960).

Pargellis, Stanley, and Ruth Lapham Butler, eds., Daniell Ellffryth's Guide to the Caribbean, 1631. Chicago: The Newberry Library, 1945.

Parker, Christopher, The English Historical Tradition since 1850. Edinburgh: John

Donald Publishers, 1990.

Patterson, Orlando, The Sociology of Slavery. London: London University Press, 1967.

Pawson, Michael, and David Buisseret, Port Royal, Jamaica. Oxford: Clarendon Press, 1975.

Penson, Lilian M., The Colonial Agents of the British West Indies. 1924. Reprint, London: Frank Cass, 1971.

Pinckard, George, Notes on the West Indies. 3 vols. London: Longman, 1806.

Pitman, Frank W., The Development of the British West Indies, 1700-1763. New

Haven: Yale University Press, 1917. 
Slavery on the British West India Plantations in the Eighteenth Century. Washington, D.C.: Association for the Study of Negro Life and History, 1926.

Postma, Johannes M., The Dutch in the Atlantic Slave Trade, 1600-1815. Cambridge: Cambridge University Press, 1990.

Powell, J[ohn] W[illiam] Damer, Bristol Privateers and Ships of War. Bristol and London: J. W. Arrowsmith, 1930.

Poyer, John, The History of Barbados from the First Discovery of the Island in the Year 1605 till the Accession of Lord Seaforth 1801. London: J. Mauman, 1808.

Proctor, Samuel, ed., Eighteenth Century Florida and the Caribbean. Gainesville: University of Florida Press, 1976.

Ragatz, Lowell J., The Fall of the Planter Class in the British Caribbean, 1763-1833: A Study in Social and Economic History. 1928. Reprint, New York: Octagon Books, 1971.

A Guide For The Study Of British Caribbean History, 1763-1834. Washington: US Government Printing Office, 1932.

Raistrick, Arthur, Quakers in Science and Industry ... during the 17th and 18th Centuries. London: Philosophical Library, 1950.

"RF," The Present State of Carolina. London: John Bringhurst, 1682.

Rice, C. Duncan, The Scots Abolitionists, 1833-1861. Baton Rouge: Louisiana State University Press, 1981.

Richardson, David, ed., Abolition and its Aftermath: The Historical Context, 1790-1916. London: Cass, 1986.

Robbins, Roy M., Our Land Heritage: The Public Domain, 1776-1936. Princeton: Princeton University Press, 1942.

Roughley, Thomas, The Jamaica Planter's Guide. London: Longman, Hurst, Rees, Orme and Brown, 1823.

Rubenstein, Hymie, Coping With Poverty: Adaptive Strategies in a Caribbean Village. Boulder, Colorado: Westview, 1987.

Rubin, Vera, and Arthur Tuden, eds., Comparative Perspectives on Slavery in New World Plantation Societies. New York: Annals of the New York Academy of Sciences, Vol. 292, 1977.

Said, Edward W., Culture and Imperialism. New York: Knopf, 1993.

Sainsbury, John, Disaffected Patriots: London Supporters of Revolutionary America, 1769-1782. Kingston and Montreal: McGill-Queen's University Press, 1987.

Sainsbury, W. Noel, et al., eds., Calendar of State Papers, Colonial Series, America and the West Indies. 20 vols. London: H. M. Stationery Office, 1860-1912.

Saunders, Gail, Bahamian Loyalists and their Slaves. London: Macmillan, 1983. Slavery in the Bahamas, 1648-1838. Nassau: By the Author, 1985.

Saunders, Hartley Cecil, The Other Bahamas. Nassau: Bodab Press, 1991.

Savelle, Max, The Origins of American Diplomacy: The International History of Anglo-America, 1492-1763. New York: Macmillan, 1967. 
Schoepf, Johann D., Travels in the Confederation, 1783-1784. Philadelphia: Campbell, 1911.

Schumpeter, Joseph A., Imperialism and Social Classes. New York: A. M. Kelley, 1951.

Sedgwick, Romney, ed., The History of Parliament: the House of Commons 1715-1754. 2 vols. New York: Oxford University Press, 1970.

Semmel, Bernard, Imperialism and Social Reform: English Social-Imperial Thought, 1895-1914. Cambridge, Mass.: Harvard University Press, 1960.

Sester, Vernon G., The Commercial Reciprocity Policy of the United States, 1774-1829. Philadelphia: University of Pennsylvania Press, 1937.

Shephard, Charles, An Historical Account of the Island of St. Vincent. London: Kidgway and Sons, 1843.

Shurtleff, Nathaniel B., ed., Records of the Governor and Company of Massachusetts Bay in New England. 5 vols. Boston: W. White, printer to the commonwealth, 1853-1854.

Shyllon, Folarin B., Black Slaves in Britain. London: Oxford University Press, 1974. , Black People in Britain, 1555-1833. London: Oxford University Press, 1977.

Simmons, R. C., and P. D. G. Thomas, Proceedings and Debates of the British Parliaments Respecting North America, 1754-1783. 5 vols. New York: Kraus International Publications, 1982.

Sloane, Sir Hans, A Voyage to the Islands Madera . . and Jamaica. 2 vols. London: Printed by B. M. for the Author, 1707, 1725.

Smith, James E., Slavery in Bermuda. New York: Vantage, 1976.

Smith, John, A Description of New England. London: Humphrey Lownes, 1616.

Soderlund, Jean R., Quakers and Slavery: A Divided Spirit. Princeton: Princeton University Press, 1985.

Solow, Barbara L., and Stanley L. Engerman, eds., British Capitalism and Caribbean Slavery: The Legacy of Eric Williams. New York: Cambridge University Press, 1987.

Sosin, Jack, Agents and Merchants: British Colonial Politics and the Origins of the American Revolution, 1765-1775. Lincoln: University of Nebraska Press, 1965.

Spiller, G., ed., Papers on Inter-Racial Problems communicated to the First Universal Races Congress held at the University of London, July 26-29, 1911. London: P.S. King, and Boston: The World's Peace Foundation, 1911.

Spurdle, Frederick G., Early West Indian Government. New Zealand: by the Author, 1963.

Starkey, David J., British Privateering Enterprise in the Eighteenth Century (Exeter Maritime Studies no. 4). Exeter: University of Exeter Press, 1990.

Steele, Ian K., The English Atlantic, 1675-1740: An Exploration of Communication and Community. New York: Oxford University Press, 1986.

Stephen, Leslie, et al., eds., Dictionary of National Biography. 63 vols. London: Smith, Elder \& Co., 1885-1901. 
Stone, Lawrence, The Past and Present Revisited. London and New York: Routledge and Kegan Paul, 1987.

Sturge, J., and T. Harvey, The West Indies in 1837. London: Hamilton and Adams, 1837.

Syrett, David, Shipping and the American War 1775-1783. London: University of London, Athlone Press, 1970.

Taylor, E. G. R., The Mathematical Practitioners of Tudor and Stuart England. Cambridge: Cambridge University Press, 1954.

Taylor, Henry, Autobiography of Henry Taylor, 1800-1875. 2 vols. New York: Harper \& Brothers, 1885.

Taylor, S. A. G., The Western Design: An Account of Cromwell's Expedition to the Caribbean. Kingston, Jamaica: Institute of Jamaica and Jamaica Historical Society, 1965.

Tedder, A, W., The Navy of the Restoration. Cambridge: Cambridge University Press, 1916.

Thomas, Peter D. G., The Townshend Duties Crisis. Oxford: Clarendon Press, 1987.

Thome, J., and J. Kimball, Emancipation in the West Indies. New York: Anti-Slavery Society, 1838.

Thornton, A. P., West-India Policy under the Restoration. Oxford: Clarendon Press, 1956.

Trotman, David, Crime in Trinidad: Conflict and Control in a Plantation Society, 1838-1900. Knoxville: University of Tennessee Press, 1986.

Tucker, Terry, Bermuda's Story. Bermuda: Baxter's, 1957.

Tuma, Elias H., Economic History and the Social Sciences: Problems of Methodology. Berkeley and Los Angeles: University of California Press, 1971.

Twaddle, Michael, ed., The Wages of Slavery: From Chattel Slavery to Wage Labour in Africa, the Caribbean and England. London: Frank Cass, 1993.

Vaughan, Herbert S., ed., The Voyages and Cruises of Commodore [George] Walker. London: Cassell, 1928.

Wakefield, Edward Gibbon, England and America: $A$ Comparison of the Social and Political State of Both Nations. New York: Harpers Brothers, 1834.

A View of the Art of Colonization: In Present Reference to the British Empire. London: John W. Parker, 1849.

Waller, John, A Voyage to the West Indies. London: Richard Phillips, 1820.

Walvin, James, Black Ivory. London: Fontana, 1992.

Walvin, James, ed., Slavery and British Society, 1776-1846. London: Macmillan, 1982.

Walvin, James, and David Eltis, eds., The Abolition of the Atlantic Slave Trade: Origins and Effects in Europe, Africa, and the Americas. Madison: University of Wisconsin Press, 1981.

Ward, John R., British West Indian Slavery, 1750-1834: The Process of Amelioration. Oxford: Clarendon Press, 1988. 
Whiteman, Anne, John S. Bromley, and Peter G. M. Dickson, eds. Statesmen, Scholars and Merchants. Essays in Eighteenth Century History Presented to Dame Lucy Sutherland. Oxford: Oxford University Press, 1973.

Wilkinson, Henry C., The Adventurers of Bermuda: A History of the Island from its Discovery until the Dissolution of the Somers Islands Company in 1684. 2d ed. 1933. Reprint, London: Oxford University Press, 1958.

Williams, Eric, Capitalism and Slavery. 1944. Reprint, London: André Deutsch, 1981. British Historians and the West Indies. London: André Deutsch, 1966.

Wylly, William, Regulations for the Government of the Slaves at Clifton and Tusculum in New Providence. Nassau: Royal Gazette, 1815.

Yorke, Philip C., ed., The Diary of John Baker. Barrister of the Middle Temple and Solicitor General of the Leeward Islands. London: Hutchinson, 1931.

Zahler, Helene S., Eastern Workingmen and National Land Policy, 1829-1862. New York: Columbia University Press, 1941. 


\section{Index}

Aberdeen, William, 329

Abingdon, Lord, 137

Abolition: and Anti-Slavery Society, 232-34, 236, 238, 243-44, 248, 265; Drescher thesis on, 260-66, 269-70n45, 270n52, 271 n62, 271nn5960; "econocide" thesis of, 258, 260-66, 269-70n45; economic basis of, 260-66; and evangelical theology, 255, 256; opposition to slaveowners' right to sexual access to slaves, 172; opposition to, by West India interest, 129, $144 \mathrm{n} 26,147 \mathrm{n} 92$; and radical politics, 257-58; role of anti-slavery movements in, 255-60; scholarship on, 253-55; of slave trade, 164, 254, 315n 14; of slavery in England, 259; slaves' role in struggle for, 259; Williams thesis of, 254-55, $259,260,264,265,267 \mathrm{nl}$; women's work for, 260. See also Emancipation

Acosta, José de, 52, 62n9

Adams, Joseph, 75

Adderley, A. F., 291

Affir, Sarah, 189-99, 206-07

Affirmation Act, 64-65, 68

Africa: Olivier on, 344, 348-52

Agriculture. See Gardens

Akers, Aretas, 135

Albemarle, Duke, 59

Alleyne, Sir John Gibbes, 130, 182

Amelioration policy, 232-49

American colonies: Boston Port Bill, 131;

Boston Tea Party, 130, 131; and British credit crisis of 1772, 5-6; and Carlisle Peace Commision, 139; and Coercive Acts of 1774, 130-31; independence of, 126-41; lobby for, 142n2; and Mutiny Bill, 133; opposition of West Indian interest, 126, 128, 129-32, 135-41; and Stamp Act, 126, 127, 128-29, 132, 141; and Sugar Act, 128, 129; support by West India interest, 126, 127-29, 132-37, 140; and Townshend Duties, 127, 129. See also United States American Revolutionary War: alliance of France and United States during, 140; British defeat in, 139; economic impact on West
Indies, 137-39, 149, 157, 261; lumber prices during, 162; and Quaker merchants, 70-71, 73-74, 75; and West India interest, 126-41

Anderson, John, 323, 324, 326-35, 339n18, 339-40n 21

Andrews, Charles McLean, 3

Animals: in Jamaica, 56-57, 61, 109; livestock

trading in plantation-economy model, 213-19

Anstey, Roger, 255-56, 262, 264, 270n52

Anti-slavery movements, 255-60

Anti-Slavery Society, 232-34, 236, 238, 243-44, 248, 265

Antigua, 6, 7, 17, 171

Apprenticeship: in the Bahamas, 284-86; in

St. Vincent, 319-37

April 1787 Act, 154-56, 164, 165

Arnold, Jeremiah, 49

Ashton, T. S., 4-5, 22, 23n17

Asparagus growing, 111-14, 121

Atkinson, Richard?, 132

Austin, Betsy, 178

Bahamas: Apprenticeship phase in, 284-86; Commonage Law in, 288; cotton production in, 278, 279; dialectic between dependency and individualism in, 289-92; free blacks in, 278, 279, 283-86; "hucksters" in, 286, 295n31; immigration to, 278; labour tenancies after Emancipation in, 288-89; Liberated Africans in, 278, 284-86; "Loyalist" blacks in, 278-79; manumission cases in, 274-75, 283; slave mariners in, 283, 295n23; slave resistance in, 281-82; slavery in, 275-81, 283, 284; transition out of slavery in, 274-92; "truck system" in, 287, 295n32

Baker, Philip, 97, 100n25

Balkney, General, 98n5

Barbados: agent from, 130, 134; and American independence, 134, 135, 137, 138; female slave manumission, 182-83; female slaves' fear of sexual violence, 174; imports for, 127, 134; land/labour ratio after emancipation, 318n43; 
miscegenation in, 171-72; prices of plantation supplies and lumber, 162; slave prostitution and mistresses in, 172-79, 181; slave uprisings in, 259; slavery in, 17, 20, 21, 134, 185n5; trade with United States, 150, 151, 155-56, 158-59;

Trelawny on duties from, 90, 96, 99n21

Barham, John Foster, 210n33

Barham, Joseph Foster, 188-89

Barham, Joseph Foster II, 188-89, 200, 204, 210n33

Barkly, Henry, 318n42

Barré, Isaac, 126

Bayley, Alexander, 238, 239-43, 246-49

Bayley, F. W., 172, 179-80, 181

Bayly, Nathaniel, 135, 140

Beckford, George, 211

Beckford, Peter, 98n12

Beckford, William, 8, 92, 93, 98-99n12, 127, 129

Bedford, John, Fourth Duke of, 92, 98n11

Beeston, William, 34

Bender, Thomas, 266

Bermuda, 275-76

Best, Lloyd, 211

Black women: as less sexually attractive to white men, 179-81; Liberated African women in the Bahamas, 286, 289-90; as owners of slave prostitutes, 181-82. See also Slave women

Blackburn, Robin, 265, 266

Blackmore, Francis, 49-50

Blake, Captain Benjamin, 117

Blake, Governor, 347

Bland, Elias, 75

Blome, Richard, 53

Blue Dove, capture of, 29, 34, 37-42, 45n38

Board of Trade: North American trade with West Indies, 161; Trelawny's suggestions to, 88-89, 93, 95-96

Bolas, Juan de, 54

Bollan, William, 131

Bolland, Nigel, 282

Boston Port Bill, 131

Boston Tea Party, 130, 131

Botanical enterprise in Jamaica, 101-23

Brade, Sabina, 178

Brathwaite, Edward, 18

Breadnut Island Pen, 102-19, 121, 123

Britain: abolition of slavery in, 259; American independence and West India interest, 126-41 credit crisis of 1772, 5-6; defeat of, in American Revolutionary War, 139; Pelham's ministry and Trelawny's letters, 87-97; Quaker merchants and war at sea, 1689-1783, 65-81; Royal Navy's impressment of U.S. seamen and capture of U.S. ships, 158, 162; trade with West Indies, 262-63, 27 ln60; United States and British West Indian trade, 1783-1807, 149-65

British Empire: attitudes of British politicians toward, 87-97; metropolitan weakness and constitutional reform in, 87-97; relationship of island and mainland colonies, 126-27, 142n2; Trelawny on governance of, 87-97. See also specific colonies

British West Indies. See West Indies; and specific countries

Broughton, Arthur, 122

Brown, Caesar, 274-75, 277, 292, 292-93n2

Brown, Henton, 75

Brown, Mrs. Sophia, 274-75, 292-93n2

Buccaneers, 30, 39-40, 42n4

Bunbury, Thomas Charles, 143-44n21

Burchell, Thomas, 265

Burke, Edmund, 83n22, 131, 132, 141

Burt, William Mathew, 143-44n21

Bussa Rebellion, 183

Bute, Lord, 147n86

Caledon, Susannah, 49

Camden, Lord, 160-6

Canada: and rum from West Indies, 164; trade with British West Indies, 150, 152-53, 157, 158, $159,163,165$

Carlisle, Lord, 139

Carlisle Peace Commission, 139

Carolinas, 276

Carrington, Selwyn, 261, 269n40

Cartwright, John, 257

Cattle trading, 213-19

Chamberlain, Joseph, 345

Champion, George, 71, 75

Champion, John, 75

Champion, Nehemiah, 70, 82n18

Champion, Nehemiah, Jr., 71, 75, 83n25

Champion, Richard, 71, 83n22

Charles II, 30, 31, 64

Chartists, 258

Clarke, Thomas, 101, 119, 122

Clarkson, Thomas, 254

"Cliometric" methods, 10-12

Cobbett, William, 257, 258

Coercive Acts of 1774, 130-31

Coffee trading, 219-21 
Colleton, James Edward, 143-44n21

Collinson, James, 75

Colonies. See British Empire; and specific colonies

Columbus, Christopher, 54

Committee of.West India Merchants and Planters, 132, 145n43, 149, 232, 236-38, 240,

244

Commonage Law, 288

Comte, Auguste, 344

Comyn, Captain Phillips, 77, 79

Comyn, Valens, 79, 85n54

Cook, Captain, 176

Cook, Captain Robert, 38, 39, 45n38

Cooper, Thomas, 175

Cope, John, 101, 103, 104, 107

Cordosa, Isaac, 34

Corfield, P. J., 4

Coupland, Reginald, 254, 255, 256, 265

Craton, Michael, 261-62, 263, 266

Crime, post-slavery redefinition of, in British West Indies, 342n74; in St. Vincent during the Apprenticeship, 319-37

Cromwell, Oliver, 30, 54

Cuba, Vernon's expedition to, 91-92

Currency laws, 129

Curtin, Philip D., 16

Darity, William, 263

Dartmouth, Lord, 145n52

Davidson, Sir William, 34

Davis, David Brion, 16, 262, 264, 265

Davis, Ralph, 262-63

De la Beche, Henry, 222

Debukes, Joseph Louis, 329

Decolonization, 8, 13

Demerara, 259

Dickinson, William, 135

Dickson, William, 174-75, 187n56

Doctors and Slaves. See Sheridan: medical and demographic aspects of slavery

Dominica, 152, 163, 164

Douglas, John St. Leger, 135-36

Doyley, commander-in-chief, 30, 37

Drax, Thomas Earle, 143-44n21

Drescher, Seymour, 258, 260-66, 269n40, 269-70n45, 270n52, 27ln62, 271nn59-60

Drysdale, William, 289-90

Duglas, John, 29-32, 37-41
Dunk, George, 87

Dunmore, Lord, 278-79

Dunn, Richard, 171-72

Dupplin, Viscount, 94, 99n18

East, Hinton, 101, 119, 122

East India Company, 131

"Econocide" thesis of abolition, 258, 260-66, 269-70n45

Edwards, Bryan, 101, 122

Ellfryth, Daniell, 52

Ellis, Charles, 236, 237-38

Ellis, John, 132-35

Emancipation: attempts at purchase of, 206, 210n35, 274-75; in the Bahamas, 286-89; Bahamian manumission cases, 274-75, 283; economic basis of, 260-66; immediate versus gradual emancipation, 307-08; in Jamaica, $316 \mathrm{n} 25$; land and labour problem at time of, 297-313; and land tax, 301, 307-10, 312; of mulatto children, 201, 206; in St. Vincent, 320-21, 323-24, 338n 11; for slave prostitutes and mistresses, 178-79, 182-83; and temperament of blacks, 307; Wakefield's plan for voluntary emancipation, 297-98. See also Abolition

Engerman, Stanley L., 16

Ensome, Captain, 41

Estates, definition of, 212

Estwick, Samuel, 135, 137, 138, 140, 147n86

Exchange patterns: within plantation economy, 211-28

Fabian Society, 345-46

Falck, N. D., 115

Falcon, 50, 54, 55

Fame, 77, 79-80, 84n41, 85nn54-55

Fane, Sir James Lowther, 143-44n21

Farquharson, Charles, 288

Fenwick, Elizabeth, 172, 173

Fisher, F. J., 3, 4, 11

Fitzwilliam, Richard, 276

Fladeland, Betty, 258

Flogging: of slaves, 202, 205, 236-37, 239, 240-41

Flowers: in Jamaica, 57, 104-22

Fogel, Robert W., 16

Food: for slaves, 235-36; trade in food supplies, 162-63

Foot, William, 109

Forrest, Captain Arthur, 105

Forrester, David, 201 
France, 140 . See also headings beginning with French

Franklin, Benjamin, 300, 301

Free blacks: in the Bahamas, 278, 279, 283-86; compared with Irish peasants, 311-12; crime and social control in St. Vincent, 319-37; and land tax, 301, 307-10, 312; as owners of slave prostitutes, 181-82; as prostitutes, 182-83; vagrancy laws for, 318n42. See also Emancipation Freebourne, George, 35

French colonies, 151-53

French Revolution, 162, 261

French Wars, 157, 163

Friends. See Quaker merchants; Quakers Fruit: in Jamaica, 57, 104-22

Fuller, John, 135, 140

Fuller, Rose, 127, 129, 131-35

Fuller, Stephen, 128, 129, 137, 138, 140

Fyfe, Christopher, 256

Gardens, asparagus in, 111-14; grafting used in, 112; in Jamaica, 101-23; mango seeds planted in, 114-15; at St. Vincent, 112, 125n14

Garvey, Marcus, 291

Gashry, Francis, 97, 100n25

Geggus, David, 269-70n45, 270-7 ln56

George II, 64

George III, 147n86

Gerald, Captain John, 79

Germain, Lord George, 138, 140

Gibbes, Sir Philip, 132-33

Glover, Richard, 133, 134

Gooden, George Robert, 119

Gordon, Sir William, 135, 136

Gotley, Richard, 68

Goulburn, Maj. Archibald, 235, 247

Goulburn, Henry: as absentee slaveowner, 232, 234; and amelioration programme, 232-49; Anti-Slavery Society's criticisms of, 232, 238, 243-44, 246, 248; and improving slave birth rate, 241-42, 248; and losses sustained by, 242 political career of, 232, 234, 238, 240, 243; and reforms at Amity Hall, 246-49; and religious instruction for slaves, 236-41; and slave management at Amity Hall, 238-43; slaves purchased by, 235

Gould, Charles, 49

Grafting, 112

Grant, Sir Alexander, 143-44n21

Grant, Hay McDowell, 319, 320, 335
Granville, Lord, 77

Greeg, Ann, 328

Greene, Jack P., 13, 127

Gregory, John, 92, 94, 98n9

Groome, Samuel, 65

Gründer, Brother John Samuel, 197, 202, 209n25

Gurnell, Jonathan, 75

Hadsall, Captain, 38

Haistwell, Edward, 65

Haitian revolution, 163-64

Halifax, Earl of, 87

Hall, Thomas, 79, 85n54

Hambrouck, Henry, 35

Hamilton, Alexander, 300, 302-03

Hanbury, Capel, 76, 80

Hanbury, John, 66, 73, 74, 75, 76-81, 85n55

Hanbury, Osgood, 80, 84n39

Hanbury, Thomas, 85n55

Hardy, Thomas, 257

Harford, Charles, 75

Harlow, Vincent, 263

Harvey, Thomas, 179

Hay, Edward, 138

Hay, Thomas (Lord Dupplin), 94, 99n 18

Health problems: of slaves, 16-21, 191-92, 194,

$195,196,198-99,200,201,204,205-06,207$ n5

Henry, 105, 107, 112, 115

Hetherington, Henry, 257

Hewitt, Henry, 103, 112, 115, 117

Higman, B. W., 1, 16, 19-20, 173, 263, 271n62

Hillsborough, Lord, 129-30

Hilton, Colonel, 172

Hochstetter, Franz, 256, 267n 11

Hollis, Patricia, 257

Horse trading, 218-19

Horsley, John, 201, 209n22

Horticultural enterprise: in Jamaica, 101-23

Hortus Eastensis (Broughton), 122

Hosier, Vice-Admiral Charles, 97, 99n23

Howick, Lord, 304, 306, 307, 308-12, 317n37, 318n4l

Hunt, E. M., 257

Hunt, Henry, 257

Husbands, Joseph, 182

Hutchinson, James, 38

Hyam, Thomas, 86n57 
Incorporated Society for the Instruction and Religious Conversion of the Negroes, 237-39, 248

Indentured servants, 59, 312-13, 315n14

Inikori, Joseph, 262

Innis, H. A., 4, 5, 24n20

Ireland: peasants of, compared with free blacks, 311-12; and rum from West Indies, 164; trade with British West Indies, 150, 157, 158, 159, 163 Ives, Charles, 290

Jackson, Joseph, 202

Jackson, Rachel, 202

Jamaica: amelioration programme on Goulburn's estate, 232-49; and American independence, $131,132,134$; animals in, 56-57, 61, 109; as base for contraband commerce with Spanish empire, 33-35; botanical and horticultural enterprise in, 58-59, 101-23; capture of the Blue Dove, 29, 34, 37-42; early accounts of, 52-53; earthquakes in, 55, 344; emancipation in, 316n25; English defeat of.Spanish in, 30, 52, 54-55; Gregory as acting governor of, $92,98 \mathrm{n} 9$; indentured servants in, 59; integrated exchange in, 224, 226-27; and internal trade in goods, 219-21; and internal trade in slaves, 221-25; Jewish merchants in, 34-35, 37, 38, 39, 45nn37 38,58 ; land in, $316 \mathrm{n} 25$; laws of, 59 ; livestock trading in, 213-19, 226; Maroons of, 20; native Indians of, 56, 58; plantation-economy model in, 211-28; plants in, 53, 56-57, 60, 104-22; population of, in 1662,30; privateers and buccaneers in, 30-42, 45n48; prostitution in, $173,175-76$; rum prices in, 164; settlements of, 58; Sheridan's writings on, 8-10, 15; slave resistance in, 18; slaves in, $17,18,21,59$, 188-207, 221-25, 232-49; sugar industry in, 212-13; Taylor Manuscript and seventeenthcentury Jamaica, 48-61; trade with United States, 154, 156, 159-62; Trelawny as governor of, 87-97; wage labourers versus slaves in, 21; wealth of, 9-10

James, Cyril L. R., 254, 259, 267n1 1

Jewish merchants: in Jamaica, 34-35, 37, 38, 39, 45nn37-38, 58

"Jobbing gangs," 222-24

Johnson, Howard, 284, 285

Johnson, Peter, 41

Johnson, Samuel, 136

Johnstone, Governor George, 139

Judd, Gerrit, 128, 143n21
Kimball, J. H., 180, 181

Knibb, William, 265

Knight, Patrick, 201

Knox, John, 150-51

Knox, William, 138

Labour force: adjustments in, due to emancipation, 297-313; indentured servants, 59, 312-13, $315 \mathrm{n} 14$; in-migration of contract labour, 312 ; and land, 300-02, 304-10; and land tax, 301, 307-10, 312; Nieboer-Domar hypothesis on, 300, 304; peasantry, 346-47; Steuart on, 299; in United States, 301-04. See also Slavery and slaves

Land: in Jamaica, 316n25; and labour supply, 300-02, 304-10; peasant cultivation of, 346-47; in United States, 301-02

Land tax, 301, 307-10, 312

Lascelles, Daniel, 135, 136

Lascelles, Edwin, 135, 136

Laurens, Henry, 139

Lee, Caroline, 178

Leeward Islands: and American independence, 134; imports for, 127, 134; migration from, to foreign West Indies, 154; slavery in, 20, 134; trade with United States, 157, 159; Trelawny on duties from, $90,96,99 \mathrm{n} 21$

Lemon, Betsy, 178

Leslie, George, 109

Lettsom, John Coakley, 115

Levy, Claude, 173

Lewis, Gordon K., 346

Lewis, Hannah, 178-79

Ligon, Richard, 52

Littleton, Sir Charles, 32, 34-35, 37, 39, 44n21

Livestock trading, 213-19, 226

Lloyd, Sampson III, 82n15

London North American Merchants, 133

London School of.Economics (LSE), 3-5, 11, 23n17, 253

Long, Beeston, 129, 131

Long, Edward, 41, 117, 125n17, 175-76

Lorimer, Douglas, 259

Lowther Fane, Sir James. See Fane, Sir James Lowther

LSE. See London School of.Economics (LSE)

Lumber trade, 162-63

Lynch, Lt.-Col. Thomas, 33, 41, 44-45n36

Macaulay, Zachary, 234, 243-44, 246, 248, 249 
MacDonald, Ramsay, 345

Macmillan, William, 254

Maitland, Richard, 129

Mango growing, 114-15

Manning, Edward, 93, 99n16

Manning, William, 139

Mansfield, Lord, 259

Manufactures, development of, 302-03

Mariners, slave, 152, 283, 295

Marriage: of slaves, 237, 240, 246, 247

Marshall, Captain, 114

Marshall, Peter, 257

Martin, Samuel, 6

Martin, Samuel, Jr., 129, 135, 136, 143-44n21

Martinique, 152

Marx, Karl, 304, 316n26

Massachusetts Regulating Act, 131

McAlpin, Andrew, 200, 209n19

McAlpin, Robert, 200

McAlpine, Robert, 199-207

McCalman, Iain, 258

McMahon, Benjamin, 218-19

McNeill, William H., 19

Mercantilism, 298-300

Merchants: in British West Indies and trade with United States, 155-56; Jewish, in Jamaica, 34-35, 37, 38, 39, 45nn37-38, 58

Mesopotamia Estate, 188-207

Mildred, Daniel, 84n38

Mintz, Sidney, 228

Miscegenation, 171

Modyford, Sir Francis, 49

Modyford, Thomas, 29, 36-37, 39-41

Molasses Act, 128

Molesworth, Governor, 41

Molesworth, Hender, 49

Monardes, Nicolás, 52, $62 \mathrm{n} 9$

Montserrat, 152

Moravian Church, 188-89, 196-98, 200, 202,

204, 206, 208nn12-13, 210n30, 236

Moreton, J. B., 175

Morgan, Sir Henry, 42n4, 55

Morris, John, 34-35, 39, 44-45n36

Moskett, Benjamin, 34

Moss, Henry, 281

Moss, James, 280

Mulattoes: craft work of slaves, 201, 202-03; emancipation of, 201, 206, 207n2; life of Robert McAlpine on Mesopotamia Estate in Jamaica,
199-207; mulatto children exempted from field labour, 194-95, 207n2; mulatto women as sexually attractive to white elite males, 179-81; reading ability of, 209n25

Musgrave, Lord, 161

Mutiny Bill, 133

Myngs, Christopher, 31

Namier, Sir Lewis, 7, 136-37

Napoleonic War, 161

Nash, Gary, 67

Navigation Acts, 149, 156, 161

Neat, William, 75

Neave, Richard, 133

Nevis, 152

"New" economic history, 11-12, 22

Nieboer-Domar hypothesis, 300, 304

Norman, Governor, 347

North, Lord, 136, 137, 138, 148n99

North American colonies. See American colonies

Nugent, Governor, 156, 160

Nugent, Robert, 76

Oastler, Richard, 257

O'Brien, Bronterre, 257

Ogilby, John, 53

Ogle, Sir Charles, 98n5

Oldmixon, John, 172

Oliver, James, 38

Oliver, Richard, 127-28, 131-33, 136

Oliver, Vere Langford, 7

Olivier, Sydney: on Africa, 344, 348-52; career of, 344-46; in Fabian Society, 345-46; published works of, 353-54nn12-13; on West Indies, 343, 346-48, 351-52

Onslow, Lord, 140-41

Orde, John, 152

Oviedo, Gonzalo Fernández de, 52, 62n9

Panama, 92

Pares, Richard, 7, 15, 21-22, 127

Parie, Andrew, 325

Parker, Alexander, 116

Parry, David, 150, 151, 156, 183

Patrickson, Henry, 206, 210n35

Patterson, Joe, 329

Patterson, Orlando, 18, 170-71

Payne, Sir Ralph, 135, 136, 139 
Pearce, James, 79

Peasantry, 311-12, 346-47

Pelham, Henry, 87-97

Pennant, Richard, 127, 131, 140

Phenney, George, 276, 277

Phillipps, Sir Thomas, 51

Phillips, Captain George, 117

Phillips, Ulrich B., 1

Pinckard, George, 177-78, 180

Pinkney, Robert, 115-16

Pirates, 55

Pitman, Frank W., 1, 3, 9, 21, 23n9

Pitt, William, the Elder, 127

Plantation-economy model: "dual economy" in, 211-12; integrated exchange, 224, 226-27; internal marketing systems of slaves versus planters, 118, 212, 228; patterns of exchange, 211-28; trade in goods, 219-21; trade in livestock, 213-19; trade in slaves, 221-25

Plantations: definition of, 212; Sheridan's writings on, 6-7, 10, 12-16. See also Slavery and slaves; Sugar industry; Sugar planters

Planters. See Sugar planters

Plants: of Jamaica in Taylor Manuscript, 53, 56-57, 60; in Thistlewood's gardens in Jamaica, $104-22$

Pommell, William, 116

Pompey's "rebellion," 282

Pope, Thomas, 68

Portland, Duke of, 158-59

Powles, Louis Diston, 287, 289, 291

Price, Charles, 94-95, 99n20, 213

Price, Rose, 213

Prisons, in St. Vincent, 320, 325-26, 334, 340nn27-31

Privateering: capture of Blue Dove by, 29, 34, 37-42; in Jamaica, 30-42, 45n48; and Quaker merchants, 67-81, 84n41

Prohibitory Act, 135-36, 154, 162

Prosopography, 7, 17, 189

Prostitution: of slave women, 171, 172-84

Quaker merchants: admonitions against armed ships aimed at, 68-74, 79; arming of ships of, 68-81; disownments of, 70-71, 80, 83n22, $84 \mathrm{n} 39$; and equity courts, 64-65; Hanbury as example of, $66,73,74,75,76-81,85 n 55$; importance of, to local Quakers, 71; letters of marque issued to, $68,72-78,80-81,82 \mathrm{n} 13$; and privateering, $67-81,84 \mathrm{n} 41$; and trade with
American colonies, 65; and war at sea, 1689-1783, 65-81

Quakers: doctrine versus discipline, 66; munitions manufacture and sale prohibited by, $81,82 \mathrm{n} 15$; slavery and slave trade condemned by, 67; war condemned by, 67

Quare, Daniel, 86n57

Quebec Act, 131

Ragatz, Lowell J., 1, 139, 255, 260, 267n11

Rape of slave women, 170-71, 174

Real Galley, 84n41

Reeve, William, 75

Religion: abolition and, 255, 256; of slaves, 188-89, 196-98, 200, 202, 204, 206, 210n30, $232,233,236-41,245,247$

Revenue Act, 131

Revolutionary War. See American Revolutionary War

Rice, C. Duncan, 257, 272n66

Richards, George, 235-36, 238, 239, 247

Richardson, Captain, 105, 107, 112, 115, 117

Richardson, David, 261, 262, 270n53

Ricketts, George Poyntz, 158-60, 181

Ricketts, William Henry, 112, 114, 115

Risby, James, 35

Ritchie, Dr., 204

Roberts, John, 84n38

Robinson, Anthony, 104, 124n6

Rockingham, Lord, 137, 140

Rodgers, William, 200

Rodney, Lord, 114

Rolle, Lord, 281, 282

Rose, James Brodie, 201, 202

Roughley, Thomas, 219

Rum sales and trading, 103-04, 161, 163-64, 210n28, 219-21, 226

Runaway slaves, 193, 198-99, 208n7, 279, 281, 282-83

St. Domingue, 152, 163, 259, 261

St. Eustatius, 152

Saint George, 49-50

St. Kitts, 152, 155

Saint Pierre, Louis de, 115

St. Thomas, 154

St. Vincent: crime and social control during the Apprenticeship in, 319-37; emancipation in, 320-21, 323-24, 338n11; free black population of, 337n 3, 338n5, 338n10; houses of "vice and debauchery" in, 327-28; penal institutions in, 
$320,325-26,334,340 \mathrm{nn} 27-31$; prices of plantation supplies and lumber, 163; riots in, 330-31, 336-37; rum prices in, 164; slavery in, 319-20; sugar industry in, 319; theft in, 331-33; trade with United States through French islands, 152; Wylly's transfer to, 281

Sample, Mary, 329

Samson, William, 234, 242

Sanderson, Frank, 257

Savanna la Mar, 101, 103, 116, 123, 188

Say, Samuel, 109, 124nl1

Schuler, Monica, 18

Scott, Francis, 112-14

Seaforth, Governor, 155-56, 182

Serfs, 313, 318n44

Seven Years' War, 66, 70, 73, 76, 77, 80, 276

Sexuality: marketing of slave women's sexuality, 169-84; sexual typology of white elite males, 180

Sharecropping, 288-89

Sharp, Ann, 49

Sharp, Captain Bartholomew, 55

Sharp, Granville, 259

Sharpe, John, 97, 100n25

Sharpe, William, 143-44n21, 174

Shaw, Bernard, 345

Sheffield, Lord, 149

Shephard, Charles, 319-20, 323, 324, 326

Shepherd, Verene, 102

Sheridan, Richard B.: appointment to faculty of University of Kansas, 5; biographical informtion on, 1-3; connections with British

Caribbean, vii-viii; contributions of, 21-22; education of, 2-5, 11, 253; Fulbright Research Scholarship received by, 7; intellectual influences on, 3-5, 7, 16, 19; at London School of Economics, 3-5, 11, 23n 17, 253; medical and demographic aspects of slavery, 18-21; methodologies and source materials employed by, 6 , $7-9,11-12,17,19$; on "new" economic history, 11-12; Ph.D. thesis of, 3, 5, 26n59; published works of, $x$-xvi, 5-10, 12-21, 253; on resources for study of Jamaica, 213; staple theory used by, 15-16; Sugar and Slavery, as authoritative study, 13-16, 26n61, 297; thematic concerns of, 5-10, 12-22, 253, 263, 297-98, 313; Thomas's critique of, 10-11; on West India interest, 126; in World War II, 2

Shirley, Governor, 154-55, 157

Slave codes: blacks described as "heathenish" in, $185 \mathrm{n} 5$; reform of, $232,236-37$
Slave resistance, 18, 119, 259, 281-82

Slave trade: abolition of, 164, 254, 315n14; condemnation of, by Quakers, 67; English entry into, 36; British expansion of, 262, 270n53; profitability of, 262; Sheridan's writings on, 6-7, 10, 16-17; and Spanish asiento, 35-36; and West India interest, 129, 144n26, 147n92

Slave women: as baby sitters for young children on estate, 195; as "beasts of burden," 184, 187n56; children of, 193-94, 204, 208n8, 235, 244-46; emancipation for prostitutes and mistresses, 178-79, 182-83; field labour of, 190-95, 241; flogging of, abolished, 236-37, 241, 245, 247; free blacks as owners of slave prostitutes, 181-82; as hired out labourers, 228; as "hucksters," 286, 295n31; and improving slave birth rate, 233, 241-42; life of Sarah Affir on Mesopotamia Estate in Jamaica, 189-99, 206-07; male preference for "mulattos" versus black women, 179-81; marketing of sexuality of, 169-84; as mistresses and housekeepers of slaveowners, $105,173-75,176,179-82$; prostitution of, 171, 172-84, 204-05; rape of, 170-71, 174; rewards for childbearing, 235; as washerwomen, 195-96, 201; white women as owners of slave prostitutes, 177

Slavery and slaves: and amelioration programme on Goulburn's estate, 232-49; and American Revolutionary War, 134; and arson, 242; in Bahamas, 274-92; in Bermuda, 275-76; blacks described as "heathenish," 185n5; chapel slaves, 202, 206; child labour patterns, 190-91, 194-95; condemnation of slavery by Quakers, 67; craft work, 201, 202-03, 205, 283; deaths and death rates of, 17, 20, 139, 189-90, 191, 199-200, 209n21, 209n23; decline in slave population, 235; demography of, 16-20; domestic labour, 195-96, 200-01, 206, 224; field labour, 190-95, 241; flogging of slaves, 202, 205, 236-37, 239, 240-41; food for slaves, 235-36; health problems of slaves, 16-21, 191-92, 194, 195, 196, 198-99, 200, 201, 204, 205-06, 207n5; infant mortality, 189-90, 199-200; internal marketing system of slaves, 118, 212, 228; in Jamaica, 18, 21, 59, 188-207; "jobbing gangs," 222-24; land and labour problem at time of legal emancipation of slaves, 297-313; lives of male and female slave, 189-207; and marriage, 237, 240, 246 , 247; night work abolished, 245, 247; participation in struggle for abolition, 259; planter profits and slave rewards, 232-49; religious instruction and conversion of slaves, 188-89, 196-98, 200, 202, 204, 206, 210n30, 232, 233, 
236-41, 245, 247; runaway slaves, 193, 198-99, $208 \mathrm{n} 7,279,281,282-83$; in St. Vincent, 319-20; savings banks, 237; as seamen, 152, 283 , 295n23; Sheridan on, 6-7, 10, 14-20, 263, 297 98,313 ; slave tradesmen, 224, 225; social costs of, 16-18; strike by slaves, 239; in Taylor Manuscript, 55, 59; Thistlewood as slave owner, 10211, 117-20; trade in slaves, 221-25; in United States, 16; violence between slaves, 201-202, 204-05. See also Abolition; Emancipation

Sloane, Sir Hans, 53

Smith, Adam, 255

Social control, in St. Vincent during the Apprenticeship, 319-37

Society of Friends. See Quaker merchants; Quakers

Society of.West India Merchants, 128-33, 138-40

Soderlund, Jean, 67

Somerset Case, 259

Spanish Succession War, 72, 75

Stamp Act, 126, 127, 128-29, 132, 141, 143n21

Stanley, Hans Sloane, 143-44n21

Staple theory, 15-16

Stapleton, Sir Thomas, 143-44n21

Steele, Joshua, 183

Steuart, Sir James, 299, 314n7

Storer, Anthony Morris, 135, 136, 138, 139

Sturge, Joseph, 179

Sugar Act, 128, 129

Sugar industry: after American Revolutionary

War, 149-50; destruction of, in St. Domingue, 163; before and after emancipation, 304, 30506; in Jamaica, 212-13; Mesopotamia Estate in Jamaica, 188-207; price drops in, 261-62; rum's role in, 103-04, 161, 163-64; in St. Vincent, 319; Sheridan's writings on, 13-16; and trade with United States, 149-50, 152, 154, 155, 157, 161-65

Sugar planters: and amelioration programme, 232 49; integrated exchange by, 224, 226-27; internal marketing system of, 228; and internal slave trade, 221-25; and plantation-economy model, 211-28; profits and slave rewards, 23249; rum sales by, 103-04, 161, 163-64; Sheridan's writings on, 5, 6, 8, 14; trade in goods by, 219-21; trade in livestock by, 213-19; and trade with United States, 149-50, 152, 154, 155, 157, 161-65. See also Plantations; Slavery and slaves Sugar trading, 219-21

Suttie, Captain Charles, 117, 125n17
Sutton, Thomas, 50

Swart, Captain, 36

Swettenham, Governor, 344

Sydney, Lord, 152

Talbot, Captain Charles, 50

Taunton, Richard, 85n54

Tawney, R. H., 4-5, 7, 23nn16-17

Taylor, Henry, 304, 306-08, 312

Taylor, John: early life of, 48; illness of, 49, 50; indentured servants of, 49; journal of, 51-61; marriage of, 48-49; nautical log of, 53-54; in the royal army, 48 ; voyage to Jamaica by, $49-50$

Taylor, Richard, 48

Taylor, Simon, 8, 150, 154

Taylor, William, 222

Tharp, John, 226

Tharp, William, 226

Thistlewood, Thomas: asparagus planted by, 111-14, 121; books consulted by, 115; death of, 119; earnings from Breadnut Island Pen, 120-21; entertainments hosted by, 111; exchange of information with other gardeners, 114, 115-16; flogging of slaves by, 202; gardeners assisting, 112-14; gardens of, 101-22; income sources of, 103-04, 118, 120-21; land purchase by, 102, 103; mango seeds planted by, 114-15; relationship with slave Phibbah, 105; rum shipments by, 103-04; sexual relations with slaves, 204-05; and slave resistance, 119; slaves of, 102-11, 117-20; work on sugar estates, 102

Thomas, Robert Paul, 10-11

Thome, J. A., 180, 181

Thomlinson, John, 77, 79, 85n55

Thompson, Robert, 159

Thompson, William, 112

Tippo, Cuffee, 192

Toleration Act of 1689, 64

Toote, Frederick Augustus, 291

Toote, T. W., 291

Toote, Thaddeus Augustus, 291

Tortuga, 37

Townshend, 70, 82n18

Townshend Duties, 127, 129

Trade: April 1787 Act, 154-56, 164, 165; British proclamations opening ports to United States trade, 157-59; British trade with West Indies, 262-63, 271n60; Canadian trade with British West Indies, 150, 152-53, 157, 158, 159, 163 , 165; French islands in United States-British West Indies trade, 151-53; governors' 
discretionary powers for West Indian trade with United States, 154-55; Irish trade with British West Indies, 150, 157, 158, 159, 163; Prohibitory Act, 135-36, 154, 162; in provisions and lumber, 162-63; United States and British West Indian trade, 1783-1807, 149-65. See also Plantation-economy model

Trelawny, Edward: on British colonial governance, 87-97; early political career of, 88 ; as governor of Jamaica, 87-97; as member of Supreme Council, 91, 98n5; text of letters to Pelham, 91-97

Trinidad, 342n74

Trotman, David, 342n74

Tullideph, Walter, 6

Tuma, Elias H., 11

Turner, Samuel, 132

Tyler, George, 324, 331

United States: and British West Indian trade, 1783-1807, 149-65; economic policy proposals in, 302-04; exclusion from British colonial markets, 149-50; "Jim Crowism" of, 350; land in, 301-02; retaliatory measures against British shipping and West Indian products, 151, 158, 162; Royal Navy's impressment of U.S. seamen and capture of U.S. ships, 158,162 ; rum production in, 164 . See also American colonies

Vagrancy laws, 318n42

Vassall, Florentius, 102, 107, 115

Vaughan, Lord, 41

Vegetables, in Jamaica, 104-22

Vernon, Edward, 91-92, 98nn5-6

Wager, Sir Charles, 97, 99n23

Wakefield, Edward Gibbon, 297-98, 316n26

Walker, Dr., 179

Walker, George, 133-35, 138

Wallas, Graham, 345

Wallen, Matthew, 101, 114, 119, 122

Waller, John, 177, 180

Walpole, Horace, 136

Walvin, James, 256

War of American Independence. See American

Revolutionary War

War at sea, and Quaker merchants, 65-81

War of the Austrian Succession, 87, 276

War of Jenkins' Ear, 98n5

War of the Spanish Succession, 99n24
Ward, John R., 233-34, 249, 263-64, 271n62

Watkins, M. H., 10

Webb, Sidney, 345

Wedderburn, Robert, 258

Wells, H. G., 346

Wentworth, General, 98n5

West India Committee, 132, 145n43, 149, 232, 236-38

West India interest: and American Revolutionary War, 126-41; and Carlisle Peace Commission, 139; and Coercive Acts of 1774, 130-31; exemptions of West Indies from British policies toward America, 129-30; and neutrality in American Revolutionary War, 139, 148n99; opposition to American colonies by, 126, 128 129-32, 135-41; in Parliament, 126, 128, 140, 143-44n21, 147nn84-85; and Prohibitory Bill of 1775, 135-36; and slave trade, 129, 144n26, 147n92; and Stamp Act, 126, 127, 128-29, 132, 141, 143n21; support for American colonies by, 126, 127-29, 132-37; and Townshend Duties, 129

West Indies: British trade with, 262-63, $27 \ln 60$; impact of American Revolutionary War on, 137-39, 149, 157, 261; land and labour problem at time of legal emancipation of slaves, 297-313; land tax in, 301, 307-10, 312; Olivier on, 343, 346-48, 351-52; peasantry in, 346-47; proclamations opening ports to United States trade, 15759; rum in economy of, 103-04, 161, 163-64; United States and British West Indian trade, 1783-1807, 149-65. See also specific countries

White women: in abolition movement, 260; involvement in slave prostitution, 177

Wilberforce, 236

Wildman, J. B., 244-48

Wilkes, John, 128

Willett, John?, 132

Williams, Burton, 280

Williams, Eric, viii, 4, 9, 10, 15, 21, 253-55, 259, 260, 264, 265, 267nll

Williams, James, 102

Willoughby, Sir Francis, 38, 39

Winchelsea, 77, 79-80, 84n4 1, 85nn54-55

Winchester, Colonel, 337

Windsor, Lord, 30, 31

Windward Islands, 20, 154, 162-63

Women. See Black women; Slave women; White women

Wood, Sampson, 174

Wright, Captain Benjamin, 117

Wylly, William, 280-81, 283 


\section{Contributors' Biographical Data}

RODERICK A. MCDONALD is Professor of History at Rider University. He is the author of The Economy and Material Culture of Slaves: Goods and Chattels on the Sugar Plantations of Jamaica and Louisiana (Baton Rouge: Louisiana State University Press, 1993), and is at present completing an editorial project, The Journal of John Anderson, St. Vincent Special Magistrate, 1836-1839.

HILARY MCD. BECKLES is Professor of History at the University of the West Indies, Cave Hill campus, Barbados. He is the author of White Servitude and Black Slavery in Barbados, 1627-1755 (Knoxville: University of Tennessee Press, 1984), Natural Rebels: A Social History of Enslaved Black Women in Barbados (New Brunswick: Rutgers University Press, 1990), and A History of Barbados: From Amerindian Settlement to NationState (Cambridge: Cambridge University Press, 1990).

DAVID BUISSERET, newly appointed to the Jenkins and Virginia Garrett Chair, Department of History, University of Texas at Arlington, directed the Smith Center for the History of Cartography at the Newberry Library in Chicago from 1980 to 1995, and before that served in the Department of History at the University of the West Indies, Mona campus, Jamaica (1964-1980). While in Jamaica, he edited the Jamaican Historical Review, and published Historic Jamaica from the Air (Barbados: Caribbean Universities Press, 1969), The Fortifications of Kingston, 1655-1914 (Kingston: Bolivar Press, 1971), A Popular History of the Port of Kingston (Kingston: The Jamaican Shipping Association, 1973), and Port Royal, Jamaica (with Michael Pawson; Oxford: Oxford University Press, 1975). He is working at present on a revision of Historic Jamaica from the Air, and on an edition of the Taylor Manuscript.

SELWYN H. H. CARRINGTON is Visiting Professor of History at Howard Univerity and Senior Lecturer in History at the University of the West Indies, St. Augustine campus, Trinidad. He is the author of The British West Indies during the American Revolution (Leiden: Royal Institute of Linguis- tics and Anthropology, 1988), and several articles on the West Indian economy in the eighteenth century. He has recently completed a major study entitled The Sugar Industry and the Abolition of the Slave Trade.

MICHAEL CRATON is Professor of History at the University of Waterloo. He is the author of $A$ History of the Bahamas (London: Collins, 1962; 2nd ed., 1968; 3rd ed., Waterloo, Ontario: San Salvador Press, 1986), A Jamaican Plantation: The History of Worthy Park (with James Walvin Toronto: University of Toronto Press, 1970), Sinews of Empire: A Short History of British Slavery (New York: Doubleday, 1974), Searching.for the Invisible Man: Slaves and Plantation Life in Jamaica (Cambridge, Mass.: Harvard University Press, 1978), and Testing the Chains: Resistance to Slavery in the British West Indies (Ithaca: Cornell University Press, 1982). He is currently completing, with Gail Saunders, a social history of the Bahamas entitled Islanders in the Stream: A History of the Bahamian People (Athens: University of Georgia Press), the first volume of which was published in 1992.

RICHARD S. DUNN is Roy F. and Jeannette P. Nichols Professor of American History at the University of Pennsylvania. He is the author of Sugar and Slaves: The Rise of the Planter Class in the English West Indies, 1624-1713 (Chapel Hill: University of North Carolina Press, 1972), and is at present completing a comparative study of slave life in Jamaica and Virginia, The People of Mesopotamia and Mount Airy.

STANLEY L. ENGERMAN is John H. Munro Professor of Economics and Professor of History at the University of Rochester. He is co-author (with Robert Fogel) of Time on the Cross: The Economics of American Negro Slavery (Boston and Toronto: Little, Brown and Co., 1974), and a co-editor of several books on slavery and emancipation in the Americas, most recently (with Robert L. Paquette) The Lesser Antilles in the Age of European Expansion (Gainesville: University Press of Florida, 1996). 
JACK P. GREENE is Andrew W. Mellon Professor in the Humanities at the Johns Hopkins University. He is the author of several books, the most recent of which are The Intellectual Construction of America: Exceptionalism and Identity from 1492 to 1800 (Chapel Hill: University of North Carolina Press, 1993), and Negotiated Authorities: Essays in Colonial Political and Constitutional History (Charlottesville: University Press of Virginia, 1994).

DOUGLAS HALL is Professor Emeritus of History at the University of the West Indies, Mona campus, Jamaica. He is the author of Free Jamaica, 1838-1865: An Economic History (New Ha ven: Yale University Press, 1959), Ideas and Illustrations in Economic History (New York: Holt, Rinehart and Winston, 1964), Five of the Leewards, 1834-1870 (Bridgetown: Caribbean Universities Press, 1971), In Miserable Slavery: Thomas Thistlewood in Jamaica, 1750-86 (London: Macmillan, 1989), and other books and articles on Caribbean history in the eighteenth and nineteenth centuries. He has recently completed a biography of Professor M. G. Smith, the distinguished Jamaican anthropologist and poet, who died in 1993.

B. W. HIGMAN is Professor of History in the Research School of Social Sciences, Australian National University, and was formerly Professor of History at the University of the West Indies, Mona campus, Jamaica. He is the author of Slave Population and Economy in Jamaica, 1807-1834 (Cambridge: Cambridge University Press, 1976), Slave Populations of the British Caribbean, 18071834 (Baltimore: The Johns Hopkins University Press, 1984), and Jamaica Surveyed: Plantation Maps and Plans of the Eighteenth and Nineteenth Centuries (Kingston: Institute of Jamaica, 1988), all of which draw on the work of Richard Sheridan.

HOWARD JOHNSON is Associate Professor of Black American Studies and History at the University of Delaware. He is the author of The Bahamas in Slavery and Freedom (Kingston and London: lan Randle Press and James Currey, 1991), and editor of After the Crossing: Immigrants and Minorities in Caribbean Creole Society (London: Frank Cass, 1988).

RICHARD A. LOBDELL is Professor of Economics at the University of Manitoba. He is the author of Economic Structure and Demographic Performance in Jamaica, 1891-1935 (New York: Garland,
1987), and co-editor of The Peasant in Economic Thought: "A Perfect Republic" (London: Edward Elgar, 1995).

WALTER MINCHINTON was Professor of Economic History at the University of Exeter from 1964 to 1986, and is now Professor Emeritus. Among other publications, he edited (with Celia King and Peter Waite) Virginia Slave-Trade Statistics, 1698-1775 (Richmond: Virginia State Library, 1984), and he is at present compiling a volume of essays on the Atlantic slave trade in the eighteenth century.

ANDREW J. O'SHAUGHNESSY is Assistant Professor of History at the University of Wisconsin Oshkosh. He is currently completing a booklength study entitled An Empire Divided: The American Revolution and the British Caribbean.

JACOB M. PRICE is Professor Emeritus of History at the University of Michigan, corresponding fellow of the British Academy, and past president of the Economic History Association. His books include France and the Chesapeake: A History of the French Tobacco Monopoly, 1674-1791 (Ann Arbor: University of Michigan Press, 1973), Capital and Credit in British Overseas Trade: The View from the Chesapeake, 1770-1776 (Cambridge, Mass.: Harvard University Press, 1980), and Perry of London: A Family and a Firm on the Seaborne Frontier (Cambridge, Mass.: Harvard University Press, 1992). The Variorum publishing house in England is currently republishing a selection of his articles, planned for three volumes. He is now working on a study of English merchant families in the seventeenth and eighteenth centuries.

MARY TURNER is Professor of History at Dalhousie University and Visiting Fellow at the Institute of Commonwealth Studies, University of London. She is the author of Slaves and Missionaries: The Disintegration of Jamaican Slave Society, 17871834 (Urbana: University of Illinois Press, 1982), and editor of Chattel Slaves to Wage Slaves: Labour Bargaining in the Americas (London, Indianapolis and Bloomington: James Currey and University of Indiana Press, 1995).

NUALA ZAHEDIEH is Lecturer in Economic and Social History at the University of Edinburgh. She has published a number of articles on Jamaica and colonial commerce in the seventeenth century. 
Seventeen prominent scholars of the Caribbean have contributed to this volume of essays honouring Richard Sheridan in recognition of his distinguished contribution to Caribbean historiography, and to mark his recent retirement as Professor of Esonomics at the University of Kansas.

Economic historians, historical geographers, historians and economists, from the Caribbean, North America and Britain, are represented in West Indies Accounts, with participation by scholars of Professor Sheridan's generation (including three fellow postgraduates at the London School of Economics - Douglas Hall, Walter Minchinton and Jacob Price), and those whom they have taught.

The articles, a number of which employ the prosopographical approach long-favoured by Sheridan, examine the history of the British Caribbean and the Atlantic economy from the seventeenth to the nineteenth centuries, embracing themes central to Sheridan's scholarship, including analyses of British West Indian trade within the context of the Atlantic economy, the social consequences of the sugar plantation system under slavery, the domestic economy of the British Caribbean, and the transition from slavery to freedom in the British West Indies.

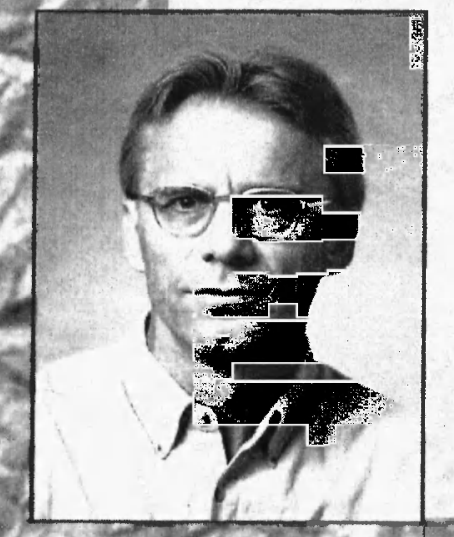

RODERICK A. MCDONALD is Professor of History at Rider University. He is the author of The Economy and Material Culture of Slaves: Goods and Chattels on the Sugar Plantations of Jamaica and Louisiona, 1993, and is at present completing an editorial project, The Journal of Jobn Anderson, St Vincent Special Magistrate, 1836-1839. Fin 